\section{TEST AREA FOR REMEDIAL ACTICNS (TARA) \\ SITE CHARACTERIZATION AND DYNAMIC COMPACTION \\ OF LOW-LEVEL RADIOACTIVE WASTE TRENCHES \\ FY 1988 PROGRESS REPORT}

E. C. Davis

B. P. Spalding

S. Y, Lee

L. K. Hyder

Environmental Sciences Division

Oak Ridge National Laboratory

Date of Issue - January 1989

Prepared for the

Office of Defense Waste and Transportation Management

\author{
Prepared by the \\ OAK RIDGE NATIONAL LABORATORY \\ Oak Ridge, Tennessee 37831-6285 \\ operated by \\ MARTIN MARIETTA ENERGY SYSTEMS, INC. \\ for the \\ U.S. Department of Energy \\ under contract DE-ACO5-84OR21400
}


This report has been reproduced directly from the best avallable copy.

Available to DOE and DOE contractors from the Office of Scientific and Technt cal Information, P.O. Box 62, Oak Ridge, TN 37831; prices avallable from (6 15) 578-8401, FTS 626-8401.

Avallable to the public from the National Technical information Service, U.S. Department of Commerce, 5285 Port Royal Rd., Springtiold, VA 22161.

NTIS price codes-Printed Copy: A 10 Microfiche A01

This report was prepared as an account of work sponsored by an agency of the United Statea Government. Neitrier the United States Government nor any acency thereot, nor any of their employees, makes any warranty, express or implled, or assumes any legal llability or responsibility for the accuracy, completeness, or usefuiness of any information, apparatus, product, or process disolosed, or represents that its use would not intringe privately owned rights. Reterence herein to any spectilic commercial product, process, or service by trade name, trademark, manufacturer, or otherwise, does not necessarily constitute or imply its endorsement, recommendation, or favoring by the United States Government or any agency thereof. The views and opinions of authors expressed herein do not necessarly state or reflect those of the United States Government or any agency thereof. 


\section{TEST AREA FOR REMEDIAL ACTIONS (TARA) \\ SITE CHARACTERIZATION AND DYNAMIC COMPACTION \\ OF LOW-LEVEL RADIOACTIVE WASTE TRENCHES \\ FY 1988 PROGRESS REPORT}

E. C. Davis

B. P. Spalding

S. Y. Lee

L. K. Hyder

\section{Environmental Sciences Division}

Oak Ridge National Laboratory

Date of Issue - January 1989

Prepared for the

Office of Defense Waste and Transportation Management

Prepared by the

OAK RIDGE NATIONAL LABORATORY

Oak Ridge, Tennessee 37831-6285

operated by

MARTIN MARIETTA ENERGY SYSTEMS, INC.

for the

U.S. Department of Energy

under contract DE-ACO5-840R21.400
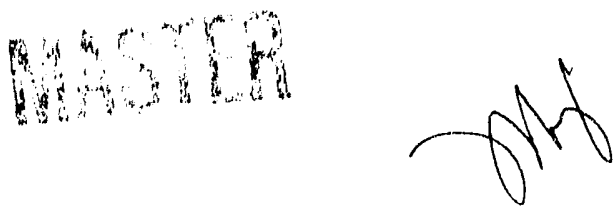

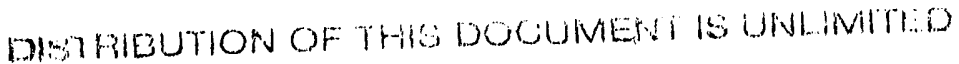


CONTENT'S

Page

LIST OF TABLES $\ldots \ldots \ldots \ldots \ldots \ldots \ldots \ldots \ldots \ldots \ldots \ldots \ldots \ldots \ldots \ldots$

LIST OF FIGURES $\ldots \ldots \ldots \ldots \ldots \ldots \ldots \ldots \ldots \ldots \ldots \ldots \ldots \ldots$

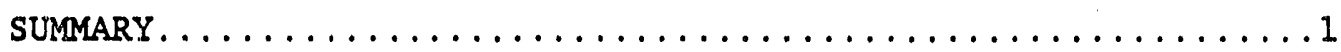

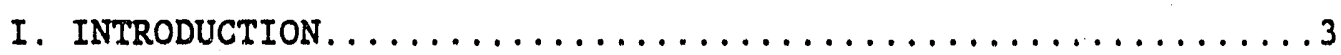

Background $\ldots \ldots \ldots \ldots \ldots \ldots \ldots \ldots \ldots \ldots \ldots \ldots \ldots \ldots \ldots \ldots \ldots$

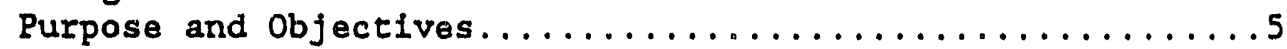

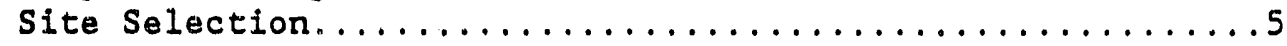

Project Documentation. ......................

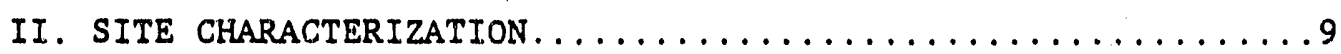

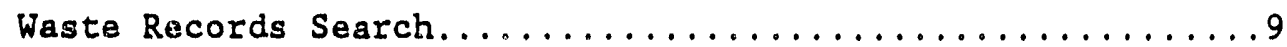

Monitoring Well Installation. ..................

Water Level Measurements ....................... 14

Grunndwater Sampling. . . . . . . . . . . . . . . . . . 22

Precompaction Nonstandard Trench Penetration Tests.......36

Standard Soil Penetration Tests and Soll Core Retrieval....39

Measurement of Trench Void Volumes..................54

Trench Cover Moisture and Bulk Density...............69

Trench Contents and Grout Compatibility............. 74

Degradation Rates for ${ }^{14} \mathrm{C}$-Labeled Polyacrylate and

Polyacrylamide Grouts in Soil.................86

Field Monitoring of SWSA 4 Grouted Trenches............ 102

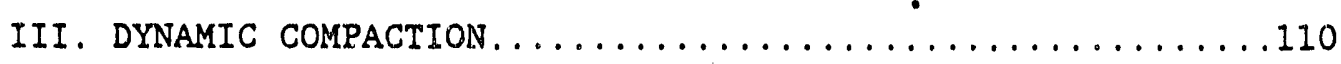

Method of Dynamic Compaction..................110

Results of Dynamic Compaction...................... 110

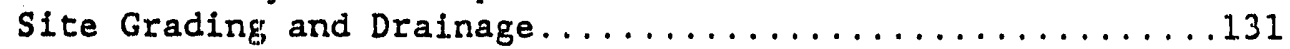

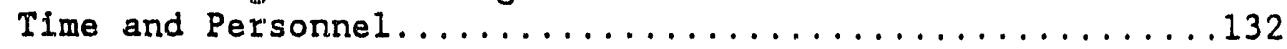

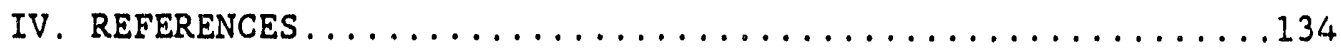

APPENDIX I - Examples of Types of Waste Placed in SWSA 6 Trenches $2,3,4$, and $5 \ldots \ldots \ldots \ldots \ldots \ldots \ldots \ldots$

APPENDIX II - Drill Logs and Construction Information for TARA Wells 1 through $13 \ldots \ldots \ldots \ldots \ldots \ldots$ II-

APPENDIX III - TARA Well Water Level Data, Hydrographs, and Area Rainfal1.....................III-1 
CONTENTS

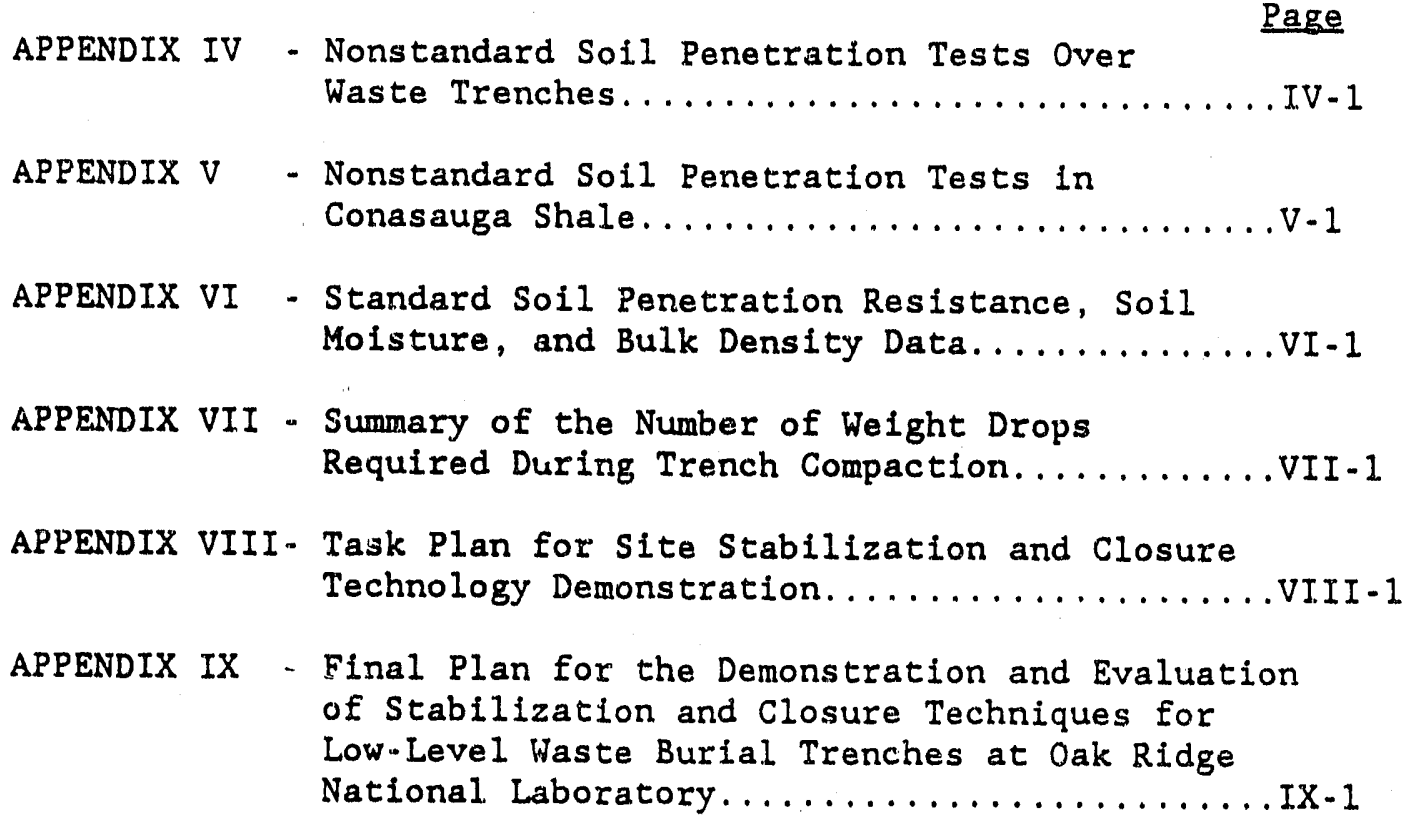

APPENDIX X - Correspondence with The State of Tennessee Department of Health and Environment.......... 


\section{LIST OF TABLES}

Table

1 Summary of TARA trench open and close dates, waste shipment records, and estimated waste volumes accordirig to ORNL Environmental Protection and Compliance Division waste records.....................10

2 Summary of TARA well construction parameters........13

3 Comparison of water elevations taken by the OMNIDATA logging system with manual measurements...........17

4 Results of groundwater analysis from 1.5 TARA wells ....23

5 Listing of semivolatile compounds that were analyzed but not detected in TARA groundwater samples.........28

6 Comparison of measured groundwater TDS with calculated TDS and measured groundwater hardness with calculated

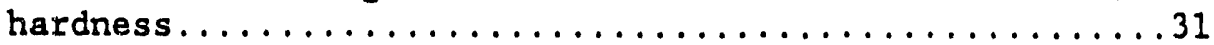

7 Water quality characteristics of monitoring well

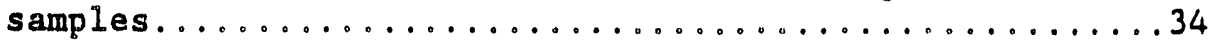

8 Organic vapor analyzer results for the undisturbed soil samples around the TARA burial trenches............46

9 Volatile organic compounds analyzed for in the TARA

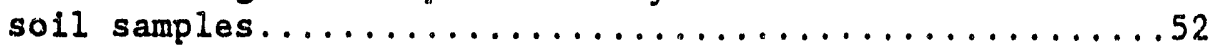

10 Organic compounds and radionuclides detected in TARA soil samples selected from organic vapor analyzer

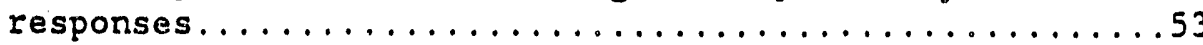

11 Radionuclides in soil samples from around the TARA

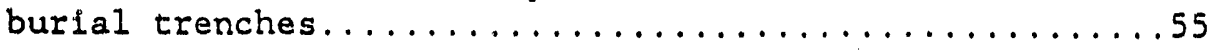

12 Sumnary of calculations of water accessible void space derived from trench water pump-in tests...........67

13 Changes in trench cap moisture and bulk density after trench compaction.......................

14 Bulk density and moisture contents of surface $(0-15 \mathrm{~cm})$ soils of trench caps after dynamic compaction........73

15 Gross chemical and radiochemical characteristics of burlal trench leachate and groundwater samples.......79 
LIST OF TABLES

Tabile

Page

16 Radionuclide and moisture contents of burial trench soil samples.............................80

17 Settling times for acrylamide grout in the presence of burial trench leachates and soils...............82

18 Residual concentrations of acrylamide and methlyenebisacrylamide in specimens of grout prepared in the presence and absence of burial trench soll

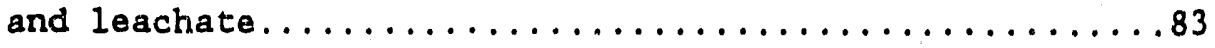

19 Hydraulic conductivities of burial trench soll columns before and after grouting with polyacrylamide........84

20 Water retention characteristics of acrylate and acrylamide polymers at various pressures...........89

21 Loss of ${ }^{14} \mathrm{C}$ activity from 108 polyacrylate grout by degradation............................90

22 Degradation rate constants and half-lives of $10 z$ polyacrylate grout in soil....................

23 Loss of ${ }^{14} \mathrm{C}$ activity from 208 polyacrylate grout

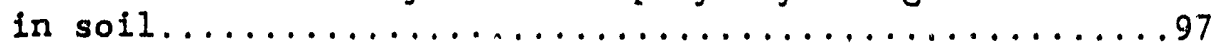

24 Degradation rate constants and half-lives of $20 \%$ polyacrylate grout in soil.....................

25 Loss of $14 \mathrm{C}$ activity from 108 polyacrylamide grout

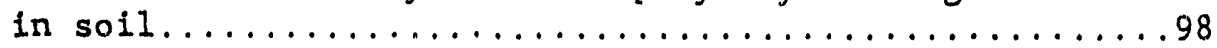

26 Degradation rate constants and half-lives of $10 \%$ polyacrylamide grout in soil..................99

27 Loss of ${ }^{14} \mathrm{C}$ activity from 208 polyacrylamide grout

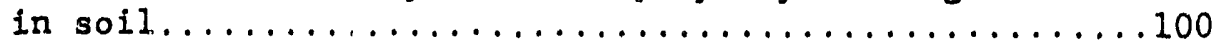

28 Degradation rate constants and half-lives of 208 polyacrylamide grout in soil.................... 100

29 Organic analyzates in groundwater samples from SWSA 4 monitoring wells around the polyacrylamide-grouted

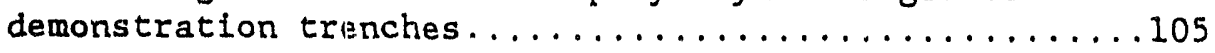

30 Water quality characteristics of SWSA 4 monitoring wells around the in situ grouting demonstration trenches.....107 
LIST OF TABLES

Table

Page

31 Elemental analyses of groundwater samples from SWSA 4 monitoring wells around the in situ grouting demonstration trenches.........................108

32 Summary of the number of weight drops required for each foot of trench compaction..................115

33 Elevation of TARA trench 2 before and after trench compaction..................................117

34 Elevation of TARA trench 3 before and after trench

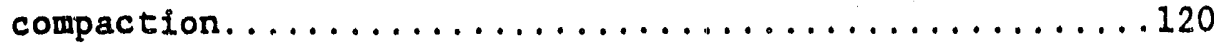

35 Elevatiun of TARA trench 4 before and after trench

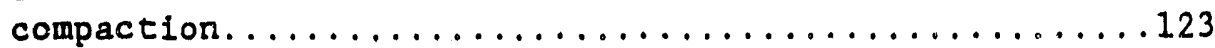

36 Elevation of TARA trench 5 before and after trench

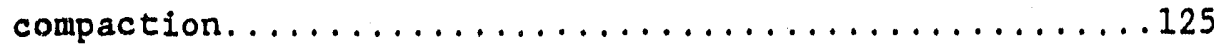

37 Elevation of TARA trench 6 before and after trench

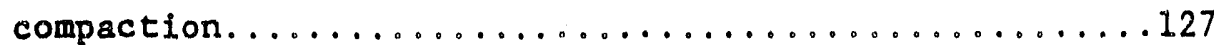

38 Percentage reduction in trench water accessible void space achieved by dynamic compaction...........131 
Page vi -

- 
LIST OF FIGURES

Figure

Page

1 Problems encountered in the shallow-land burial of low-level and transuranic solid waste.............4

2 Plan view of SWSA 6 showing the TARA site..........6

3 Aerial view of the TARA site...................

4 Location of TARA site groundwater monitoring wells....12

5 Location of the four water elevation data logging systems at the TARA site.....................

6 Topographic contour of the TARA site water table on March 18, 1988..........................18

7 Topographic contour of the TARA site water table on

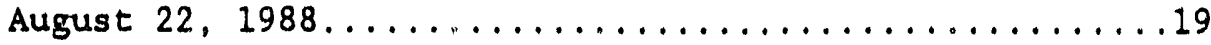

8 North-South cross section of the TARA site..........20

9 East-West cross section of the TARA site...........21

10 Quality control chart for anion-cation balance........30

11 Tritium contours at the TARA site approximated using Golden Graphics contouring software..............32

12 Location of standard and nonstandard penetration test sites...................................

13 Comparison of within trench and out of trench nonstandard penetration tests................... 38

14 Relationship between soil penetration resistance and percentage soil moisture at the TARA site..........41

15 Relationship between soil penetration resistance and soil bulk density at the TARA site...............42

16 Relationship between soll moisture and soll bulk density at the TARA site....................43

17 Positions for undisturbed soll sampling during standard penetration tests around five TARA burfal trenches.....45

18 Frequency distribution of adjusted organic vapor analyzer readings for TARA soil samples............51 
LIST OF FIGURES

Figure

Page

19 Water pump-in test hydrograph for TARA trench $2 \ldots \ldots \ldots 61$

20 Water pump-in test hydrograph for TARA trench $3 \ldots \ldots \ldots 62$

21 Water pump-in test hydrograph for TARA trench $4 \ldots \ldots \ldots 63$

22 Water pump-in test hydrograph for TARA trench $5 \ldots \ldots \ldots 64$

23 Water pump-in test hydrograph for TARA trench $6 \ldots \ldots \ldots 65$

24 TARA site soil moisture as a function of depth.......70

25 TARA site soil bulk density as a function of depth....71

26 Degradation of $10814 \mathrm{C}$-polyacrylate grout in soil plotted according to Equation 1 ( $k$ represents rate constants shown in Table 2)...................92

27 Degradation of $20 \% 14 \mathrm{C}$-polyacrylate grout in soll plotted according to Equation 1 (k represents rate constants shown in Table 4 )....................994

28 Degradation of $10 \%{ }^{14} \mathrm{C}$-polyacrylamide grout in soil plotted according to Equation 1 ( $k$ represents rate constants shown in Table 6) ...................95

29 Degradation of $20 \%{ }^{14} \mathrm{C}$-polyacrylamide grout in soil plotted according to Equation 1 ( $k$ represents rate constants shown in Table 8) .................

30 Map of Solid Waste Storage Area 4, ORNL, showing area selected for demonstration of in situ grouting of burled transuranic waste........................ 103

31 Plan view of trench caps and monitoring well locations in the study area for buried transuranic waste in situ

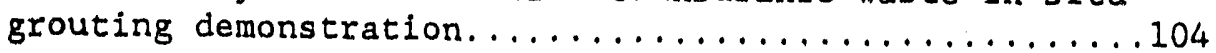

32 Dynamic compaction of TARA burial trenches using a $4 \mathrm{Mg}$ weight dropped from height of $7 \mathrm{~m} \ldots \ldots \ldots \ldots \ldots 11$

33 Dynamic compaction of a control area at TARA site using a $4 \mathrm{Mg}$ weight...................... 112

34 Dynamic compaction crater over a TARA burial trench being surveyed for surface radioactivity...........113 
LIST OF FIGURES

Eigure

Page

35 Location of the compaction positions on tire TARA trenches.................................114

36 Location of the control trench surface elevation points before and after trench compaction...........129

37 Location of drainage berm showing finished grade

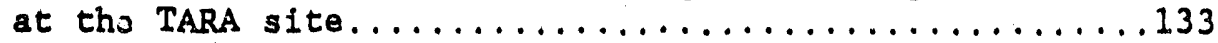


Page 1

\section{SUMMARY}

As part of a low-level radioactive waste burlal ground stabilization and closure technoiogy demonstration project, a group of five burial trenches in Oak Ridge National Laboratory (ORNL) Solid Waste Storage Area (SWSA) 6 was selected as a demonstration site for testing trench compaction, trench grouting, and trench cap installation and performance. This report focuses on site characterization, trench compaction, and grout-trench leachate compatibility. Trench grouting and cap design and construction will be the subject of future reports.

The five trenches, known as the Test Area for Remedial Actions (TARA) site, are contained within a hydrologically isolated area of SWSA 6; for that reason, any effects of stabilization activities on site performance and groundwater quality will be separable from the influence of other waste disposal units in SWSA 6 . To obviate the chronic problem of burial trench subsidence and to provide support for an infiltration barrier cap, these five trenches were dynainically compacted by repeated dropping of a 4-ton weight onto each trench from heights of approximately $7 \mathrm{~m}$. Such a procedure was found to be effective in collapsing trench voids in a previous demonstration using one trench in SWSA 6 (Spalding 1986). However, experience with more than one trench is desirable to substantiate the technique's effectiveness.

Prior to trench dynamic compaction, a group of 13 groundwater monitoring wells was installed at the TARA site for purposes of collecting background information on site watnr quality and for monitoring water table elevation fluctuations. Sampling has shown that the groundwatex contains tritium in concentrations as high as $270,000 \mathrm{~Bq} / \mathrm{L}$ and is dominated by the sulfate, bicarbonate, and chloride anions, and the potassium, calcium, magnesium, and solium cations. Water table fluctuations are monitored using an automated daca logging system and appear to be similar to other areas within SWSA 6 (on the order of 1 to 2 in between winter high and summer low). The water table at the site has not been observed to intersect the trench bottoms as is the case with waste trenches located in lower topographic areas of SWSA 6 .

Soll penetration resistance tests carried out at the site prior to compaction show that there is a significant difference between the stability of the existing trench covers and the native Conasauga Shale in which the waste trenches were placed. Trench void space, which causes this lack of stability, was measured prior to compaction by means of water pump-in tests. Results indicated that from 26 to $61 \mathrm{~m}^{3}$ of water-accessible voids existed in the trenches, accounting for between 8 and 238 of the total trench volume.

From July 27 to August 4, 1988, the five TARA trenches were compacted to a maximum depth of $1.2 \mathrm{~m}$ and the site was graded to facilitate surface runoff. A total of $21417-\mathrm{m}$ drops of the 4-ton weight were required, or approximately $5.5 \mathrm{drops} / \mathrm{m}^{2}$ of trench. Measurement of the volume reduction achieved through compaction was made by determining the volume of the resulting trench crater. Results indicate that an average water-accessible-void volume reduction of 778 was achieved. As further tests at the TARA site evaluate the effectiveness of trench grouting and cap performance, ORNL will be in a better position to select effective stabilization techniques for closure of 
its existing radioactive waste disposal sites.

To ensure good control of future in situ grouting of the five compacted trenches, samples of leachate and bottom soll were collected from each trench and tested for compatibility with the polyacrylamide grout. Addition of trench soil or leachate did not significantly retard the set time of the grout, and it was determined that the percent polymerization of the acrylamide in the presence of soil or leachate was identical to that achieved with unamended or neat grout (i.e., 99.58). In addition, specimens of the burial trench soil were converted from high to unmeasurably low hydraulic conductivity by percolation with reacting grout. Thus, it appears that these burial trenches pose no interference with polyacrylamide grout set.

Laboratory degradation studies using ${ }^{14} \mathrm{C}$-labeled acrylate and acrylamide grouts have been monitored for periods up to two years. The microbiological half-lives of polyacrylate grouts, under steady-state conditions, range between 50 and 60 years while polyacrylamide grouts have half-lives greater than 300 years. Specimens of 10 and 208 polyacrylamide failed to lose detectable water even when equilibrated against 15 bars of moisture tension. Thus, desiccation in the subsurface soil environment will probably not be a significant problem for polyacrylamide grout performance.

Performance monitoring of groundwater around two small transuranic waste burial trenches in SWSA 4, grouted with polyacrylamide in 1986, has not revealed any contamination by grout constituents. Background water quality in the area has not been perturbed by either the grouting operations or by the buried waste except for occasional elevated levels of $3 \mathrm{H}$ and gross beta activities. 


\section{INTRODUCTION}

\section{BACKGROUND}

The Oak Ridge National Laboratory (ORNL) has been directed by the Department of Energy (DOE), the Tennessee Department of Health and Environment (TDHE), and the Environmental Protection Agency (EPA) to initiate closure of its current operational solid low-level radioactive waste disposal area (SWSA 6) by November of 1988. Anticipating the need for an extensive evaluation of the feasibility and effectiveness of waste trench closure techniques likely to be used on a large scale within SWSA 6 beyond the November 1988 closure initiation date, the ORNL Remedial Action Program (RAP) began an investigation in 1987 designed to evaluate several candidate remedial actions likely to be employed at the ORNL site.

The need for remedial actions originates in the many problems with shallow-land burlal which have been experienced through the years. Figure 1 depicts a hypothetical burial trench in a humid climate which illustrates these performance problems in need of correction. The problem of trench cap permeability can lead to excessive leaching or inundation of buried waste either from direct infiltration of precipitation or from trapping of surface runoff which originates in adjacent areas. When the trench cap is much more permeable than the surrounding soll formation, the burial trench can actually fill with water to the point where radioactive leachate can overflow to the surface and flow offsite. If disposal area covers are made more impermeable, then a relatively large proportion of incoming precipitation will be converted to surface runoff; such runoff must be managed carefully so that soil erosion does not create new pathways to the waste or, in extreme cases, expose waste at the soil surface. In arid regions, wind erosion of cover material can result in similar waste exposure problems.

Regardless of trench cap construction or surface runoff management design, trench subsidence can result in surface depressions or cavities which will compromise performance. Trench subsidence is caused by the gradual consolidation of backfill or cover soil, by sedimentation of soil within burfec waste voids, or by waste container degradation creating new trench voids. Surface subsidence depressions can then function to direct runoff and precipitation into contact with buried waste. Groundwater can also intrude into the trench through, for example, the seasonal fluctuation of the water table. Although the water-table elevation at the site may be below burial depth when measured before vegetation clearing or during seasonally dry periods, it may subsequently rise and intercept buried waste. A shortening of groundwater migration pathways may also be facilitated by trench construction. For example, a trench may connect previously separated groundwater flow paths or conductive geologic features for transient: saturated flow.

In addition to these direct water management problems, the comparatively easy penetrability of cover soil and trench backfill may attract burrowing animals and/or facilitate plant root intrusion into buried waste. Such intrusion problems can be potentially serious even in arid regions where access to trench-stored moisture by plant roots can be obtained during normal 
Page 4

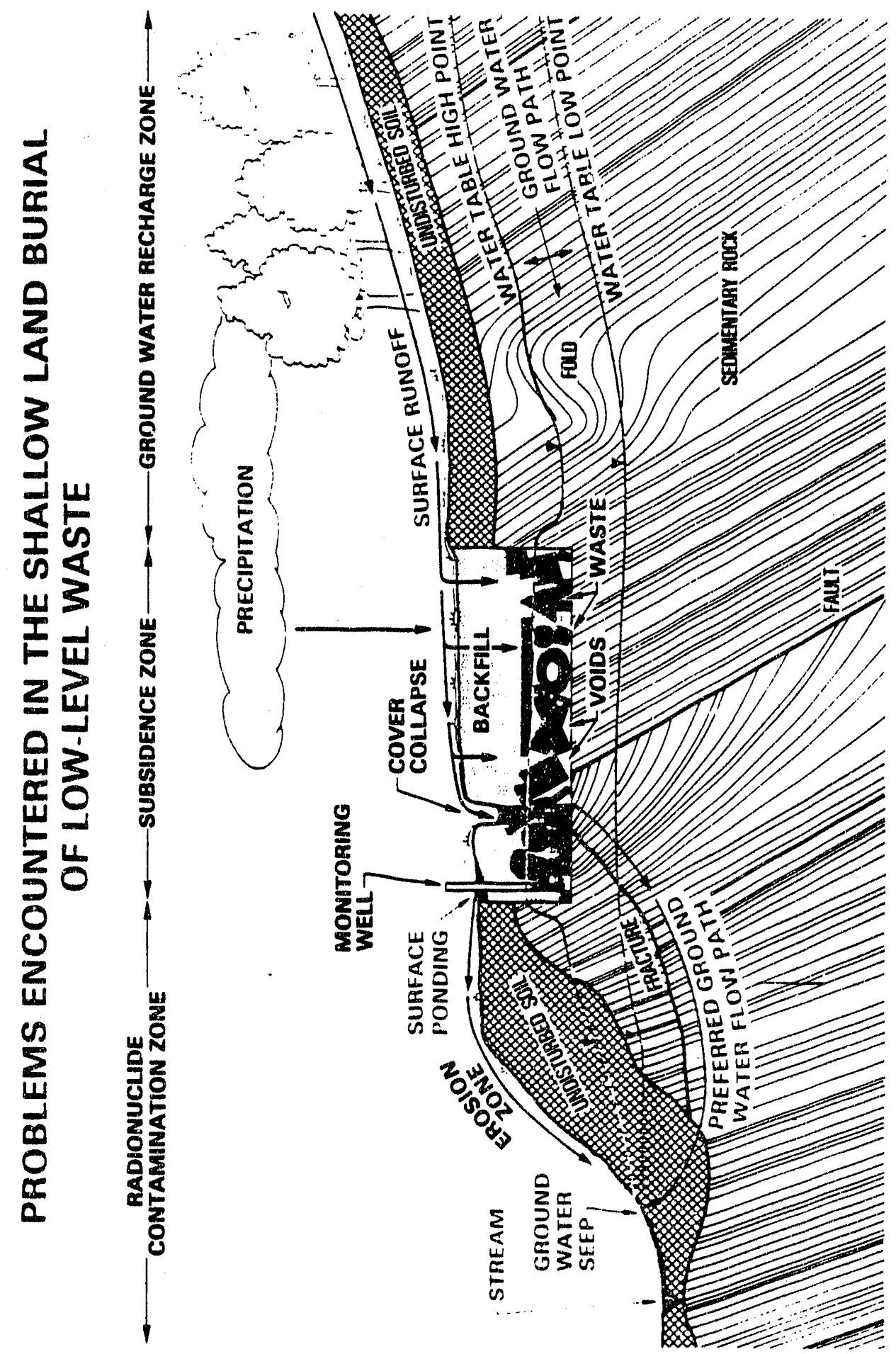

Fig. 1. Problems encountered in the shallow-land burial of low-level and transuranic solid waste. 
seasonal moisture stresses. In addition, the animal burrows and the relict channels of plant roots can be condults bringing surface runoff and precipitation directly into contact with burled waste. Plants growing on burial trenches can translocate radionuclides to their aboveground parts, creating a possibly significant mechanism for offsite dispersal via consumption by grazing animals, leaching of senescent plant material by surface water, or wind suspension or erosion of plant remains.

Many of the problems with burial trench performance stem from the inherent instability of the buried waste and backfill. Dynamic compaction was selected for demonstration as a remedial technique to address this primary fault. If dynamic compaction can establish a structurally sound ground surface, then various caps and moisture barriers can be constructed over burial trenches with assurance that they will not subside. In addition, in situ grouting was selected as a potential technique to provide hydrologic isolation of buried waste from either groundwater intrusion or infiltration of precipitation. Its use in combination with dynamic compaction will also be attempted. Only the first of these activities, dynamic compaction, was scheduled for FY 1988 and is the subject of this progress report. Chemical grouting and cover design and installation will be performed in FY 1989 and will be addressed in future reports.

\section{PURPOSE AND OBJECTIVES}

The purpose of this investigation, known as the Test Area for Remedial Actions (TARA) project, is to (1) identify promising trench stabilization and closure techniques applicable to the ORNL setting, (2) carry out these stabilization and closure techniques on a field scale using actual low-level waste trenches, and ( 3 ) collect the necessary data to evaluate each technique as to its feasibility, effectiveness, and cost. In this manner, the RAP will be in a position to select trench stabilization and closure alternatives which have been proven to be successful at the ORNL site.

\section{SITE SELECTION}

The site chosen for the TARA project lies on a small hillock in the northeast corner of SWSA 6 (Fig. 2). The site was selected based primarily on the following two criteria (1) it was away from operational areas within SWSA 6 and would, therefore, not incerfere with daily waste management activities or vice versa; and (2) it was located on high ground and is thus isolated hydrologically from any peripheral recharge areas which would complicate performing a site water budget and performance monitoring as part of the stabilization and closure evaluation. In addition, the water table at the site is well below the bottoms of the trenches (see section on water level measurements) and, according to Davis et al. (1987), the trenches in the area are classified as unsaturated throughout the majority of the year, as opposed to being inundated or bathtubbing, as is the case with other trench areas within SWSA 6 . The site also contains some of the first burial trenches used in SWSA 6 which contain higher-level (>200mrem/h) low-level solid waste. Figure 3 shows an aerial view of the TARA site illustrating the steep topography surrounding the waste trenches. 
Page 6

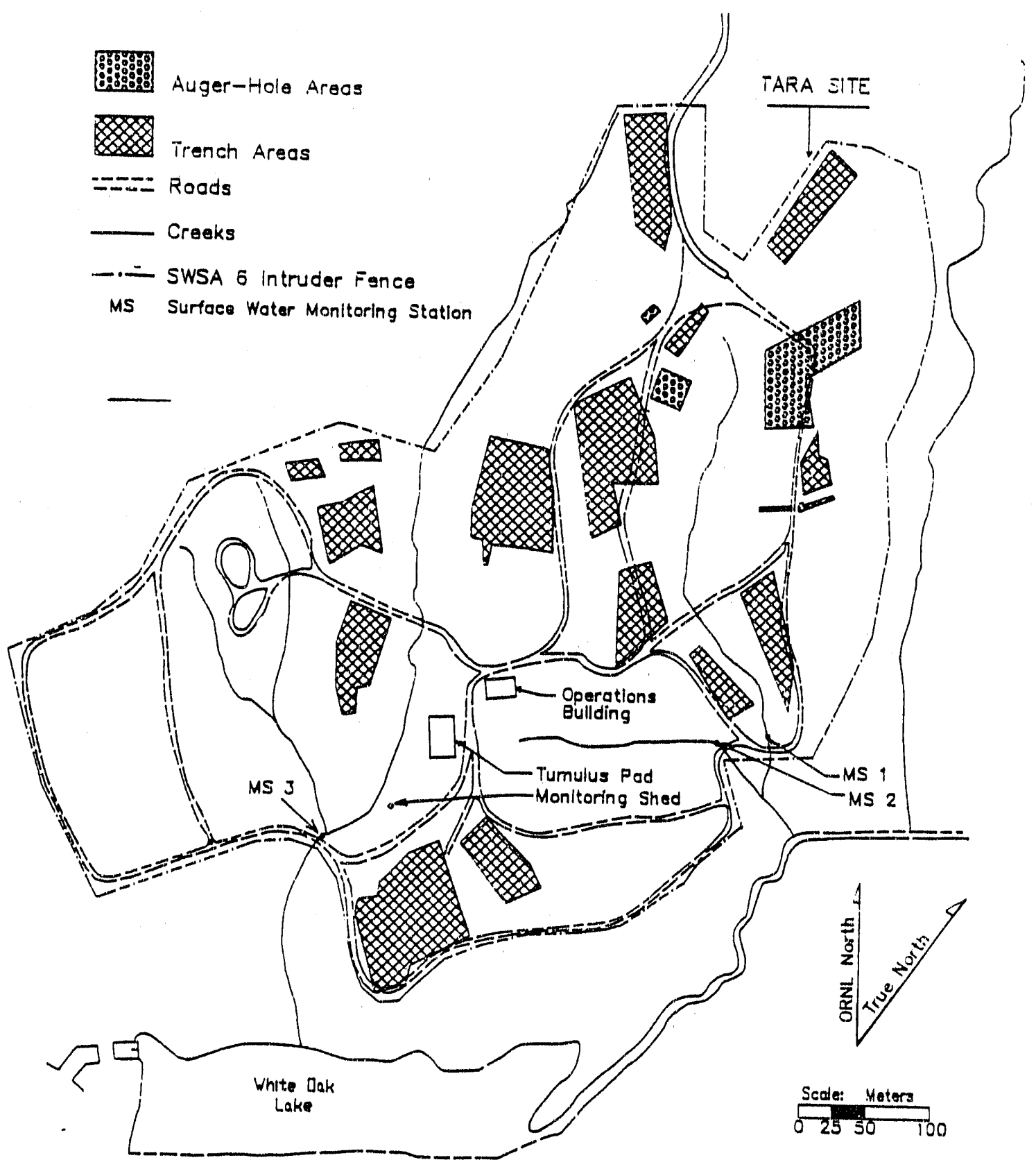

Fig. 2. Plan view of Solid Waste Storage Area 6 showing the Test Area for Remedial Actions (TARA) site. 


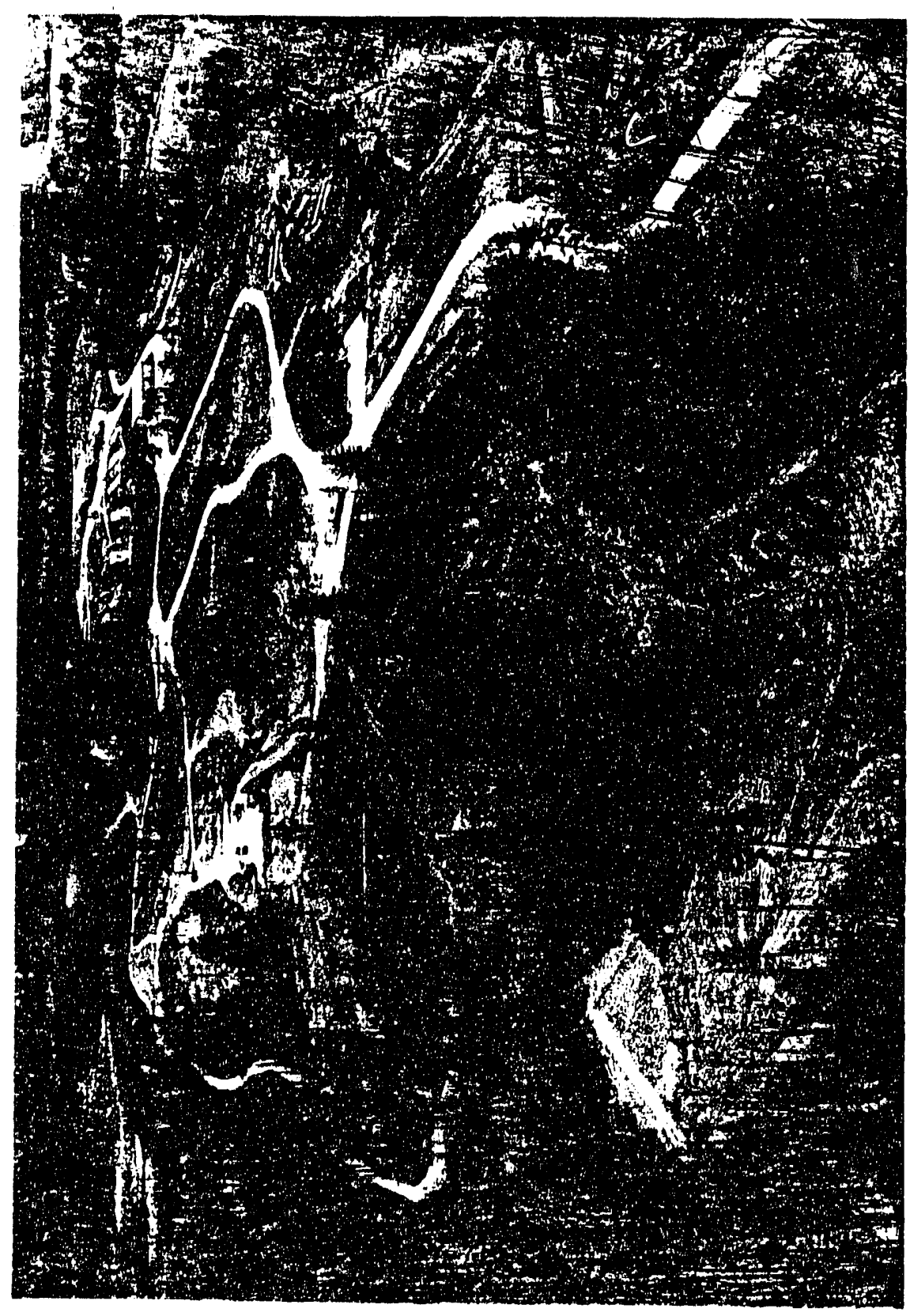

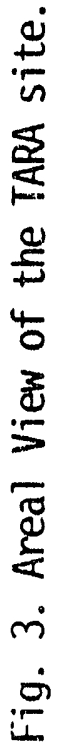


Initlally, plans were made to compact 19 waste trenches located at the TARA site. As planning progressed and cost estimates were made for quantities of grout and construction of a cover that included the entire hillock, the idea of compacting 19 trenches was abandoned and the easternmost 5 of the 19 trenches were selected for compaction, grouting, and covering (ASGI 1987). By considering only the five easternmost trenches (trenches 2 through 6), the volume of grout needed was cut by 758 and the need for an expensive and possibly unbuildable retaining wall to support the final site cover in areas of steep slope was eliminated. Thus, the TARA project considered only 5 of the more than 500 waste trenches located in SWSA 6 .

\section{PROJECT DOCUMENTATION}

Planning for the field activities to be conducted at the TARA site began in FY 1986 with the preparation of a draft task plan proposal of work to be carried out. This plan outlined the task as one which would focus on developing a closure strategy for the TARA site acceptable both to regulatory government agencies (EPA, TDHE, and DOE) and to ORNL environmental management.

The first task performed in FY 1987 was to conceptualize a plan for trench stabilization that had the necessary input of all groups concerned. This task was accomplished through subcontract with Automated Sciences Group, Inc., of Oak Ridge and the preparation of a final plan for trench stabilization and closure (See Appendix VIII). In this final plan, the field demonstration was broken down into four separate activities: (1) trench compaction, (2) trench grouting, (3) trench cover construction, and (4) site monitoring. Each activity was described, a cost estimate was prepared, and a list of potential contractors was compiled. Plans were made to proceed with the first activity (dynamic compaction) using Rust Engineering Company as the contractor.

Before any field activities could begin, an Action Description Memorandum (ADM) (Valentine 1986) had to be prepared, followed by an Environmental ALARA Memorandum (EAM) (Bly 1988). Additional documents, called for in the ADM and the EAM, were prepared next and included a construction excavation permit, a project Waste Management Plan, a project Safety Assessment (Doyle 1988), and finally a project Quality Assurance Plan. Several oral briefings for regulatory agency personnel were conducted through the regular DOE Waste Management Interface meetings. Several design and site monitoring changes were incorporated into project planning as a result of these meetings and resulting written correspondence with TDHE and EPA is contained in Appendix VIII. Although these extramural interactions, as well as the intramural documentation requirements, resulted in many extensions of the original project schedule, the project has been improved by them. Copies of the original ORNL task plan, the ASG, Inc., task plan, which was submitted to TDHE and EPA for comment, and the resulting exchange of comments are attached as Appendix VIII. Dynamic compaction activities finally began in July 1988. 
Page 9

\section{SITE CHARACTERIZATION}

\section{WASTE RECORDS SEAR.CH}

One of the first tasks to be performed in planning for the dynamic compaction demonstration was to identify the trench contents. This was seen as an Important step in the event that the trenches contained significant quantities of hazardous liquids, such as waste oils that had been stored in drums prior to disposal in trenches. In addition, wastes likely to contain large quantities of small particulates, which would be of concern for potential airborne release during dynamic compaction, would need to be noted. To investigate trench contents, a search of the Environmental and Health Protection Division's waste records was made. The search consisted of manually going through files containing UCN 2822 forms (forms documenting each waste shipment to the ORNL burial grounds) and photocopying those forms that indicated disposal in SWSA 6 trenches 2, 3, 4, 5, or 6. Table 1 summarizes the trench open and close dates, the number of waste shipments made to each trench according to the computer data basa known as MOD 1 , the number of UCN 2822 forms that could be retrieved and photocopied, the percentage of UCN 2822 forms missing from the records, and an estimate of the total volume of waste according to the MOD 1 data base.

In addition to the data presented in Table 1, Duguid and Sealand (1975) reported that a total of $3415 \mathrm{ft}^{3}\left(97 \mathrm{~m}^{3}\right)$ of contaminated soil (weathered Conasauga shale) was removed from the vicinity of a liquid waste transfer line leak at ORNL and was placed in SWSA 6 trenches 3 and 4. A total of 875 $\mathrm{ft}^{3}\left(25 \mathrm{~m}^{3}\right)$ of contaminated soil was placed in trench 3 and $2540 \mathrm{ft}^{3}\left(72 \mathrm{~m}^{3}\right)$ was placed in trench 4. Analysis of soll samples taken from the leak site prior to disposal in SWSA 6 are summarized by Duguid and Sealand (1975) and indicate that the soil contained the alpha emitters $244 \mathrm{Cm}, 241_{\mathrm{Am}}, 238 \mathrm{Pu}$ and

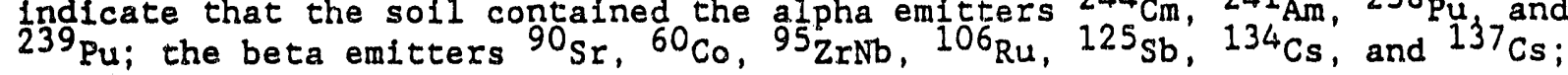
and unknown gamma emitters. The MOD 1 computer data base confirms these volumes of contaminated soil as originating from $P$ it Number 7 , and 1 ists 3375 $\mathrm{ft}^{3}\left(95.6 \mathrm{~m}^{3}\right)$ as containing "low" alpha and "high" beta activity, while 40 $\mathrm{ft}^{3}\left(1 \mathrm{~m}^{3}\right)$ contained "high" alpha and "low" beta activity.

As seen in Table 1, there are no waste shipment records describing wastes reported to have gone to trench 6 . This was not understood until the burial ground operators' $\log$ book was consulted and it was found that trench 6 was opened for only one day and was filled with the contents of parts of trenches 2,3 , and 4 that were exposed while attempting to recover a piece of missing equipment that had been thrown away inadvertently. Thus, trenches $2,3,4$, and 6 probably contain more soil backfill than would normally be expected in typical SWSA 6 trenches because of the nature of the waste (contaminated soil) and the additional excavation and reburial that took place.

While reviewing the individual UCN 2822 forms, selected documents containing a more descriptive account of the waste type were compiled into a summary table (Appendix I). In reviewing Appendix I, it can be seen that the trench number, date, volume, and radiation level of individual waste 
Table 1. Summary of TARA trench open and close dates, waste shipment records, and estimated waste volumes according to ORNL Environmental Protection and Compliance Division waste records

\begin{tabular}{|c|c|c|c|c|c|}
\hline \multirow[b]{3}{*}{ Open Date } & \multicolumn{5}{|c|}{ SWSA 6 Trench } \\
\hline & 2 & 3 & 4 & 5 & 6 \\
\hline & $11-2-72$ & $4-12-73$ & $7-30-73$ & $8-28-73$ & $10-10-73$ \\
\hline Close Date & $5-30-73$ & $7-30-73$ & $8-28-73$ & $10-10-73$ & $10-11-73$ \\
\hline Time Open & $6 \mathrm{mo}$ & $3 \mathrm{mo}$ & I mo & 2 mo & 1 day \\
\hline $\begin{array}{l}\text { Number of Waste } \\
\text { Shipments According } \\
\text { to MOD } 1 \text { Data Base }\end{array}$ & 49 & 41 & 77 & 26 & 0 \\
\hline $\begin{array}{l}\text { Number of UCN } \\
2822 \text { Forms } \\
\text { Retrieved }\end{array}$ & 14 & 20 & 28 & 18 & 0 \\
\hline $\begin{array}{l}\text { Percentage of } \\
\text { UCN } 2822 \text { Forms } \\
\text { Missing }(\mathrm{g})\end{array}$ & 71 & 51 & 64 & 31 & 0 \\
\hline $\begin{array}{l}\text { Total Volume } \\
\text { of Waste }\left(\mathrm{m}^{3}\right) \\
\text { Reported in } \\
\text { MOD } 1 \text { Data Base }\end{array}$ & 63.2 & 95.3 & 195.4 & 86.5 & 0 \\
\hline
\end{tabular}


Page 11

shipments are summarlzed, along with the isotopes and a brief written description of the waste. These records are only estimates made by the orfginal waste generators, and their accuracy would be expected to vary widely. The description contains such entries as "misc. cell waste in lead dumpster, funk from cell $\mathrm{A}$, and contraminated waste on hot truck wrapped in plastic," which make it impossible to quantify the contents or total activity within the five trenches of interest. Because there was no thorough 11sting of trench contents, dynamic compaction proceeded with contingency plans in the event that liquids, dust, or high radiation levels were encountered during the process.

\section{MONITORING WELI INSTALLATION}

To facilitate groundwater sampling, establish background water quality conditions, and monitor changes in the water-table elevation at the TARA site, a group of 13 wells was planned and constructed in 1987. Criteria for siting the welis fincluded (1) distributing them across the site so that the waste trenches would be completely surrounded, (2) locating wells in the near field (close to the waste trenches) as well as farcher away from the waste in a down-gradient direction (far field), (3) establishing both east-west and north-south transects for future graphical representations of the cross. sectional water table in the vicinity of the waste trenches, and (4) making use of existing SWSA 6 piezometers and water quality wells constructed during the summers of 1986 and 1987, respectively. Figure 4 shows the 13 well locations in plan view along with existing plezometers $(369,367,646$, and 655 ) and water quality monitoring wells ( 843 and 844).

We11 construction began in March 1987 at TARA well 5 located in the southwestern corner of the TARA site. A track-mounted drill rig was used by ORNL's Plant and Equipment Division with field assistance from personnel in the Environmental Sciences Division. A $15-\mathrm{cm}(6-1 \mathrm{n}$.) diam auger with a rock bit head was used to auger each of the 13 holes. Drflling records were kept at each $30.5-\mathrm{cm}(1-\mathrm{ft})$ depth interval describing the presence or absence of rock (inferred from drilling resistance), cuttings color, presence of water, and general drilling conditions. Appendix II summarizes the drilling logs and well construction data in pictorial form. As expected, many hard imestone layers interbedded with softer shale layers were encouritered during the drilling process.

As drilling of each of the 13 holes was completed, cleaning was accomplished by repeated rapid revolution of the auger combined with vertical movement of the auger sections to bring cuttings to the surface. The auger was then broken down in $1.5-m(5-F t)$ sections and removed from the hole. Prepackaged $7.6-\mathrm{cm}$ ( $3-\mathrm{in}$.)- dlam threaded PVC casing material was then lowered down each hole beginning with a $6.1-\mathrm{m}(20-\mathrm{ft})$ length of $0.51 \mathrm{~mm}$ $(0.02-1 n$.$) slot opening screen followed by enough solid riser pipe to$ protrude approximately $1 \mathrm{~m}$ above the ground surface. Prewashed, coarse silica sand was then added to the annular space to cover the $6.1 \mathrm{~mm}$ length of well screen by approximately $1 \mathrm{~m}$. Continuous health physics coverage was provided throughout the drilling operation, and no radioactivity was detected in cuttings from any of the 13 wells. 


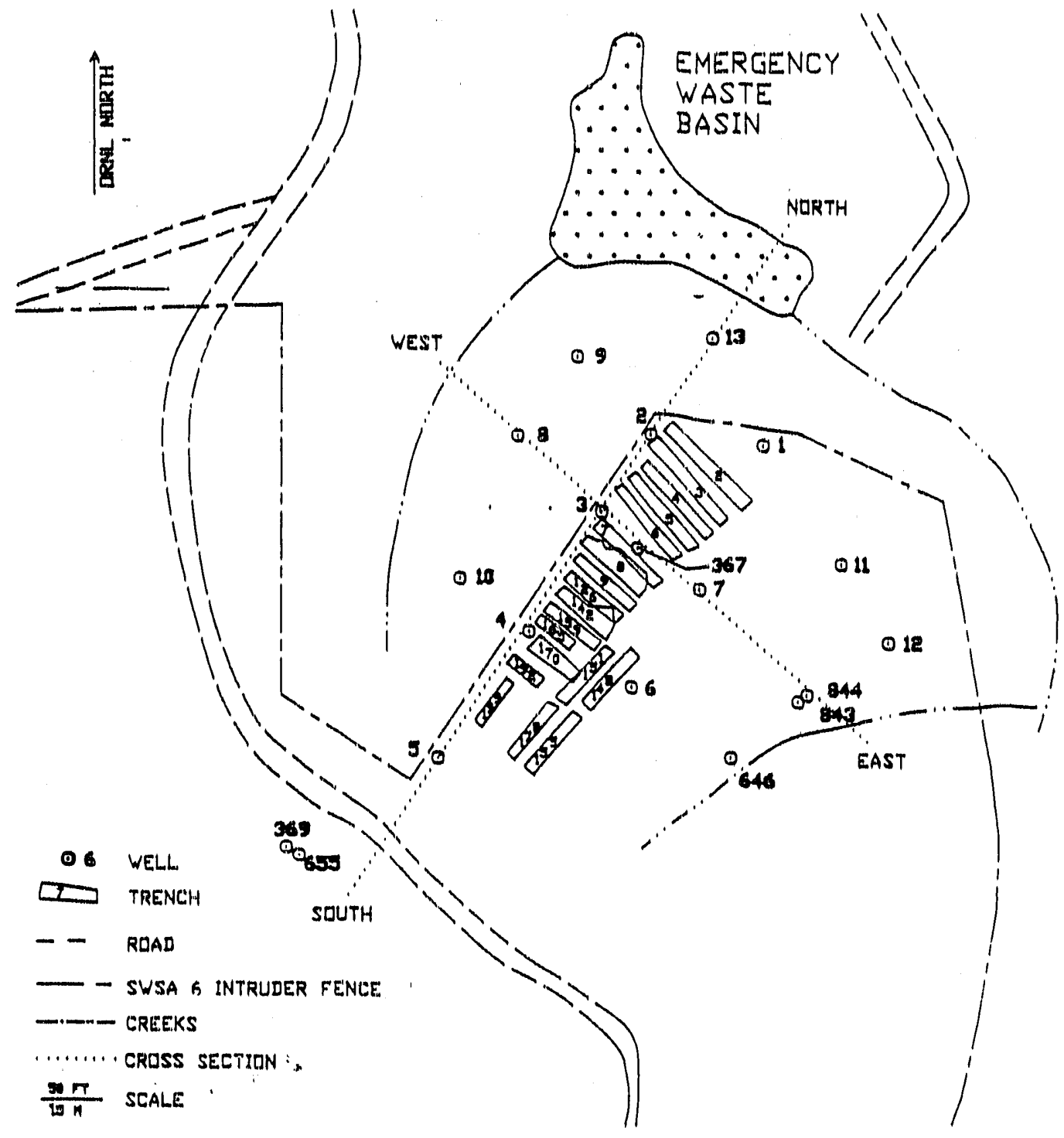

Fig. 4. Location of TARA site groundwater monitoring wells. 
After sampling and radioactivity analyses in April 1987, each of the TARA wells, along with existing plezometer 367, was flushed (cleaned out) using water from a nearby prnd (emergency liquid waste storage basin shown in Figs. 3 and 4). Flow-rates used were approximately $7.4 \mathrm{~L} / \mathrm{mln}(28 \mathrm{gal} / \mathrm{mIn}$ )

delivared to each well usirig a traller-mounted diesel water pump and $5-\mathrm{cm}$ (2. in.) rubber delivery hose run to the bottom of each we11. Each well, in turn, was repeatedly flushed by water surges untll fines were lifted from the casing and the stream of wash water became clear (approximately $30 \mathrm{~min}$ to 1 h). After flushing was completed, excess water remaining in the casing was siphoned out via the rubber hose water delivery line. Bentonite clay pellets were added to the annular volume outside the casing above the sand to form an approximate $1-m$-thick impermeable barrier to vertical water movement, and the remainder of the annular space was backfilled with soll cuttings. At this point the wells were considered completed and were labeled with metal tags and surveyed for exact location, top of casing elevation, and ground - levation (Table 2).

Table 2. Summary of TARA woll construction parameters

\begin{tabular}{|c|c|c|c|c|c|c|c|c|}
\hline $\begin{array}{l}\text { TARA } \\
\text { WeII }\end{array}$ & 1 ORNLN & ORNLE & $\begin{array}{l}\text { TUC } \\
\text { Elev. } \\
\text { (m) }\end{array}$ & $\begin{array}{c}\text { Ground } \\
\text { Elev. } \\
\text { (m) }\end{array}$ & $\begin{array}{l}\text { Wel1 } \\
\text { Depth } \\
\text { (m) }\end{array}$ & $\begin{array}{c}\text { Screen } \\
\text { Length } \\
\text { (m) }\end{array}$ & $\begin{array}{l}\text { Depth to } \\
\text { Sand } \\
\text { (Ia) }\end{array}$ & $\begin{array}{c}\text { Depth to } \\
\text { Volclay } \\
\text { (m) }\end{array}$ \\
\hline $\begin{array}{c}1 \\
2 \\
3 \\
4 \\
5 \\
6 \\
7 \\
8 \\
9 \\
10 \\
11 \\
12 \\
13 \\
367 \\
369 \\
646 \\
655\end{array}$ & $\begin{array}{r}17806.99 \\
17816.12 \\
17752.28 \\
17654.24 \\
17549.76 \\
17608.96 \\
17689.47 \\
17814.50 \\
17879.49 \\
17697.16 \\
17709.84 \\
17645.69 \\
17895.08 \\
17723 \\
17476 \\
17550.78 \\
17469.72\end{array}$ & $\begin{array}{r}25192.38 \\
25102.46 \\
25062.08 \\
25002.46 \\
2.492 .8 .23 \\
25086.38 \\
25141.24 \\
24993.14 \\
25041.76 \\
24945.94 \\
25256.02 \\
25295.15 \\
25151.41 \\
25091 \\
24805 \\
25167.05 \\
24815.30\end{array}$ & $\begin{array}{l}254.47 \\
256.08 \\
256.00 \\
255.34 \\
255.65 \\
255.46 \\
256.04 \\
246.59 \\
245.99 \\
246.57 \\
248.09 \\
239.17 \\
245.36 \\
257.39 \\
256.32 \\
239.84 \\
255.91\end{array}$ & $\begin{array}{l}253.58 \\
255.14 \\
255.43 \\
254.38 \\
254.87 \\
254.74 \\
255.76 \\
245.75 \\
245.39 \\
245.90 \\
247.45 \\
238.63 \\
245.01 \\
256.61 \\
255.48 \\
239.31 \\
255.50\end{array}$ & $\begin{array}{r}19.15 \\
19.32 \\
16.40 \\
17.83 \\
19.27 \\
19.23 \\
19.32 \\
11.89 \\
11.89 \\
11.89 \\
14.87 \\
9.14 \\
11.89 \\
22.17 \\
14.63 \\
11.89 \\
38.10\end{array}$ & $\begin{array}{l}6.10 \\
6.10 \\
6.10 \\
6.10 \\
6.10 \\
6.10 \\
6.10 \\
6.10 \\
6.10 \\
6.10 \\
6.10 \\
6.10 \\
6.10 \\
3.05 \\
3.05 \\
3.05 \\
7.62\end{array}$ & $\begin{array}{r}9.30 \\
12.19 \\
9.27 \\
10.85 \\
9.07 \\
8.23 \\
5.03 \\
2.32 \\
5.79 \\
5.03 \\
9.14 \\
2.44 \\
4.57 \\
. \\
\ldots \\
7.31 \\
28.95\end{array}$ & $\begin{array}{r}7.16 \\
10.97 \\
8.02 \\
9.75 \\
7.64 \\
7.1 .6 \\
3.81 \\
1.43 \\
4.57 \\
3.96 \\
7.92 \\
0.73 \\
3.35 \\
\ldots \\
\ldots \\
7.01 \\
28.35\end{array}$ \\
\hline
\end{tabular}


Page 14

WATER LEVEL MEASUREMENTS

Manual water level measurements have been made on 15 of the TARA wells (wells 1 through 13,367 , and 646) since the time of well construction (April 1987). These manual measurements were taken at approximate 1-week time intervals and consisted of lowering an electronic tape down the well to the depth of the water surface and recording this distance from the top of the casing to the water surface. The depths to water were then converted to absolute elevation above National Geodetic Vertical Datum (by subtracting them from the top of the well casing elevation) and are summarized in Appendix III. Along with the tabular water elevation data, well hydrographs have been constructed for each well for the period April 1987 to August 1988 along with rainfall for the period January 1987 to August 1988 (Appendix III). Responses of monitoring wells to trench water pump-in tests conducted in July and October 1987 are annotated on each hydrograph.

To ease the task of measuring water levels by the manual method described above, and to facilitate taking water elevations at shorter time steps through particular storm events, an automatic water level monitoring system was installed at the TARA site. The system consisted of 15 Druck, Inc.. pressure transducers (one for each of the 15 TARA wells) connected to four OMNIDATA, Inc., Easy Logger data logging devices located at four stations across the TARA site. Data logging stations 1 through 4, and the wells they serve, are shown in plan view in Fig. 5.

After laboratory calibration, the pressure transducirs were taken to the site and installed in each well. at a depth of 1.5 to $3 \mathrm{~m}$ below the water surface. The lead wires running to the data loggers were secured to the well casing so the transducer could not accidentally be moved, thus changing elevation. The transducer leads were then run along the ground and connected to the logging devices which were set to record (daily) the pressure due to the height of the column of water above the transducer. The pressure, recorded by the data logger as a millivolt signal, is converted to a water head using the equation

$$
\begin{gathered}
Y-S X+0 \\
\text { where, } Y \text { - water head }(\mathrm{m}) \\
S=\text { slope }(\mathrm{m} / \mathrm{mV}) \\
X-\text { probe signal }(\mathrm{mV}) \\
O=\text { probe offset }(\mathrm{m}) .
\end{gathered}
$$

Values of $S$ and $O$ were determined for each probe during laboratory callbration prior to field use and were programmed into the individual data loggers.

The loggers were programmed to scan the pressure transducers each day at $1200 \mathrm{~h}$ EST and to record the instantaneous water level in each of the 15 wells. Water elevation data collected by the data loggers have been combined with manual measurements and are summarized in tabular and graphical form in Appendix III. 


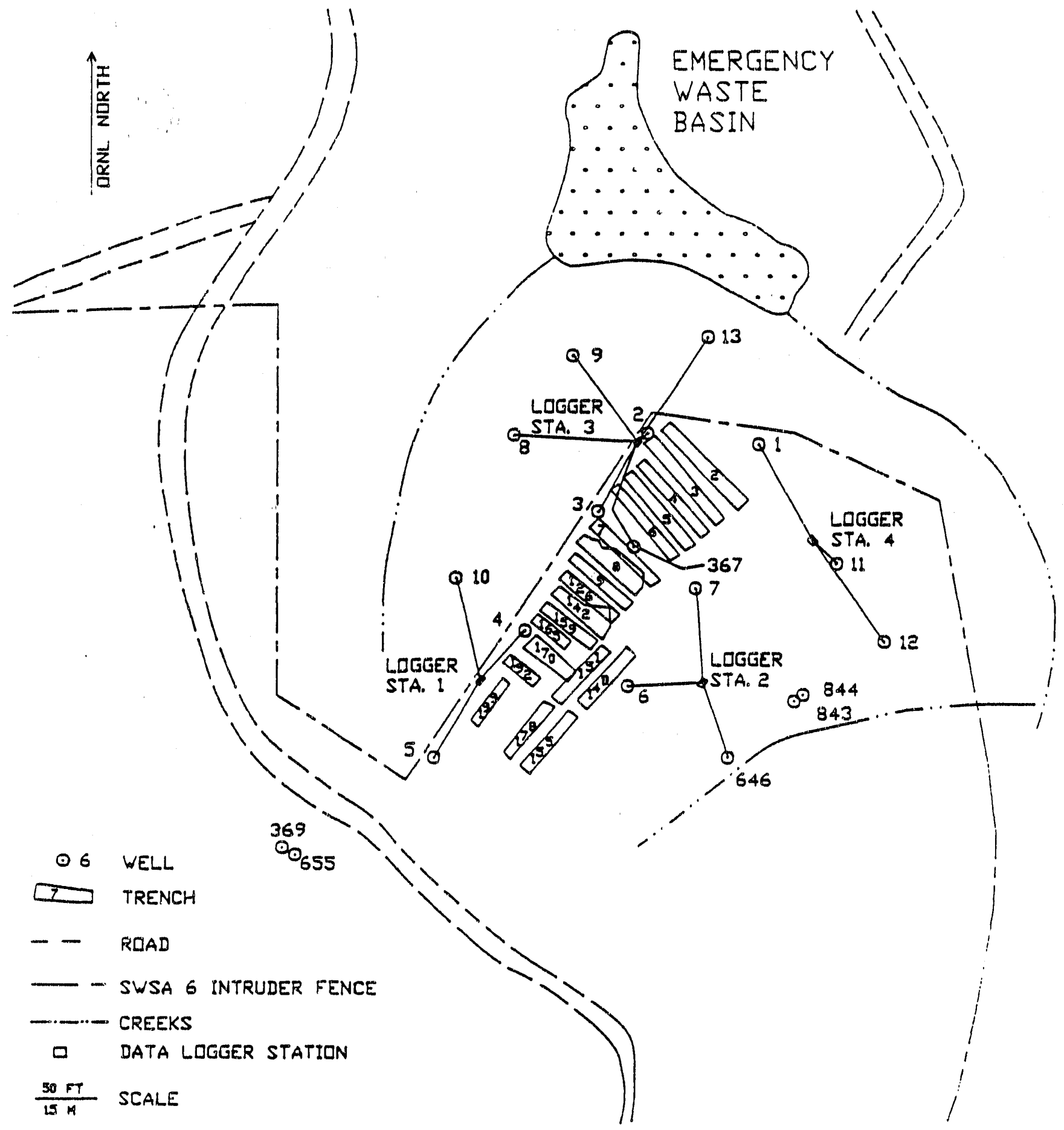

Fig. 5. Location of the four water elevation data logging systems at the TARA site. 
To ensure that the pressure transducers are functioning properiy, manual water level readings have been compared to the instantaneous pressure transducer readings on a monthly basis. Table 3 summarizes the results of two such comparisons made on April 4 and May 18, 1988. An insignificant difference, on the order of centimeters, is typically found between manual readings and pressure transducer readings indicating that the pressure transducers have been quite accurate in measuring the site water table elevation.

The water elevation data collected at the TARA site can be used to construct a topographic map of the water surface as well as hydrologic cross sections of the site. The groundwater topography was mapped on two separate dates: March 18, 1988, which represents relatively high water table conditions, and August 22, 1988, which represents a lower water table condition (Figs. 6 and 7) resulting from a regional drought. Both maps show that there is a gradient from west to east across the site with a localized high in the vicinity of TARA 3 . The reason for this localized high is not understood at this time and is under investigation. Assuming the groundwater flow direction to be perpendicular to the contours of Figs. 6 and 7 , infiltration, from the vicinity of TARA trenches 2 through 6 should move in a southeasterly direction toward wells 7,11 , and 12 . Future groundwater sanpling of these and the other TARA wells will determine if this inference is correct.

In addition to the topographic contour maps, two cross sections of the site have been constructed along the two dotted lines shown in Fig. 4 (see Figs. 8 and 9). Again, the water levels for March 18 and August 22, I9áo, were used. The slight mounding of water around well 3 is apparent in these drawings also and could be caused by perched water near well 3 ox by well 367 acting as a drain or discharge point. Again, this is the subject of further investigation. 
Table 3. Comparison of water elevations taken by the OMNIDATA logging system with manual measurements

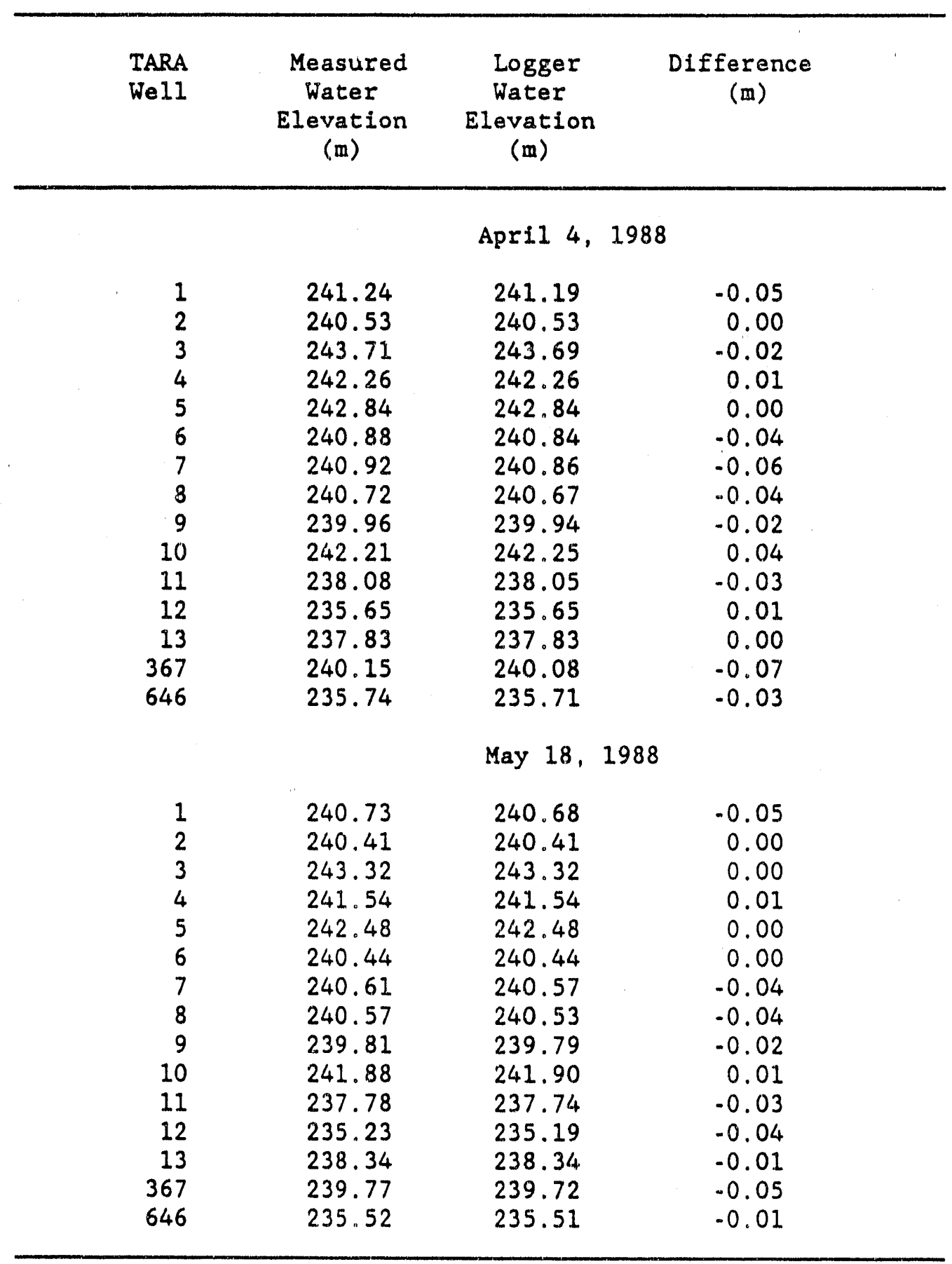




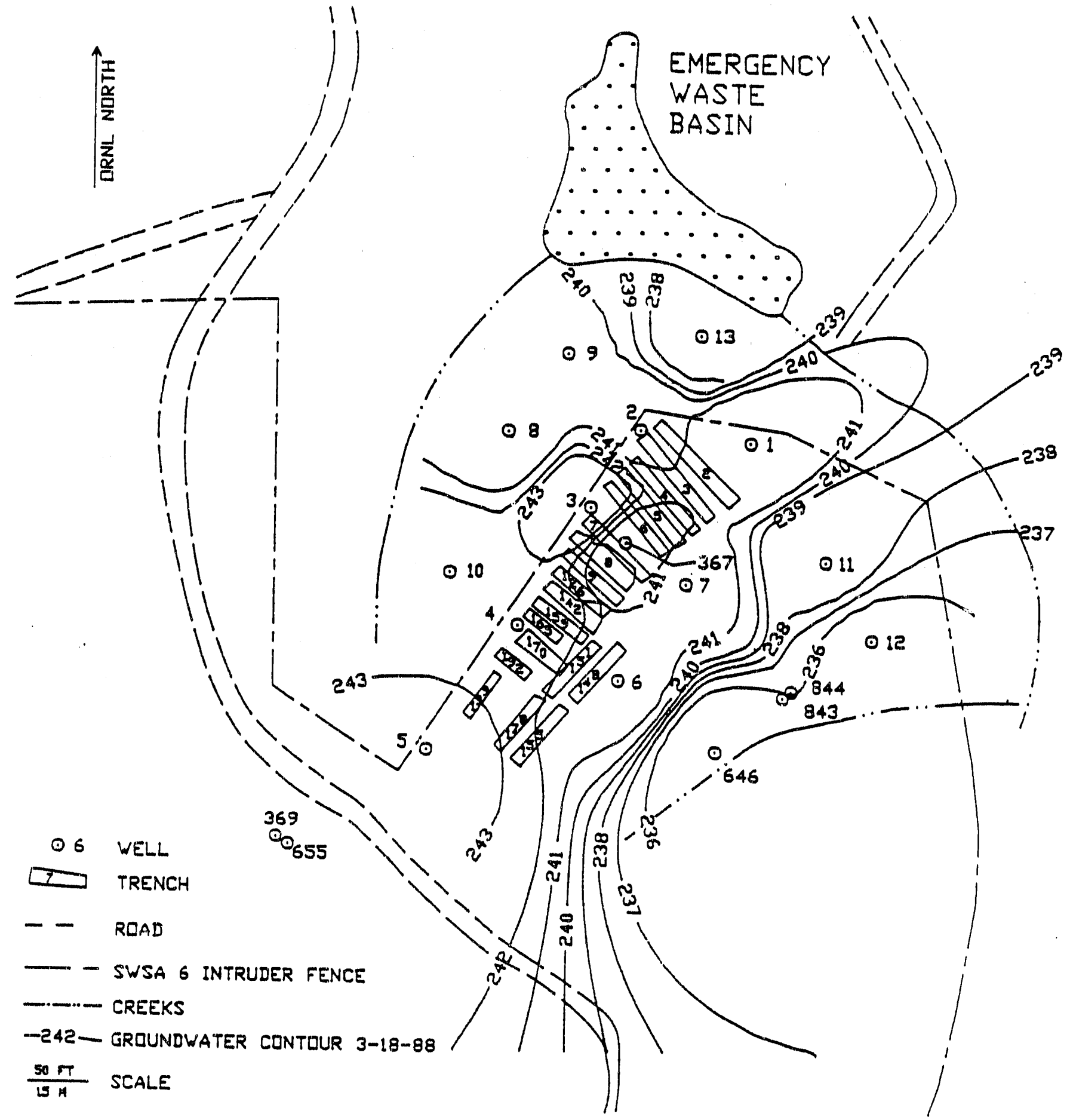

Fig. 6. Topographic contour of the TARA site water table on March 18, 1988. 


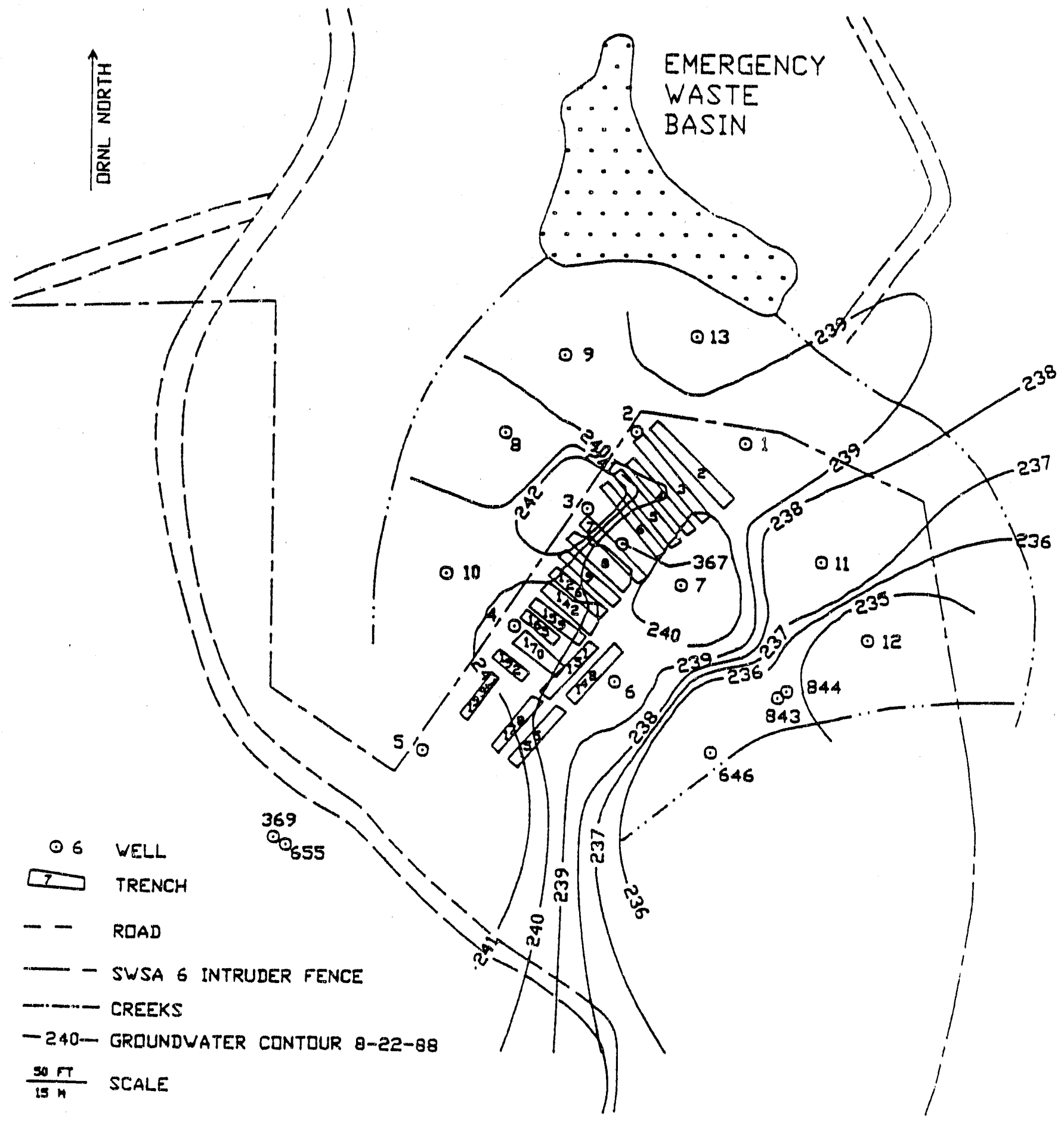

Fig. 7. Topographic contour of the TARA site water table on August 22, 1988. 


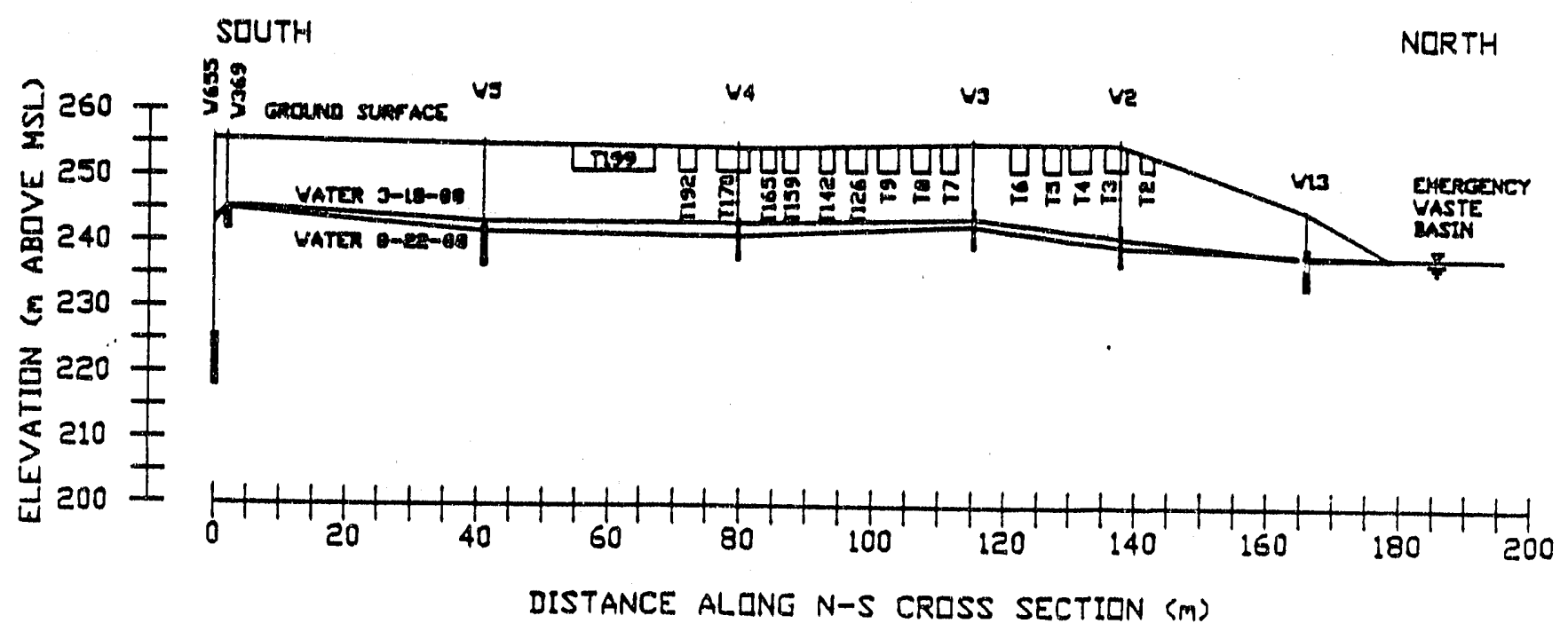

Fig. 8. North-South cross section of the TARA site. 


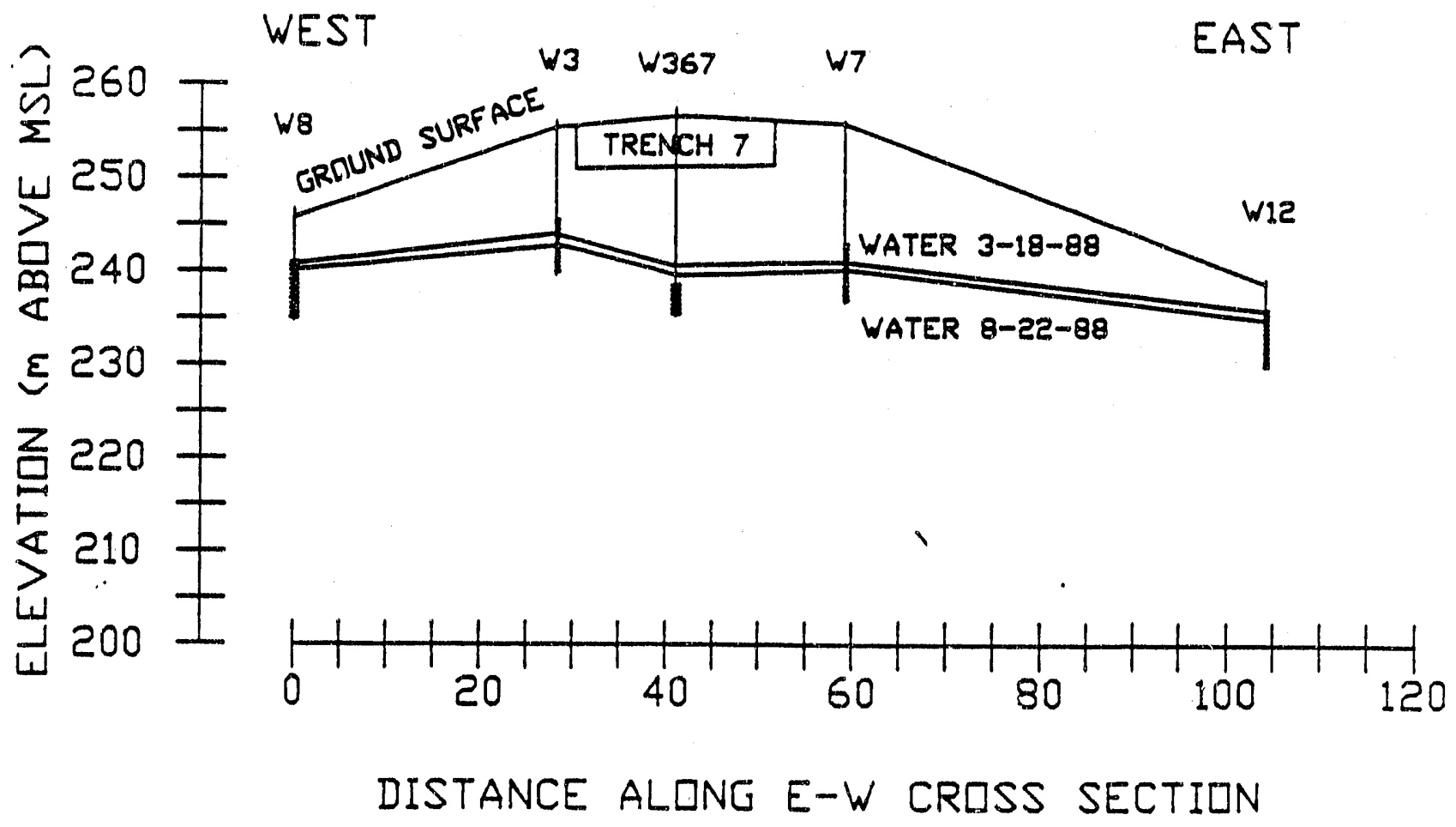

Fig. 9. East-West cross section of the TARA site. 
Page 22

\section{GROUNDWATER SAMPLING}

To establish baseline water quality at the TARA site (before compaction activities were initiated), water samples were collected from each of the 15 wells listed in Table 4. Sampling was conducted between November 18 and 23, 1987, and consisted of repeatedly evacuating each well casing using a stainless steel, compressed air driven, submersible pump lowered by reel and cable to within approximately $0.5 \mathrm{~m}$ of the well bottom. Pumping rates varying between 75 and $230 \mathrm{~L} / \mathrm{h}$ were maintained in each well until the water was completely pumped from the well casing. Only well 12, which is located in a guily to the southeast of the trenches, was able to recover at a rate greater than the $230-\mathrm{L} / \mathrm{h}$ maximum pumping rate such that it could not be completely evacuated. All water withdrawn from each well as part of the evacuation procedure was collected in plastic carboys until chemical and radiochemical analysis confirmed it was safe to discard.

The water evacuation procedure was repeated two or three times on each we11, often over several days, before a representative sample was collected for chemical analysis. Total volumes of water removed from each well prior to sampling are summarized in Table 4.

As water was being pumped from each well and into a plastic carboy, flow was directed through a Hydrolab Corporation Surveyor II water analyzer connected in series with the pump. The analyzer was set up to measure water temperature, $\mathrm{pH}$, dissolved oxygen (DO), and elestrical conductivity (EC). At the desired sampling time, water was pumped directly into prewashed sample bottles which were capped, labeled, and stored directly on ice for transport to the laboratory. This method avolded splitting samples into individual sample bottles in the laboratory. Table 4 summarizes each of these four parameters measured at the time groundwater samples were collected.

In addition to the four parameters measured in the field, samples were analyzed for a number of elements using inductively coupled plasma (ICP) emission spectroscopy techniques (APHA 1980), hardness, alkalinity, total organic carbon (TOC), total dissolved solids (TDS), 91 semivolatile organic compounds (EPA Method 624, Table 5), radionuclides, $\mathrm{Hg}$ and $\mathrm{K}$ via atomic adsorption (AA) spectroscopy, and major anions via high-pressure liquid chromatography (HPLC). None of the 91 organic compounds listed in Table 5 was detected in any of the TARA groundwater samples. In the laboratory, electrical conductivity, $\mathrm{pH}$, dissolved solids (after filtration through $0.45 \mu \mathrm{m}$ nitrocellulose membranes), and gross alpha and beta activities were measured (APHA 1980). Tritium was measured without distillation using a $2-\mathrm{mL}$ aliquot with $18 \mathrm{~mL}$ of Ecolume (ICN Radiochemicals, Ine.) scintillation cocktail; the near background levels of gross alpha and beta activities in the samples justified this abridged $3 \mathrm{H}$ assay technique. The values for ${ }^{\mathrm{H}}$ and other radionuclides reported in Table 4 were performed by standard (not abridged) procedures and, therefore, are not subject to ambiguity.

To determine how complete the groundwater analysis was, an anion-cation charge balance was performed on each water sample. Major anions considered were bicarbonate (measured by alkalinity titration), chloride, and sulfate. The additional anions nitrite and phosphate were below detection limits while 
Table 4. Results of groundwater analysis from 15 TARA wells

\begin{tabular}{cccccccc}
\hline TARA & $\begin{array}{c}\text { Sample } \\
\text { Date }\end{array}$ & $\begin{array}{c}\text { Water } \\
\text { Removed } \\
\text { Before } \\
\text { Sampling } \\
\text { (L) }\end{array}$ & $\begin{array}{c}\text { Field } \\
\text { Temp. } \\
\left({ }^{\circ} \mathrm{C}\right)\end{array}$ & $\begin{array}{c}\text { Field } \\
\text { pH } \\
\text { (units) }\end{array}$ & $\begin{array}{c}\text { Lab } \\
\text { pH } \\
\text { (units) }\end{array}$ & $\begin{array}{c}\text { Field } \\
\text { Do } \\
\text { (mg/L) }\end{array}$ & $\begin{array}{c}\text { Field } \\
\text { EC } \\
(\text { mmhos } / \mathrm{cm})\end{array}$ \\
\hline & & & & & & \\
1 & $11 / 20 / 87$ & 125 & 14.5 & 5.8 & 6.6 & 4.4 & 0.24 \\
2 & $11 / 20 / 87$ & 46 & 13.8 & 6.3 & 6.8 & 3.5 & 0.28 \\
3 & $11 / 20 / 87$ & 71 & 11.9 & 6.3 & 6.4 & 2.5 & 0.47 \\
4 & $11 / 20 / 87$ & 152 & 13.1 & 6.5 & 6.6 & 0.5 & 0.46 \\
5 & $11 / 20 / 87$ & 92 & 13.2 & 6.8 & 6.8 & 3.5 & 0.27 \\
6 & $11 / 20 / 87$ & 37 & 13.0 & 6.5 & 6.8 & 1.1 & 0.29 \\
7 & $11 / 20 / 87$ & 92 & 12.9 & 6.2 & 6.9 & 0.6 & 0.36 \\
8 & $11 / 23 / 87$ & 100 & 14.4 & 6.6 & 7.2 & 0.5 & 0.35 \\
9 & $11 / 23 / 87$ & 62 & 14.0 & 6.8 & 7.2 & 5.0 & 0.24 \\
10 & $11 / 23 / 87$ & 112 & 15.0 & 6.9 & 6.4 & 6.0 & 0.23 \\
11 & $11 / 20 / 87$ & 144 & 13.2 & 6.4 & 6.5 & 6.5 & 0.46 \\
12 & $11 / 18 / 87$ & 200 & 14.9 & 6.4 & 6.8 & 2.5 & 0.35 \\
13 & $11 / 23 / 87$ & 42 & 13.7 & 6.5 & 7.1 & 3.3 & 0.21 \\
367 & $11 / 20 / 87$ & 78 & 13.1 & 6.3 & 6.9 & 3.3 & 0.55 \\
646 & $11 / 23 / 87$ & 20 & 15.8 & 6.4 & 7.3 & 1.2 & 0.23 \\
\hline
\end{tabular}

Table 4. (Continued)

\begin{tabular}{|c|c|c|c|c|c|c|c|}
\hline $\begin{array}{l}\text { TARA } \\
\text { We11 }\end{array}$ & $\begin{array}{c}\text { Lab } \\
\text { EC } \\
\text { (mmhos } / \mathrm{cm})\end{array}$ & $\begin{array}{c}\text { TOC } \\
(\mathrm{mg} / \mathrm{L})\end{array}$ & $\begin{array}{c}\text { TDS } \\
(\mathrm{mg} / \mathrm{L})\end{array}$ & $\begin{array}{c}\text { Hardness } \\
\text { (mg } \mathrm{CaCO}{ }_{3} \\
\text { per L) }\end{array}$ & $\begin{array}{l}\text { Alkalinity } \\
\text { (mg } \mathrm{CaCO}_{3} \\
\text { per L) }\end{array}$ & $\begin{array}{c}\mathrm{Cl} \\
(\mathrm{mg} / \mathrm{L})\end{array}$ & $\begin{array}{c}\mathrm{SO}_{4} \\
(\mathrm{mg} / \mathrm{L})\end{array}$ \\
\hline 1 & 0.49 & 2.9 & 440 & 454 & 340 & 2.5 & 59 \\
\hline 2 & 0.51 & 3.1 & 420 & 416 & 382 & 2.4 & 45 \\
\hline 3 & 0.91 & 3.5 & 840 & 718 & 506 & 10 & 290 \\
\hline 4 & 0.49 & 4.4 & 380 & 400 & 366 & 9.6 & 31 \\
\hline 5 & 0.45 & 1.5 & 420 & 398 & 292 & 3.1 & 81 \\
\hline 6 & 0.66 & 9.6 & 600 & 568 & 492 & 11 & 65 \\
\hline 7 & 0.67 & 10.1 & 2560 & 550 & 532 & 21 & 24 \\
\hline 8 & 0.38 & 9.1 & 240 & 278 & 258 & 4.5 & 35 \\
\hline 9 & 0.45 & 9.0 & 200 & 356 & 306 & 1.8 & 50 \\
\hline 10 & 0.35 & 7.7 & 260 & 286 & 244 & 4.6 & 38 \\
\hline 11 & 0.89 & 1.6 & 920 & 758 & 512 & 21 & 250 \\
\hline 12 & 0.60 & 2.2 & 2420 & 470 & 466 & 14 & 59 \\
\hline 13 & 0.42 & 0.8 & 1.120 & 314 & 292 & 1.5 & 42 \\
\hline 367 & 1.10 & 1.7 & 1020 & 900 & 554 & 240 & 390 \\
\hline 646 & 0.48 & 1.6 & 200 & 352 & 316 & 2.9 & 41 \\
\hline
\end{tabular}


Table 4. (Continued)

\begin{tabular}{cccccccc}
\hline $\begin{array}{c}\text { TARA } \\
\text { Well }\end{array}$ & $\begin{array}{c}\mathrm{NO}_{2} \\
(\mathrm{mg} / \mathrm{L})\end{array}$ & $\begin{array}{c}\mathrm{NO}_{3} \\
(\mathrm{mg} / \mathrm{L})\end{array}$ & $\begin{array}{c}\mathrm{PO}_{4} \\
(\mathrm{mg} / \mathrm{L})\end{array}$ & $\begin{array}{c}\mathrm{K} \\
(\mathrm{mg} / \mathrm{L})\end{array}$ & $\begin{array}{c}\mathrm{Ca} \\
(\mathrm{mg} / \mathrm{L})\end{array}$ & $\begin{array}{c}\mathrm{Mg} \\
(\mathrm{mg} / \mathrm{L})\end{array}$ & $\begin{array}{c}\mathrm{Na} \\
(\mathrm{mg} / \mathrm{L})\end{array}$ \\
\hline 1 & $<5$ & $<5$ & $<5$ & 2.91 & 150 & 28 & 13 \\
2 & $<5$ & $<5$ & $<5$ & 3.40 & 160 & 35 & 9.1 \\
3 & $<5$ & $<5$ & $<5$ & 4.82 & 180 & 70 & 39 \\
4 & $<5$ & 5.9 & $<5$ & 1.69 & 140 & 20 & 9.1 \\
5 & $<5$ & $<5$ & $<5$ & 3.36 & 120 & 35 & 13 \\
6 & $<5$ & $<5$ & $<5$ & 6.40 & 190 & 40 & 17 \\
7 & $<5$ & 32 & $<5$ & 2.30 & 22.0 & 31 & 20 \\
8 & $<5$ & $<5$ & $<5$ & 2.00 & 96 & 16 & 6.1 \\
9 & $<5$ & $<5$ & $<5$ & 2.51 & 120 & 19 & 18 \\
10 & $<5$ & $<5$ & $<5$ & 2.75 & 110 & 14 & 6.5 \\
11 & $<5$ & $<5$ & $<5$ & 3.18 & 230 & 60 & 38 \\
12 & $<5$ & 8.7 & $<5$ & 1.50 & 180 & 26 & 18 \\
13 & $<5$ & $<5$ & $<5$ & 1.66 & 140 & 15 & 9.6 \\
367 & $<5$ & $<5$ & $<5$ & 3.37 & 240 & 80 & 34 \\
646 & $<5$ & $<5$ & $<5$ & 1.1 .6 & 120 & 37 & 16 \\
\hline
\end{tabular}

Table 4. (Continued)

\begin{tabular}{cccccccc}
\hline $\begin{array}{c}\text { TARA } \\
\text { Well }\end{array}$ & $\begin{array}{c}\mathrm{Fe} \\
(\mathrm{mg} / \mathrm{L})\end{array}$ & $\begin{array}{c}\mathrm{Hg} \\
(\mathrm{mg} / \mathrm{L})\end{array}$ & $\begin{array}{c}\mathrm{Br} \\
(\mathrm{mg} / \mathrm{L})\end{array}$ & $\begin{array}{c}\mathrm{F} \\
(\mathrm{mg} / \mathrm{L})\end{array}$ & $\begin{array}{c}\mathrm{Ag} \\
(\mathrm{mg} / \mathrm{L})\end{array}$ & $\begin{array}{c}\mathrm{Al} \\
(\mathrm{mg} / \mathrm{L})\end{array}$ & $\begin{array}{c}\mathrm{As} \\
(\mathrm{mg} / \mathrm{L})\end{array}$ \\
\hline 1 & 0.88 & 0.0002 & $<5$ & 1.0 & $<0.05$ & 0.44 & $<0.10$ \\
2 & 1.40 & 0.0001 & $<5$ & 1.0 & $<0.05$ & 0.51 & $<0.10$ \\
3 & 0.09 & 0.0001 & $<5$ & 1.0 & $<0.05$ & 0.22 & $<0.10$ \\
4 & 0.08 & 0.0002 & $<5$ & $<1$ & $<0.05$ & 0.20 & $<0.10$ \\
5 & 0.28 & 0.0001 & $<5$ & $<1$ & $<0.05$ & 0.28 & $<0.10$ \\
6 & 1.50 & $<0.0001$ & $<5$ & 1.0 & $<0.05$ & 0.56 & $<0.10$ \\
7 & 0.78 & 0.0002 & $<5$ & 1.0 & $<0.05$ & 0.56 & $<0.10$ \\
8 & 0.19 & 0.0001 & $<5$ & $<1$ & $<0.05$ & 0.22 & $<0.10$ \\
9 & 0.85 & 0.0002 & $<5$ & $<1$ & $<0.05$ & 0.41 & $<0.10$ \\
10 & 0.64 & 0.0001 & $<5$ & $<1$ & $<0.05$ & 0.34 & $<0.10$ \\
11 & 1.50 & 0.0001 & 5.0 & 1.0 & $<0.05$ & 0.61 & $<0.10$ \\
12 & 0.28 & 0.0001 & $<5$ & 1.0 & $<0.05$ & 0.31 & $<0.10$ \\
13 & 0.97 & 0.0001 & $<5$ & $<1$ & $<0.05$ & 0.63 & $<0.10$ \\
367 & 0.76 & 0.0003 & $<5$ & 1.0 & $<0.05$ & 0.37 & $<0.10$ \\
646 & 1.70 & 0.0002 & $<5$ & $<1$ & $<0.05$ & 0.43 & $<0.10$ \\
\hline
\end{tabular}


Table 4. (Continued)

\begin{tabular}{cccccccc}
\hline $\begin{array}{c}\text { TARA } \\
\text { We } 11\end{array}$ & $\begin{array}{c}\mathrm{B} / \mathrm{mg}) \\
(\mathrm{mg} / \mathrm{L})\end{array}$ & $\begin{array}{c}\mathrm{Ba} \\
(\mathrm{mg} / \mathrm{L})\end{array}$ & $\begin{array}{c}\mathrm{Cd} \\
(\mathrm{mg} / \mathrm{L})\end{array}$ & $\begin{array}{c}\mathrm{Co} \\
(\mathrm{mg} / \mathrm{L})\end{array}$ & $\begin{array}{c}\mathrm{Cr} \\
(\mathrm{mg} / \mathrm{L})\end{array}$ & $\begin{array}{c}\mathrm{Cu} \\
(\mathrm{mg} / \mathrm{L})\end{array}$ \\
\hline 1 & $<0.08$ & 0.13 & $<0.002$ & $<0.005$ & $<0.01$ & $<0.04$ & $<0.02$ \\
2 & $<0.08$ & 0.13 & $<0.002$ & $<0.005$ & $<0.01$ & $<0.04$ & $<0.02$ \\
3 & $<0.08$ & 0.07 & $<0.002$ & $<0.005$ & $<0.01$ & $<0.04$ & $<0.02$ \\
4 & $<0.08$ & 0.13 & $<0.002$ & $<0.005$ & $<0.01$ & $<0.04$ & $<0.02$ \\
5 & $<0.08$ & 0.06 & $<0.002$ & $<0.005$ & $<0.01$ & $<0.04$ & $<0.02$ \\
6 & $<0.08$ & 0.34 & $<0.002$ & $<0.005$ & $<0.01$ & $<0.04$ & $<0.02$ \\
7 & $<0.08$ & 0.16 & $<0.002$ & $<0.005$ & $<0.01$ & $<0.04$ & $<0.02$ \\
8 & $<0.08$ & 0.14 & $<0.002$ & $<0.005$ & $<0.01$ & $<0.04$ & $<0.02$ \\
9 & $<0.08$ & 0.11 & $<0.002$ & $<0.005$ & $<0.01$ & $<0.04$ & $<0.02$ \\
10 & $<0.08$ & 0.19 & $<0.002$ & $<0.005$ & $<0.01$ & $<0.04$ & $<0.02$ \\
11 & $<0.08$ & 0.04 & $<0.002$ & $<0.005$ & $<0.01$ & $<0.04$ & $<0.02$ \\
12 & $<0.08$ & 0.19 & $<0.002$ & $<0.005$ & $<0.01$ & $<0.04$ & $<0.02$ \\
1.3 & $<0.08$ & 0.21 & $<0.002$ & $<0.005$ & $<0.01$ & $<0.04$ & $<0.02$ \\
367 & $<0.08$ & 0.03 & $<0.002$ & $<0.005$ & $<0.01$ & $<0.04$ & $<0.02$ \\
646 & $<0.08$ & 0.20 & $<0.002$ & $<0.005$ & $<0.01$ & $<0.04$ & $<0.02$ \\
\hline
\end{tabular}

Table 4, (Continued)

\begin{tabular}{cccccccc}
\hline $\begin{array}{c}\text { TARA } \\
\text { Well }\end{array}$ & $\begin{array}{c}\mathrm{Ga} \\
(\mathrm{mg} / \mathrm{L})\end{array}$ & $\begin{array}{c}\mathrm{LL} \\
(\mathrm{mg} / \mathrm{L})\end{array}$ & $\begin{array}{c}\mathrm{Mn} \\
(\mathrm{mg} / \mathrm{L})\end{array}$ & $\begin{array}{c}\mathrm{Mo} \\
(\mathrm{mg} / \mathrm{L})\end{array}$ & $\begin{array}{c}\mathrm{Ni} \\
(\mathrm{mg} / \mathrm{L})\end{array}$ & $\begin{array}{c}\mathrm{P} \\
(\mathrm{mg} / \mathrm{L})\end{array}$ & $\begin{array}{c}\mathrm{Pb} \\
(\mathrm{mg} / \mathrm{L})\end{array}$ \\
\hline 1 & $<0.3$ & $<0.2$ & 0.27 & $<.04$ & $<0.06$ & $<0.3$ & $<0.2$ \\
2 & $<0.3$ & $<0.2$ & 0.40 & $<.04$ & $<0.06$ & $<0.3$ & $<0.2$ \\
3 & $<0.3$ & $<0.2$ & 0.47 & $<.04$ & $<0.06$ & $<0.3$ & $<0.2$ \\
4 & $<0.3$ & $<0.2$ & 0.03 & $<.04$ & $<0.06$ & $<0.3$ & $<0.2$ \\
5 & $<0.3$ & $<0.2$ & 0.06 & $<.04$ & $<0.06$ & $<0.3$ & $<0.2$ \\
6 & $<0.3$ & $<0.2$ & 0.26 & $<.04$ & $<0.06$ & $<0.3$ & $<0.2$ \\
7 & $<0.3$ & $<0.2$ & 0.24 & $<.04$ & $<0.06$ & $<0.3$ & $<0.2$ \\
8 & $<0.3$ & $<0.2$ & 0.09 & $<.04$ & $<0.06$ & $<0.3$ & $<0.2$ \\
9 & $<0.3$ & $<0.2$ & 0.25 & $<.04$ & $<0.06$ & $<0.3$ & $<0.2$ \\
10 & $<0.3$ & $<0.2$ & 0.20 & $<.04$ & $<0.06$ & $<0.3$ & $<0.2$ \\
11 & $<0.3$ & $<0.2$ & 0.25 & $<.04$ & $<0.06$ & $<0.3$ & $<0.2$ \\
12 & $<0.3$ & $<0.2$ & 0.07 & $<.04$ & $<0.06$ & $<0.3$ & $<0.2$ \\
13 & $<0.3$ & $<0.2$ & 0.55 & $<.04$ & $<0.06$ & $<0.3$ & $<0.2$ \\
367 & $<0.3$ & $<0.2$ & 0.07 & $<.04$ & $<0.06$ & $<0.3$ & $<0.2$ \\
646 & $<0.3$ & $<0.2$ & 0.68 & $<.04$ & $<0.06$ & $<0.3$ & $<0.2$ \\
\hline
\end{tabular}


Table 4. (Continued)

\begin{tabular}{cccccccc}
\hline TARA & $\begin{array}{c}\mathrm{Sb} \\
\text { Wo11 }\end{array}$ & $\begin{array}{c}\mathrm{Se} \\
(\mathrm{mg} / \mathrm{L})\end{array}$ & $\begin{array}{c}\mathrm{SI} \\
(\mathrm{mg} / \mathrm{L})\end{array}$ & $\begin{array}{c}\mathrm{Sn} \\
(\mathrm{mg} / \mathrm{L})\end{array}$ & $\begin{array}{c}\mathrm{Sr} \\
(\mathrm{mg} / \mathrm{L})\end{array}$ & $\begin{array}{c}\mathrm{TI} \\
(\mathrm{mg} / \mathrm{L})\end{array}$ & $\begin{array}{c}\mathrm{V} \\
(\mathrm{mg} / \mathrm{L})\end{array}$ \\
\hline 1 & $<0.2$ & $<0.2$ & 7.1 & $<0.05$ & 0.31 & $<0.02$ & $<0.02$ \\
2 & $<0.2$ & $<0.2$ & 7.5 & $<0.05$ & 0.34 & $<0.02$ & $<0.02$ \\
3 & $<0.2$ & $<0.2$ & 8.9 & $<0.05$ & 0.42 & $<0.02$ & $<0.02$ \\
4 & $<0.2$ & $<0.2$ & 6.7 & $<0.05$ & 0.26 & $<0.02$ & $<0.02$ \\
5 & $<0.2$ & $<0.2$ & 11 & $<0.05$ & 0.31 & $<0.02$ & $<0.02$ \\
6 & $<0.2$ & $<0.2$ & 11 & $<0.05$ & 0.49 & $<0.02$ & $<0.02$ \\
7 & $<0.2$ & $<0.2$ & 11 & $<0.05$ & 0.34 & $<0.02$ & $<0.02$ \\
8 & $<0.2$ & $<0.2$ & 5.2 & $<0.05$ & 0.22 & $<0.02$ & $<0.02$ \\
9 & $<0.2$ & $<0.2$ & 8.3 & $<0.05$ & 0.21 & $<0.02$ & $<0.02$ \\
10 & $<0.2$ & $<0.2$ & 6.4 & $<0.05$ & 0.26 & $<0.02$ & $<0.02$ \\
11 & $<0.2$ & $<0.2$ & 8.8 & $<0.05$ & 0.46 & $<0.02$ & $<0.02$ \\
12 & $<0.2$ & $<0.2$ & 9.6 & $<0.05$ & 0.29 & $<0.02$ & $<0.02$ \\
13 & $<0.2$ & $<0.2$ & 6.0 & $<0.05$ & 0.20 & $<0.02$ & $<0.02$ \\
367 & $<0.2$ & $<0.2$ & 8.9 & $<0.05$ & 0.43 & $<0.02$ & $<0.02$ \\
646 & $<0.2$ & $<0.2$ & 14 & $<0.05$ & 1.5 & $<0.02$ & $<0.02$ \\
\hline
\end{tabular}

Table 4. (Continued)

\begin{tabular}{|c|c|c|c|c|c|c|c|}
\hline $\begin{array}{l}\text { TARA } \\
\text { WeII }\end{array}$ & $\begin{array}{c}\mathrm{Zn} \\
(\mathrm{mg} / \mathrm{L})\end{array}$ & $\begin{array}{c}\mathrm{Zr} \\
(\mathrm{mg} / \mathrm{L})\end{array}$ & $\begin{array}{r}\mathrm{Co} 60 \\
(\mathrm{~Bq} / \mathrm{L})\end{array}$ & $\begin{array}{l}\mathrm{Cs} 137 \\
(\mathrm{~Bq} / \mathrm{L})\end{array}$ & $\begin{array}{c}\text { Tutal } \\
\text { Sr } \\
(\mathrm{Bq} / \mathrm{L})\end{array}$ & $\begin{array}{c}\operatorname{Tr} 1 t f(u m \\
(\mathrm{Bq} / \mathrm{L})\end{array}$ & $\begin{array}{l}\text { Major } \\
\text { Anjons } \\
(\mathrm{me} / \mathrm{L})\end{array}$ \\
\hline 1 & 0.034 & $<0.02$ & $<0.2$ & $<0,2$ & 0.23 & 74 & 8,10 \\
\hline 2 & 0.050 & $<0,02$ & $<0,1$ & $<0,1$ & 0.85 & 1100 & 8.65 \\
\hline 3 & 0.046 & $<0.02$ & 0.89 & 0.31 & 1.4 & 4400 & 16.144 \\
\hline 4 & 0.026 & $<0,02$ & 0.43 & $<0.1$ & 0 & 270000 & 8.33 \\
\hline 5 & 0.032 & $<0.02$ & $<0.1$ & $<0.1$ & 0.39 & 390 & 7.61 \\
\hline 6 & 0.053 & $<0.02$ & 0.51 & $<0.1$ & 2.9 & 7500 & 11.50 \\
\hline 7 & 0.039 & $<0.02$ & $<0,2$ & $<0.2$ & 0.78 & 1700 & 12.25 \\
\hline 8 & 0.020 & $<0.02$ & $<0.2$ & $<0.1$ & 0 & 7000 & 6.02 \\
\hline 9 & 0.037 & $<0.02$ & $<0,1$ & $<0,1$ & 0.49 & 450 & 7.21 \\
\hline 10 & 0.022 & $<0.02$ & $<0.2$ & $<0.2$ & 0.046 & 13000 & 5.80 \\
\hline 11 & 0.054 & $<0.02$ & 1.3 & $<0.1$ & 0.17 & 3300 & 16.04 \\
\hline 12 & 0.022 & $<0.02$ & 0.24 & $<0.1$ & 0.07 & 8200 & 11.08 \\
\hline 1.3 & 0.032 & $<0.02$ & $<0.2$ & 0.15 & 0.28 & 34000 & 6.76 \\
\hline 367 & 0.058 & $<0.02$ & 0.19 & $<0.1$ & 0.65 & 280 & 25.97 \\
\hline 646 & 0.034 & $<0.02$ & $<0,1$ & $<0.1$ & 0.75 & 0 & 7.26 \\
\hline
\end{tabular}

Tillequivalents/liter. 
Table 4. (Continued)

\begin{tabular}{crc}
\hline $\begin{array}{ccc}\text { TARA } \\
\text { Wel1 }\end{array}$ & $\begin{array}{c}\text { Major } \\
\text { Cations } \\
\text { (me/L) }\end{array}$ & $\begin{array}{c}\text { Andon-Cation } \\
\text { Ratio }\end{array}$ \\
\hline 1 & 10.43 & 0.78 \\
2 & 11.35 & 0.76 \\
3 & 16.56 & 0.99 \\
4 & 9.07 & 0.92 \\
5 & 9.52 & 0.80 \\
6 & 13.67 & 0.84 \\
7 & 14.46 & 0.85 \\
8 & 6.42 & 0.94 \\
9 & 8.40 & 0.86 \\
10 & 6.99 & 0.83 \\
11 & 18.13 & 0.88 \\
12 & 11.94 & 0.93 \\
13 & 8.68 & 0.78 \\
367 & 20.12 & 1.29 \\
64.6 & 10.02 & 0.72 \\
\hline
\end{tabular}


I'able 5. Listing of semivolatile compounds that were analyzed but not detected in TARA groundwater samples

phenol.

bis (2-chloroethy 1 ) ether

2-chlorophenol

1,3-dichlorobenzene

1,4-dichlorobenzene

benzyl alcohol.

1,2-d1chlorobenzene

2 - methylphenol

bis (2-chloroisopropy 1 ) ether

n-nitroso-di-n-propylamine

hexachloroethane

nitrobenzene

isophorone

2-nitrophenol

2,4-dime thylphenol

benzolc acid

bis (2-chloroe thoxy) me thane

2,4 -dichlorophenol

1, 2,4-trichlorobenzene

naphthalene

4-chloroantline

hexachlorobutadiene

4-chloro-3-me thy lphenol

2-methylnaph thalene

hexachlorocyclopentadiene

$2,4,6$-trichlorophenol.

$2,4,5$-trichlorophenol

2 -chloronap thalene

2-nitroaniline

dime thylphthalate

acenaph thy lene

2,6-dinf trotoluene

3-nitroaniline

acenaph thene

2,4 -dinftrophenol

4-nitrophenol

dibenzo furan

2,4-dinitrotoluene

die thylphthalate

4-chloropheny 1 -phenyle ther

fluorene

4-nitroaniline

4,6-dinitro-2-methylphenol

n-nitrosodiphenylamine (1)

4-bromophenyl-phenylether hexachlorobenzene

pentachlorophenol

phenanthrene

anthracene

di-n-butylphthalate

fluoranthene

pyrene

butylbenzylphthalate

$3,3^{\prime}$-dichlorobenzidine

benzo (a) anthracene

chrysene

bis (2-ethylhexy1) phthalate

d1-n-octylphthalate

benzo (b) fluoranthene

benzo (k) fluoranthene

benzo (a) pyrene

indeno $(1,2,3-c d)$ pyrene

dibenz $(a, h)$ anthracene

benzo $(g, h, 1)$ perylene

alpha-BHC

beta-BHC

delta-BHC

gamma-BHC (Lindane)

heptachlor

aldrin

heptachlor epoxide

endosulfan I

dieldrin

4, $4^{\prime}$ - DDE

endx. in

endosulfan II

$4,4^{\prime}$ - DDD

endosulfan sulfate

4, 4' - DDT

methoxychlor

endrin ketone

alpha-chlordane

gamma-chlordane

toxaphene

Aroclor-1016

Aroclnr -1221

Aroclor -1232

Aroclor- 1242

Aroclor -1248

Aroclor-1254

Aroclor -1260 
nitrate was detected in measurable amounts in wells 4 and 12 only. Major cations considered were potassium, calcium, magnesium, and sodium. Concentrations of each of these major anions and cations were expressed in milliequivalents per liter (me/L) and summed in Table 4. The charge ratio of anions to cations (expected to be 1 if analytical work is precise and all lons are considered) is summarized as the last column of Table 4 and shows that there was generally a low anion concentration (ratio <1) except for well 367 , which had an anion to cation ratio of 1.29 . Most of the ratios range from 0.76 to 0.99 , indicating that the three major anions and four major cations being considered adequately account for charged species present in the TARA groundwater.

A procedure recommended in Standard Methods for the Examination of Water and Wastewater (APHA 1980) for checking the correctness of anion and cation analyses was used and consisted of plotting the difference in anions and cations expressed as me/L against the sum of the anions (FIg. 10). Iines representing plus or minus one standard deviation, the acceptable error limit, are also shown in this figure and were derived from the equation

$$
\text { Sum Anions-Sum Cations }= \pm(0.1065+0.0155 * \text { Sum Anions }) \text {. }
$$

Points lying outside the two acceptable limits indicate possible problems with the chemical: alyses. The deficiency of anions could have resulted from a loss of alkalinity in the samples due to outgassing of $\mathrm{CO}_{2}$ between the time of sampling and analysis; such an outgassing would be accompanied by a slight rise in $\mathrm{pH}$, which was observed in the laboratory-measured $\mathrm{pH}$ versus field-measured $\mathrm{pH}$. Alternately, an excess of cations, particularly $\mathrm{Ca}$ and $\mathrm{Mg}$, could result from dissoiution of colloidal $\mathrm{CaCO}_{3}$ on addition of the $\mathrm{HNO}_{3}$ preservative after sample filtration. Regardless of its source, the discrepancy between anions and cations probably results from differences in $\mathrm{Ca}, \mathrm{Mg}$, and alkalinity and would have little consequence in the interpretation of groundwater quality for these background samples.

Another check was made of the TDS values by a "rough calculation" method suggested in Standard Methods. Electrical conductivity ( $\mu$ mhos/cm) values multiplied by a factor in the range of 0.55 to 0.7 should approximate TDS in $\mathrm{mg} / \mathrm{L}$. Results, along with the percentage differences between measured and approximated values of TDS, are summarized in Table 6.

A final check of the hardness by calculation was made using the equation

$$
\mathrm{H}=2.497[\mathrm{Ca}]+4.118[\mathrm{Mg}]
$$

where: $\mathrm{H}$ - hardnes:;, $\mathrm{mg} / \mathrm{L}$ as $\mathrm{CaCO}_{3}$

$\mathrm{Ca}=$ calcium, mg/L

$\mathrm{Mg}$ = magnesium, $\mathrm{mg} / \mathrm{L}$.

Results of the calculated values of hardness are compared to the measured values in Table 6. The calculated hardnesses were all greater than the measured hardnesses, and this systematic difference could arise from the causes discussed above. 


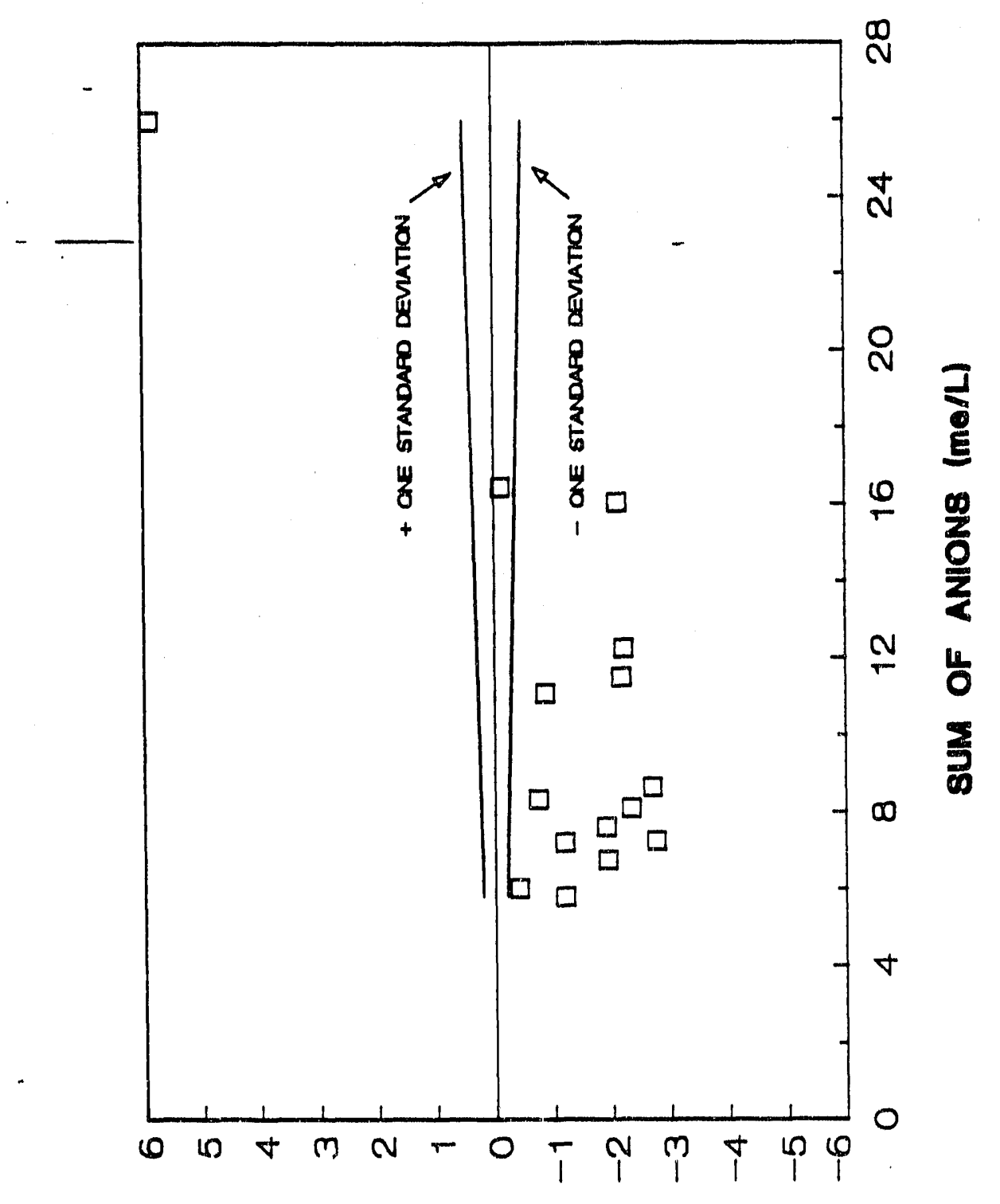

(7/OW) SNOILYO WnS - SNOINY WnS

Fig. 10. Quality control chart for anion-cation balance. 
Table 6. Comparison of measured groundwater total dissolved solids (TDS) with calculated TDS (calculated TDS - EC $\times 0.7$ ) and measured groundwater hardness with calculated hardness (calculated hardness $-2.497 \times[\mathrm{Ca}, \mathrm{mg} / \mathrm{L}]+4.118 \times[\mathrm{Mg}, \mathrm{mg} / \mathrm{L}]$ )

\begin{tabular}{rcccccr}
\hline $\begin{array}{c}\text { TARA } \\
\text { Well }\end{array}$ & $\begin{array}{c}\text { Measured } \\
\text { TDS } \\
(\mathrm{mg} / \mathrm{L})\end{array}$ & $\begin{array}{c}\text { Calculated } \\
\text { TDS } \\
(\mathrm{mg} / \mathrm{L})\end{array}$ & $\begin{array}{c}\text { Percent } \\
\text { Diff. }\end{array}$ & $\begin{array}{c}\text { Measured } \\
\text { Hardness } \\
\left(\mathrm{mg} \mathrm{CaCO}_{3} / \mathrm{L}\right)\end{array}$ & $\begin{array}{c}\text { Calculated } \\
\text { Hardness } \\
\left(\text { mg } \mathrm{CaCO}_{3} / \mathrm{L}\right)\end{array}$ & $\begin{array}{c}\text { Percent } \\
\text { Diff. }\end{array}$ \\
\hline & & & & & & \\
\hline 1 & 440 & 343 & 22 & 454 & 490 & 8 \\
2 & 420 & 357 & 15 & 416 & 544 & 31 \\
3 & 840 & 637 & 24 & 718 & 738 & 3 \\
4 & 380 & 343 & 10 & 400 & 432 & 8 \\
5 & 420 & 315 & 25 & 398 & 444 & 11 \\
6 & 600 & 462 & 23 & 568 & 639 & 13 \\
7 & 2560 & 469 & 82 & 550 & 677 & 23 \\
8 & 240 & 266 & 11 & 278 & 306 & 10 \\
9 & 200 & 315 & 58 & 356 & 378 & 6 \\
10 & 260 & 245 & 6 & 286 & 332 & 16 \\
11 & 920 & 623 & 32 & 758 & 821 & 8 \\
12 & 2420 & 420 & 83 & 470 & 557 & 18 \\
13 & 1120 & 294 & 74 & 314 & 411 & 31 \\
367 & 1020 & 770 & 25 & 900 & 929 & 3 \\
646 & 200 & 336 & 68 & 352 & 452 & 28 \\
\hline
\end{tabular}

Tritium concentrations measured in the groundwater were contoured using the SURFER (Golden Software, Inc.) GRID and TOPO contouring programs. Tritium was selected from the list of parameters in Table 4 because it was detected in all but one well (646), it is mobile and would tend to follow the water flow, and its source is likely to be waste placed in the upgradient waste trenches. Because of the large range in tritium concentrations that was measured ( $0 \mathrm{~Bq} / \mathrm{L}$ in well 646 to $270,000 \mathrm{~Bq} / \mathrm{L}$ in well 4 ), only selected contour lines are shown in Fig. 11. It is seen that the highest tritium concentrations are in the vicinity of wells $4(270,000 \mathrm{~Bq} / \mathrm{L}), 10(13,000$ $\mathrm{Bq} / \mathrm{L})$, and $13(34,000 \mathrm{~Bq} / \mathrm{L})$, which lie to the north and west of the trenches. The remaining wells contained approximately two-orders-of-magnitude-lower concentrations, in the range of 100 to $8000 \mathrm{~Bq} / \mathrm{L}$. The distribution of tritium at the TARA site points out that, although the water contours indicate primarily a southwest flow direction, drainage from the trench area is moving down gradient in all directions and is being intercepted by both the near and far fleld TARA wells.

It is important to realize that the contours shown in Fig. 11 are computer generated from observations at irregularly spaced well locations and can only be used to approximate the actual distribution of tritium at the site. The interpolation methods employed by SURFER for computing concentrations between wells may or may not be valid and would certainly be inappropriate if water flow at the site is dominated by fractures or other flow conduits 


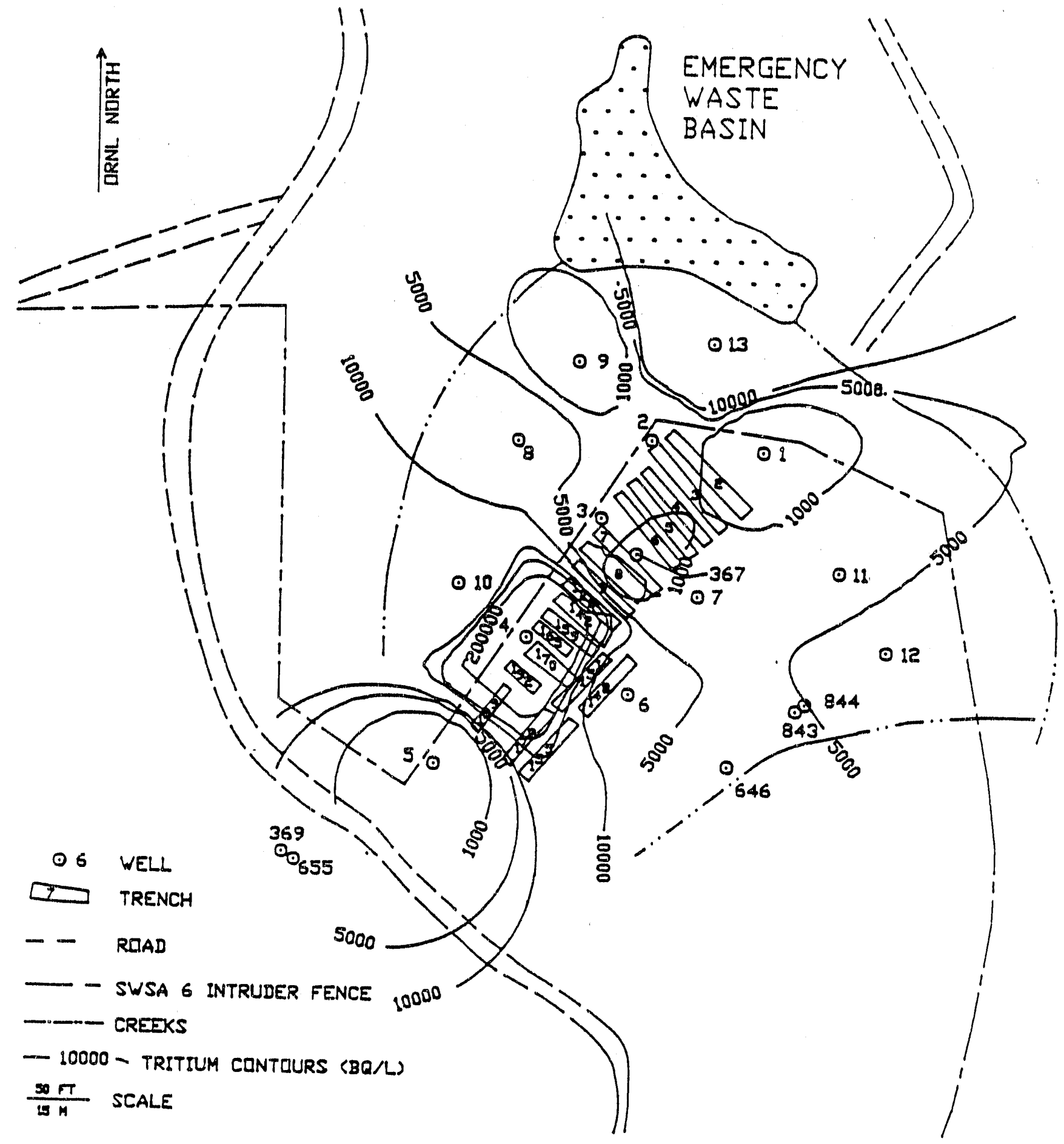

Fig. 11. Tritium contours at the TARA site approximated using Golden Graphics contouring software. 
existing between trenches and wells.

To determine how the groundwater quality changes with time, additional samples were collected from these 15 wells on April 8, 1987; November 11, 1987; June 24, 1988; and August 29, 1988, for analysis of radionuclides and macroscopic chemical characteristics. Grab samples of water were collected from each well using a dedicated PVC bailer attached to a nylon string that could be lowered down each well. Resules are presented in Table 7 . No significant trends in either the chemical or radiochemical characteristics are apparent. There was no immediate change between precompaction (June 24 , 1988 ) and the first postcompaction (August 29, 1988) sampling dates. Because the compacted trenches are at least $10 \mathrm{~m}$ above the seasonally hign water table in the area, possible contamination of groundwater via mass transport of dissolved constituents from the compacted trenches would not be expected immediately after the completion of trench compaction. Interpretation of temporal trends in water quality characteristics at TARA will be attempted in 1989 when hydrologic models of the site are developed. 
Page 34

Table 7. Water quality characteristics of monitoring well samples

\begin{tabular}{|c|c|c|c|c|c|c|c|c|}
\hline $\begin{array}{l}\text { Well } \\
\text { Number }\end{array}$ & $\mathrm{pH}$ & $\begin{array}{r}\text { E.C. } \\
(\mathrm{dS} / \mathrm{m})\end{array}$ & $\begin{array}{l}\text { Hardnes } \\
(\ldots \ldots \text { mg }\end{array}$ & $\begin{array}{l}\text { ss Alkalinit } \\
\left(\mathrm{CaCO}_{3} / \mathrm{L} \ldots\right)\end{array}$ & $\begin{array}{l}\text { Dissolve } \\
\text { ty Solids } \\
\text { (mg/L) }\end{array}$ & ${ }^{3} \mathrm{H}$ & $\begin{array}{l}\text { Gross } \\
\text { Beta } \\
(\mathrm{Bq} / \mathrm{L})\end{array}$ & $\begin{array}{l}\text { Gross } \\
\text { Alpha } \\
\text { ( } \mathrm{Bq} / \mathrm{L})\end{array}$ \\
\hline \multicolumn{9}{|c|}{ Sampling Date $-8-29-88$} \\
\hline TARA-1 & 6.9 & 628 & 222 & 162 & 540 & 1 & nd & nd \\
\hline TARA $\cdot 2$ & 6.9 & 635 & 220 & 175 & 580 & 23 & 16 & 4 \\
\hline TARA - 3 & 6.8 & 1098 & 385 & 214 & 1340 & 189 & nd & nd \\
\hline TARA-4 & 6.8 & 535 & 185 & 145 & 520 & 208 & 3 & nd \\
\hline TARA - 5 & 7.1 & 625 & 208 & 153 & 540 & 1 & nd & 6 \\
\hline TARA-6 & 6.7 & 883 & 277 & 212 & 780 & 392 & nd & 11 \\
\hline TARA - 7 & 6.7 & 817 & 300 & 244 & 940 & 38 & 4 & nd \\
\hline TARA-8 & 7 & 448 & 156 & 123 & 480 & 389 & nd & 2 \\
\hline TARA-9 & 7.2 & 580 & 153 & 136 & 460 & 13 & nd & $\mathrm{n}$ \\
\hline TARA -10 & 7.1 & 469 & 150 & 110 & 420 & 2591 & nd & nd \\
\hline TARA -11 & 6.8 & 1203 & 401 & 227 & 1560 & 208 & 19 & 15 \\
\hline TARA-12 & 6.8 & 668 & 214 & 182 & 640 & 2285 & nd & $\mathrm{nc}$ \\
\hline TARA-13 & 7.3 & 358 & 94 & 86 & 320 & 33 & nd & $\mathrm{n}$ \\
\hline TARA -367 & 7 & 921 & 267 & 182 & 1200 & 11 & nd & . \\
\hline \multicolumn{9}{|c|}{ Sampling Date $-6-24-88$} \\
\hline TARA - 1 & 7.5 & 588 & 286 & 210 & 340 & 4 & nd & nd \\
\hline TARA-2 & 7.5 & 708 & 362 & 340 & 460 & 32 & nd & 27 \\
\hline TARA - 3 & 7.4 & 1120 & 626 & 440 & 900 & 214 & 4 & 4 \\
\hline TARA - 4 & 7.5 & 550 & 260 & 250 & 340 & 179 & 12 & 6 \\
\hline TARA - 5 & 7.7 & 664 & 310 & 220 & 460 & 7 & nd & 4 \\
\hline TARA- 6 & 7.4 & 817 & 406 & 370 & 560 & 515 & nd & 9 \\
\hline TARA - 7 & 7.2 & 857 & 388 & 360 & 580 & 58 & nd & 15 \\
\hline TARA - 8 & 7.7 & 545 & 264 & 220 & 340 & 419 & nd & 6 \\
\hline TARA-9 & 7.8 & 555 & 238 & 240 & 280 & 14 & nd & 13 \\
\hline TARA - 10 & 7.8 & 464 & 234 & 210 & 280 & 1173 & nd & 9 \\
\hline TARA-II & 7.4 & 1176 & 606 & 330 & 960 & 180 & 15 & 9 \\
\hline TARA-12 & 7.5 & 663 & 334 & 310 & 440 & 1462 & nd & 4 \\
\hline TARA -13 & 7.8 & 365 & 162 & 160 & 240 & 21 & nd & 6 \\
\hline TARA -367 & 7.3 & 1295 & 722 & 420 & 1200 & 18 & nd & 13 \\
\hline \multicolumn{9}{|c|}{ Sampling Date $-11-18-87$} \\
\hline TARA - 1 & 6.6 & 490 & 454 & 340 & 440 & 4.44 & nd & $n$ \\
\hline TARA - 2 & 6.8 & 510 & 416 & 382 & 420 & 66 & nd & $\mathrm{n}$ \\
\hline TARA - 3 & 6.4 & 900 & 718 & 506 & 840 & 264 & 12 & $\mathrm{n}$ \\
\hline TARA -4 & 6.7 & 495 & 400 & 366 & 380 & 16200 & nd & $n$ \\
\hline TARA - 5 & 6.8 & 450 & 398 & 308 & 420 & 23.4 & nd & $\mathrm{n}$ \\
\hline TARA - 6 & 6.8 & 660 & 568 & 492 & 600 & 450 & 11 & 6 \\
\hline TARA - 7 & 6.9 & 670 & 550 & 532 & 560 & 102 & 9 & no \\
\hline
\end{tabular}


Table 7. (Continued)

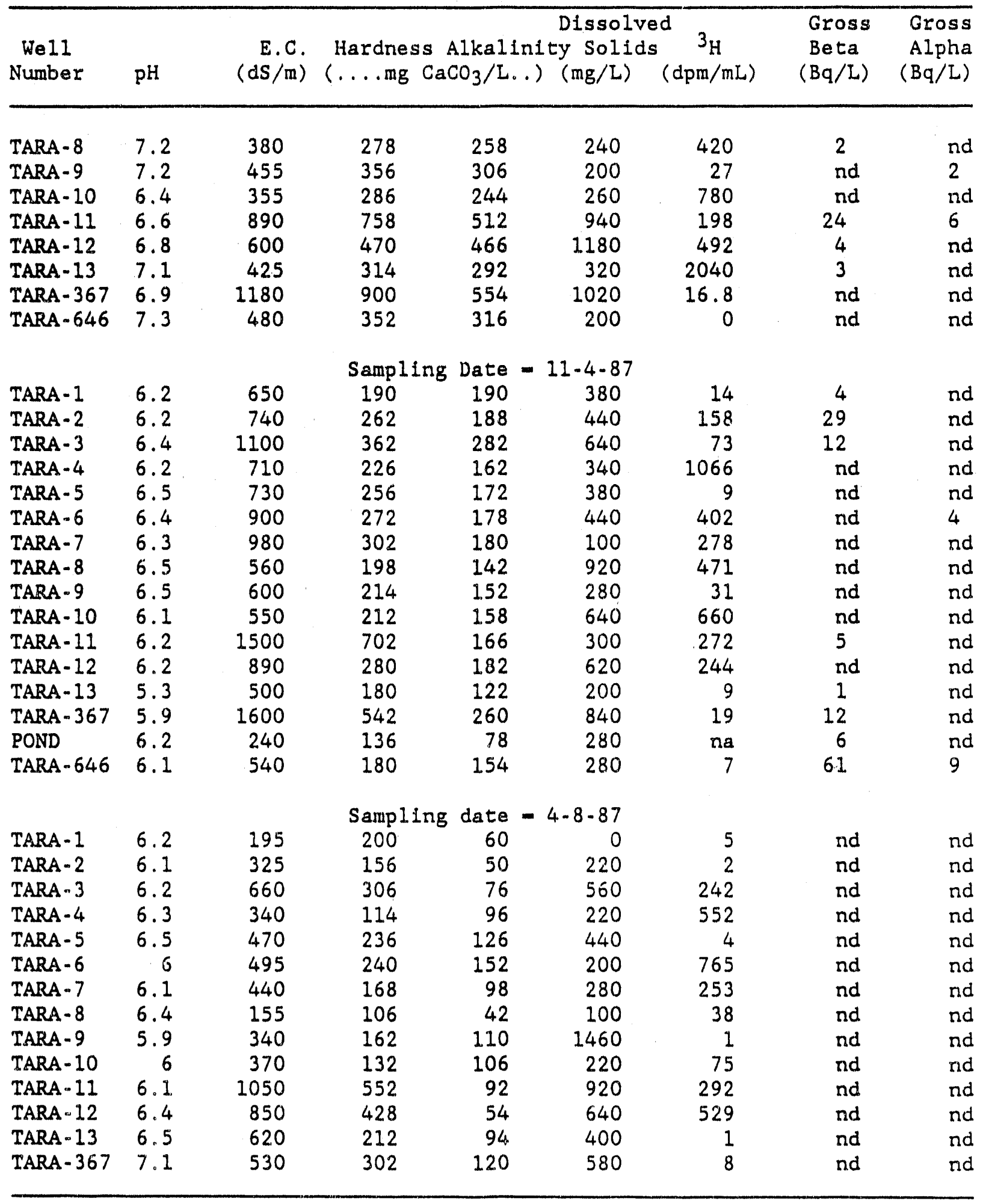


Page 36

PRECOMPACTION NONSTANDARD TRENCH PENETRATION TESTS

The rationale for compacting the TARA trenches as a part of the closure demonstration was to reduce trench void volume and stabilize the ground surface prior to constructing a permanent cover. Water-induced trench cover subsidence, which takes place with time, would be undesirable and could cause differential settling, resulting in shear forces that could compromise the performance of an impermeable membrane or other cover components. To quantify the benefits resulting from trench dynamic compaction, soll penetration tests were carried out at 5 positions over each of the 19 waste trenches, as well as at 34 locations over the surrounding soil and saprolite weathered from the Conasauga formation (Fig. 12). A nonstandard test was developed for use over the trenches f.n order to avoid augering, which is required in the standard soil penetration test (ASTM TEST D $1586-67$ Penetration test and split barrel sampling of soils), and to prevent bringing contaminated waste to the surface.

The nonstandard test consisted of using a $63.5 \mathrm{~kg}(140-1 \mathrm{~b})$ drill.rigmounted drop hammer to drive a $4.4-\mathrm{cm}$ diam AW-size drill rod into the soil. The end of the drill rod was fitted with a $5.1-\mathrm{cm}$ diam $60^{\circ}$ cone point, and the rod was marked off in 30-crn lengths. At each nonstandard penetration site shown in Fig. 12, the rod was hammered into the soll and the hammer blows for each $30-\mathrm{cm}$ depth were recorded. The deepest penetration hole in each trench was used for installation of a monitoring well. A $5.1-\mathrm{cm}-\mathrm{diam}$ stainless steel wire-wound well screen section ( $1.5 \mathrm{~m}$ long) with a tapered well point was hammered into the hole and coupled with threaded flush-joint casing (Johnson Company). Appendices IV (data obtained within trenches) and $V$ (data obtained in Conasauga Shale) summarize the nonstandard trench penetration data by tabulating the number of hammer blows required to drive the drill rod each $30 \mathrm{~cm}$ increment of depth. This nonstandard penetration is similar to the Dutch cone penetration test (DCPT) except that the test borehole was not augered out every $46 \mathrm{~cm}$ (18 in.) to ralieve drill stem friction. Blow count values (penetration resistance) obtained by the DCPT have often been found equivalent to blow count values obtained with the standard penetration test (SPT) (Solymar and Reed 1986). The DCPT, like the herein reported nonstandard penetration test, is not employed frequently in geotechnical work because it does not produce a soil sample for subsequent geotechnical or chemical tests.

An examination of the nonstandard penetration data shows that there is a significantly lower resistance to penetration within the trenches as compared to the resistance to penetration in the undisturbed Conasauga Shale. In some cases, large voids were encountered and one or two blows with the hammer would send the drill rod to the bottom of the trench. This difference, which was expected, is graphically displayed in Fig. 13 by showing the number of drop hammer blows required to achieve each $30 \mathrm{~cm}$ ( $1 \mathrm{ft}$ ) of penetration as a function of depth. A marked increase in the number of blows per foot of penetration occurred as a function of depth for setups outside the trenches, whereas within the trenches, this increase was not as apparent. The large voids within trenches apparently resulted in little frictional resistance to drill rod penetration in comparison to the relatively dense soil formation. 


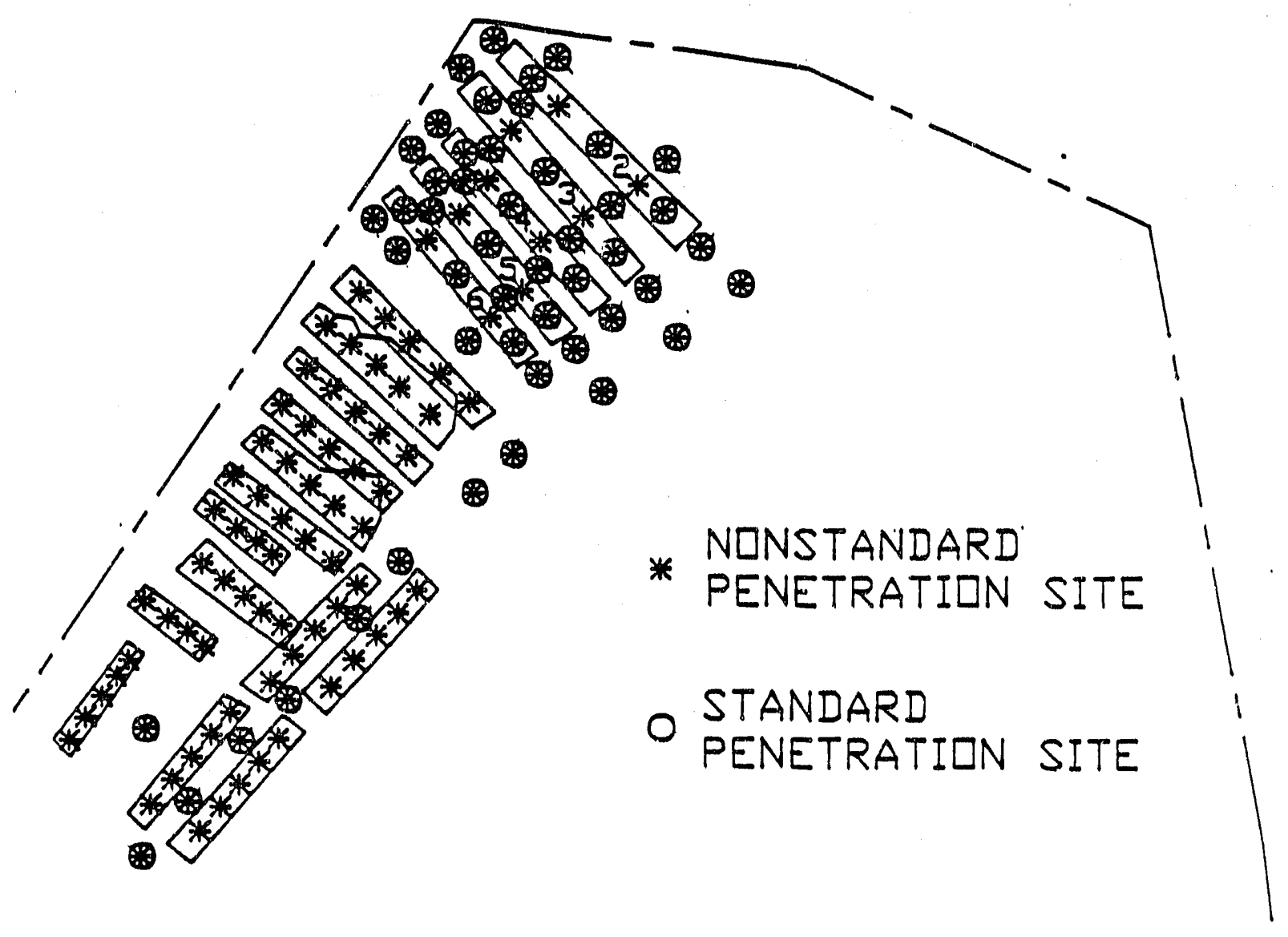

Fig. 12. Location of standard and nonstandard penetration test sites. 


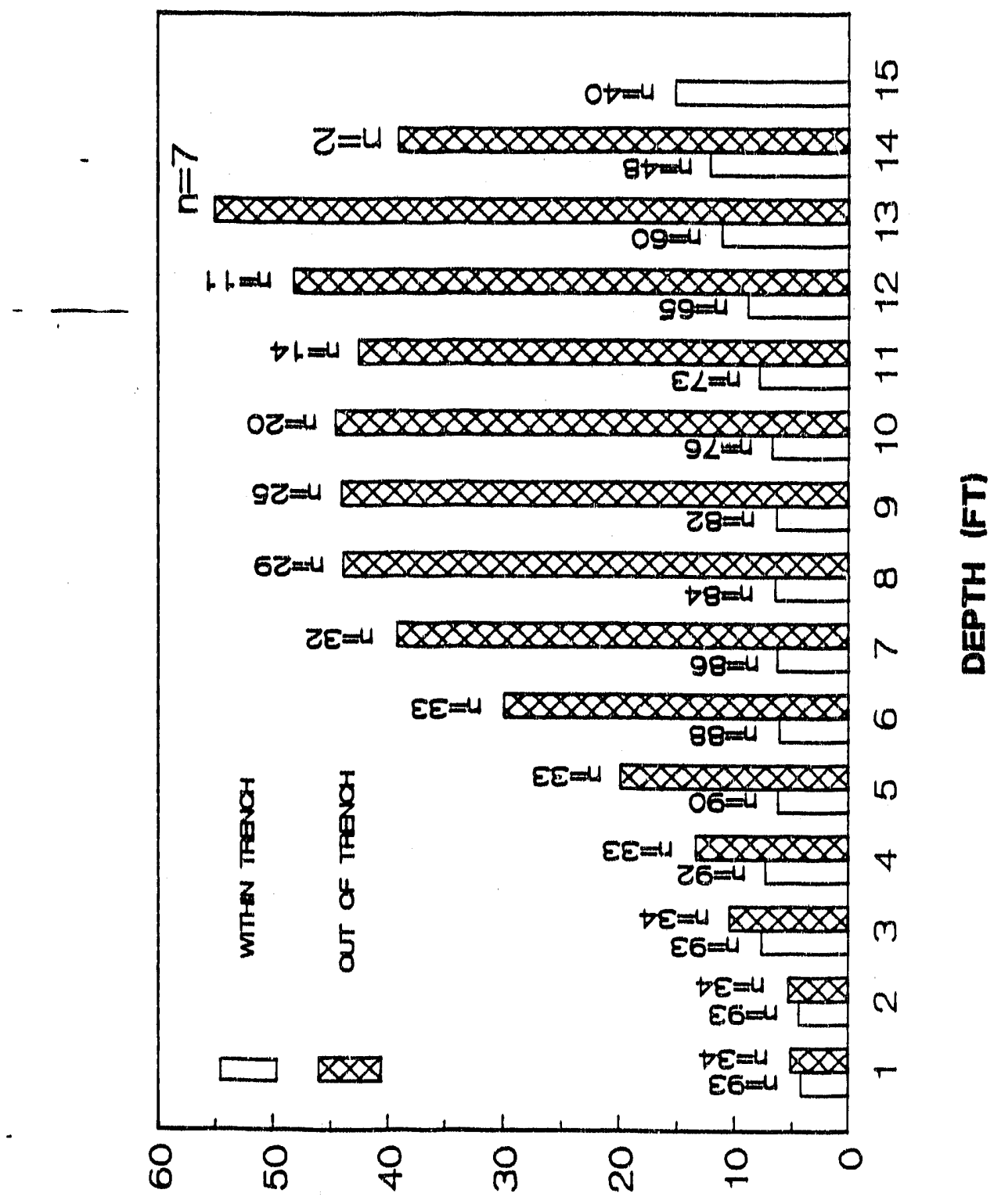

8MO7g УWWVH dOצव

Fig. 13. Comparison of within-trench and out-of-trench nonstandard penetration tests. 
Similar penetration tests conducted within the compacted trenches in FY 1989 will be compared to data shown In Fig. 13 to determine to what extent compaction has stabilized the trenches relative to the undisturbed soll formation.

Figure 13 also provides some useful statistical information for planning the Installation of monltoring wells in ORNL burlal trenches. More than half of the test penetrations ( 48 of 93 ) achloved a depth equal to the nominal bottom of the burial trench $(1 . \theta, 14 \mathrm{ft}$ ). In the other test penetrations, refusal was encountered at shallower depths due, presumably, to hard waste components such as concrete or steel. In the deeper holes, well casing can be inserted after drill rod removal resulting in a facile installation of an intratrench monitoring well. This installation technique avolds the problem of augering boreholes and exposing drill operators to trench contents. In addition, because the penetration point remalned in the hole and the drill rod was cleaned somewhat in the process of removal from the hole, 1ittle residual contamination was found on the drill rod even in these $>200-\mathrm{mrem} / \mathrm{h}$ waste burial trenches. Decontamination of the lower section of drill rod was achleved by wiping the rod with a towel. Only 7 instances of rod contamination were encuuntered during the 93 intratrench penetration tests. No contamination level was greater than $10 \mathrm{mrem} / \mathrm{h}$ at contact, and no $\mathrm{dr} 111$ rod falled decontamination. One penetrometer point housing could not be decontaminated in the fleld. The waste generated in producing 48 potentlal intratrench monitoring wells amounted to four cotton towels and one penetrometer point housing. Thus, the penetration well installation technique looks to be a safe and economical method.

\section{STANDARD SOIL PENETRATION TESTS AND SOIL CORE RETRIEVAL}

In addition to the nonstandard penetration tests discussed above, standard engineering methods (ASTM TEST 1586-67) of determining soli penetration resistance and collecting undisturbed soil cores were used at the locations shown as circles in Fig. 12. Those 15 locations shown as being above the waste trenches were sites where shallow cores into the trench covers were collected (to $91.4 \mathrm{~cm}$ only), whereas the 34 locations shown outsicle the trenches were sites where cores were collected to a maximum depth of $4.6 \mathrm{~m}$ (15 ft).

The standard soil penetration test consisted of driving a $69 \mathrm{~cm}-10 \mathrm{co}$, $0.54-\mathrm{cm}-\mathrm{diam}$, split spoon soll sampler into the ground to a depth of $46 \mathrm{~cm}$ (18 in.) using a $63.5-\mathrm{kg}$ drop hammer. The length of the extracted soll core was then measured and scanned with a Gelger-Mueller meter for the presence of radioactivity. The core was immediately removed from the sampler and placed in a prewashed sample bottle for later determination of volatile and semivolatile oliganics, moisture content, and welght (bulk density). A $15 \cdot \mathrm{cm}$ hollow stem auger was then used to drill down to the elevation of the bottom of the soll core and another $46 \mathrm{~cm}$ soll. core was collected using the split spoon sampler inserted into the hollow center of the auger. As the spoon was being driven into the ground, the blow counts to achleve each $15 \mathrm{~cm}$ of depth were recorded in an identical manner to that used in the nonstandard penetration tests. Alternate augering and soll core sampling were repeated in $46-\mathrm{cm}$ Increments until elther a depth of $4.6 \mathrm{~m}$ was reached or the auger 
met refusal (no progress with approximately $10 \mathrm{~min}$ of driling) due to hard rock layers.

The standard penatration teats and core retrieval sarved three purposes (1) to collest standard penetration resistanco data that oan be oortelated to the nonstandard data of Appendices IV and $V_{1}$ (2) to retrieve noll cores from between and around the flve TARA tronches for chemical and radlochemloal analyses prior to trenoh compation, and (3) to obtaln a rough ploture of the clepth to augar refusal at the TA.RA site. Spealfianlly, core ratrieval allowed for determining if there was radioactivity and/or organic contamination present around the trenches prior to oompaction, as well as to provide means of determining soll molsture and bulk denslty as a function of depth. Appendix VI summarizes the penetration test data obtained from the standard penetration tests, along with the sore molsture and bulk density values. Flgures 14,15 , and 16 show the relationship between penetration resistance and soll molsture, penetration reslatance and bulk density, and moisture and bulk denaity, respectively. There was an expected positive correlation $(x-0,66)$ between penetration resistance and soll bulk density; the denser the matertal, the more resistance to penetration would be expected. The negative correlation between penetration reslstance and molsture content probably results from the lnverse correlation between soll molsture content and bulk denslty; the less dense a soll or saprolite layer, the more water it would be expected to hold agalngt a given molsture tension or drying stress. Additional soli and saprolite varlables, such as texture, structure, and lithologio properties, likely contribute to the additional. varlation in penetration resistanco.

The undisturbed soll samples from the standard penetration tests were collected between Tebruary 29 and Apr11 8, 1988, and al1 samples were stored at $4^{\circ} \mathrm{C}$ until laboratory analyses for organic vapor and radionuclides were initiated. Organic vapor analysis was attempted as a screening tool to select a smali group of samples for detalled organic analyses. An organte vapor analyzer, using a photolonization detector (Photovac Tip-II Analyzar), was employed for all measurements. The instrument was turned on unt 11 a stable readirig was attalned. Calibration was carrled out using a 32 ppm ethanol standard prepared by injecting $500 \mathrm{\mu L}$ of an othanol saturated atmosphere $\left(48.8-\right.$ mum partial pressure at $\left.22.0^{\circ} \mathrm{C}\right)$ into a $1-\mathrm{L}$ glass bottle fitted with Teflon tubing connectors using a glass-barrel, gas-tight syringe with Tefion plunger. The bottle was shaken for several seconds, was allowed to stand for $30 \mathrm{~s}$, and the Intake tubling of the TIP-I analyzer was connected to one of the tube flttings. The readings of the analyzar were rocorded after 10,30 , and $60 \mathrm{~s}$ from attachment of the analyzer as well as the reading immediately before attachment. The intake tubing of the analyzer was then disconnected from the standardization chamber (botite) and the standardization repeated twloe more. Soll samples in the l-L bottles were run Identically to the standards after baing allowed to warm to room temperature $\left(22.0^{\circ} \mathrm{C}\right)$. Standards were run at the beginning, middle, and end of each day's group of soll samples. Rather than adjust the span and zero setting controls on the TIP.II analyzer, all readings were linearly adjusted to an equivalent raading for the 32 -ppm ethanol standard for the standardization closest to the time of sample analysis. The $30-\mathrm{s}$ reading was 


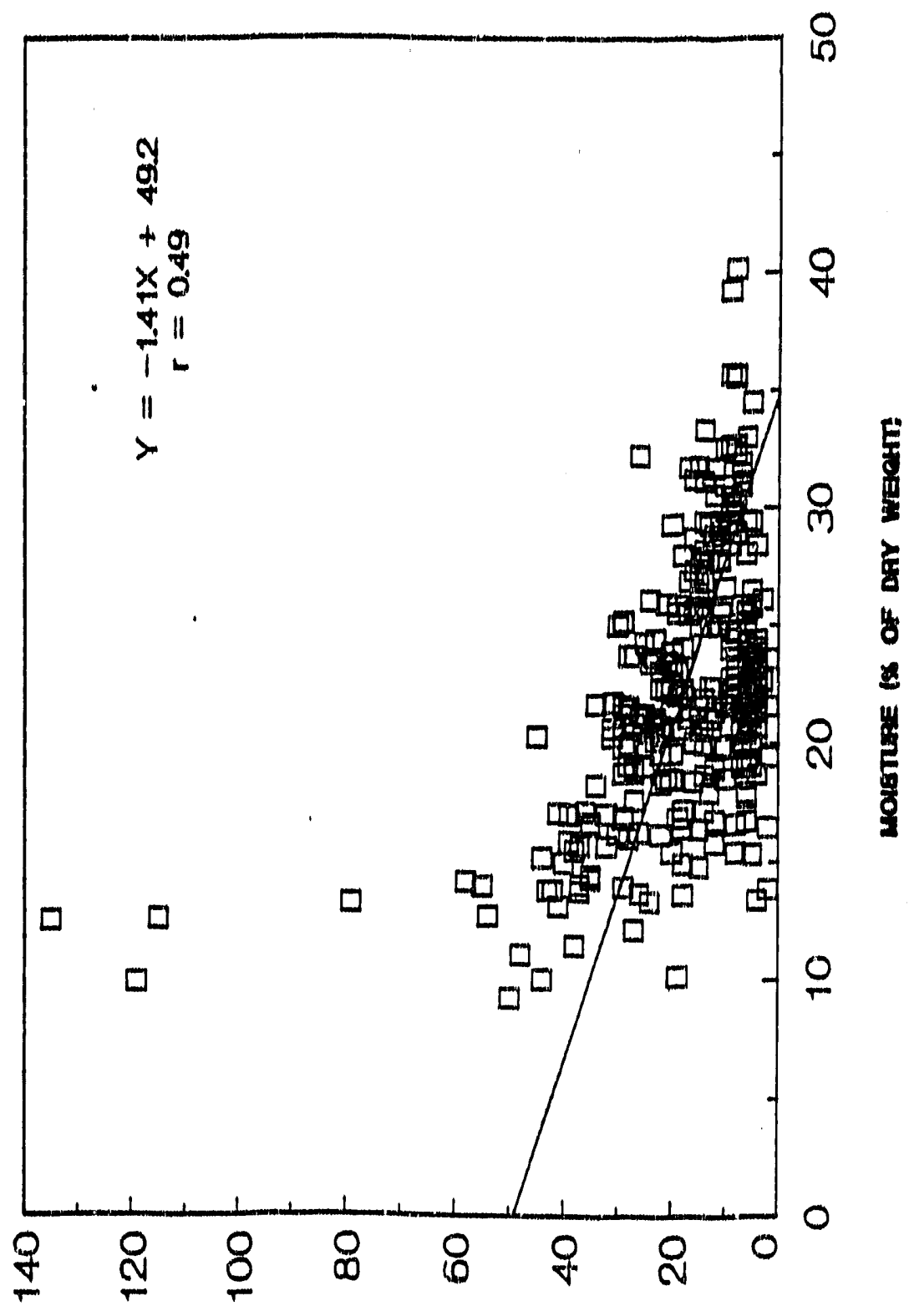

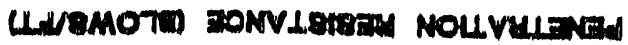

F1g. 14. Relationship between soll penetration resistance and percentage soll moisture at the TARA site. 


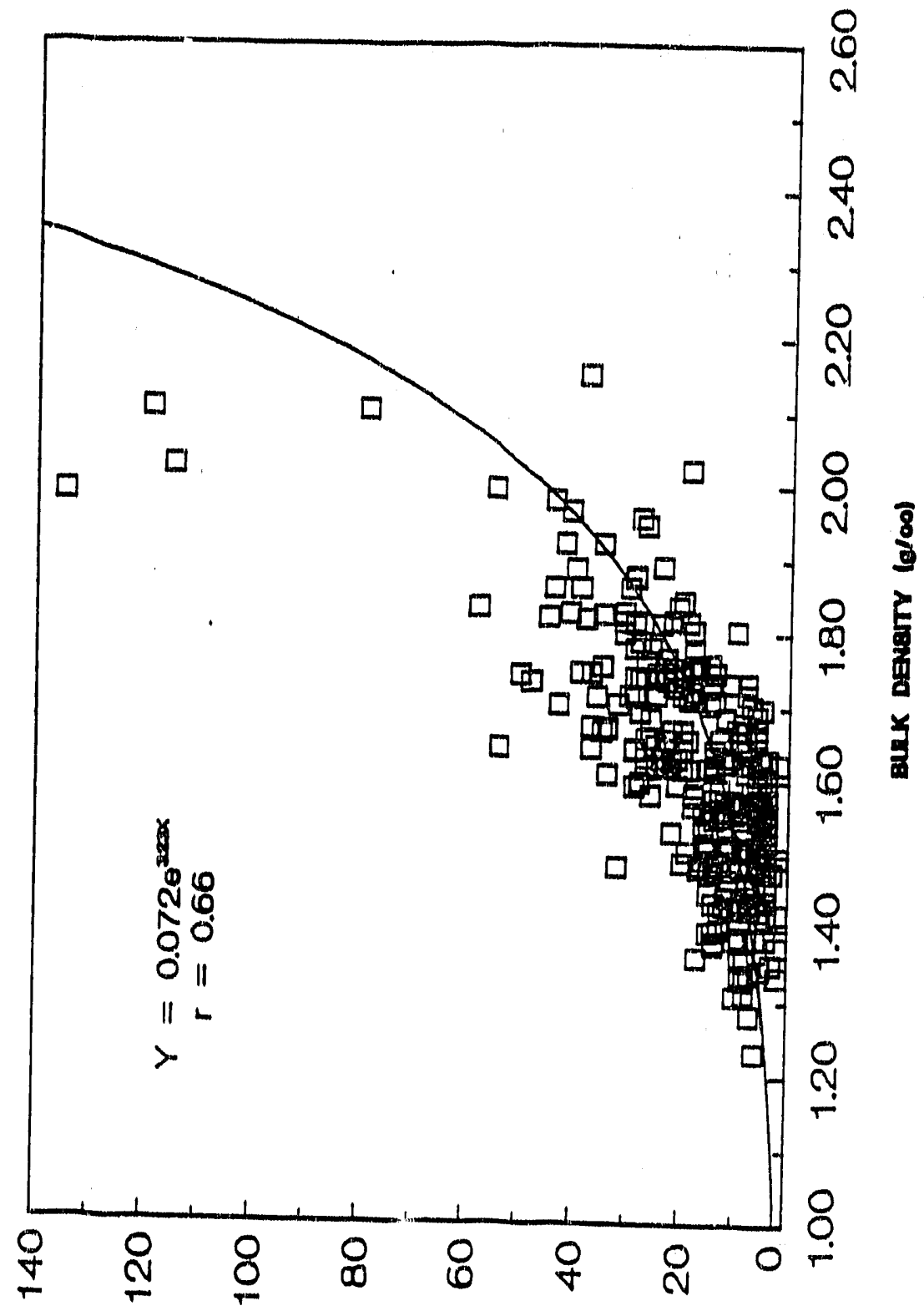

Levamo7m Borrdoraps Nouvuaved

F1g. 15. Relationship betwen soil penetration resistance and soil bulk density at the TARA sice. 


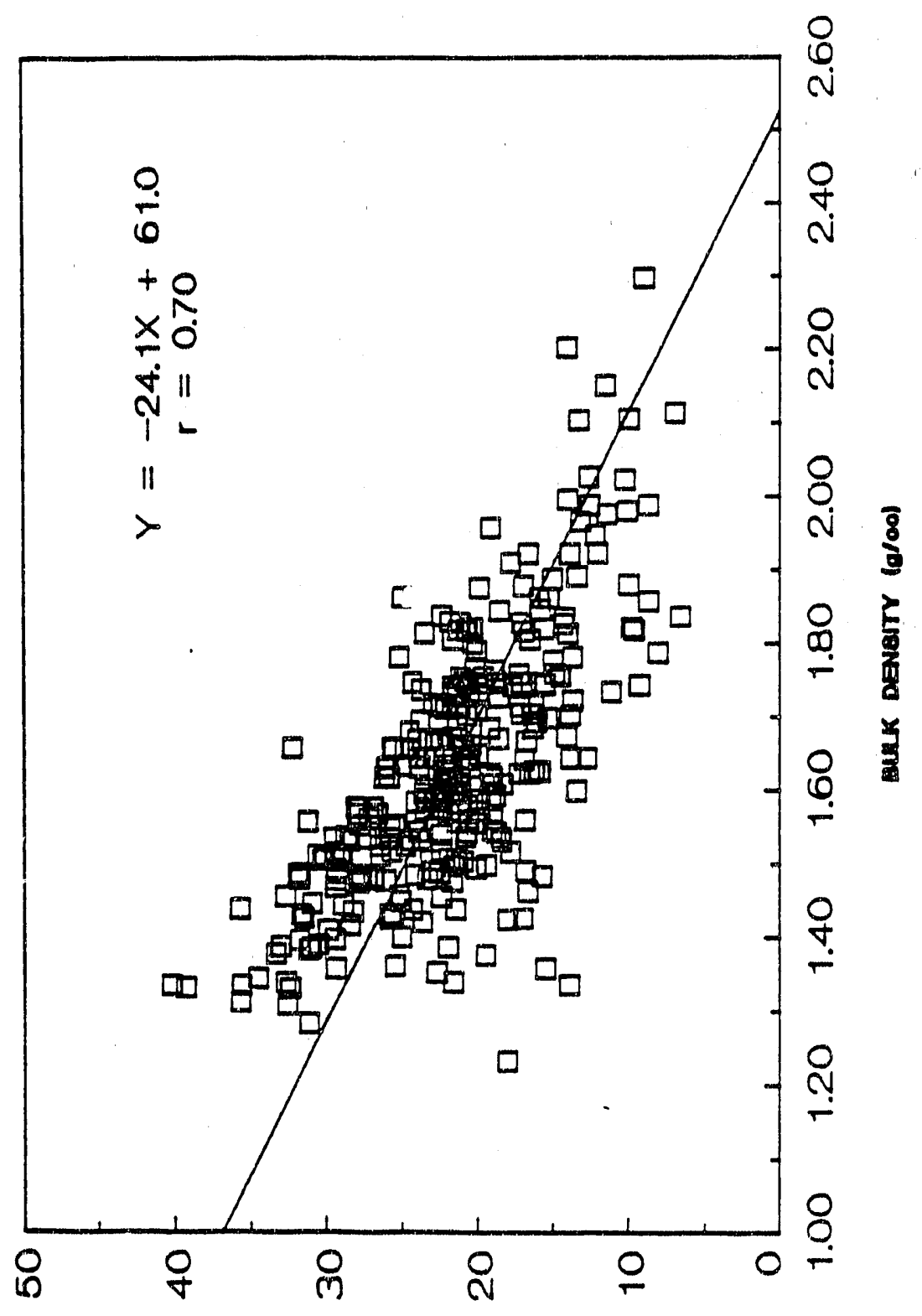

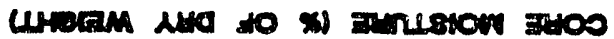

Fig. 16. Relationship between soil moisture and soil bulk density at the TARA site. 
found to be the most reproducible of the three time intervals; therefore, this reading was used for sample comparison (Table 8 ). The location of the sampling positions relative to the five burial trenches is depicted in Fig. 17. A frequency distribution of the adjusted organic vapor analyzer readings over the range of soil samples is depicted in Fig. 18. The range of response was over four orders of magnitude. Subsamples of ten of the high reading samples were prepared by sieving about $100 \mathrm{~g}$ of fresh core material to <2 $\mathrm{mm}$; these samples were submitted to the ORNL Analytical Chemistry Division for analysis of volatile (Table 9) and semivolatile (Table 5) organic compounds via EPA method 624 .

The selected samples are listed in Table 10 along with the identified and quantified organic species determined. The only unqualified identification in all samples was methylene chloride in the 10 - to $100-\mu \mathrm{g} / \mathrm{kg}$ range; all other identified species were either below the quantitation limit or appeared in background blanks also. Clearly, the identified organic species account for only a trivial fraction of the volatile species causing the high organic vapor analyzer readings, e.g., up to $12,800 \mathrm{mg} / \mathrm{L}$ of soil atmosphere. It should be pointed out that most of the volatile and semivolatile species analyzed for are not natural products of organic matter decay in soil. The majority of the organic species causing the organic vapor analyzer readings are probably simple decomposition products from plant roots and waste packages (e.g. wood) and do not constitute hazardous materials. Similarly, the utility of the nonspecific organic vapor analyzer as either a screening tool or a field monitoring device must be questioned given the high "background" of natural organic vapors present within the SWSA 6 soils. Also in Table 10, the measured radionuclide activities in these ten soil samples are listed; most of these were near the detection limit for the radionuclide assay, although occasional low levels of $137 \mathrm{Cs}$ and/or $90 \mathrm{Sr}$ were detected. Obviously, the radionuclides originate from the burial trenches, and it might be expected that if the sources of high organic vapor also originated from the burial trenches, some degree of correlation or ranking similarity might be expected. Wowever, this obviously did not hold true for either the trench perimeter or trench cap samples.

After completion of the organic vapor screening, all soil samples were dried at $105^{\circ} \mathrm{C}$ for $48 \mathrm{~h}$ in their original glass bottles. Samples were reweighed to determine their oven dry weights and moisture contents. A representative subsample of about $100 \mathrm{~cm}^{3}$ was removed and sieved to $<2 \mathrm{~mm}$. All residual soil samples were transferred to seal-lock polyethylene bags for archiving. Into plastic 25 -mL scintillation vials, $10.00 \mathrm{~g}$ of the sieved soil was weighed and used for assay of $137 \mathrm{Cs}, 60^{\mathrm{Co}}$, and $90 \mathrm{Sr}$. These samples were counted for 10 min each using a NaI detector for gamma ray spectroscopy (Cerling and Spalding 1981). The activity of $90 \mathrm{Sr}$ was estimated from bremsstrahlung radiation deiention in the lower-energy region of the gamma ray spectrum below the $137 \mathrm{Cs}$ photopeal region. Crosstalk into this bremsstrahlung window was subtracted using factors determined from $137 \mathrm{Cs}$ and ${ }^{60} \mathrm{Co}$ standards in $10-\mathrm{g}$ soil samples and the measured samples activities of
$137 \mathrm{Cs}$ and $60 \mathrm{Co}$. Other background counts in the bremsstrahlung window were subtracted using soil blanks without added isotopes. Standards of $90_{\mathrm{Sr}}$ in soil were prepared to measure the bremsstrahlung counting efficiency, which generally averaged about 4.48 . The bremstrahlung method for $90_{\mathrm{Sr}}$ assay is 


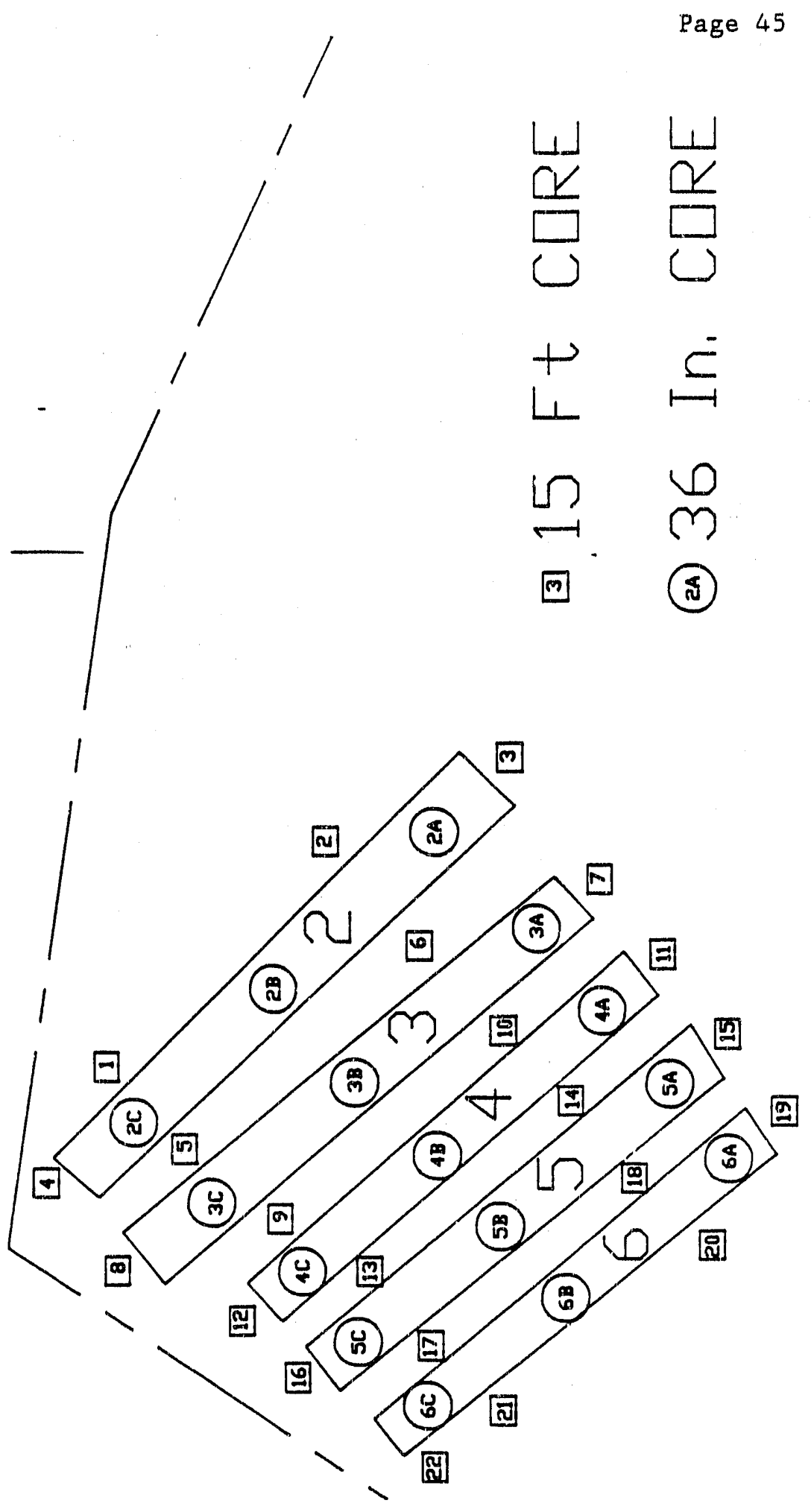

Fig. 17. Positions for undisturbed soil sampling during standard penetration tests around five TARA burial trenches. 
Table 8. Organic vapor analyzer results for the undisturbed soil samples around the TARA burial trenches

\begin{tabular}{cccclll}
\hline Sample & Depth & Start & 30 Sec. Standard & Adjusted Sample & Log of Adj. \\
Hole & Top (in.) & (units) & (units) & (units) & $\begin{array}{l}\text { Reading Ranking } \\
\text { (units) }\end{array}$ & Reading \\
\end{tabular}

\begin{tabular}{|c|c|c|c|c|c|c|c|}
\hline 1 & 0 & -4.7 & -1.6 & 18.4 & 3.8 & 53 & 0.579783 \\
\hline 1 & 18 & -5.9 & -2.6 & 18.4 & 4 & 59 & 0.602059 \\
\hline 1 & 36 & -6 & -3 & 18.4 & 3.7 & 50 & 0.568201 \\
\hline 1 & 54 & -5.2 & -2.6 & 18.4 & 3.2 & 42 & 0.505149 \\
\hline 1 & 72 & -5.1 & -1.9 & 18.4 & 3.9 & 55 & 0.591064 \\
\hline 1 & 90 & -4.8 & -1.1 & 18.4 & 4.5 & 72 & 0.653212 \\
\hline 1 & 108 & -3.9 & -3.6 & 3.9 & 1.7 & 19 & 0.230448 \\
\hline 2 & 0 & -4.2 & -4 & 3.9 & 1.1 & 12 & 0.041392 \\
\hline 2 & 18 & -4.1 & -3.8 & 3.9 & 1.7 & 20 & 0.230448 \\
\hline 2 & 36 & -4.1 & -4 & 3.9 & 0.6 & 8 & -0.22184 \\
\hline 2 & 54 & -4.1 & -3.9 & 3.9 & 1.1 & 11 & 0.041392 \\
\hline 2 & 72 & -4.2 & -4.1 & 3.9 & 0.6 & 7 & -0.22184 \\
\hline 2 & 90 & -4.2 & -4.1 & 3.9 & 0.6 & 5 & -0.22184 \\
\hline 2 & 108 & -4.2 & -4.1 & 3.9 & 0.6 & 6 & -0.22184 \\
\hline 2 & 126 & -4 & -3.3 & 3.9 & 4 & 60 & 0.602059 \\
\hline 2 & 144 & -4.1 & -4 & 3.9 & 0.6 & 4 & -0.22184 \\
\hline 2 & 162 & -4.1 & -3.8 & 3.9 & 1.7 & 21 & 0.230448 \\
\hline 3 & 0 & -12.7 & -10.8 & 13.1 & 3.2 & 43 & 0.505149 \\
\hline 3 & 18 & -12.4 & -10.7 & 13.1 & 2.9 & 39 & 0.462397 \\
\hline 3 & 36 & -12.6 & -9.9 & 13.1 & 4.6 & 74 & 0.662757 \\
\hline 3 & 54 & -11.4 & -10.4 & 13.1 & 1.7 & 22 & 0.230448 \\
\hline 3 & 72 & -11.4 & -10.3 & 13.1 & 1.9 & 24 & 0.278753 \\
\hline 3 & 90 & -11.8 & -10.4 & 13.1 & 2.4 & 30 & 0.380211 \\
\hline 3 & 108 & -11.4 & -10.5 & 13.1 & 1.5 & 17 & 0.176091 \\
\hline 3 & 126 & -11.6 & -10.4 & 13.1 & 2.1 & 28 & 0.322219 \\
\hline 3 & 144 & -11.8 & -10.3 & 13.1 & 2.6 & 31 & 0.414973 \\
\hline 3 & 162 & -11.4 & -8.5 & 13.1 & 5 & 85 & 0.698970 \\
\hline 4 & 0 & -14.5 & -11.5 & 13.1 & 5.1 & 89 & 0.707570 \\
\hline 4 & 18 & -14.3 & -11.6 & 13.1 & 4.6 & 75 & 0.662757 \\
\hline 4 & 36 & -12 & -9.7 & 13.1 & 3.9 & 56 & 0.591064 \\
\hline 4 & 54 & -13.7 & -11.1 & 13.1 & 4.4 & 70 & 0.643452 \\
\hline 4 & 72 & -12.1 & -9.9 & 13.1 & 3.8 & 54 & 0.579783 \\
\hline 5 & 0 & -10.3 & -8.6 & 8.7 & 4.4 & 71 & 0.643452 \\
\hline 5 & 18 & -10.6 & -8.6 & 8.7 & 5.1 & 91 & 0.707570 \\
\hline 5 & 36 & -10.2 & -7.8 & 8.7 & 6.2 & 113 & 0.792391 \\
\hline 5 & 54 & -10.6 & -8.5 & 8.7 & 5.4 & 95 & 0.732393 \\
\hline 5 & 72 & -8 & -4.5 & 8.7 & 9 & 141 & 0.954242 \\
\hline 5 & 90 & -10.3 & -7.9 & 8.7 & 6.2 & 112 & 0.792391 \\
\hline 5 & 108 & -10.1 & -8.1 & 8.7 & 5.1 & 90 & 0.707570 \\
\hline 6 & 0 & -9.4 & -7.5 & 8.7 & 4.9 & 83 & 0.690196 \\
\hline 6 & 18 & -8.5 & -5.4 & 8.7 & 8 & 136 & 0.903089 \\
\hline 6 & 36 & -9.1 & -3.1 & 8.7 & 15.4 & 171 & 1.187520 \\
\hline 6 & 54 & -10.1 & -7.4 & 8.7 & 7 & 126 & 0.845098 \\
\hline 6 & 72 & -8.9 & -1.2 & 8.7 & 19.8 & 190 & 1.296665 \\
\hline 6 & 90 & -5.6 & -2.3 & 3.3 & 22.4 & 195 & 1. 350248 \\
\hline
\end{tabular}


Table 8. (Continued)

\begin{tabular}{|c|c|c|c|c|c|c|c|}
\hline $\begin{array}{l}\text { ample } \\
\text { Hole }\end{array}$ & $\begin{array}{c}\text { Depth } \\
\text { Section } \\
\text { Top (in.) }\end{array}$ & $\begin{array}{l}\text { Start } \\
\text { Reading } \\
\text { (units) }\end{array}$ & $\begin{array}{l}30 \text { Sec. } \\
\text { Reading } \\
\text { (units) }\end{array}$ & $\begin{array}{l}\text { Standard } \\
\text { Reading } \\
\text { (units) }\end{array}$ & $\begin{array}{l}\text { Adjusted } \\
\text { Reading } \\
\text { (units) }\end{array}$ & $\begin{array}{l}\text { Sample } \\
\text { Ranking }\end{array}$ & $\begin{array}{l}\text { Log of Adj } \\
\text { Reading }\end{array}$ \\
\hline
\end{tabular}

\begin{tabular}{|c|c|c|c|c|c|c|c|}
\hline 6 & 108 & -9.2 & -6.4 & 8.7 & 7.2 & 129 & 0.857332 \\
\hline 6 & 126 & 1.5 & $325^{\circ}$ & 3.3 & 2195.9 & 256 & 3.341612 \\
\hline 6 & 144 & -8.9 & 0.1 & 8.7 & 23.2 & 199 & 1.365487 \\
\hline 6 & 162 & -9.6 & 0.7 & 8.7 & 26.5 & 210 & 1.423245 \\
\hline 7 & 0 & -10.5 & .7 .6 & 4.3 & 15.1 & 170 & 1.178976 \\
\hline 7 & 18 & -10.6 & -5.8 & 13.1 & 8.2 & 137 & 0.913813 \\
\hline 7 & 36 & -10.5 & -7.9 & 4.3 & 13.5 & 161 & 1.130333 \\
\hline 7 & 54 & -12 & -9.8 & 4.3 & 11.5 & 152 & 1.060697 \\
\hline 7 & 72 & -12.3 & -9.6 & 4.3 & 14.1 & 165 & 1.149219 \\
\hline 7 & 90 & -9.7 & -6.3 & 4.3 & 17.7 & 184 & 1.247973 \\
\hline 7 & 108 & -11.8 & -10 & 4.3 & 9.4 & 143 & 0.973127 \\
\hline 8 & 0 & -11.4 & -9.3 & 13.1 & 3.6 & 49 & 0.556302 \\
\hline 8 & 18 & -11.4 & -9.4 & 13.1 & 3.4 & 46 & 0.531478 \\
\hline 8 & 36 & -9.7 & -5.4 & 8.7 & 11.1 & 150 & 1.045322 \\
\hline 8 & 54 & -3 & 1884 & 3.3 & 12808.7 & 259 & 4.107505 \\
\hline 8 & 72 & -13 & -9.5 & 13.1 & 6 & 111 & 0.778151 \\
\hline 9 & 0 & -1.3 & 0.4 & 13.8 & 2.8 & 33 & 0.447158 \\
\hline 9 & 18 & -0.8 & 0 & 13.8 & 1.3 & 15 & 0.113943 \\
\hline 9 & 36 & -5.2 & 0 & 13.8 & 8.4 & 139 & 0.924279 \\
\hline 9 & 54 & -19.6 & -5.1 & 12.3 & 26.4 & 209 & 1.421603 \\
\hline 9 & 72 & -9.3 & -2.8 & 13.1 & 11.1 & 151 & 1.045322 \\
\hline 9 & 90 & -5.5 & -3.8 & 13.8 & 2.8 & 34 & 0.447158 \\
\hline 9 & 108 & 1.2 & 5.6 & 13.8 & 7.1 & 127 & 0.851258 \\
\hline 9 & 126 & -10.2 & -4.3 & 13.1 & 10.1 & 147 & 1.004321 \\
\hline 9 & 144 & -6.8 & .4 .4 & 13.8 & 3.9 & 57 & 0.591064 \\
\hline 9 & 162 & -4.8 & -0.1 & 13.8 & 7.6 & 134 & 0.880813 \\
\hline 10 & 0 & -7.4 & -6.3 & 13.8 & 1.8 & 23 & 0.255272 \\
\hline 10 & 18 & -2.8 & -1.1 & 13.8 & 2.8 & 35 & 0.447158 \\
\hline 10 & 36 & -10.3 & -8.1 & 8.7 & 5.7 & 102 & 0.755874 \\
\hline 10 & 54 & -5.6 & -1.9 & 3.3 & 25.1 & 204 & 1.399673 \\
\hline 10 & 72 & -5.7 & -2.3 & 3.3 & 23.1 & 198 & 1.363611 \\
\hline 10 & 90 & -11 & 4.1 & 13.1 & 25.8 & 207 & 1.411619 \\
\hline 10 & 108 & -5.7 & -2.4 & 3.3 & 22.4 & 196 & 1.350248 \\
\hline 10 & 126 & -5.5 & -2.4 & 3.3 & 21 & 193 & 1.322219 \\
\hline 10 & 144 & -5.4 & -2.1 & 3.3 & 22.4 & 197 & 1.350248 \\
\hline 10 & 162 & -6 & -2.2 & 3.3 & 25.8 & 206 & 1.411619 \\
\hline 11 & 0 & -11.6 & -10.9 & 13.1 & 1.2 & 13 & 0.079181 \\
\hline 11 & 18 & -10.7 & -8.9 & 13.1 & 3.1 & 41 & 0.491361 \\
\hline 11 & 36 & -11.9 & -10.6 & 13.1 & 2.2 & 29 & 0.342422 \\
\hline 11 & 54 & .7 .3 & -3.9 & 10.5 & 7.3 & 130 & 0.863322 \\
\hline 11 & 72 & -10.6 & -8.4 & 4.3 & 11.5 & 153 & 1.060697 \\
\hline 11 & 90 & -12 & -9.9 & 4.3 & 10.9 & 149 & 1.037426 \\
\hline 11 & 108 & -11.9 & -9.9 & 4.3 & 10.4 & 148 & 1.017033 \\
\hline 11 & 126 & -8.4 & -5.1 & 4.3 & 17.2 & 183 & 1.235528 \\
\hline 11 & 144 & -8.5 & -0.9 & 4.3 & 39.6 & 22.1 & 1. .597695 \\
\hline 11 & 162 & -11.9 & -10.1 & 4.3 & 9.4 & 144 & 0.973127 \\
\hline
\end{tabular}


Page 48

Table 8. (Continued)

\begin{tabular}{|c|c|c|c|c|c|c|c|}
\hline $\begin{array}{l}\text { Sample } \\
\text { Hole }\end{array}$ & $\begin{array}{c}\text { Depth } \\
\text { Section } \\
\text { Top (in.) }\end{array}$ & $\begin{array}{l}\text { Start } \\
\text { Reading } \\
\text { (units) }\end{array}$ & $\begin{array}{l}30 \text { Sec. } \\
\text { Reading } \\
\text { (units) }\end{array}$ & $\begin{array}{l}\text { Standard } \\
\text { Reading } \\
\text { (units) }\end{array}$ & $\begin{array}{l}\text { Adjusted } \\
\text { Reading } \\
\text { (units) }\end{array}$ & $\begin{array}{l}\text { Sample } \\
\text { Ranking }\end{array}$ & $\begin{array}{l}\text { Log of Adf. } \\
\text { Reading }\end{array}$ \\
\hline 12 & 0 & -10.6 & -9.3 & 5.2 & 5.6 & 97 & 0.748188 \\
\hline 12 & 18 & -10.6 & -9.1 & 5.2 & 6.5 & 115 & 0.812913 \\
\hline 12 & 36 & -10.9 & -8.9 & 5.2 & 8.6 & 140 & 0.934498 \\
\hline 12 & 54 & -10.6 & -9 & 5.2 & 6.9 & 120 & 0.838849 \\
\hline 12 & 72 & -10.9 & -9.2 & 5.2 & 7.3 & 131 & 0.863322 \\
\hline 12 & 90 & -19.4 & -4.4 & 12.3 & 27.3 & 213 & 1.436162 \\
\hline 12 & 108 & -20.2 & -2.5 & 12.3 & 32.2 & 219 & 1.507855 \\
\hline 12 & 126 & -12.1 & -9.3 & 13.1 & 4.8 & 82 & 0.681241 \\
\hline 13 & 0 & .4 & 145.7 & 6.6 & 508.1 & 250 & 2.705949 \\
\hline 13 & 18 & .6 .5 & 19.6 & 1.8 & 324.8 & 247 & 2.511616 \\
\hline 13 & 36 & -3.3 & 3.6 & 6.6 & 23.4 & 200 & 1.369215 \\
\hline 13 & 54 & -4.5 & 8 & 6.6 & 42.4 & 224 & 1.627365 \\
\hline 13 & 72 & -6.4 & -2.3 & 1.8 & 51 & 225 & 1.707570 \\
\hline 13 & 90 & -4.1 & 7.5 & 6.6 & 39.4 & 220 & 1.595496 \\
\hline 13 & 108 & -6.7 & -3.4 & 1.8 & 41.1 & 223 & 1.613841 \\
\hline 13 & 126 & -3.6 & 3.5 & 6.6 & 24.1 & 202 & 1.382017 \\
\hline 13 & 144 & -3.6 & 3.4 & 6.6 & 23.8 & 201 & 1.376576 \\
\hline 13 & 162 & -1.2 & 7.5 & 6.6 & 29.5 & 216 & 1.469822 \\
\hline 14 & 18 & -7.2 & -2 & 1.8 & 64.7 & 229 & 1.810904 \\
\hline 14 & 36 & -7.2 & -4.6 & 3.9 & 14.9 & 169 & 1.173186 \\
\hline 14 & 54 & -2.6 & 5.3 & 6.6 & 26.8 & 2.11 & 1.428134 \\
\hline 14 & 72 & -7.1 & -4.8 & 3.9 & 13.2 & 156 & 1.120573 \\
\hline 14 & 90 & .7 .1 & -4.6 & 3.9 & 14.4 & 166 & 1.158362 \\
\hline 14 & 108 & -7.1 & -4.8 & 3.9 & 13.2 & 158 & 1.120573 \\
\hline 14 & 126 & -7.2 & -4.5 & 3.9 & 15.5 & 172 & 1.190331 \\
\hline 14 & 144 & -7 & -4.7 & 3.9 & 13.2 & 157 & 1.120573 \\
\hline 14 & 162 & -7.1 & -4.5 & 3.9 & 14.9 & 168 & 1.173186 \\
\hline 15 & 0 & -11.6 & -8.4 & 13.1 & 5.5 & 96 & 0.740362 \\
\hline 15 & 18 & -10.7 & -6.9 & 13.1 & 6.5 & 116 & 0.812913 \\
\hline 15 & 36 & -11.9 & -9 & 13.1 & 5 & 86 & 0.698970 \\
\hline 15 & 54 & -11.3 & -6.7 & 13.1 & 7.9 & 135 & 0.897627 \\
\hline 15 & 72 & -11.5 & -8.6 & 13.1 & 5 & 88 & 0.698970 \\
\hline 15 & 90 & -12.4 & -9.1 & 13.1 & 5.6 & 98 & 0.748188 \\
\hline 15 & 108 & -11.8 & -8.9 & 13.1 & 5 & 87 & 0.698970 \\
\hline 15 & 126 & -12.7 & -8.8 & 13.1 & 6.7 & 117 & 0.826074 \\
\hline 15 & 144 & -10.4 & -7.9 & 13.1 & 4.3 & 67 & 0.633468 \\
\hline 15 & 162 & -11 & -7.6 & 13.1 & 5.8 & 110 & 0.763427 \\
\hline 16 & 0 & -10.7 & -9.4 & 5.2 & 5.6 & 100 & 0.748188 \\
\hline 16 & 18 & -10.4 & -9.1 & 5.2 & 5.6 & 99 & 0.748188 \\
\hline 16 & 36 & -2.9 & -2.8 & 10.5 & 0.2 & 1 & -0.69897 \\
\hline 16 & 54 & -2.6 & -1.9 & 10.5 & 1.5 & 18 & 0.176091 \\
\hline 16 & 72 & -1.8 & 2.8 & 10.5 & 9.8 & 145 & 0.991226 \\
\hline 16 & 90 & -6.4 & -4.5 & 10.5 & 4.1 & 64 & 0.612783 \\
\hline 16 & 108 & -10.4 & -9.3 & 5.2 & 4.7 & 79 & 0.672097 \\
\hline 16 & 126 & -10.5 & -8.2 & 5.2 & 9.9 & 146 & 0.995635 \\
\hline 17 & 0 & -4.9 & -3.9 & 18.4 & 1.2 & 14 & 0.079181 \\
\hline
\end{tabular}


Page 49

Table 8. (Continued)

\begin{tabular}{ccccccc}
\hline Depth & Start & 30 Sec. Standard & Adjusted Sample & Log of Adj. \\
Hole & Section Reading & Reading & Reading & Reading Ranking & Reading \\
Top (in.) (units) & (units) & (units) & (units) & &
\end{tabular}

\begin{tabular}{|c|c|c|c|c|c|c|c|}
\hline 17 & 18 & -0.6 & 3.9 & 13.8 & 7.3 & 132 & 0.863322 \\
\hline 17 & 36 & -6.1 & -3.1 & 18.4 & 3.7 & 51 & 0.568201 \\
\hline 17 & 54 & -6.4 & -2.6 & 18.4 & 4.6 & 76 & 0.662757 \\
\hline 17 & 72 & 1.5 & 2.3 & 13.8 & 1.3 & 16 & 0.113943 \\
\hline 17 & 90 & 0.7 & 2.4 & 13.8 & 2.8 & 36 & 0.447158 \\
\hline 17 & 108 & 0.9 & 3.9 & 13.8 & 4.9 & 84 & 0.690196 \\
\hline 17 & 126 & -6 & -3.1 & 18.4 & 3.5 & 48 & 0.544068 \\
\hline 17 & 144 & 1.4 & 3.9 & 13.8 & 4.1 & 65 & 0.612783 \\
\hline 17 & 162 & 1.4 & 5.8 & 13.8 & 7.1 & 128 & 0.851258 \\
\hline 18 & 0 & -7 & -4.6 & 3.9 & 13.8 & 162 & 1.139879 \\
\hline 18 & 18 & -5.9 & .2 .6 & 18.4 & 4 & 62 & 0.602059 \\
\hline 18 & 36 & -3.6 & 3.3 & 6.4 & 24.2 & 203 & 1.383815 \\
\hline 18 & 54 & -5.2 & -3 & 18.4 & 2.7 & 32 & 0.431363 \\
\hline 18 & 72 & -2.4 & 4.3 & 18.4 & 8.2 & 138 & 0.913813 \\
\hline 18 & 90 & -2.8 & 0.2 & 18.4 & 3.7 & 52 & 0.568201 \\
\hline 18 & 108 & -1.4 & 1.9 & 18.4 & 4 & 61 & 0.602059 \\
\hline 18 & 126 & -2.2 & 0.6 & 18.4 & 3.4 & 47 & 0.531478 \\
\hline 18 & 144 & -0.6 & 3.3 & 18.4 & 4.7 & 80 & 0.672097 \\
\hline 18 & 1.62 & -2.5 & 0.2 & 18.4 & 3.3 & 45 & 0.518513 \\
\hline 19 & 0 & .6 .2 & -4.9 & 10.5 & 2.8 & 37 & 0.447158 \\
\hline 19 & 18 & -3.2 & -3.1 & 10.5 & 0.2 & 2 & -0.69897 \\
\hline 19 & 36 & -2.4 & -1.5 & 10.5 & 1.9 & 25 & 0.278753 \\
\hline 19 & 54 & -0.1 & 0.2 & 10.5 & 0.6 & 9 & -0.22184 \\
\hline 19 & 72 & -6.7 & -4.7 & 10.5 & 4.3 & 68 & 0.633468 \\
\hline 19 & 90 & -1.6 & -0.7 & 10.5 & 1.9 & 26 & 0.278753 \\
\hline 19 & 108 & -1.1 & -0.2 & 10.5 & 1.9 & 27 & 0.278753 \\
\hline 19 & 126 & -10.7 & -9.1 & 5.2 & 6.9 & 121 & 0.838849 \\
\hline 19 & 144 & -10.3 & -9 & 5.2 & 5.6 & 101 & 0.748188 \\
\hline 19 & 162 & -12.1 & -9.3 & 5.2 & 12.1 & 154 & 1.082785 \\
\hline 20 & 0 & -5.3 & -0.9 & 3.3 & 29.9 & 217 & 1.475671 \\
\hline 20 & 18 & -5.6 & -0.9 & 6.6 & 16 & 175 & 1.204119 \\
\hline 20 & 36 & -5.5 & -0.7 & 6.6 & 16.3 & 179 & 1.212187 \\
\hline 20 & 54 & -5.9 & -1.3 & 3.3 & 31.2 & 218 & 1.494154 \\
\hline 20 & 72 & -5.5 & -0.9 & 6.6 & 15.6 & 174 & 1.193124 \\
\hline 20 & 90 & -5.6 & .0 .9 & 6.6 & 16 & 176 & 1.204119 \\
\hline 20 & 108 & -5.2 & -1.1 & 6.6 & 13.9 & 164 & 1.143014 \\
\hline 20 & 126 & -0.5 &.-0.4 & 6.6 & 0.3 & 3 & -0.52287 \\
\hline 20 & 144 & -3.7 & 1.3 & 6.6 & 17 & 181 & 1.230448 \\
\hline 20 & 162 & -5.3 & -0.5 & 6.6 & 16.3 & 178 & 1.212187 \\
\hline 21 & 0 & -6.8 & -5.8 & 3.9 & 5.7 & .105 & 0.755874 \\
\hline 21 & 18 & -7 & -6 & 3.9 & 5.7 & 103 & 0.755874 \\
\hline 21 & 36 & -5.7 & -4.6 & 3.9 & 6.3 & 114 & 0.799340 \\
\hline 21 & 54 & -3.2 & -0.8 & 3.9 & 13.8 & 163 & 1.139879 \\
\hline 21 & 72 & -7.3 & -4.5 & 3.9 & 16.1 & 177 & 1.206825 \\
\hline 21 & 90 & -6.8 & -5.8 & 3.9 & 5.7 & 104 & 0.755874 \\
\hline 21 & 108 & -5.8 & -5.1 & 3.9 & 4 & 63 & 0.602059 \\
\hline
\end{tabular}


Page 50

Table 8. (Continued)

\begin{tabular}{|c|c|c|c|c|c|c|c|}
\hline $\begin{array}{l}\text { Sample } \\
\text { Hole }\end{array}$ & $\begin{array}{c}\text { Depth } \\
\text { Section } \\
\text { Top (in.) }\end{array}$ & $\begin{array}{l}\text { Start } \\
\text { Reading } \\
\text { (units) }\end{array}$ & $\begin{array}{l}30 \text { Sec. } \\
\text { Reading } \\
\text { (units) }\end{array}$ & $\begin{array}{l}\text { Standard } \\
\text { Reading } \\
\text { (units) }\end{array}$ & $\begin{array}{l}\text { Adjusted } \\
\text { Reading } \\
\text { (units) }\end{array}$ & $\begin{array}{l}\text { Sample } \\
\text { Ranking }\end{array}$ & $\begin{array}{l}\text { Log of Adf. } \\
\text { Reading }\end{array}$ \\
\hline 21 & 126 & -5 & -3.8 & 3.9 & 6.9 & 1.22 & 0.838849 \\
\hline 22 & 0 & -7.3 & -5 & 3.9 & 13.2 & 159 & 1.120573 \\
\hline 22 & 18 & -7.1 & -4.6 & 3.9 & 14.4 & 167 & 1.158362 \\
\hline 22 & 36 & -6.2 & -5 & 3.9 & 6.9 & 124 & 0.838849 \\
\hline 22 & 54 & -7.5 & -4.8 & 3.9 & 15.5 & 173 & 1.190331 \\
\hline 22 & 72 & -19.6 & -4.3 & 12.3 & 27.9 & 214 & 1.445604 \\
\hline 22 & 90 & -6 & -2.5 & 18.4 & 4.3 & 69 & 0.633468 \\
\hline 22 & 108 & -3.8 & -1.5 & 18.4 & 2.8 & 38 & 0.447158 \\
\hline 22 & 126 & -6 & -0.5 & 18.4 & 6.7 & 118 & 0.826074 \\
\hline 22 & 144 & -5.2 & -1.8 & 18.4 & 4.1 & 66 & 0.612783 \\
\hline 22 & 162 & -3.7 & 0 & 18.4 & 4.5 & 73 & 0.653212 \\
\hline $2 \mathrm{~A}$ & 0 & -5.8 & 7.2 & 1.8 & 161.8 & 239 & 2.208978 \\
\hline $2 \mathrm{~A}$ & 18 & -6.1 & 3.3 & 1.8 & 117 & 237 & 2.068185 \\
\hline 2B & 0 & -11.9 & -9.3 & 8.7 & 6.7 & 119 & 0.826074 \\
\hline $2 B$ & 18 & -10 & -7.9 & 5.2 & 9 & 142 & 0.954242 \\
\hline $2 \mathrm{C}$ & 0 & -7.1 & -3.3 & 18.4 & 4.6 & 77 & 0.662757 \\
\hline $2 \mathrm{C}$ & 18 & -5.6 & -3 & 18.4 & 3.2 & 44 & 0.505149 \\
\hline $3 A$ & 0 & -0.1 & 211 & 3.3 & 1432.9 & 255 & 3.156215 \\
\hline $3 \mathrm{~A}$ & 18 & -0.2 & 132.5 & 3.3 & 900.8 & 253 & 2.954628 \\
\hline $3 B$ & 0 & -10.8 & -8.6 & 8.7 & 5.7 & 106 & 0.755874 \\
\hline $3 B$ & 18 & -10.3 & -8.6 & 5.2 & 7.3 & 133 & 0.863322 \\
\hline $3 \mathrm{C}$ & 0 & -9.9 & -8.4 & 8.7 & 3.9 & 58 & 0.591064 \\
\hline $3 C$ & 18 & -11 & -8.8 & 8.7 & 5.7 & 107 & 0.755874 \\
\hline $4 \mathrm{~A}$ & 0 & -5.9 & 5.7 & 1.8 & 144.4 & 238 & 2.159567 \\
\hline $4 A$ & 18 & -4 & 184 & 1.8 & 2339.6 & 257 & 3.369141 \\
\hline 4B & 0 & -4.5 & 64.9 & 1.8 & 863.6 & 252 & 2.936312 \\
\hline $4 B$ & 18 & -2.3 & 2 & 18.4 & 5.2 & 94 & 0.716003 \\
\hline $4 C$ & 0 & -10 & -8.4 & 5.2 & 6.9 & 125 & 0.838849 \\
\hline $4 \mathrm{C}$ & 18 & -10.6 & -8.6 & 8.7 & 5.1 & 92 & 0.707570 \\
\hline $5 \mathrm{~A}$ & 0 & -3.5 & 105.6 & 1.8 & 1357.7 & 254 & 3.132803 \\
\hline $5 \mathrm{~A}$ & 18 & -5.3 & 44 & 1.8 & 613.5 & 251 & 2.787814 \\
\hline $5 B$ & 0 & -5.8 & 7.8 & 1.8 & 169.2 & 240 & 2.228400 \\
\hline $5 \mathrm{C}$ & 0 & -10 & -8.9 & 5.2 & 4.7 & 81 & 0.672097 \\
\hline $5 \mathrm{C}$ & 18 & -11 & -8.8 & 8.7 & 5.7 & 108 & 0.755874 \\
\hline $6 \mathrm{~A}$ & 0 & -3.7 & 0.1 & 18.4 & 4.6 & 78 & 0.662757 \\
\hline $6 \mathrm{~A}$ & 18 & -1.4 & 1 & 18.4 & 2.9 & 40 & 0.462397 \\
\hline $6 \mathrm{~B}$ & 0 & -5.4 & 324 & 1.8 & 4099.2 & 258 & 3.612699 \\
\hline $6 \mathrm{~B}$ & 18 & -6.1 & 2.9 & 1.8 & 112 & 235 & 2.049218 \\
\hline $6 \mathrm{C}$ & 0 & -10.6 & -8.6 & 8.7 & 5.1 & 93 & 0.707570 \\
\hline $6 \mathrm{C}$ & 18 & -11.4 & -9.2 & 8.7 & 5.7 & 109 & 0.755874 \\
\hline
\end{tabular}




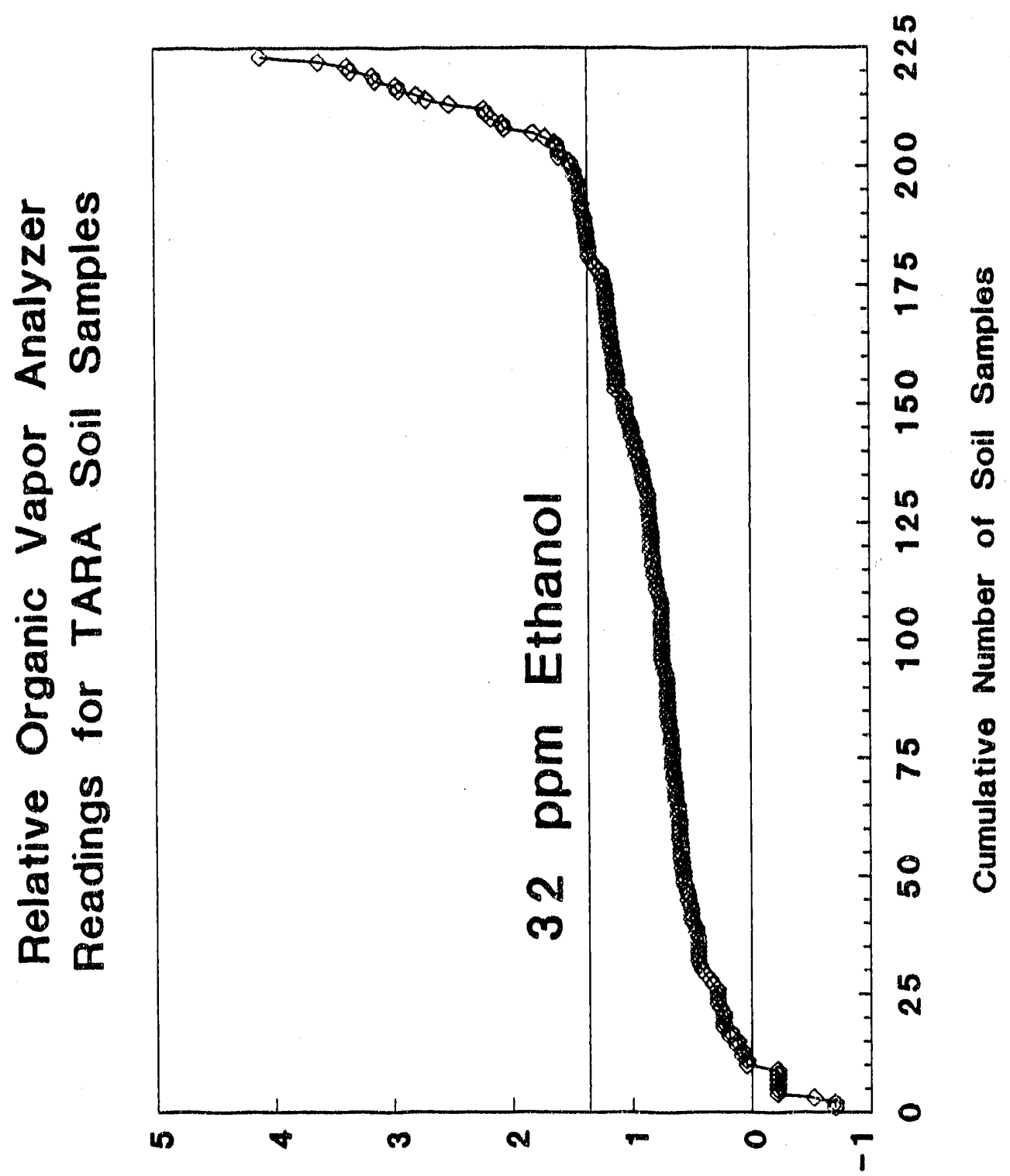

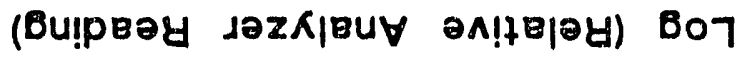

Fig. 18. Frequency distribution of adjusted organic vapor analyzer readings for TARA soil samples. 
Table 9. Volatile organic compounds analyzed for in TARA soll samples

\begin{tabular}{llc}
\hline Compound & CAS No & $\begin{array}{c}\text { Detection Limlt } \\
(\mu \mathrm{Hg} / \mathrm{kg})\end{array}$ \\
& & 10 \\
\hline Chloromethane & $74-87-3$ & 10 \\
Bromomethane & $74-83-9$ & 10 \\
Vinyl chloride & $75-01-4$ & 10 \\
Chloroethane & $75-00-3$ & 10 \\
Methylene chloride & $75-09-2$ & 10 \\
Acetone & $67-64-1$ & 5 \\
Carbon disulfide & $75-15-0$ & 5 \\
1,1-Dichloroethene & $75-35-4$ & 5 \\
1,1-Dichloroethane & $75-34-3$ & 5 \\
1,2-Dichloroethene & $540-59-0$ & 5 \\
Chloroform & $67-66-3$ & 5 \\
1,2-Dichloroethane & $107-06-2$ & 10 \\
2-Butanone & $78-93-3$ & 5 \\
1,1,1-Tr1chloroethane & $71-55-6$ & 5 \\
Carbon tetrachloride & $56-23-5$ & 10 \\
Vinyl acetate & $108-05-4$ & 5 \\
Bromodichloromethane & $75-27-4$ & 5 \\
1,2-Dichloropropane & $78-87-5$ & 5 \\
cis-1,3-Dichloropropene & $10061-01-5$ & 5 \\
Trichloroethene & $79-01-6$ & 5 \\
Dibromochloromethane & $124-48-1$ & 5 \\
1,1,2-Trichloroethane & $79-00-5$ & 5 \\
Benzene & $71-43-2$ & 5 \\
trans-1,3-Dichloropropene & $10061-02-06$ & 5 \\
Bromoform & $75-25-2$ & 5 \\
4-Methyl-2-pentanone & $108-10-1$ & 5 \\
2-Hexanone & $591-78-6$ & 5 \\
Tetrachloroethene & $127-18-4$ & 5 \\
1,1,2,2-Tetrachloroethane & $79-34-5$ & 5 \\
Toluene & $108-88-3$ & 5 \\
Chlorobenzene & $108-90-7$ & 5 \\
Ethylbenzene & $100-41-4$ & 5 \\
Styrene & $100-42-5$ & 5 \\
Xylene (total) & $1330-20-7$ & 5 \\
& & 5 \\
\hline
\end{tabular}


Table 10. Organic compounds detected In TARA soll samples selected from organic vapor analyzer responses

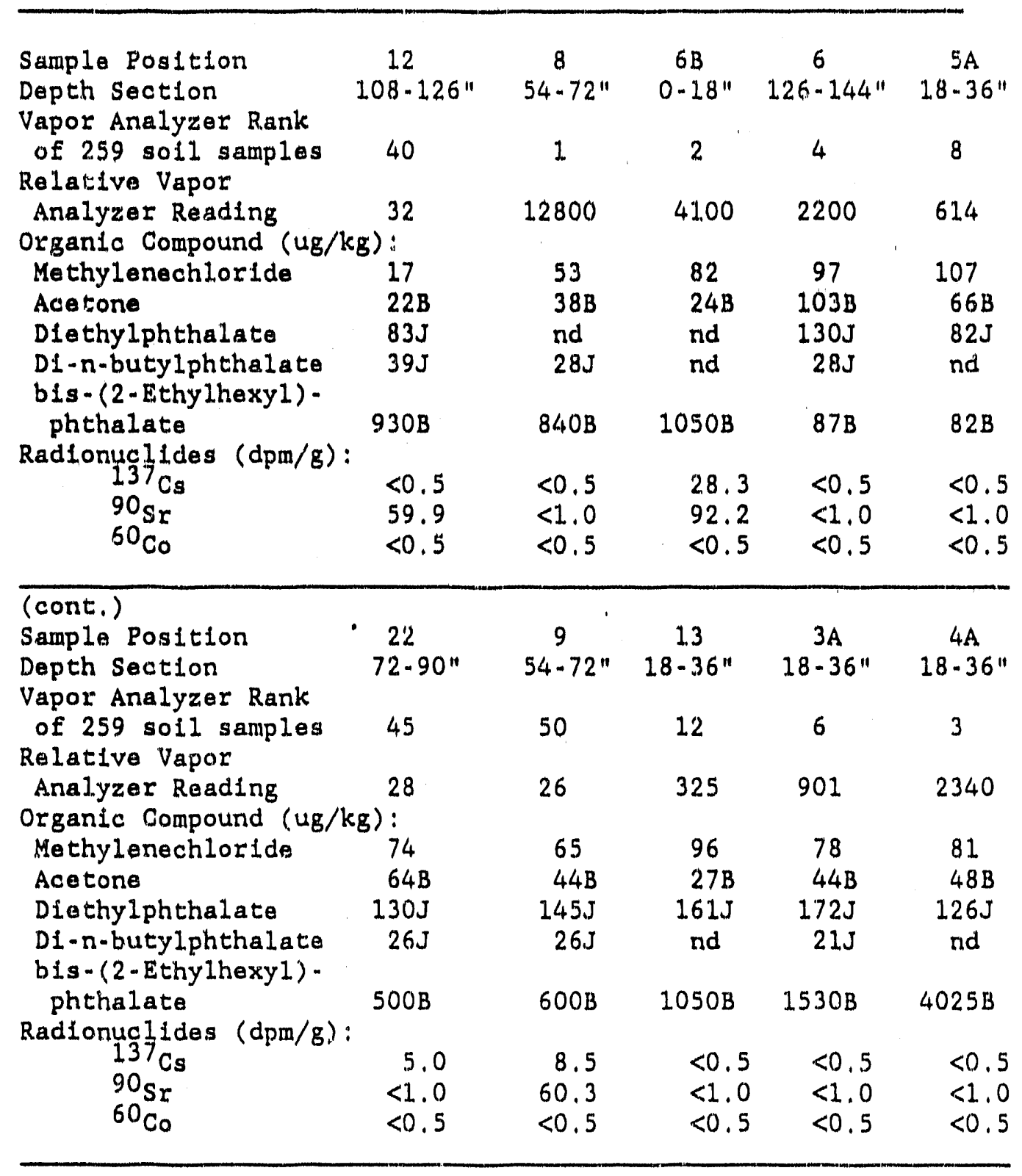

NOTES :

nd - not detected.

B - This data qualifier appears for a compound which was detected in both the sample and 1 ts assoclated blank.

$\mathrm{J}$ - Indicates that the quantitative value is estimated. It appears after a value which is below the quantitation limit but above the detection limit. 
known to be highly dependent on counting geometry and aample material characteristlgg, but these were held constant for all samples and standards. The reported $90 \mathrm{Sx}$ activities would also include other hard-beta emitters, other than $137 \mathrm{Cs}$ and $60 \mathrm{Co}$, whloh $\mathrm{mlght}$ also produce bremastrahlung emission. Unamblguous methods for the determination of $90_{\mathrm{Sr}}$ in soll involva complate sample dissolution and radiochemical fractionation with final beta counting. The savings in cost and time were fudged adequate compensation for the increase in ease and spoed of sample assay. It ls reassuring that the technique does not produce Ealse negatives; if $90 \mathrm{Sr}$ is present in a soll sample above the detection limit of $1.0 \mathrm{dpm} / \mathrm{g}$, then 1 is detected.

Results of these radionuclide assays are presented in Table 11. Two general observations about this group of samples are worthy of mention. Flrst, although all these samples were taken within a few feet of trenoh bouridaries, relatively fow showed significant lovels of contamination partlcularly at depth; only the bottom section of position 9 (between trenches 3 and 4) exhibited a high level $(186,000 \mathrm{dpm} / \mathrm{g})$ of $90_{\mathrm{Sr}}$ at the 162 . to 180-in. Interval. Lower levela of contamination by several isotopes were found in the samples just below the surface $\left(1, e_{1},>18 \mathrm{ln}\right.$, and $\left.<54 \mathrm{ln},\right)$ in samples both off and over the trenches. The presence of radioactivity at shallow depth at positions not dreotly over the trenches indicates that the radioactivity may have been spread to these positions during elther the attempted package retrleval in 1973 or during the installation of the shallow bentonite seal in 1976. It would seam unlikely that this contamination would have resulted from the water filing tests in July and October 1987 bacause most of the contamination is associated with $137 \mathrm{Cs}$. Not only is $137 \mathrm{Cs}$ strongly adsorbed to soll and, hence, lmmoblie in these solls (Ceriling and Spalding 1981), but samples of the trench leachate, collected from the trenches during the water filling tests, showed mostly hard-beta activity assoclated with ${ }^{90} \mathrm{Sr}$ (Table 15 , next section), not ${ }^{13} \mathrm{Cs}$. It should also be noted that only one sample, with the highest level of $90 \mathrm{Sr}$ contamination, was detected using the fleld Geiger-Mueller counter as a screening tool.

\section{MEASUREMENT OF TRENCH VOID VOLUMES}

An important quantitative indlcator of the beneflts of trench compaction is the reduction of trench volds which is achieved. The method selected to measure these volds prior to trench compaction was the filining of the flve trenches with a known volume of water, taking into consideration the losses due to seepage into the surrounding soll. that takes place during filifing. Water was pumped from the emergency waste holding basin to the north of the TARA site into one of the five trenches. Trench 2 was filled between Dctober 26 and 28,1987 , and recelved $55 \mathrm{~m}^{3}(14,555 \mathrm{gal})$ of water, Trench 3 was fllled between October 19 and 20,1987 , and received $53 \mathrm{~m}^{3}$ (14,071 gal.) of water, Trench 4 was filled between July 27 and August 3, 1987, and recelved $100 \mathrm{~m}^{3}(26,422 \mathrm{gal})$ of water. Trench 5 was filled between October 22 and 23 , 1987, and received $77 \mathrm{~m}^{3}(20,367 \mathrm{gal})$ of water. Trench 6 was filled between October 28 and November 2, 1987, and recelved $55 \mathrm{~m}^{3}(14,440 \mathrm{gal})$ of water.

Water was delivered to the trenches vla a $5-\mathrm{cm}(2-\mathrm{ln}$.) rubber hose run to the bottom of one of the irtratrench wells. The water delivery was allowed 
Table 1.1. Radionuclides In soli gamples from around the TARA burlal trenches

\begin{tabular}{|c|c|c|c|c|c|}
\hline \multirow{2}{*}{$\begin{array}{l}\text { Sample } \\
\text { posttion }\end{array}$} & \multicolumn{2}{|c|}{ Section } & \multirow[b]{2}{*}{$\begin{array}{c}137 \mathrm{Cs} \\
(\mathrm{dpm} / \mathrm{g})\end{array}$} & \multirow[b]{2}{*}{$\begin{array}{c}{ }^{60} \mathrm{Co} \\
(\mathrm{dpm} / \mathrm{g})\end{array}$} & \multirow[b]{2}{*}{$\begin{array}{c}90 \mathrm{Sr} \\
(\mathrm{dpm} / \mathrm{g})\end{array}$} \\
\hline & $\begin{array}{l}\text { Top } \\
(\ln ,)\end{array}$ & $\begin{array}{c}\text { Bottom } \\
\left(\ln n_{1}\right)\end{array}$ & & & \\
\hline 1 & 0 & 18 & 30.5 & $<0.5$ & 192.1 \\
\hline$i$ & 18 & 36 & $<0,5$ & $<0.3$ & 76.3 \\
\hline 1 & 36 & 54 & $<0.5$ & $<0.5$ & $<1.0$ \\
\hline 1 & 54 & 72 & $<0.5$ & $<0.5$ & $<1,0$ \\
\hline 1 & 72 & 90 & $<0.5$ & $<0.5$ & $<1.0$ \\
\hline 1 & 90 & 108 & $<0.5$ & $<0.5$ & $<1,0$ \\
\hline 1. & 108 & 12.6 & $<0,5$ & $<0.5$ & $<1.0$ \\
\hline 2 & 0 & 18 & 121.9 & $<0.5$ & $<1.0$ \\
\hline 2 & 18 & 36 & $<0,5$ & $<0.5$ & $<1,0$ \\
\hline 2 & 36 & 54 & $<0,5$ & $<0,5$ & 133.5 \\
\hline 2 & 54 & 72 & $<0,5$ & $<0.5$ & $<1,0$ \\
\hline 2 & 72 & 90 & $<0.5$ & $<0.5$ & $<1.0$ \\
\hline 2 & 90 & 108 & $<0.5$ & $<0.5$ & 16.3 \\
\hline 2 & 108 & 126 & $<0,5$ & $<0.5$ & $<1.0$ \\
\hline 2 & 126 & 1.44 & $<0.5$ & $<0.5$ & $<1.0$ \\
\hline 2 & 144 & 162 & $<0,5$ & $<0,5$ & $<1.0$ \\
\hline 2 & 162 & 180 & $<0.5$ & $<0.5$ & $<1.0$ \\
\hline 3 & 0 & 18 & $<0.5$ & $<0.5$ & 117.2 \\
\hline 3 & 18 & 36 & $<0.5$ & $<0.5$ & $<1,0$ \\
\hline 3 & 36 & 54 & 29.8 & $<0.5$ & 7.8 \\
\hline 3 & 54 & 72 & $<0.5$ & $<0.5$ & $<1.0$ \\
\hline 3 & 72 & 90 & 2.8 & $<0,5$ & $<1.0$ \\
\hline 3 & 90 & 108 & $<0.5$ & $<0.5$ & $<1,0$ \\
\hline 3 & 108 & 126 & $<0.5$ & $<0.5$ & $<1,0$ \\
\hline 3 & 126 & 144 & $<0,5$ & $<0.5$ & $<1.0$ \\
\hline 3 & 144 & 162 & $<0.5$ & $<0.5$ & $<1.0$ \\
\hline 3 & 1.62 & 180 & $<0.5$ & $<0.5$ & $<1,0$ \\
\hline 4 & 0 & 18 & $<0.5$ & $<0.5$ & $<1.0$ \\
\hline 4 & 18 & 36 & $<0.5$ & $<0.5$ & 46,3 \\
\hline 4 & 36 & 54 & $<0.5$ & 9.5 & $<1.0$ \\
\hline 4 & 54 & 72 & $<0.5$ & $<0.5$ & $<1,0$ \\
\hline 4 & 72 & 90 & $<0.5$ & $<0.5$ & 122.6 \\
\hline 5 & 0 & 18 & $<0.5$ & $<0.5$ & $<1.0$ \\
\hline 5 & 18 & 36 & 3604.5 & $<0.5$ & 1.481 .4 \\
\hline 5 & 36 & 54 & $<0,5$ & $<0.5$ & 359.7 \\
\hline 5 & 54 & 72 & 4.3 & $<0.5$ & 39.4 \\
\hline 5 & 72 & 90 & $<0,5$ & $<0.5$ & $<1.0$ \\
\hline 5 & 90 & 108 & $<0.5$ & $<0.5$ & $<1.0$ \\
\hline 5 & 108 & 126 & 42.5 .9 & $<0.5$ & $<1.0$ \\
\hline 6 & 0 & 18 & $<0,5$ & $<0.5$ & 32.7 \\
\hline 6 & 18 & 36 & 58.8 & $<0.5$ & 3.7 \\
\hline 6 & 36 & 54 & $<0.5$ & $<0.5$ & $<1,0$ \\
\hline 6 & 54 & 72 & $<0.5$ & $<0.5$ & $<1,0$ \\
\hline 6 & 72 & 90 & $<0.5$ & $<0.5$ & $<1.0$ \\
\hline 6 & 90 & 108 & 43.2 & $<0.5$ & $<1,0$ \\
\hline
\end{tabular}


Table 11. (Continued)

\begin{tabular}{|c|c|c|c|c|c|}
\hline \multirow{2}{*}{$\begin{array}{l}\text { Sample } \\
\text { Position }\end{array}$} & \multicolumn{2}{|c|}{ Section } & \multirow[b]{2}{*}{$\begin{array}{c}137 \mathrm{Cs} \\
(\mathrm{dpm} / \mathrm{g})\end{array}$} & \multirow[b]{2}{*}{$\begin{array}{c}{ }^{60} \mathrm{Co} \\
(\mathrm{dpm} / \mathrm{g})\end{array}$} & \multirow[b]{2}{*}{$\begin{array}{c}90_{\mathrm{Sr}} \\
(\mathrm{dpm} / \mathrm{g})\end{array}$} \\
\hline & $\begin{array}{l}\text { Top } \\
(\ln .)\end{array}$ & $\begin{array}{l}\text { Bottom } \\
(1 \mathrm{n} .)\end{array}$ & & & \\
\hline 6 & 108 & 126 & $<0.5$ & $<0.5$ & $<1.0$ \\
\hline 6 & 126 & 144 & $<0.5$ & $<0.5$ & $<1.0$ \\
\hline 6 & 1.44 & 162 & $<0.5$ & $<0.5$ & $<1.0$ \\
\hline 6 & 162 & 180 & 3.5 & $<0.5$ & $<1,0$ \\
\hline 7 & 0 & 18 & $<0.5$ & $<0.5$ & $<1.0$ \\
\hline 7 & 18 & 36 & $<0.5$ & $<0.5$ & $<1.0$ \\
\hline 7 & 36 & 54 & $<0.5$ & $<0.5$ & 2.7 \\
\hline 7 & 54 & 72 & $<0.5$ & $<0.5$ & 40.9 \\
\hline 7 & 72 & 90 & $<0.5$ & $<0.5$ & $<1.0$ \\
\hline 7 & 90 & 108 & $<0.5$ & $<0.5$ & $<1.0$ \\
\hline 7 & 108 & 126 & $<0.5$ & $<0.5$ & $<1.0$ \\
\hline 8 & 0 & 18 & $<0.5$ & $<0.5$ & $<1.0$ \\
\hline 8 & 18 & 36 & $<0.5$ & $<0.5$ & $<1.0$ \\
\hline 8 & 36 & 54 & $<0.5$ & $<0,5$ & $<1.0$ \\
\hline 8 & 54 & 72 & $<0.5$ & $<0,5$ & $<1.0$ \\
\hline 8 & 72 & 90 & $<0.5$ & $<0.5$ & $<1.0$ \\
\hline 9 & 0 & 18 & 60.2 & $<0.5$ & $<1,0$ \\
\hline 9 & 18 & 36 & $<0.5$ & $<0.5$ & $<1.0$ \\
\hline 9 & 36 & 54 & $<0.5$ & $<0.5$ & $<1.0$ \\
\hline 9 & 54 & 72 & 8.5 & $<0.5$ & 60.3 \\
\hline 9 & 72 & 90 & $<0.5$ & $<0.5$ & $<1.0$ \\
\hline 9 & 90 & 108 & 9.9 & $<0.5$ & $<1.0$ \\
\hline 9 & 108 & 126 & $<0.5$ & $<0.5$ & $<1,0$ \\
\hline 9 & 126 & $14 / 4$ & $<0.5$ & 9.5 & $<1.0$ \\
\hline 9 & 144 & 162 & $<0.5$ & $<0.5$ & $<1.0$ \\
\hline 9 & 162 & 180 & $<0.5$ & 7846.21 & 86501.4 \\
\hline 10 & 0 & 18 & $<0.5$ & $<0.5$ & 392.4 \\
\hline 10 & 18 & 36 & 17 & $<0.5$ & $<1.0$ \\
\hline 10 & 36 & 54 & $<0.5$ & $<0.5$ & 57.2 \\
\hline 10 & 54 & 72 & 1.4 & $<0.5$ & 112.3 \\
\hline 10 & 72 & 90 & 31.2 & $<0.5$ & 112 \\
\hline 10 & 90 & 108 & 2.8 & $<0.5$ & $<1.0$ \\
\hline 10 & 108 & 126 & $<0.5$ & $<0.5$ & $<1.0$ \\
\hline 10 & 126 & 144 & $<0.5$ & $<0.5$ & $<1.0$ \\
\hline 10 & 144 & 1.62 & $<0.5$ & $<0.5$ & $<1.0$ \\
\hline 10 & 162 & 180 & $<0.5$ & $<0.5$ & $<1.0$ \\
\hline 11 & 0 & 18 & $<0.5$ & $<0.5$ & $<1.0$ \\
\hline 11 & 18 & 36 & 53.2 & $<0.5$ & $<1.0$ \\
\hline 11 & 36 & 54 & $<0.5$ & $<0.5$ & $<1,0$ \\
\hline 11 & 54 & 72 & 4.3 & $<0.5$ & $<1.0$ \\
\hline 11 & 72 & 90 & $<0.5$ & $<0.5$ & $<1.0$ \\
\hline 11 & 90 & 108 & $<0.5$ & $<0.5$ & $<1.0$ \\
\hline 11 & 108 & 126 & $<0.5$ & $<0.5$ & $<1.0$ \\
\hline 11. & 126 & 144 & $<0.5$ & $<0.5$ & $<1,0$ \\
\hline 11 & 144 & 162 & $<0.5$ & $<0,5$ & $<1.0$ \\
\hline 11 & 162 & 180 & $<0.5$ & $<0.5$ & $<1.0$ \\
\hline
\end{tabular}


Table 11. (Continued)

\begin{tabular}{|c|c|c|c|c|c|}
\hline \multirow{2}{*}{$\begin{array}{l}\text { Sample } \\
\text { Position }\end{array}$} & \multicolumn{2}{|c|}{ Section } & \multirow[b]{2}{*}{$\begin{array}{c}137 \mathrm{Cs} \\
(\mathrm{dpm} / \mathrm{g})\end{array}$} & \multirow[b]{2}{*}{$\begin{array}{c}{ }^{60} \mathrm{Co} \\
(\mathrm{dpm} / \mathrm{g})\end{array}$} & \multirow[b]{2}{*}{$\begin{array}{r}{ }^{90} \mathrm{Sr} \\
(\mathrm{dpm} / \mathrm{g})\end{array}$} \\
\hline & $\begin{array}{l}\text { Top } \\
\text { (in.) }\end{array}$ & $\begin{array}{l}\text { Bottom } \\
\text { (in.) }\end{array}$ & & & \\
\hline 12 & 0 & 18 & $<0.5$ & $<0.5$ & $<1.0$ \\
\hline 12 & 18 & 36 & 23.4 & $<0.5$ & $<1.0$ \\
\hline 12 & 36 & 54 & $<0.5$ & $<0.5$ & $<1.0$ \\
\hline 12 & 54 & 72 & $<0.5$ & $<0.5$ & 68.1 \\
\hline 12 & 72 & 90 & $<0.5$ & $<0.5$ & $<1.0$ \\
\hline 12 & 90 & 108 & $<0.5$ & $<0.5$ & $<1.0$ \\
\hline 12 & 108 & 126 & $<0.5$ & $<0.5$ & 59.9 \\
\hline 12 & 90 & 108 & $<0.5$ & $<0.5$ & $<1.0$ \\
\hline 12 & 108 & 126 & $<0.5$ & $<0.5$ & 59.9 \\
\hline 12 & 126 & 144 & $<0.5$ & $<0.5$ & $<1.0$ \\
\hline 13 & 0 & 18 & 2.1 & $<0.5$ & 7.7 \\
\hline 13 & 18 & 36 & $<0.5$ & $<0.5$ & $<1.0$ \\
\hline 13 & 36 & 54 & $<0.5$ & $<0.5$ & $<1.0$ \\
\hline 13 & 54 & 72 & $<0.5$ & $<0.5$ & 19.1 \\
\hline 13 & 72 & 90 & $<0.5$ & $<0.5$ & $<1.0$ \\
\hline 13 & 90 & 108 & 31.2 & $<0.5$ & $<1.0$ \\
\hline 13 & 108 & 126 & 20.6 & $<0.5$ & $<1.0$ \\
\hline 13 & 126 & 144 & $<0.5$ & $<0.5$ & $<1.0$ \\
\hline 13 & 144 & 162 & $<0.5$ & $<0.5$ & $<1.0$ \\
\hline 13 & 162 & 180 & $<0.5$ & $<0.5$ & $<1.0$ \\
\hline 14 & 0 & 18 & $<0.5$ & $<0.5$ & $<1.0$ \\
\hline 14 & 18 & 36 & 15.6 & $<0.5$ & $<1.0$ \\
\hline 14 & 36 & 54 & $<0.5$ & $<0.5$ & $<1.0$ \\
\hline 14 & 54 & 72 & $<0.5$ & $<0.5$ & $<1.0$ \\
\hline 14 & 72 & 90 & $<0.5$ & $<0.5$ & $<1.0$ \\
\hline 14 & 90 & 108 & $<0.5$ & $<0.5$ & $<1.0$ \\
\hline 14 & 108 & 126 & $<0.5$. & $<0.5$ & $<1.0$ \\
\hline 14 & 126 & 144 & $<0.5$ & $<0.5$ & $<1.0$ \\
\hline 14 & 144 & 162 & 14.2 & $<0.5$ & $<1.0$ \\
\hline 14 & 162 & 180 & $<0.5$ & $<0.5$ & $<1.0$ \\
\hline 15 & 0 & 18 & $<0.5$ & $<0.5$ & $<1.0$ \\
\hline 15 & 18 & 36 & $<0.5$ & $<0.5$ & $<1.0$ \\
\hline 15 & 36 & 54 & $<0.5$ & $<0.5$ & $<1.0$ \\
\hline 15 & 54 & 72 & $<0.5$ & $<0.5$ & $<1.0$ \\
\hline 15 & 72 & 90 & $<0.5$ & $<0.5$ & $<1.0$ \\
\hline 15 & 90 & 108 & $<0.5$ & $<0.5$ & $<1.0$ \\
\hline 15 & 108 & 126 & $<0.5$ & $<0.5$ & $<1.0$ \\
\hline 15 & 126 & 144 & $<0.5$ & $<0.5$ & $<1.0$ \\
\hline 15 & 144 & 162 & $<0.5$ & $<0.5$ & $<1.0$ \\
\hline 15 & 162 & 180 & $<0.5$ & $<0.5$ & $<1.0$ \\
\hline 16 & 0 & 18 & 474.1 & 530.2 & 1210.9 \\
\hline 16 & 18 & 36 & 134.7 & 111.2 & 410.8 \\
\hline 16 & 36 & 54 & 107 & $<0,5$ & 290.8 \\
\hline 16 & 54 & 72 & $<0.5$ & $<0.5$ & $<1.0$ \\
\hline 16 & 72 & 90 & $<0,5$ & $<0.5$ & $<1.0$ \\
\hline 16 & 90 & 108 & $<0.5$ & $<0.5$ & $<1.0$ \\
\hline
\end{tabular}


Table 11. (Continued)

\begin{tabular}{|c|c|c|c|c|c|}
\hline \multirow{2}{*}{$\begin{array}{l}\text { Sample } \\
\text { Position }\end{array}$} & \multicolumn{2}{|c|}{ Section } & \multirow[b]{2}{*}{$\begin{array}{c}{ }^{137} \mathrm{Cs} \\
(\mathrm{dpm} / \mathrm{g})\end{array}$} & \multirow[b]{2}{*}{$\begin{array}{c}{ }^{60} \mathrm{Co} \\
(\mathrm{dpm} / \mathrm{g})\end{array}$} & \multirow[b]{2}{*}{$\begin{array}{c}{ }^{90} \mathrm{Sr} \\
(\mathrm{dpm} / \mathrm{g})\end{array}$} \\
\hline & $\begin{array}{l}\text { Top } \\
\text { (in.) }\end{array}$ & $\begin{array}{l}\text { Bottom } \\
\text { (In.) }\end{array}$ & & & \\
\hline 16 & 108 & 126 & $<0.5$ & $<0.5$ & $<1.0$ \\
\hline 16 & 126 & 144 & $<0.5$ & $<0.5$ & $<1.0$ \\
\hline 17 & 0 & 18 & $<0.5$ & $<0.5$ & $<1.0$ \\
\hline 17 & 18 & 36 & 59.5 & $<0.5$ & 76.2 \\
\hline 17 & 36 & 54 & 14.9 & $<0.5$ & $<1.0$ \\
\hline 17 & 54 & 72 & $<0.5$ & $<0.5$ & $<1.0$ \\
\hline 17 & 72 & 90 & $<0.5$ & $<0.5$ & $<1.0$ \\
\hline 17 & 90 & 108 & $<0.5$ & $<0.5$ & $<1.0$ \\
\hline 17 & 108 & 126 & $<0.5$ & 16.6 & $<1.0$ \\
\hline 17 & 126 & 144 & $<0.5$ & $<0.5$ & $<1.0$ \\
\hline 17 & 144 & 162 & 2.1 & $<0.5$ & $<1.0$ \\
\hline 17 & 162 & 180 & $<0.5$ & $<0.5$ & $<1.0$ \\
\hline 18 & 0 & 18 & $<0.5$ & $<0.5$ & $<1.0$ \\
\hline 18 & 18 & 36 & $<0.5$ & $<0.5$ & $<1.0$ \\
\hline 18 & 36 & 54 & 775.3 & 42.6 & 220.2 \\
\hline 18 & 54 & 72 & 82.2 & $<0.5$ & 16.1 \\
\hline 18 & 72 & 90 & $<0.5$ & $<0.5$ & $<1.0$ \\
\hline 18 & 90 & 108 & $<0.5$ & $<0.5$ & $<1.0$ \\
\hline 18 & 108 & 126 & $<0.5$ & $<0.5$ & $<1.0$ \\
\hline 18 & 126 & 144 & $<0.5$ & $<0.5$ & $<1.0$ \\
\hline 18 & 144 & 162 & $<0.5$ & 33.1 & 147.1 \\
\hline 18 & 162 & 180 & $<0.5$ & $<0.5$ & $<1.0$ \\
\hline 19 & 0 & 18 & $<0.5$ & $<0.5$ & $<1.0$ \\
\hline 19 & 18 & 36 & 38.3 & $<0.5$ & $<1.0$ \\
\hline 19 & 36 & 54 & $<0.5$ & $<0.5$ & $<1.0$ \\
\hline 19 & 54 & 72 & 1.4 & $<0.5$ & $<1.0$ \\
\hline 19 & 72 & 90 & $<0.5$ & $<0.5$ & $<1.0$ \\
\hline 19 & 90 & 108 & $<0.5$ & $<0.5$ & $<1.0$ \\
\hline 19 & 108 & 126 & $<0.5$ & $<0.5$ & $<1.0$ \\
\hline 19 & 126 & 144 & $<0.5$ & $<0.5$ & $<1.0$ \\
\hline 19 & 144 & 162 & $<0.5$ & $<0.5$ & $<1.0$ \\
\hline 19 & 162 & 180 & $<0.5$ & $<0.5$ & $<1.0$ \\
\hline 20 & 0 & 18 & 19.1 & $<0.5$ & $<1.0$ \\
\hline 20 & 18 & 36 & $<0.5$ & $<0.5$ & $<1.0$ \\
\hline 20 & 36 & 54 & $<0.5$ & $<0.5$ & $<1.0$ \\
\hline 20 & 54 & 72 & $<0.5$ & $<0.5$ & $<1,0$ \\
\hline 20 & 72 & 90 & $<0.5$ & $<0.5$ & $<1.0$ \\
\hline 20 & 90 & 108 & $<0.5$ & $<0.5$ & $<1.0$ \\
\hline 20 & 108 & 126 & $<0.5$ & $<0.5$ & $<1.0$ \\
\hline 20 & 126 & 144 & $<0.5$ & $<0.5$ & 261.6 \\
\hline 20 & 144 & 162 & 22 & $<0.5$ & 1 \\
\hline 20 & 162 & 180 & $<0.5$ & $<0.5$ & $<1.0$ \\
\hline 21 & 0 & 18 & $<0.5$ & $<0.5$ & $<1.0$ \\
\hline 21 & 18 & 36 & $<0.5$ & $<0.5$ & $<1.0$ \\
\hline 21 & 36 & 54 & $<0.5$ & $<0.5$ & $<1.0$ \\
\hline 21 & 54 & 72. & $<0.5$ & $<0.5$ & $<1.0$ \\
\hline
\end{tabular}


Table 11. (Continued)

\begin{tabular}{|c|c|c|c|c|c|}
\hline \multirow{2}{*}{$\begin{array}{l}\text { Sample } \\
\text { Position }\end{array}$} & \multicolumn{2}{|c|}{ Section } & \multirow[b]{2}{*}{$\begin{array}{c}137 \mathrm{Cs} \\
(\mathrm{dpm} / \mathrm{g})\end{array}$} & \multirow[b]{2}{*}{$\begin{array}{c}{ }^{60} \mathrm{Co} \\
(\mathrm{dpm} / \mathrm{g})\end{array}$} & \multirow[b]{2}{*}{$\begin{array}{c}{ }^{90} \mathrm{Sr} \\
(\mathrm{dpm} / \mathrm{g})\end{array}$} \\
\hline & $\begin{array}{l}\text { Top } \\
\text { (in.) }\end{array}$ & $\begin{array}{l}\text { Bottom } \\
\text { (in.) }\end{array}$ & & & \\
\hline 21 & 72 & 90 & $<0.5$ & 14.2 & $<1.0$ \\
\hline 21 & 90 & 108 & $<0.5$ & $<0.5$ & $<1.0$ \\
\hline 21 & 108 & 126 & $<0.5$ & $<0.5$ & $<1.0$ \\
\hline 21 & 126 & 144 & $<0.5$ & $<0.5$ & $<1.0$ \\
\hline 22 & 0 & 18 & $<0.5$ & $<0.5$ & $<1.0$ \\
\hline 22 & 18 & 36 & 92.1 & $<0.5$ & $<1.0$ \\
\hline 22 & 36 & 54 & $<0.5$ & 20.1 & $<1.0$ \\
\hline 22 & 54 & 72 & $<0.5$ & $<0.5$ & $<1.0$ \\
\hline 22 & 72 & 90 & 5 & $<0.5$ & $<1.0$ \\
\hline 22 & 90 & 108 & $<0.5$ & $<0.5$ & $<1.0$ \\
\hline 22 & 108 & 126 & $<0.5$ & $<0.5$ & $<1.0$ \\
\hline 22 & 126 & 144 & $<0.5$ & $<0.5$ & $<1.0$ \\
\hline 22 & 144 & 162 & $<0.5$ & $<0.5$ & $<1.0$ \\
\hline 22 & 162 & 180 & $<0.5$ & $<0.5$ & $<1.0$ \\
\hline $2 \mathrm{~A}$ & 0 & 18 & 50.3 & $<0.5$ & 19.6 \\
\hline $2 A$ & 18 & 36 & 7779.6 & $<0.5$ & $<1.0$ \\
\hline $2 B$ & 0 & 18 & $<0.5$ & $<0.5$ & $<1.0$ \\
\hline $2 B$ & 18 & 36 & 644.9 & $<0.5$ & $<1.0$ \\
\hline $2 C$ & 0 & 18 & 39 & $<0.5$ & $<1.0$ \\
\hline $2 \mathrm{C}$ & 18 & 36 & 0.7 & $<0.5$ & $<1.0$ \\
\hline $3 \mathrm{~A}$ & 0 & 18 & $<0.5$ & $<0.5$ & $<1.0$ \\
\hline $3 \mathrm{~A}$ & 18 & 36 & $<0.5$ & $<0.5$ & $<1.0$ \\
\hline $3 B$ & 0 & 18 & 11.3 & $<0.5$ & $<1.0$ \\
\hline $3 B$ & 18 & 36 & 856.1 & $<0.5$ & $<1.0$ \\
\hline $3 C$ & 0 & 18 & $<0.5$ & $<0.5$ & $<1.0$ \\
\hline $3 C$ & 18 & 36 & $<0.5$ & $<0.5$ & $<1.0$ \\
\hline $4 \mathrm{~A}$ & 0 & 18 & 7.8 & $<0.5$ & $<1.0$ \\
\hline $4 A$ & 18 & 36 & $<0.5$ & $<0.5$ & $<1.0$ \\
\hline $4 B$ & 0 & 18 & 12 & $<0.5$ & 90.4 \\
\hline $4 B$ & 18 & 36 & 10.6 & $<0.5$ & $<1.0$ \\
\hline $4 C$ & 0 & 18 & 15.6 & $<0.5$ & 125.5 \\
\hline $4 C$ & 18 & 36 & 107 & $<0.5$ & $<1.0$ \\
\hline $5 \mathrm{~A}$ & 0 & 18 & $<0.5$ & $<0.5$ & $<1.0$ \\
\hline $5 A$ & 18 & 36 & 110.6 & $<0.5$ & 562.9 \\
\hline $5 B$ & 0 & 18 & $<0.5$ & $<0.5$ & $<1.0$ \\
\hline $5 B$ & 18 & 36 & 1255.1 & $<0.5$ & $<1.0$ \\
\hline $5 \mathrm{C}$ & 0 & 18 & $<0.5$ & $<0.5$ & $<1.0$ \\
\hline $5 \mathrm{C}$ & 18 & 36 & 854 & 34.3 & $<1.0$ \\
\hline $6 \mathrm{~A}$ & 0 & 18 & $<0.5$ & $<0.5$ & $<1.0$ \\
\hline $6 \mathrm{~A}$ & 1.8 & 36 & $<0.5$ & $<0.5$ & $<1.0$ \\
\hline $6 B$ & 0 & 18 & 28.3 & $<0.5$ & 92.2 \\
\hline $6 B$ & 18 & 36 & 322.5 & 29.6 & 529 \\
\hline $6 \mathrm{C}$ & 0 & 18 & $<0.5$ & $<0.5$ & $<1.0$ \\
\hline $6 \mathrm{C}$ & 18 & 36 & 2679.7 & $<0.5$ & $<1.0$ \\
\hline
\end{tabular}


to continue overnight under continuous surveillance until water level monitoring in additional intratrench wells indicated that the water was within approximately $0.5 \mathrm{~m}$ of the ground surface. At this point, the flow rate was elther adjusted downward to determine the minimum flow required to maintain the existing head or turned off. When the pump was turned off, the head in the observation wells was monitored periodically until the trench was completely drained. This made possible the determination of seepage rates required to correct for seepage during the water delivery interval and indicated when it would be possible to begin the next water pump-in test in the adjacent trench. Water levels, or more frequently the lack of standing water, in neighboring trenches were also monitored during the filling and draining intervals to identify any hydrologic connection among the burial trenches. Among the five trenches at the eastern end of the TARA site, no interconnection of burial trenches was observed during the filling tests. Figures 19 through 23 summarize the intratrench well hydrographs during the water pump-in tests for trenches 2 through 6 , respectively. Water levels in the 15 groundwater monitoring wells were measured periodically during the trench-filling process to determine which, if any, of the wells would respond to trench filling. Results are included in the well hydrographs of Appendix III. 


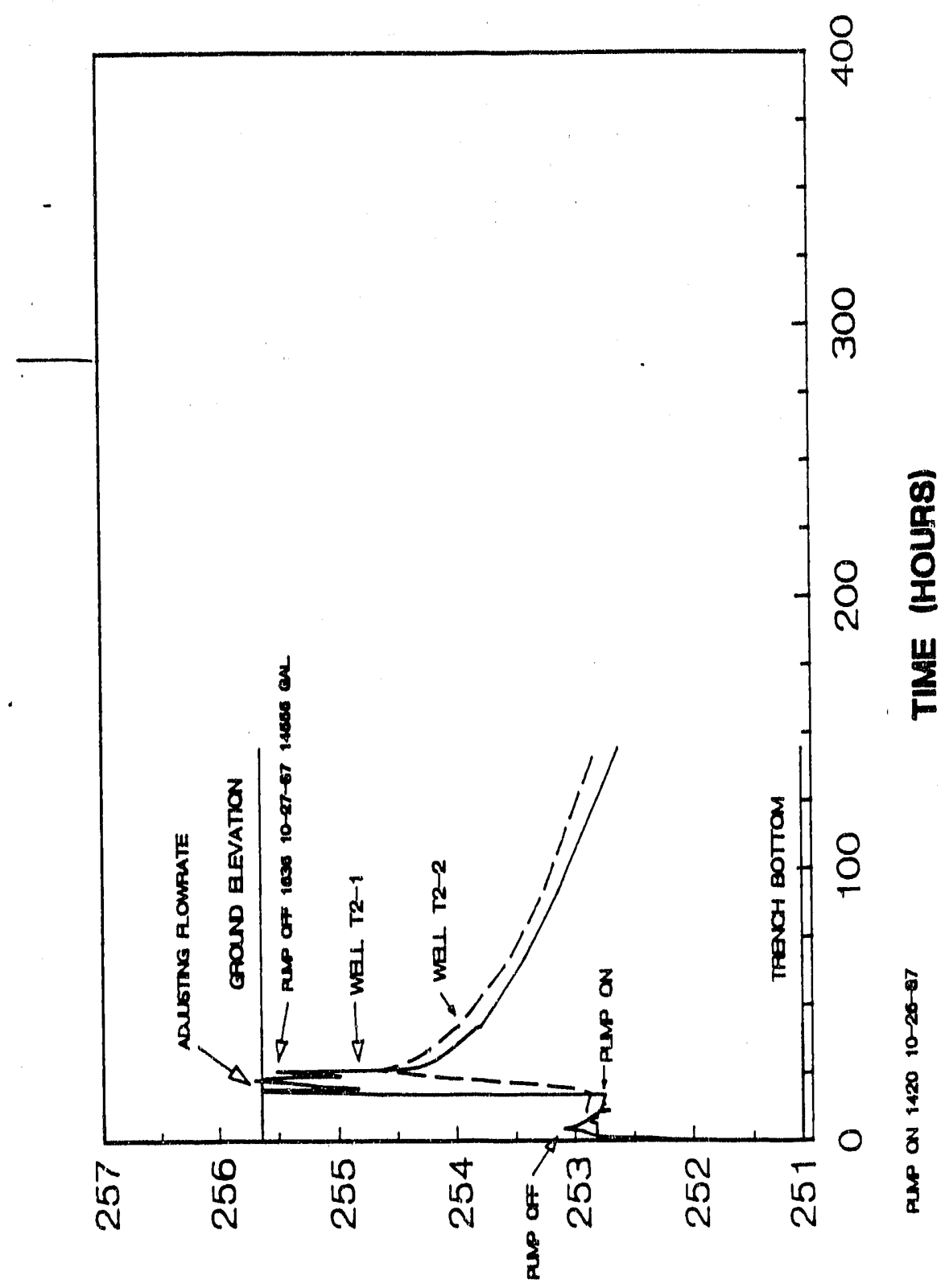

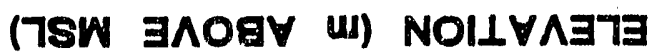

Fig. 19. Water pump-in test hydrograph for TARA trench 2. 


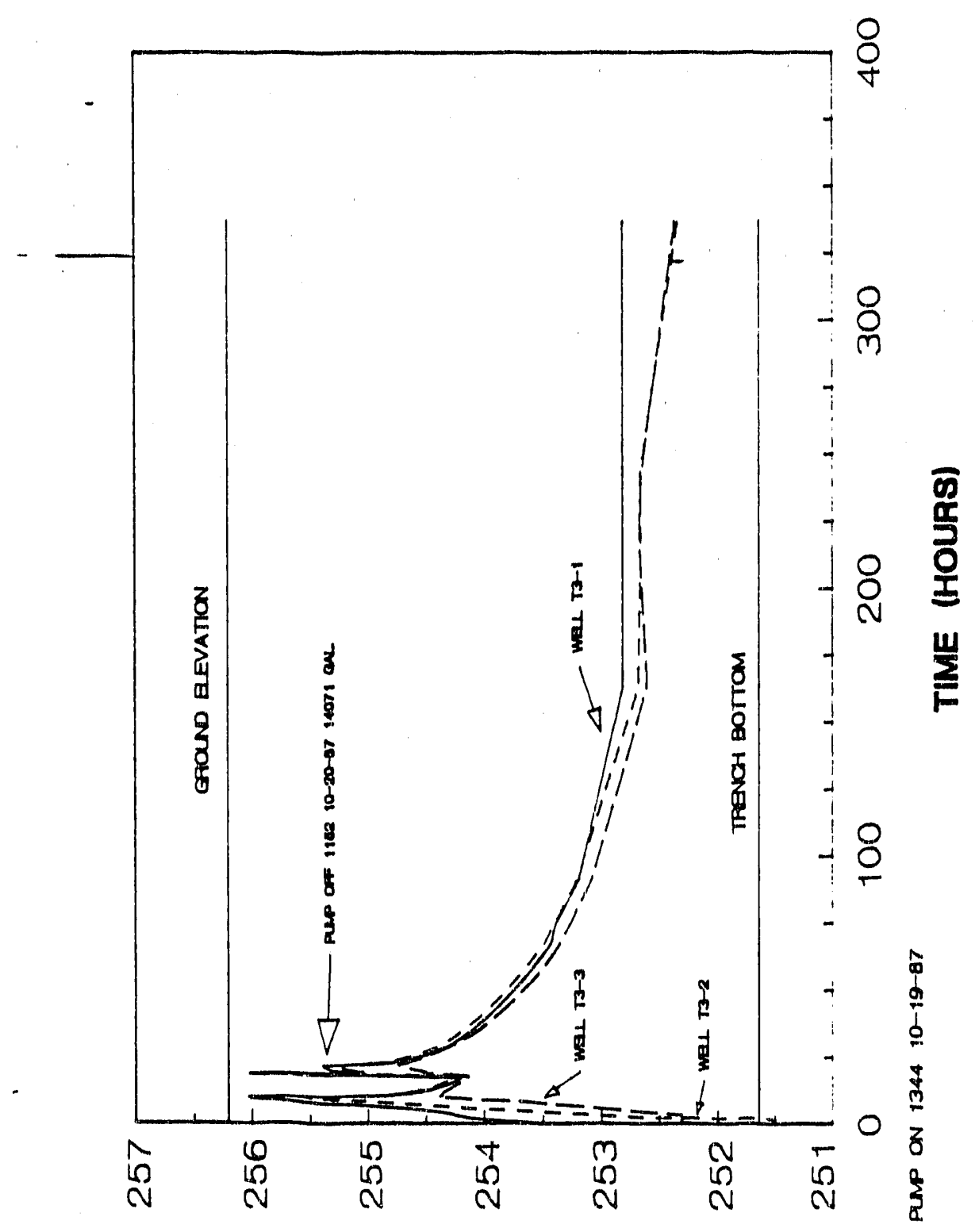

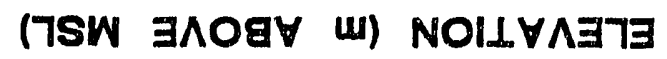

Fig. 20. Water pump-in test hydrograph for TARA trench 3. 


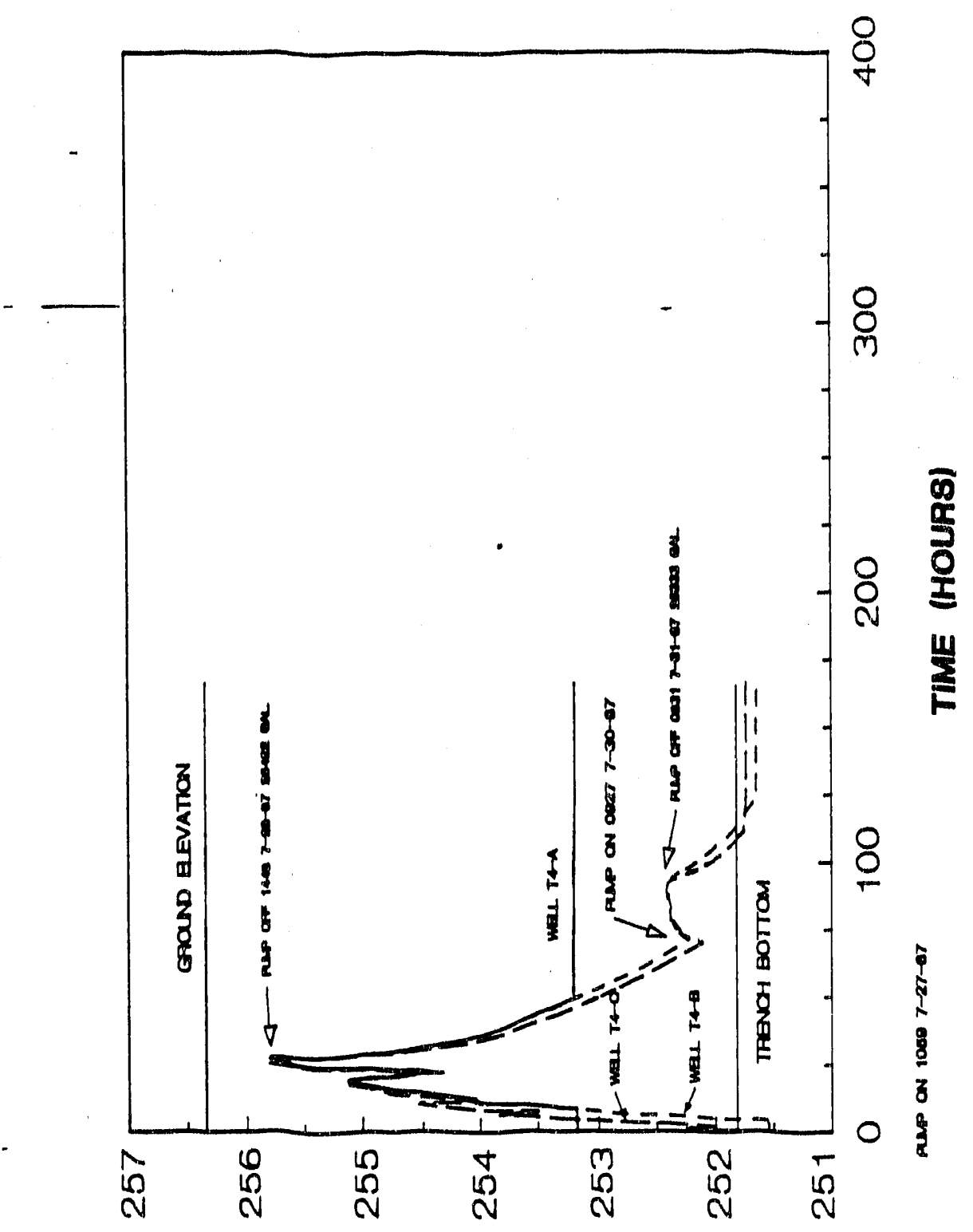

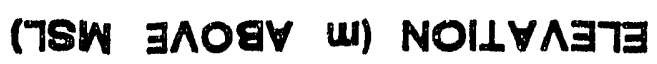

Fig. 21. Water pump-in test hydrograph for TARA trench 4. 


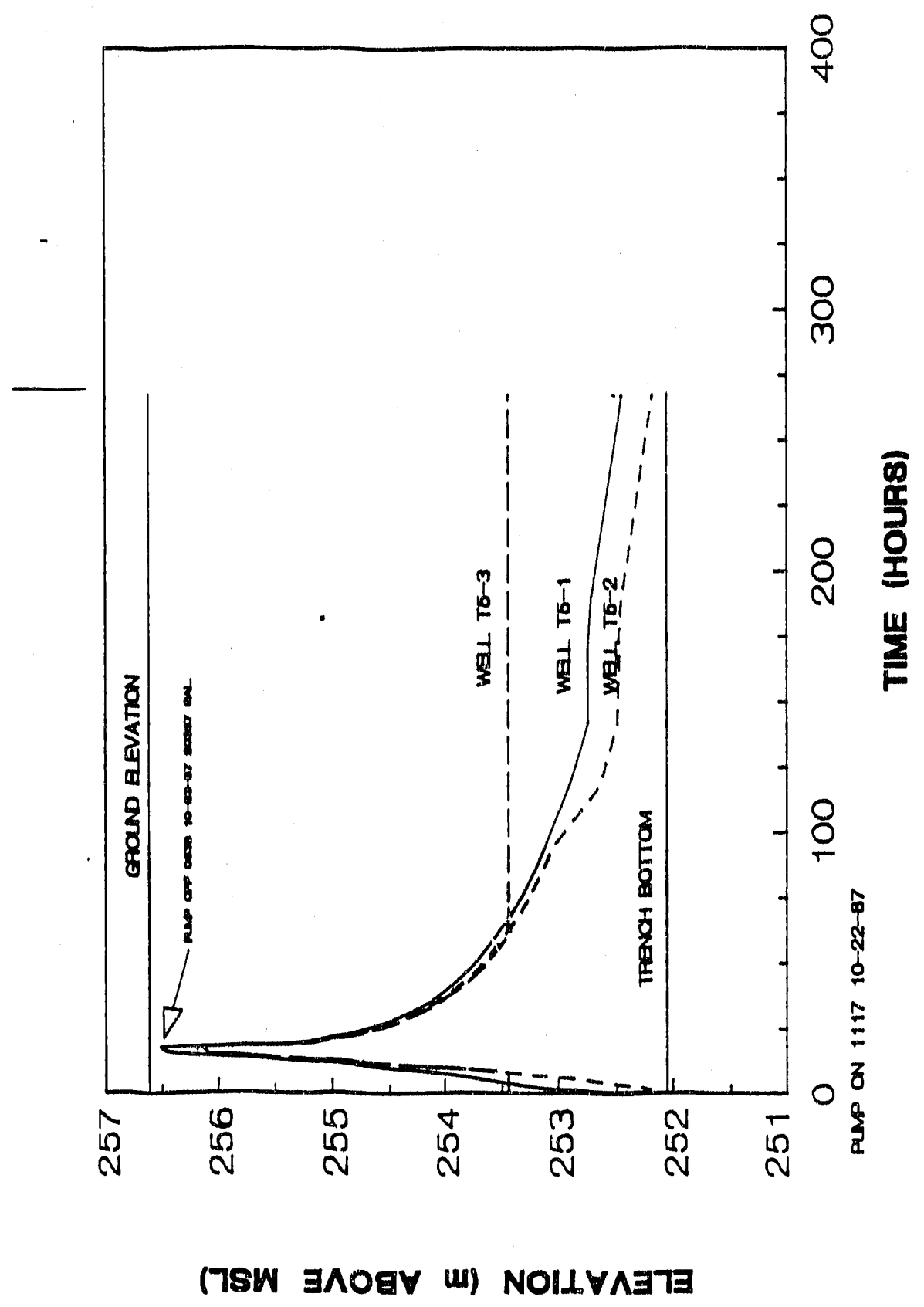

Fig. 22. Water pump-in test hydrograph for TARA trench 5. 


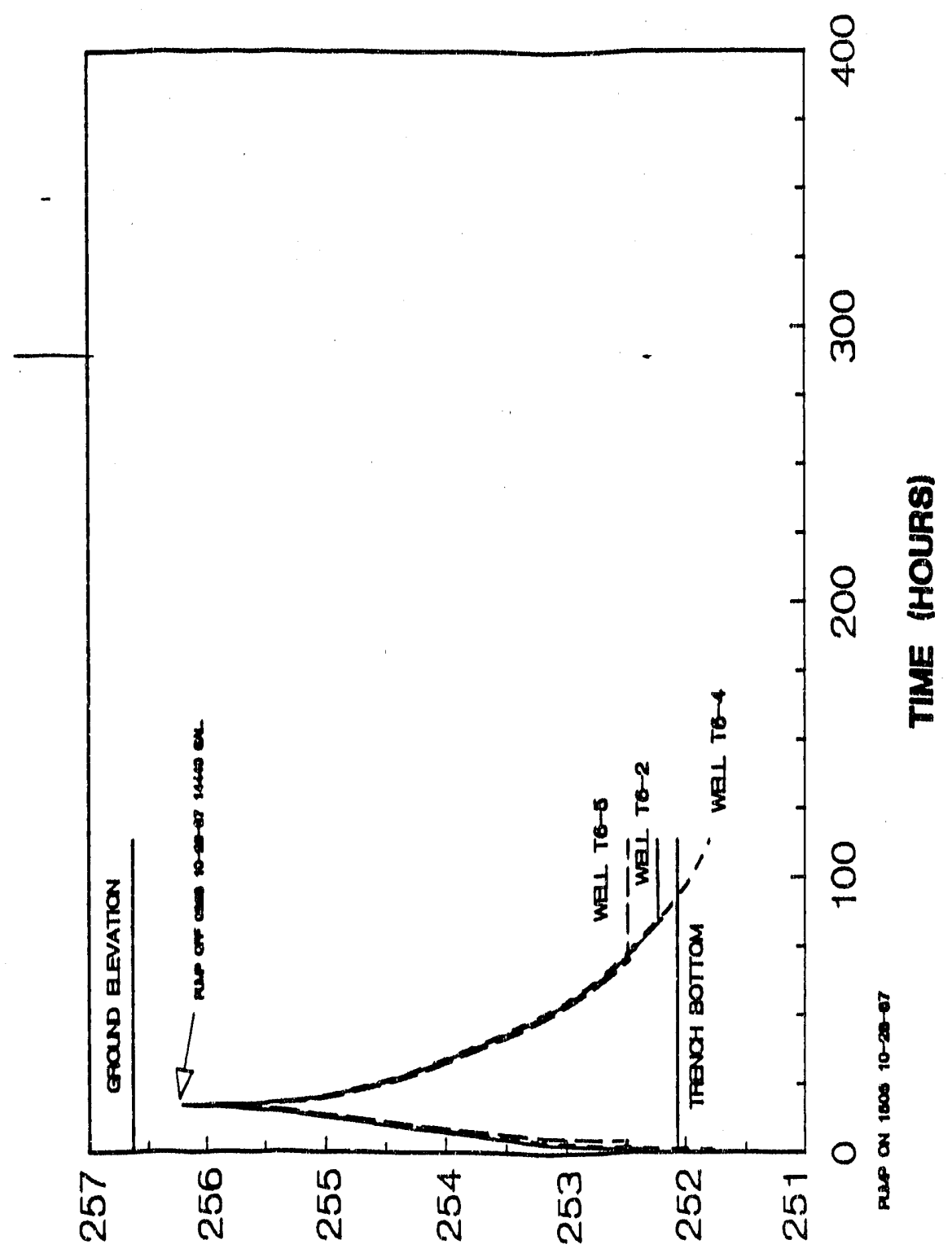

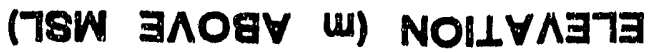

Fig. 23. Water pump-in test hydrograph for TARA trench 6 . 
To determine the trench volds from the water pump-in test data, each trench was divided into several regions (horizontal cross sections of varying but defined thickness) starting at the trench bottom and moving upward unil the last trench region was immediately below the trench soll cover. The area and thickness of each region was recorded along with the flow rate maintained while filling that region as well as the region's filling and emptying times. A seepage rate for each region was calculated as

$$
\text { where, } \begin{aligned}
\mathrm{x}_{0} & -\left(\mathrm{x}_{1} \mathrm{x}_{0} \mathrm{~T}_{1}\right) /\left(\mathrm{T}_{0}+\mathrm{T}_{1}\right) \\
\mathrm{x}_{1} & - \text { seepage rate, } \mathrm{m}^{3} / \mathrm{h} \\
\mathrm{T}_{1} & - \text { region's filling time, } \mathrm{h} \\
\mathrm{T}_{0} & =\text { region's emptying time, } \mathrm{h} .
\end{aligned}
$$

A net filling rate for each region was then calculated as

$$
\begin{aligned}
& N=X_{1}-X_{0} \\
\text { where, } N & =\text { net filling rate, } \mathrm{m}^{3} / \mathrm{h} \\
X_{1} & =\text { water delivery } \mathrm{rate}^{3}, \mathrm{~m}^{3} / \mathrm{h} \\
\mathrm{X}_{0} & =\text { seepage rate, } \mathrm{m}^{3} / \mathrm{h} .
\end{aligned}
$$

Finally, the region vold volume was calculated as

$$
v_{r}=\left(X_{1} * T_{1}\right) \cdot\left(X_{0} * T_{1}\right)
$$

$$
\begin{aligned}
& \text { where, } v_{r} \text { - void volume of the region, } \mathrm{m}^{3} \\
& \mathrm{x}_{1}, \mathrm{x}_{0}, \mathrm{~T}_{1}=\text { previously defined. }
\end{aligned}
$$

The regional void volumes could then be summed to yield the total wateraccessible trench void volume, and this, in turn, could be expressed as a percentage of the total trench volume. Table 12 summarizes the calculations of water-accessible trench void volumes made for TARA trenches 2 through 6 using this method. The calculated fractional void volumes were between 8 and 23\%. These values are similar to the $20 \%$ values found for trenches in SWSA 4 (Spalding et al. 1987) but smaller than the 308 value found for txench 271 in SWSA 6 (Spalding 1986). There now appears to be a sufficient sample of burial trench fractional vold volumes from this and preylous work for assessing stabilization and closure needs for ORNL SWSAs. The measurement of the residual vold volumes in these trenches, after dynamic compaction, will be repeated using the grout filling volumes. Thus, a direct quantifiable comparison of trench volds can be obtained before and after compaction. 
Table 12. Summary of calculations of water-accessible vold volume derived from trench water pump-in tests.

\begin{tabular}{|c|c|c|c|c|c|c|c|c|c|c|}
\hline Region & $\begin{array}{l}\text { Bottom } \\
\text { Elev. } \\
\text { (m) }\end{array}$ & $\begin{array}{l}\text { Top } \\
\text { Elev. } \\
\text { (m) }\end{array}$ & $\begin{array}{l}\text { Region } \\
\text { Height } \\
\text { (m) }\end{array}$ & $\begin{array}{c}\text { Region } \\
\text { Flow } \\
\text { Rate } \\
\left(\mathrm{m}^{3} / \mathrm{h}\right) \\
\left(\mathrm{x}_{1}\right)\end{array}$ & $\begin{array}{l}\text { Region } \\
\text { Fili } \\
\text { Time } \\
\left(T_{1}\right)\end{array}$ & $\begin{array}{l}\text { Region } \\
\text { Empty } \\
\text { Time } \\
\left(\mathrm{T}_{0}\right)\end{array}$ & $\begin{array}{c}\text { Seep } \\
\text { Rate } \\
\left(\mathrm{m}^{3} / \mathrm{h}\right) \\
\left(\mathrm{X}_{0}\right)\end{array}$ & $\begin{array}{l}\text { Net } \\
\text { Flli } \\
\text { Rate } \\
\left(m^{3} / h\right)\end{array}$ & $\begin{array}{r}\text { Vold } \\
\text { Volume } \\
\left(\mathrm{m}^{3}\right)\end{array}$ & $\begin{array}{l}\text { Vold } \\
\text { Volume } \\
\text { (8) }\end{array}$ \\
\hline \multicolumn{11}{|c|}{ Trench 2, Area $=84.5 \mathrm{~m}^{2}$} \\
\hline \multirow[t]{2}{*}{$\begin{array}{l}1 \\
2 \\
3\end{array}$} & $\begin{array}{l}252.87 \\
253.83 \\
254.12\end{array}$ & $\begin{array}{l}253.83 \\
254.12 \\
254.66\end{array}$ & $\begin{array}{l}0.96 \\
0.29 \\
0.54\end{array}$ & $\begin{array}{l}4.18 \\
3.45 \\
2.75\end{array}$ & $\begin{array}{l}5.50 \\
1.00 \\
2.50\end{array}$ & $\begin{array}{r}89.00 \\
9.50 \\
11.50\end{array}$ & $\begin{array}{l}0.24 \\
0.33 \\
0.49\end{array}$ & $\begin{array}{l}3.94 \\
3.12 \\
2.26\end{array}$ & $\begin{array}{r}21.65 \\
3.12 \\
5.65\end{array}$ & $\begin{array}{l}26.69 \\
12.74 \\
12.38\end{array}$ \\
\hline & & & $\overline{1.79}$ & & & & & & $\overline{30,42}$ & $\overline{20.1 .1}$ \\
\hline
\end{tabular}

\begin{tabular}{|c|c|c|c|c|c|c|c|c|c|c|}
\hline \multirow{3}{*}{$\begin{array}{l}1 \\
2 \\
3 \\
4\end{array}$} & \multirow{3}{*}{$\begin{array}{l}251.61 \\
253.00 \\
254.00 \\
255.00\end{array}$} & \multirow{3}{*}{$\begin{array}{l}253.00 \\
254.00 \\
255.00 \\
255.56\end{array}$} & \multicolumn{4}{|c|}{ Trench 3, Area $=77.2$} & \multicolumn{2}{|l|}{$a^{2}$} & \multirow[b]{2}{*}{$\begin{array}{r}5.30 \\
9.30 \\
10.19 \\
0.93\end{array}$} & \multirow[b]{2}{*}{$\begin{array}{r}4.94 \\
12.04 \\
13.20 \\
2.15\end{array}$} \\
\hline & & & $\begin{array}{l}1.39 \\
1.00 \\
1.00 \\
0.56\end{array}$ & $\begin{array}{l}4.25 \\
4.25 \\
4.25 \\
4.25\end{array}$ & $\begin{array}{l}1.25 \\
2.25 \\
2.75 \\
1.75\end{array}$ & $\begin{array}{r}480.00 \\
78.75 \\
18.75 \\
0.25\end{array}$ & $\begin{array}{l}0.01 \\
0.12 \\
0.54 \\
3.72\end{array}$ & $\begin{array}{l}4.24 \\
4.13 \\
3.71 \\
0.53\end{array}$ & & \\
\hline & & & $\overline{3.95}$ & & & & & & $\overline{25.72}$ & 8.43 \\
\hline \multirow{3}{*}{$\begin{array}{l}1 \\
2 \\
3 \\
4\end{array}$} & \multirow{3}{*}{$\begin{array}{l}251.55 \\
253.00 \\
254.00 \\
255.13\end{array}$} & \multirow{3}{*}{$\begin{array}{l}253.00 \\
254.00 \\
255.13 \\
255.70\end{array}$} & \multicolumn{2}{|c|}{ Trench 4} & Area & -63.5 & $\mathrm{~m}^{2}$ & & & \\
\hline & & & $\begin{array}{l}1.45 \\
1.00 \\
1.13 \\
0.57\end{array}$ & $\begin{array}{l}5.45 \\
5.45 \\
3.91 \\
4.20\end{array}$ & $\begin{array}{l}6.09 \\
3.38 \\
6.83 \\
1.42\end{array}$ & $\begin{array}{r}51.07 \\
17.05 \\
7.33 \\
0.83\end{array}$ & $\begin{array}{l}0.58 \\
0.90 \\
1.89 \\
2.65\end{array}$ & $\begin{array}{l}4.87 \\
4.55 \\
2.02 \\
1.55\end{array}$ & $\begin{array}{r}29.65 \\
15.37 \\
13.82 \\
2.20\end{array}$ & $\begin{array}{r}32.21 \\
24.21 \\
19.27 \\
6.08\end{array}$ \\
\hline & & & $\overline{4.15}$ & & & & & & 61.04 & $\overline{23.17}$ \\
\hline
\end{tabular}


Table 12, (Continued)

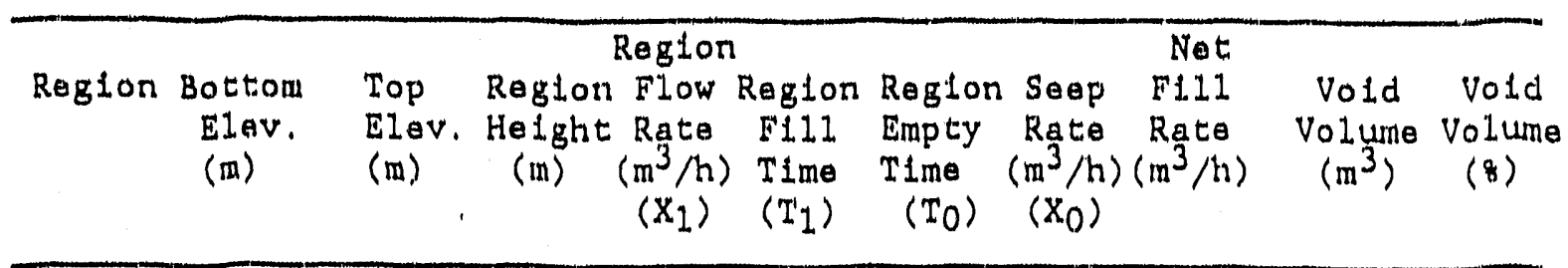

Trench 5, Axea $-64.1 \mathrm{~m}^{2}$

$\begin{array}{rrrrrrrrrrrr}1 & 252.20 & 253.00 & 0.80 & 4.27 & 6.25 & 172.61 & 0.15 & 4.12 & 25.75 & 50.22 \\ 2 & 253.00 & 254.00 & 1.00 & 4.27 & 3.50 & 57.25 & 0.25 & 4.02 & 14.08 & 21.97 \\ 3 & 254.00 & 255.00 & 1.00 & 4.27 & 3.00 & 16.25 & 0.67 & 3.60 & 10.81 & 16.87 \\ 4 & 255.00 & 256.20 & 1.20 & 4.27 & 5.25 & 3.00 & 2.72 & 1.55 & 8.15 & 10.60 \\ & & & & 4.00 & & & & & & \overline{58.79} & \overline{22.93}\end{array}$

Trench 6, Area $-56.9 \cdot \mathrm{m}^{2}$

$\begin{array}{rrrrrrrrrrr}1 & 252.00 & 253.00 & 1.00 & 3.13 & 2.25 & 41.25 & 0.16 & 2.97 & 6.68 & 11.74 \\ 2 & 253.00 & 254.00 & 1.00 & 3.13 & 4.25 & 20.75 & 0.53 & 2.60 & 11.04 & 19.40 \\ 3 & 254.00 & 255.00 & 1.00 & 3.13 & 5.00 & 13.65 & 0.84 & 2.29 & 11.45 & 20.13 \\ 4 & 255.00 & 256.11 & 1.11 & 3.13 & 4.25 & 3.50 & 1.72 & 1.41 & 6.01 & 9.51 \\ & & & \overline{4.11} & & & & & & \overline{35.18} & \overline{15.04}\end{array}$


TRENCH COVER MOISTURE AND BULK DENSITY

The soll cores collected by the standard split spoun sampling technique desoribed above were taken to the laboratory and, after preliminary screaning for volatille organtos, were welghed, drled at $104^{\circ} \mathrm{C}$ until all molsture was driven off, and rowelghed to determine the percentage molstura. The lengths of the cores had already been measured in the fileld and could be used to caloulace the mass of dry soll per unit volume (bulk denslty) of each cora. Figures 24 and 25 iliustrate soli molsture and bulk density as a funotion of depth, respectvely. No slentficant varlation in molsture content: with soll depth was appaxent. Bulk denslty, however, dld tend to Increase with soll depth as might be expected for soll weathered in place. It should be pointed out that all sampling was carried out botween Fobruary and mid-Apri1, 1987, when sol.1 molsture condftions would normally be expected to be at seasonal. maxima. Drler soll moloture contents would be expeated, partloularly in the surface samples, if sampling were carrled out in sumer or early fall.

After the compaction of each trench was completed, a hand-held soll coring device of $944 \mathrm{~cm} \mathrm{~cm}^{3}$ volume was used to obtain a shallow soll cora from three positions along ach trench for molsture and bulk density measurements (Blake and Hartge 1986). The core reached only to a depth of $11 \mathrm{~cm}$ and was thus compared to the 0 . to $46 \mathrm{~cm}$ sections of core taken before compaction to access the changes that occurred in bulk density. Table 13 summardzes the changes in trench cap molsture and bulk density before and after trench compaction. Table 14 presents all the molsture and bulk density measurements made on the five trenches after compaction. No significant change in the bulk density of the soil cap rosulted from the dynamio compaction. This result leads to the conolusion that the consolidation of the trench ocourred largely in the subsurface. 


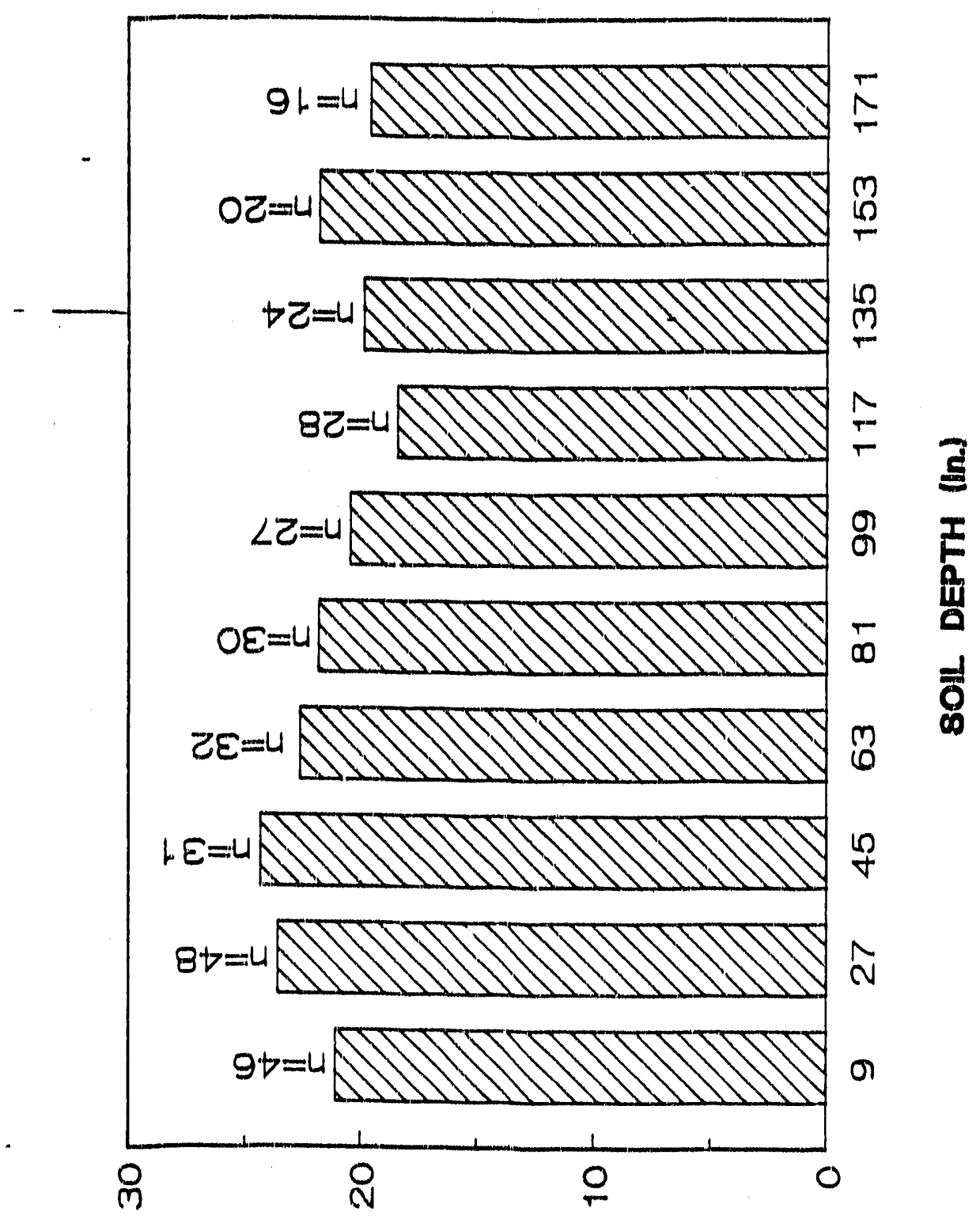

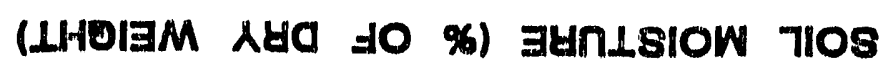

Fig, 24. Tara site soll molsture as a function of depth. 


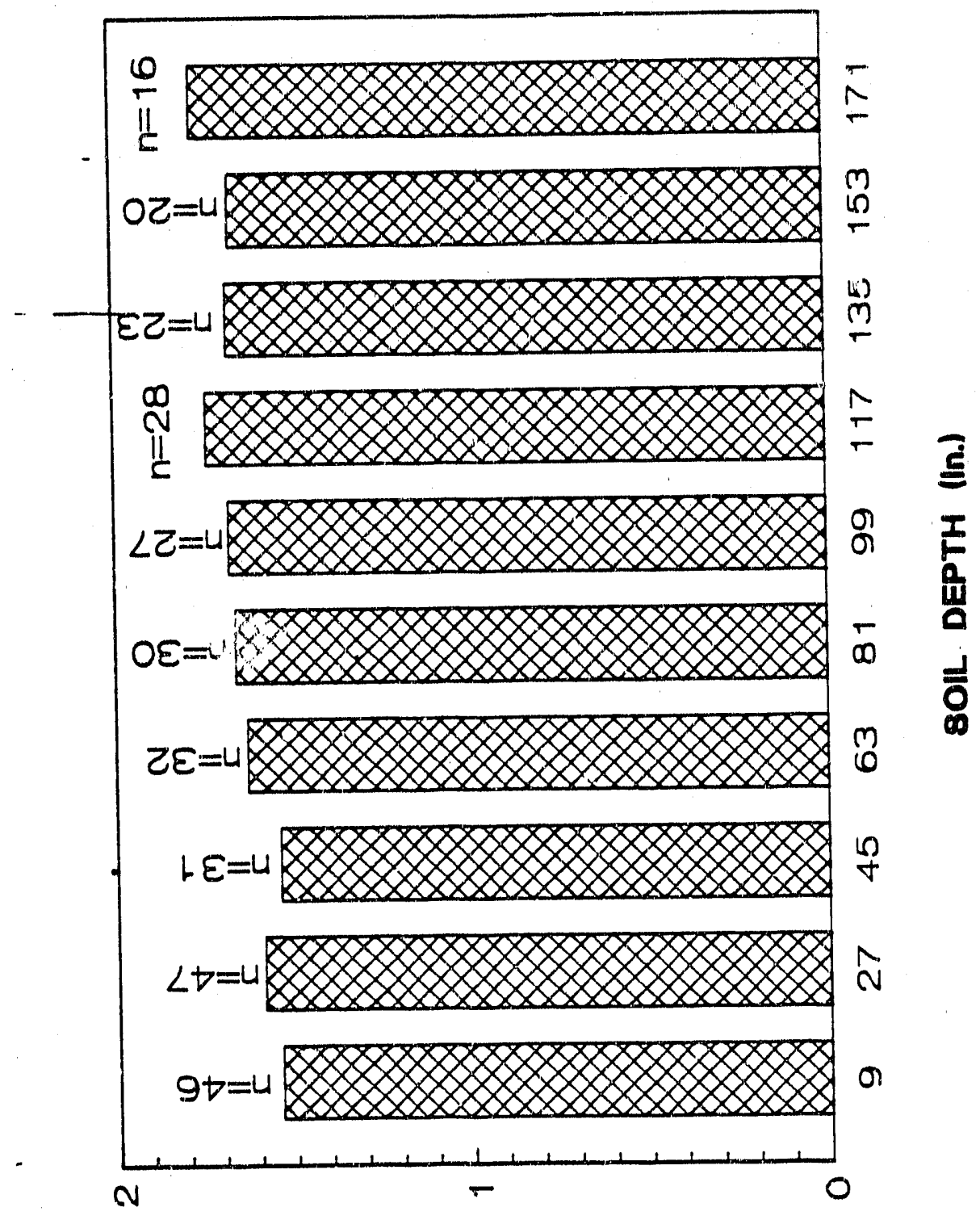

(00/0) NLISNヨQ Y'Tก

Fig. 25. TARA site soil bulk density as a function of depth. 
Table 13. Changes in trench cap toisture and bulk density after trench compaction

\begin{tabular}{|c|c|c|c|c|c|}
\hline \multirow[b]{3}{*}{ Soil } & \multirow[b]{3}{*}{ Depth (ca) } & \multicolumn{4}{|c|}{ Before Compaction } \\
\hline & & \multicolumn{2}{|c|}{ Average Moisture } & \multirow{2}{*}{$\begin{array}{l}\text { Average Bulk } \\
\text { Trench Cap }\end{array}$} & \multirow{2}{*}{$\frac{\text { Density }}{\text { Area }}$} \\
\hline & & Trench Cap & $\overline{\text { Area }}$ & & \\
\hline \multirow[t]{4}{*}{$\begin{array}{r}0 \\
46\end{array}$} & $\begin{array}{r}-46 \\
-\quad 92\end{array}$ & $\begin{array}{l}21.8 \\
22.5\end{array}$ & $\begin{array}{l}20.8 \\
24.0\end{array}$ & $\begin{array}{l}1.56 \\
1.62\end{array}$ & $\begin{array}{l}1.53 \\
1.57\end{array}$ \\
\hline & & \multicolumn{4}{|c|}{ After Compaction } \\
\hline & & \multicolumn{2}{|c|}{ Average Moisture } & Average Bulk & Density \\
\hline & & Trench Cap & $\overline{\text { Area }}$ & Trench Cap & Area \\
\hline 0 & -15 & 18.8 & & 1.45 & \\
\hline
\end{tabular}


Table 14. Bulk density and moisture contents of surface (0-11 $\mathrm{cm}$ ) solls of trench caps after dynamic compaction

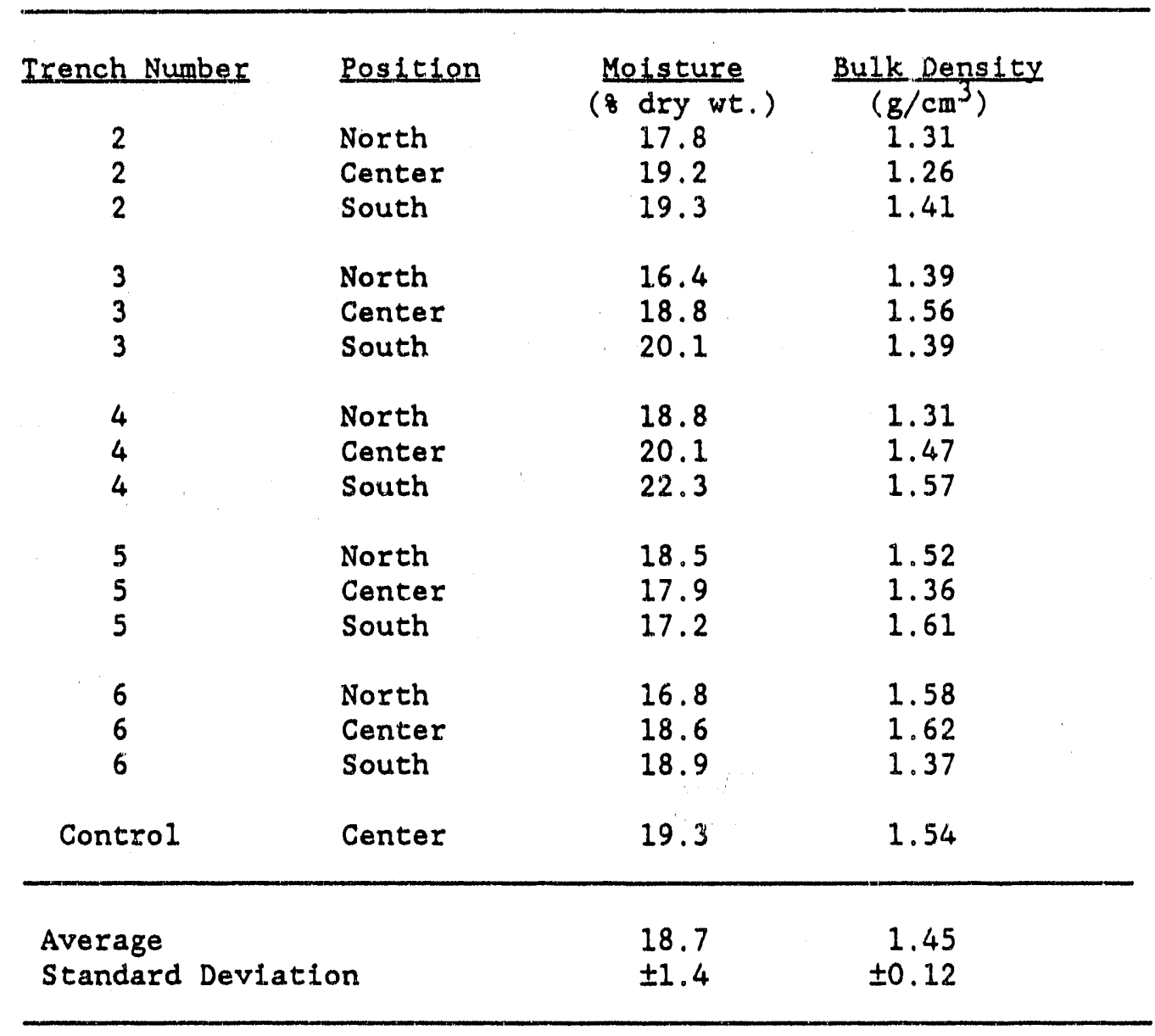


Page 74

\section{TRENCH CONTENTS AND GROUT COMPATIBILITY}

Because of the large inventory of radioactivity in some burial trenches in SWSA 6, assurance of hydrologic isolation of trench contents from groundwater intrusion and/or percolation, beyond that provided by an infiltration barrier, may be warranted for particular trenches. In situ grouting is a technique for providing assurance of hydrologic isolation of burial trench contents, regardless of assurance of infiltration barrier integrity or performance. Two in situ grouting field demonstrations have been completed at ORNL (Spalding et al. 1985 and 1987). Both of these demonstrations involved placing acrylamide grout into uncompacted burial trenches. Both were successful in changing the burial trenches from a condition of extreme permeability and facile water intrusion to a condition of unmeasurable permeability. However, based on these demonstrations, it became apparent that the costs of in situ grouting were quite high (i.e. about $\$ 50,000$ per typical burial trench, due to the large amount of volds per trench). Dynamic compaction, on the other hand, is a relatively inexpensive method to eliminate many of the large voids within a trench, leaving a potentially much smaller residual void volume to be grouted. One of the major goals of the proposed in situ grouting demonstration is to demonstrate that dynamically compacted trenches can be grouted with acrylamide and achieve the same degree of hydrologic isolation that has been demonstrated on unperturbed burial trenches. If this compatibility of in situ grouting with dynamic compaction can be demonstrated, then not only will in situ grouting costs be considerably lower (probably $80 \%$ due to the trench void reduction by dynamic compaction) but an effective and safe method for stabilizing the burial trench ground surface to support an infiltration barrier cap will be established to a degree that acrylamide grouting alone cannot achieve.

In seeking advice from environmental regulatory agencies and other scientists and engineers, a number of questions were raised concerning the hazards and risks of using acrylamide in the proposed demonstration. Acrylamide is a toxic substance and, therefore, poses certain risks not only for those who prepare and inject the grout but also for potential groundwater contamination in the area where the grout is being infected. Once the acrylamide polymerizes (sets), it becomes nontoxic and nonhazardous like the majority of polymers in the materials of commerce. Most of the concerns raised center on the ability to control the polymerization process during infection into burial trenches and provide assurance that the grout will set to an impermeable state and not result in any contamination of groundwater at the demonstration site. The setting of polyacrylamide is known to be Inhibited by strong acids, bases, and concentrated (10\%) solutions of reducing agents (Larson and May 1983). What assurances exist that similar substances are not present in the five proposed trenches which may potentially inhibit the grout set? How is 1 known that a grout formulation of a given design set time will not reach the water table below the trenches before it sets?

One approach to test compatibility of acrylamide grout with the burial trench contents would be to perform chemical analyses of the inorganic and organic constituents in each of the burfal trenches and, then, perform grout compatibility tests with each component at the measured concentrations. This 
approach is enormously costly and technically difficult. Characterization of trench contents is quite difficult due to the heterogeneous nature of the burfed waste. As an alternative, samples of trench leachate, where avallable, and trench bottom soil could be obtained and tested for compatibility with the acrylamide grout. The samples of leachate and trench bottom soil would be characterized in a screening method for gross chemical and radiochemical properties without a detalled examination and analysis for specific hazardous constituents. Not only could grout set time be measured in the presence of trench leachate and soll, but quantitative measurements of the degree of polymerization could be determined by assaying the set grouts for residual concentrations of the acrylamide monomer. In addition, the hydraulic conductivity of trench soil specimens could be determined before and after grouting to verify the degree of permeability expected during actual trench grouting. If it can be demonstrated that grout set time is not affected adversely by the trench leachates or trench soils, that the degree of polymerization achieved in the presence of trench leachate or trench soil is equivalent to what can be achieved with a neat grout, and that trench soil can be converted to an impermeable state by the grout, then high confidence can be attained that grout set control can be ensured in the field demonstration.

Samples of trench bottom soll were collected on July 1, 1988, from the five burial trenches (SWSA 6 trench numbers $2,3,4,5$, and 6 ) by inserting a hand auger into uncased residual penetration testing holes and/or existing bottomless well casings that were placed in each trench during filling. The penetration test holes were made in February and March 1987 during stablifty (nonstandard soil penetration) tests on the burial trenches prior to dynamic compaction. Composites of all samples from an findividual trench were made in the field in seal-lock polyethylene bags. Typically, about 100-200 $\mathrm{g}$ of fleld-moist soll could be obtained from each trench. Samples were screened as collected for gross beta/gamma radioactivity with a field survey GeigerMueller meter; several read about $10 \mathrm{mR} / \mathrm{h}$ at contact with the sample bag. To reduce the soil moisture content to a level where the samples could be sleved and homogenized, the samples were dried in the opened bags at $80^{\circ} \mathrm{C}$ for $2 \mathrm{~h}$. Care was taken that the samples did not completely dry. Samples were then sieved to $<2 \mathrm{~mm}$ by hand, and the coarse fragments (mostly gravels) were discarded as radioactive waste. Moisture contents of the sieved and homogenized soil were determined by drying subsamples at $105^{\circ} \mathrm{C}$ for $2 \mathrm{~h}$. These samples of oven-dried soil were used for determination of ${ }^{13} 7^{2} \mathrm{Cs},{ }^{60} \mathrm{Co}$, and $90 \mathrm{Sr}$ via gamma-ray spectroscopy and bremstrahlung detection using an NaI detector with a multiple channel analyzer.

Samples of trench leachate were collected between October 27 and November 20 , 1987, during trench water filling for void determination. Since January 1987, when the first access wells were placed during initial penetration tests on these five trenches, a seasonally ephemeral level of standing water has been observed in only one of these trenches following a sustained rainy period in February 1987. Thus, "natural" trench leachate samples were not available for this grout compatibility study. However, the induced leachate samples were collected at the time near the emptying of the trench and, therefore, likely represent types of leachate with maximal exposure to trench waste contents. These leachate samples were characterized 
for thelr gross chemical and radiochemical propertias by measuring $\mathrm{pH}$, electrical conductivity, dissolved solids, hardness, alkalinity, gross alpha, and gross beta activities (APHA 1980). In addition, a sample of the emergency waste holding pond water (used as the source of water for the tranch filling tests) was included in this characterizalion as a point of reference for water quality before contacting the bujida wastie trenches. Also included, for comparison, are the mean veluse tho the same water characteristics for samples of groundwater collob thed three weeks after the completion of the last trench-filling test from tive 15 groundwater monitoring wells within and around the test area.

To measure grout set time in the presence of trench leachate, $10.0 \mathrm{~mL}$ of a 208 (weight/volume) solution of Q-1 (Cues, Inc., Orlando, Fla.) grout in water was placed in a $50-\mathrm{mL}$ capacity polypropylene beaker. The Q-1 grout is a mixture of 958 acrylamide and 58 methylenebisacrylamide. The 208 grout solution also contained 18 (volume/volume) triethanolamine, the grout-free radical transfer agent, and 0.028 (weight/volume) potassium ferricyanide, the grout set retarder. After adding the grout to the beaker, $5 \mathrm{~mL}$ of either trench leachate or water were added. Then, $5 \mathrm{~mL}$ of a 48 (weight/volume) solution of ammonium persulfate, the grout catalyst, was added and swirled gently to mix the beaker contents. Time of grout set was measured from the time of catalyst addition until grout would no longer flow within the beaker. The setting of acrylamide grout is a relatively abrupt change in viscosity occurring within a few seconds. Thus, unlike set time measurement with cements or silicate grouts, no elaborate test methods or apparatuses are required. Insufficient anounts of the leachate of trench 4 were available for study.

To measure grout set in the presence of soil, the procedure was identical to that described above except that $5.00 \mathrm{~g}$ of fresh (undried) sieved soil was used instead of the $5 \mathrm{~mL}$ of leachate or water. The beaker contents were swirled at frequent intervals to keep the soil in suspension to maintain an intimate contact between soil and grout. This method maximizes the potential for observing possible interference of grout set by the soll or its contaminants. Otherwise, the soil would settle to the bottom of the beaker and the overlying grout could set without interference from the burial trench soll or its possible adsorbed constituents. The observed set times of the grout were recorded to the nearest minute.

After storing the $20 \mathrm{~mL}$ grouted soil and leachate specimens in a sealed container overnight $(16 \mathrm{~h})$, the samples were extracted with water to determine concentrations of residual monomer and, hence, to calculate the degree of polymerization achieved in the presence and absence of burial trench soil and leachate. The grouted specimen was placed in a $250-\mathrm{mL}$ stainless steel container with $100 \mathrm{~mL}$ of distilled water and macerated for 15 $s$ with a commercial rotating knife blender at $21,000 \mathrm{rpm}$. The resulting viscous homogenate was filtered through a borosilicate glass microfiber filter ( $1 \mu \mathrm{m}$ particle size retention) overlain by a 1 -cm-thick sand layer as a prefilter to prevent clogging by the filtrate. The sand was acid-washed and ignited quartz. The resulting clear filtrate was stored in capped polyethylene containers at $4 \mathrm{C}$ until analysis. Four samples of the unpolymerized grout were also prepared by substituting $5 \mathrm{~mL}$ of water for the 
ammonium persulfate catalyst solution or $5 \mathrm{~mL}$ of a 48 ammonitum sulfate solution.

Analysis for acrylamide, methylenebisacrylamide, and acrylic acid was carrled out using a direct injection on a high-pressure liquid chromatograph (HPLC). A $4.6 \mathrm{~mm} \times 25 \mathrm{~cm}$ long stainless steel column was employed contalning octadecylsilane reversed-phase spherical silica absorbent ( $10 \mu \mathrm{m}$ particle size) with 208 methanol:water $(v: v)$ as the eluant. An injection volume of $0.25 \mathrm{~mL}$ was employed using a fixed-volume sample loop attached to the injection valve of a Perkin-Elmer 15B Liquid Chromatograph equipped with an ultraviolet detector and a flow rate of $1 \mathrm{~mL} / \mathrm{min}$. Good separation between the three components was achieved, and a detection 1 imit of about $1 \mathrm{mg} / \mathrm{L}$ of acrylamide was attained. Standards for acrylamide in the range of 20 to 100 mg/L were prepared, and dilutions of the grout extracts were made to be within this range. Elution peak height was used as a measure of acrylamide concentration and was found to be linearly correlated ( $r-.9982)$ with acrylamide concentration within the range of standards. Percent of polymerization was calculated from the difference between the amount of acrylamide in the unpolymerized specimens and that measured in the grouted specimens.

The effect of grouting of burlal trench soll on its permeability was determined by measuring the hydraulic conductivity of small columns of burial trench soll before and after permeating them with grout. Five grams of moist soil, overlying $3 \mathrm{~g}$ of quartz sand, was placed into a $1.0 \mathrm{~cm}$ diam $x 10 \mathrm{~cm}$ long glass column equipped with polypropylene fittings to regulate flow. A 20-mL aliquot of grout solution, prepared identically to that described above, was careifully poured onto the top of the column. A constant head was maintained manually by keeping the level of grout fixed above the column. From the measured volume of excess grout eluting from the soil column in a measured time intarval, a hydraulic conductivity for the soi? sample was calculated for the geometric configuration of liquid level and length of soll column (Klute 1965). The bulk density of the soll in the columns was calculated from the known fresh weights of soil added, their measured moisture contertis, and the volume occupied by the soil in the column. Several columns equired that their flow be interrupted to prevent grour from running out of thle soil, while others attained grout set before grout solution had perclolated the soll. After grout set, any set grout on top of the column was rejnoved with a spatula. The glass surface near the column bottom was scored and broken off to allow for the removal of any grouted sand from the column. Otherwise, grouted sand at the column bottom may have reduced hydraulic conductivity of the sample, the effect of which could not be determined indlapendently of any grouting of the soil. The postgrouting permeability, easurements were, therefore, performed on columns containing only soil. A head of water was placed on top of each column, and a collecting tube, with only a pinhole opening to the atmosphere to prevent evaporation of any eluant, was placed on each column. The collection tubes were observed periodically over the following $48 \mathrm{~h}$ for che presence of eluant, but none was observed. A minimum postgrouting hydraulic conductivity was calculated for each column based on the minimum detectable amount of eluant ( 1 drop or $0.1 \mathrm{~mL}$ ) in $48 \mathrm{~h}$ and the column geometry as in the pregrouting hydraulic conductivity calculation. 
The chemical and radiochemical characteristics of the five samples of burial trench leachate are presented in Table 15 along with the characteristics of the pond water used to fill these trenches and the average characteristics of groundwater beneath and surrounding the five burial trenches.

Several conclusions about the characteristics of waste burfed in the five trenches can be deduced from the information about these leachates. First, the trenches do not contain readily leachable contaminants such as acids, bases, or soluble ionic species. The placement of pond water into the trenches did not significantly alter the $\mathrm{pH}$, alkalinity, hardness, dissolved solids, or electrical conductivity of the water. Nor are there significant amounts of nonvolatile organic species which would have perturbed the dissolved solids level in the water. Most of the modest increases in the chemical properties of the pond water as it evolved into trench leachate can be explained as an interaction between the limestone-containing soil at the site. Due to this interaction, groundwaters tend to be rather hard, with readily measurable levels of dissolved constituents. The average level of dissolved solids in the 15 samples of groundwater was greater than that of the dissolved solids in any of the trench leachates. Thus, the chemical environment, which the grout will encounter when placed into the burial trenches at the site, will not be much different than that anticipated for areas unperturbed by waste burial. Thus, the reported interferences in acrylamide grout setting by strong acids, bases, and reducing agent (Larson and May 1983) would not occur in these trenches.

Evidence that the pond water, which filled the trenches, did have signiffcant interaction with the buried waste contents can be seen in the dramatic increase in dissolved radioactivity, particularly the gross beta activity. The significant level of gross alpha activity in the sample from trench 5 is due to the presence of $233_{U}$, which has been identified following alpha spectroscopic assay of this sample. It should be emphasized that this area was used for disposal of higher-level ( $>200 \mathrm{mR} / \mathrm{h}$ at package surface) low-level radioactive solid waste. Thus, it is less likely to contain the directly handled laboratory waste which is the likely source of hazardous organic materials (e.g., scintillation vials) probably contained in other areas of SWSA 6 used for disposal of lower-level low-level solid waste.

The moisture content and radionuclide content of the six burial trench soil samples are listed in Table 16. The presence of such significant activities of radionuclides in these trench bottom solls indicates that they have experienced significant interaction with the buried contents of the trenches through the years. Thus, trace levels of inorganic and organic contaminants may also be present in these samples, and represent a good material for testing compatibility with acrylamide grouts. It should be noted that the sample of cap material from trench 3 was taken from a depth of 2-3 ft below the ground surface and does not represent surface contamination at the site. It represents a soil which would potentially interact with grout at the last stages of trench filling. 
Table 15. Gross chemical and radiochemical characteristics of burlal trench leachate anc' groundwater samples

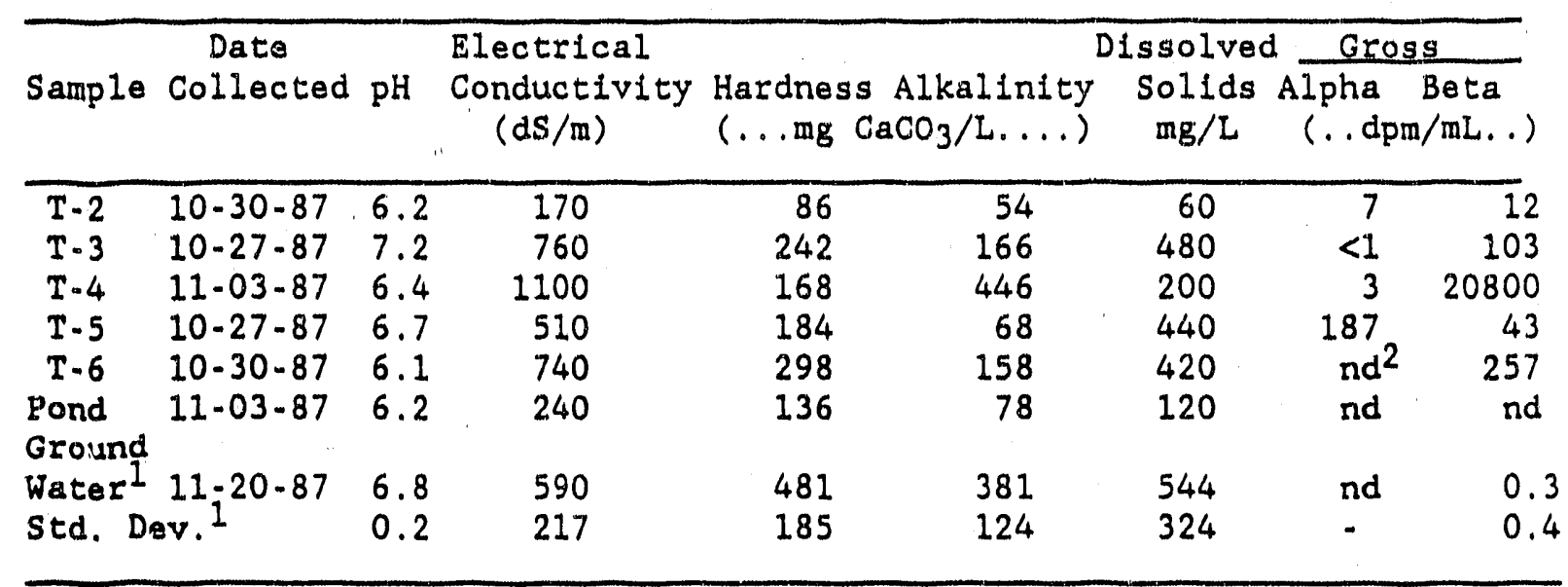

1 Groundwater characteristics are the average and standard deviation for 15 samples collected from the monitoring wells in and surrounding the test area.

2 not detected. 
Page 80

Table 16. Radionuclide and moisture contents of burial trench soil. samples

\begin{tabular}{|c|c|c|c|c|}
\hline Sample & $\begin{array}{l}\text { Moisture } \\
(8)\end{array}$ & $\begin{array}{l}{ }^{137} \mathrm{Cs} \\
(\ldots \ldots\end{array}$ & $\begin{array}{l}{ }^{60} \mathrm{Co} \\
\mathrm{dpm} / \mathrm{g}\end{array}$ & $\begin{array}{c}{ }^{90} \mathrm{Sr}_{\mathrm{r}} \\
\ldots \ldots \ldots)\end{array}$ \\
\hline Trench 2 & 17.9 & 1060 & $\mathrm{nd}^{1}$ & 3590 \\
\hline Trench 3 & 18.3 & 3350 & nd & 72800 \\
\hline Trench 4 & 16.4 & 128 & nd & 410 \\
\hline Trench 5 & 5.9 & 622 & 995 & nd. \\
\hline Trench 6 & 13.7 & 9580 & nd & 15800 \\
\hline $\begin{array}{c}\text { Trench } 3 \\
\text { Cap }\end{array}$ & 15.2 & 17 & nd & nd \\
\hline
\end{tabular}

1 not detected. Detection 1 imits were $1.4 \mathrm{dpm} / \mathrm{g}, 2 \mathrm{dpm} / \mathrm{g}$, and $6 \mathrm{dpm} / \mathrm{g}$ for ${ }^{137} \mathrm{Cs},{ }^{60} \mathrm{Co}$, and $90 \mathrm{Sr}$, respectively. 
None of the trench leachate samples posed any interference with the setting time of the acrylamide grout formulation (Table 17). None of the six solls samples caused any delay or inhtbition of grout setting time elther. Soil samples from trenches 3 and 4 did, however, cause a detectable acceleration of grout setting time. The causes of this effect are not known, but even if the same effect were manifested in actual field operations, no Increase in hazard risk would result.

As discussed previously, grout set alone is not a quantitative indication of the degree of polymerization achieved by the grout. The HPLC analyses of the extracts of the grouted specimens for residual monomer, acrylamide, and cross-linking agent, wethylenebisacrylamide, does provide a quantitative method to calculate the degree of polymerization and, thus, to observe any interference with the polymerization reaction by either soll or leachate. Table 18 summarizes the measured residual acrylanide concentrations within the grout specimens produced for the setting time determinations above. Also included are samples of the unpolymerized grout, prepared with either water or ammonium sulfate to replace the ammonium persulfate catalyst, which function to provide the concentration of monomer expected without any polymerization.

None of the samples of burial trench soll or leachate showed any effect on the degree of polymerization of the acrylamide, as all samples exhibited $99+8$ polymerization. The uncatalyzed grout samples were formulated to contain 10\% acrylamide, and it is very reassuring that $100,800 \mathrm{mg} / \mathrm{L}$ were found by analysis. This verifled that his bulk grout solution had not deterforated in over 2 years of storage in the laboratory. All grout specimens contained a residual concentration of about $500 \mathrm{mg} / \mathrm{L}$ of acrylamide within their polymerized volume. The extremely low permeability of the set grout provides the mechanism to retain this residual level within the grouted mass preventing it from leaching and possibly contaminating groundwatex. This would be true not only for this application for radioactive waste stabilization but also for the more common non-waste engineering applications such as dam seepage sealing or ground stablilzation for improving bearing strength. In addition, low levels of acrylamide are readily biodegradable in soil (Lande et al. 1979). Thus, both the hydrologic isolation afforded by the polymer and the facile biodegradation of small amounts of residual acrylamide, which might leach from the surface of the grouted mass, provide adequate assurance that acrylamide will not reach groundwater at the proposed demonstration site.

In addition to the assurance of predictable set times and a high degree of polymerization in the presence of burlal trench soil and leachate, the acrylamide also resulted in unmeasurable hydraulic conductivities in columns of burlal trench soll after percolation and grout set (Table 19). The postgrouting hydraulic conductivities, listed in Table 19, may be quite lower than the calculated detection limit based on the minimum detectable volume of water at the small gravlty head maintained on the columns. Thus, the burial 
Page 82

Table 17. Setting times for acrylamide grout in the presence of burlal trench leachates and solls

\begin{tabular}{llr}
\hline Sample & Type & $\begin{array}{c}\text { Setting Time } \\
\text { (min) }\end{array}$ \\
\hline Water & Water & 9 \\
Trench 2 & Leachate & 9 \\
Trench 3 & Leachate & 9 \\
Trench 5 & Leachate & 9 \\
Trench 6 & Laachate & 9 \\
Trench 2 & So11 & 11 \\
Trench 3 & Soil & 7 \\
Trench 4 & So11 & 5 \\
Trench 5 & So11 & 10 \\
Trench 6 & Sol1 & 10 \\
Trench 3 & Soil-Cap & 11 \\
\hline
\end{tabular}


Table 18, Resldual concentrations of acrylamide and methylenebisacrylamide in specimens of grout prepared in the presence and absence of burlal trench soll and leachate

\begin{tabular}{|c|c|c|c|}
\hline Sample & $\begin{array}{l}\text { Aorylamildo } \\
(\ldots \ldots \ldots \ldots\end{array}$ & $\begin{array}{l}\text { Methy lenabis : } \\
\text { acrylamide } \\
\text {.mg/L,.......) }\end{array}$ & $\begin{array}{l}\text { Degrea of } \\
\text { Polymerization } \\
(8)\end{array}$ \\
\hline $\begin{array}{l}\text { Uncatalyzed Grout } \\
\text { (4 samples) } \\
\text { Neat Grout A (no soil) } \\
\text { Neat Grout B (no scili) } \\
\text { Neat Grout C (no soil) }\end{array}$ & $\begin{array}{r}100,800 \\
450 \\
516 \\
462\end{array}$ & $\begin{array}{r}5360 \\
0.7 \\
0.6 \\
0.9\end{array}$ & $\begin{array}{l}\text { None } \\
99.55 \\
99.56 \\
99.49\end{array}$ \\
\hline $\begin{array}{ll}\text { Trench } 2 & \text { Leachate } \\
\text { Trench } 3 & \text { Leachate } \\
\text { Trench } 5 & \text { Leachate } \\
\text { Trench } 6 \text { Leachate }\end{array}$ & $\begin{array}{l}480 \\
462 \\
486 \\
510\end{array}$ & $\begin{array}{l}0.9 \\
0.7 \\
0.7 \\
0.9\end{array}$ & $\begin{array}{l}99.52 \\
99.54 \\
99.51 \\
99.49\end{array}$ \\
\hline $\begin{array}{lll}\text { Trench } 2 & \text { Sol1 } \\
\text { Trench } 3 & \text { Sol1 } \\
\text { Trench } 4 & \text { Sol1 } \\
\text { Trench } 5 & \text { Sol1 } \\
\text { Trench } 6 & \text { So11 } \\
\text { Trench } 3 & \text { Cap Sol1 }\end{array}$ & $\begin{array}{l}498 \\
342 \\
348 \\
570 \\
516 \\
456\end{array}$ & $\begin{array}{r}3.0 \\
2.1 \\
<10.0 \\
3.4 \\
2.8 \\
2.4\end{array}$ & $\begin{array}{l}99.50 \\
99.66 \\
99.65 \\
99.43 \\
99.49 \\
99.54\end{array}$ \\
\hline
\end{tabular}

1 Degree of polymerization - (starting concentration of acrylamide - sample residual concentration of acrylamide) / starting concentration of acrylamide, where the starting concentration of acrylamide $-100,800 \mathrm{mg} / \mathrm{L}$. 
Table 19. Hydraulic conductivities of burtal trench soll columns before and after grouting with polygorylamido

\begin{tabular}{llll}
\hline $\begin{array}{l}\text { Sol1 } \\
\text { Column }\end{array}$ & $\begin{array}{c}\text { Bulk } \\
\text { Density } \\
\left(\mathrm{g} / \mathrm{cm}^{3}\right)\end{array}$ & $\frac{\text { Hydraulic Condugtivity }}{\text { Before }}(\ldots \ldots \ldots \mathrm{cm} / \mathrm{s} \ldots \ldots \ldots \ldots \ldots)$ \\
\hline Trench 2 & 0.83 & $1.2 \times 10^{-2}$ & $<2.4 \times 10^{-7}$ \\
Trench 3 & 0.80 & $4.8 \times 10^{-2}$ & $<2.5 \times 10^{-7}$ \\
Trench 4 & 0.78 & $4.0 \times 10^{-2}$ & $<2.6 \times 10^{-7}$ \\
Trench 6 & 0.95 & $3.2 \times 10^{-3}$ & $<2.2 \times 10^{-7}$ \\
Trench 3 Cap & 0.80 & $2.5 \times 10^{-2}$ & $<2.5 \times 10^{-7}$ \\
\hline
\end{tabular}


trench soil is not expected to pose any deleterious effect on the permeability of the grout. Neat acrylanide grouts have measured hydraulic conductivities of about $10^{-10} \mathrm{~cm} / \mathrm{s}$ (Avanti International 1985). This extremely. low permeability is adequate to retain the low residual concentrations of monomeric acrylamide within the polymeric grout to a diffusion-controlled level.

In summary, the proposed in situ grouting of five burial trenches with polyacrylamide had raised several concerns about potential environmental contamination by acrylamide. To establish the compatibility of the acrylamide grout set reaction with potential interference by buried waste constituents, several tests were performed to verify the ability to predict and control the polymerization or set of the acrylamide grout. Samples of soil from the bottom of five trenches and samples of burial trench leachate were collected and added to grout solutions before set. No soil or leachate significantly retarded the grout set time. By chemical analysis of extracts of grout/soil specimens, it was determined that the percent polymerization in the presence of soil or leachate was identical to that achieved with unamended grout, i.e., 99.58. In addition, specimens of burial trench soil were converted from high to unmeasurably low hydraulic conductivities by percolation with reacting grout. Thus, it appears that these burial trench soils and leachate pose no interference with acrylamide grout set. Both the degree of polymerization and the impermeable nature of the resulting polyacrylamide grout lead to the assurance that environmental contamination of groundwater by grout injection into these burial trenches is extremely improbable. 
Page 86

DEGRADATION RATES FOR ${ }^{14} \mathrm{C}$-LABELED POLYACRYLATE AND POLYACRYLAMIDE GROUTS IN SOIL

Chemical and microbial stability is one of the critical issues to be resolved for performance evaluation of organic-based grouts. Laboratory experiments have been conducted for the determination of degradation rates for ${ }^{14} \mathrm{C}$-tagged polyacrylate and polyacrylamide grouts. This subtask reports results of degradation experiments conducted on grouts of $10 \%$ polyacrylate, 208 polyacrylate, $10 \%$ polyacrylamide, and 208 polyacrylamide, over periods of 757 days, 153 days, 153 days, and 440 days, respectively.

The soil used in this experiment was obtained from the $C$ horizon ( 1 to $2 \mathrm{~m}$ from surface) of a Typic Dystrochrept; loamy-skeletal, mixed, thermic (Berks variant series) soil profile, developed on residuum of Maryville Limestone (Conasauga Group), located in Solid Waste Storage Area 6 of the Oak Ridge Reservation. Detailed characterization of the soil sample ( $<2 \mathrm{~mm}$ in diam) showed a clay loam texture ( 288 sand, 358 silt, and 378 clay), ow organic matter content ( 0.178 carbon), moderate cation exchange capacity ( 11 meq/100 g), and acidic $\mathrm{pH}(5.4)$. Vermiculite and illite were the major clay minerals.

The 108 polyacrylate grout components were prepared in two flasks: the first contained $50 \mu 1$ of ${ }^{14} \mathrm{C}$-tagged acrylic acid ( $98 \%$ by wt., $9.43 \mu \mathrm{Ci}$ total activity) supplied by Pathfinder Laboratories, Inc., to which was added 125 mL of AC400 magnesium acrylate monomer ( 408 solids by weight), $4.5 \mathrm{~mL}$ triethanolamine ( 998 by weight), and $68 \mathrm{mg}$ potassium ferricyanide. The second flask contained $250 \mathrm{~mL}$ of $0.1 \mathrm{M}$ ammonium persulfate. The 208 polyacrylate grout was prepared by combining $250 \mathrm{~mL}$ of AC400, $100 \mathrm{mg}$ potassium ferricyanide, and $50 \mu \mathrm{L}$ of $14 \mathrm{C}$-tag with a $250 \mathrm{~mL} 0.1 \mathrm{M}$ ammonium persulfate solution containing $9.0 \mathrm{~mL}$ triethanolamine.

In the case of the polyacrylamide grouts, a ${ }^{14} \mathrm{C}$-acrylamide solution was first prepared by transferring $10 \mathrm{mg}$ of dry acrylamide-UL. ${ }^{14} \mathrm{C}(94.2 \mu \mathrm{Ci}$ total activity) supplied by Pathfinder Laboratories, Inc., to a tared bottle and dissolving it in $10 \mathrm{~mL}$ distilled deionized water. To prepare the 108 polyacrylamide grout, $1 \mathrm{~mL}(9.42 \mu \mathrm{Ci})$ of the tag solution was transferred to a flask which also contained $50 \mathrm{~g}$ of $\mathrm{Q}$ Seal acrylamide monomer (928 by weight), $47 \mathrm{mg}$ potassium ferricyanide, $4.2 \mathrm{~mL}$ triethanolamine ( 998 by weight), and $190 \mathrm{~mL}$ distilled deionized water. A second flask contained 250 $\mathrm{mL}$ of $0.1 \mathrm{M}$ ammonium persulfate. The 208 polyacrylamide grout was prepared using $100 \mathrm{~g}$ Q Seal, $92 \mathrm{mg}$ potassium ferricyanide, $8.2 \mathrm{~mL}$ triethanolamine, and $1 \mathrm{~mL}$ of ${ }^{14} \mathrm{C}$-tag in the first flask, and $250 \mathrm{~mL}$ of $0.1 \mathrm{M}$ ammonium persulfate in the second flask.

Water retention characteristics of untagged 10 and 208 polyacrylamide and 108 polyacrylate prepared in the same manner as for the other experiments were measured at $1 / 3,3,8$, and 15 bars on a soil moisture 5-bar and 15-bar pressure plate extractor.

For each experiment, six successive $40 \mathrm{~mL}$ aliquots of grout were prepared by mixing equal volumes $(20 \mathrm{~mL})$ from the two flasks. Each of the four grout compositions were added to a set of six $450-\mathrm{mL}$ jars containing $50 \mathrm{~g}$ each of air-dried soil which had been sieved to <2-mm grain size, making 24 jars 
altogether. Based on scintillation counting of $1-\mathrm{mL}$ aliquots of the unpolymerized $14 \mathrm{C}$-acrylate and acrylamide solutions, the $14 \mathrm{C}$ activities added to the soil jars were calculated to be $0.620 \mu \mathrm{Ci}$ in the case of the 108 polyacrylate, $0.645 \mu \mathrm{Ci}$ for the 208 polyacrylate, $0.652 \mu \mathrm{Ci}$. For the 108 polyacrylamide, and $0.626 \mu \mathrm{Ci}$ for the 208 polyacrylamide. After the groutc had set thoroughly, the soil/grout mixtures in three of the jars (designated 4,5 , and 6) in each experiment were macerated using a spatula. Jars 1, 2, and 3 in each experiment were left undisturbed. An open scintillation vial containing $1 \mathrm{~mL}$ of $1.0 \mathrm{~N} \mathrm{NaOH}$ was placed in each $j$ ar; the $j$ ars were then sealed and stored in an incubator at $25^{\circ} \mathrm{C}$. The scintillation vials were replaced at 3- to 5-d intervals initially, later at weekly intervals, and in some cases monthly intervals. ${ }^{14} \mathrm{CO}_{2}$ collected in the vials was determined by adding $1 \mathrm{~mL}$ distilled water and $18 \mathrm{~mL}$ ACS scintillation cocktail to each vial, mixing, then measuring radioactivity with a Packard TriCarb Model 3255 liquid scintillation spectrometer.

In the course of the experiments, it was observed that as the carbonate contents of some of the vials increased, precipitation of $\mathrm{Na}_{2} \mathrm{CO}_{3}$ began to occur upon addition of the scintillation cocktail. To prevent this, two methods for dilution were used. Initially, a $0.5-\mathrm{mL}$ aliquot of $1.0 \mathrm{~N} \mathrm{NaOH}$ solution was transferred from a "problem" vial to a new vial and diluted with $1.5 \mathrm{~mL}$ distilled water before addition of scintillation cocktail. When this became insufficient, an alternate method was used: $2 \mathrm{~mL}$ of $1.0 \underline{\mathrm{N}} \mathrm{NaOH}$ was added to the vials before $\mathrm{CO}_{2}$ collection, then $0.5 \mathrm{~mL}$ was transferred after collection and diluted as before. This prevented precipitation and made for a fourfold dilution of the ${ }^{14} \mathrm{C}$-bearing $\mathrm{NaOH}$ solution.

Later, when activity levels in the jars declined sufficiently, dilutions were reduced to twofold by transfer of $1 \mathrm{~mL}$ of $\mathrm{NaOH}$ from the sampling vial, with addition of $1 \mathrm{~mL}$ of distilled water. As the experiments continued, it was possible to eliminate the dilutions altogether and return to the original sampling procedures.

A first-order rate law for grout degradation was calculated by plotting concentration (radioactivity) versus time

$$
\mathrm{C}=\mathrm{C}_{0}-\mathrm{kt}, \quad \text { (Equation 1) }
$$

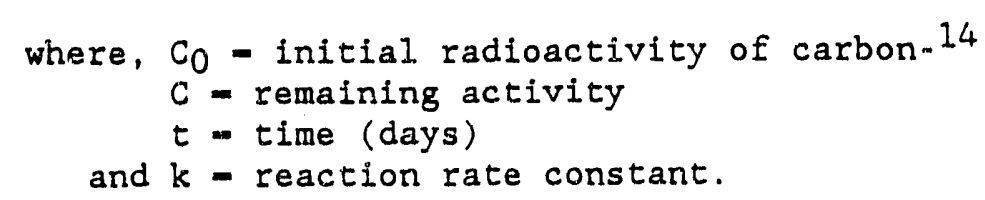

The half-life $(t)$ of the reaction was calculated using the equation

$$
t=0.6931 / k \text {. }
$$

(Equation 2)

Thus, the half-life of the grout is independent of its initial quantity.

Several factors could affect the degradation of added grout materials. The biological degradation rate of a given organic substrate will depend upon its composition and the physicochemical conditions in the surrounding 
Page 88

environment. Temperature, $\mathrm{O}_{2}$ supply, moisture, $\mathrm{pH}$, available nutrients, $\mathrm{C}: \mathrm{N}$ ratio of soil organics, and the indigenous microbial population are the main environmental influences. In these laboratory experiments, incubation temperature was $25^{\circ} \mathrm{C}$, under moist but unsaturated conditions, and aerobic conditions were maintained by periodic opening of the fars for sampling.

Water contents of acrylamide and acrylate polymers depend on the amount of monomers and catalysts used initially. Understanding the behavior of water in the polymers is important because the water molecules control their stability. The polymers will shrink when they lose water, resulting in the formation of undesirable voids between the polymer block and trench wall and cap. Therefore, water retention characteristics of the polymers were investigated under various tension pressures $(1 / 3,3$, and 15 bars) that have been widely used in other studies. The field water capacity of a soil is determined in the laboratory by measuring the water content of a soil sample under $1 / 3$ bar tension. Under these conditions, most large pores have drained free of water. The water associated with the tension zone between field capacity and about 3 bars is easily extracted by plants with minimal expenditure of energy. Soll water under tension between 3 and 15 bars becomes more difficult to extract by plants. As water tension increases in this range, plants undergo drought stress. Finally, a tension is reached under which a plant can no longer extract water. This tension is commonly termed the permanent wilting point and is observed at 15 bars in the laboratory.

The average water contents measured under 0 bars pressure after oven drying at $105^{\circ} \mathrm{C}$ for $24 \mathrm{~h}$, were 86.48 for $10 \mathrm{z}$ polyacrylate, $84.6 \mathrm{z}$ for $10 \mathrm{z}$ polyacrylamide, and 74.28 for 208 polyacrylamide (Table 20). The water contents after equilibration at $1 / 3,3,8$, and 15 bars tension were not significantly different. The ability of both polyacrylamide and polyacrylate to retain water at 15 bars tension indicates that plants should not be able to extract any of this bound water. The only movement of polymer-bound water to the surrounding medium should be by diffusion, a slow process that would occur only if there were a large differential in moisture content.

Conversely, when the surrounding medium is saturated, diffusion should be in the reverse direction. Subsurface solls could remain in an unsaturated condition for a significant period, but in a humid region, the soil water tension should remain close to field capacity. Therefore, void formation between the injected polymers and trench walls due to shrinkage of the polymers is not expected and is not considered a limiting factor for their application in this region.

Degradation of $108{ }^{14} \mathrm{C}$-polyacrylate: When the results from scintillation counting of the $\mathrm{CO}_{2}$ collection vials exposed to the polyacrylate-grouted soil were plotted in terms of evolved ${ }^{14} \mathrm{C}$ activity versus time, the three undisturbed soil/grout replicates (1, 2, and 3) showed an initially high activity, followed by a gradual decline. Replicates 1 and 2 appear to have "bottomed out" by approximately day 40, but replicate 3 underwent a sharp increase in activity, beginning around day 30 , peaking near day 48 , and declining gradually thereafter. Near day 60 , replicate 2 began a similar pattern, peaking near day 75 at half again the activity of replicate 3 . 
Table 20. Water retention characteristics of acrylate and acrylamide polymers at various pressures

Water Retention, \&

0 bar $1 / 3$ bar 3 bars 8 bars 15 bars

\begin{tabular}{llllll}
108 polyacrylate & 86.4 & 86.3 & 85.1 & 85.5 & 85.9 \\
\hline 108 polyacrylamide & 86.6 & 86.8 & 86.2 & 86.4 & 85.9 \\
208 polyacrylamide & 74.2 & 73.8 & 73.3 & 72.2 & 72.9 \\
\hline
\end{tabular}

About that date, replicate 1 also increased sharply and peaked around day 90 at well over twice the maximum level of replicate 3 . In each case, the increase in ${ }^{14} \mathrm{C}$ activity measured in the scintillation vials was directly correlated with visual observation of fungal mycelia in the undisturbed soil/grout jars.

The three macerated soil/grout replicates $(4,5$, and 6 ) displayed a similar pattern, only later. All had a sharp but relatively low ${ }^{14} \mathrm{C}$ peak within the first week after grouting, followed by a rapid decline and gradual leveling off of activity. This was succeeded in each case by a period of rapid degradation accompanied by the appearance of fungal mycelia, beginning with replicate 6 on day 150 , then replicate 4 around day 210 , and replicate 5 after day 250. Activities released from the macerated grout forms during these periods of rapid fungal growth, though occurring later, were nearly twice as great $(0.063 \mu \mathrm{Ci}$ average, as compared with $0.034 \mu \mathrm{Cl}$ for the undisturbed grouts) (Table 21).

To calculate the grout degradation rates, the data were plotted as concentration versus time, i.e. In $\left(C_{0} / C\right)$ versus $t$, assuming the degradation processes to be first-order reactions (Fig. 26). The slopes of these curves represent different degradation rate constants, from which grout half-lives can be calculated. "Steady degradation" rate constants $\left(k_{1}-k_{7}\right)$ were determined for the $10 \%$ polyacrylate grout replicates (Table 22 ).

Although "steady degradation" constituted an average of 75.78 of the time-period measured, it generated an average of only 14.28 of the total ${ }^{14} \mathrm{C}$ activity released from the $10 \%$ polyacrylate grouts ( 18.48 for undisturbed, 10.08 for macerated forms). Of the tagged carbon given off as $\mathrm{CO}_{2}$ during the monitoring period, 85.28 was released during short bursts of rapid degradation by soll microorganisms. However, there has been no renewal of this sort of activity since approximately day 355, and it appears that the rate constants from the latter portion of the plot $\left(k_{2}-k_{7}\right)$ reflect long-term grout behavior. 
Page 90 Table 21. Loss of ${ }^{14} \mathrm{C}$ activity from $10 \%$ polyacrylate grout, by degradation

\begin{tabular}{|c|c|c|c|c|c|c|c|}
\hline \multicolumn{4}{|c|}{ Undisturbed } & \multicolumn{4}{|c|}{ Macerated } \\
\hline Replicate & Day & $\mu \mathrm{CI}$ & 8 loss & Replicate & Day & $\mu \mathrm{Ci}$ & $\&$ loss \\
\hline 1 & $\begin{array}{c}0-74 \\
74-161 \\
161-757 \\
\text { Total }\end{array}$ & $\begin{array}{l}0.0078 \\
0.0361 \\
0.0092 \\
0.0531\end{array}$ & $\begin{array}{l}1.26 \\
5.82 \\
1.48 \\
8.56\end{array}$ & 4 & $\begin{array}{l}0-60 \\
60-208 \\
208-355 \\
355-757 \\
\text { Total }\end{array}$ & $\begin{array}{l}0.0059 \\
0.0031 \\
0.0569 \\
0.0051 \\
0.0717\end{array}$ & $\begin{array}{r}0.95 \\
0.50 \\
9.18 \\
0.82 \\
11.56\end{array}$ \\
\hline 1 & $\begin{array}{c}0-60 \\
60-147 \\
147-757 \\
\text { Total }\end{array}$ & $\begin{array}{l}0.0075 \\
0.0394 \\
0.0089 \\
0.0558\end{array}$ & $\begin{array}{l}1.21 \\
6.35 \\
1.43 \\
9.00\end{array}$ & 5 & $\begin{array}{c}0-60 \\
60-249 \\
249-355 \\
355-757 \\
\text { Total }\end{array}$ & $\begin{array}{l}0.0059 \\
0.0043 \\
0.0687 \\
0.0040 \\
0.0837\end{array}$ & $\begin{array}{r}0.95 \\
0.69 \\
11.08 \\
0.65 \\
13.50\end{array}$ \\
\hline 3 & $\begin{array}{c}0-28 \\
28-161 \\
61-757 \\
\text { Total }\end{array}$ & $\begin{array}{l}0.0051 \\
0.0263 \\
0.0089 \\
0.0403\end{array}$ & $\begin{array}{l}0.82 \\
4.24 \\
1.43 \\
6.50\end{array}$ & 6 & $\begin{array}{r}0-60 \\
60-147 \\
147-347 \\
347-757 \\
\text { Total }\end{array}$ & $\begin{array}{l}0.0059 \\
0.0021 \\
0.0632 \\
0.0046 \\
0.0767\end{array}$ & $\begin{array}{r}0.95 \\
0.34 \\
10.20 \\
0.74 \\
12.37\end{array}$ \\
\hline
\end{tabular}


Table 22. Degradation rate constants and half-lives of 10 polyacrylate grout in soil

\begin{tabular}{|c|c|c|c|c|}
\hline $\begin{array}{l}\text { Rate Constant } \\
\left(\text { day }^{-1}\right)\end{array}$ & $\begin{array}{c}\text { Half-1ife } \\
\text { (years) }\end{array}$ & & & Remarks \\
\hline$k_{1} 3.5 \times 10^{-5}$ & 53.7 & $1 s t$ & steady & degradation \\
\hline $\begin{array}{llll}k_{2} & 3.4 \times 10^{-5} \\
k_{3} & 3.8 \times 10^{-5} \\
k_{4} & 4.1 \times 10^{-5}\end{array}$ & $\begin{array}{l}55.0 \\
49.8 \\
46.8\end{array}$ & $\begin{array}{l}2 \mathrm{nd} \\
2 \mathrm{nd} \\
2 \mathrm{nd}\end{array}$ & $\begin{array}{l}\text { steady } \\
\text { steady } \\
\text { steady }\end{array}$ & $\begin{array}{l}\text { degradation } \\
\text { degradation } \\
\text { degradation }\end{array}$ \\
\hline $\begin{array}{llll}k_{5} & 3.4 \times 10^{-5} \\
k_{6} & 3.5 \times 10^{-5} \\
k_{7} & 3.2 \times 10^{-5}\end{array}$ & $\begin{array}{l}55.0 \\
54.8 \\
60.0\end{array}$ & $\begin{array}{l}\text { 2nd } \\
\text { 2nd } \\
\text { 2nd }\end{array}$ & $\begin{array}{l}\text { steady } \\
\text { steady } \\
\text { steady }\end{array}$ & $\begin{array}{l}\text { degradation } \\
\text { degradation } \\
\text { degradation }\end{array}$ \\
\hline
\end{tabular}




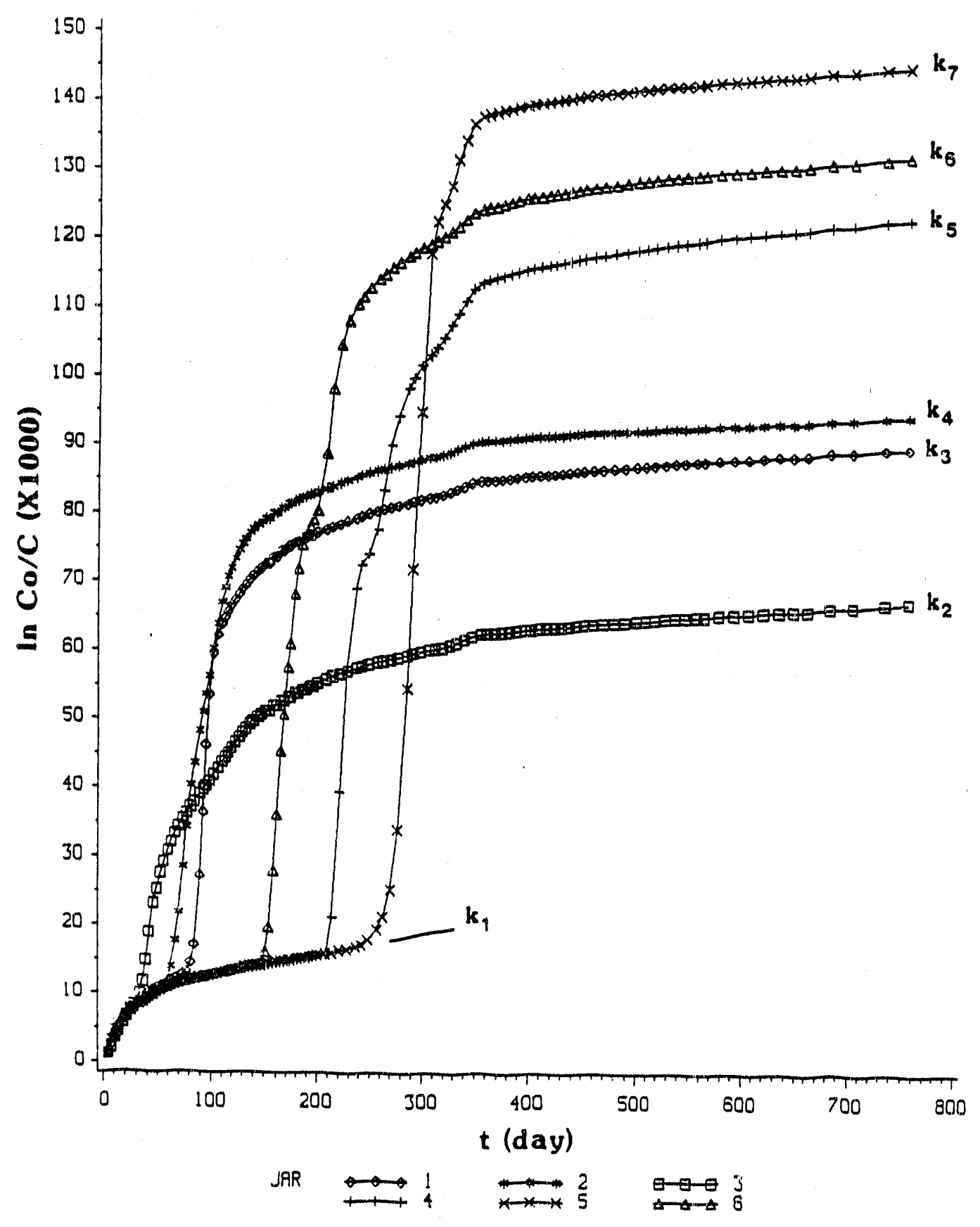

Figure 26. Degradation of $108{ }^{14} \mathrm{C}$.polyacrylate grout in so11, plotted according Equation 1 ( $k$ represents rate constants shown in Table 21). 
Degradation of $20 \%{ }^{14} \mathrm{C}$-polyacrylate: After 153 days of monitoring, it appears that only since Day 139 has the $20 \%$ polyacrylate grout degradation begun to pass from an "initial" to a "steady" phase (Fig. 27, Table 24). Comparison of 108 and 208 polyacrylate grout half-lives may therefore not be especially useful at this time. However, activity released from the 208 polyacrylate grout composition has been significantly less than from the 108 polyacrylate composition (nearly an order of magnitude less, when measured over the same time period as percent of initialiy added activity), and the six replicates have shown remarkable consistency in rate and timing of degradation stages. The combination of low released ${ }^{14} \mathrm{C}$-activity, relatively high degradation rate constants, and virtually identical behavior of macerated and undisturbed 208 polyacrylate grout forms, in contrast with the relatively erratic behavior of the 108 polyacrylate forms, may represent a toxicity effect which is delaying achievement of a "steady-state" microbial population.

Degradation of $108{ }^{14} \mathrm{C}$-polyacrylamide: The plot of $\ln \left(\mathrm{C}_{\mathrm{O}} / \mathrm{C}\right)$ versus $t$ for the $10 \%$ polyacrylamide grout (Fig. 28) shows a distinct resemblance to that for 108 polyacrylate, with the various grout forms degrading at different rates. The macerated replicates display consistently lower degradation rate ( $k_{11}$ and $k_{12}$, Table 26), while the undisturbed replicates have degraded more rapidily and exratically. It is unclear why the undisturbed samples should degrade more rapidly; however, a slight downturn in $\ln \left(\mathrm{C}_{0} / C\right)$ for the last pair of samples from jars 1-3 may be the beginning of a "steady" phase with rate constants similar to those for jars 4-6. Perhaps the 108 polyacrylamide degradation will follow a path similar to that of the 108 polyacrylate - the undisturbed forms undergoing rapid degradation earlier, but releasing less activity overall, while rapid degradation of the macerated forms is delayed but ultimately releases more activity due to increased surface area available for microbial attack.

Degradation of $208{ }^{14} \mathrm{C}$-polyacrylamide: Data for the first 440 days of the $20814 \mathrm{C}$-polyacrylamide experiment have been plotted as $\ln \left(C_{0} / C\right)$ versus $t$ (Fig. 29). Two major phases of grout degradation based on $14 \mathrm{C}$-actlvity have appeared so far: an initial, very rapid phase $\left(k_{17}\right)$ lasting approximately 20 days, and a slower phase observed from day 21 onward. This latier phase probably does not represent "steady" degradation, however; it may represent a long-term toxicity effect like that of the $20 \%$ polyacrylate grout, impeding microbial growth toward a stable population level. During the initial rapid phase, average $14 \mathrm{C}$ loss anong the replicates was $0.048 \%$ of the total activity applied for each far (Table 27). The percent activity losses between days 21 and 440 were 0.1598 for undisturbed and 0.2778 for macerated replicates. A feature of this latter phase has been the divergence of degradation rates for the undisturbed $\left(k_{18}-20\right)$ versus macerated $\left(k_{21}-23\right)$ grout replicates. The consistently higher rate of $14 \mathrm{C}$-release from the macerated replicates may indicate that a larger surface area facilitates microbial activity and/or diffusion of unreacted monomer into the atmosphere (Table 28), though this leaves unresolved the question of why the 108 polyacrylamide composition should behave in the opposite manner, with undisturbed forms degrading faster than macerated. 


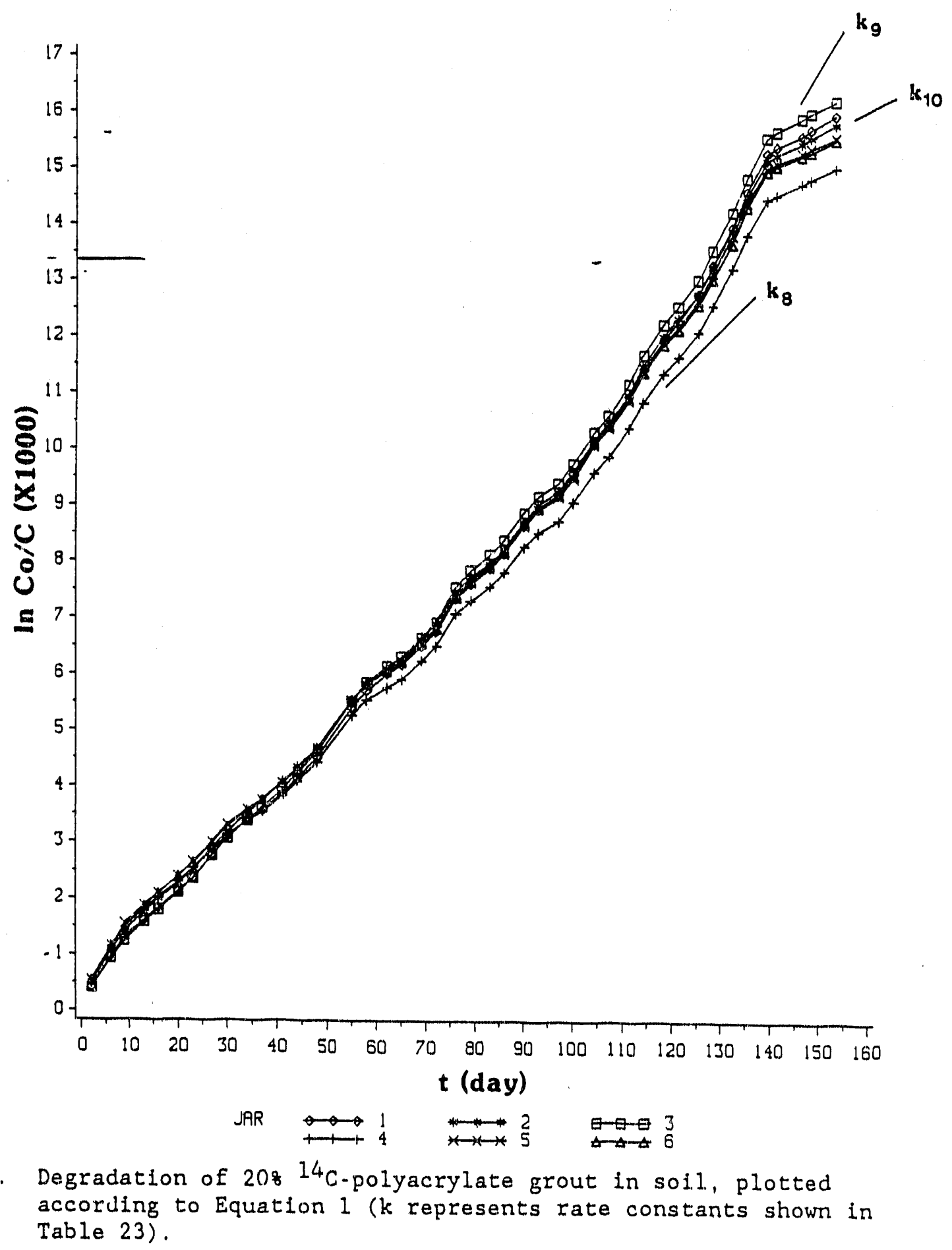




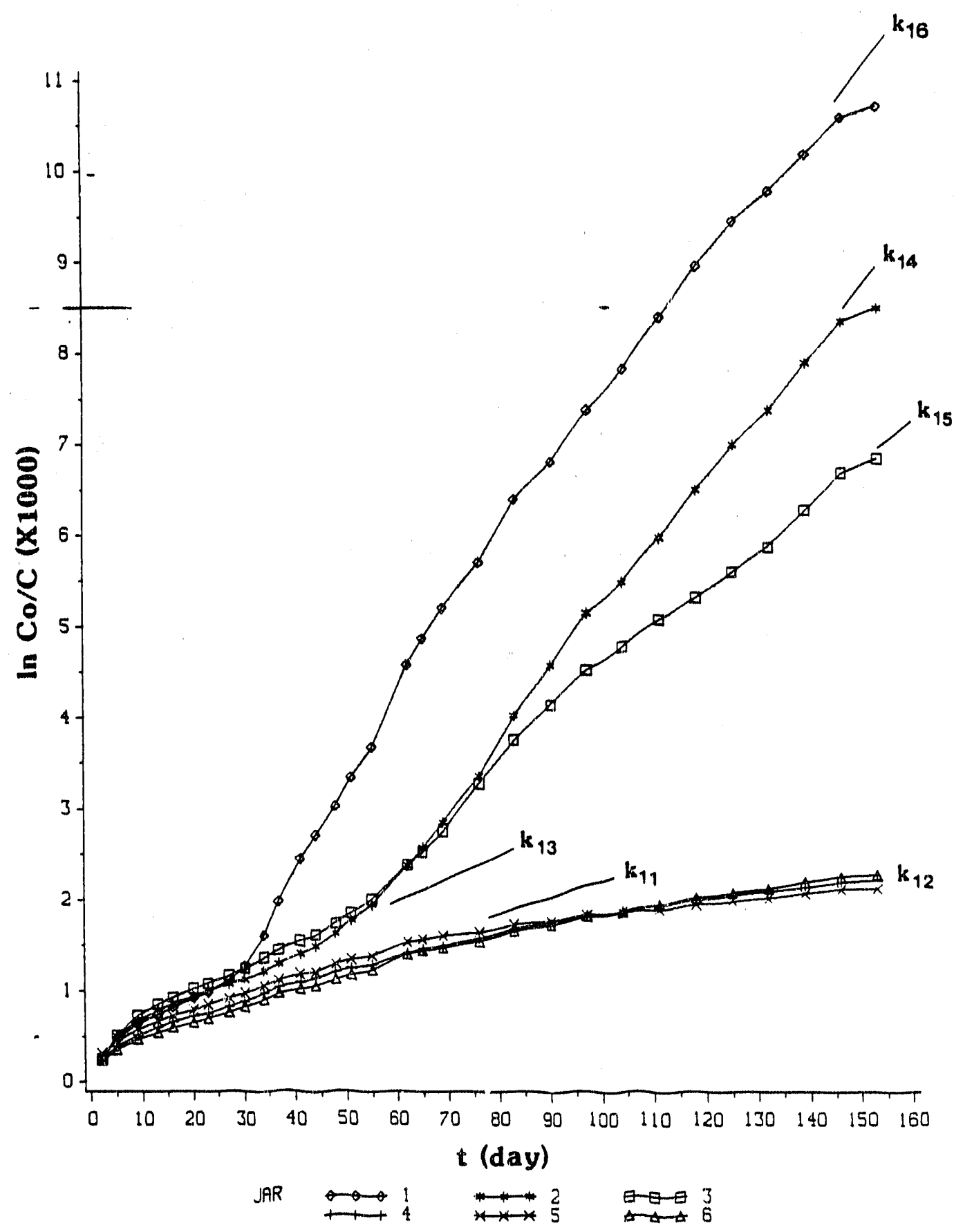

Fig. 28. Degradation of $10 \% 14 \mathrm{C}$-polyacrylamide grout in soil, plotted according to Equation 1 ( $k$ represents rate constants shown in Table 25). 


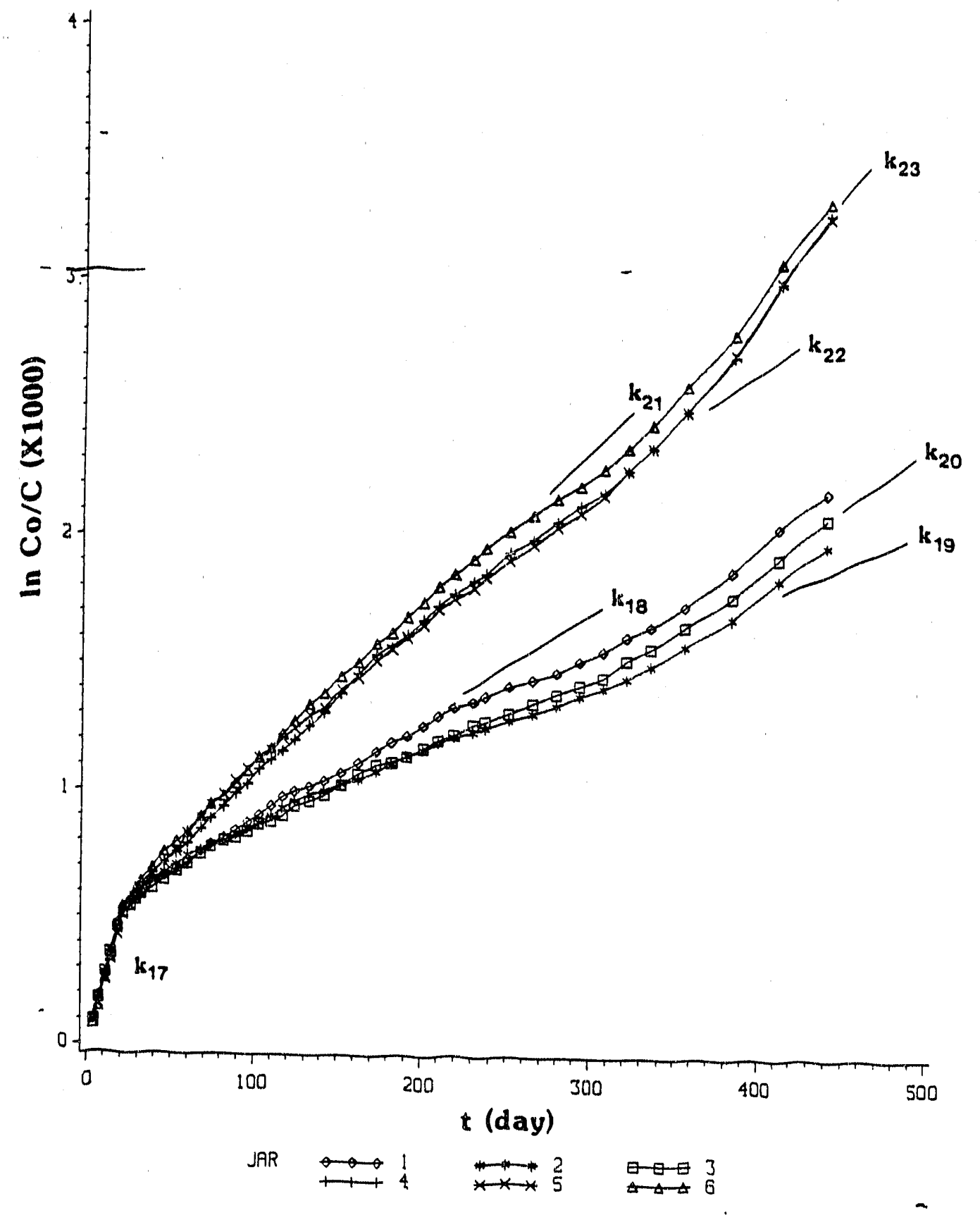

Fig. 29. Degradation of $20814 \mathrm{C}$-polyacrylamide grout in soil, plotted according to Equation 1 ( $k$ represents rate constants shown in Table 27). 
Page 97

Table 23. Loss of ${ }^{14} \mathrm{C}$ activity from 208 polyacrylate grout in soil

\begin{tabular}{lccc}
\hline Replicate & Day & 14C loss, $\mu \mathrm{Cl}$ & \& loss \\
\hline \multirow{2}{*}{1.6 (averaged) } & 0.97 & 0.0059 & 0.915 \\
& $97-139$ & 0.0037 & 0.574 \\
& $139-153$ & 0.0035 & 0.054 \\
& Total & 0.0131 & 1.543 \\
\hline
\end{tabular}

Table 24. Degradation rate constants and half-lives of $20 \%$ polyacrylate grout in soil

\begin{tabular}{|c|c|c|c|}
\hline Rate & $\begin{array}{l}\text { Constant } \\
\left(\text { day }^{-1}\right)\end{array}$ & $\begin{array}{c}\text { Half-Life } \\
\text { (years) }\end{array}$ & Remarks \\
\hline $\begin{array}{l}k_{8} \\
k_{9} \\
k_{10}\end{array}$ & $\begin{array}{l}8.8 \times 10^{-5} \\
1.4 \times 10^{-4} \\
6.4 \times 10^{-5}\end{array}$ & $\begin{array}{l}21.6 \\
13.5 \\
29.6\end{array}$ & $\begin{array}{l}\text { Initial degradation } \\
\text { Accelerated degradation } \\
\text { Steady degradation? }\end{array}$ \\
\hline
\end{tabular}


Table 25. Loss of ${ }^{14} \mathrm{C}$ activity from 108 polyacrylamide grout in soil

\begin{tabular}{|c|c|c|c|}
\hline Replicate & Day & ${ }^{14} \mathrm{C}$ loss, $\mu \mathrm{Cl}$ & $\&$ loss \\
\hline 1 & $\begin{array}{c}0.9 \\
9-30 \\
30-153 \\
\text { Total }\end{array}$ & $\begin{array}{l}0.0004 \\
0.0004 \\
0.0061 \\
0.0069\end{array}$ & $\begin{array}{l}0.06 \\
0.06 \\
0.94 \\
1.07\end{array}$ \\
\hline 2 & $\begin{array}{c}0-9 \\
9-48 \\
48-153 \\
\text { Total }\end{array}$ & $\begin{array}{l}0.0004 \\
0.0006 \\
0.0045 \\
0.0055\end{array}$ & $\begin{array}{l}0.07 \\
0.09 \\
0.68 \\
0.85\end{array}$ \\
\hline 3 & $\begin{array}{c}0-9 \\
9-48 \\
48-83 \\
83-153 \\
\text { Total }\end{array}$ & $\begin{array}{l}0.0005 \\
0.0006 \\
0.0013 \\
0.0020 \\
0.0044\end{array}$ & $\begin{array}{l}0.07 \\
0.10 \\
0.20 \\
0.31 \\
0.68\end{array}$ \\
\hline 4 & $\begin{array}{c}0-9 \\
9-62 \\
62-153 \\
\text { Total }\end{array}$ & $\begin{array}{l}0.0003 \\
0.0006 \\
0.0005 \\
0.0014\end{array}$ & $\begin{array}{l}0.05 \\
0.09 \\
0.08 \\
0.22\end{array}$ \\
\hline 5 & $\begin{array}{c}0-9 \\
9-62 \\
62-1.53 \\
\text { Total }\end{array}$ & $\begin{array}{l}0.0004 \\
0.0006 \\
0.0004 \\
0.0014\end{array}$ & $\begin{array}{l}0.06 \\
0.09 \\
0.06 \\
0.21\end{array}$ \\
\hline 6 & $\begin{array}{c}0-9 \\
9-62 \\
62-153 \\
\text { Total }\end{array}$ & $\begin{array}{l}0.0003 \\
0.0006 \\
0.0006 \\
0.0015\end{array}$ & $\begin{array}{l}0.05 \\
0.09 \\
0.09 \\
0.23\end{array}$ \\
\hline
\end{tabular}


Table 26. Degradation rate constants and half-lives of 108 polyacrylamide grout in soil

\begin{tabular}{|c|c|c|}
\hline $\begin{array}{l}\text { Rate Constant } \\
\left(\text { day }^{-1}\right)\end{array}$ & $\begin{array}{l}\text { Half-Life } \\
\text { (years) }\end{array}$ & Remarks \\
\hline $\begin{array}{lll}k_{11} & 1.76 \times 10^{-5} \\
k_{12} & 7.99 \times 10^{-6} \\
k_{13} & 2.48 \times 10^{-5} \\
k_{14} & 7.22 \times 10^{-5} \\
k_{15} & 4.28 \times 10^{-5} \\
k_{16} & 7.43 \times 10^{-5}\end{array}$ & $\begin{array}{r}107.8 \\
237.5 \\
76.5 \\
26.3 \\
44.3 \\
25.5\end{array}$ & $\begin{array}{l}\text { Initial degradation } \\
\text { lst Steady degradation } \\
\text { Initial degradation } \\
\text { Accelerated degradation } \\
\text { Accelerated degradation } \\
\text { Accelerated degradation }\end{array}$ \\
\hline
\end{tabular}


Page 100

Table 27. Loss of ${ }^{14} \mathrm{C}$ activity from 208 polyacrylamide grout in soil

\begin{tabular}{|c|c|c|c|c|}
\hline Replicate & Treatment & Day & ${ }^{14} \mathrm{C}$ loss, $\mu \mathrm{CI}$ & \& Ioss \\
\hline $1 \cdot 3$ & Undisturbed & $\begin{array}{c}0-21 \\
21-124 \\
124-321 \\
321-440 \\
\text { Total }\end{array}$ & $\begin{array}{l}0.0003 \\
0.0003 \\
0.0003 \\
0.0003 \\
0.0012\end{array}$ & $\begin{array}{l}0.048 \\
0.048 \\
0.056 \\
0.055 \\
0.207\end{array}$ \\
\hline $4-6$ & Macerated & $\begin{array}{c}0-21 \\
21-230 \\
230-307 \\
307-440 \\
\text { Total }\end{array}$ & $\begin{array}{l}0.0003 \\
0.0008 \\
0.0002 \\
0.0007 \\
0.0020\end{array}$ & $\begin{array}{l}0.048 \\
0.133 \\
0.036 \\
0.108 \\
0.325\end{array}$ \\
\hline
\end{tabular}

Table 28. Degradation rate constants and half-lives of 208 polyacrylamide grout in soil

\begin{tabular}{|c|c|c|}
\hline $\begin{array}{l}\text { Rate Constant } \\
\left(\text { day }^{-1}\right)\end{array}$ & $\begin{array}{l}\text { Half-1ife } \\
\text { (years) }\end{array}$ & Remarks \\
\hline $\begin{array}{ll}k_{17} & 2.6 \times 10^{-5} \\
k_{18} & 4.3 \times 10^{-6} \\
k_{19} & 3.0 \times 10^{-6} \\
k_{20} & 4.9 \times 10^{-6} \\
k_{21} & 6.7 \times 10^{-6} \\
k_{22} & 4.5 \times 10^{-6} \\
k_{23} & 7.8 \times 10^{-6}\end{array}$ & $\begin{array}{r}73.0 \\
441.3 \\
632.5 \\
388.1 \\
283.2 \\
421.7 \\
243.3\end{array}$ & $\begin{array}{l}\text { Initial degradation } \\
\text { 1st Steady degradation } \\
\text { 2nd Steady degradation } \\
\text { Accelerated degradation } \\
\text { lst Steady degradation } \\
\text { 2nd Steady degradation } \\
\text { Accelerated degradation }\end{array}$ \\
\hline
\end{tabular}


Based on the results to date, the 10 polyacrylate grout has an average "steady" decomposition rate constant of $3.6 \times 10^{-5}$ day-1 $^{-1}$ and an average half-life of 53 years. Although the other three grout compositions may not yet have achieved a "steady" rate, due to toxicity or other effects, there is a clear pattern of superior resistance to decomposition by the polyacrylamide forms. The smallest 208 polyacrylate rate constant obtained to date is $6.4 \mathrm{x}$ $10^{-5}$ day $^{-1}$, corresponding to a half-1ife of 29.6 years (Table 24), while average degradation rates for the $10 z$ and 208 polyacrylamide grouts are respectively $4.0 \times 10^{-5}$ day $^{-1}$ and $5.2 \times 10^{-6}$ day -1 (excluding $k_{17}$ ) (Tables 26 and 28). These correspond to 47- and 365-year half-lives, respectively. The 108 polyacrylate experiment is now over 2 years old, with an apparently stable microblal population, while the other experiments can only look forward to decreased decomposition rates in the long term. The data thus suggest that half-lives of 50-60 years for polyacrylate grouts, versus greater than 300 years for polyacrylamide grout compositions, are quite likely. 
Page 102

\section{FIELD MONITORING OF SWSA 4 GROUTED TRENCHES}

In 1986, a demonstration and evaluation of hydrologic isolation of buried transuranic waste via in situ grouting was carried out in SWSA 4. Two small trenches in the central. region of SWSA 4 (Fig. 30) were filled with $34,000 \mathrm{~L}$ of polyacrylamide grout. These trenches were not dynamically compacted prior to the grouting, and their water accessible voids were completely filled by the grout (Spalding et al. 1987). Intratrench hydraulic conductivity was reduced to below field-measurable values after grout set. A group of monitoring wells (Fig. 31) for the shallow groundwater in the area were installed prior to grouting to establish water quality characteristics in the area and to monitor for potential leaching of grout constituents through time.

The HPLC analysis for grout constituents was used to assay samples from wells on two occasions (Table 29). In the initial sampling on September 21, 1987, no acrylic acid, acrylamide, methylene-bis-acrylamide, or ethylene glycol was found in any of the groundwater monitoring well samples nor was any found in the one intratrench well (number 4) which yielded a water sample. All samples were at or below the detection limit of the technique. However, for samples taken on June 27, 1988, several wells indicated apparent detectable concentrations of either acrylamide, acrylic acid, or methylenebis-acrylamide. First, the detection limit for this sampling date was considerably higher ( 10 versus $0.5 \mathrm{mg} / \mathrm{L}$ ) due to the smaller injection volumes employed. More importantly, several of these apparent concentrations of grout monomers are inconsistent with the total organic carbon (TOC) concentrations. For example, acrylamide contains 50.698 carbon and, therefore, each $\mathrm{mg} / \mathrm{L}$ of acrylamide would require $0.5 \mathrm{mg} / \mathrm{L}$ of $\mathrm{TOC}$. The inconsistency of the reported acrylamide concentration of $16 \mathrm{mg} / \mathrm{L}$ in well 17 with a TOC of $1.9 \mathrm{mg} / \mathrm{L}$ is apparent; if acrylamide concentration was in reality $16 \mathrm{mg} / \mathrm{L}$, then the TOC must be at least $8 \mathrm{mg} / \mathrm{L}$ and probably greater if there were any other organic species present in the sample. Similarly, the well 5 acrylic acid concentration of $24 \mathrm{mg} / \mathrm{L}$ is inconsistent with a TOC of only $0.8 \mathrm{mg} / \mathrm{L}$. The TOC measurements are more accurate for these field samples. The HPLC analysis is based on the measurement of an elution peak from the chromatographic column with a retention time equivalent to a standard, e.g. acrylamide. Other organic or inorganic species, which may be present in the sample, should they elute with the same retention time, would be measured as the standard. In the HPLC analysis of laboratory-prepared grouts, alternate species are not present because of the known additions made in the preparation of the grouts. Thus, the residual monomer analyses, reported previously, are quite accurately measured by the HPLC technique. In field samples, however, unknowns may be present that yield apparent concentrations greater than those actually present. It should be emphasized that if grout monomers are present above the detection limit, they will be detected by the technique; thus, a less-than number in Table 29 is accurate and false negatives are not possible. A refinement of the HPLC technique will be attempted next year to avoid the obvious false positives for grout constituents in the SWSA 4 monitoring wells.

The intratrench monitoring wells (Numbers $1,2,4,8$, and 10) all showed significantly elevated. TOC values. These are probably associated with the 
Page 103

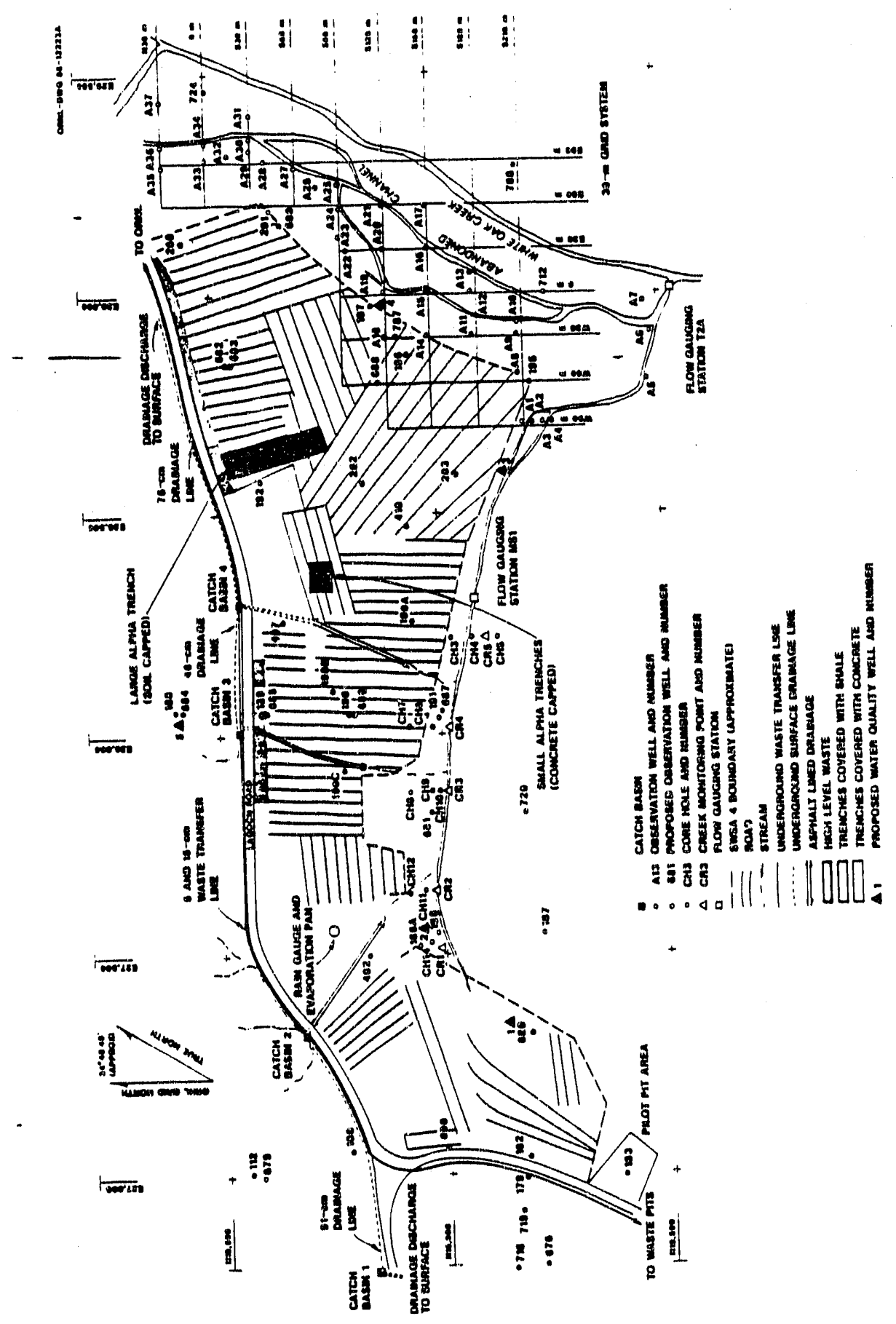

Fig. 30. Map of Solid Waste Storage Area 4, ORNL, showing area selected for demonstration of in situ grouting of buried transuranic waste. 


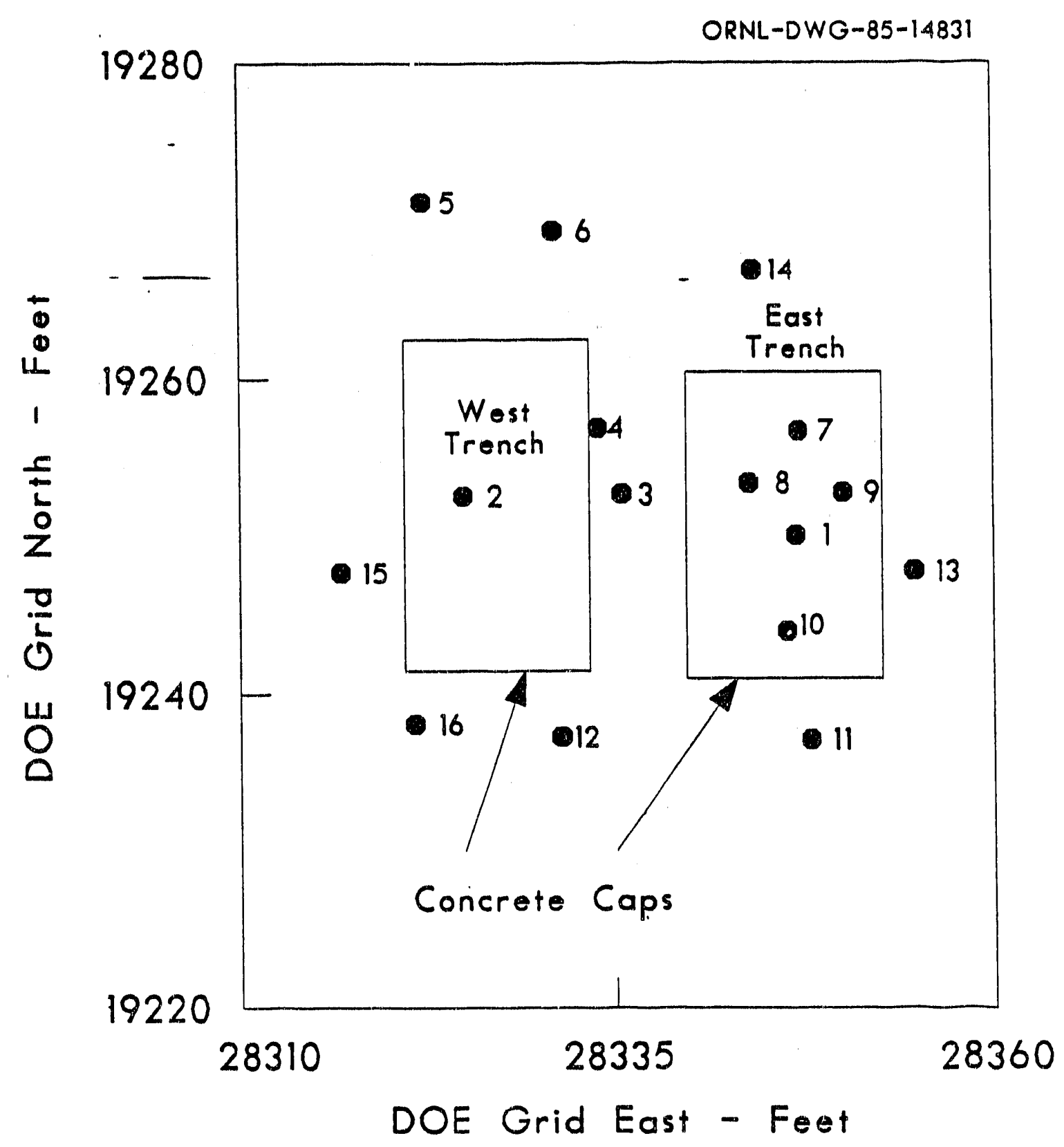

Fig. 31. Plan view of trench caps and monitoring well locations in the study area for buried transuranic waste in situ grouting demonstration. 
Table 29. Organic analyzates in groundwater samples from the SWSA 4. monitoring wells around the polyacrylamide grouting demonstration trenches

\begin{tabular}{|c|c|c|c|c|c|}
\hline Well & $\begin{array}{l}\text { Total } \\
\text { Organic } \\
\text { Carbon }\end{array}$ & Acrylamide & $\begin{array}{l}\text { Acrylic } \\
\text { Acid }\end{array}$ & $\begin{array}{l}\text { Methylene- } \\
\text { bis -acrylamide }\end{array}$ & $\begin{array}{l}\text { Ethylene } \\
\text { Glycol }\end{array}$ \\
\hline & $(\ldots \ldots)$ & & $. \mathrm{mg} / \mathrm{L}$. & $\ldots \ldots \ldots$ & 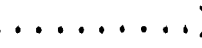 \\
\hline
\end{tabular}

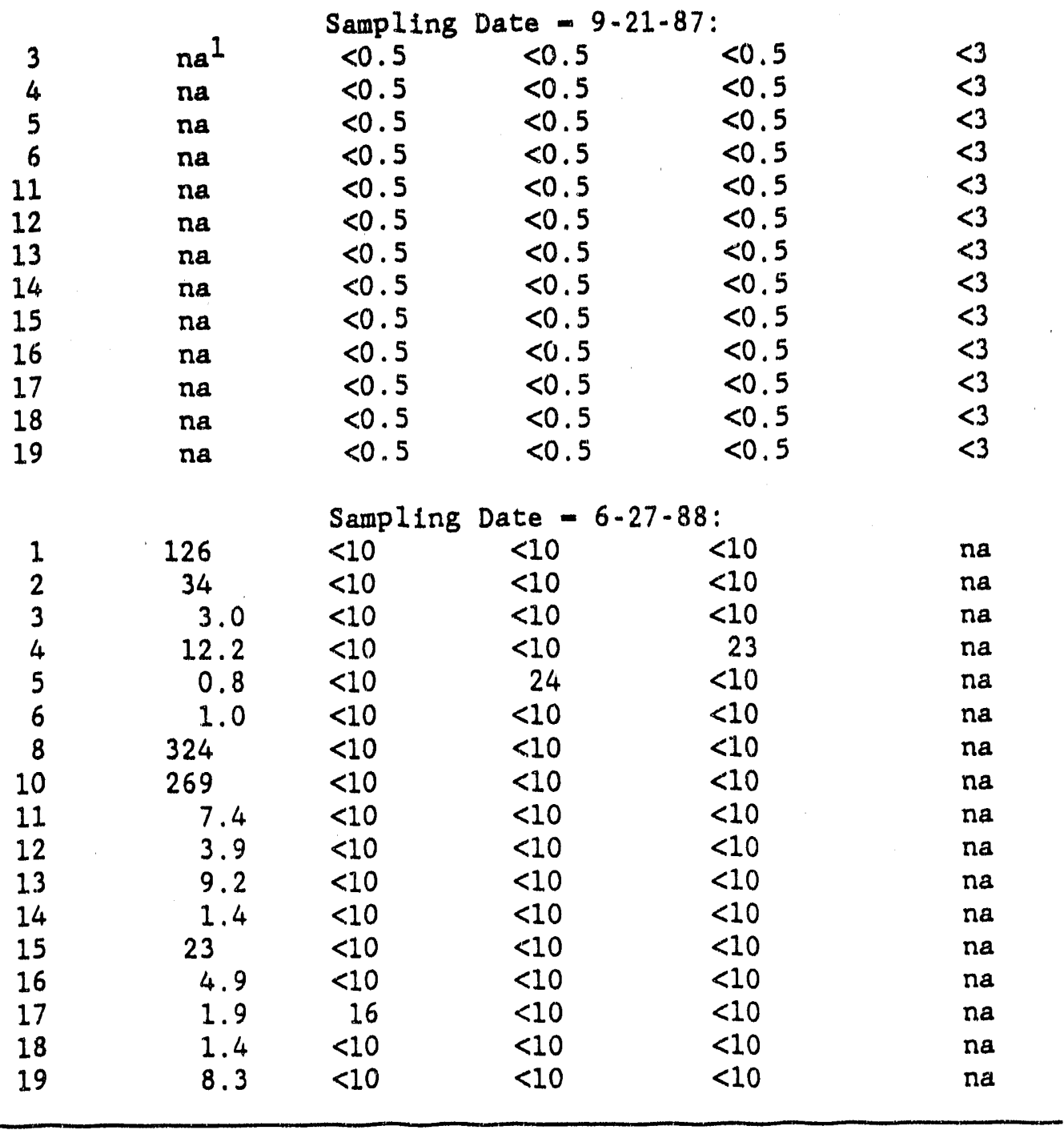

1 not analyzed for. 
hydrocarbon ofl which was found floating on the standing water in these two trenches when they were characterized prior to grouting. A sample of the oil was skimmed from the trench and submitted for analysis; it contained no PCBs and was composed of aliphatic hydrocarbons typical of a machining o1l. Many metallic turnings and shavings were augered from these trenches during the placement of intratrench monitoring wells, and the presence of machining oil would be consistent with the nature of the waste. The high TOCs are probably associated with the residuals of this hydrocarbon oil which adheres to the surfaces of all the intratrench well casings. It should also be noted that this oil is immiscible with the aqueous acrylamide grout and that encapsulation of hydrophoblc species or water-immiscible fluids by acrylamide grout would not be expected without the addition of some surfactant or soap.

Values for the gross chemical and radiochemical characteristics of these monitoring well samples are presented in Table 30. No consistent or significant changes in these characteristics is observable between these recent values and those reported previously for samples taken before and Immediately after grouting (Spalding et al. 1987). Additionally, the samples taken on September 21, 1987, were submitted for ICP elements as a documentation of water quality in the area (Table 31). No particularly anomalous values for heavy metals were apparent, and the major cations ( $\mathrm{Ca}$, $\mathrm{Mg}, \mathrm{Na}, \mathrm{Al}$, and $\mathrm{Fe}$ ) and $\mathrm{S} I$ were typical for shallow groundwaters in the Conasauga formation. 
Table 30. Water quality characteristics of SWSA 4 monitoring wells around the in situ grouting demonstration trenches

\begin{tabular}{|c|c|c|c|c|c|c|c|c|}
\hline \multirow[t]{2}{*}{$\begin{array}{l}\text { Wel1 } \\
\text { Number }\end{array}$} & \multirow[t]{2}{*}{$\mathrm{pH}$} & \multirow[t]{2}{*}{$\begin{array}{c}\text { E.C. } \\
(\mathrm{dS} / \mathrm{m})\end{array}$} & \multicolumn{2}{|c|}{$\begin{array}{l}\text { Hardness } \mathrm{Alkalind}^{\mathrm{D}} \\
(\ldots \mathrm{mg} \mathrm{CaCO} \\
\mathrm{L}\end{array}$} & $\begin{array}{l}\text { Dissolved } \\
\text { y Solids } \\
(\mathrm{mg} / \mathrm{L})\end{array}$ & \multirow[t]{2}{*}{ 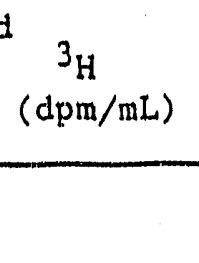 } & \multirow[t]{2}{*}{$\begin{array}{c}\text { Gross } \\
\text { Beta } \\
(\mathrm{Bq} / \mathrm{L})\end{array}$} & \multirow[t]{2}{*}{$\begin{array}{l}\text { Gross } \\
\text { Alpha } \\
(\mathrm{Bq} / \mathrm{L})\end{array}$} \\
\hline & & & Samplin & ng Date -6 & $5-27-88$ & & & \\
\hline $\begin{array}{l}\text { SWSA4-3 } \\
\text { SWSA4-4 } \\
\text { SWSA4-5 } \\
\text { SWSA4-6 } \\
\text { SWSA 4-11 } \\
\text { SWSA4-12 } \\
\text { SWSA4 - } 13 \\
\text { SWSA4-14 } \\
\text { SWSA4-15 } \\
\text { SWSA4-16 } \\
\text { SWSA4-17 } \\
\text { SWSA4-18 } \\
\text { SWSA4-19 } \\
\text { SWSA4-1 } \\
\text { SWSA4-2 } \\
\text { SWSA4-8 } \\
\text { SWSA4-10 }\end{array}$ & $\begin{array}{r}6.4 \\
6.9 \\
7.6 \\
7.4 \\
7 \\
7 \\
6.8 \\
7.5 \\
8.8 \\
6.2 \\
6.9 \\
7.6 \\
7.1 \\
8 \\
7.9 \\
6.7 \\
8.1\end{array}$ & $\begin{array}{r}696 \\
1278 \\
290 \\
301 \\
1001 \\
922 \\
692 \\
469 \\
1822 \\
642 \\
631 \\
438 \\
907 \\
2350 \\
559 \\
508 \\
3050\end{array}$ & $\begin{array}{r}258 \\
560 \\
184 \\
188 \\
488 \\
366 \\
368 \\
240 \\
50 \\
232 \\
312 \\
184 \\
372 \\
122 \\
124 \\
168 \\
96\end{array}$ & $\begin{array}{r}40 \\
220 \\
140 \\
140 \\
510 \\
540 \\
370 \\
220 \\
480 \\
170 \\
320 \\
180 \\
280 \\
1120 \\
180 \\
0 \\
1620\end{array}$ & $\begin{array}{r}700 \\
1000 \\
160 \\
200 \\
620 \\
620 \\
480 \\
280 \\
2220 \\
600 \\
400 \\
280 \\
920 \\
520 \\
340 \\
1220 \\
960\end{array}$ & $\begin{array}{r}5 \\
7 \\
1 \\
4 \\
7 \\
5 \\
7 \\
7 \\
7 \\
10 \\
8 \\
5 \\
7 \\
9 \\
28 \\
24 \\
10\end{array}$ & $\begin{array}{l}\text { nd }^{1} \\
1 \\
\text { nd } \\
\text { nd } \\
\text { nd } \\
10 \\
\text { nd } \\
2 \\
18 \\
\text { nd } \\
\text { nd } \\
\text { nd } \\
\text { nd } \\
5 \\
8 \\
12 \\
7\end{array}$ & $\begin{array}{c}\text { nd } \\
15 \\
2 \\
6 \\
9 \\
\text { nd } \\
13 \\
9 \\
25 \\
13 \\
\text { nd } \\
13 \\
11 \\
4 \\
6 \\
11 \\
13\end{array}$ \\
\hline & & & Samplin & ng Date $=9$ & $9.21-87$ & & & \\
\hline 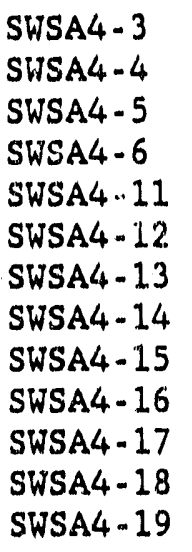 & $\begin{array}{l}6.4 \\
6.9 \\
7.5 \\
7.5 \\
6.4 \\
6.3 \\
6.4 \\
7.3 \\
7.1 \\
6.2 \\
6.8 \\
7.3 \\
7.2\end{array}$ & $\begin{array}{r}1300 \\
1450 \\
280 \\
295 \\
720 \\
740 \\
590 \\
460 \\
1700 \\
840 \\
810 \\
420 \\
910\end{array}$ & $\begin{array}{r}237 \\
368 \\
83 \\
93 \\
218 \\
212 \\
174 \\
126 \\
126 \\
181 \\
255 \\
124 \\
235\end{array}$ & $\begin{array}{l}\text { na } \\
\text { na } \\
\text { na } \\
\text { na } \\
\text { na } \\
\text { na } \\
\text { na } \\
\text { na } \\
\text { na } \\
\text { na } \\
\text { na } \\
\text { na } \\
\text { na }\end{array}$ & $\begin{array}{r}300 \\
740 \\
0 \\
20 \\
380 \\
460 \\
2040 \\
80 \\
1540 \\
460 \\
300 \\
0 \\
1000\end{array}$ & $\begin{array}{l}\text { na } \\
\text { na } \\
\text { na } \\
\text { na } \\
\text { na } \\
\text { na } \\
\text { na } \\
\text { na } \\
\text { na } \\
\text { na } \\
\text { na } \\
\text { na } \\
\text { na }\end{array}$ & $\begin{array}{l}3 \\
16 \\
1 \\
\text { nd } \\
\text { nd } \\
1 \\
\text { nd } \\
\text { nd } \\
2 \\
\text { nd } \\
\text { nd } \\
\text { nd } \\
7\end{array}$ & $\begin{array}{c}\text { nd } \\
56 \\
6 \\
\text { nd } \\
\text { nd } \\
\text { nd } \\
\text { nd } \\
\text { nd } \\
9 \\
\text { nd } \\
\text { nd } \\
18 \\
\text { nd }\end{array}$ \\
\hline
\end{tabular}

not detected.

2 not analyzed. 
Page 108

Table 31. Elemental analyses of groundwater samples from SWSA 4 monftoring wells around the in situ grouting demonstration trenches (sampling date 9-21-87)

\begin{tabular}{|c|c|c|c|c|c|c|c|}
\hline Well & $\stackrel{\mathrm{Ag}}{(\mathrm{mg} / \mathrm{L})}$ & $\frac{\mathrm{Al}}{(\mathrm{mg} / \mathrm{L})}$ & $\begin{array}{c}\text { As } \\
(\mathrm{mg} / \mathrm{L})\end{array}$ & $\begin{array}{c}B \\
(m g / L)\end{array}$ & $\begin{array}{c}\mathrm{Ba} \\
(\mathrm{mg} / \mathrm{L})\end{array}$ & $\begin{array}{c}\mathrm{Be} \\
(\mathrm{mg} / \mathrm{L})\end{array}$ & $\frac{\mathrm{Ca}}{(\mathrm{mg} / \mathrm{L})}$ \\
\hline 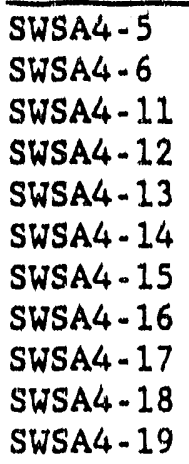 & $\begin{array}{l}<5.0 \mathrm{E}-02 \\
<5.0 \mathrm{E}-02 \\
<5.0 \mathrm{E}-02 \\
<5.0 \mathrm{E}-02 \\
<5.0 \mathrm{E}-02 \\
<5.0 \mathrm{E}-02 \\
<5.0 \mathrm{E}-02 \\
<5.0 \mathrm{E}-02 \\
<5.0 \mathrm{E}-02 \\
<5.0 \mathrm{E}-02 \\
<5.0 \mathrm{E}-02\end{array}$ & $\begin{array}{l}1.6 \\
6.9 \\
0.3 \\
1.6 \\
42 \\
<0.2 \\
1.4 \\
1.4 \\
3.2 \\
0.3 \\
5.7\end{array}$ & $\begin{array}{l}<1 . O E-O 1 \\
<1 . O E-01 \\
<1 . O E-01 \\
<1 . O E-01 \\
<1 . O E-01 \\
<1 . O E-01 \\
<1 . O E-01 \\
<1 . O E-01 \\
<1 . O E-01 \\
<1 . O E-01 \\
<1 . O E-01\end{array}$ & $\begin{array}{l}<8.0 \mathrm{OE}-02 \\
<8 . \mathrm{OE}-02 \\
<8 . \mathrm{OE}-02 \\
<8.0 \mathrm{E}-02 \\
<8.0 \mathrm{E}-02 \\
<8 . \mathrm{OE}-02 \\
<8 . \mathrm{OE}-02 \\
<8 . \mathrm{OE}-02 \\
<8 . \mathrm{OE}-02 \\
<8 . \mathrm{OE}-02 \\
<8 . \mathrm{OE}-02\end{array}$ & $\begin{array}{r}0.21 \\
0.24 \\
0.46 \\
0.49 \\
0.95 \\
0.17 \\
0.27 \\
0.98 \\
0.85 \\
0.26 \\
2\end{array}$ & $\begin{array}{l}<2.0 \mathrm{E}-03 \\
<2.0 \mathrm{E}-03 \\
<2.0 \mathrm{E}-03 \\
<2.0 \mathrm{E}-03 \\
0.0029 \\
<2.0 \mathrm{E}-03 \\
<2.0 \mathrm{E}-03 \\
<2.0 \mathrm{E}-03 \\
<2.0 \mathrm{E}-03 \\
2.0 \mathrm{E}-03 \\
<2.0 \mathrm{E}-03\end{array}$ & $\begin{array}{r}48 \\
51 \\
140 \\
100 \\
100 \\
75 \\
81 \\
59 \\
110 \\
66 \\
150\end{array}$ \\
\hline We11 & $\begin{array}{c}\mathrm{Cd} \\
(\mathrm{mg} / \mathrm{L})\end{array}$ & $\begin{array}{c}\mathrm{Co} \\
(\mathrm{mg} / \mathrm{L})\end{array}$ & $\frac{\mathrm{Cr}}{(\mathrm{mg} / \mathrm{L})}$ & $\frac{\mathrm{Cu}}{(\mathrm{mg} / \mathrm{L})}$ & $\begin{array}{c}F e \\
(\mathrm{mg} / \mathrm{L})\end{array}$ & $\frac{\mathrm{Ga}}{(\mathrm{mg} / \mathrm{L})}$ & $\begin{array}{c}\mathrm{Li} \\
(\mathrm{mg} / \mathrm{L})\end{array}$ \\
\hline $\begin{array}{l}\text { SWSA4-5 } \\
\text { SWSA4-6 } \\
\text { SWSA4-11 } \\
\text { SWSA4-12 } \\
\text { SWSA }-13 \\
\text { SWSA4-14 } \\
\text { SWSA 4-15 } \\
\text { SWSA4-16 } \\
\text { SWSA 4-17 } \\
\text { SWSA4-18 } \\
\text { SWSA4-19 }\end{array}$ & $\begin{array}{l}<5 . O E-03 \\
<5 . O E-03 \\
<5 . O E-03 \\
<5 . O E-03 \\
<5 . O E-03 \\
<5 . O E-03 \\
<5 . O E-03 \\
<5 . O E-03 \\
<5 . O E-03 \\
<5 . O E-03 \\
<5 . O E-03\end{array}$ & $\begin{array}{c}<0.01 \\
<0.01 \\
0.012 \\
<0.01 \\
0.071 \\
<0.01 \\
0.01 \\
0.037 \\
0.013 \\
<0.01 \\
0.013\end{array}$ & $\begin{array}{r}<4 . \mathrm{OE}-02 \\
<4 . \mathrm{OE}-02 \\
<4 . \mathrm{OE}-02 \\
<4.0 \mathrm{E}-02 \\
0.13 \\
<4 . \mathrm{OE}-02 \\
<4 . \mathrm{OE}-02 \\
<4 . \mathrm{OE}-02 \\
<4 . \mathrm{OE}-02 \\
<4 . \mathrm{OE}-02 \\
<4 . \mathrm{OE}-02\end{array}$ & $\begin{array}{r}<2.0 \mathrm{OE}-02 \\
<2.0 \mathrm{E}-02 \\
<2.0 \mathrm{OE}-02 \\
<2.0 \mathrm{E}-02 \\
0.054 \\
<2.0 \mathrm{E}-02 \\
<2.0 \mathrm{E}-02 \\
<2 . \mathrm{OE}-02 \\
<2.0 \mathrm{OE}-02 \\
<2 . \mathrm{OE}-02 \\
<2 . \mathrm{OE}-02\end{array}$ & $\begin{array}{r}2.4 \\
1.0 \\
1.8 \\
2.6 \\
69 \\
0.21 \\
2.3 \\
5.5 \\
6.7 \\
0.3 \\
16\end{array}$ & $\begin{array}{l}<0.3 \\
<0.3 \\
<0.3 \\
<0.3 \\
<0.3 \\
<0.3 \\
<0.3 \\
<0.3 \\
<0.3 \\
<0.3 \\
<0.3\end{array}$ & $\begin{array}{l}<0.2 \\
<0.2 \\
0.4 \\
0.79 \\
<0.2 \\
<0.2 \\
75 . \\
7.9 \\
<0.2 \\
<0.2 \\
<0.2\end{array}$ \\
\hline Wo11 & $\begin{array}{c}\mathrm{Mg} \\
(\mathrm{mg} / \mathrm{L})\end{array}$ & $\frac{\mathrm{Mn}}{(\mathrm{mg} / \mathrm{L})}$ & $\begin{array}{c}\text { Mo } \\
(m g / L)\end{array}$ & $\begin{array}{c}\mathrm{Na} \\
(\mathrm{mg} / \mathrm{L})\end{array}$ & $\begin{array}{c}\mathrm{Ni} \\
(\mathrm{mg} / \mathrm{L})\end{array}$ & $\frac{P}{(m g / L)}$ & $\begin{array}{c}\mathrm{Pb} \\
(\mathrm{mg} / \mathrm{L})\end{array}$ \\
\hline 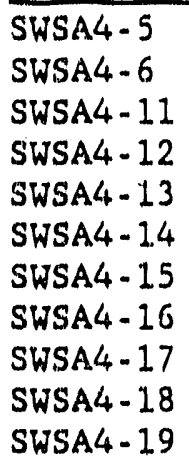 & $\begin{array}{l}9.5 \\
12 \\
20 \\
23 \\
36 \\
21 \\
17 \\
21 \\
28 \\
15 \\
38\end{array}$ & $\begin{array}{r}0.42 \\
0.97 \\
3.2 \\
2.7 \\
11 \\
0.79 \\
0.84 \\
5.4 \\
2.9 \\
0.66 \\
5.6\end{array}$ & $\begin{array}{l}<4.0 \mathrm{E}-02 \\
<4 . \mathrm{E}-02 \\
<4.0 \mathrm{E}-02 \\
<4.0 \mathrm{E}-02 \\
<4.0 \mathrm{E}-02 \\
<4.0 \mathrm{E}-02 \\
<4.0 \mathrm{E}-02 \\
<4.0 \mathrm{E}-02 \\
<4.0 \mathrm{E}-02 \\
<4 . \mathrm{OE}-02 \\
<4 . \mathrm{E}-02\end{array}$ & $\begin{array}{r}9.3 \\
9.3 \\
22 \\
<10 \\
18 \\
14 \\
14 \\
10 \\
14 \\
10 \\
12\end{array}$ & $\begin{array}{r}<6 . \mathrm{OE}-02 \\
<6 . \mathrm{OE}-02 \\
0.1 \\
<6 . \mathrm{OE}-02 \\
0.2 \\
<6 . \mathrm{OE}-02 \\
<6.0 \mathrm{E}-02 \\
3.063 \\
<6 . \mathrm{OE}-02 \\
<6 . \mathrm{OE}-02 \\
<6 . \mathrm{OE}-02\end{array}$ & $\begin{array}{l}<0.3 \\
<0.3 \\
<0.3 \\
<0.3 \\
0.61 \\
<0.3 \\
<0.3 \\
<0.3 \\
<0.3 \\
<0.3 \\
<0.3\end{array}$ & $\begin{array}{l}<0.2 \\
<0.2 \\
<0.2 \\
<0.2 \\
<0.2 \\
<0.2 \\
<0.2 \\
<0.2 \\
<0.2 \\
<0.2 \\
<0.2\end{array}$ \\
\hline
\end{tabular}


Page 109

Table. 31 (Continued)

\begin{tabular}{|c|c|c|c|c|c|c|c|}
\hline Well & $\begin{array}{c}S b \\
(m g / L)\end{array}$ & $\begin{array}{c}\mathrm{Se} \\
(\mathrm{mg} / \mathrm{L})\end{array}$ & $\begin{array}{c}S i \\
(\mathrm{mg} / \mathrm{L})\end{array}$ & $\underset{(\mathrm{mg} / \mathrm{L})}{\mathrm{Sn}}$ & $\begin{array}{c}\mathrm{Sr} \\
(\mathrm{mg} / \mathrm{L})\end{array}$ & $\begin{array}{c}\mathrm{Ti} \\
(\mathrm{mg} / \mathrm{L})\end{array}$ & $\begin{array}{c}\mathrm{V} \\
(\mathrm{mg} / \mathrm{L})\end{array}$ \\
\hline $\begin{array}{l}\text { SWSA4-5 } \\
\text { SWSA4-6 } \\
\text { SWSA4-11 } \\
\text { SWSA4-12 } \\
\text { SWSA4-13 } \\
\text { SWSA4-14 } \\
\text { SWSA4-15 } \\
\text { SWSA4-16 } \\
\text { SWSA4-17 } \\
\text { SWSA4-18 } \\
\text { SWSA4-19 }\end{array}$ & $\begin{array}{l}<0.2 \\
<0.2 \\
<0.2 \\
<0.2 \\
<0.2 \\
<0.2 \\
<0.2 \\
<0.2 \\
<0.2 \\
<0.2 \\
<0.2\end{array}$ & $\begin{array}{l}<0.2 \\
<0.2 \\
<0.2 \\
<0.2 \\
<0.2 \\
<0.2 \\
<0.2 \\
<0.2 \\
<0.2 \\
<0.2 \\
<0.2\end{array}$ & $\begin{array}{r}15 \\
22 \\
13 \\
12 \\
43 \\
8.5 \\
11 \\
13 \\
16 \\
11 \\
23\end{array}$ & $\begin{array}{l}<0.05 \\
<0.05 \\
<0.05 \\
<0.05 \\
<0.05 \\
<0.05 \\
<0.05 \\
<0.05 \\
<0.05 \\
<0.05 \\
<0.05\end{array}$ & $\begin{array}{l}0.23 \\
0.18 \\
0.19 \\
0.18 \\
0.23 \\
0.17 \\
0.17 \\
0.15 \\
0.25 \\
0.18 \\
0.79\end{array}$ & $\begin{array}{r}<<0.02 \\
0.039 \\
<0.02 \\
<0.02 \\
0.58 \\
<0.02 \\
<0.02 \\
<0.02 \\
<0.02 \\
<0.02 \\
0.037\end{array}$ & $\begin{array}{l}<0.02 \\
0.058 \\
<0.02 \\
<0.02 \\
<0.02 \\
<0.02 \\
0.077 \\
<0.02 \\
<0.02 \\
<0.02 \\
0.058\end{array}$ \\
\hline Wel1 & $\begin{array}{c}\mathrm{Zn} \\
(\mathrm{mg} / \mathrm{L})\end{array}$ & $\begin{array}{c}\mathrm{Zr} \\
(\mathrm{mg} / \mathrm{L})\end{array}$ & & & & & \\
\hline $\begin{array}{l}\text { SWSA4-5 } \\
\text { SWSA4-6 } \\
\text { SWSA4-11 } \\
\text { SWSA4-12 } \\
\text { SWSA4-13 } \\
\text { SWSA4-14 } \\
\text { SWSA4 - } 15 \\
\text { SWSA4-16 } \\
\text { SWSA4-17 } \\
\text { SWSA4-18 } \\
\text { SWSA4 - } 19\end{array}$ & $\begin{array}{r}<0.02 \\
0.13 \\
<0.02 \\
0.053 \\
0.25 \\
<0.02 \\
0.035 \\
0.095 \\
0.059 \\
<0.02 \\
0.2\end{array}$ & $\begin{array}{l}<0.02 \\
<0.02 \\
<0.02 \\
<0.02 \\
<0.02 \\
<0.02 \\
<0.02 \\
<0.02 \\
<0.02 \\
<0.02 \\
<0.02\end{array}$ & & & & & \\
\hline
\end{tabular}


Page 110

\section{DYNAMIC COMPACTION}

\section{METHOD OF DYNAMIC COMPACTION}

The method selected for compacting the contents of TARA trenches 2 through 6 was the repeated dropping of a 4-metric-ton, cylindrical, concrete weight at positions or settings along the trench cover. The method had been previously tested and been found to be successful during the 1985 experimental compaction of SWSA 6 trench 271 (Spalding 1986). A trackmounted crane with a maximum lifting capacity of 60 tons was used to straddle the trench and drop the weight from a helght of approximately $7 \mathrm{~m}$. As the weight was lifted and positioned over the trench cap, the break on the cable holding the weight was released and the weight was allowed to fall. Upon impact, the cable break was quickly engaged to prevent excess cable from unroling from the drum due to the downward momentum of the cable. A steelbelted truck tire was used as a connection between the crane cable and weight to act as a shock absorber. On several occisions during the trench compaction operation, the tire was replaced due to excessive wear. Figures 32 through 34 show the weight being dropped over the cover of one of the TARA trenches.

The method found to be most successful in compacting the trenches involved beginning at one end of the trench and laying out an approximate $3 \mathrm{~m} \times 3 \mathrm{~m}$ square section. The four corners of this section were compacted first to a depth of $1.2 \mathrm{~m}$ ( $4 \mathrm{ft}$ ), followed by compaction of the center portion of the section to the same depth. After the entire trench section had been lowered to a depth of $1.2 \mathrm{~m}$, the bottom of the resulting crater was leveled by numerous short drops of the weight. When leveling of the section was completed, the crane was repositioned and an adjoining $3 \mathrm{~m} \times 3 \mathrm{~m}$ section of the trench was compacted. Figure 35 summarizes the compaction method by showing the locations of the trench sections and the compaction positions within each section. In total, 39 trench sections were laid out over the five TARA trenches, and 211 compaction positions were used.

\section{RESULTS OF DYNAMIC COMPACTION}

As a part of the compaction avaluation, the number of drops of the weight required for each $30 \mathrm{~cm}(1 \mathrm{ft}$ ) of depth at each compaction position was counted, along with the number of short drops to level out each section, and the radiation reading in $\mathrm{aR} / \mathrm{h}$ at each compaction position. Table 32 summarizes the average drop counts per foot of compaction for the five TARA trenches and a $3 \mathrm{~m}$ by $3 \mathrm{~m}$ control trench that was laid out immediately to the southeast of trench 3 . Appendix VII contains the entire trench compaction data set, including the location of the settings found to register radloactivity at the soil surface.

As expected, the average number of drops increased with each $30 \mathrm{~cm}$ of depth; 1.2 drops were required for the first $30 \mathrm{~cm}, 2$ drops for the next 30 $\mathrm{cm}, 2.8$ drops for the next $30 \mathrm{~cm}$, and 3.8 drops for the last $30 \mathrm{~cm}$. This increase was due to the compaction of soil and waste that was taking place immediately below the point of impact. Also summarized in Table 32 are the corresponding number of drops required for the $3 \mathrm{~m} \times 3 \mathrm{~m}$ control section. 
Page 111

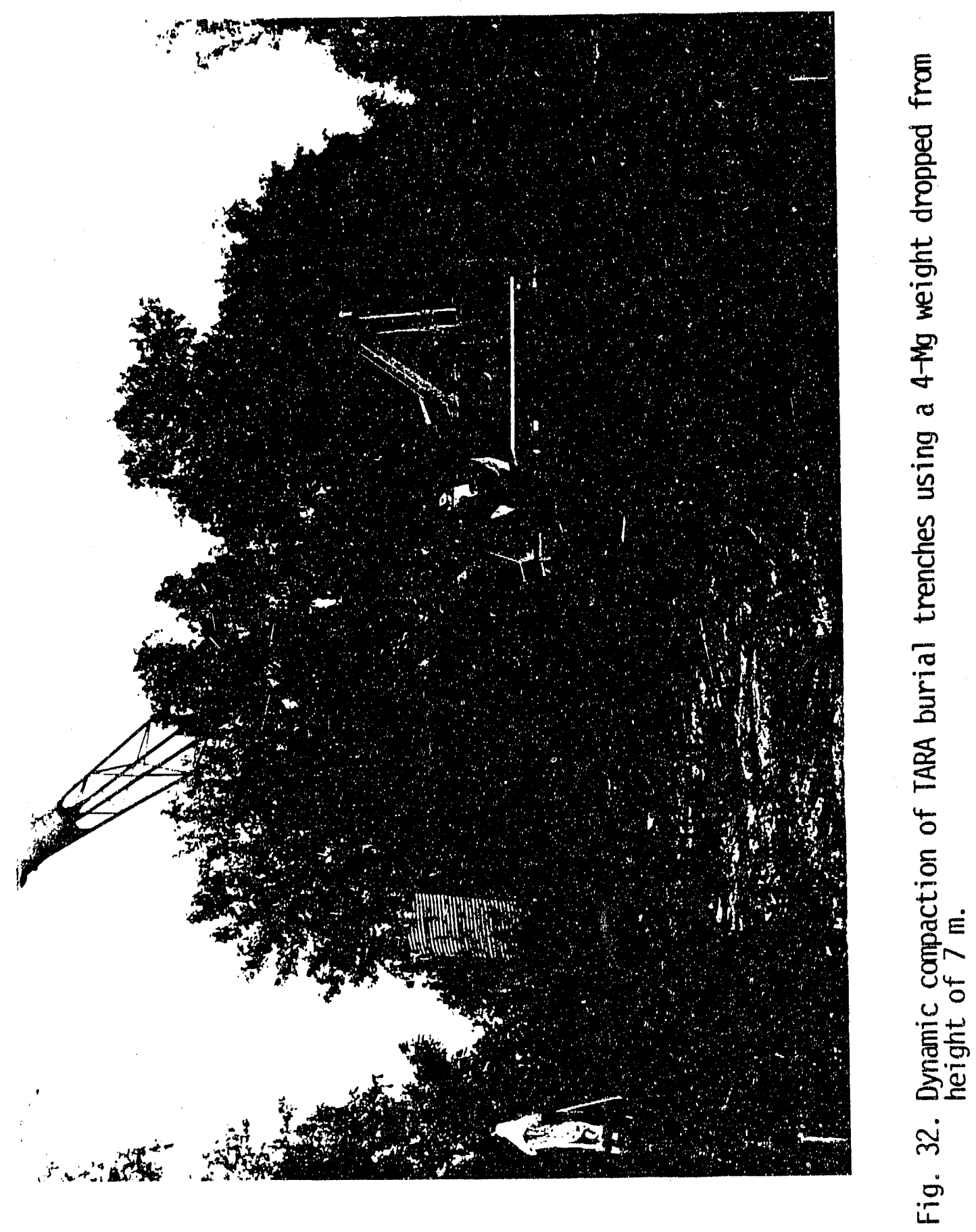




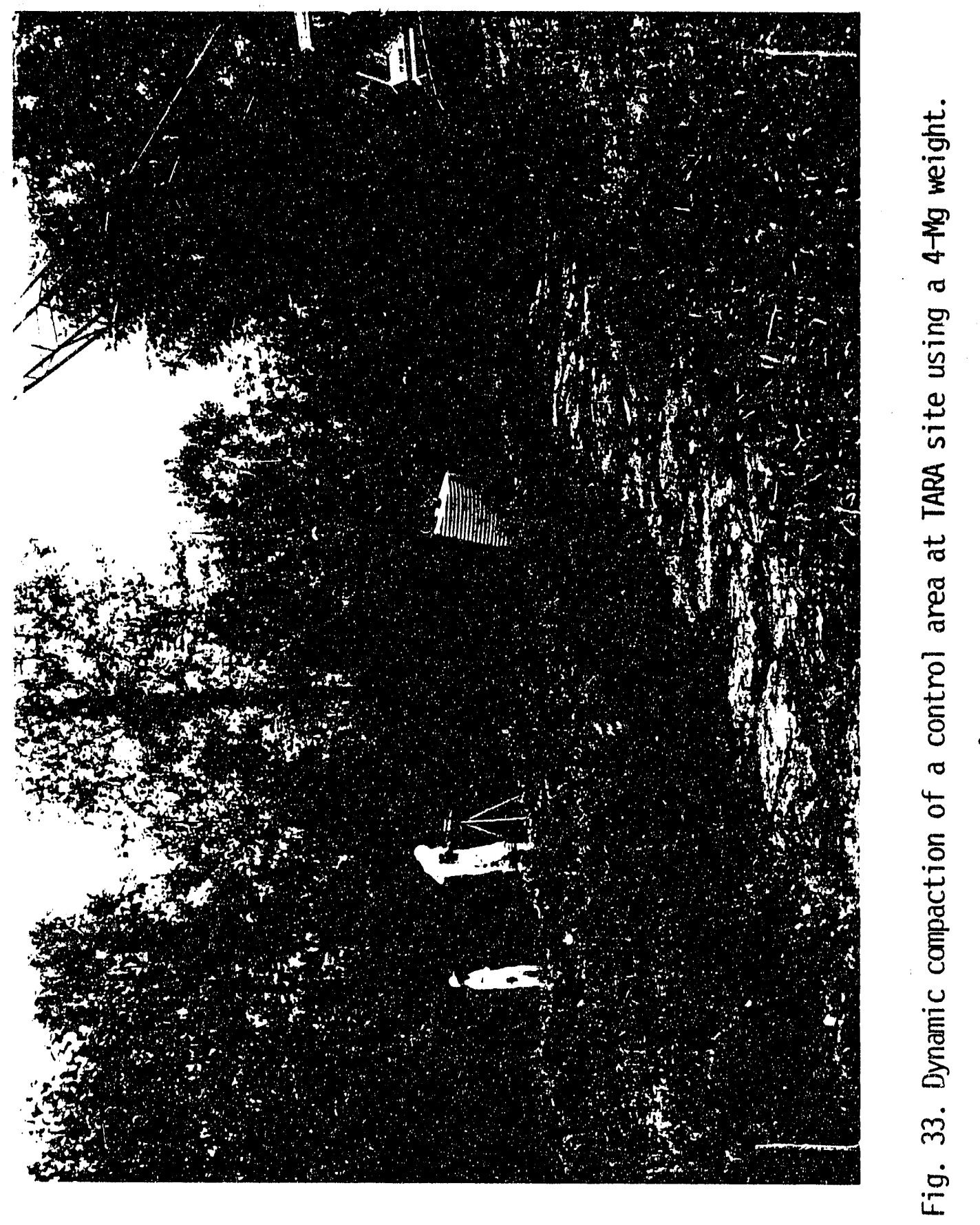




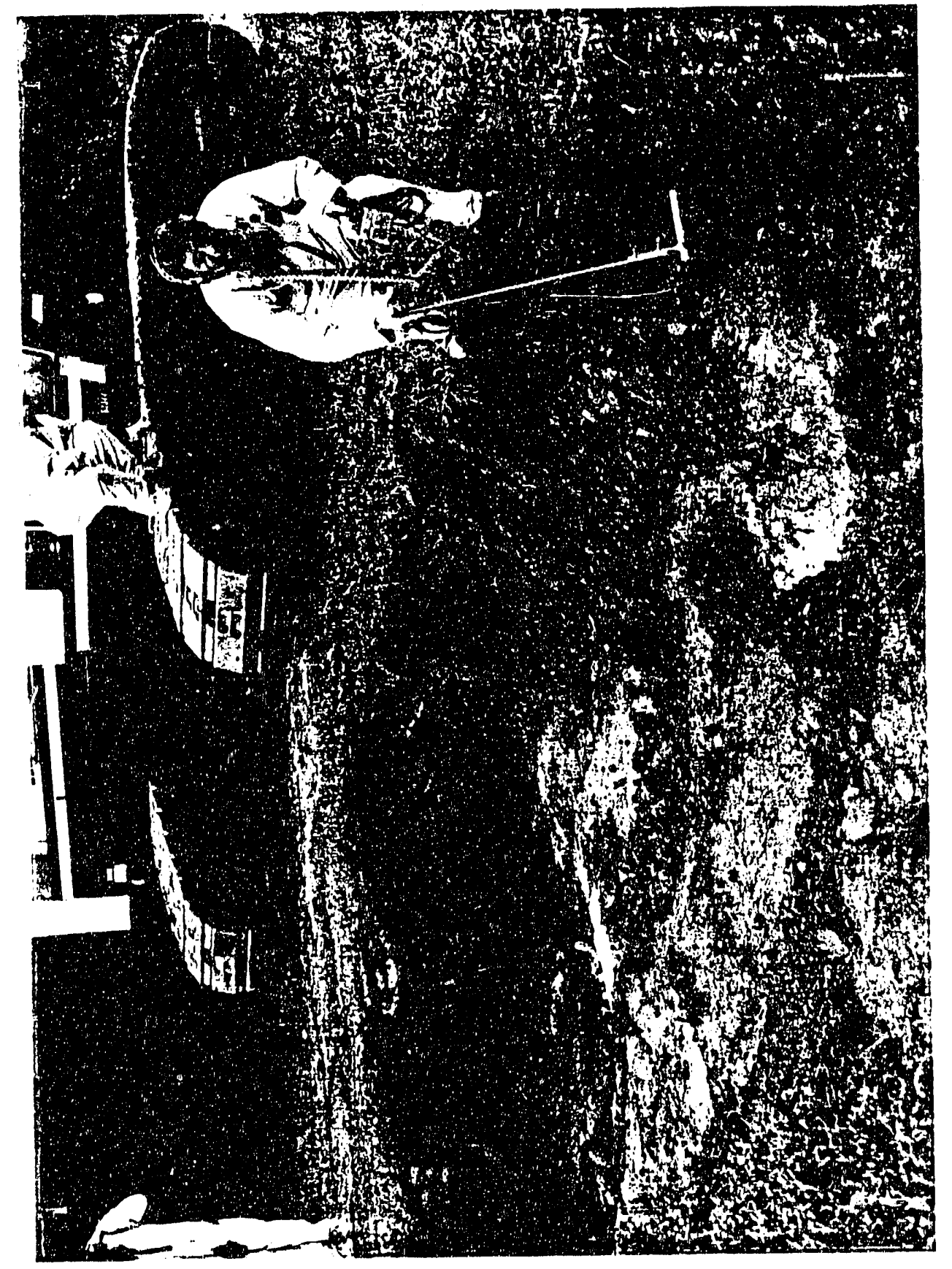

ชั

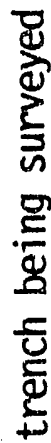

$\pi$

है

垔

$\sigma$

ชั

先

농

宅约

लं 
Page 114

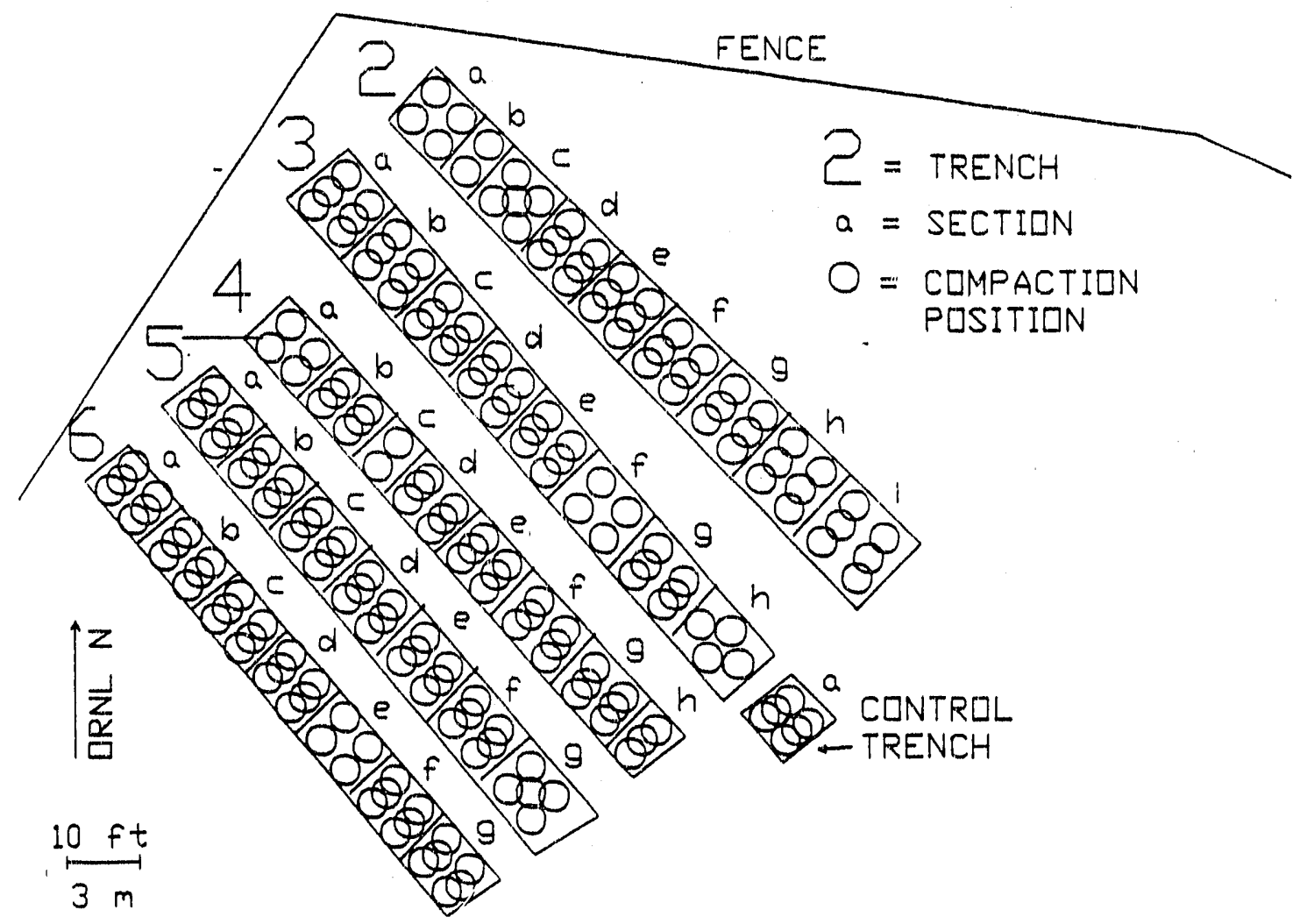

Fig. 35. Location of the compaction positions on the TARA trenches. 
Table 32. Summary of the number of weight drops required for each foot of trench compaction

\begin{tabular}{|c|c|c|c|c|c|c|c|c|}
\hline $\begin{array}{c}\text { Depth } \\
\text { (ft) }\end{array}$ & & $\begin{array}{c}\text { Trench } \\
2\end{array}$ & $\begin{array}{c}\text { Trench } \\
3\end{array}$ & $\begin{array}{c}\text { Trench } \\
4\end{array}$ & $\begin{array}{c}\text { Trench } \\
5\end{array}$ & $\begin{array}{c}\text { Trench } \\
6\end{array}$ & Total & $\begin{array}{r}\text { Control } \\
\text { Trench }\end{array}$ \\
\hline 1 & $\begin{array}{l}\mathrm{N}= \\
\text { AVG - } \\
\text { STD - } \\
\text { MAX - } \\
\text { MIN - } \\
\text { SUM = }\end{array}$ & $\begin{array}{r}47 \\
1.79 \\
1.27 \\
8 \\
0 \\
84\end{array}$ & $\begin{array}{r}44 \\
1.11 \\
0.80 \\
3 \\
0 \\
49\end{array}$ & $\begin{array}{r}39 \\
0.85 \\
0.58 \\
2 \\
0 \\
33\end{array}$ & $\begin{array}{r}41 \\
1.02 \\
0.84 \\
3 \\
0 \\
42\end{array}$ & $\begin{array}{r}40 \\
1.13 \\
0.93 \\
4 \\
0 \\
45\end{array}$ & $\begin{array}{r}211 \\
1.20 \\
0.98 \\
8 \\
0 \\
253\end{array}$ & $\begin{array}{r}6 \\
3.17 \\
2.11 \\
6 \\
0 \\
19\end{array}$ \\
\hline 2 & $\begin{array}{l}\mathrm{N}= \\
\text { AVG }= \\
\text { STD }= \\
\text { MAX = } \\
\text { MIN = } \\
\text { SUM = }\end{array}$ & $\begin{array}{r}47 \\
2.51 \\
1.50 \\
7 \\
1 \\
118\end{array}$ & $\begin{array}{r}44 \\
1.98 \\
1.12 \\
5 \\
0 \\
87\end{array}$ & $\begin{array}{r}39 \\
1.72 \\
0.78 \\
3 \\
0 \\
67\end{array}$ & $\begin{array}{r}41 \\
1.68 \\
1.00 \\
4 \\
0 \\
69\end{array}$ & $\begin{array}{r}39 \\
2.03 \\
1.19 \\
5 \\
0 \\
79\end{array}$ & $\begin{array}{r}210 \\
2.00 \\
1.20 \\
7 \\
0 \\
420\end{array}$ & $\begin{array}{r}6 \\
5.50 \\
2.75 \\
10 \\
2 \\
33\end{array}$ \\
\hline 3 & $\begin{array}{l}N= \\
\text { AVG = } \\
\text { STD = } \\
\text { MAX = } \\
\text { MIN = } \\
\text { SUM = }\end{array}$ & $\begin{array}{r}47 \\
3.53 \\
2.18 \\
13 \\
1 \\
166\end{array}$ & $\begin{array}{r}44 \\
3.36 \\
1.58 \\
8 \\
1 \\
148\end{array}$ & $\begin{array}{r}39 \\
2.23 \\
0.95 \\
4 \\
1 \\
87\end{array}$ & $\begin{array}{r}41 \\
2.29 \\
1.17 \\
5 \\
1 \\
94\end{array}$ & $\begin{array}{r}40 \\
2.48 \\
1.40 \\
8 \\
1 \\
99\end{array}$ & $\begin{array}{r}211 \\
2.82 \\
1.64 \\
13 \\
1 \\
594\end{array}$ & $\begin{array}{r}6 \\
7.33 \\
3.40 \\
13 \\
2 \\
44\end{array}$ \\
\hline 4 & $\begin{array}{l}N= \\
\text { AVG = } \\
\text { STD = } \\
\text { MAX = } \\
\text { MIN = } \\
\text { SUM = }\end{array}$ & $\begin{array}{r}46 \\
4.74 \\
2.46 \\
12 \\
1 \\
218\end{array}$ & $\begin{array}{r}44 \\
3.86 \\
2.04 \\
8 \\
1 \\
170\end{array}$ & $\begin{array}{r}39 \\
3.26 \\
1.50 \\
6 \\
1 \\
127\end{array}$ & $\begin{array}{r}41 \\
2.93 \\
1.47 \\
7 \\
1 \\
120\end{array}$ & $\begin{array}{r}40 \\
3.88 \\
2.03 \\
11 \\
1 \\
155\end{array}$ & $\begin{array}{r}210 \\
3.76 \\
2.05 \\
12 \\
1 \\
790\end{array}$ & $\begin{array}{r}4 \\
6.75 \\
2.68 \\
11 \\
4 \\
27\end{array}$ \\
\hline 5 & $\begin{array}{l}N= \\
\text { AVG = } \\
\text { STD = } \\
\text { MAX - } \\
\text { MIN = } \\
\text { SUM = }\end{array}$ & $\begin{array}{r}6 \\
6.00 \\
2.65 \\
10 \\
3 \\
36\end{array}$ & $\begin{array}{r}9 \\
2.89 \\
1.66 \\
6 \\
1 \\
26\end{array}$ & & & & $\begin{array}{r}15 \\
4.13 \\
2.60 \\
10 \\
1 \\
62\end{array}$ & \\
\hline 6 & $\begin{array}{l}\text { N = } \\
\text { AVG - } \\
\text { STD = } \\
\text { MAX - } \\
\text { MIN = } \\
\text { SUM = }\end{array}$ & $\begin{array}{r}5 \\
3.60 \\
1.02 \\
5 \\
2 \\
18\end{array}$ & $\begin{array}{r}3 \\
1.33 \\
0.47 \\
2 \\
1 \\
4\end{array}$ & & & & $\begin{array}{r}8 \\
2.75 \\
1.39 \\
5 \\
1 \\
22\end{array}$ & \\
\hline
\end{tabular}


This section, which is similar in all respects to the trenches except that there was no underlying waste trench, required an average of 3.2 drops for the first $30 \mathrm{~cm}, 5.5$ drops for the second $30 \mathrm{~cm}, 7.3$ drops for the third 30 $\mathrm{cm}$, and 6.7 drops for the fourth $30 \mathrm{~cm}$. In addition to the greater number of drops required to achieve a desired depth, a considerable amount of soil upheaval was noted around the control trench, extending to a distance of approximately $2 \mathrm{~m}$ from the trench. This upheaved soil volume was estimated using pre- and postcompaction elevation surveys which allowed an actual (corrected for upheaved soil) depth of compaction to be determined for the control section.

In summary, the dynamic compaction of the five TARA trenches required 2141 drops of the weight from a height of $7 \mathrm{~m}$ and approximately 2445 drops of the weight from a lower height $(1-2 \mathrm{~m})$ for leveling purposes. Knowing that the total area of the five trenches is $387 \mathrm{~m}^{2}$, these total drop numbers can be expressed as $5.5 \mathrm{drops} / \mathrm{m}^{2}$ of trench for compaction and $6.3 \mathrm{drops} / \mathrm{m}^{2}$ for leveling purposes.

The depth of compaction of each trench was determined by comparison of a trench surface elevation survey made before compaction with that of a postcompaction elevation survey. In contrast to the control section, an insignificant amount of soil upheaval was noticed adjacent to each of the five trenches; thus, depth corrections for upheaval did not have to be made for the waste trenches as they were for the control section. Tables 33 through 37 summarize the pre- and postcompaction elevation surveys and indicate that an average depth of compaction of $0.46 \mathrm{~m}, 0.49 \mathrm{~m}, 0.60 \mathrm{~m}, 0.63$ $m$, and $0.54 \mathrm{~m}$ was achieved for trenches $2,3,4,5$, and 6 , respectively. Knowing the length and width of each trench allows one to calculate the total volume of compaction that took place for each trench. These uncorrected volumes (uncorrected for compaction that took place in the control section) are summarized for each trench in Tables 33 through 37.

The depths and volumes of trench compaction reported in the previous paragraph are uncorrected [ 1 .e. the values have not been corrected for the degree of compaction that could be achieved in the trench cover alone (without an underlying trench)]. To obtain this correction value, a $3 \mathrm{~m} \times 3$ m control section was laid out adjacent to trench 3 (Fig. 35) and compacted with the concrete weight in a manner identical to the waste trench compaction. Elevation survey points were established at 41 locations around the perimeter of the trench out to a distance of $1.5 \mathrm{~m}$ (Fig. 36). By comparing the elevations at the survey points before and after compaction, the depth of the control section crater could be determined $(0.75 \mathrm{~m})$ and the total volume of soil upheaval that occurred could be estimated. Dividing the perimeter of the control section into a set of concentric octagonal elements (shown as dotted lines in Fig. 36), and suming element volumes, resulted in a total upheaved soil volume of $4.44 \mathrm{~m}^{3}$. The corrected control cratex volume (i.e. the actual volume reduction achieved at the control section had the soil not been able to be pushed up) was calculated using the following equation 
Page 117

Table 33. Elevation of TARA trench 2 before and after trench compaction

\begin{tabular}{|c|c|c|c|c|c|c|c|}
\hline \multirow{2}{*}{\multicolumn{2}{|c|}{$\begin{array}{l}\text { Before Compaction } \\
\text { Dist. from Elev. } \\
\text { Trench North (m) } \\
\text { End (m) }\end{array}$}} & \multicolumn{2}{|c|}{ After Compaction } & \multirow[b]{2}{*}{$\begin{array}{l}\text { Change } \\
\text { In Elev. } \\
\text { (m) }\end{array}$} & \multirow[b]{2}{*}{$\begin{array}{l}\text { Trench } \\
\text { W1dth } \\
\text { (m) }\end{array}$} & \multirow[b]{2}{*}{$\begin{array}{l}\text { Unit } \\
\text { Width } \\
\text { (m) }\end{array}$} & \multirow[b]{2}{*}{$\begin{array}{l}\text { Unit } \\
\text { volume } \\
\left(\mathrm{m}^{3}\right)\end{array}$} \\
\hline & & $\begin{array}{l}\text { Dist. fro } \\
\text { Trench Nor } \\
\text { End }(m)\end{array}$ & $\begin{array}{l}\text { Elev. } \\
\mathrm{h}(\mathrm{m})\end{array}$ & & & & \\
\hline $\begin{array}{l}2 \\
2 \\
2 \\
2 \\
2 \\
2 \\
2 \\
2 \\
2 \\
2 \\
2 \\
2 \\
2 \\
2 \\
2 \\
2 \\
2 \\
2 \\
2 \\
2 \\
2 \\
2 \\
2 \\
2 \\
2 \\
2 \\
2 \\
2 \\
2 \\
2 \\
2 \\
2 \\
2 \\
2 \\
2 \\
2 \\
2 \\
2\end{array}$ & $\begin{array}{l}55.21 \\
255.21 \\
255.21 \\
255.21 \\
255.21 \\
255.21 \\
255.21 \\
255.21 \\
255.21 \\
255.21 \\
255.20 \\
255.20 \\
255.20 \\
255.20 \\
255.20 \\
255.20 \\
255.20 \\
255.20 \\
255.20 \\
255.20 \\
255.21 \\
255.23 \\
255.24 \\
255.25 \\
255.27 \\
255.28 \\
255.29 \\
255.31 \\
255.32 \\
255.33 \\
255.35 \\
255.36 \\
255.37 \\
255.39 \\
255.40 \\
255.41 \\
255.42 \\
255.43 \\
255.44 \\
255.45 \\
255.47 \\
255.48 \\
255.49 \\
255.50\end{array}$ & $\begin{array}{r}0.3 \\
0.6 \\
0.9 \\
1.2 \\
1.5 \\
1.8 \\
2.1 \\
2.4 \\
2.7 \\
2.7 \\
3.0 \\
3.4 \\
3.7 \\
3\end{array}$ & $\begin{array}{l}254.95 \\
254.68 \\
254.68 \\
254.64 \\
254.64 \\
254.65 \\
254.69 \\
254.64 \\
254.63 \\
254.63 \\
254.69 \\
254.76 \\
254.79 \\
254.80 \\
254.78 \\
254.78 \\
254.95 \\
255.04 \\
255.11 \\
255.08 \\
254.86 \\
254.82 \\
254.79 \\
255.00 \\
255.08 \\
255.10 \\
254.98 \\
254.95 \\
254.96 \\
254.97 \\
254.95 \\
254.93 \\
254.91 \\
254.95 \\
254.97 \\
254.93 \\
254.97 \\
255.03 \\
255.06 \\
255.02 \\
255.04 \\
255.08 \\
255.09 \\
255.00\end{array}$ & $\begin{array}{l}0.26 \\
0.53 \\
0.53 \\
0.57 \\
0.57 \\
0.56 \\
0.52 \\
0.57 \\
0.58 \\
0.58 \\
0.51 \\
0.44 \\
0.41 \\
0.40 \\
0.42 \\
0.42 \\
0.25 \\
0.16 \\
0.09 \\
0.12 \\
0.35 \\
0.41 \\
0.45 \\
0.25 \\
0.19 \\
0.18 \\
0.32 \\
0.36 \\
0.35 \\
0.36 \\
0.39 \\
0.42 \\
0.46 \\
0.44 \\
0.43 \\
0.48 \\
0.45 \\
0.40 \\
0.38 \\
0.44 \\
0.42 \\
0.39 \\
0.40 \\
0.50\end{array}$ & $\begin{array}{l}3.05 \\
3.06 \\
3.07 \\
3.07 \\
3.08 \\
3.09 \\
3.10 \\
3.11 \\
3.12 \\
3.12 \\
3.13 \\
3.14 \\
3.15 \\
3.16 \\
3.16 \\
3.1 .7 \\
3.18 \\
3.19 \\
3.20 \\
3.21 \\
3.21 \\
3.22 \\
3.23 \\
3.24 \\
3.25 \\
3.25 \\
3.26 \\
3.27 \\
3.28 \\
3.29 \\
3.30 \\
3.30 \\
3.31 \\
3.32 \\
3.33 \\
3.34 \\
3.35 \\
3.35 \\
3.36 \\
3.37 \\
3.38 \\
3.39 \\
3.39 \\
3.40\end{array}$ & $\begin{array}{l}0.305 \\
0.305 \\
0.305 \\
0.305 \\
0.305 \\
0.305 \\
0.305 \\
0.305 \\
0.305 \\
0.305 \\
0.305 \\
0.305 \\
0.305 \\
0.305 \\
0.305 \\
0.305 \\
0.305 \\
0.305 \\
0.305 \\
0.305 \\
0.305 \\
0.305 \\
0.305 \\
0.305 \\
0.305 \\
0.305 \\
0.305 \\
0.305 \\
0.305 \\
0.305 \\
0.305 \\
0.305 \\
0.305 \\
0.305 \\
0.305 \\
0.305 \\
0.305 \\
0.305 \\
0.305 \\
0.305 \\
0.305 \\
0.305 \\
0.305 \\
0.305\end{array}$ & $\begin{array}{l}0.24 \\
0.49 \\
0.49 \\
0.54 \\
0.54 \\
0.53 \\
0.49 \\
0.54 \\
0.55 \\
0.55 \\
0.49 \\
0.42 \\
0.39 \\
0.38 \\
0.40 \\
0.41 \\
0.25 \\
0.16 \\
0.09 \\
0.12 \\
0.34 \\
0.40 \\
0.44 \\
0.25 \\
0.19 \\
0.18 \\
0.31 \\
0.36 \\
0.35 \\
0.37 \\
0.40 \\
0.43 \\
0.46 \\
0.44 \\
0.44 \\
0.49 \\
0.46 \\
0.41 \\
0.39 \\
0.45 \\
0.44 \\
0.41 \\
0.41 \\
0.52\end{array}$ \\
\hline
\end{tabular}


Page 118

Table 33. (Continued)

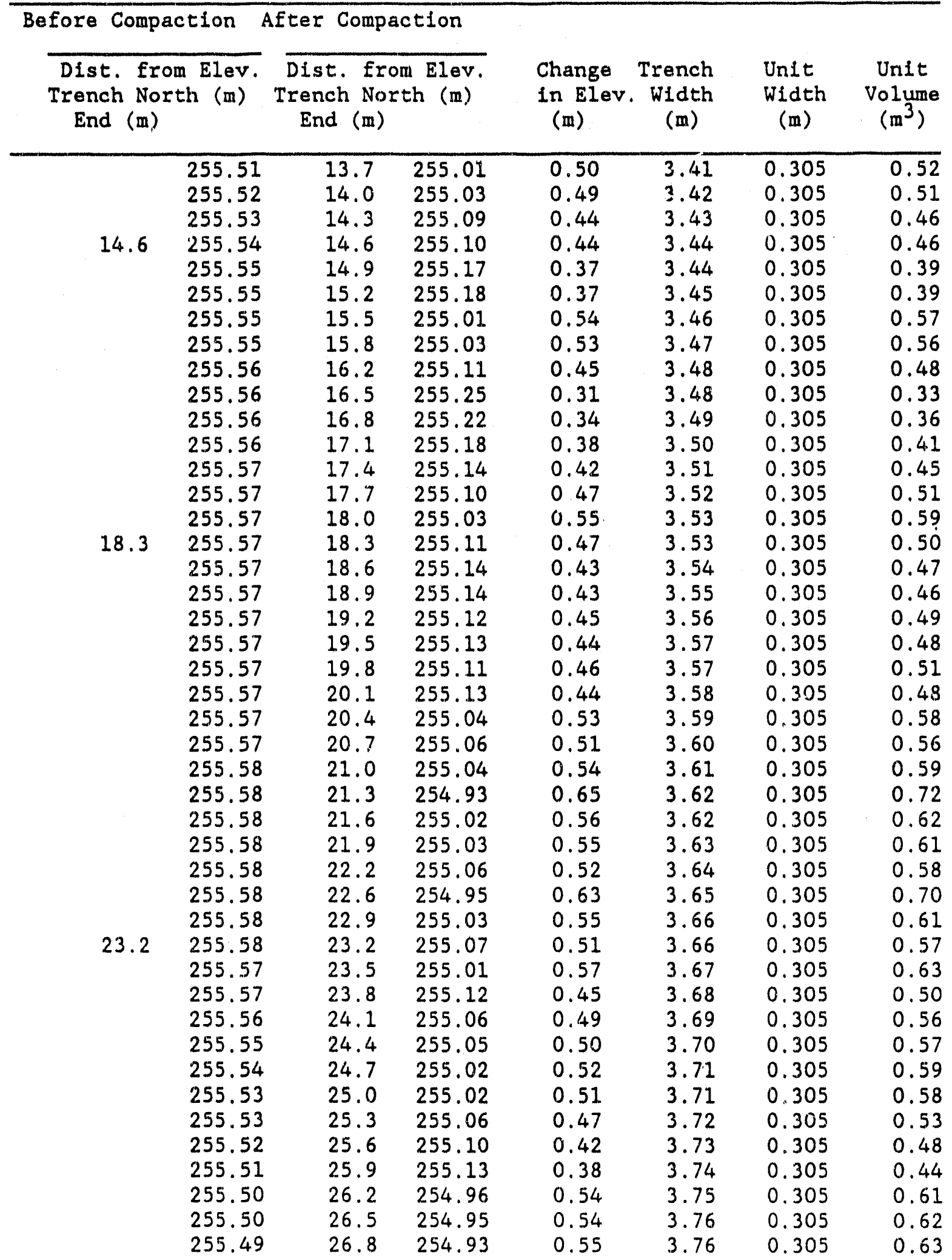


Page 119

Table 33. (Continued)

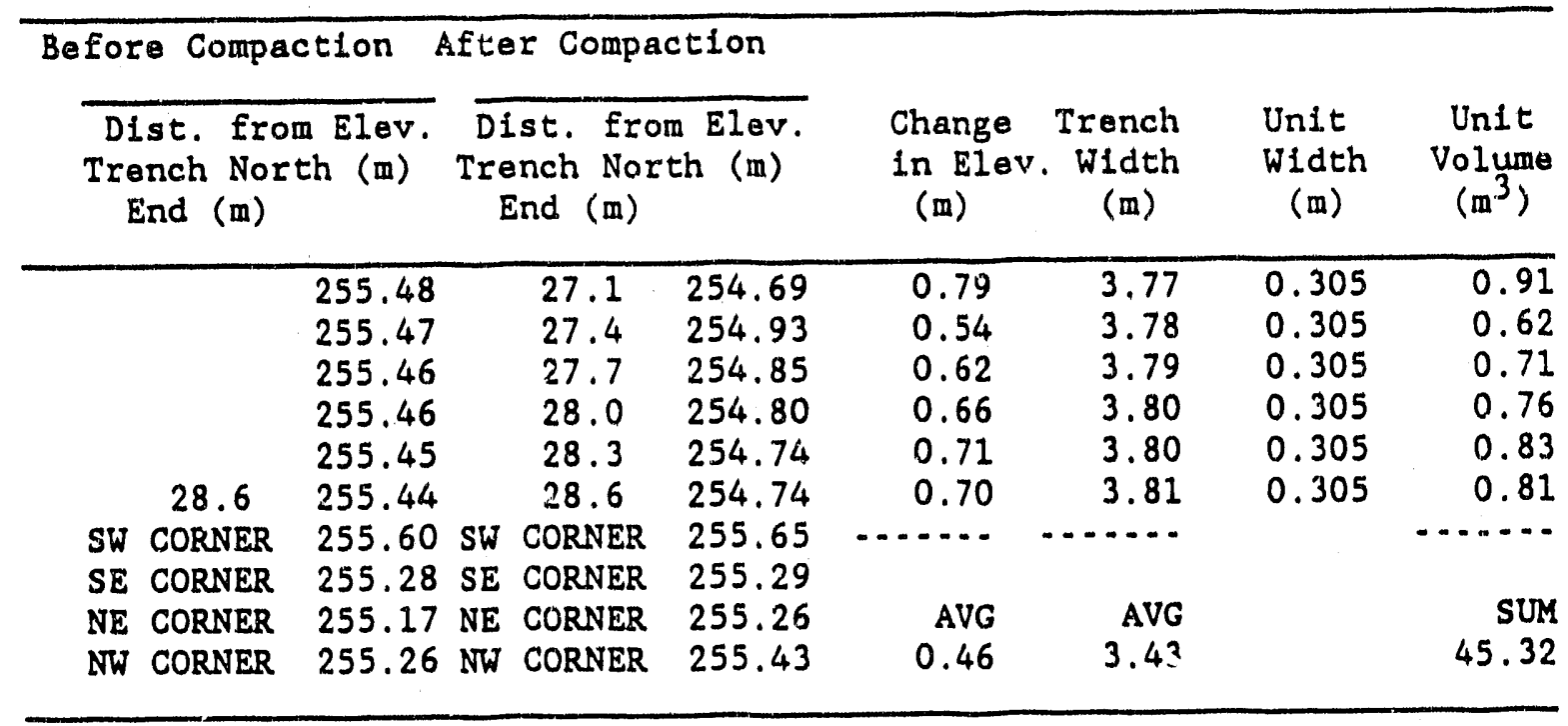


Page 120

Table 34. Elevation of TARA trench 3 before and after trench compaction

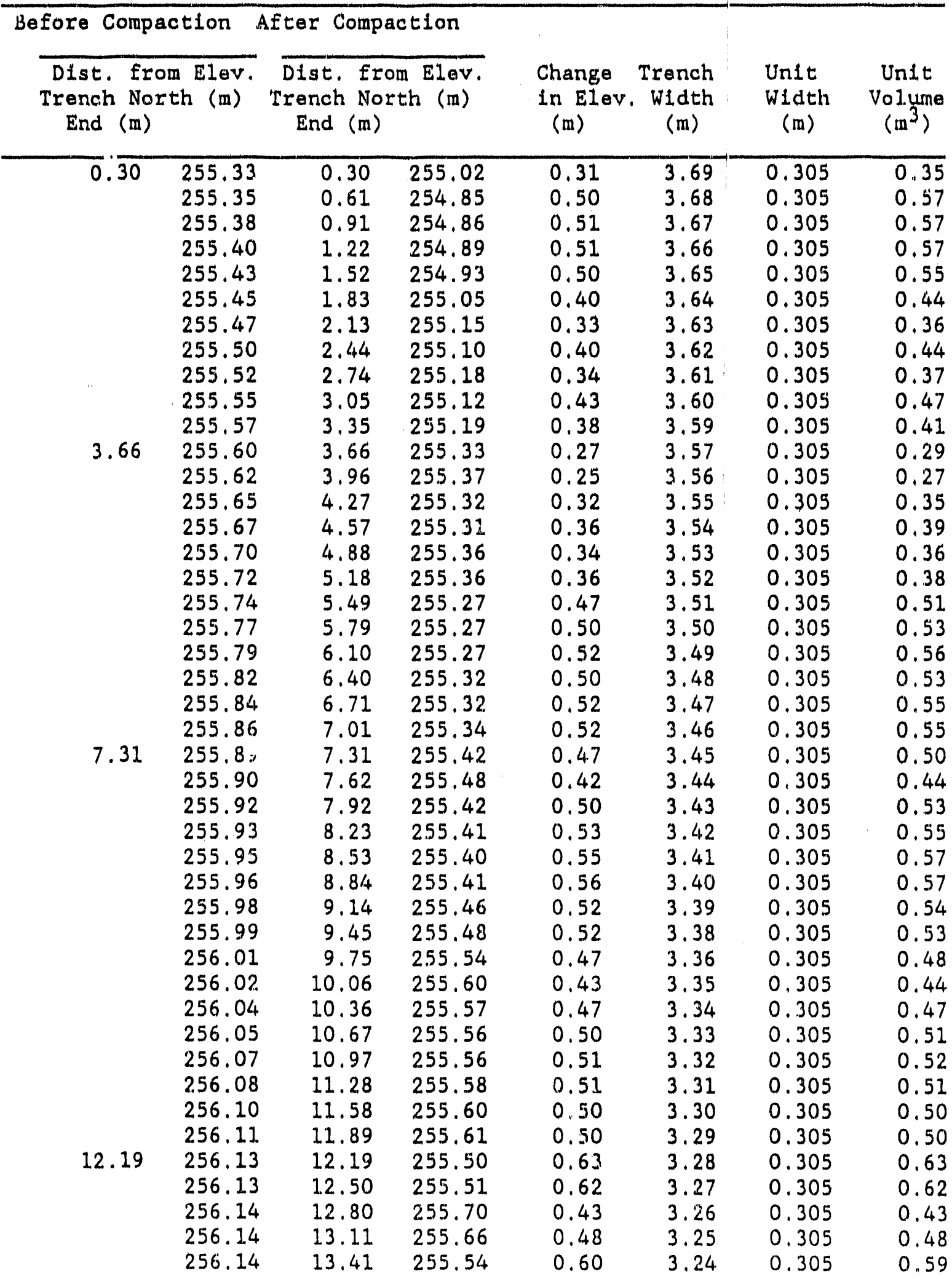


Page 121

Table 34. (Continued)

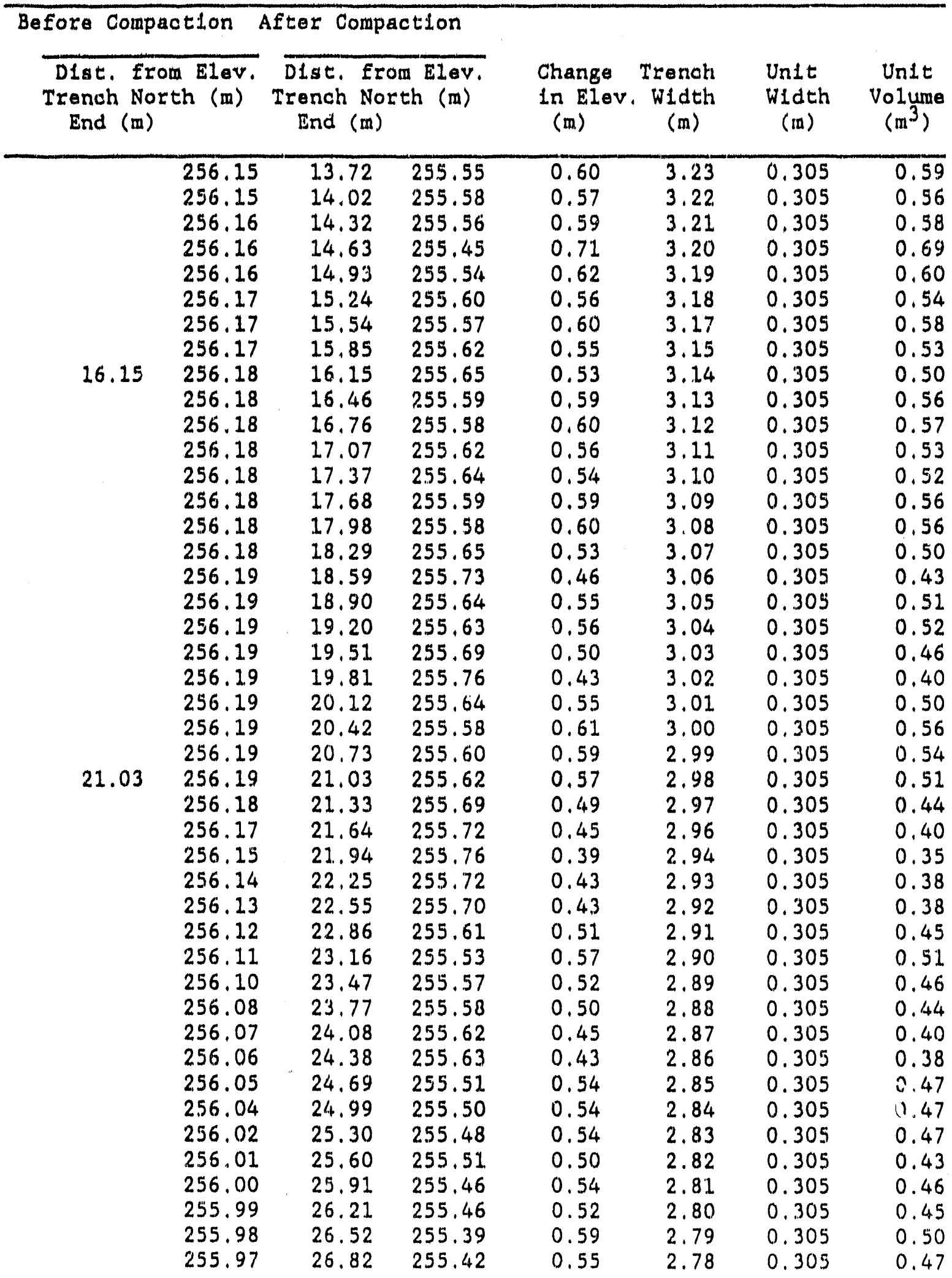


Page 1.22

Table 34. (Continued)

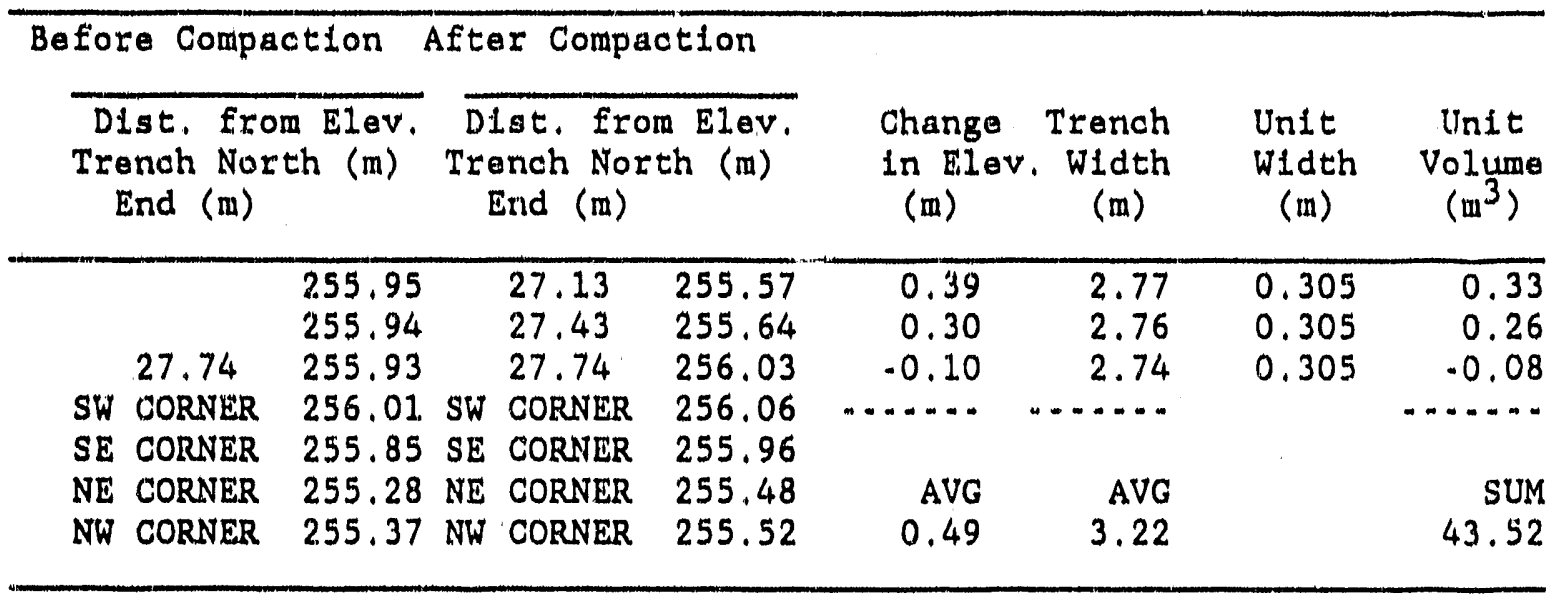


Page 123

Table 35. Elevation of TARA trench 4 before and after trench compaction

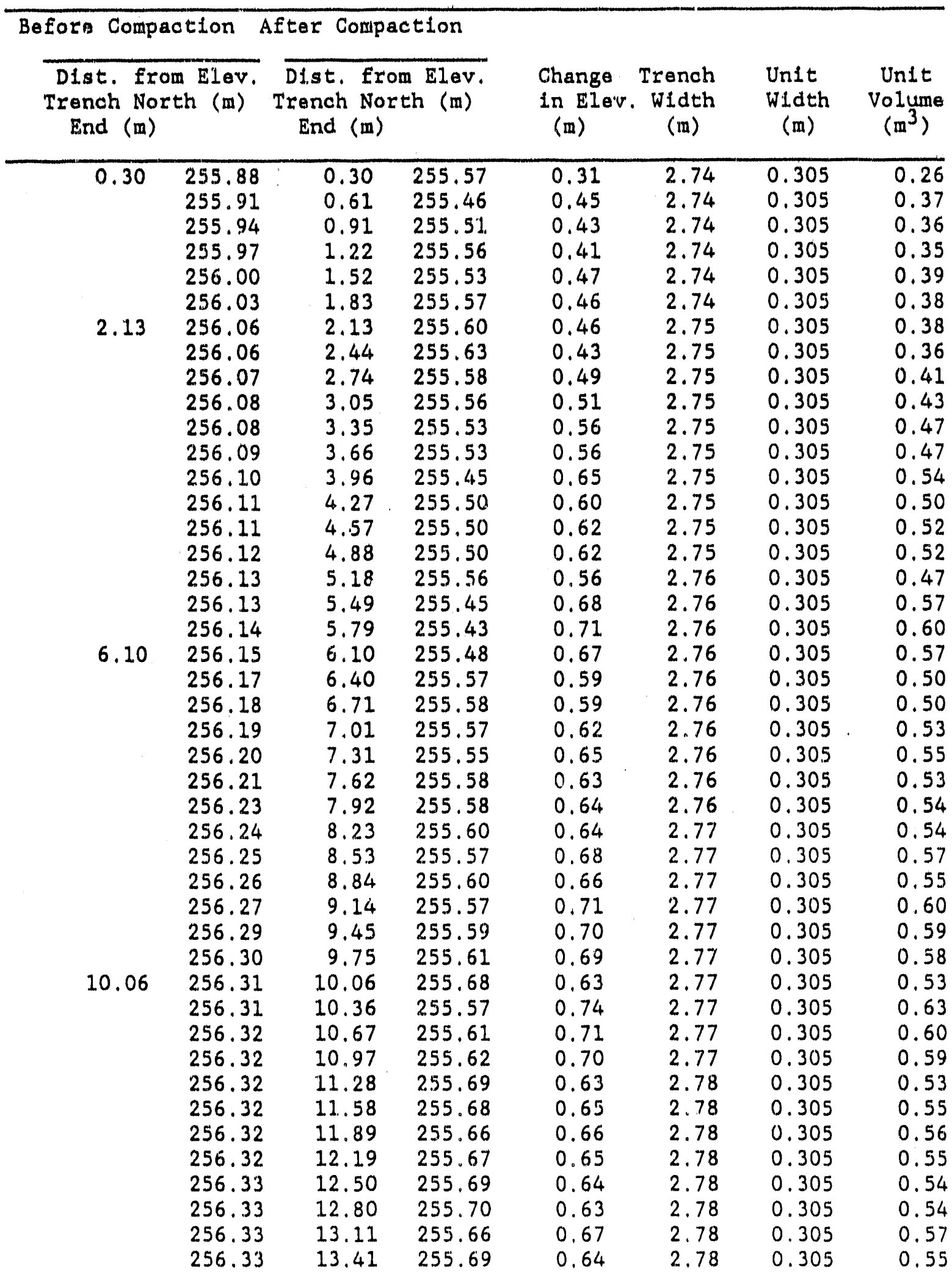


Page 124

Table 35. (Continued)

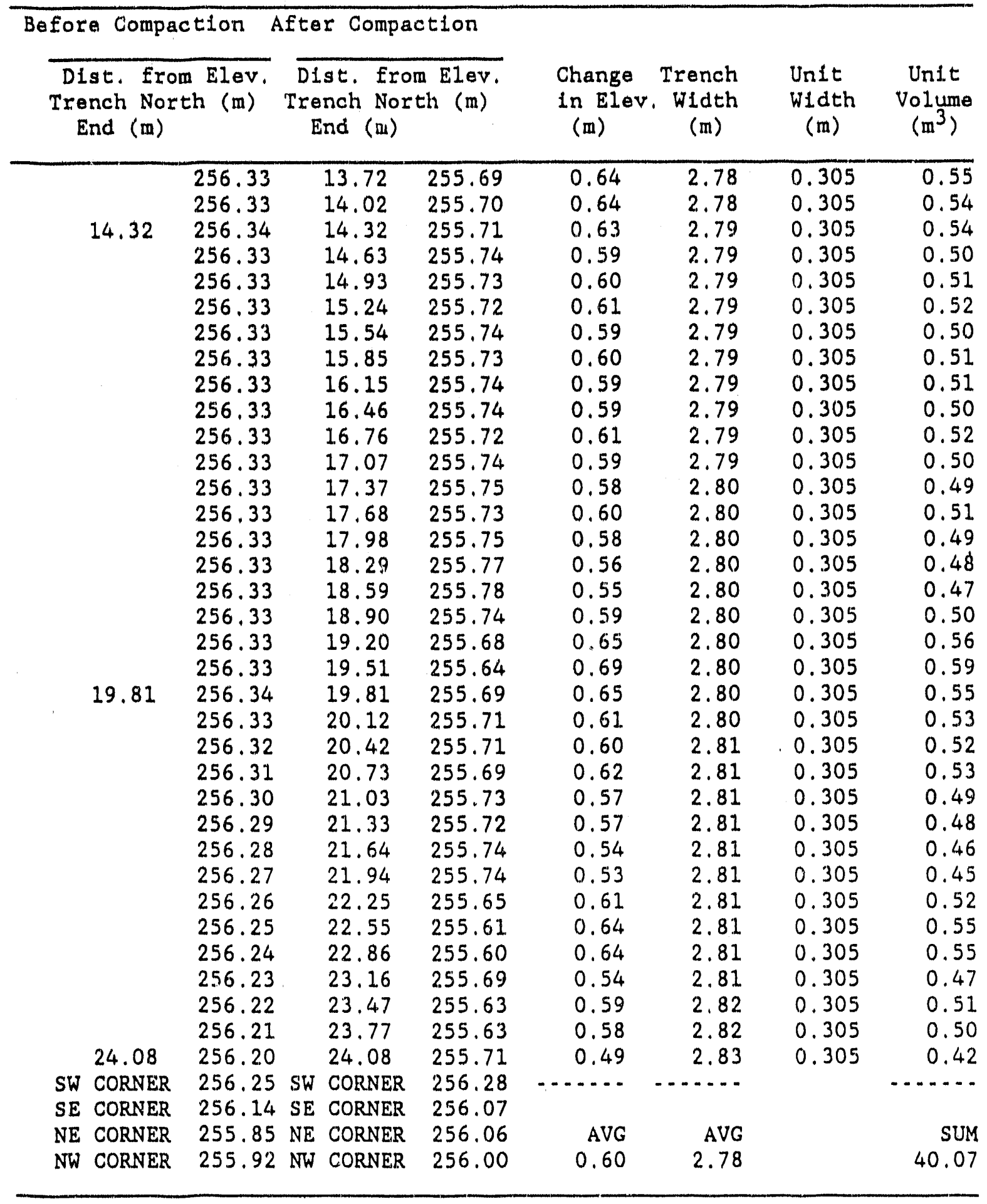


Page 125

Table 36. Elevation of TARA trench 5 before and after trench compaction

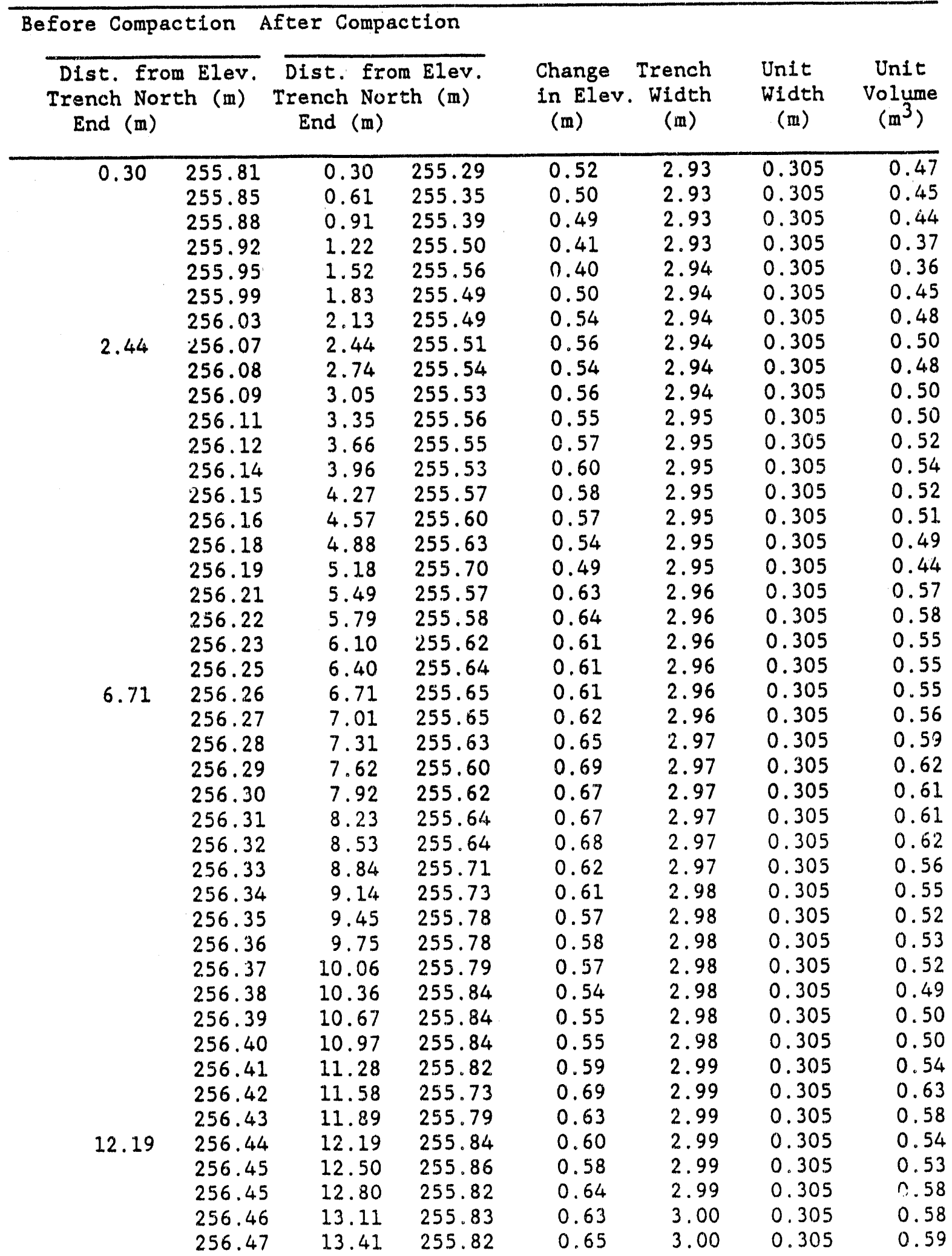


Page 126

Table 36. (Continued)

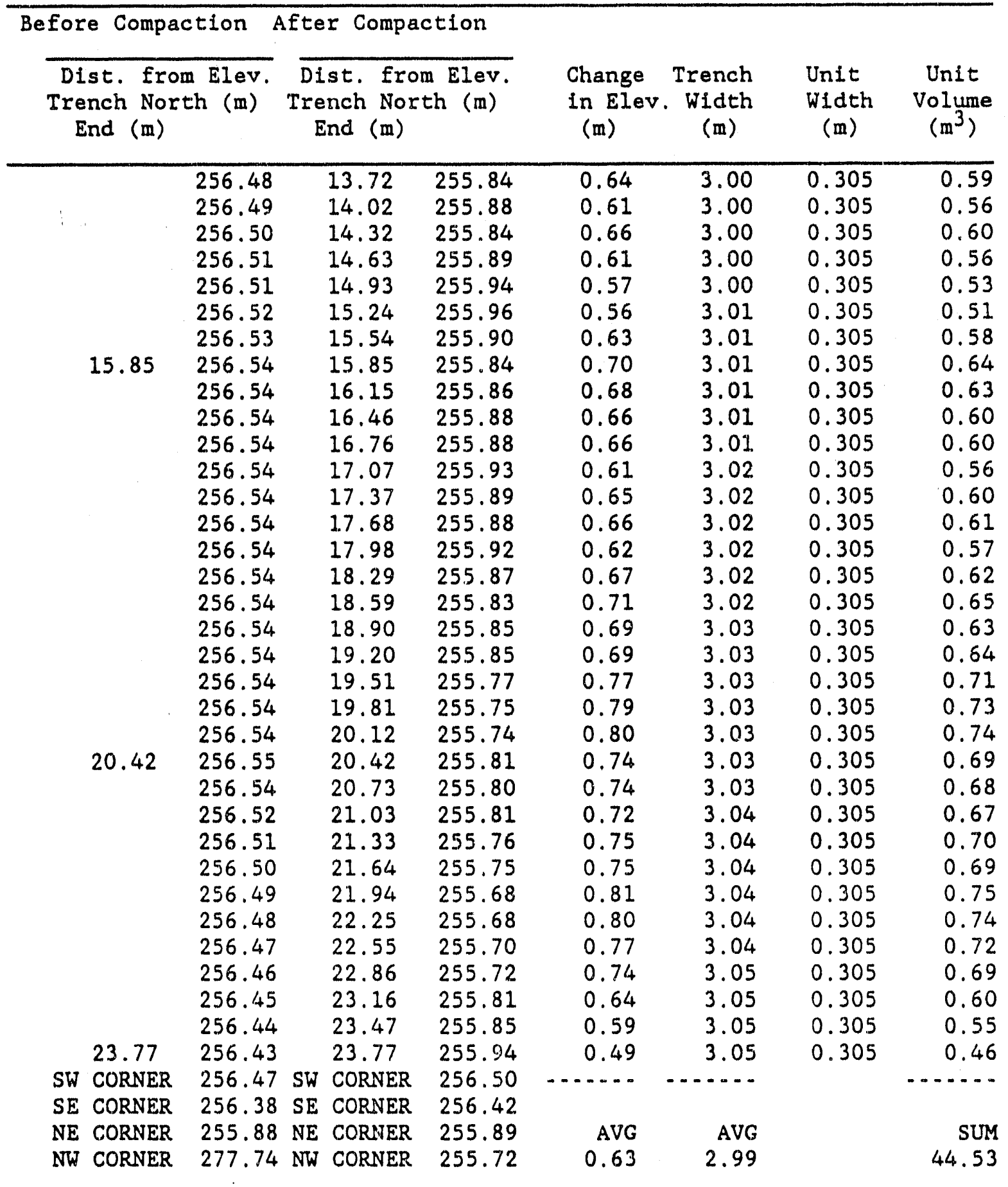


Page 127

Table 37. Elevation of TARA trench 6 before and after trench compaction

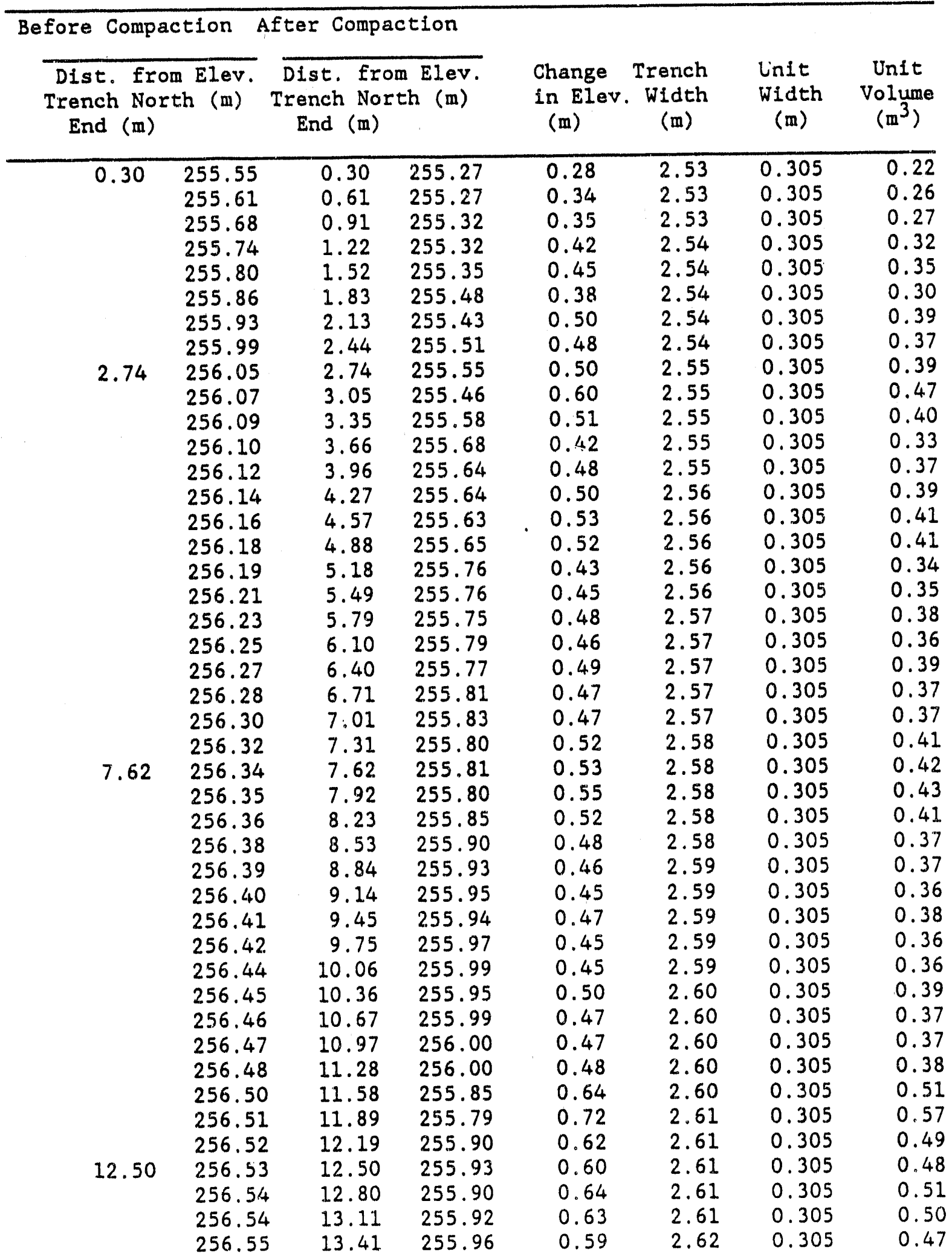


Page 128

Table 37. (Continued)

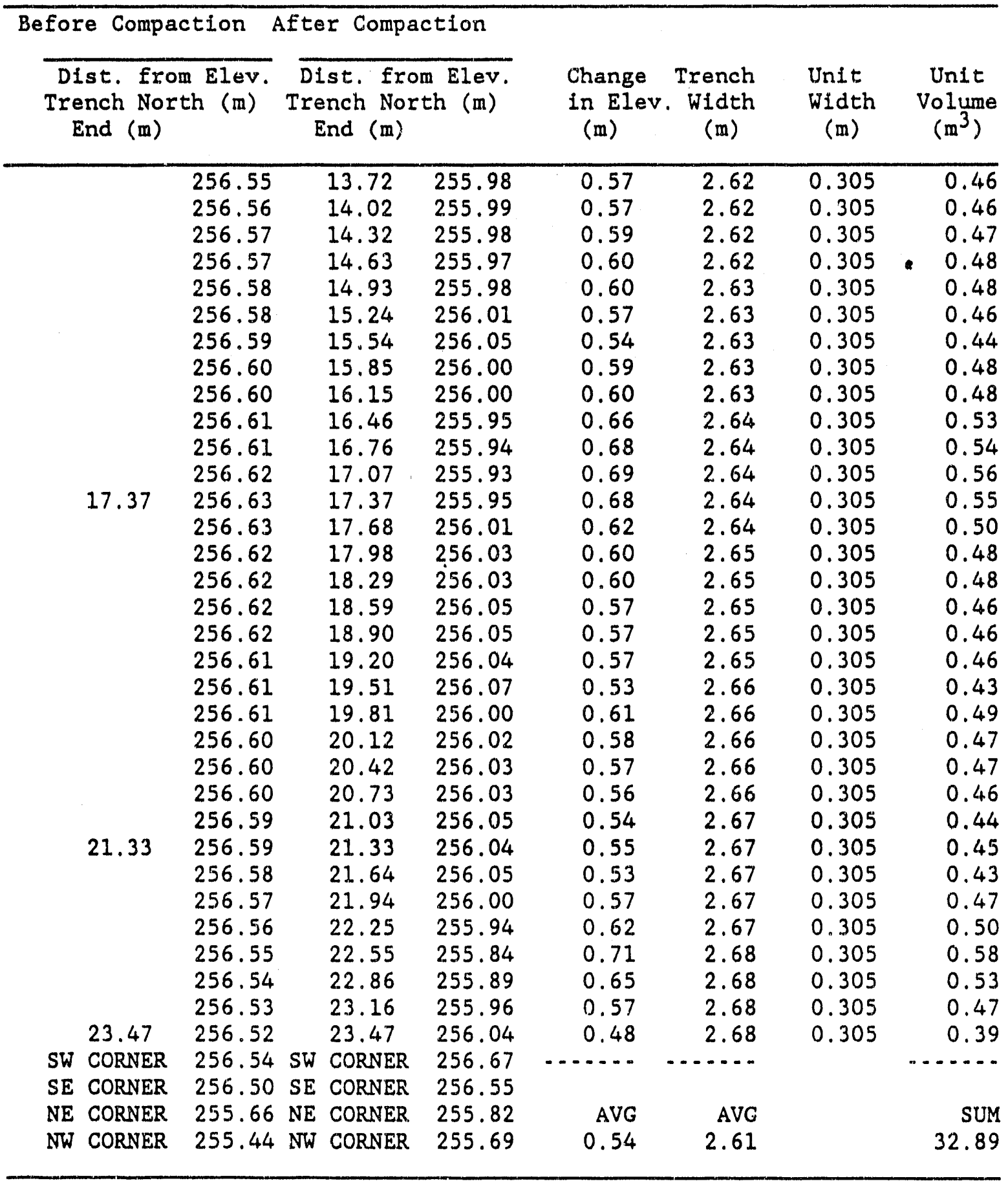



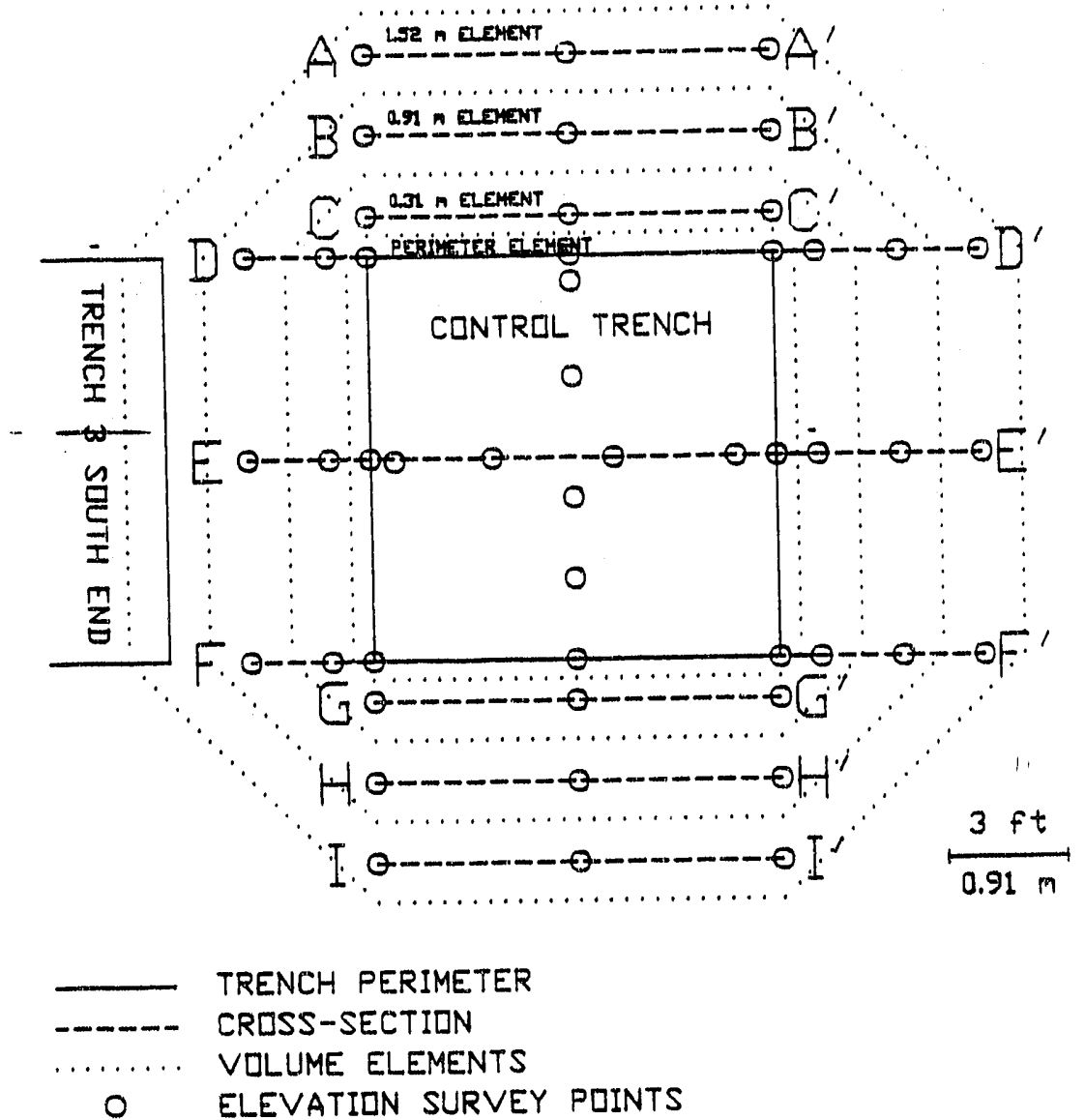

Fig. 36. Location of the control trench surface elevation points before and after trench compaction. 


$$
\begin{aligned}
C V_{C C} & -(L \times W \times D)-4.44 \mathrm{~m}^{3} \\
\text { where, } & C V_{C c}=\text { corrected control crater volume, } \mathrm{m}^{3} \\
\mathrm{~L} & =\text { control section length, } 2.74 \mathrm{~m} \\
W & =\text { control section width, } 2.74 \mathrm{~m} \\
D & - \text { control section depth, } 0.75 \mathrm{~m} .
\end{aligned}
$$

Solving the above equation yields a corrected control crater volume of 1.21 $\mathrm{m}^{3}$ and, therefore, a corrected control crater depth of $0.16 \mathrm{~m}$. In other words, the approximate $3 \mathrm{~m} \mathrm{x} 3 \mathrm{~m}$ control section could actually be compacted to a depth of $0.16 \mathrm{~m}$, yielding a total compacted volume of $1.21 \mathrm{~m}^{3}$.

The control section depth of $0.16 \mathrm{~m}$ was then subtracted from the average trench crater depths, resulting in corrected trench crater depths. These depths are summarized in Table 38 and range from a minimum of $0.30 \mathrm{~m}$ in trench 2 to a maximum of $0.47 \mathrm{~m}$ in trench 5 . The corrected trench crater volume was then calculated as

$$
\begin{aligned}
C V_{t c} & -\left(D_{t}-0.16\right) \times W \times L \\
\text { where, } & C V_{t c}=\text { corrected trench crater volume, } \mathrm{m}^{3} \\
D_{t} & =\text { trench depth, m } \\
W & =\text { trench width, m } \\
L & =\text { trench length, } \mathrm{m} .
\end{aligned}
$$

The corrected trench crater volumes were then compared to the volume of water-accessible void space (measured via the water pump-in tests described above) and expressed as a percentage of this value. For example, Table 38 shows that a compaction volume of $29.48 \mathrm{~m}^{3}$ was achieved over trench 2 , accounting for 96.98 of the measured water-accessible void space of $30.42 \mathrm{~m}^{3}$. These water-accessible void space reductions ranged from a low of 48.28 to a high of 1158, with an average value of 778 .

Several sources of error could account for the variations in trench vold reduction that were observed. First, the water pump-in tests could underestimate the actual trench void volume if all observation wells along the trench did not maintain equal elevations during the filling process. In other words, only one side of the trench would have actually been filled with water while the other side of the trench would have been partially filled. This would lead to an overestimate in the trench void reduction such as was the case with trench 3 ( 1158 reduction). Another source of error could be void volume within waste packages themselves that was not measured in the water punp-in tests but was accounted for in the trench crater volume after the waste packages were smashed by dynamic compaction. This would again lead to an overestimate of the trench void reduction such as was the case for trench 3. One last point to consider is that the actual void volume (volume of air) of the TARA trenches was not measured by the water pump-in tests, only the water-accessible void volume, which is smaller. This is because the trenches contain a certain volume that cannot be saturated during the relatively short water pump-in tests and also because of the formation of air pockets in and around the waste and soil backfill. 
Page 131

Table 38. Percentage reduction in trench water-accessible void space achieved by dynamic compaction

\begin{tabular}{|c|c|c|c|c|c|c|c|}
\hline $\begin{array}{l}\text { Trench } \\
\text { Number }\end{array}$ & $\begin{array}{l}\text { Average } \\
\text { Crater } \\
\text { Width } \\
\text { (m) }\end{array}$ & $\begin{array}{l}\text { Average } \\
\text { Crater } \\
\text { Length } \\
\text { (m) }\end{array}$ & $\begin{array}{l}\text { Average } \\
\text { Crater } \\
\text { Depth } \\
\text { (m) }\end{array}$ & $\begin{array}{l}\text { Corrected } \\
\text { Crater } \\
\text { Depth } \\
\text { (m) }\end{array}$ & $\begin{array}{l}\text { Corrected } \\
\text { Crater } \\
\text { Volume } \\
\left(\mathrm{m}^{3}\right)\end{array}$ & $\begin{array}{cc}\text { Water } & V \\
\text { Vold } & R \\
\left(\mathrm{~m}^{3}\right) & \end{array}$ & $\begin{array}{l}\text { Void } \\
\text { Redu. } \\
(8)\end{array}$ \\
\hline $\begin{array}{c}2 \\
3 \\
4 \\
5 \\
6 \\
\text { Control }\end{array}$ & $\begin{array}{l}3.43 \\
3.22 \\
2.78 \\
2.99 \\
2.61 \\
2.74\end{array}$ & $\begin{array}{r}28.65 \\
27.74 \\
24.08 \\
23.77 \\
23.47 \\
2.74\end{array}$ & $\begin{array}{l}0.46 \\
0.49 \\
0.60 \\
0.63 \\
0.54 \\
0.16\end{array}$ & $\begin{array}{l}0.30 \\
0.33 \\
0.44 \\
0.47 \\
0.38 \\
.\end{array}$ & $\begin{array}{l}29.48 \\
29.48 \\
29.45 \\
33.40 \\
23.28 \\
.\end{array}$ & $\begin{array}{l}30.42 \\
25.72 \\
61.04 \\
58.79 \\
35.18\end{array}$ & $\begin{array}{ll}+2 & 96.9 \\
2 & 115 \\
4 & 48.2 \\
79 & 56.8 \\
8 & 66.2 \\
& \end{array}$ \\
\hline
\end{tabular}

This results in a somewhat lower reduction of total trench void space than of water-accessible void space depending on the actual ratio of total void space to water-accessible voids. Considering these sources of error, the best estimate of water-accessible void reduction achieved by compaction of the . five TARA trenches is the average of the five calculated values, or 778 . This estimate will be verifled next year by the independent measurement of residual void volume in the trenches as determined by the volumes of grout accepted by the compacted trenches.

\section{SITE GRADING AND DRAINAGE}

After compaction of the five trenches was completed, a thorough walkover radiation survey of the craters was carried out by ORNL Health Physics personnel. A maximum activity of $2000 \mathrm{cpm}$ (background - 50 to $100 \mathrm{cpm}$ ) was noted in the center of trench 6 , with lower activity "hot spots" found scattered over all five trenches. In all cases, activity was due to the reduction in hielding that had occurred as a result of compacting the trench cover and was not the result of contaminated soil. This was verified by removing shovelfuls of soil from "hot spots" to background areas and then failing to detect radiation in the removed soil.

Shortly after the radiation survey was completed, a bulldozer was used to cut the walls between the trench craters and move this excess dirt to the northwest edge of the trenches to lessen the existing slope in this region. The intertrench walls were carefully removed in approximate $15-\mathrm{cm}$ cuts to an elevation approximately $15 \mathrm{~cm}$ above the trench crater floors. Every pass of the dozer was followed by an area survey by the site health physicist looking for possible contamination. The elevations of the trench crater floors were determined before and after site grading to ensure that at least $15 \mathrm{~cm}$ of cover was left over the craters and that the dozer did not accidentally cut into the compacted trench which could possibly spread contamination. Final site grading was done with a small rubber-tired road grader. 
When site grading was completed, a soli berm was constructed around the perimeter of the site to direct surface runoff away from the trenches to the north. The berm will be an important component of the eventual trench cap and will allow for infiltrating water to be trapped by an impermeable membrane and directed to a flow measuring station where its quantity can be measured. Figure 37 iliustrates the berm construction and the finished site grade.

Under routine operation, a group of compacted trenches would immediately be covered with some type of impermeable cap to prevent rainfall

infiltration. At the TARA site, however, this step would prevent the planned postcompaction penetration testing as well as the use of solution grouting in further stabilizing these compacted trenches with high radioisotope

inventories. For these reasons, the site was seeded and mulched after grading and the construction of a cap was delayed until testing and gxouting are completed.

\section{TIME AND PERSONNEL}

Compaction of the five trenches began the morning of July 27,1988 , at the north end of trench 2. Trench 6 was completed at 1012 on August 4, 1988. Of the 7 working days during this time period, a total of $48 \mathrm{~h}$ was spent actually dropping the weight over the 5 trenches. An additional $1 \mathrm{~h}$ was spent compacting the control section. During the 7-day working perlod, the cable break mechanism of the crane had to be adjusted periodically, as well as crane lubrication, fueling, and cable inspection. In total, the crane was operating $85 \mathrm{~g}$ of the time $(48 \mathrm{~h})$, with the additional 158 downtime due to malutenance activities.

The Rust Engineering Company personnel assigned full time to the compaction project consisted of 1 heavy equipment operator, one machine oiler, two laborers, and one metal worker. Additional truck drivers, mechanics, metal workers, and laborers were used on an as-needed basis. Personnel from ORNL consisted of one health physicist, one site supervisor, and two field technicians recording data and filming the drops on videotape as part of the overall project documentation. Excluding the part-time RUST personnel, it was estimated that approximately 504 employee hours were spent during the 7-day working period compacting the trenches. Site grading, seeding, and mulching, which followed compaction, required 2 days to complete. Additional time was spent in relocating a section of the SWSA 6 fence which was required for future cap construction purposes. 


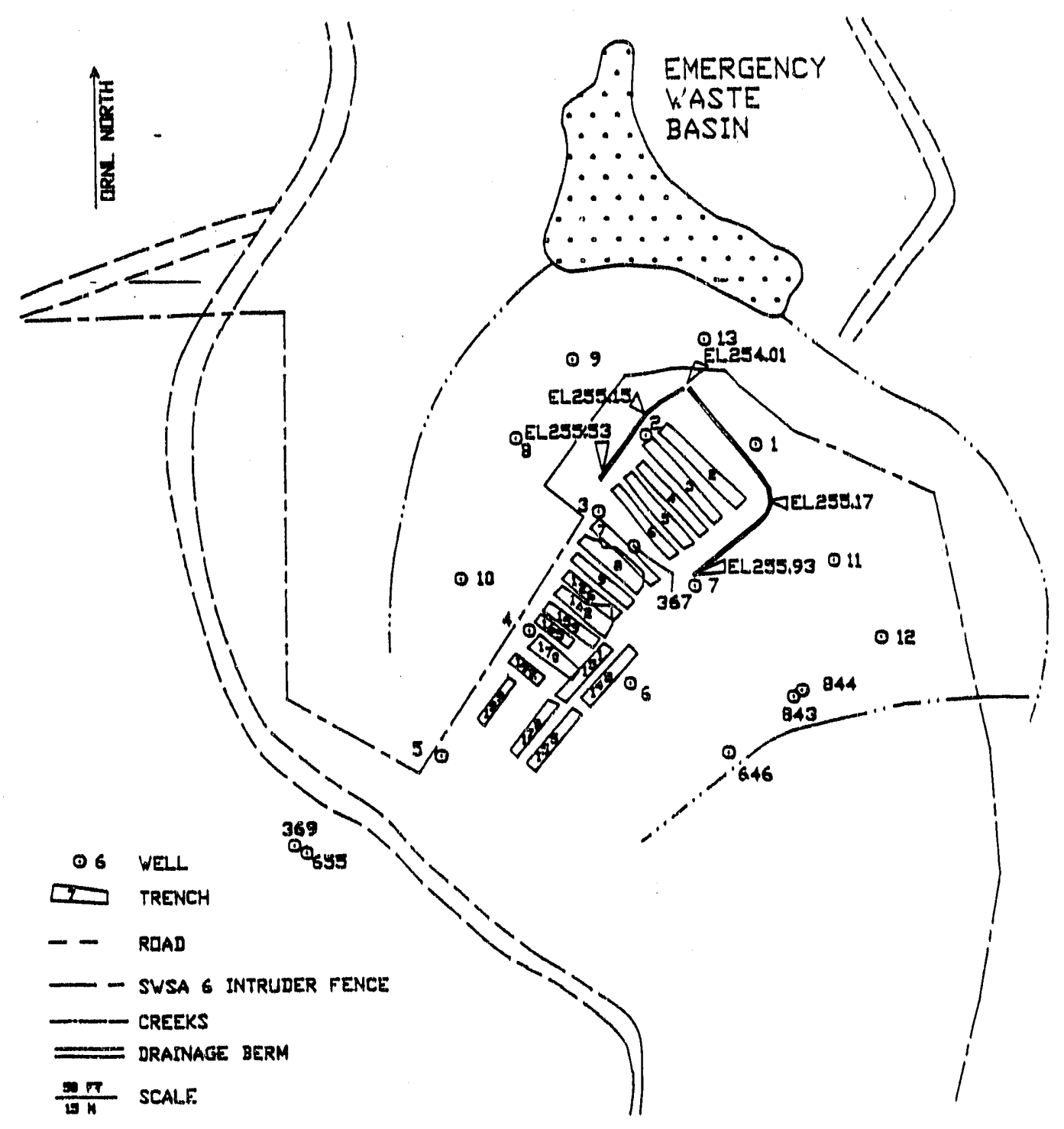

Fig. 37. Location of dralnage berm showing finished grade at the TARA site. 
Page 134

IV. REFERENCES

APHA (American Public Health Assoclation), 1980. Standard Methods for the Examination of Water and Wastewater. Am. Pub. Health Assoc, Washington, D. C.

ASGI (Automated Sclences Group Ino.). 1987. Enal Plan for the Demonstration and Evaluation of Stabilization and Closure Techniques for Low-Lavel Waste Burlal Trenches at Oak Ridge NatLonal Laboratory. Oak Ridge National Laboratory, Oak Ridge, TN ORNL/RAP - 42.

Avant1 International. 1985. AV-100 Chomical Grout Technical Manual. Avanti International, Webster, Tertas.

Blake, G. R. and K. H. Hartge. 1986, "Bulk Denslty." pp. $363-375$ in, Methods of Soll Analysis, Part 1 . Amer. Soc. of Agronomy, Madjson, Wisconsin.

Bly, S. G. 1988. Dynamic Compaction Demonstration SWSA-6. Oak Ridge National Laboratory. Oak Ridge, TN EAM 0640X.

Cerling, T. E. and B. P. Spalding. 1981, Areal Distribution of $60 \mathrm{Co}, 137_{\mathrm{Cs}}$ and 20 in Streambed Gravels of White Oak Creek Watershed, Oak Ridge. Tennessea, Oak Ridge National Laboratory, Oak Ridge, TN ORNL/TM-7318.

Davis, E. C., D. K. Solomon, R. B. Dreler, S. Y. Lee, P. M. Cralg, A. D. Kelmers, and D. A. Lietzke. 1987. Summary of Enyironmental Characterization Activities at the Oak Ridge National Jaboratory Solid Waste Storage Area Six Fy 1986 through 1987, Oak RIdge National Laboratory. Oak Ridge, TN ORNL/RAP/LTR-87/68.

Doyle, G. M. 1988. Solfd Waste Storage Area 6 Closure Demonstration. Dynamic Corpaction Phase, Oak Ridge National Laboratory. Oak Ridge, TN ORNL/ENG/SA2027.

Duguid, J. O., and O. M. Sealand, 1975. Reconnalssance Survey of the Intermediate-Leve1 Liquid Waste Transfer Line Between $X-10$ and the Hydrofracture Site, Oak Ridge National Laboratory. Oak Ridge, TN ORNL-TM. 4743.

Klute, A. 1965. "Laboratory Measurement of Hydraulic Conductivity of Saturated Soll." C. A. Bl.ack (ed.), Methods of Soll Analys 1s, Part 1. Agronomy $2: 210 \cdot 221$.

Lande, S. S., S. J. Bosch, and P. H. Howard, 1979. "Degradation and Leaching of Acrylamide in Sol1." J, Environ. Quale 8:133-137.

Larson, R. J., and J. H. May. 1983. "Geotechnlical Aspects of Bottom Sealing Existing Hazardous Waste Landflils by Injection Grouting (Phase I Compatibility Studies)." pp. 513-529 1n, Proceedings of the First Annual Hazardous Materials Management Conference. Tower Conference Management Company, Wheaton, I111nols. 
Solymar, Z. V., and D. J. Reed, 1986. "Comparison Between Ln-situ T'est: Methods," pp. 1236-1248. in, Use of In S1tu Tests in Gootechuleal Englneertine. S, P. Clemence (ed.). Amer. Soc, Olvil Englnuers. New York, New York.

Spalding, B, P., L. K. Hyder, and I, L. Munro, 1985. "Grouting as a Remedial Technique for Burled Low-Level Radioactlve Wasteg," J. Eriviron. Qual. 14: $389-396$.

Spalding, B. R. 1986. Burlal Irench Denamic Compaction at a Humide Site. CONF-8509121. pp. 676-698, EGSG Idaho, Ino., Idaho Falls, Idaho.

Spalding, B. P., S. Y. Lee, C. D. Farmer, L. K. Hyder, and P. Supaok1t. 1987. "In S1tu Grouting of Burled Transuranio Waste with Polyacrylamide," in, Qak Ridre Medel Conference Preceedings, Pp. 39.76, CONF-871075, Volume I, Part: 3. Martin Marletta Energy Systems, Inc., Oak R1dge, TN.

Valentine, C. K, 1986, Olesure Technology Dernenstration 19 Trench Section. Oak RIdge National Laboratory, Oak RIdge, TN ADM 0363X. 


\section{APEENDIX I}

Examplos of Types of Waste Placod In SWSA 6 Trenches 2, 3, 4, and 5. 
APPENDIX I

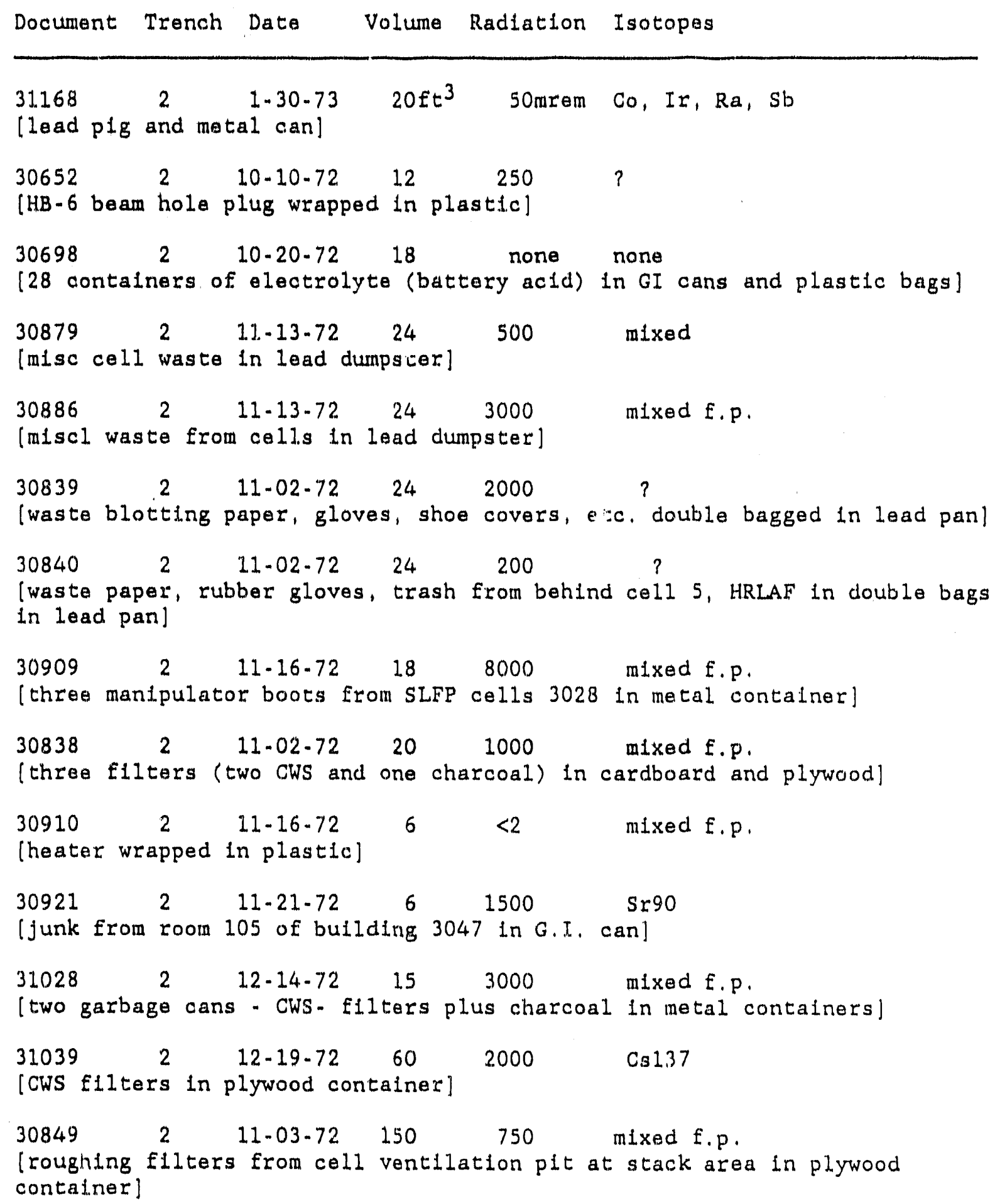


APPENDIX I

Document Trench Date Volume Radiation Isotopes

$32124 \quad 3 \quad 6-22-73 \quad 20 \quad 6.5 \quad$ U, Cs

[ 8 glass beakers of reactor ash in lead pigs and 2 other shielded contalners]

$\begin{array}{llllll}32123 & 3 & 6-22.73 & 40 & 140\end{array}$

[2-1/2 ton cylinder wrapped in plastic and traps]

$\begin{array}{llllll}32121 & 3 & 6-22-73 & 50 & 0.6 & U, \mathrm{Pu}, \mathrm{Np}\end{array}$

[ 3 cobaltous fluoride traps and transfer line in plastic]

$\begin{array}{lllll}32170 & 3 & 07.03-73 & 24 & 400\end{array}$ mixed f.p.

[ 3 drums contaminated resin - water slurry in SS drums]

$\begin{array}{llllll}32162 & 3 & 07-02-73 & 24 & 100\end{array}$

[hot can in lead pan]

$\begin{array}{llllll}32174 & 3 & 07-06-73 & 6 & 4000\end{array}$

[2 $\mathrm{Be} \mathrm{NO}_{3}$ pellets in hot can]

$\begin{array}{llllll}32179 & 3 & 07-09.73 & 24 & 400 & \mathrm{C} 14, \mathrm{Be}\end{array}$

[unspecifled in lead pan]

$\begin{array}{llllll}32189 & 3 & 07-11-73 & 8 & <5 & \mathrm{Ca}\end{array}$

[1 sS drum]

$\begin{array}{llllll}32209 & 3 & 07-17-73 & 20 & 2000 & \text { Eu }\end{array}$

[SS Table in clean plastic]

$\begin{array}{llllll}32233 & 3 & 07-25-73 & 6 & 2000 & \text { Eu }\end{array}$

[junk from cell A]

$\begin{array}{llllll}32169 & 3 & 07-03-73 & 125 & 1000 \quad \text { f.p. + alpha }\end{array}$

[HEPA filters in plastic and wood box]

$\begin{array}{llllll}32181 & 3 & 07.09-73 & 24 & 1000 & \mathrm{Cs} 137, \mathrm{Be}, \mathrm{Co}\end{array}$

[can in lead pan]

$\begin{array}{llllll}32180 & 3 & 07.09 .73 & 10 & 10000 & \text { Co, Eu }\end{array}$

[waste in 2 plerce containers]

$\begin{array}{llllll}32208 & 3 & 07-16-73 & 50 & 50 & \mathrm{Cs} 137, \operatorname{Sr} 90\end{array}$

[blotter paper and plywood box on hot truck]

$\begin{array}{llllll}32211 & 3 & 07-18-73 & 250 & 800 & \mathrm{Sr} 90\end{array}$

[furnace from cell - 11 in armor plate shleld bottom in plastic] 
APPENDIX I

Document Trench Date Volume Radiation Isotopes

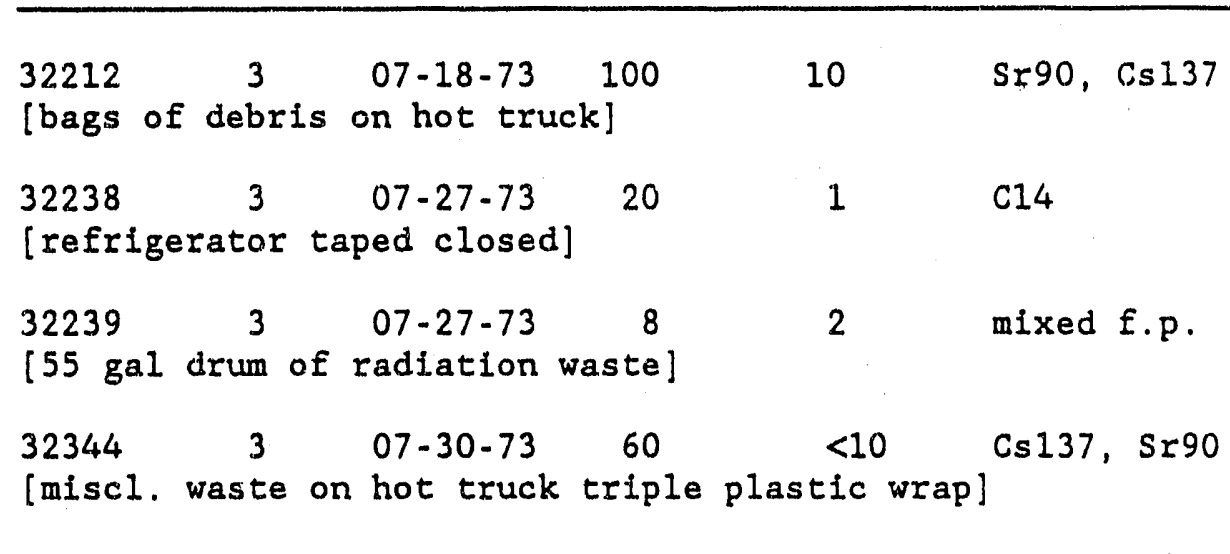

$\begin{array}{llllll}32241 & 3 & 07-27-73 & \text { u } & 20000 & \text { Sr90, Cs } 137\end{array}$

[CV filter in plywood box plastic wrapped]

$32309 \cdot 4 \quad 8-15-73 \quad 21 \quad 50 \quad$ Th

[3 - 20 gal cans and 1 - 5 gal can]

$\begin{array}{llllll}32296 & 4 & 8-10-73 & 150 & 6000 & \operatorname{sr} 90\end{array}$

[contaminated waste on hot truck wrapped in plastic]

$\begin{array}{llllll}32268 & 4 & 08-02-73 & 10 & 15 & \text { Ag110 }\end{array}$

[three 1-galion bottles of EDM dielectric oil, small holding tank, waste rags and approximately 1-pint of waste acetone in plastic bag]

$\begin{array}{llllll}32303 & 4 & 08-14-73 & 100 & 10 & \text { U233 }\end{array}$

[old resin clo. 2 plus trash from pent house + cell V plentum in black iron drums and in plastic]

$\begin{array}{llllll}32334 & 4 & 08-09-73 & 8 & <.5 & \text { H3 }\end{array}$

[aluminum drum]

$\begin{array}{llllll}32344 & 4 & 08-20-73 & 5 & 10\end{array}$

[scrap from cell A, farious Alum. S.S., + debris. Class A scrap in bucket]

$\begin{array}{llllll}32305 & 4 & 08-14-73 & 60 & 10 & \mathrm{Cm} 244\end{array}$

[Waste from charging area - wipes, hoses, clothing, etc. 8 - GI cans, 1

cardboard box, 1 SS 55 gal drum]

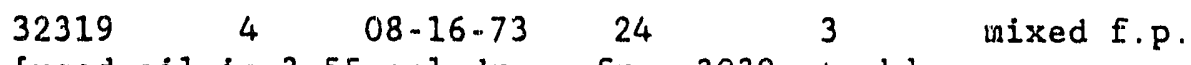

[used oil in 355 gal drums from 3039 stack]

$32306 \quad 4 \quad 08-14-73 \quad 12 \quad 2000 \quad$ ?

[spent filter from ORR pool primary water system in $30 \mathrm{gal}$ drum] 
APPENDIX I

Document Trench Date Volume Radiation Isotopes

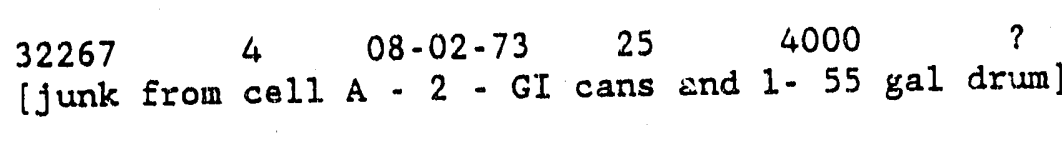

$\begin{array}{llllll}32285 & 4 & 08-08-73 & 8 & 1200\end{array}$

[junk from cell $A$ in $55 \mathrm{gal}$ drum]

$32355 \quad 4 \quad 08-21-73 \quad 20 \quad 3000 \quad$ ?

[junk from cell A in two hot cans + table]

$\begin{array}{lccccc}32304 & 4 & 08-14-73 & 12 & 1200 & ? \\ \text { [spent filters } & \text { from } \text { ORR primary water system in drums and plastic] }\end{array}$

$32369 \quad 4 \quad 08-24-73 \quad 50 \quad 100$ mixed f.p.

[absolute filters from 3092 off gas scrubber in plywood box]

$32269 \quad 4 \quad 08-02-73 \quad 120 \quad 10 \quad$ mixed f.p. +alpha

[wood, paper, and plastic in plastic bags]

$\begin{array}{llllll}32343 & 4 & 08-20-73 & 3 & 5\end{array}$

[used pump oil in can]

$32339 \quad 4 \quad 08-20-73 \quad 30 \quad$ none none

[approx. 10 bags (90\#) CaO lime)]

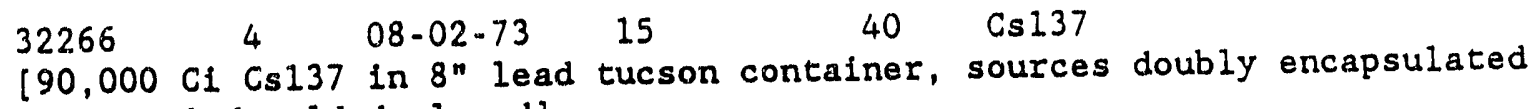
and carried welded closed]

$\begin{array}{lccccc}32247 & 4 & 07-31-73 & 20 & <.5 & ? \\ \text { [sample preparation stage } & \text { for EM-100 microscope (obsolete), 4D file cabinet] }\end{array}$

$32261 \quad 4 \quad 08-01-73 \quad 20 \quad<.5 \quad ?$

[misc lab ware]

$\begin{array}{llllll}32290 & 4 & 08-09-73 & 18 & <.2 & \text { U234 }\end{array}$

[glovebox X-44735 in plywood box]

$32323 \quad 4 \quad 08-16-73 \quad 12 \quad<.2 \quad$ H3

[used oil]

$32258 \quad 4 \quad 08-01-73 \quad 36 \quad 20 \quad$ ?

[broken glass (some mercury) + radiation waste in yellow cans] 
APPENDIX I

Document Trench Date Volume Radiation Isotopes

\begin{tabular}{llllll}
\hline 32348 & 4 & $08-21-73$ & 30 & 20 & $?$ \\
[radiation waste in 5 yellow & GI cans] & & \\
$32321 \quad 4$ & $08-16-73$ & 40 & 15 & Sr90, Cs137, Cm244 \\
[used plywood and boards] & & & \\
32302 & $4 \quad 08-14-73$ & 6 & 6 & $?$ \\
[1 - empty acid carboy with busted bottor] &
\end{tabular}

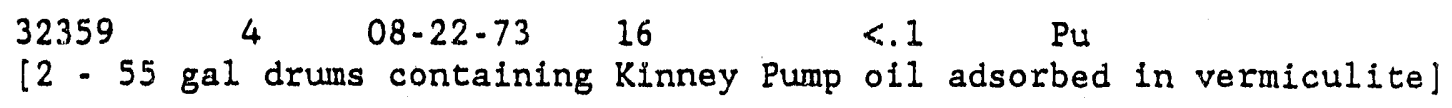

$\begin{array}{llllll}32360 & 4 & 08-22-73 & 78 & 7 & \mathrm{Pu}\end{array}$

[misc. Pu salvage in cardboard boxes]

????? $4 \quad 08-07-73 \quad 12 \quad 300$ mixed f.p.

[alpha, beta, + gamma contaminated equipment from hot cell operations sealed in metal drum in yellow dumpster]

\begin{tabular}{|c|c|c|c|c|c|}
\hline $\begin{array}{l}32504 \\
{[\text { misc cell }}\end{array}$ & $\begin{array}{l}5 \\
\text { waste }\end{array}$ & $\begin{array}{l}09-28-73 \\
\text { in lead pan }\end{array}$ & 24 & 200 & mixed \\
\hline $\begin{array}{l}32476 \\
\text { [plastic st } \\
\text { boxes] }\end{array}$ & $\begin{array}{l}5 \\
\text { dits, }\end{array}$ & $\begin{array}{l}09-20-73 \\
\text { plastic boot }\end{array}$ & $\begin{array}{l}16 \\
\text { ies }\end{array}$ & $\begin{array}{c}<10 \\
\text { surgeons gloves + }\end{array}$ & $\begin{aligned} & \text { Cm244 } \\
+ & \text { other debris } i\end{aligned}$ \\
\hline $\begin{array}{l}32492 \\
\text { [one charco }\end{array}$ & $\begin{array}{l}5 \\
\text { sal ro }\end{array}$ & $\begin{array}{l}09-25-73 \\
\text { oughing filte }\end{array}$ & $\begin{array}{l}8 \\
\text { in }\end{array}$ & $\begin{array}{c}850 \\
\text { plywood box }\end{array}$ & mixed $f . p$. \\
\hline $\begin{array}{l}32425 \\
{[\text { cell waste }}\end{array}$ & 5 in 3 & $\begin{array}{l}09-05-73 \\
3 \text { hot cans in }\end{array}$ & $\begin{array}{l}24 \\
\text { leac }\end{array}$ & d pan] & $\operatorname{Ir} 192$ \\
\hline $\begin{array}{l}3242.6 \\
{[3 \text { GI cans }}\end{array}$ & $\begin{array}{l}5 \\
\text { and } 1\end{array}$ & $\begin{array}{l}09-05-73 \\
\text { gal bucket }\end{array}$ & $\begin{array}{l}24 \\
\text { wast }\end{array}$ & $\begin{array}{c}1200 \\
e \text { in lined dumpste }\end{array}$ & $\begin{array}{l}\text { Eu, Gd } \\
\text { er] }\end{array}$ \\
\hline $\begin{array}{l}32375 \\
\text { [waste fron }\end{array}$ & $51 a b$ & $\begin{array}{l}08-28-73 \\
\# 207 \text { in hot }\end{array}$ & $\begin{array}{c}6 \\
\text { can] }\end{array}$ & 400 & K43, Au199, Au197 \\
\hline $\begin{array}{l}32451 \\
{[2 \mathrm{~s} . \mathrm{S} . \mathrm{tr}}\end{array}$ & $\begin{array}{l}5 \\
\text { [ays }\end{array}$ & $09-12-73$ & 50 & 1000 & Co, $\mathrm{Sr}$ \\
\hline $\begin{array}{l}32459 \\
\text { [junk from }\end{array}$ & $\begin{array}{l}5 \\
\text { cel1 }\end{array}$ & $\begin{array}{l}09-14-73 \\
\text { C] }\end{array}$ & $30^{\circ}$ & 2000 & Co6o \\
\hline
\end{tabular}


APPENDIX I

\begin{tabular}{|c|c|c|c|}
\hline Document & Trench & Volume & Radiation Isotopes \\
\hline $\begin{array}{l}32506 \\
\text { [waste in }\end{array}$ & $\begin{array}{l}5 \\
\text { Pierce }\end{array}$ & $\begin{array}{l}09-28-73 \\
\text { carrier] }\end{array}$ & Eu, Sr, Co \\
\hline $\begin{array}{l}32481 \\
\text { [junk from }\end{array}$ & $\begin{array}{l}5 \\
\operatorname{cel} 1\end{array}$ & $\begin{array}{ll}09-20.73 & 30 \\
C, \text { stainless } & \text { steel }\end{array}$ & $\begin{array}{l}5000 \\
\text { ductwork and } 2 \text { GI cans] }\end{array}$ \\
\hline $\begin{array}{l}32498 \\
\text { [misc soli }\end{array}$ & $i d^{5}$ waste & $\begin{array}{l}09-27-73 \quad 6 \\
e+\text { debris from } \mathrm{fl}\end{array}$ & $\begin{array}{c}500 \quad \text { Co60, Sr90 } \\
\text { oor of cell A in garbage can] }\end{array}$ \\
\hline $\begin{array}{l}32500 \\
\text { [SSt duct }\end{array}$ & 5 & $\begin{array}{c}09-27-73 \quad 50 \\
\text { aminated in plywoo }\end{array}$ & d box ${ }^{800}$ \\
\hline $\begin{array}{l}32480 \\
\text { [HEPA filt }\end{array}$ & $\begin{array}{l}5 \\
\text { ters, bl }\end{array}$ & $\begin{array}{l}09-20-73 \quad 60 \\
\text { lotter paper, plas }\end{array}$ & 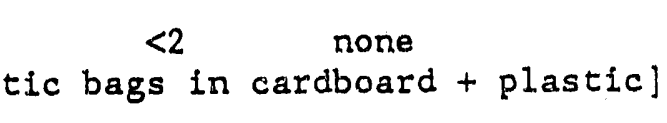 \\
\hline $\begin{array}{l}32442 \\
\text { [HEPA filt }\end{array}$ & $\begin{array}{l}5 \\
\text { ters, b1 }\end{array}$ & $\begin{array}{c}09-10-73 \quad 77 \\
\text { lotter paper, plas }\end{array}$ & $\begin{array}{c}<1 \\
\text { tic, cardboard in cardboard and }\end{array}$ \\
\hline
\end{tabular}

$\begin{array}{llllll}32443 & 5 & 09-10-73 & 42 & 20 & ?\end{array}$

[waste material from ORIC (radiation waste) in 7 yellow cans]

$32460 \quad 5 \quad 09-14-73 \quad 375 \quad 500 \quad$ mixed f.p.

[misc contaminated scrap in plastic]

$\begin{array}{llllll}32470 & 5 & 09-19-73 & 200 & 180 & \text { Transuranic }\end{array}$

[transuranium contaminated filters + equipment in double bagged wooden box]

$\begin{array}{llllll}32548 & 5 & 10-03-73 \quad 18 & 2000 \quad \text { mixed }\end{array}$

[misc waste from cell in 3 GI cans]

$32557 \quad 5 \quad 10-05-73 \quad 450 \quad 10 \quad$ Cs137, Co60, other

[excavated dirt, shrubs, and grass in plastic lined truck]

$32558 \quad 5 \quad 10-05-73 \quad 925 \quad 10 \quad$ Cs137, Co60, other

[excavated dirt, shrubs, and grass in plastic lined truck]

$\begin{array}{llllll}32527 & 5 & 10-01-73 & 20 & 20 & \text { alpha }\end{array}$

[contaminated HEPA filters in metal container]

????? $5 \quad 09-13-73 \quad 200 \quad 6000 \quad$ Cm244

[VOG filter in concrete container]

????? $5 \quad 09-20-73 \quad 60 \quad 0.1 \quad$ none

[HEPA filters, blotter paper, plastic bags in cardboard and plastic] 
II - 1

\section{APPENDIX. II}

Drill Logs and Construction Information for TARA Wells 1 - 13 
I I - 2

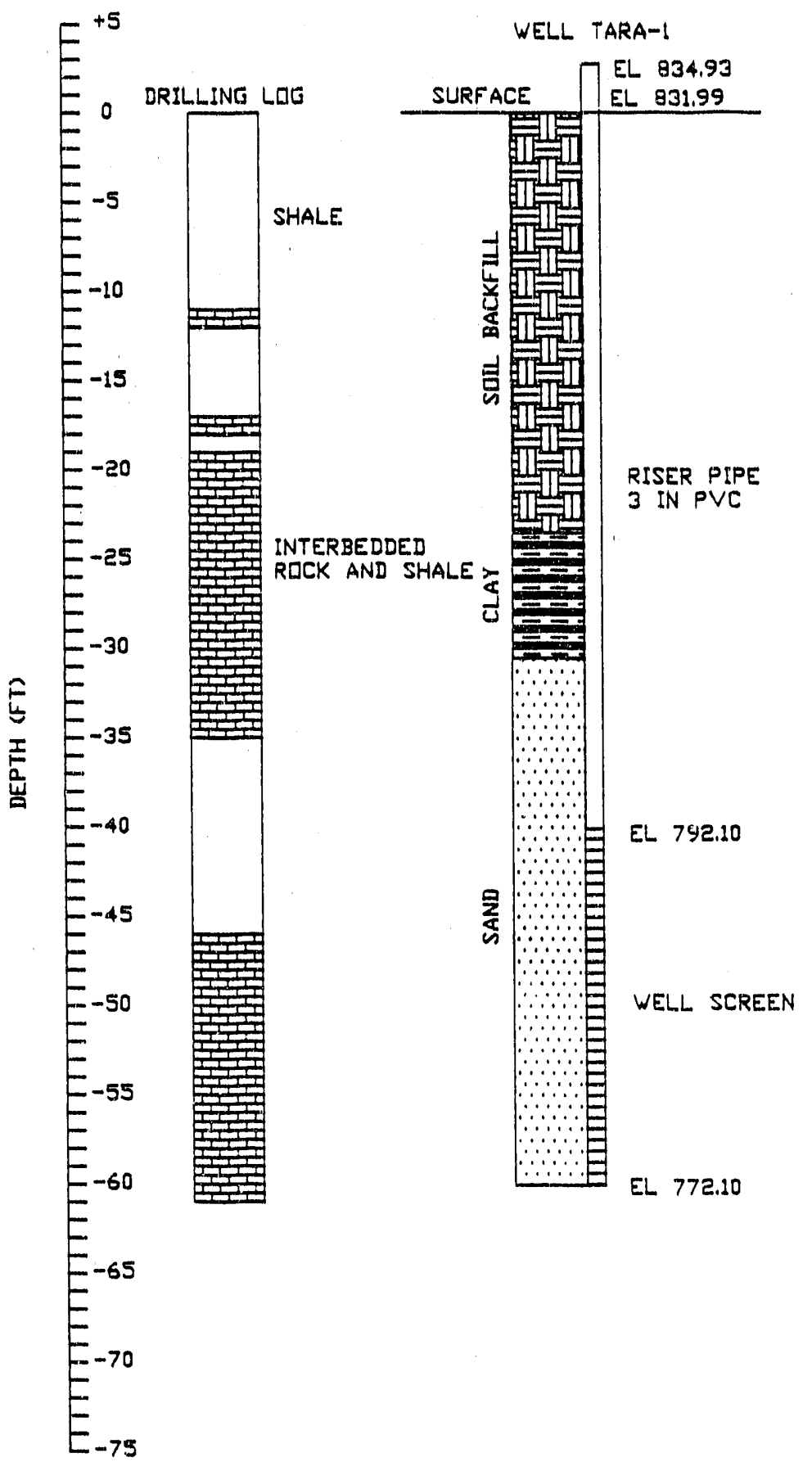

WELL TARA-1 


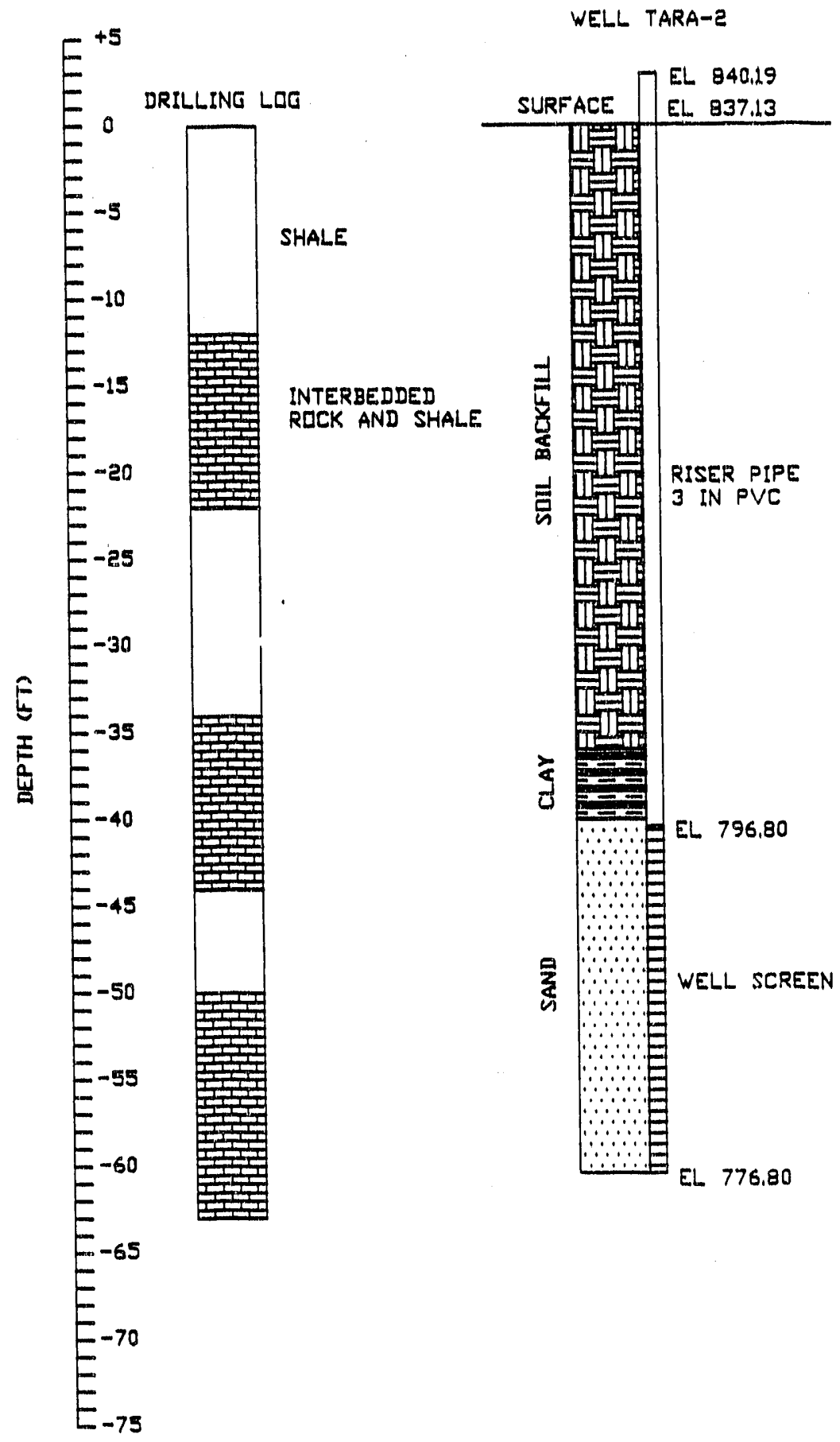

WELL TARA-2 
II -4

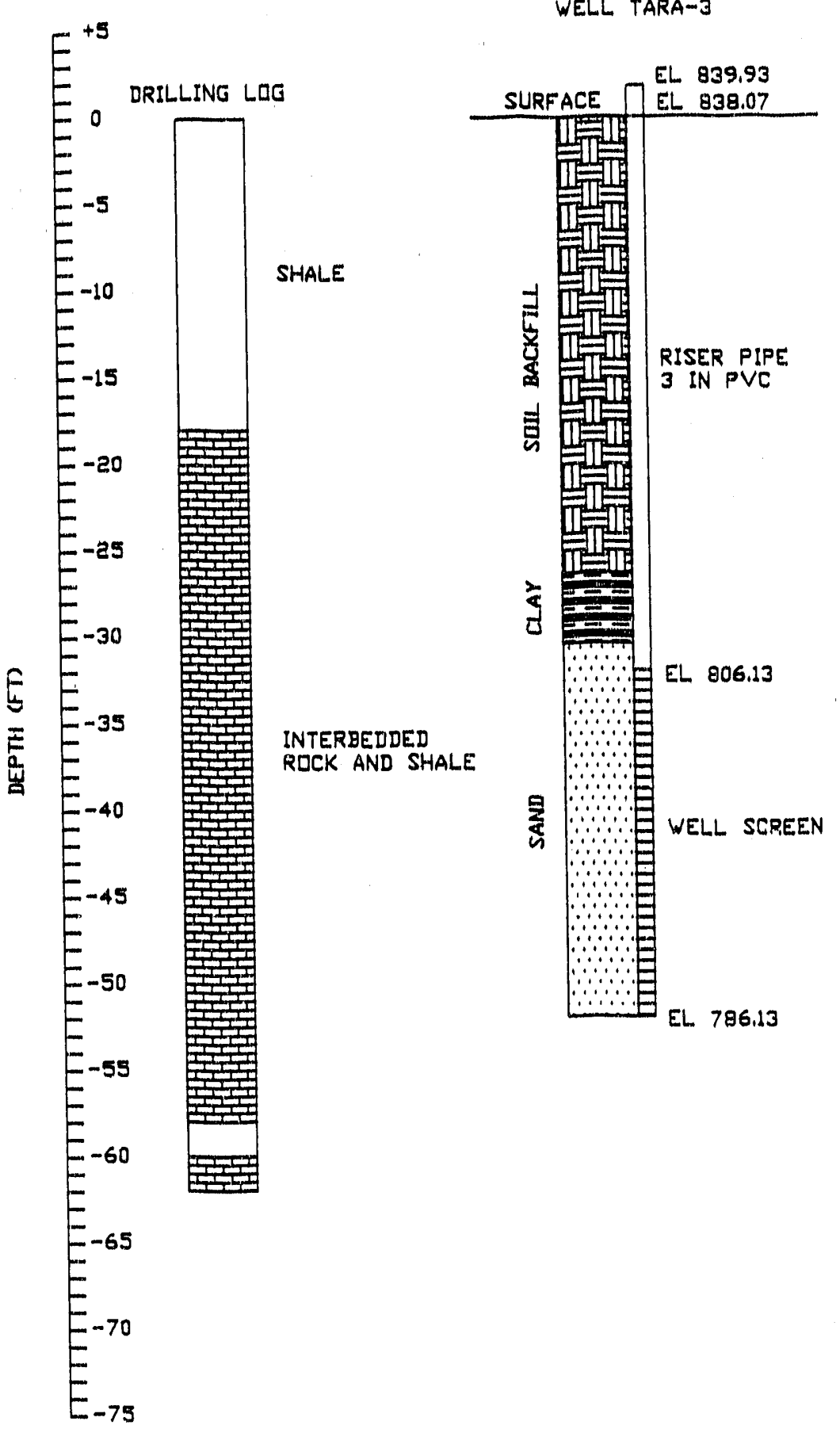

WELL TARA-3 


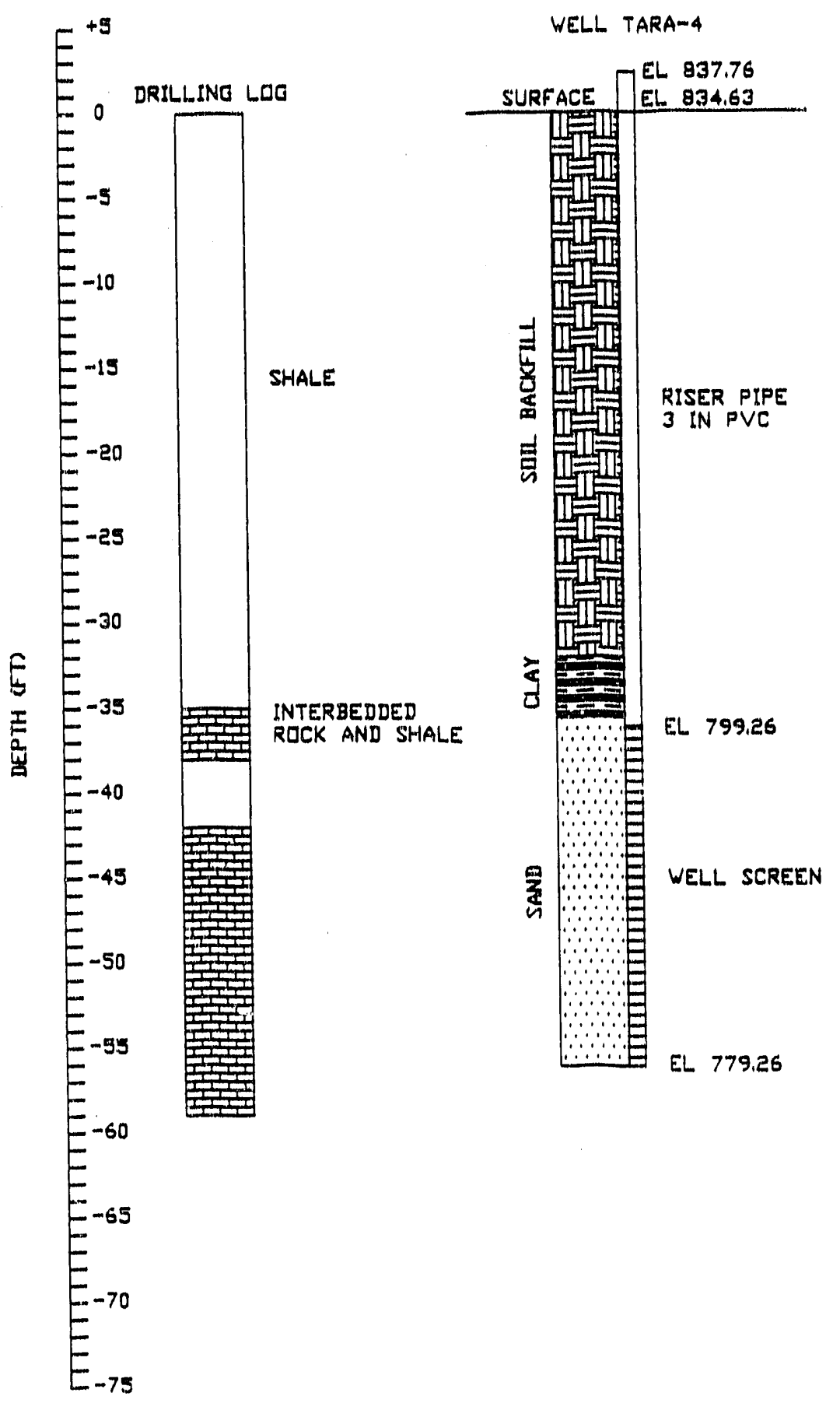

WELL TARA- 4 


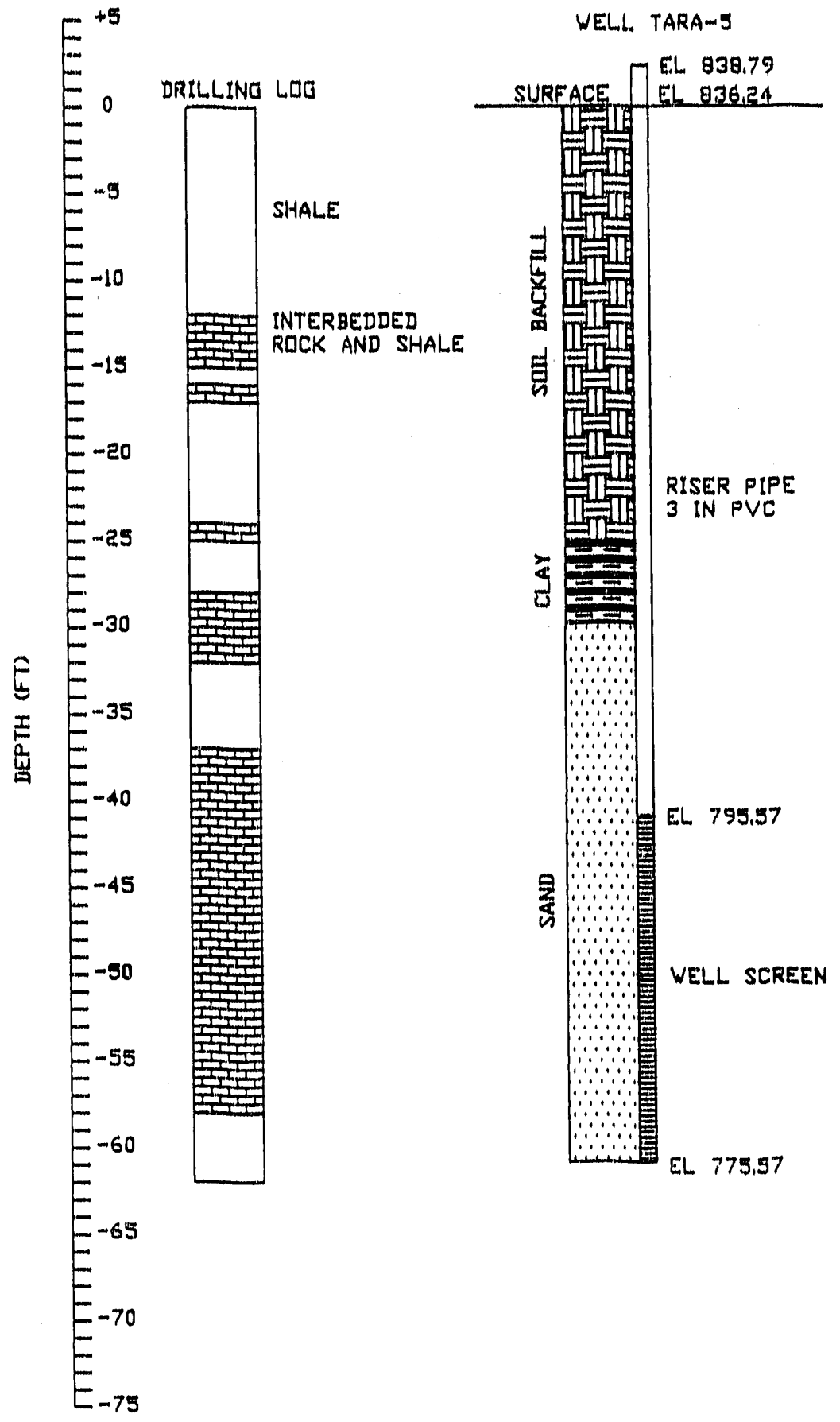

WELL TARA - 5 


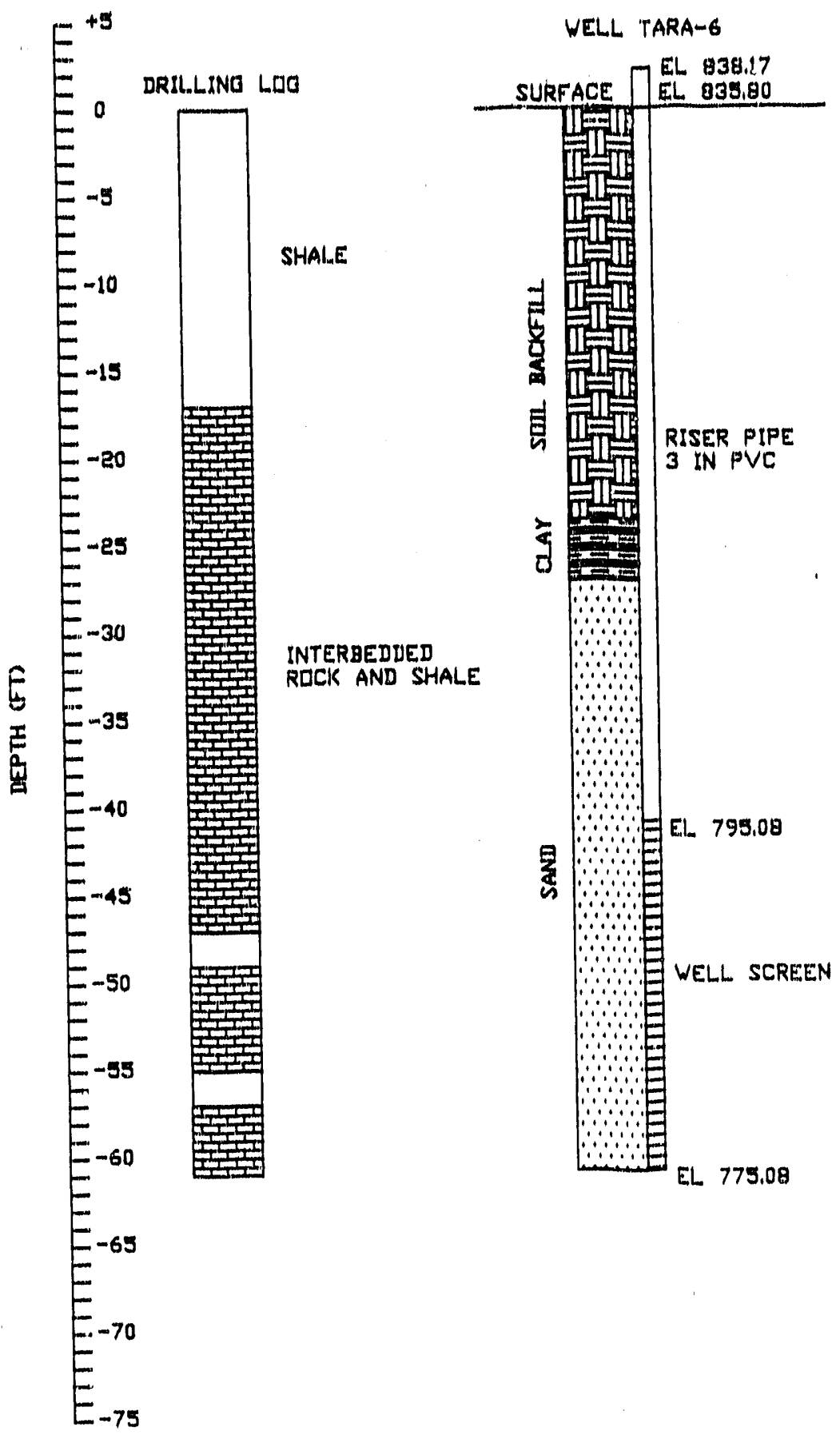

WELL TARA- 6 
II. 8

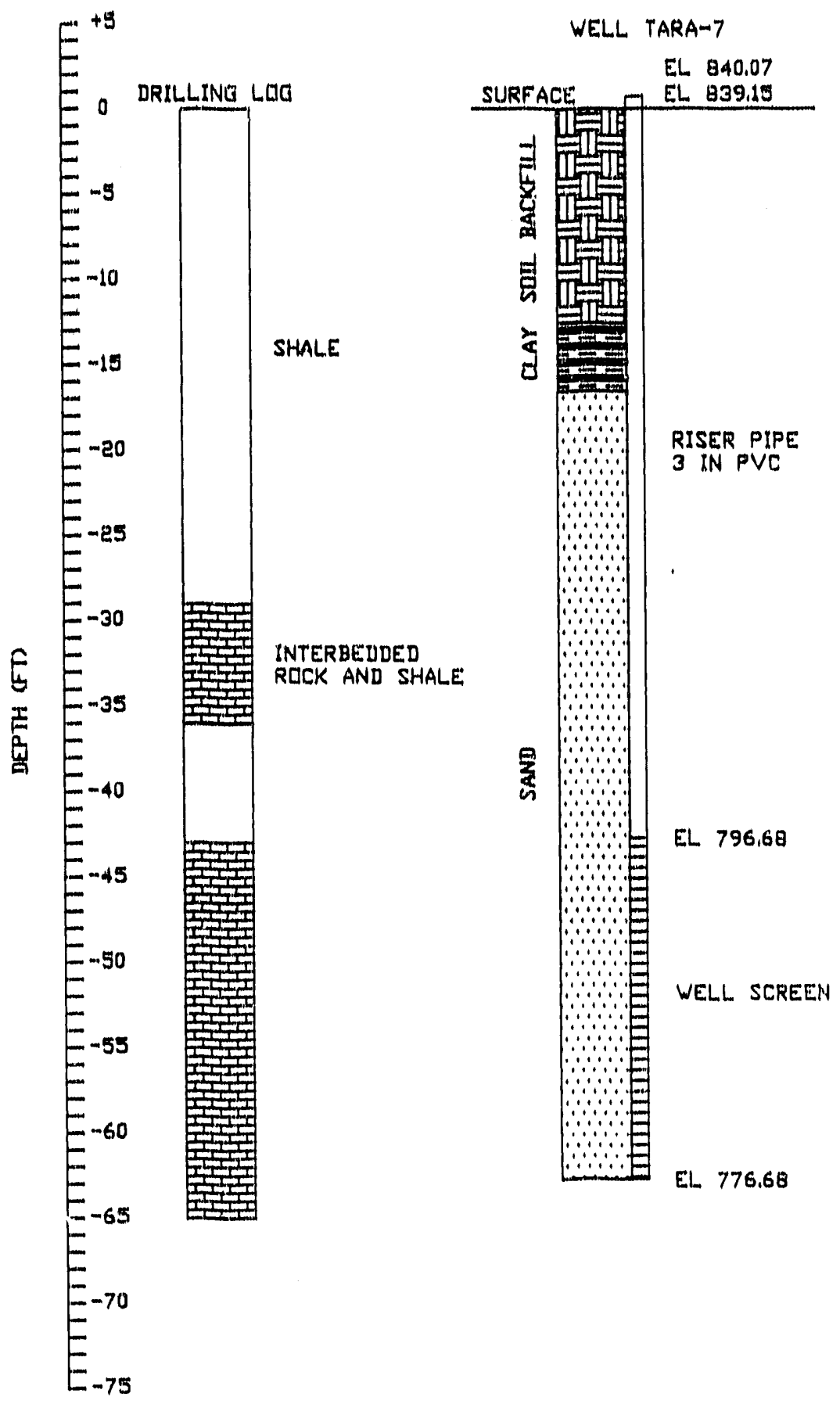

WELL TARA-7 


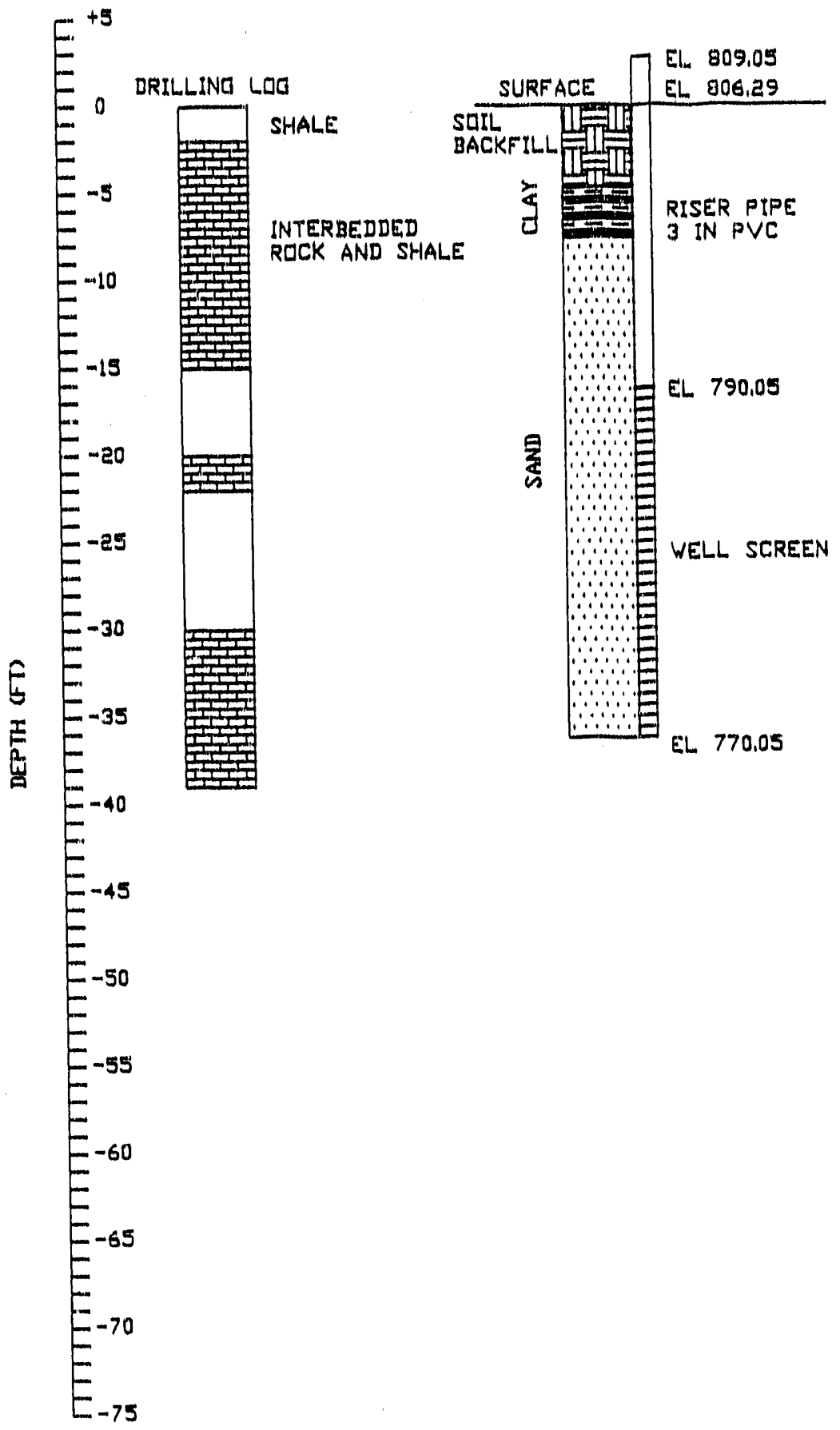

WELL TARA-8 
II -10

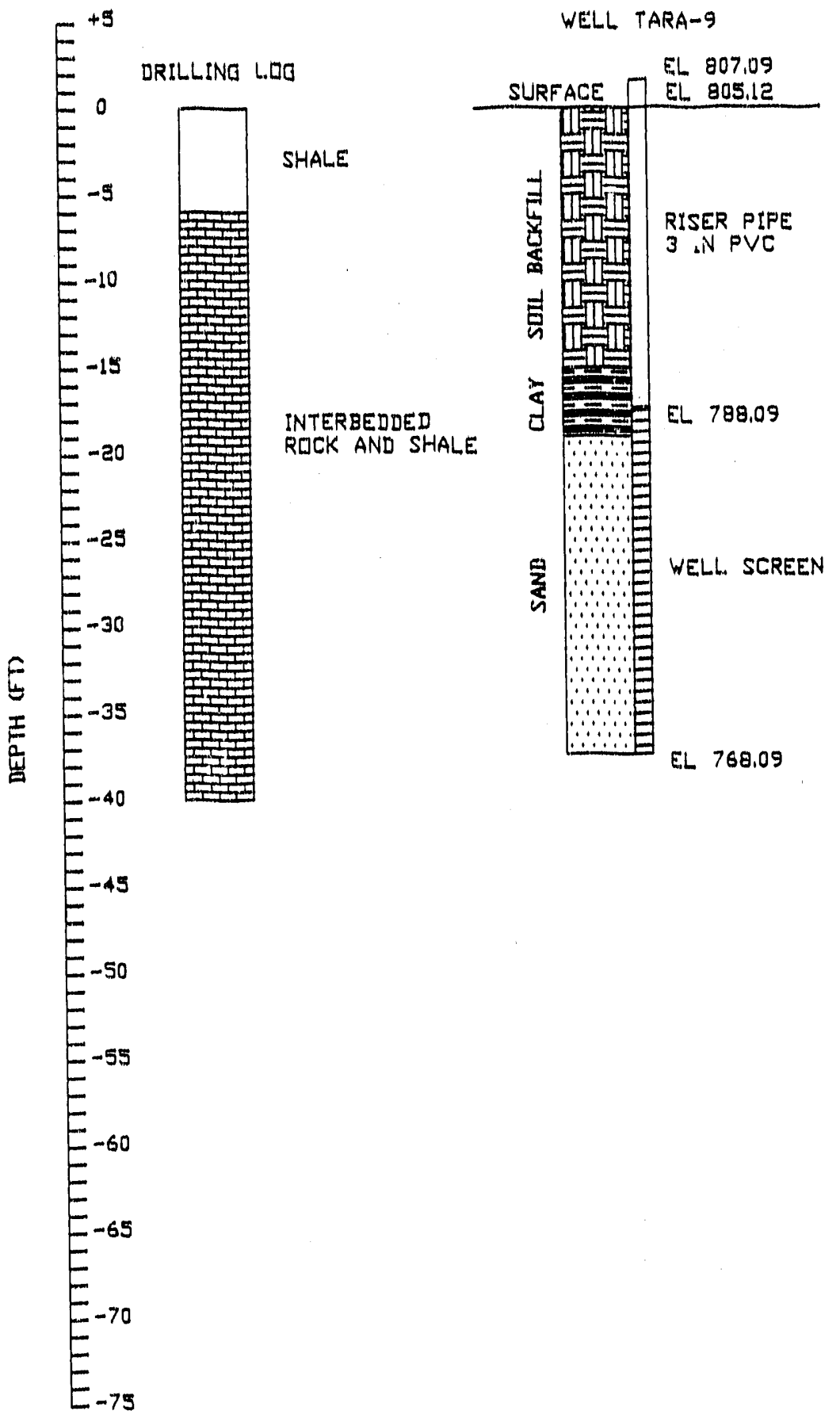

WELL TARA-9 


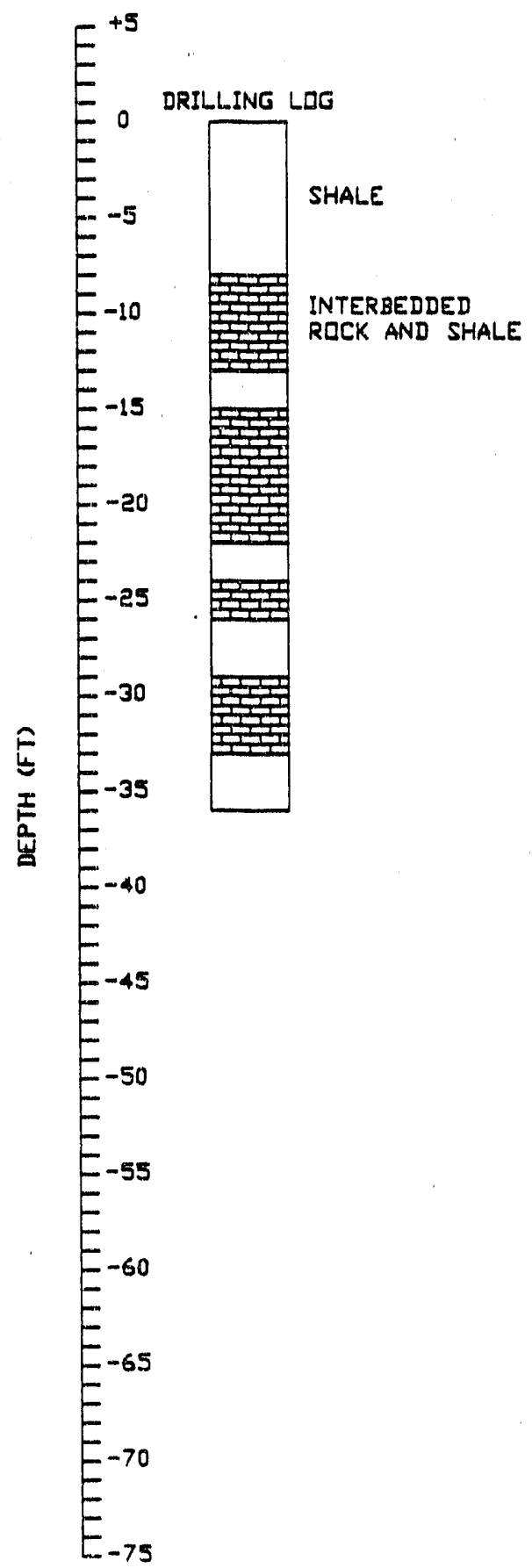

WELL TARA-10

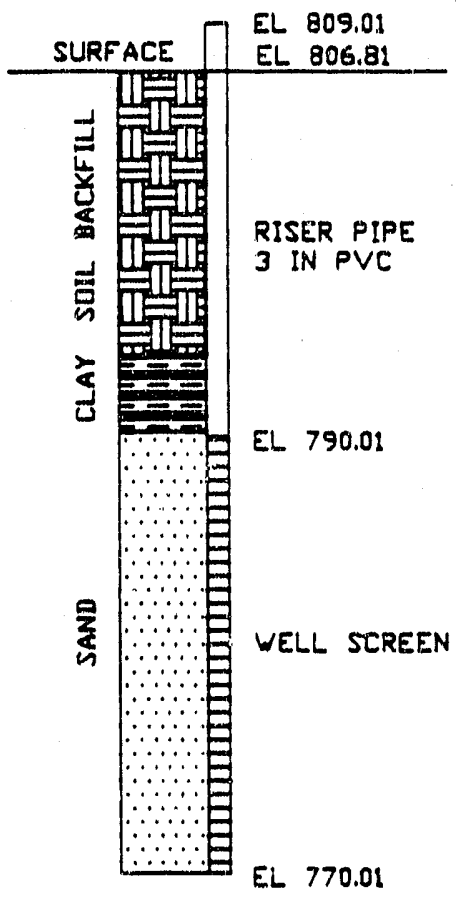

WELL TARA-10 
I I -12

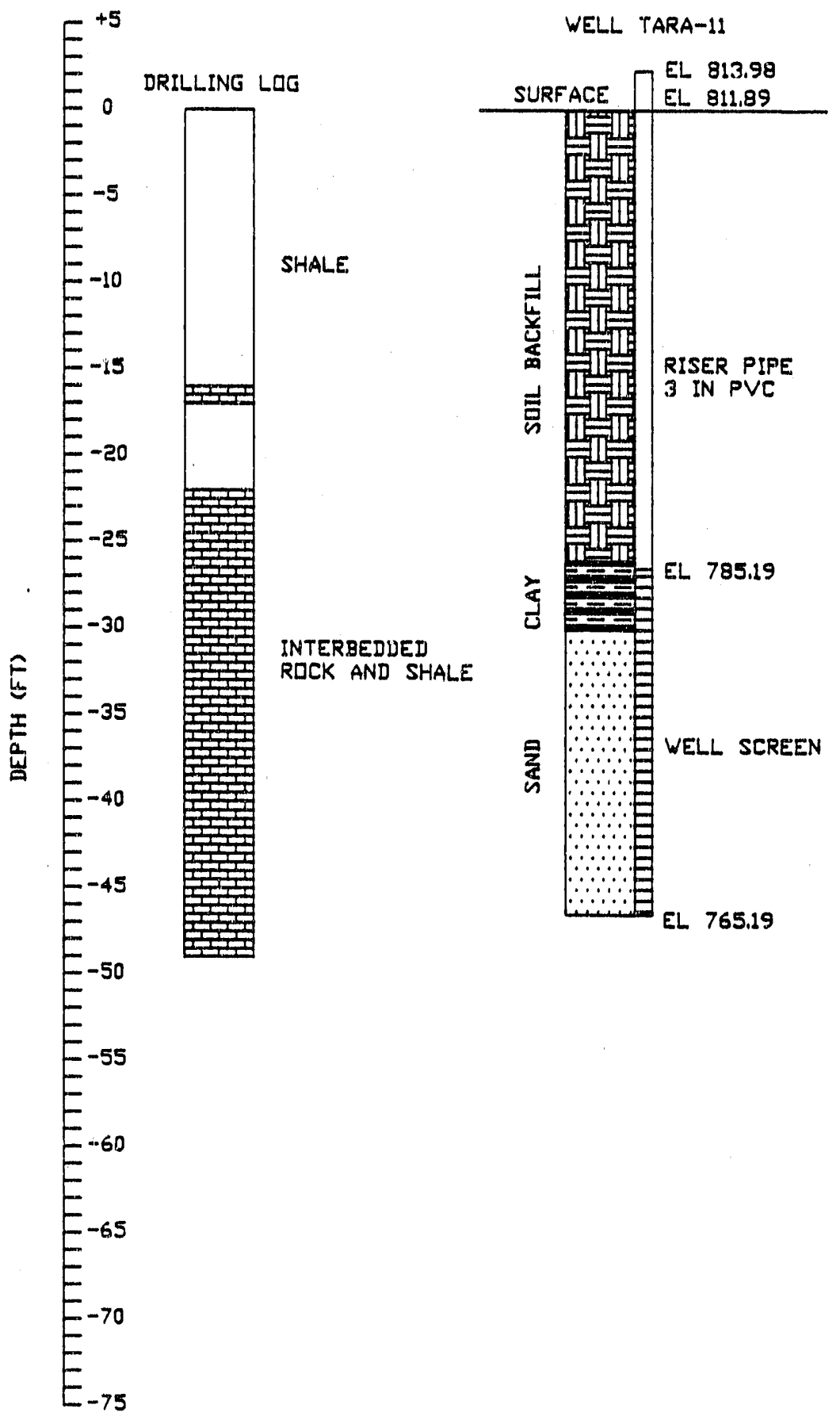

WELL TARA-11 


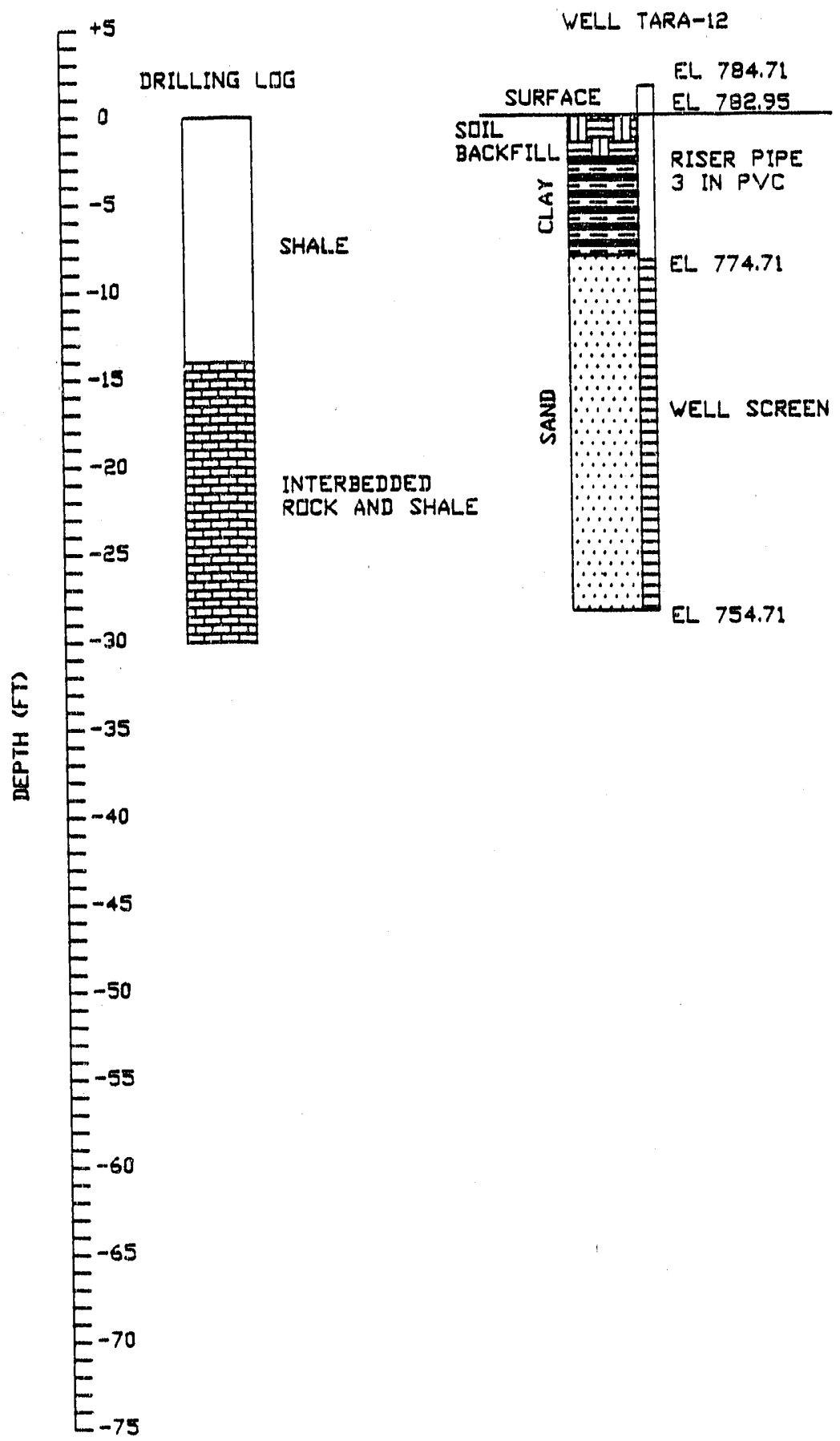

WELL TARA-12 


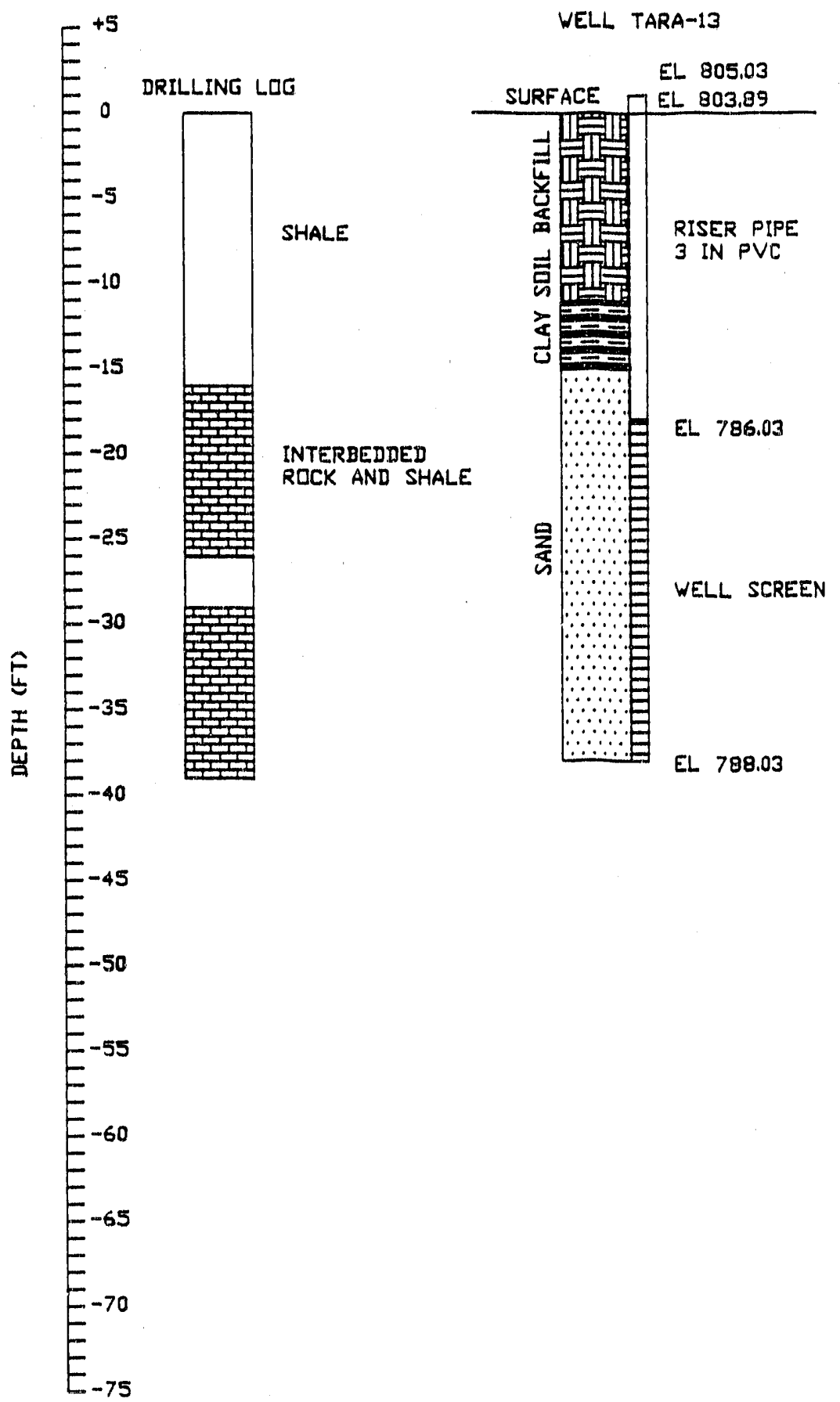

WELL TARA-13 
III - 1

APPENDIX III

TARA Well Water Level Data, Well Hydrographs, and Rainfall 
APPENDIX III

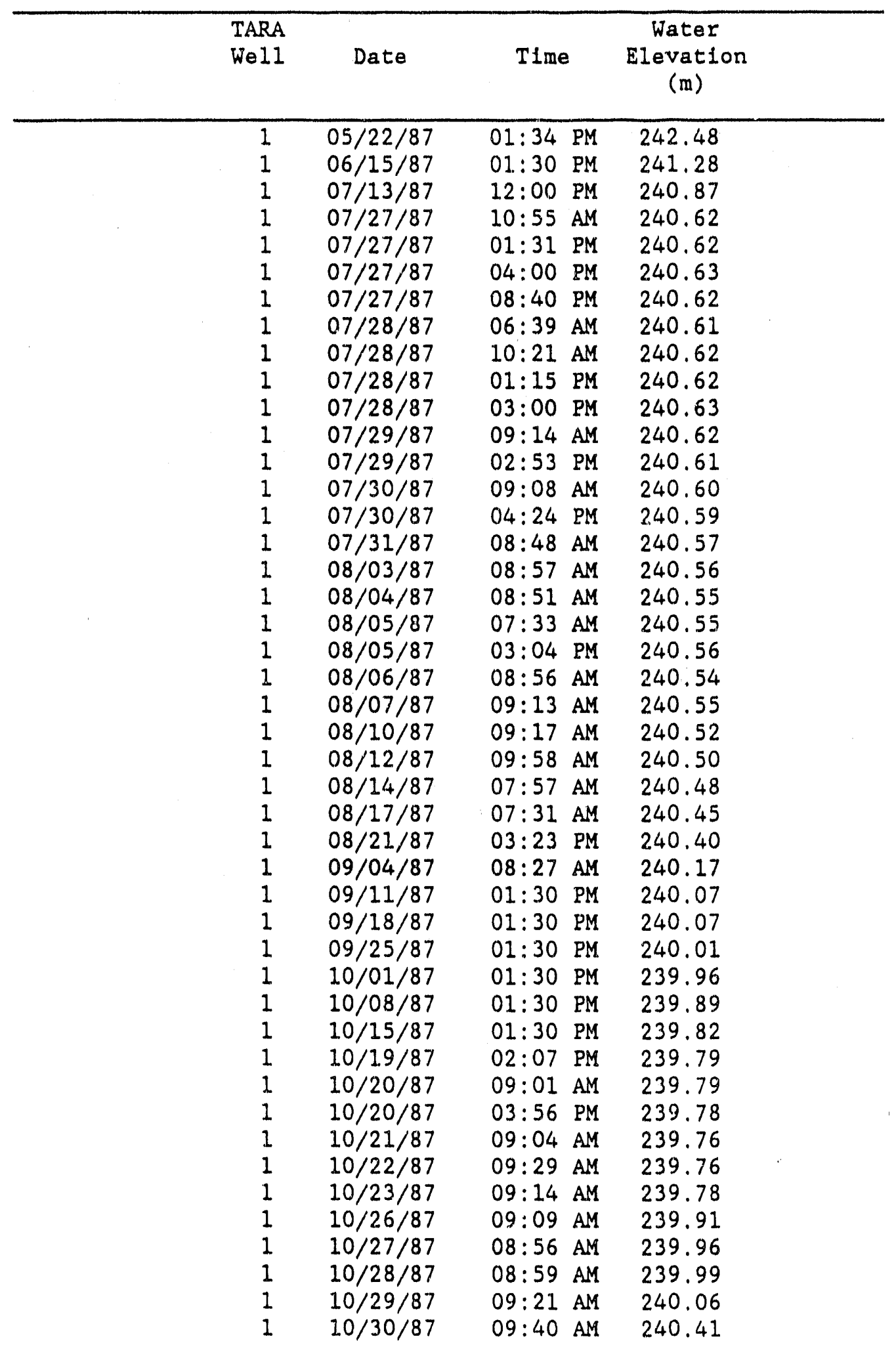


APPENDIX III

\begin{tabular}{|c|c|c|c|c|}
\hline $\begin{array}{l}\text { TARA } \\
\text { Wel1 }\end{array}$ & Date & Time & $\begin{array}{c}\text { Water } \\
\text { Elevation } \\
\text { (m) }\end{array}$ & \\
\hline $\begin{array}{l}1 \\
1 \\
1 \\
1 \\
1 \\
1 \\
1 \\
1 \\
1 \\
1 \\
1 \\
1 \\
1 \\
1 \\
1 \\
1 \\
1 \\
1 \\
1 \\
1 \\
1 \\
1 \\
1 \\
1 \\
1 \\
1 \\
1 \\
1 \\
1 \\
1 \\
1 \\
1 \\
1 \\
1 \\
1 \\
1 \\
1 \\
1 \\
1 \\
1 \\
1 \\
1 \\
1 \\
1 \\
1 \\
1\end{array}$ & $\begin{array}{l}11 / 02 / 87 \\
11 / 04 / 87 \\
11 / 05 / 87 \\
11 / 10 / 87 \\
11 / 12 / 87 \\
11 / 17 / 87 \\
11 / 17 / 87 \\
12 / 03 / 87 \\
12 / 11 / 87 \\
12 / 16 / 87 \\
12 / 21 / 87 \\
12 / 28 / 87 \\
12 / 31 / 87 \\
01 / 04 / 88 \\
01 / 08 / 88 \\
01 / 14 / 88 \\
01 / 21 / 88 \\
01 / 22 / 88 \\
01 / 25 / 88 \\
01 / 28 / 88 \\
02 / 01 / 88 \\
02 / 11 / 88 \\
02 / 18 / 88 \\
02 / 26 / 88 \\
03 / 03 / 88 \\
03 / 09 / 88 \\
03 / 16 / 88 \\
03 / 16 / 88 \\
03 / 17 / 88 \\
03 / 18 / 88 \\
03 / 19 / 88 \\
03 / 20 / 88 \\
03 / 21 / 88 \\
03 / 22 / 88 \\
03 / 23 / 88 \\
03 / 24 / 88 \\
03 / 25 / 88 \\
03 / 26 / 88 \\
03 / 27 / 88 \\
03 / 28 / 88 \\
03 / 28 / 88 \\
03 / 29 / 88 \\
03 / 30 / 88 \\
03 / 31 / 88 \\
04 / 01 / 88 \\
04 / 02 / 88\end{array}$ & 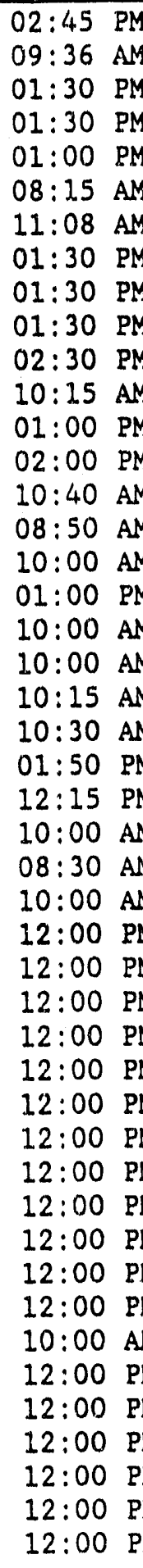 & $\begin{array}{l}241.31 \\
241.36 \\
241.34 \\
241.16 \\
241.03 \\
240.89 \\
240.89 \\
240.41 \\
240.24 \\
240.20 \\
240.07 \\
240.28 \\
240.10 \\
240.10 \\
240.05 \\
240.00 \\
240.44 \\
240.31 \\
240.28 \\
240.25 \\
240.28 \\
240.60 \\
240.71 \\
240.68 \\
240.67 \\
240.63 \\
241.70 \\
241.64 \\
241.59 \\
241.58 \\
241.53 \\
241.48 \\
241.43 \\
241.37 \\
241.32 \\
241.29 \\
241.26 \\
241.25 \\
241.18 \\
241.18 \\
241.13 \\
241.11 \\
241.08 \\
241.04 \\
241.03 \\
241.01\end{array}$ & • \\
\hline
\end{tabular}


APPENDIX III

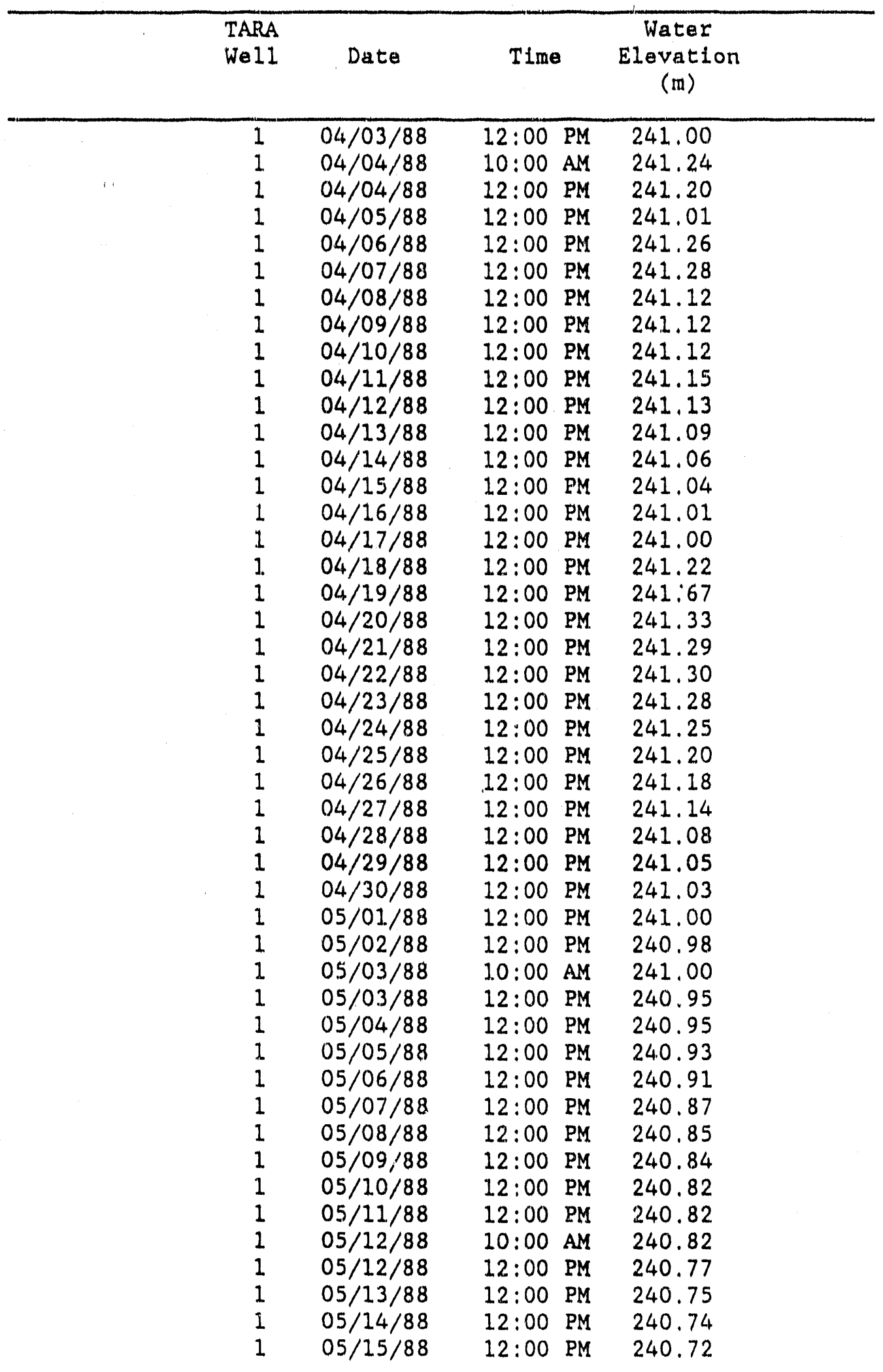


APPENDIX III

\begin{tabular}{|c|c|c|}
\hline $\begin{array}{l}\text { TARA } \\
\text { Well }\end{array}$ & Date & $\begin{array}{cc} & \text { Water } \\
\text { Time Elevation } & \text { (m) }\end{array}$ \\
\hline
\end{tabular}

\begin{tabular}{|c|c|c|c|}
\hline $\begin{array}{l}1 \\
1 \\
1 \\
1 \\
1 \\
1 \\
1 \\
1 \\
1 \\
1 \\
1 \\
1 \\
1 \\
1 \\
1 \\
1 \\
1 \\
1 \\
1 \\
1 \\
1 \\
1 \\
1 \\
1 \\
1 \\
1 \\
1 \\
1 \\
1 \\
1 \\
1 \\
1 \\
1 \\
1 \\
1 \\
1 \\
1 \\
1 \\
1 \\
1 \\
1 \\
1 \\
1 \\
1 \\
1 \\
1\end{array}$ & $\begin{array}{ll}1 & 05 / 16 / 88 \\
1 & 05 / 17 / 88 \\
1 & 05 / 18 / 88 \\
1 & 05 / 19 / 88 \\
1 & 05 / 20 / 88 \\
1 & 05 / 20 / 88 \\
1 & 05 / 21 / 88 \\
1 & 05 / 22 / 88 \\
1 & 05 / 23 / 88 \\
1 & 05 / 24 / 88 \\
1 & 05 / 25 / 88 \\
1 & 05 / 26 / 88 \\
1 & 05 / 26 / 88 \\
1 & 05 / 27 / 88 \\
1 & 05 / 28 / 88 \\
1 & 05 / 29 / 88 \\
1 & 05 / 30 / 88 \\
1 & 05 / 31 / 88 \\
1 & 06 / 01 / 88 \\
1 & 06 / 02 / 88 \\
1 & 06 / 02 / 88 \\
1 & 06 / 03 / 88 \\
1 & 06 / 04 / 88 \\
1 & 06 / 05 / 88 \\
1 & 06 / 06 / 88 \\
1 & 06 / 07 / 88 \\
1 & 06 / 08 / 88 \\
1 & 06 / 09 / 88 \\
1 & 06 / 09 / 88 \\
1 & 06 / 10 / 88 \\
1 & 06 / 11 / 88 \\
1 & 06 / 12 / 88 \\
1 & 06 / 13 / 88 \\
1 & 06 / 14 / 88 \\
1 & 06 / 15 / 88 \\
1 & 06 / 16 / 88 \\
1 & 06 / 17 / 88 \\
1 & 06 / 18 / 88 \\
1 & 06 / 19 / 88 \\
1 & 06 / 20 / 88 \\
1 & 06 / 21 / 88 \\
1 & 06 / 21 / 88 \\
1 & 06 / 22 / 88 \\
1 & 06 / 23 / 88 \\
1 & 06 / 24 / 88 \\
1 & 06 / 25 / 88\end{array}$ & 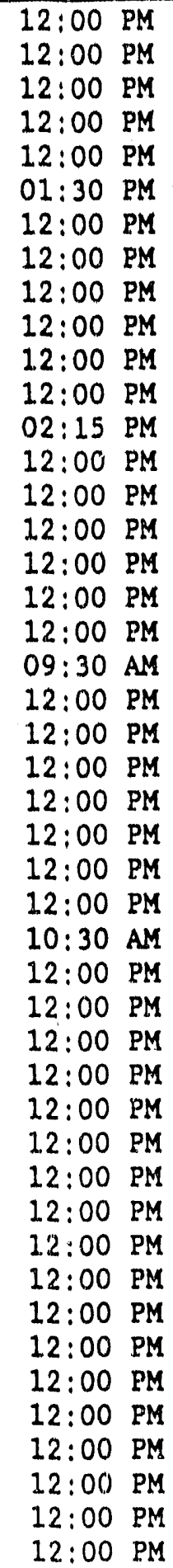 & $\begin{array}{l}240.71 \\
240.70 \\
240.69 \\
240.67 \\
240.64 \\
240.69 \\
240.62 \\
240.60 \\
240.59 \\
240.58 \\
240.57 \\
240.56 \\
240.61 \\
240.54 \\
240.52 \\
240.51 \\
240.49 \\
240.48 \\
240.47 \\
240.50 \\
240.46 \\
240.45 \\
240.41 \\
240.39 \\
240.37 \\
240.37 \\
240.36 \\
240.38 \\
240.35 \\
240.30 \\
240.29 \\
240.27 \\
240.26 \\
240.24 \\
240.22 \\
240.22 \\
240.21 \\
240.19 \\
240.16 \\
240.15 \\
240.14 \\
240.17 \\
240.13 \\
240.12 \\
240.10 \\
240.08\end{array}$ \\
\hline
\end{tabular}


APPENDIX III

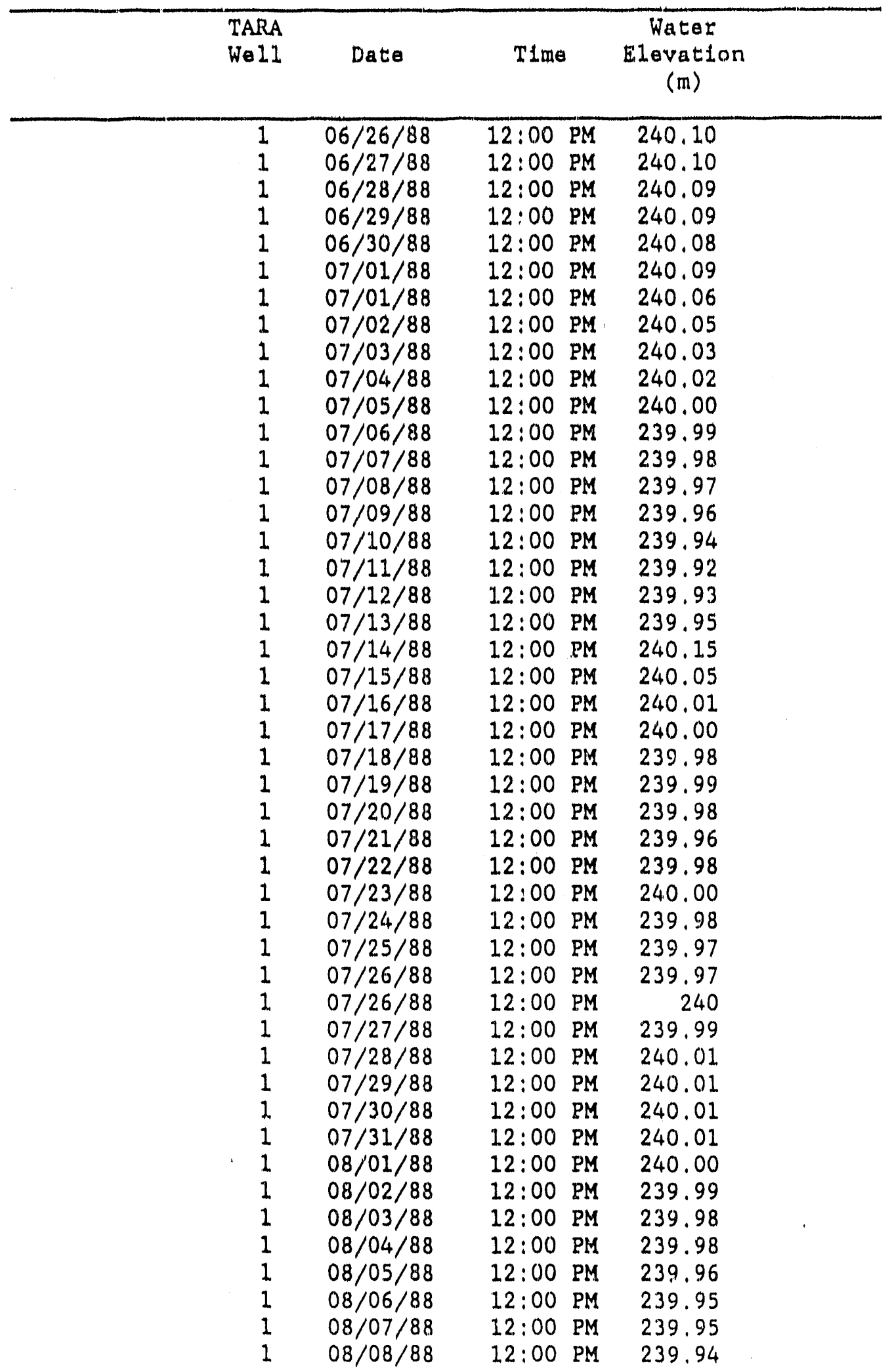


APPENDIX III

\begin{tabular}{ccccc}
\hline $\begin{array}{c}\text { TARA } \\
\text { Wel1 }\end{array}$ & Date & Time & $\begin{array}{c}\text { Water } \\
\text { Elevation } \\
(\mathrm{m})\end{array}$ \\
\hline 1 & $08 / 09 / 88$ & $12: 00 \mathrm{PM}$ & 239.93 \\
1 & $08 / 10 / 88$ & $12: 00 \mathrm{PM}$ & 239.91 \\
1 & $08 / 11 / 88$ & $12: 00 \mathrm{PM}$ & 239.91 \\
1 & $08 / 12 / 88$ & $12: 00 \mathrm{PM}$ & 239.91 \\
1 & $08 / 1.3 / 88$ & $12: 00 \mathrm{PM}$ & 239.91 \\
1 & $08 / 14 / 88$ & $12: 00 \mathrm{PM}$ & 239.91 \\
1 & $08 / 15 / 88$ & $12: 00 \mathrm{PM}$ & 239.91 \\
1 & $08 / 16 / 88$ & $12: 00 \mathrm{PM}$ & 239.90 \\
1 & $08 / 17 / 88$ & $12: 00 \mathrm{PM}$ & 239.89 \\
1 & $08 / 18 / 88$ & $12: 00 \mathrm{PM}$ & 239.88 \\
1 & $08 / 19 / 88$ & $12: 00 \mathrm{PM}$ & 239.88 \\
1 & $08 / 20 / 88$ & $12: 00 \mathrm{PM}$ & 239.87 \\
1 & $08 / 21 / 88$ & $1.2: 00 \mathrm{PM}$ & 239.86 \\
1 & $08 / 22 / 88$ & $12: 00 \mathrm{PM}$ & 239.85 \\
1 & $08 / 23 / 88$ & $12: 00 \mathrm{PM}$ & 239.87
\end{tabular}


APPENDIX III

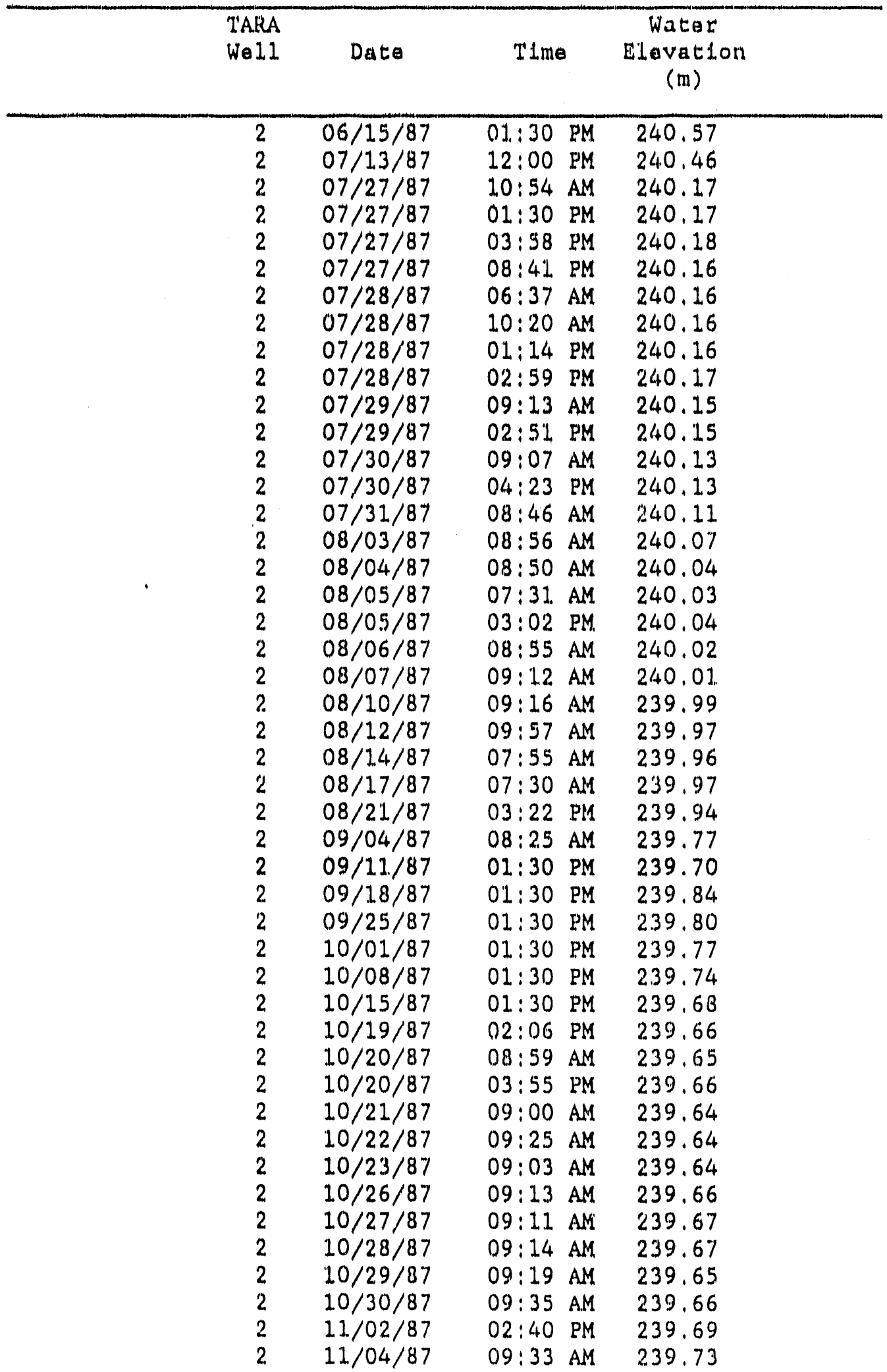


APPENDIX III

\begin{tabular}{|c|c|c|c|}
\hline $\begin{array}{l}\text { TARA } \\
\text { WeI1 }\end{array}$ & Date & Time & $\begin{array}{l}\text { Watar } \\
\text { Elovation } \\
\text { (m) }\end{array}$ \\
\hline $\begin{array}{l}2 \\
2 \\
2 \\
2 \\
2 \\
2 \\
2 \\
2 \\
2 \\
2 \\
2 \\
2 \\
2 \\
2 \\
2 \\
2 \\
2 \\
2 \\
2 \\
2 \\
2 \\
2 \\
2 \\
2 \\
2 \\
2 \\
2 \\
2 \\
2 \\
2 \\
2 \\
2 \\
2 \\
2 \\
2 \\
2 \\
2 \\
2 \\
2 \\
2 \\
2 \\
2 \\
2 \\
2 \\
2 \\
2\end{array}$ & $\begin{array}{l}11 / 05 / 87 \\
11 / 10 / 87 \\
11 / 12 / 87 \\
11 / 17 / 87 \\
11 / 18 / 87 \\
12 / 03 / 87 \\
12 / 11 / 87 \\
12 / 16 / 87 \\
12 / 21 / 87 \\
12 / 28 / 87 \\
12 / 31 / 87 \\
01 / 04 / 88 \\
01 / 08 / 88 \\
01 / 14 / 88 \\
01 / 21 / 88 \\
01 / 22 / 88 \\
01 / 25 / 88 \\
01 / 28 / 88 \\
02 / 01 / 88 \\
02 / 11 / 88 \\
02 / 18 / 88 \\
02 / 26 / 88 \\
03 / 03 / 88 \\
03 / 04 / 88 \\
03 / 05 / 88 \\
03 / 06 / 88 \\
03 / 07 / 88 \\
03 / 08 / 88 \\
03 / 09 / 88 \\
03 / 09 / 88 \\
03 / 10 / 88 \\
03 / 11 / 88 \\
03 / 12 / 88 \\
03 / 13 / 88 \\
03 / 14 / 88 \\
03 / 15 / 88 \\
03 / 16 / 88 \\
03 / 16 / 88 \\
03 / 17 / 88 \\
03 / 18 / 88 \\
03 / 19 / 88 \\
03 / 20 / 88 \\
03 / 21 / 88 \\
03 / 22 / 88 \\
03 / 23 / 88 \\
03 / 24 / 88\end{array}$ & 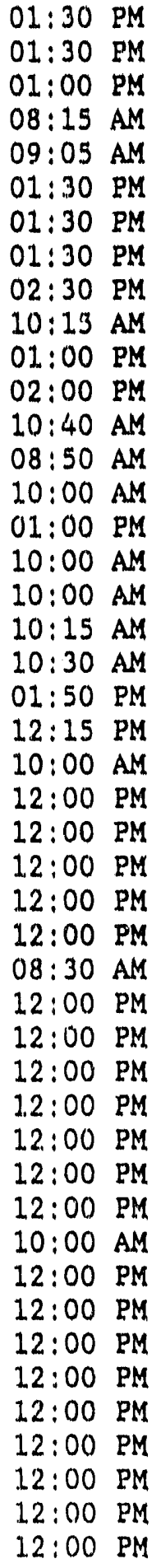 & $\begin{array}{l}239.75 \\
239.80 \\
239.84 \\
239.89 \\
239.88 \\
239.86 \\
239.83 \\
239.76 \\
239.83 \\
239.94 \\
239.91 \\
239.97 \\
239.97 \\
239.94 \\
240.37 \\
240.26 \\
240.22 \\
240.14 \\
240.15 \\
240.40 \\
240.43 \\
240.40 \\
240.38 \\
240.38 \\
240.34 \\
240.34 \\
240.33 \\
240.33 \\
240.35 \\
240.35 \\
240.48 \\
241.35 \\
241.06 \\
241.38 \\
241.55 \\
241.20 \\
241.09 \\
241.12 \\
240.96 \\
240.94 \\
240.89 \\
240.84 \\
240.80 \\
240.74 \\
240.71 \\
240.69\end{array}$ \\
\hline
\end{tabular}


APPENDIX III

$\begin{array}{ccc}\text { TARA } & \text { Water } \\ \text { Well Date Time Elevation } & (\mathrm{m})\end{array}$

(m)

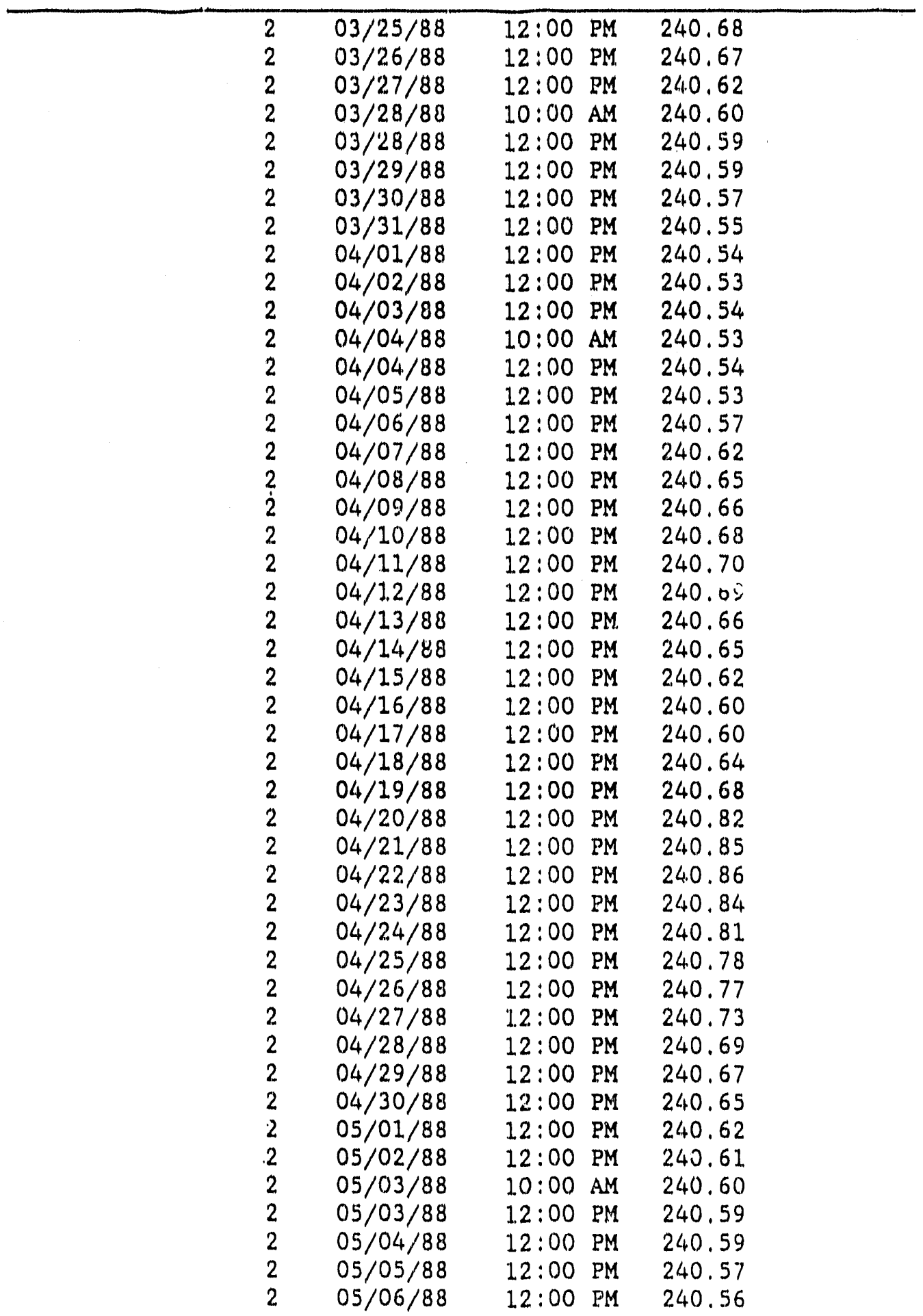


AEPENDIX III

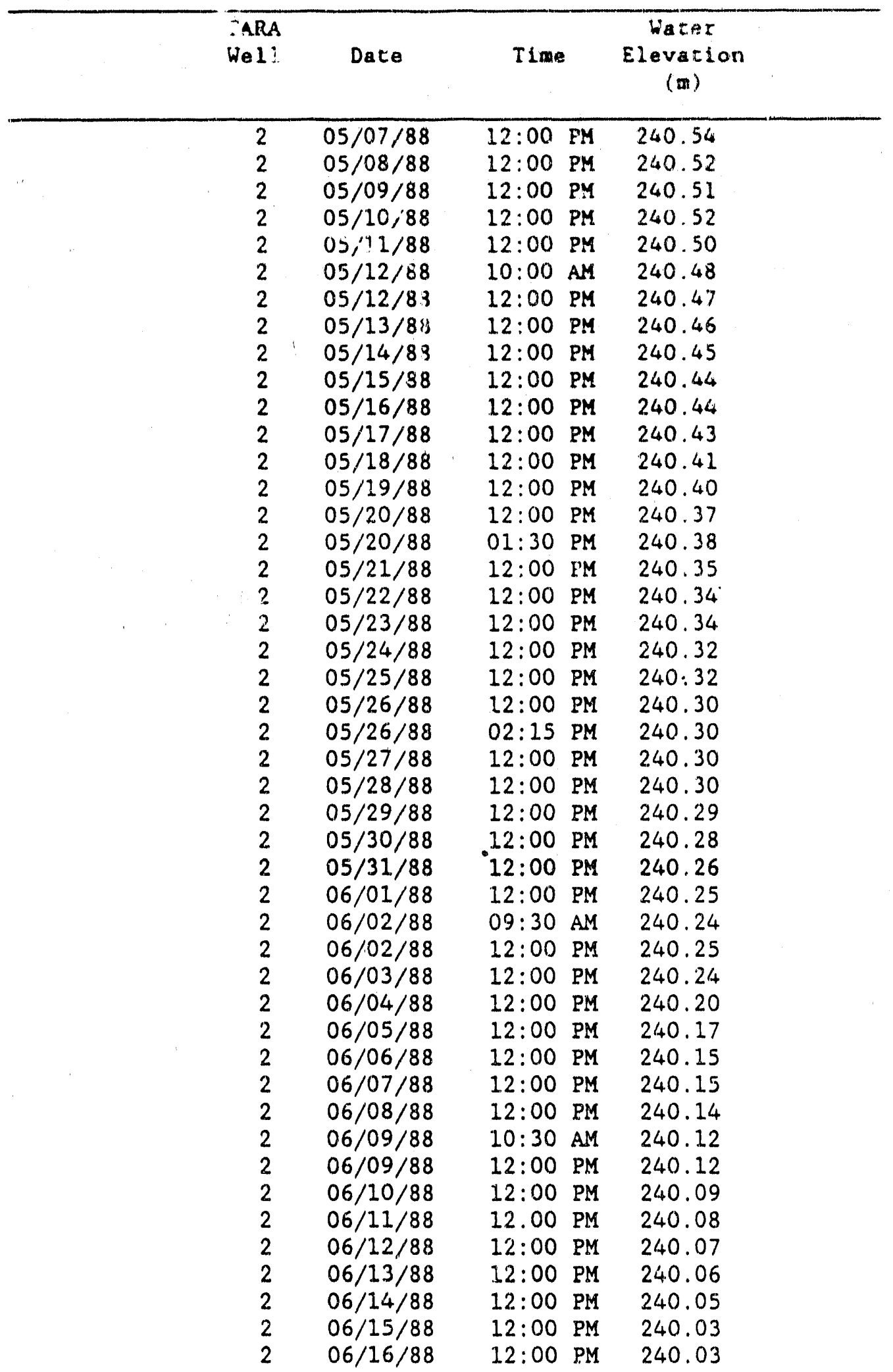


APPENDIX III

\begin{tabular}{|c|c|c|c|}
\hline $\begin{array}{l}\text { TARA } \\
\text { We } 11\end{array}$ & Date & Tlme & $\begin{array}{l}\text { Wacer } \\
\text { Elevation } \\
\text { (m) }\end{array}$ \\
\hline 2 & $06 / 17 / 88$ & $12: 00 \mathrm{P}$ & 240.02 \\
\hline 2 & $06 / 28,88$ & $12 \cdot 20 ?$ & 240.00 \\
\hline 2 & $06 / 19 / 88$ & $12: 00$ & 239.97 \\
\hline 2 & $06 / 20 / 88$ & $12: 00$ & 239.96 \\
\hline 2 & $06 / 21 / 88$ & $12: 00$ & 239.95 \\
\hline 2 & $06 / 21 / 88$ & $12: 00 ?$ & 239.93 \\
\hline 2 & $06 / 23,88$ & $12: 00 \mathrm{P:}$ & 239.93 \\
\hline 2 & $06 / 24 / 88$ & $12: 00 \mathrm{P!}$ & 239.91 \\
\hline 2 & $06 / 25 / 88$ & $12: 00 \mathrm{P}$ & 239.88 \\
\hline 2 & $06 / 26 / 88$ & $12: 00 \mathrm{pl}$ & 240.27 \\
\hline 2 & $06 / 27 / 88$ & $12: 00$ & 240.29 \\
\hline 2 & $06 / 28 / 88$ & $12: 00 \mathrm{P}$ & 240.28 \\
\hline 2 & $06 / 29 / 88$ & $12: 00$ & 240.29 \\
\hline 2 & $06 / 30 / 88$ & $12: 00 \quad P !$ & 240.28 \\
\hline 2 & $07 / 01 / 88$ & 12:00 & 239.89 \\
\hline 2 & $07 / 01 / 88$ & $12: 00$ & 240.27 \\
\hline 2 & $07 / 03 / 88$ & $12: 00 \mathrm{PI}$ & 240.24 \\
\hline 2 & $07 / 04 / 88$ & $12: 00 \mathrm{Pl}$ & 240.23 \\
\hline 2 & $07 / 05 / 88$ & $12: 00 \mathrm{Pl}$ & 240.21 \\
\hline 2 & $07 / 06 / 88$ & $22: 00$ & 240.20 \\
\hline 2 & $07 / 07 / 88$ & $12: 00 \quad P$ & 240.20 \\
\hline 2 & $07 / 09 / 88$ & $12: 00 \quad \mathrm{Pl}$ & 239.79 \\
\hline 2 & $07 / 10 / 88$ & $12: 00$ & 239.77 \\
\hline 2 & $07 / 11 / 88$ & $i 2: 00 \mathrm{P}$ & 239.76 \\
\hline 2 & $07 / 12 / 88$ & $12: 00 \mathrm{P}$ & 239.76 \\
\hline 2 & $07 / 13 / 88$ & $12: 00 \quad \mathrm{P}$ & 239.80 \\
\hline 2 & $07 / 14 / 88$ & $12: 00 \mathrm{P}$ & 239.88 \\
\hline 2 & $07 / 15 / 88$ & $12: 00 \mathrm{P}$ & 239.91 \\
\hline 2 & $07 / 16 / 88$ & $12: 00 \quad \mathrm{P}$ & 239.92 \\
\hline 2 & $07 / 17 / 88$ & $12: 00$ & 239.92 \\
\hline 2 & $07 / 18 / 88$ & $12: 00 \mathrm{P}$ & 239.91 \\
\hline 2 & $07 / 19 / 88$ & $12: 00 \mathrm{P}$ & 239.91 \\
\hline 2 & $07 / 20 / 88$ & $12: 00 \mathrm{P}$ & 239.89 \\
\hline 2 & $07 / 21 / 88$ & $12: 00 \mathrm{P}$ & 239.88 \\
\hline 2 & $07 / 22 / 88$ & $12: 00 \mathrm{P}$ & 239.92 \\
\hline 2 & $07 / 23 / 88$ & $12: 00 \mathrm{P}$ & 239.94 \\
\hline 2 & $07 / 24 / 88$ & $12: 00 \mathrm{p}$ & 239.93 \\
\hline 2 & $07 / 25 / 88$ & $12: 00 \mathrm{P}$ & 239.93 \\
\hline 2 & $07 / 26 / 88$ & $12: 00 \mathrm{P}$ & 239.93 \\
\hline 2 & $07 / 26 / 88$ & $12: 00 \mathrm{P}$ & 239.94 \\
\hline 2 & $07 / 27 / 88$ & $12: 00 \mathrm{P}$ & 239.95 \\
\hline 2 & $07 / 28 / 88$ & $12: 00 \mathrm{P}$ & 239.97 \\
\hline 2 & $07 / 29 / 88$ & $12: 00 \mathrm{P}$ & 239.97 \\
\hline 2 & $07 / 30 / 88$ & $12: 00 \mathrm{P}$ & 239.97 \\
\hline 2 & $07 / 31 / 88$ & $12: 00 \mathrm{P}$ & 239.97 \\
\hline 2 & $08 / 01 / 88$ & $12: 00 \mathrm{P}$ & 239.95 \\
\hline
\end{tabular}


III - 13

APPENDIX III

\begin{tabular}{ccccc}
\hline $\begin{array}{c}\text { TARA } \\
\text { We11 }\end{array}$ & Date & Time & $\begin{array}{c}\text { Water } \\
\text { Elevation } \\
\text { (m) }\end{array}$ \\
\hline 2 & $08 / 02 / 88$ & $12: 00 \mathrm{PM}$ & 239.93 \\
2 & $08 / 23 / 88$ & $12: 00 \mathrm{PM}$ & 239.73
\end{tabular}


APPENDIX III

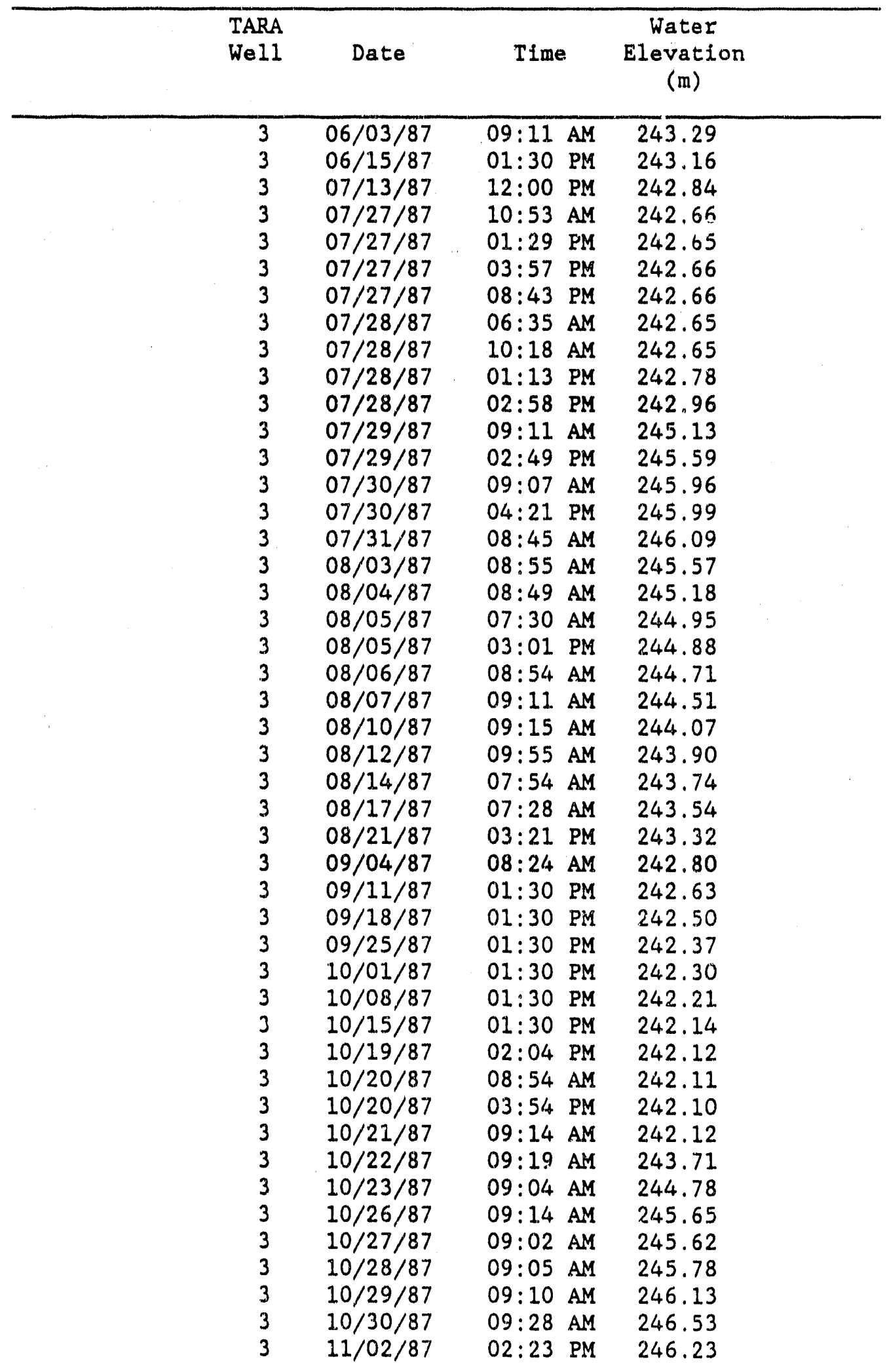


APPENDIX III

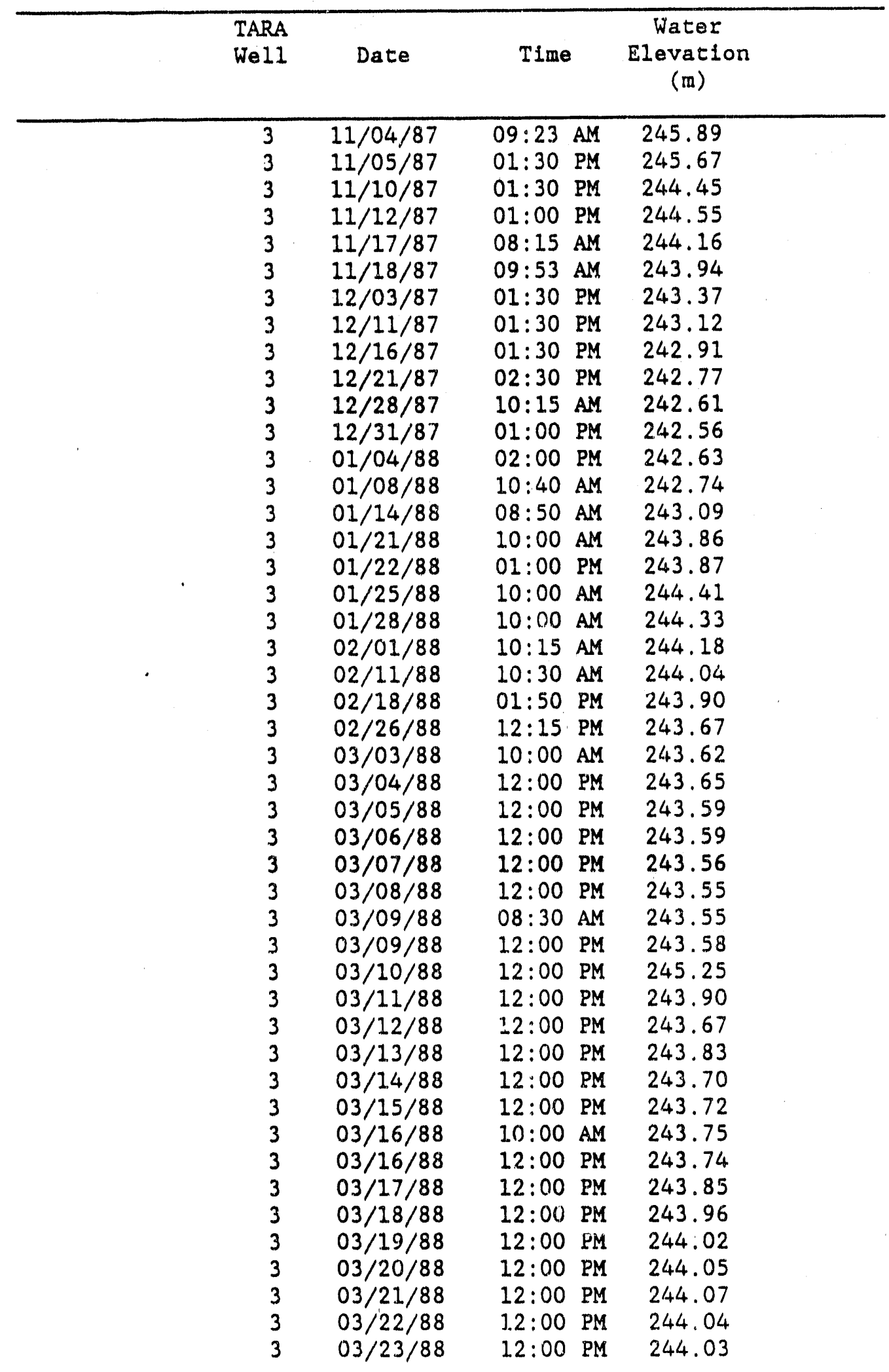


APPENDIX III

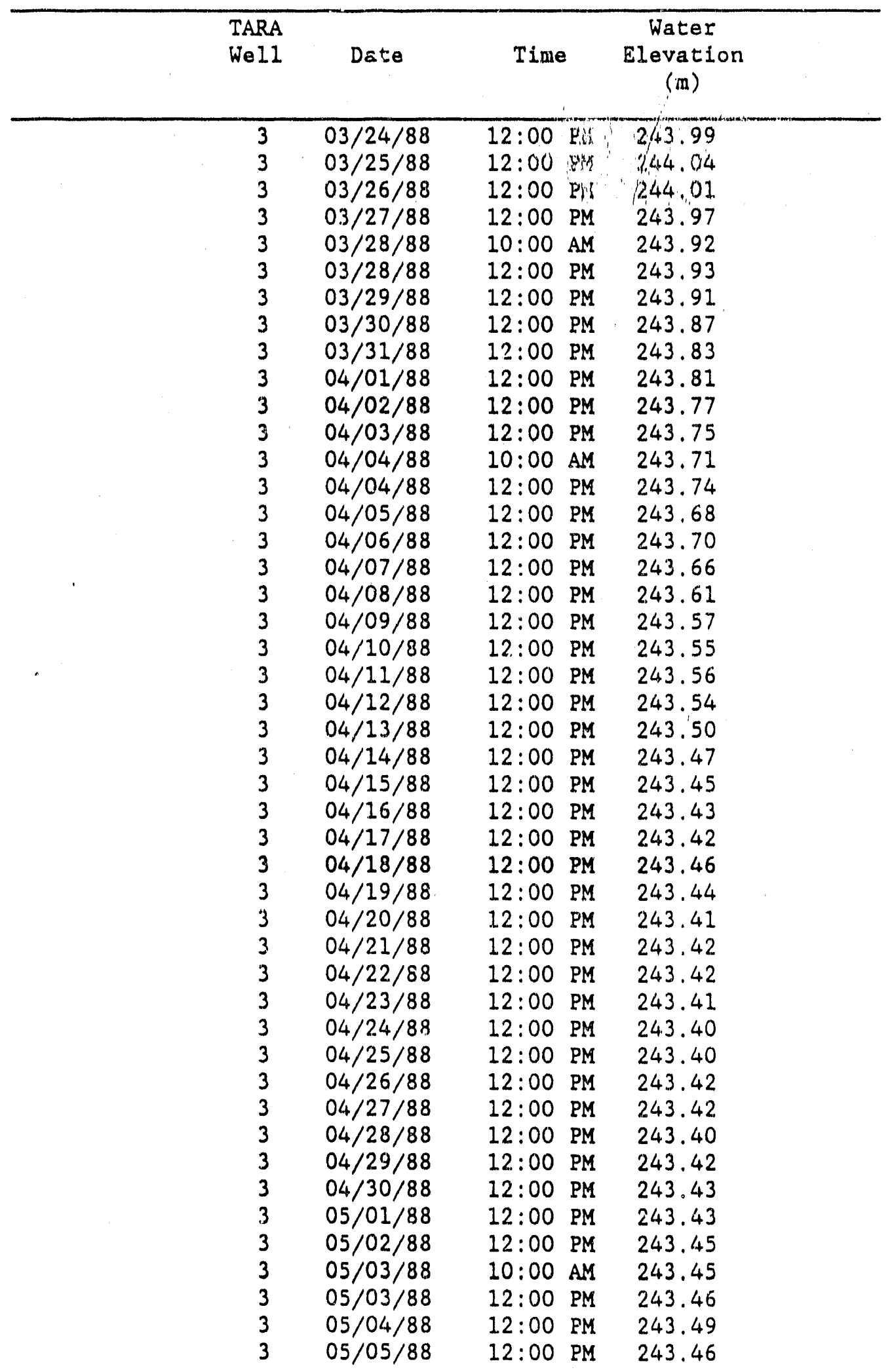


APPENDIX III

\begin{tabular}{|c|c|c|c|}
\hline $\begin{array}{l}\text { TARA } \\
\text { Well }\end{array}$ & Date & Time & $\begin{array}{l}\text { Water } \\
\text { Elevation } \\
\text { (m) }\end{array}$ \\
\hline $\begin{array}{l}3 \\
3 \\
3 \\
3 \\
3 \\
3 \\
3 \\
3 \\
3 \\
3 \\
3 \\
3 \\
3 \\
3 \\
3 \\
3 \\
3 \\
3 \\
3 \\
3 \\
3 \\
3 \\
3 \\
3 \\
3 \\
3 \\
3 \\
3 \\
3 \\
3 \\
3 \\
3 \\
3 \\
3 \\
3 \\
3 \\
3 \\
3 \\
3 \\
3 \\
3 \\
3 \\
3 \\
3 \\
3 \\
3\end{array}$ & $\begin{array}{l}05 / 06 / 88 \\
05 / 07 / 88 \\
05 / 08 / 88 \\
05 / 09 / 88 \\
05 / 10 / 88 \\
05 / 11 / 88 \\
05 / 12 / 88 \\
05 / 12 / 88 \\
05 / 13 / 88 \\
05 / 14 / 88 \\
05 / 15 / 88 \\
05 / 16 / 88 \\
05 / 17 / 88 \\
05 / 18 / 88 \\
05 / 19 / 88 \\
05 / 20 / 88 \\
05 / 20 / 88 \\
05 / 21 / 88 \\
05 / 22 / 88 \\
05 / 23 / 88 \\
05 / 24 / 88 \\
05 / 25 / 88 \\
05 / 26 / 88 \\
05 / 26 / 88 \\
05 / 27 / 88 \\
05 / 28 / 88 \\
05 / 29 / 88 \\
05 / 30 / 88 \\
05 / 31 / 88 \\
06 / 01 / 88 \\
06 / 02 / 88 \\
06 / 02 / 88 \\
06 / 03 / 88 \\
06 / 04 / 88 \\
06 / 05 / 88 \\
06 / 06 / 88 \\
06 / 07 / 88 \\
06 / 08 / 88 \\
06 / 09 / 88 \\
06 / 09 / 88 \\
06 / 10 / 88 \\
06 / 11 / 88 \\
06 / 12 / 88 \\
06 / 13 / 88 \\
06 / 14 / 88 \\
06 / 15 / 88\end{array}$ & 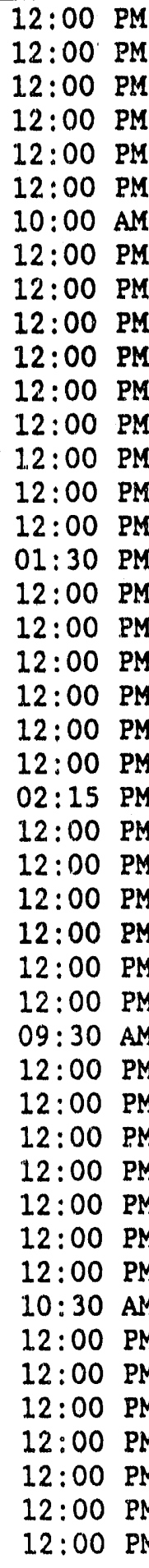 & $\begin{array}{l}243.46 \\
243.44 \\
243.43 \\
243.43 \\
243.42 \\
243.43 \\
243.37 \\
243.38 \\
243.37 \\
243.36 \\
243.36 \\
243.36 \\
243.35 \\
243.33 \\
243.32 \\
243.29 \\
243.28 \\
243.26 \\
243.25 \\
243.24 \\
243.22 \\
243.20 \\
243.15 \\
243.14 \\
243.13 \\
243.12 \\
243.10 \\
243.08 \\
243.06 \\
243.05 \\
243.04 \\
243.05 \\
243.04 \\
243.00 \\
242.96 \\
242.94 \\
242.94 \\
242.95 \\
242.91 \\
242.93 \\
242.86 \\
242.81 \\
242.80 \\
242.78 \\
242.76 \\
242.75\end{array}$ \\
\hline
\end{tabular}


APPENDIX III

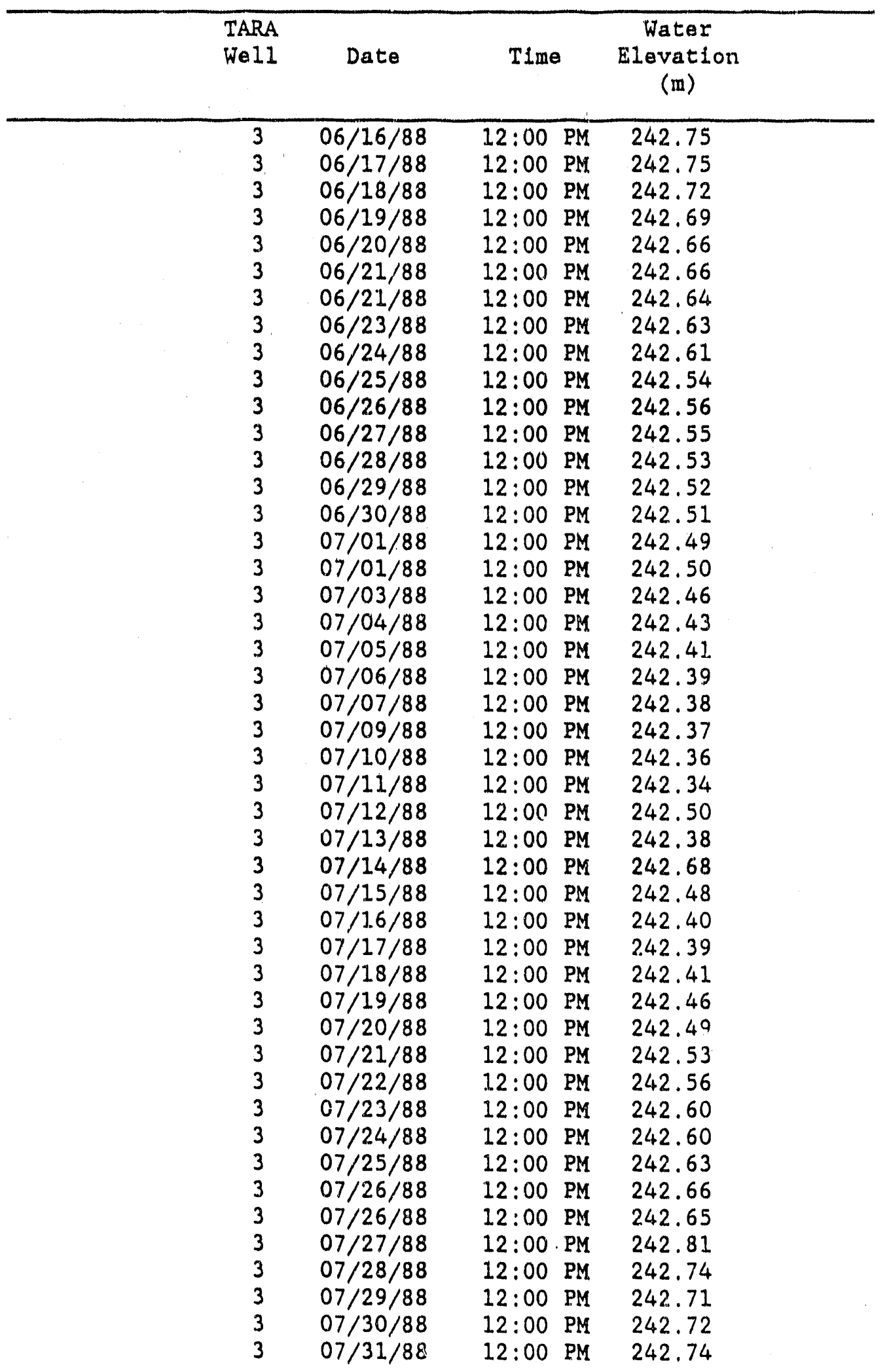


APPENDIX III

\begin{tabular}{cccc}
$\begin{array}{c}\text { TARA } \\
\text { We11 }\end{array}$ & Date & Time & $\begin{array}{c}\text { Water } \\
\text { Elevation } \\
(\mathrm{m})\end{array}$ \\
\hline 3 & $08 / 01 / 88$ & $12: 00 \mathrm{PM}$ & 242.76 \\
3 & $08 / 02 / 88$ & $12: 00 \mathrm{PM}$ & 242.77 \\
3 & $08 / 23 / 88$ & $12: 00 \mathrm{PM}$ & 242.83
\end{tabular}


APPENDIX III

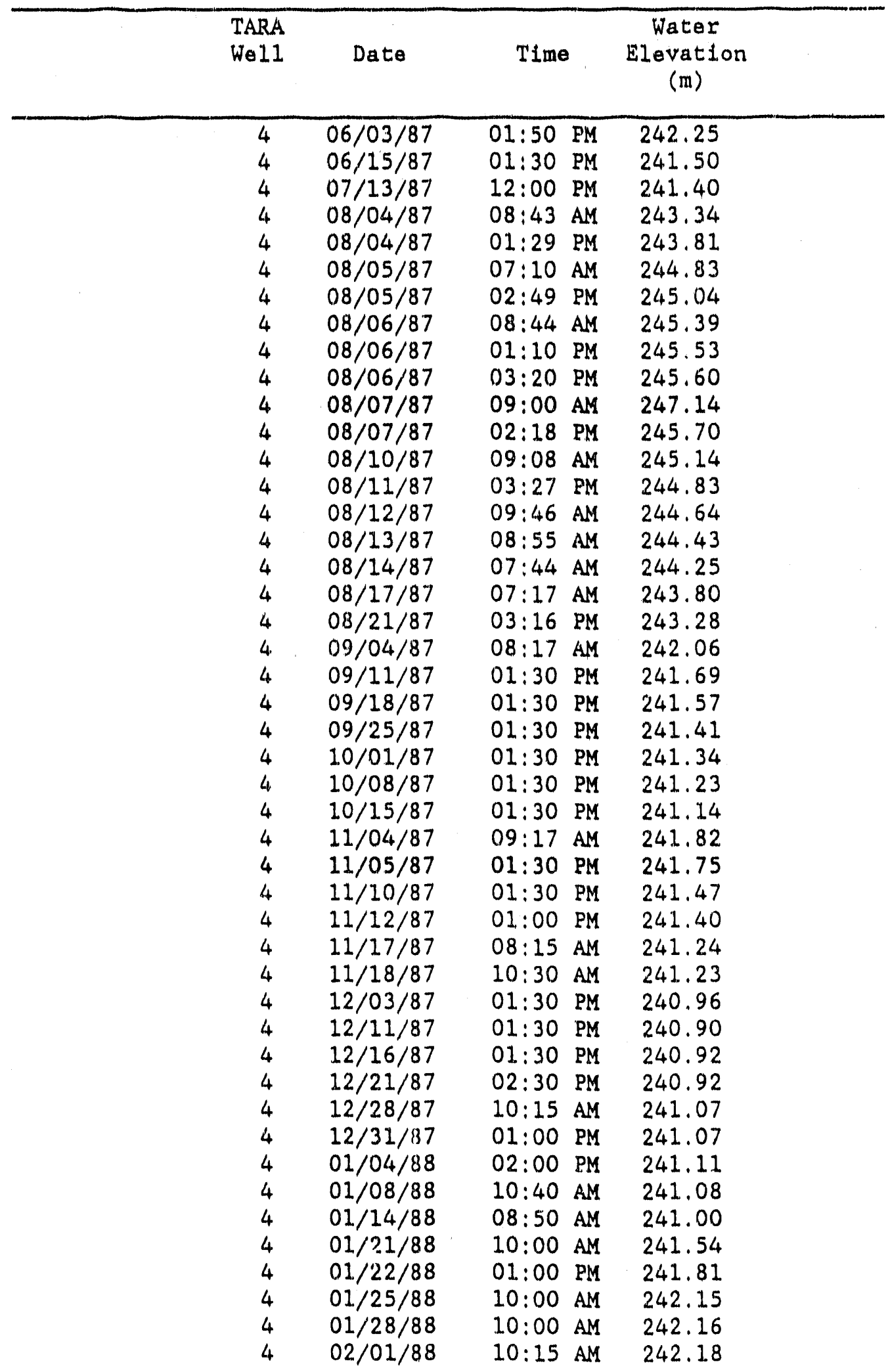


APPENDIX III

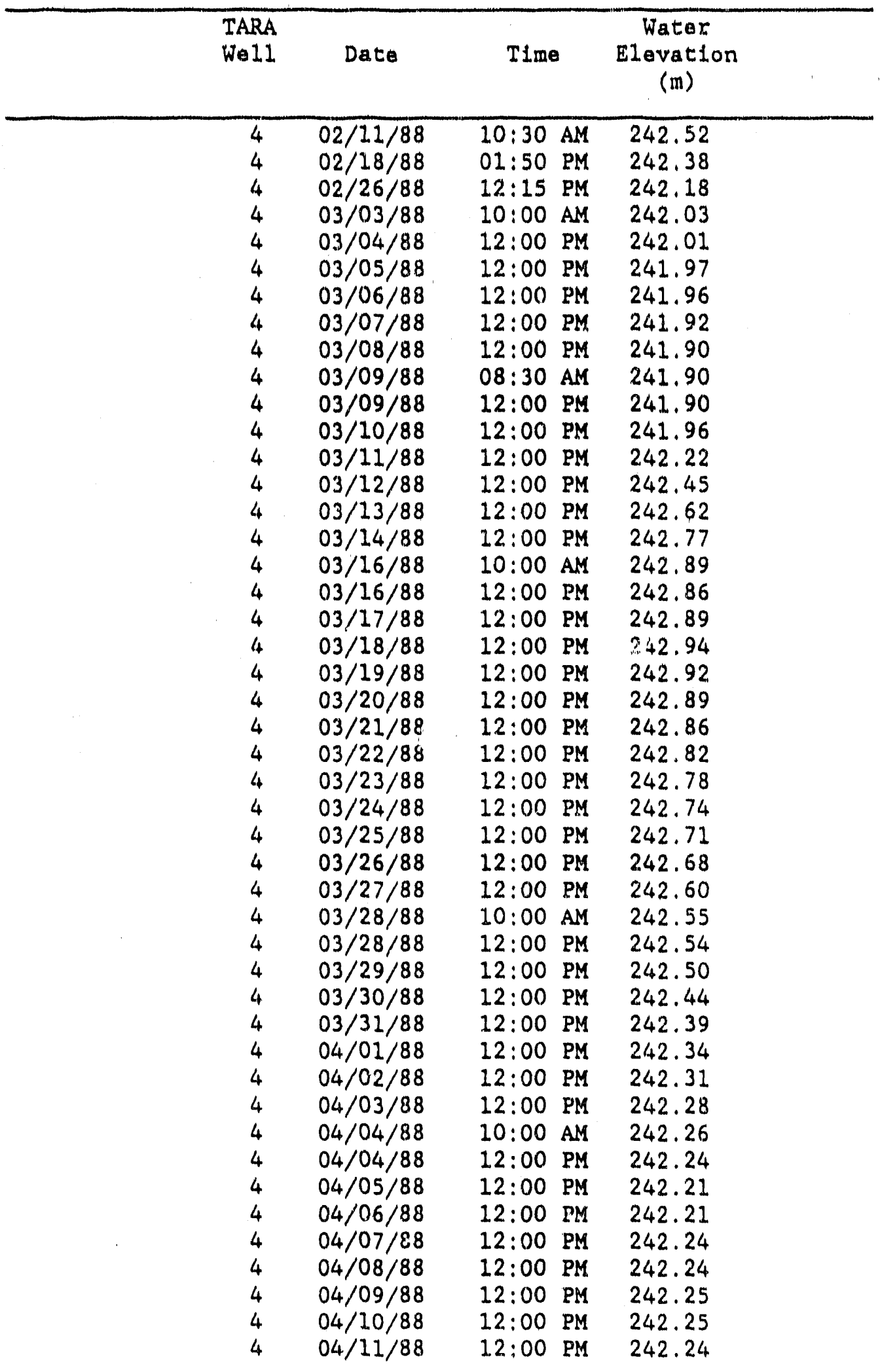


APPENDIX III

\begin{tabular}{|c|c|c|c|}
\hline $\begin{array}{l}\text { TARA } \\
\text { We } 11\end{array}$ & Date & TIme & $\begin{array}{c}\text { Water } \\
\text { E1ovation } \\
\text { (II) }\end{array}$ \\
\hline 4 & $04 / 12 / 88$ & $12: 00 \mathrm{PM}$ & 242.21 \\
\hline 4 & $04 / 13 / 88$ & $12: 00 \mathrm{pM}$ & 242,16 \\
\hline 4 & $04 / 14 / 88$ & $12: 00 \mathrm{PM}$ & 242.13 \\
\hline 4 & $04 / 15 / 88$ & $12: 00 \mathrm{PM}$ & 242.07 \\
\hline 4 & $04 / 16 / 88$ & $12: 00 \mathrm{PM}$ & 242.03 \\
\hline 4 & $04 / 17 / 88$ & $12: 00 \mathrm{PM}$ & 242.01 \\
\hline 4 & $04 / 18 / 88$ & $12: 00 \mathrm{PM}$ & 242.02 \\
\hline 4 & $04 / 19 / 88$ & $12: 00 \mathrm{pM}$ & 242.05 \\
\hline 4 & $04 / 20 / 88$ & $12: 00 \mathrm{PM}$ & 242.12 \\
\hline 4 & $04 / 21 / 88$ & $12: 00 \mathrm{pM}$ & 242.19 \\
\hline 4 & $04 / 22 / 88$ & $12: 00 \mathrm{DM}$ & 242.23 \\
\hline 4 & $04 / 23 / 88$ & $12: 00 \mathrm{PM}$ & 242.22 \\
\hline 4 & $04 / 24 / 88$ & $12: 00 \mathrm{PM}$ & 242.19 \\
\hline 4 & $04 / 25 / 88$ & $12: 00 \mathrm{PM}$ & 242,14 \\
\hline 4 & $04 / 26 / 88$ & $12: 00 \mathrm{PM}$ & 242.11 \\
\hline 4 & $04 / 27 / 88$ & $12: 00 \mathrm{PM}$ & 242.05 \\
\hline 4 & $04 / 28 / 88$ & $12: 00 \mathrm{PM}$ & 242.00 \\
\hline 4 & $04 / 29 / 88$ & $12: 00 \mathrm{PM}$ & 241.95 \\
\hline 4 & $04 / 30 / 88$ & $12: 00 \mathrm{PN}$ & 241.91 \\
\hline 4 & $05 / 01 / 88$ & $12: 00 \mathrm{PM}$ & 241.87 \\
\hline 4 & $05 / 02 / 88$ & $12: 00 \mathrm{PM}$ & 241.84 \\
\hline 4 & $05 / 03 / 88$ & $10: 00 \mathrm{AM}$ & 241.81 \\
\hline 4 & $05 / 03 / 88$ & $12: 00 \mathrm{PM}$ & 241.81 \\
\hline 4 & $05 / 04 / 88$ & $12: 00 \mathrm{PM}$ & 241.80 \\
\hline 4 & $05 / 05 / 88$ & $12: 00 \mathrm{PM}$ & 241.79 \\
\hline 4 & $05 / 06 / 88$ & $1.2: 00 \mathrm{PM}$ & 241.77 \\
\hline 4 & $05 / 07 / 88$ & $12: 00 \mathrm{PM}$ & 241.73 \\
\hline 4 & $05 / 08 / 88$ & $12: 00 \mathrm{PM}$ & 241.71 \\
\hline 4 & $05 / 09 / 88$ & $12: 00 \mathrm{MM}$ & 241.69 \\
\hline 4 & $05 / 10 / 88$ & $12: 00 \mathrm{PM}$ & 241.68 \\
\hline 4 & $05 / 11 / 88$ & $12: 00 \mathrm{PM}$ & 241.67 \\
\hline 4 & $05 / 12 / 88$ & $10: 00 \mathrm{AM}$ & 241.64 \\
\hline 4 & $05 / 12 / 88$ & $12: 00 \mathrm{PM}$ & 241.64 \\
\hline 4 & $05 / 13 / 88$ & $12: 00 \mathrm{PM}$ & 241.62 \\
\hline 4 & $05 / 14 / 88$ & $12: 00 \mathrm{PM}$ & 241.61 \\
\hline 4 & $05 / 15 / 88$ & $1.2 ; 00 \mathrm{PM}$ & 241.59 \\
\hline 4 & $05 / 16 / 88$ & $12: 00 \mathrm{PM}$ & 241.57 \\
\hline 4 & $05 / 17 / 88$ & $12: 00 \mathrm{PM}$ & 241.56 \\
\hline 4 & $05 / 18 / 88$ & $12: 00 \mathrm{PM}$ & 241.56 \\
\hline 4 & $05 / 19 / 88$ & $12: 00 \mathrm{PM}$ & 241.53 \\
\hline 4 & $05 / 20 / 88$ & $12: 00 \mathrm{PM}$ & 241.51 \\
\hline 4 & $05 / 20 / 88$ & $01: 30 \mathrm{PM}$ & 241.52 \\
\hline 4 & $05 / 21 / 88$ & $12: 00 \mathrm{PM}$ & 241.50 \\
\hline 4 & $05 / 22 / 88$ & $12: 00 \mathrm{PM}$ & 241.48 \\
\hline 4 & $05 / 23 / 88$ & $12: 00 \mathrm{PM}$ & 241.47 \\
\hline 4 & $05 / 24 / 88$ & $12: 00 \mathrm{PM}$ & 241.46 \\
\hline
\end{tabular}


APPENDIX III

$\begin{array}{ccc}\text { TARA } & \text { Water } \\ \text { Well Date } & \text { Time Elevation } \\ \text { (m) }\end{array}$

(in)

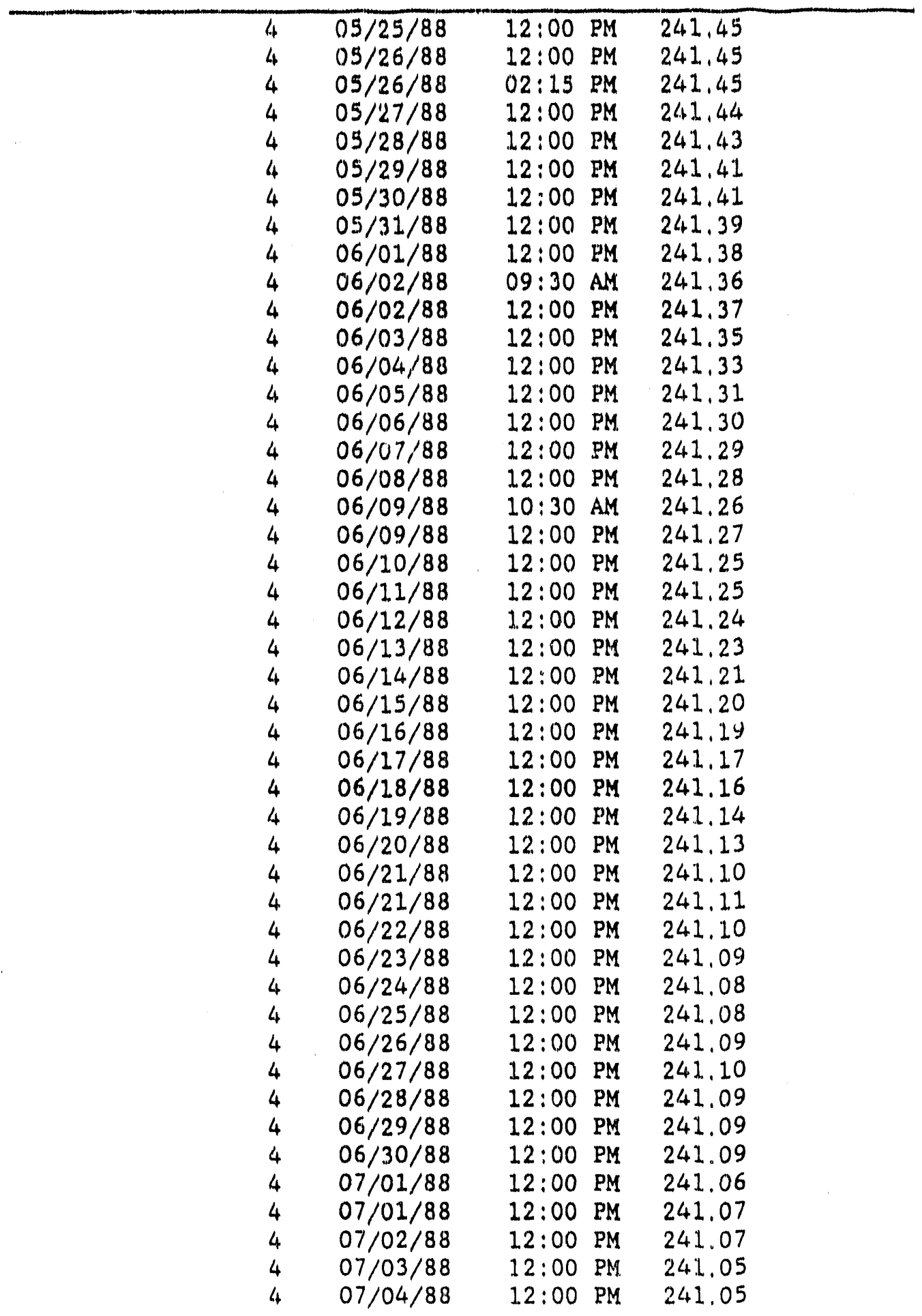


APPENDIX III

\begin{tabular}{|c|c|c|c|c|}
\hline $\begin{array}{l}\text { TARA } \\
\text { We11 }\end{array}$ & Date & Time & $\begin{array}{c}\text { Water } \\
\text { Elevation } \\
\text { (m) }\end{array}$ & • \\
\hline 4 & $01 / 05 / 88$ & $12: 00 \mathrm{EM}$ & 241.03 & \\
\hline 4 & $07 / 06 / 88$ & $12: 00 \mathrm{PM}$ & 241.02 & \\
\hline 4 & $07 / 07 / 88$ & $12: 00 \mathrm{PM}$ & 241.02 & \\
\hline 4 & $07 / 08 / 88$ & $12: 00 \mathrm{PM}$ & 241.01 & \\
\hline 4 & $07 / 09 / 88$ & $12: 00 \mathrm{PM}$ & 241.00 & \\
\hline 4 & $07 / 10 / 88$ & $12: 00 \mathrm{PM}$ & 241.00 & \\
\hline 4 & $07 / 11 / 88$ & $12: 00 \mathrm{PM}$ & 240.99 & \\
\hline 4 & $07 / 12 / 88$ & $12: 00 \mathrm{PM}$ & 241.03 & \\
\hline 4 & $07 / 13 / 88$ & $12: 00 \mathrm{PM}$ & 241.05 & \\
\hline 4 & $07 / 14 / 88$ & $12: 00 \mathrm{PM}$ & 241.12 & \\
\hline 4 & $07 / 15 / 88$ & $12: 00 \mathrm{PM}$ & 241.15 & \\
\hline 4 & $07 / 16 / 88$ & 12::00 PM & 241.14 & \\
\hline 4 & $07 / 17 / 88$ & $12: 00 \mathrm{RM}$ & 241.13 & \\
\hline 4 & $07 / 18 / 88$ & $12: 00 \mathrm{PM}$ & 241.13 & \\
\hline 4 & $07 / 19 / 88$ & $12: 00 \mathrm{PM}$ & 241.11 & \\
\hline 4 & $07 / 20 / 88$ & $12: 00 \mathrm{PM}$ & 241.10 & \\
\hline 4 & $07 / 21 / 88$ & $12: 00 \mathrm{PM}$ & 241.09 & \\
\hline 4 & $07 / 22 / 88$ & $12: 00 \mathrm{PM}$ & 241.14 & \\
\hline 4 & $07 / 23 / 88$ & $12: 00 \mathrm{PM}$ & 241.14 & \\
\hline 4 & $07 / 24 / 88$ & $12: 00 \mathrm{PM}$ & 241.13 & \\
\hline 4 & $07 / 25 / 88$ & $12: 00 \mathrm{PM}$ & 241.12 & \\
\hline 4 & $07 / 26 / 88$ & $12: 00 \mathrm{PM}$ & 241.1 & \\
\hline 4 & $07 / 26 / 88$ & $12: 00 \mathrm{PM}$ & 241.11 & \\
\hline 4 & $07 / 27 / 88$ & $12: 00 \mathrm{PM}$ & 241.15 & \\
\hline 4 & $07 / 2.8 / 88$ & $12: 00 \mathrm{PM}$ & 241.16 & \\
\hline 4 & $07 / 29 / 88$ & $12: 00 \mathrm{PM}$ & 241.16 & \\
\hline 4 & $07 / 30 / 88$ & 12:00 PM & 241.15 & \\
\hline 4 & $07 / 31 / 88$ & $1.2: 00 \mathrm{PM}$ & 241.13 & \\
\hline 4 & $08 / 01 / 88$ & $12: 00 \mathrm{PM}$ & 241.12 & \\
\hline 4 & $08 / 02 / 88$ & $12: 00 \mathrm{PM}$ & 241,11 & \\
\hline 4 & $08 / 03 / 88$ & $12: 00 \mathrm{PM}$ & 241.09 & \\
\hline 4 & $08 / 04 / 88$ & $12: 00 \mathrm{PM}$ & 241.08 & \\
\hline 4 & $08 / 05 / 88$ & $12: 00 \mathrm{PM}$ & 241.07 & \\
\hline 4 & $08 / 06 / 88$ & $12: 00 \quad \mathrm{PM}$ & 241.05 & \\
\hline 4 & $08 / 07 / 88$ & $12: 00 \mathrm{PM}$ & 241.05 & \\
\hline 4 & $08 / 08 / 88$ & $12: 00 \mathrm{PM}$ & 241.04 & \\
\hline 4 & $08 / 09 / 88$ & $12: 00 \mathrm{PM}$ & 241.03 & \\
\hline 4 & $08 / 10 / 88$ & $12: 00 \mathrm{PM}$ & 241.02 & \\
\hline 4 & $08 / 11 / 88$ & $12: 00 \mathrm{PM}$ & 241.01 & \\
\hline 4 & $08 / 12 / 88$ & $12: 00 \quad \mathrm{PM}$ & 241.01 & \\
\hline 4 & $08 / 13 / 88$ & $12: 00 \mathrm{PM}$ & 241.01 & \\
\hline 4 & $08 / 14 / 88$ & $12: 00 \mathrm{PM}$ & 241.01 & \\
\hline 4 & $08 / 15 / 88$ & $12: 00 \mathrm{PM}$ & 241.00 & \\
\hline 4 & $08 / 16 / 88$ & $12: 00 \mathrm{PM}$ & 240.99 & \\
\hline 4 & $08 / 17 / 88$ & 12:00 PM & 240.98 & \\
\hline 4 & $08 / 18 / 88$ & $12: 00 \mathrm{PM}$ & 240.98 & \\
\hline
\end{tabular}


APPENDIX III

\begin{tabular}{ccccc}
\hline $\begin{array}{c}\text { TARA } \\
\text { Well }\end{array}$ & Date & Time & $\begin{array}{c}\text { Water } \\
\text { Elevation } \\
\text { (m) }\end{array}$ \\
\hline 4 & $08 / 19 / 88$ & $12: 00 \mathrm{PM}$ & 240.98 \\
4 & $08 / 20 / 88$ & $12: 00 \mathrm{PM}$ & 240.98 \\
4 & $08 / 21 / 88$ & $12: 00 \mathrm{PM}$ & 240.99 \\
4 & $08 / 22 / 88$ & $12: 00 \mathrm{PM}$ & 240.98 \\
4 & $08 / 23 / 88$ & $12: 00 \mathrm{PM}$ & 240.96
\end{tabular}


APPENDIX III

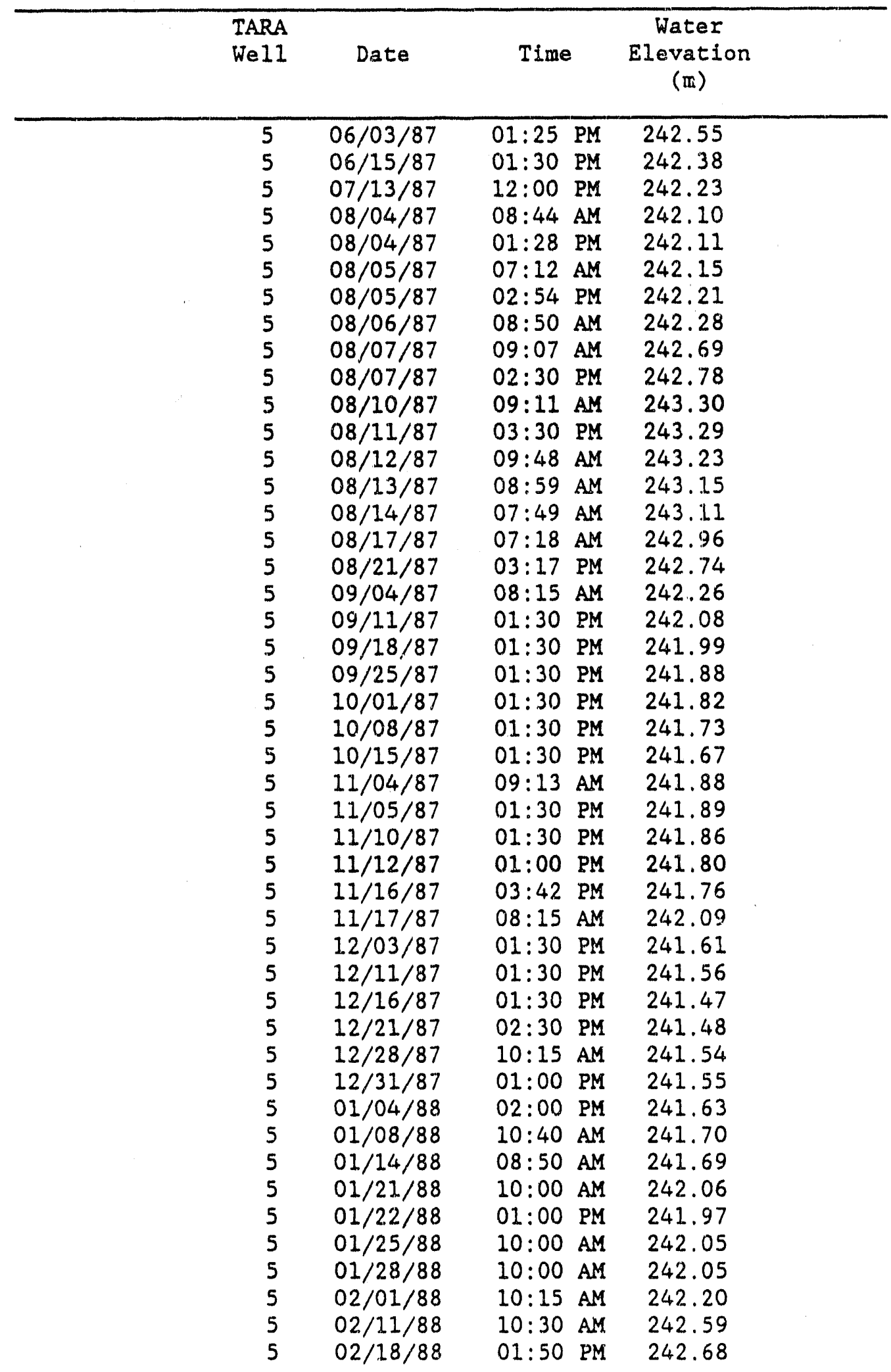


APPENDIX III

\begin{tabular}{|c|c|c|c|}
\hline $\begin{array}{l}\text { TARA } \\
\text { We11 }\end{array}$ & Date & Time & $\begin{array}{c}\text { Water } \\
\text { Elevation } \\
\text { (m) }\end{array}$ \\
\hline $\begin{array}{l}5 \\
5 \\
5 \\
5 \\
5 \\
5 \\
5 \\
5 \\
5 \\
5 \\
5 \\
5 \\
5 \\
5 \\
5 \\
5 \\
5 \\
5 \\
5 \\
5 \\
5 \\
5 \\
5 \\
5 \\
5 \\
5 \\
5 \\
5 \\
5 \\
5 \\
5 \\
5 \\
5 \\
5 \\
5 \\
5 \\
5 \\
5 \\
5 \\
5 \\
5 \\
5 \\
5 \\
5 \\
5 \\
5 \\
5 \\
5 \\
5\end{array}$ & 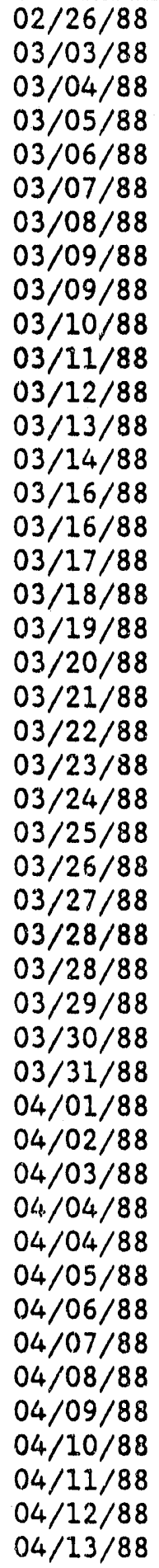 & 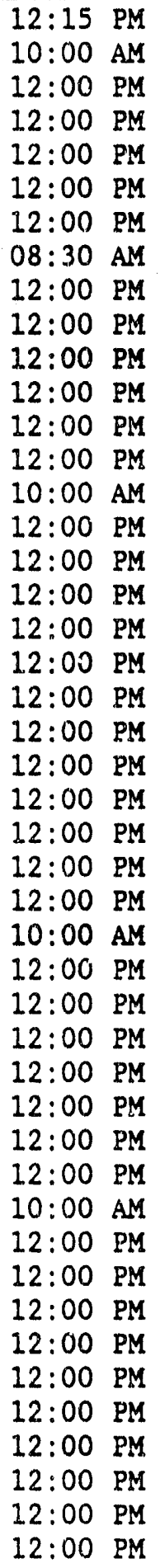 & $\begin{array}{l}242.68 \\
242.68 \\
242.69 \\
242.62 \\
242.63 \\
242.60 \\
242.58 \\
242.61 \\
242.62 \\
242.65 \\
242.69 \\
242.74 \\
242.81 \\
242.88 \\
242.94 \\
242.94 \\
242.97 \\
243.05 \\
243.07 \\
243.06 \\
243.05 \\
243.01 \\
243.00 \\
242.99 \\
243.01 \\
243.03 \\
242.96 \\
242.93 \\
242.92 \\
242.93 \\
242.90 \\
242.88 \\
242.87 \\
242.85 \\
242.85 \\
242.84 \\
242.83 \\
242.81 \\
242.84 \\
242.83 \\
242.80 \\
242.79 \\
242.82 \\
242.86 \\
242.81\end{array}$ \\
\hline
\end{tabular}


APPENDIX III

\begin{tabular}{|c|c|c|c|c|}
\hline$\ldots$ & $\begin{array}{l}\text { TARA } \\
\text { We } 11\end{array}$ & Date & Time & $\begin{array}{c}\text { Water } \\
\text { Elevation } \\
\text { (m) }\end{array}$ \\
\hline & 5 & $04 / 14 / 88$ & $12: 00 \mathrm{PM}$ & 242.79 \\
\hline & 5 & $04 / 15 / 88$ & $12: 00 \mathrm{PM}$ & 242.76 \\
\hline & 5 & $04 / 16 / 88$ & $12: 00 \mathrm{PM}$ & 242.75 \\
\hline & 5 & $04 / 17 / 88$ & $12: 00 \mathrm{PM}$ & 242.75 \\
\hline & 5 & $04 / 18 / 88$ & $12: 00 \mathrm{PM}$ & 242.80 \\
\hline & 5 & $04 / 19 / 88$ & $12: 00 \mathrm{PM}$ & 242.79 \\
\hline & 5 & $04 / 20 / 88$ & $12: 00 \mathrm{PM}$ & 242.78 \\
\hline & 5 & $04 / 21 / 88$ & $12: 00 \mathrm{PM}$ & 242.82 \\
\hline & 5 & $04 / 22 / 88$ & $12: 00 \mathrm{PM}$ & 242.86 \\
\hline & 5 & $04 / 23 / 88$ & $12: 00 \mathrm{PM}$ & 242.86 \\
\hline & 5 & $04 / 24 / 88$ & $12: 00 \mathrm{PM}$ & 242.86 \\
\hline & 5 & $04 / 25 / 88$ & $12: 00 \mathrm{PM}$ & 242.84 \\
\hline & 5 & $04 / 26 / 88$ & 12:00 PM & 242.86 \\
\hline & 5 & $04 / 27 / 88$ & $12: 00 \mathrm{PM}$ & 242.85 \\
\hline & 5 & $04 / 28 / 88$ & 12:00 PM & 242.82 \\
\hline & 5 & $04 / 29 / 88$ & $12: 00 \mathrm{PM}$ & 242.81 \\
\hline & 5 & $04 / 30 / 88$ & $12: 00 \mathrm{PM}$ & 242.79 \\
\hline & 5 & $05 / 01 / 88$ & $12: 00 \mathrm{PM}$ & 242.78 \\
\hline & 5 & $05 / 02 / 88$ & $12: 00 \mathrm{PM}$ & 242.77 \\
\hline & 5 & $05 / 03 / 88$ & $10: 00 \mathrm{AM}$ & 242.76 \\
\hline & 5 & $05 / 03 / 88$ & $12: 00 \mathrm{PM}$ & 242.76 \\
\hline & 5 & $05 / 04 / 88$ & $12: 00 \mathrm{PM}$ & 242.77 \\
\hline & 5 & $05 / 05 / 88$ & $12: 00 \mathrm{PM}$ & 242.74 \\
\hline & 5 & $05 / 06 / 88$ & $12: 00 \mathrm{PM}$ & 242.72 \\
\hline & 5 & $05 / 07 / 88$ & $12: 00 \mathrm{PM}$ & 242.69 \\
\hline & 5 & $05 / 08 / 88$ & $12: 00 \mathrm{PM}$ & 242.66 \\
\hline & 5 & $05 / 09 / 88$ & $12: 00 \mathrm{PM}$ & 242.65 \\
\hline & 5 & $05 / 10 / 88$ & $12: 00 \mathrm{PM}$ & 242.64 \\
\hline & 5 & $05 / 11 / 88$ & $12: 00 \mathrm{PM}$ & 242.61 \\
\hline & 5 & $05 / 12 / 88$ & $10: 00 \mathrm{AM}$ & 242.57 \\
\hline & 5 & $05 / 12 / 88$ & $12: 00 \mathrm{PM}$ & 242.57 \\
\hline & 5 & $05 / 13 / 88$ & $12: 00 \mathrm{PM}$ & 242.55 \\
\hline & 5 & $05 / 14 / 88$ & $12: 00 \mathrm{PM}$ & 242.54 \\
\hline & 5 & $05 / 15 / 88$ & $12: 00 \mathrm{PM}$ & 242.54 \\
\hline & 5 & $05 / 16 / 88$ & $12: 00 \mathrm{PM}$ & 242.53 \\
\hline & 5 & $05 / 17 / 88$ & $12: 00 \mathrm{PM}$ & 242.52 \\
\hline & 5 & $05 / 18 / 88$ & $12: 00 \mathrm{PM}$ & 242.50 \\
\hline & 5 & $05 / 19 / 88$ & $12: 00 \mathrm{PM}$ & 242.47 \\
\hline & 5 & $05 / 20 / 88$ & $12: 00 \mathrm{PM}$ & 242.44 \\
\hline & 5 & $05 / 20 / 88$ & $01: 30 \mathrm{PM}$ & 242.44 \\
\hline & 5 & $05 / 21 / 88$ & $12: 00 \mathrm{PM}$ & 242.41 \\
\hline & 5 & $05 / 22 / 88$ & $12: 00 \mathrm{PM}$ & 242.39 \\
\hline & 5 & $05 / 23 / 88$ & $12: 00 \mathrm{PM}$ & 242.39 \\
\hline & 5 & $05 / 24 / 88$ & $12: 00 \mathrm{PM}$ & 242.37 \\
\hline & 5 & $05 / 25 / 88$ & $12: 00 \mathrm{PM}$ & 242.35 \\
\hline & 5 & $05 / 26 / 88$ & $12: 00 \mathrm{PM}$ & 242.29 \\
\hline
\end{tabular}


APPENDIX III

\begin{tabular}{|c|c|c|c|c|}
\hline $\begin{array}{l}\text { TARA } \\
\text { Well }\end{array}$ & Date & Time & & $\begin{array}{l}\text { Water } \\
\text { Elevation } \\
\text { (m) }\end{array}$ \\
\hline $\begin{array}{l}5 \\
5 \\
5 \\
5 \\
5 \\
5 \\
5 \\
5 \\
5 \\
5 \\
5 \\
5 \\
5 \\
5 \\
5 \\
5 \\
5 \\
5 \\
5 \\
5 \\
5 \\
5 \\
5 \\
5 \\
5 \\
5 \\
5 \\
5 \\
5 \\
5 \\
5 \\
5 \\
5 \\
5 \\
5 \\
5 \\
5 \\
5 \\
5 \\
5 \\
5 \\
5 \\
5 \\
5 \\
5 \\
5\end{array}$ & $\begin{array}{l}05 / 26 / 88 \\
05 / 27 / 88 \\
05 / 28 / 88 \\
05 / 29 / 88 \\
05 / 30 / 88 \\
05 / 31 / 88 \\
06 / 01 / 88 \\
06 / 02 / 88 \\
06 / 02 / 88 \\
06 / 03 / 88 \\
06 / 04 / 88 \\
06 / 05 / 88 \\
06 / 06 / 88 \\
06 / 07 / 88 \\
06 / 08 / 88 \\
06 / 09 / 88 \\
06 / 09 / 88 \\
06 / 10 / 88 \\
06 / 11 / 88 \\
06 / 12 / 88 \\
06 / 13 / 88 \\
06 / 14 / 88 \\
06 / 15 / 88 \\
06 / 16 / 88 \\
06 / 17 / 88 \\
06 / 18 / 88 \\
06 / 19 / 88 \\
06 / 20 / 88 \\
06 / 21 / 88 \\
06 / 21 / 88 \\
06 / 22 / 88 \\
06 / 23 / 88 \\
06 / 24 / 88 \\
06 / 25 / 88 \\
06 / 26 / 88 \\
06 / 27 / 88 \\
06 / 28 / 88 \\
06 / 29 / 88 \\
06 / 30 / 88 \\
07 / 01 / 88 \\
07 / 01 / 88 \\
07 / 02 / 88 \\
07 / 03 / 88 \\
07 / 04 / 88 \\
07 / 05 / 88 \\
07 / 06 / 88\end{array}$ & $\begin{array}{l}02: 15 \\
12: 00 \\
12: 00 \\
12: 00 \\
12: 00 \\
12: 00 \\
12: 00 \\
09: 30 \\
12: 00 \\
12: 00 \\
12: 00 \\
12: 00 \\
12: 00 \\
12: 00 \\
12: 00 \\
10: 30 \\
12: 00 \\
12: 00 \\
12: 00 \\
12: 00 \\
12: 00 \\
12: 00 \\
12: 00 \\
12: 00 \\
12: 00 \\
12: 00 \\
12: 00 \\
12: 00 \\
12: 00 \\
12: 00 \\
12: 00 \\
12: 00 \\
12: 00 \\
12: 00 \\
12: 00 \\
12: 00 \\
12: 00 \\
12: 00 \\
12: 00 \\
12: 00 \\
12: 00 \\
12: 00 \\
12: 00 \\
12: 00 \\
12: 00 \\
12: 00 \\
\end{array}$ & 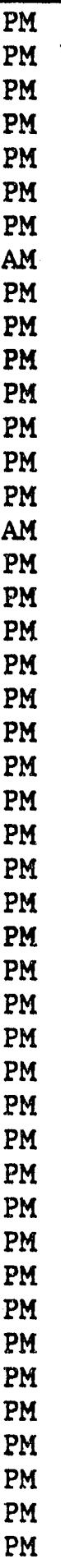 & $\begin{array}{l}242.29 \\
242.28 \\
242.28 \\
242.27 \\
242.26 \\
242.24 \\
242.23 \\
242.25 \\
242.25 \\
242.25 \\
242.20 \\
242.16 \\
242.15 \\
242.15 \\
242.17 \\
242.15 \\
242.16 \\
242.08 \\
242.06 \\
242.05 \\
242.03 \\
242.01 \\
242.01 \\
242.02 \\
242.02 \\
242.00 \\
241.97 \\
241.95 \\
241.93 \\
241.95 \\
241.94 \\
241.94 \\
241.92 \\
241.89 \\
241.91 \\
241.90 \\
241.88 \\
241.88 \\
241.88 \\
241.85 \\
241.85 \\
241.84 \\
241.82 \\
241.80 \\
241.77 \\
241.76\end{array}$ \\
\hline
\end{tabular}


APPENDIX III

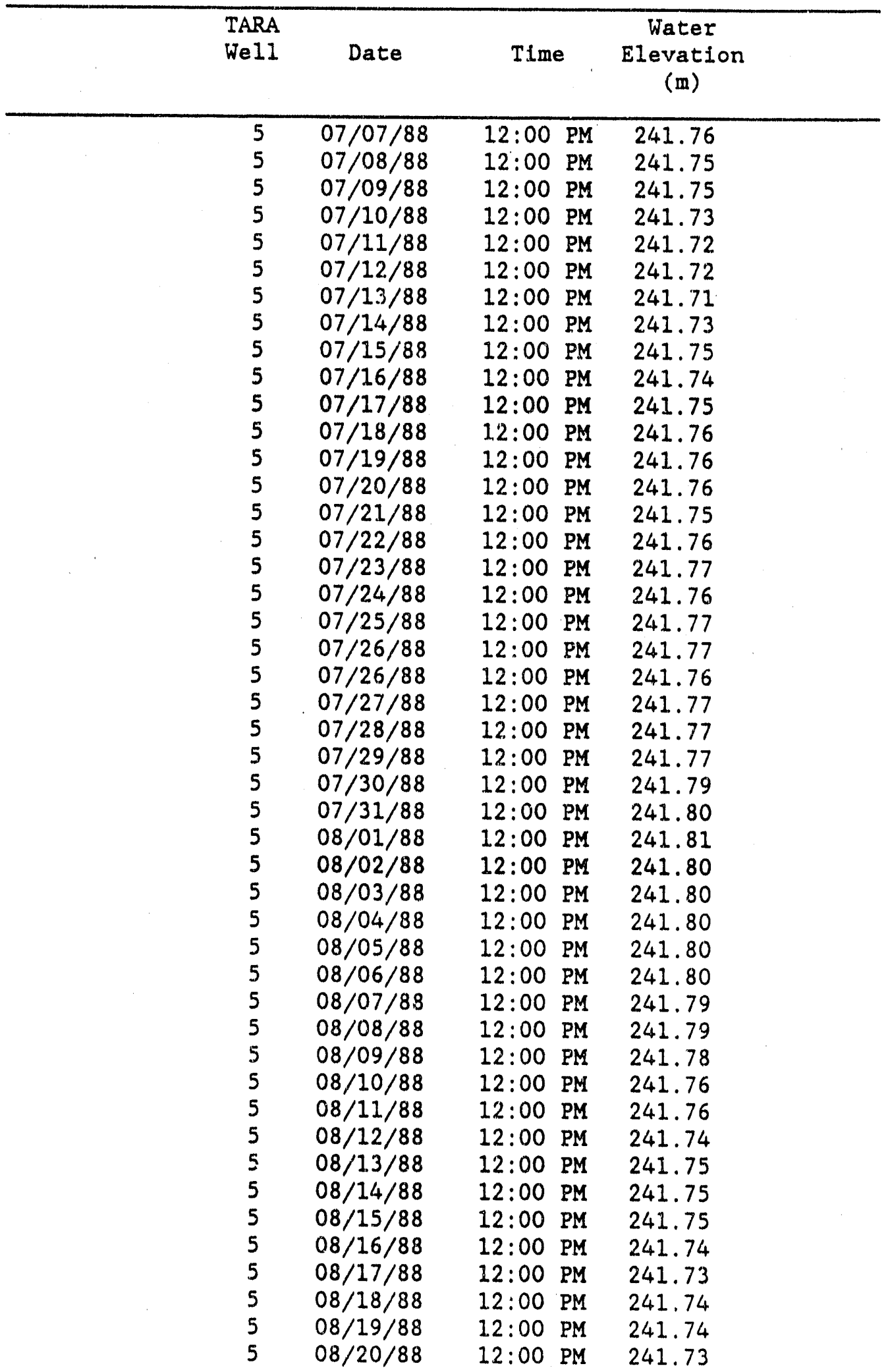


APPENDIX III

\begin{tabular}{ccccc}
\hline TARA & Dell & Date & Time & $\begin{array}{c}\text { Water } \\
\text { Elevation } \\
\text { (m) }\end{array}$ \\
\hline 5 & $08 / 21 / 88$ & $12: 00$ PM & 241.73 \\
5 & $08 / 22 / 88$ & $12: 00$ PM & 241.70 \\
5 & $08 / 23 / 88$ & $12: 00$ PM & 241.69
\end{tabular}


APPENDIX III

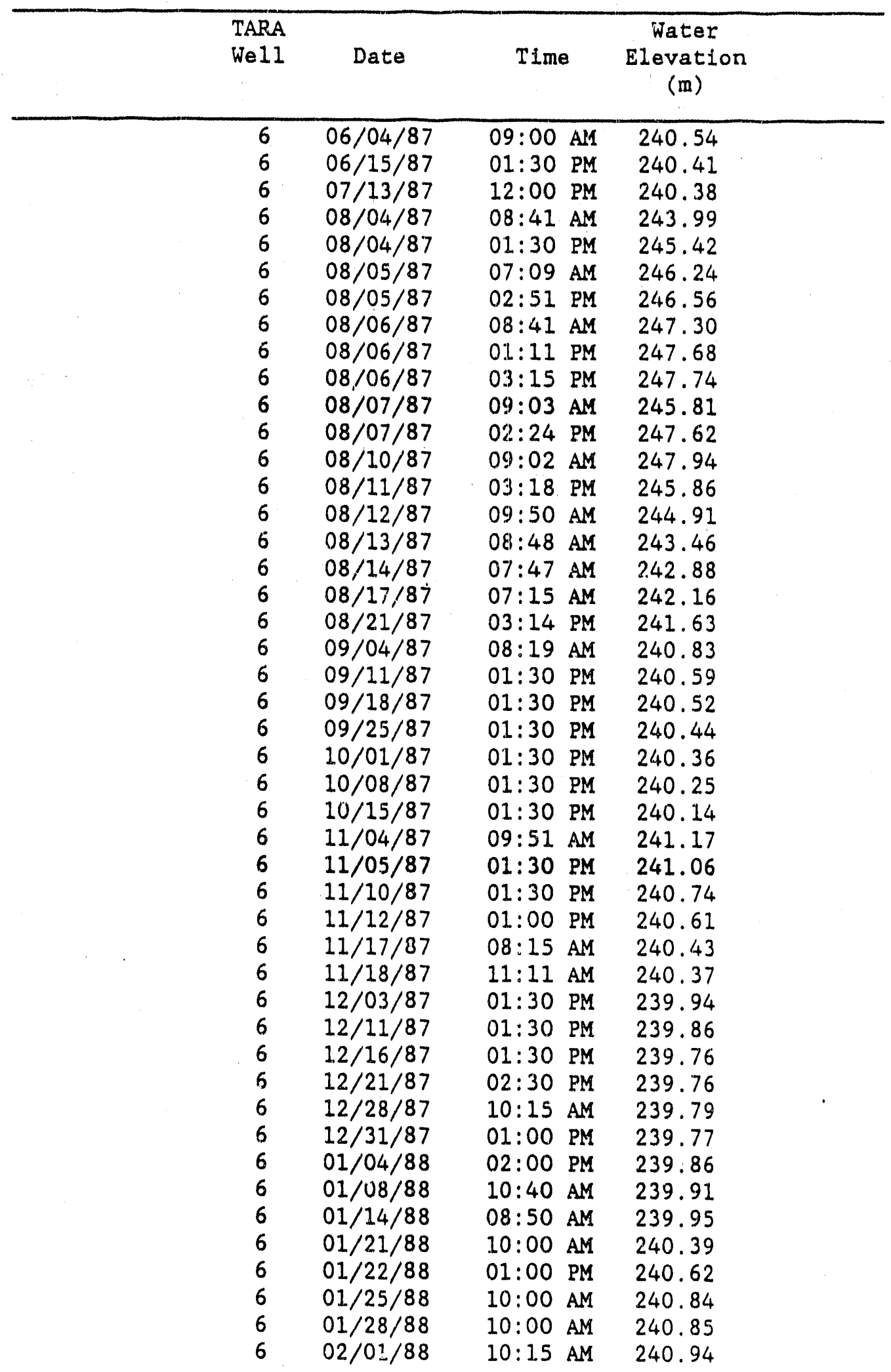


APPENDIX III

\begin{tabular}{|c|c|c|c|}
\hline $\begin{array}{l}\text { TARA } \\
\text { Well }\end{array}$ & Date & Time & $\begin{array}{l}\text { Water } \\
\text { Elevation } \\
\text { (m) }\end{array}$ \\
\hline $\begin{array}{l}6 \\
6 \\
6 \\
6 \\
6 \\
6 \\
6 \\
6 \\
6 \\
6 \\
6 \\
6 \\
6 \\
6 \\
6 \\
6 \\
6 \\
6 \\
6 \\
6 \\
6 \\
6 \\
6 \\
6 \\
6 \\
6 \\
6 \\
6 \\
6 \\
6 \\
6 \\
6 \\
6 \\
6 \\
6 \\
6 \\
6 \\
6 \\
6 \\
6 \\
6 \\
6 \\
6 \\
6 \\
6 \\
6\end{array}$ & $\begin{array}{l}02 / 11 / 88 \\
02 / 18 / 88 \\
02 / 26 / 88 \\
03 / 03 / 88 \\
03 / 04 / 88 \\
03 / 05 / 88 \\
03 / 06 / 88 \\
03 / 07 / 88 \\
03 / 08 / 88 \\
03 / 09 / 88 \\
03 / 09 / 88 \\
03 / 10 / 88 \\
03 / 11 / 88 \\
03 / 12 / 88 \\
03 / 13 / 88 \\
03 / 14 / 88 \\
03 / 15 / 88 \\
03 / 16 / 88 \\
03 / 16 / 88 \\
03 / 17 / 88 \\
03 / 18 / 88 \\
03 / 19 / 88 \\
03 / 20 / 88 \\
03 / 21 / 88 \\
03 / 22 / 88 \\
03 / 23 / 88 \\
03 / 24 / 88 \\
03 / 25 / 88 \\
03 / 26 / 88 \\
03 / 27 / 88 \\
03 / 28 / 88 \\
03 / 28 / 88 \\
03 / 29 / 88 \\
03 / 30 / 88 \\
03 / 31 / 88 \\
04 / 01 / 88 \\
04 / 02 / 88 \\
04 / 03 / 88 \\
04 / 04 / 88 \\
04 / 04 / 88 \\
04 / 05 / 88 \\
04 / 06 / 88 \\
04 / 07 / 88 \\
04 / 08 / 88 \\
04 / 09 / 88 \\
04 / 10 / 88\end{array}$ & 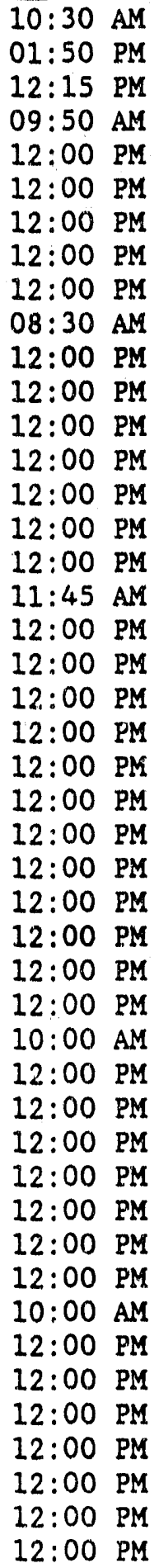 & $\begin{array}{l}241.09 \\
240.98 \\
240.86 \\
240.83 \\
240.84 \\
240.78 \\
240.76 \\
240.74 \\
240.72 \\
240.75 \\
240.75 \\
240.76 \\
240.77 \\
240.82 \\
240.91 \\
241.04 \\
241.10 \\
241.13 \\
241.13 \\
241.16 \\
241.23 \\
241.23 \\
241.23 \\
241.21 \\
241.19 \\
241.16 \\
241.13 \\
241.14 \\
241.12 \\
241.08 \\
241.04 \\
241.03 \\
241.02 \\
240.98 \\
240.95 \\
240.93 \\
240.91 \\
240.89 \\
240.88 \\
240.90 \\
240.84 \\
240.85 \\
240.84 \\
240.80 \\
240.78 \\
240.79\end{array}$ \\
\hline
\end{tabular}


APPENDIX III

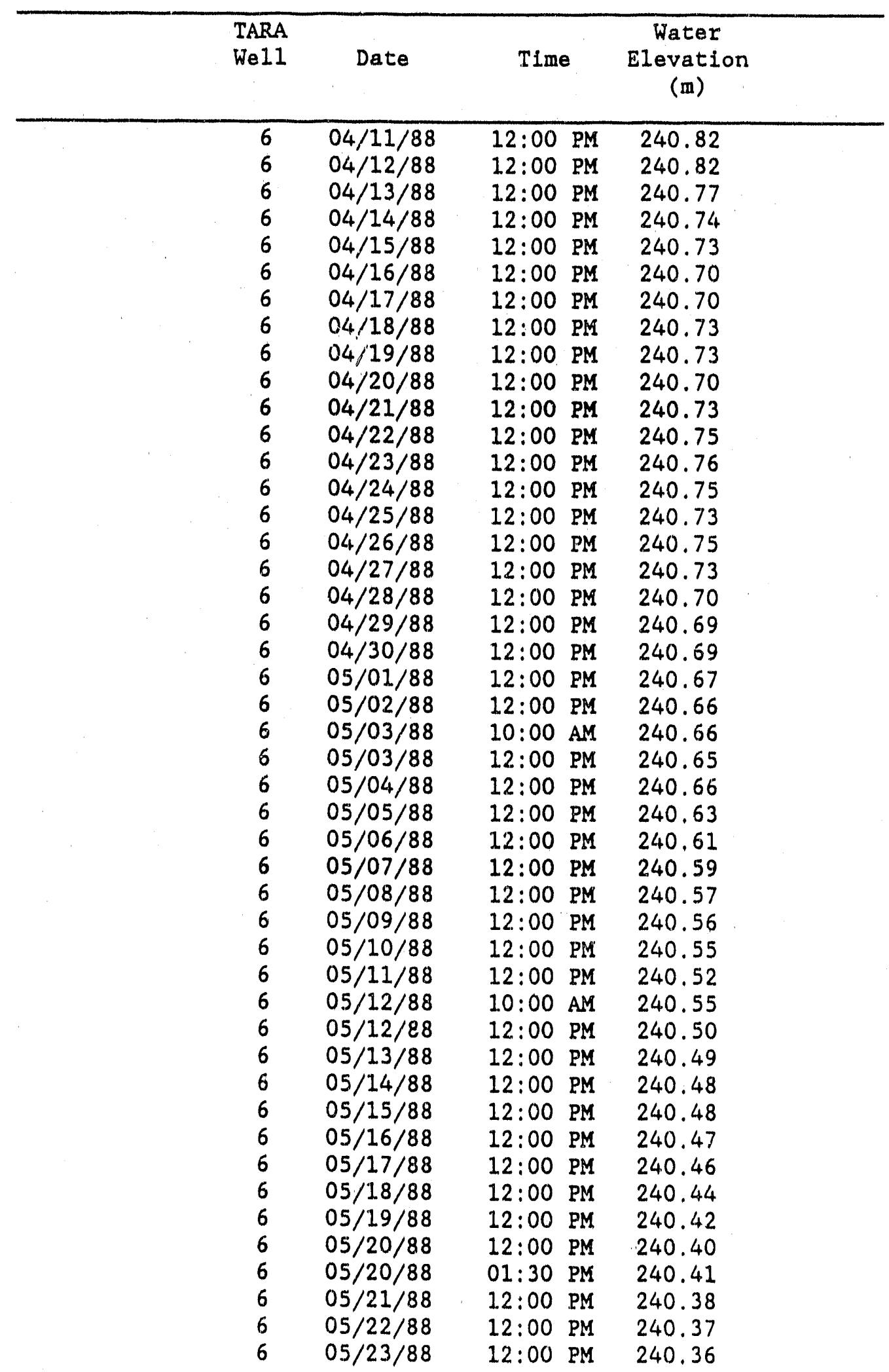


APPENDIX III

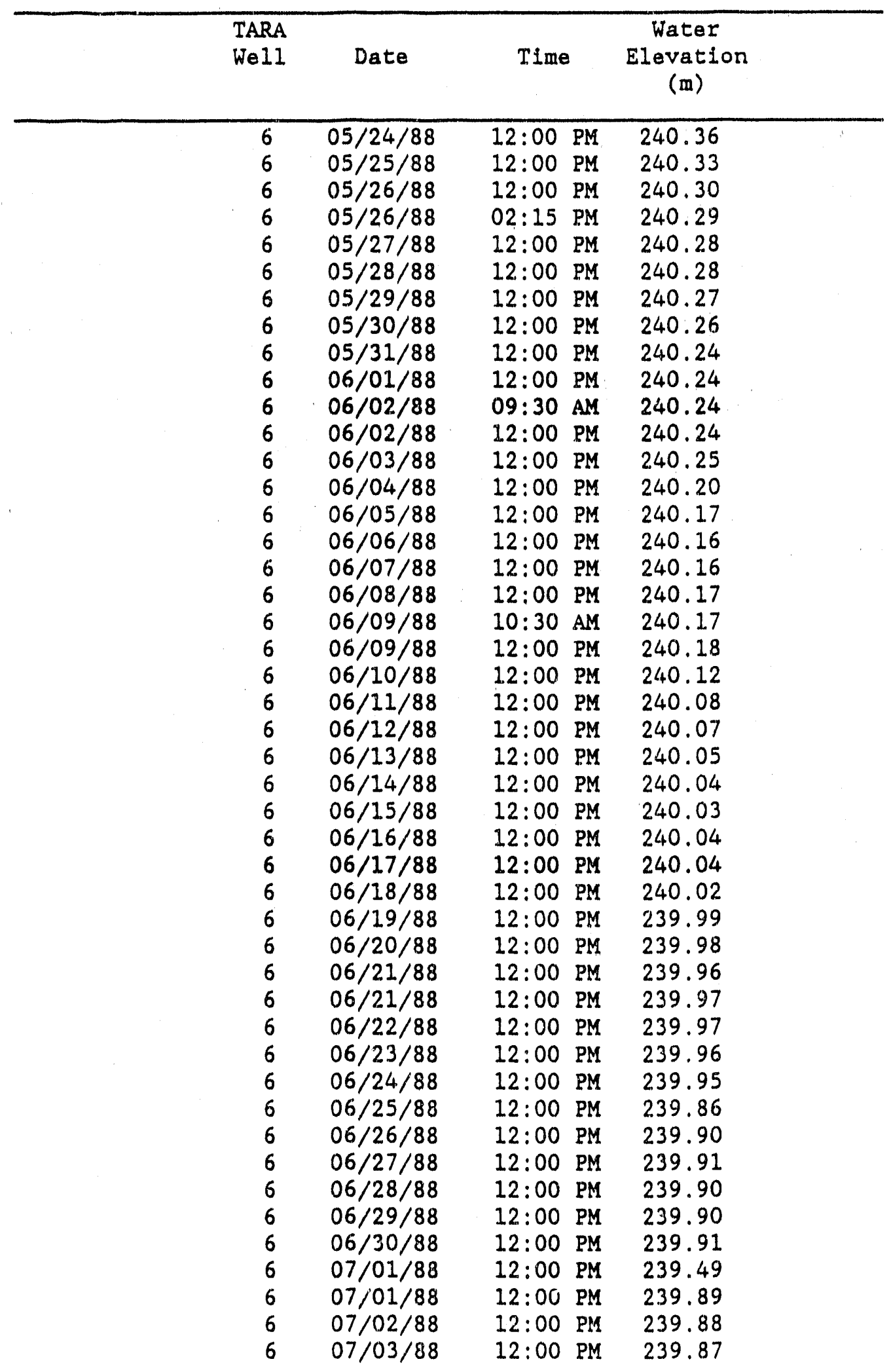


APPENDIX III

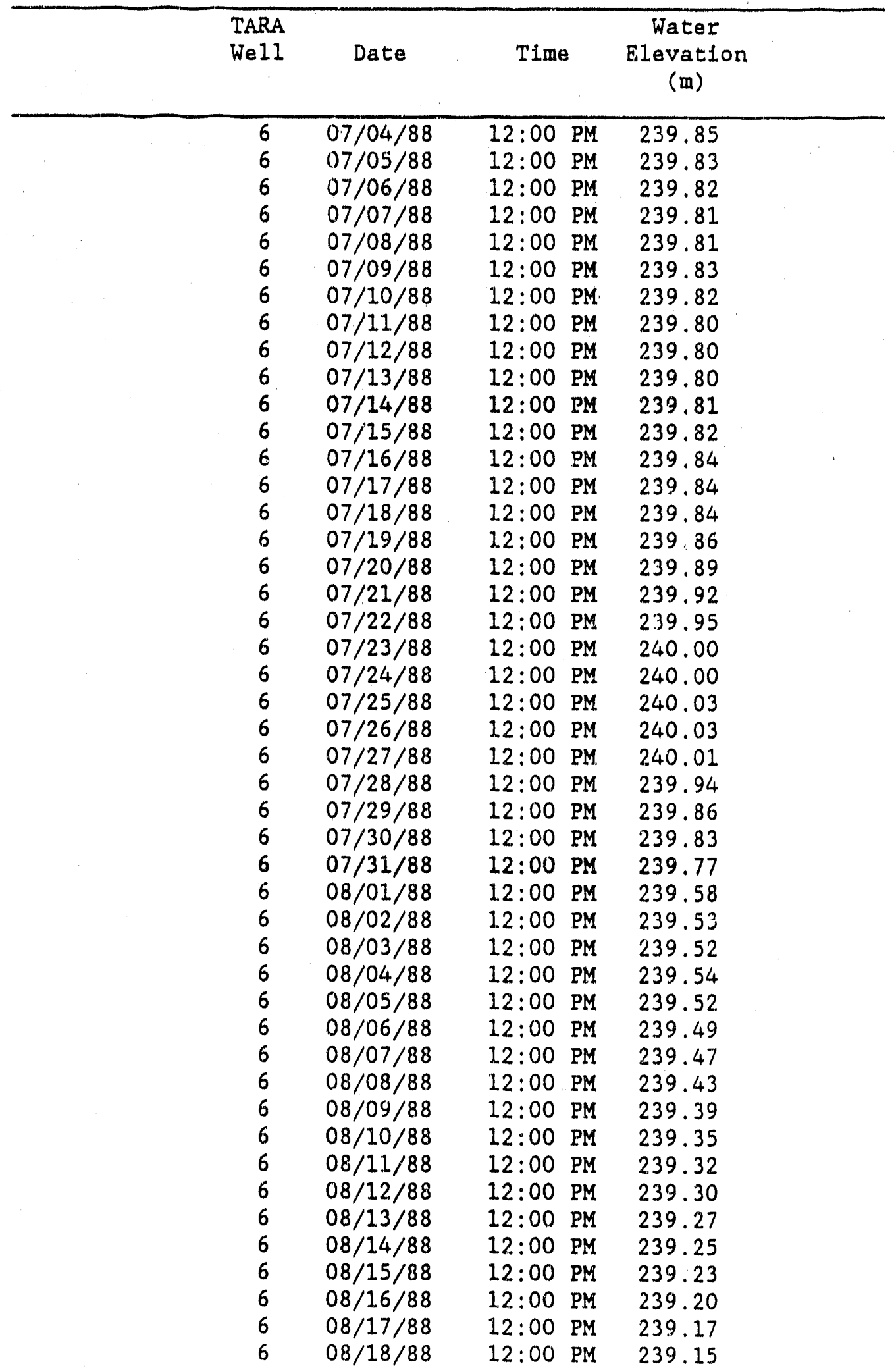


APPENDIX III

\begin{tabular}{ccccc}
\hline $\begin{array}{c}\text { TARA } \\
\text { Well }\end{array}$ & Date & Time & $\begin{array}{c}\text { Water } \\
\text { Elevation } \\
\text { (m) }\end{array}$ \\
\hline 6 & $08 / 19 / 88$ & $12: 00$ PM & 239.13 \\
6 & $08 / 20 / 88$ & $12: 00$ PM & 239.11 \\
6 & $08 / 21 / 88$ & $12: 00$ PM & 239.07 \\
6 & $08 / 22 / 88$ & $12: 00$ PM & 239.02 \\
6 & $08 / 23 / 88$ & $12: 00$ PM & 239.9
\end{tabular}


APPENDIX III

\begin{tabular}{|c|c|c|c|}
\hline $\begin{array}{l}\text { TARA } \\
\text { We11 }\end{array}$ & Date & Time & $\begin{array}{l}\text { Water } \\
\text { Elevation } \\
\text { (m) }\end{array}$ \\
\hline 7 & $06 / 04 / 87$ & $09: 25 \mathrm{AM}$ & 240.73 \\
\hline 7 & $06 / 15 / 87$ & $01: 30 \mathrm{PM}$ & 240.68 \\
\hline 7 & $07 / 13 / 87$ & $12: 00 \mathrm{PM}$ & 240.59 \\
\hline 7 & $07 / 27 / 87$ & $10: 51 \mathrm{AM}$ & 240.51 \\
\hline 7 & $07 / 27 / 87$ & $01: 32 \mathrm{PM}$ & 240.51 \\
\hline 7 & $07 / 27 / 87$ & 04:01 PM & 240.52 \\
\hline 7 & $07 / 27 / 87$ & $08: 37 \mathrm{PM}$ & 240.51 \\
\hline 7 & $07 / 28 / 87$ & $06: 31 \mathrm{AM}$ & 240.51 \\
\hline 7 & $07 / 28 / 87$ & $10: 16 \mathrm{AM}$ & 240.52 \\
\hline 7 & $07 / 28 / 87$ & $01: 10 \mathrm{PM}$ & 240.54 \\
\hline$?$ & $07 / 28 / 87$ & $03: 01 \mathrm{PM}$ & 240.55 \\
\hline 7 & $07 / 29 / 87$ & $09: 15 \mathrm{AM}$ & 241.32 \\
\hline 7 & $07 / 29 / 87$ & $02: 54 \mathrm{PM}$ & 241.55 \\
\hline 7 & $07 / 30 / 87$ & $09: 10 \mathrm{AM}$ & 241.92 \\
\hline 7 & $07 / 30 / 87$ & $04: 18 \mathrm{PM}$ & 241.99 \\
\hline 7 & $07 / 31 / 87$ & $08: 42 \mathrm{AM}$ & 242.07 \\
\hline 7 & $08 / 03 / 87$ & $08: 58 \mathrm{AM}$ & 241.87 \\
\hline 7 & $08 / 04 / 87$ & $08: 48 \mathrm{AM}$ & 241.67 \\
\hline 7 & $08 / 05 / 87$ & $07: 26 \mathrm{AM}$ & 241.74 \\
\hline 7 & $08 / 05 / 87$ & $03: 03 \mathrm{PM}$ & 241.81 \\
\hline 7 & $08 / 06 / 87$ & $08: 53 \mathrm{AM}$ & 242.03 \\
\hline 7 & $08 / 07 / 87$ & 09:09 AM & 242.38 \\
\hline 7 & $08 / 10 / 87$ & $09: 13 \mathrm{AM}$ & 242.61 \\
\hline 7 & $08 / 12 / 87$ & $09: 53 \mathrm{AM}$ & 242.43 \\
\hline 7 & $08 / 14 / 87$ & $07: 51 \mathrm{AM}$ & 242.22 \\
\hline 7 & $08 / 17 / 87$ & $07: 26 \mathrm{AM}$ & 241.91 \\
\hline 7 & $08 / 21 / 87$ & $03: 19 \mathrm{PM}$ & 241.55 \\
\hline 7 & $09 / 04 / 87$ & $08: 21 \mathrm{AM}$ & 240.78 \\
\hline 7 & $09 / 11 / 87$ & $01: 30 \mathrm{PM}$ & 240.61 \\
\hline 7 & $09 / 18 / 87$ & $01: 30 \mathrm{PM}$ & 240.54 \\
\hline 7 & $09 / 25 / 87$ & $01: 30 \mathrm{PM}$ & 240.49 \\
\hline 7 & $10 / 01 / 87$ & $01: 30 \mathrm{PM}$ & 240.46 \\
\hline 7 & $10 / 08 / 87$ & $01: 30 \mathrm{PM}$ & 240.43 \\
\hline 7 & $10 / 15 / 87$ & $01: 30 \mathrm{PM}$ & 240.41 \\
\hline 7 & $10 / 19 / 87$ & $02: 02 \mathrm{PM}$ & 240.41 \\
\hline 7 & $10 / 20 / 87$ & $08: 48 \mathrm{AM}$ & 240.39 \\
\hline 7 & $10 / 20 / 87$ & $03: 51 \mathrm{PM}$ & 240.40 \\
\hline 7 & $10 / 21 / 87$ & $09: 17 \mathrm{AM}$ & 240.39 \\
\hline 7 & $10 / 22 / 87$ & $09: 15 \mathrm{AM}$ & 240.40 \\
\hline 7 & $10 / 23 / 87$ & $09: 08 \mathrm{AM}$ & 240.42 \\
\hline 7 & $10 / 26 / 87$ & $09: 18 \mathrm{AM}$ & 242.34 \\
\hline 7 & $10 / 27 / 87$ & 09:00 AM & 242.33 \\
\hline 7 & $10 / 28 / 87$ & $09: 03 \mathrm{AM}$ & 242.23 \\
\hline 7 & $10 / 29 / 87$ & $09: 29 \mathrm{AM}$ & $<43.03$ \\
\hline 7 & $10 / 30 / 87$ & $09: 43 \mathrm{AM}$ & 243.81 \\
\hline 7 & $11 / 02 / 87$ & $02: 15 \mathrm{PM}$ & 243.10 \\
\hline
\end{tabular}


APPENDIX III

$\begin{array}{ccc}\text { TARA } & \text { Water } \\ \text { Well Date } & \text { Time Elevation }\end{array}$

(m)

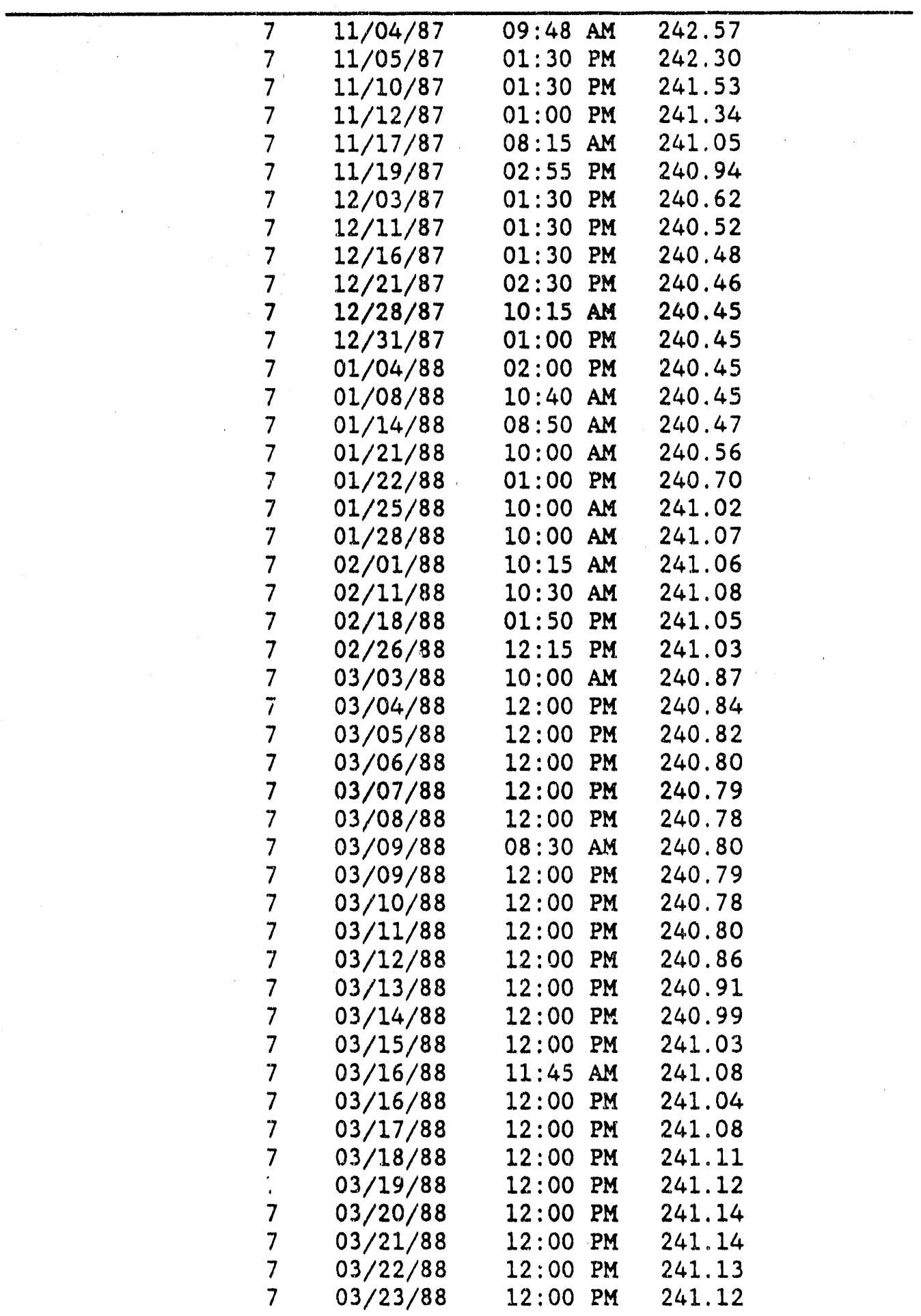


APPENDIX III

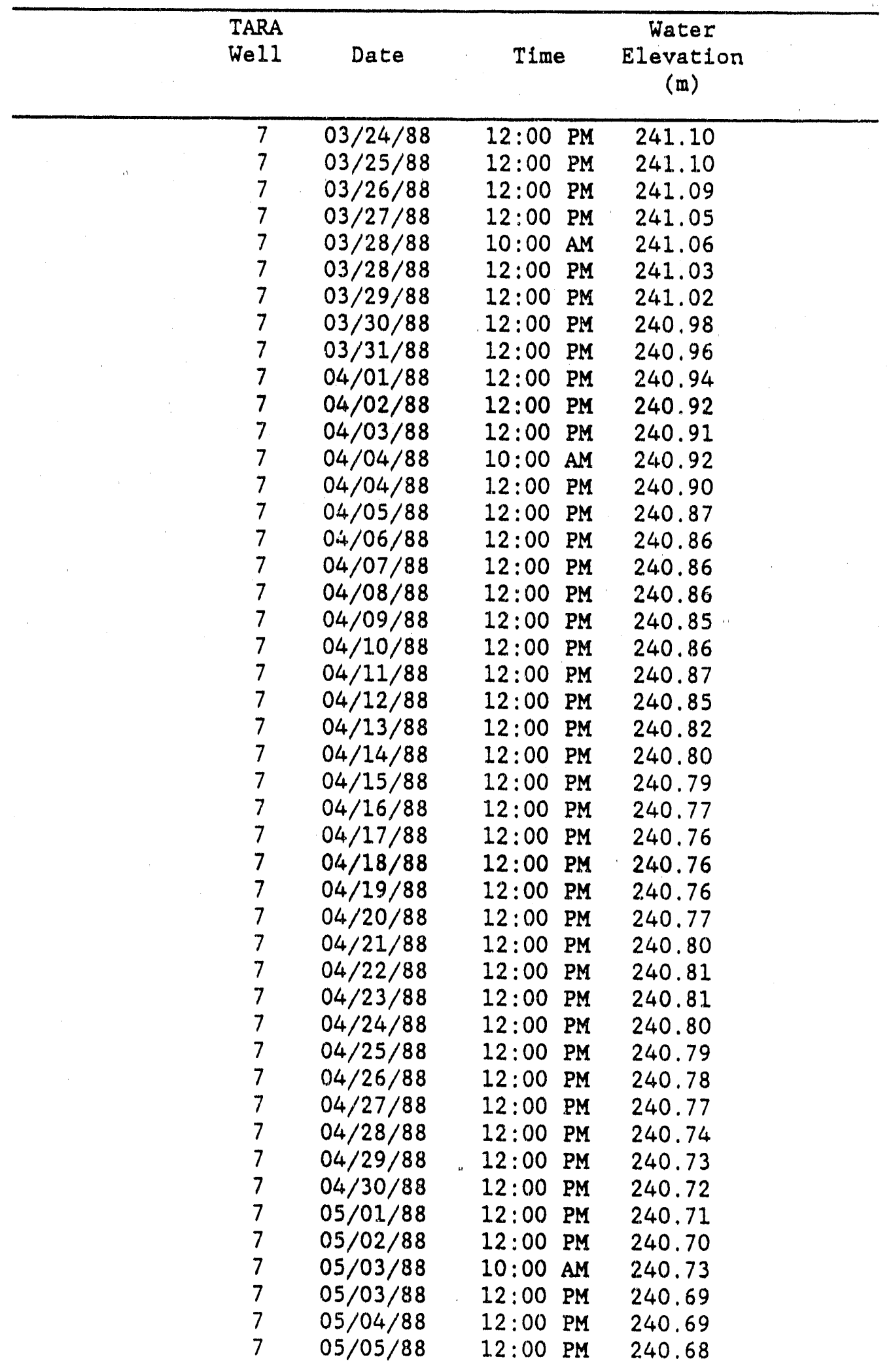


APPENDIX III

\begin{tabular}{|c|c|c|c|}
\hline $\begin{array}{l}\text { TARA } \\
\text { We } 11\end{array}$ & Date & Time & $\begin{array}{l}\text { Water } \\
\text { Elevation } \\
\text { (m) }\end{array}$ \\
\hline $\begin{array}{l}7 \\
7 \\
7 \\
7 \\
7 \\
7 \\
7 \\
7 \\
7 \\
7 \\
7 \\
7 \\
7 \\
7 \\
7 \\
7 \\
7 \\
7 \\
7 \\
7 \\
7 \\
7 \\
7 \\
7 \\
7 \\
7 \\
7 \\
7 \\
7 \\
7 \\
7 \\
7 \\
7 \\
7 \\
7 \\
7 \\
7 \\
7 \\
7 \\
7 \\
7 \\
7 \\
7 \\
7 \\
7 \\
7\end{array}$ & $\begin{array}{l}05 / 06 / 88 \\
05 / 07 / 88 \\
05 / 08 / 88 \\
05 / 09 / 88 \\
05 / 10 / 88 \\
05 / 11 / 88 \\
05 / 12 / 88 \\
05 / 12 / 88 \\
05 / 13 / 88 \\
05 / 14 / 88 \\
05 / 15 / 88 \\
05 / 16 / 88 \\
05 / 17 / 88 \\
05 / 18 / 88 \\
05 / 19 / 88 \\
05 / 20 / 88 \\
05 / 20 / 88 \\
05 / 21 / 88 \\
05 / 22 / 88 \\
05 / 23 / 88 \\
05 / 24 / 88 \\
05 / 25 / 88 \\
05 / 26 / 88 \\
05 / 26 / 88 \\
05 / 27 / 88 \\
05 / 28 / 88 \\
05 / 29 / 88 \\
05 / 30 / 88 \\
05 / 31 / 88 \\
06 / 01 / 88 \\
06 / 02 / 88 \\
06 / 02 / 88 \\
06 / 03 / 88 \\
06 / 04 / 88 \\
06 / 05 / 88 \\
06 / 06 / 88 \\
06 / 07 / 88 \\
06 / 08 / 88 \\
06 / 09 / 88 \\
06 / 09 / 88 \\
06 / 10 / 88 \\
06 / 11 / 88 \\
06 / 12 / 88 \\
06 / 13 / 88 \\
06 / 14 / 88 \\
06 / 15 / 88\end{array}$ & 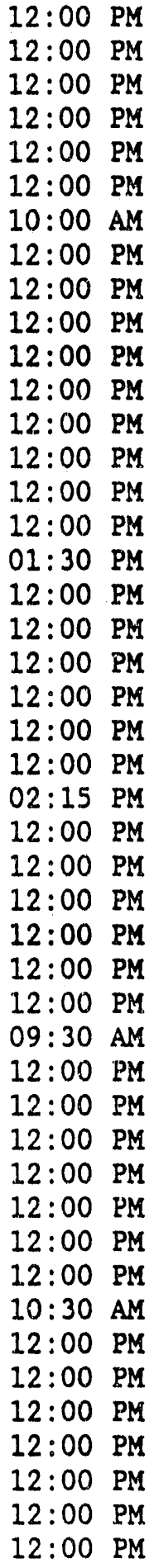 & $\begin{array}{l}240.67 \\
240.66 \\
240.65 \\
240.64 \\
240.63 \\
240.62 \\
240.66 \\
240.61 \\
240.60 \\
240.60 \\
240.59 \\
240.59 \\
240.58 \\
240.57 \\
240.56 \\
240.55 \\
240.60 \\
240.55 \\
240.54 \\
240.53 \\
240.53 \\
240.52 \\
240.51 \\
240.56 \\
240.50\end{array}$ \\
\hline
\end{tabular}


APPENDIX III

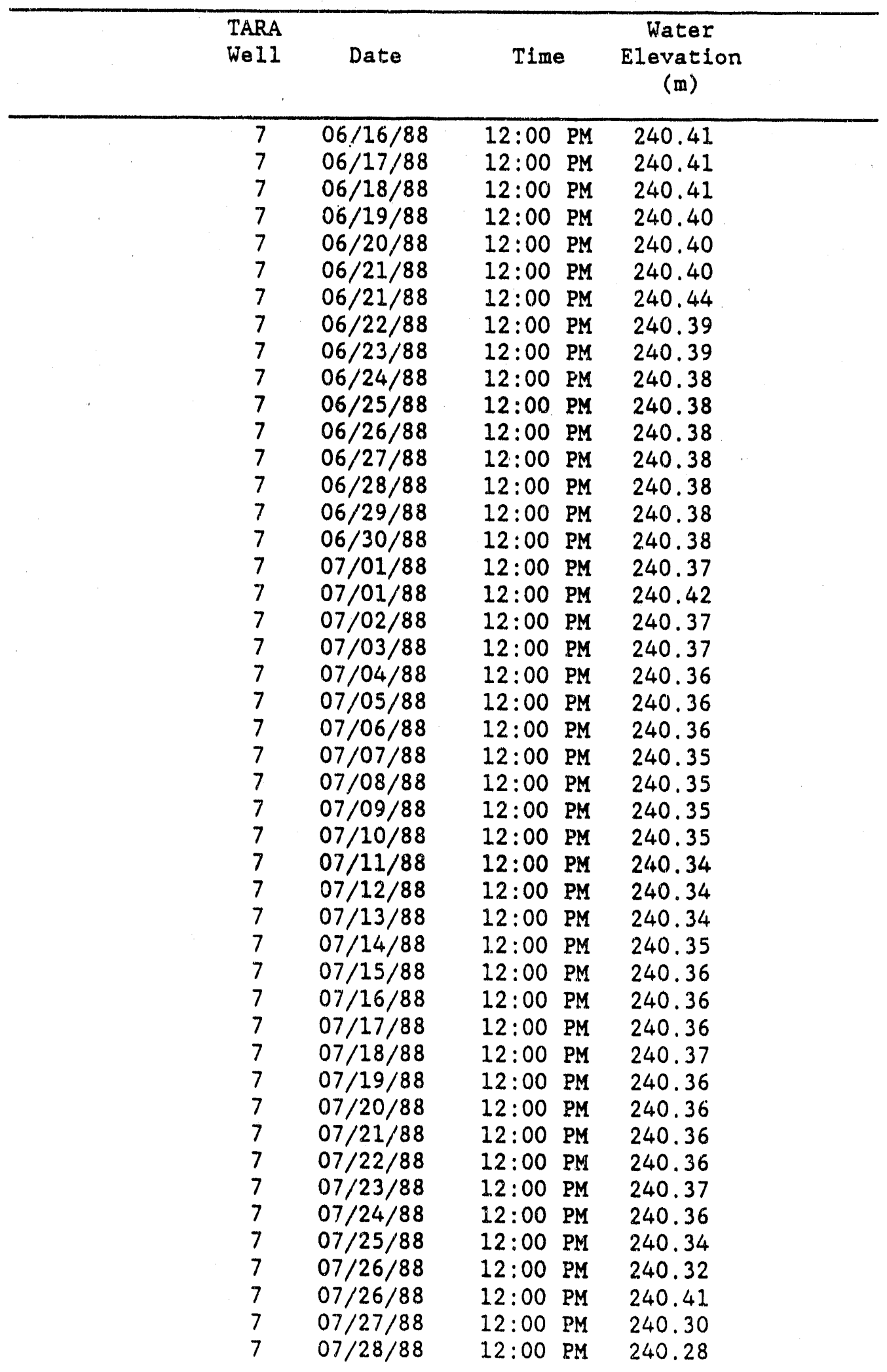


APPENDIX III

\begin{tabular}{lcccc}
\hline $\begin{array}{c}\text { TARA } \\
\text { We11 }\end{array}$ & Date & Time & $\begin{array}{c}\text { Water } \\
\text { Elevation } \\
(\mathrm{m})\end{array}$ \\
\hline 7 & $07 / 29 / 88$ & $12: 00$ PM & 240.28 \\
7 & $07 / 30 / 88$ & $12: 00$ PM & 240.28 \\
7 & $07 / 31 / 88$ & $12: 00$ PM & 240.28 \\
7 & $08 / 01 / 88$ & $12: 00$ PM & 240.28 \\
7 & $08 / 02 / 88$ & $12: 00$ PM & 240.27 \\
7 & $08 / 03 / 88$ & $12: 00$ PM & 240.27 \\
7 & $08 / 04 / 88$ & $12: 00$ PM & 240.27 \\
7 & $08 / 05 / 88$ & $12: 00$ PM & 240.27 \\
7 & $08 / 06 / 88$ & $12: 00$ PM & 240.27 \\
7 & $08 / 07 / 88$ & $12: 00$ PM & 240.27 \\
7 & $08 / 08 / 88$ & $12: 00$ PM & 240.27 \\
7 & $08 / 09 / 88$ & $12: 00$ PM & 240.26 \\
7 & $08 / 10 / 88$ & $12: 00$ PM & 240.26 \\
7 & $08 / 11 / 88$ & $12: 00$ PM & 240.25 \\
7 & $08 / 12 / 88$ & $12: 00$ PM & 240.23 \\
7 & $08 / 13 / 88$ & $12: 00$ PM & 240.23 \\
7 & $08 / 14 / 88$ & $12: 00$ PM & 240.24 \\
7 & $08 / 15 / 88$ & $12: 00$ PM & 240.23 \\
7 & $08 / 16 / 88$ & $12: 00$ PM & 240.23 \\
7 & $08 / 17 / 88$ & $12: 00$ PM & 240.23 \\
7 & $08 / 18 / 88$ & $12: 00$ PM & 240.24 \\
7 & $08 / 19 / 88$ & $12: 00$ PM & 240.24 \\
7 & $08 / 20 / 88$ & $12: 00$ PM & 240.24 \\
7 & $08 / 21 / 88$ & $12: 00$ PM & 240.23 \\
7 & $08 / 22 / 88$ & $12: 00$ PM & 240.23 \\
7 & $08 / 23 / 88$ & $12: 00$ PM & 240.34 \\
& & & &
\end{tabular}


APPENDIX III

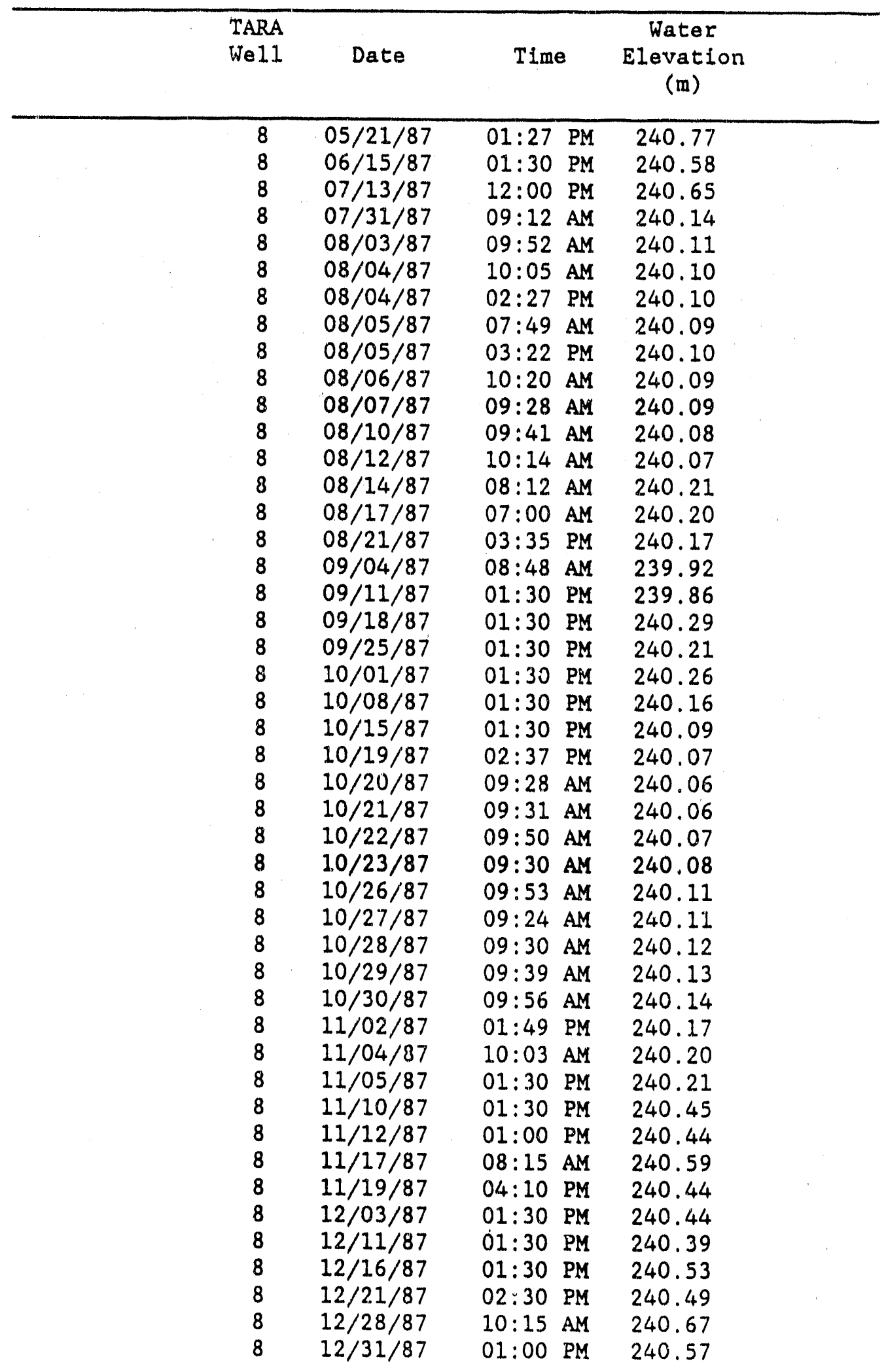


APPENDIX III

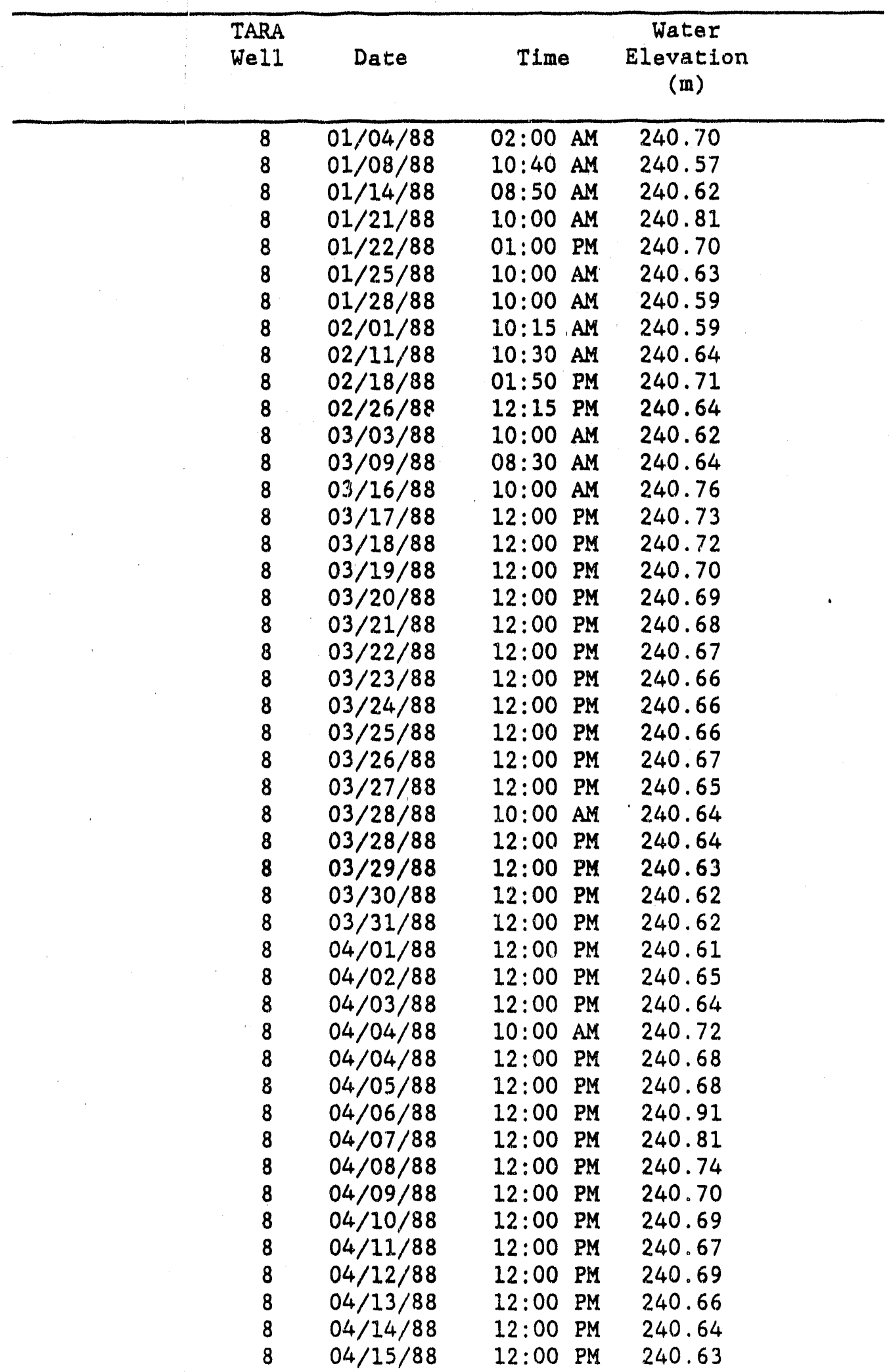


APPENDIX III

\begin{tabular}{|c|c|c|c|}
\hline $\begin{array}{l}\text { TARA } \\
\text { We11 }\end{array}$ & Date & Time & $\begin{array}{l}\text { Water } \\
\text { Elevation } \\
\text { (m) }\end{array}$ \\
\hline $\begin{array}{l}8 \\
8 \\
8 \\
8 \\
8 \\
8 \\
8 \\
8 \\
8 \\
8 \\
8 \\
8 \\
8 \\
8 \\
8 \\
8 \\
8 \\
8 \\
8 \\
8 \\
8 \\
8 \\
8 \\
8 \\
8 \\
8 \\
8 \\
8 \\
8 \\
8 \\
8 \\
8 \\
8 \\
8 \\
8 \\
8 \\
8 \\
8 \\
8 \\
8 \\
8 \\
8 \\
8 \\
8 \\
8 \\
8\end{array}$ & $\begin{array}{l}04 / 16 / 88 \\
04 / 17 / 88 \\
04 / 18 / 88 \\
04 / 19 / 88 \\
04 / 20 / 88 \\
04 / 21 / 88 \\
04 / 22 / 88 \\
04 / 23 / 88 \\
04 / 24 / 88 \\
04 / 25 / 88 \\
04 / 26 / 88 \\
04 / 27 / 88 \\
04 / 28 / 88 \\
04 / 29 / 88 \\
04 / 30 / 88 \\
05 / 01 / 88 \\
05 / 02 / 88 \\
05 / 03 / 88 \\
05 / 03 / 88 \\
05 / 04 / 88 \\
05 / 05 / 88 \\
05 / 06 / 88 \\
05 / 07 / 88 \\
05 / 08 / 88 \\
05 / 09 / 88 \\
05 / 10 / 88 \\
05 / 11 / 88 \\
05 / 12 / 88 \\
05 / 12 / 88 \\
05 / 13 / 88 \\
05 / 14 / 88 \\
05 / 15 / 88 \\
05 / 16 / 88 \\
05 / 17 / 88 \\
05 / 18 / 88 \\
05 / 19 / 88 \\
05 / 20 / 88 \\
05 / 20 / 88 \\
05 / 21 / 88 \\
05 / 22 / 88 \\
05 / 23 / 88 \\
05 / 24 / 88 \\
05 / 25 / 88 \\
05 / 26 / 88 \\
05 / 26 / 88 \\
05 / 27 / 88\end{array}$ & 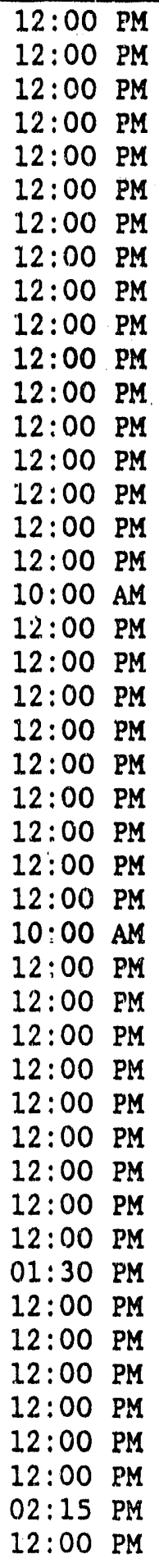 & $\begin{array}{l}240.66 \\
240.64 \\
240.82 \\
240.89 \\
240.84 \\
240.78 \\
240.73 \\
240.71 \\
240.69 \\
240.67 \\
240.65 \\
240.64 \\
240.63 \\
240.62 \\
240.62 \\
240.61 \\
240.60 \\
240.65 \\
240.60 \\
240.70 \\
240.67 \\
240.64 \\
240.62 \\
240.60 \\
240.67 \\
240.65 \\
240.63 \\
240.65 \\
240.61 \\
240.59 \\
240.58 \\
240.57 \\
240.56 \\
240.55 \\
240.53 \\
240.52 \\
240.51 \\
240.61 \\
240.50 \\
240.49 \\
240.48 \\
240.52 \\
240.65 \\
240.62 \\
240.66 \\
240.59\end{array}$ \\
\hline
\end{tabular}


APPENDIX III

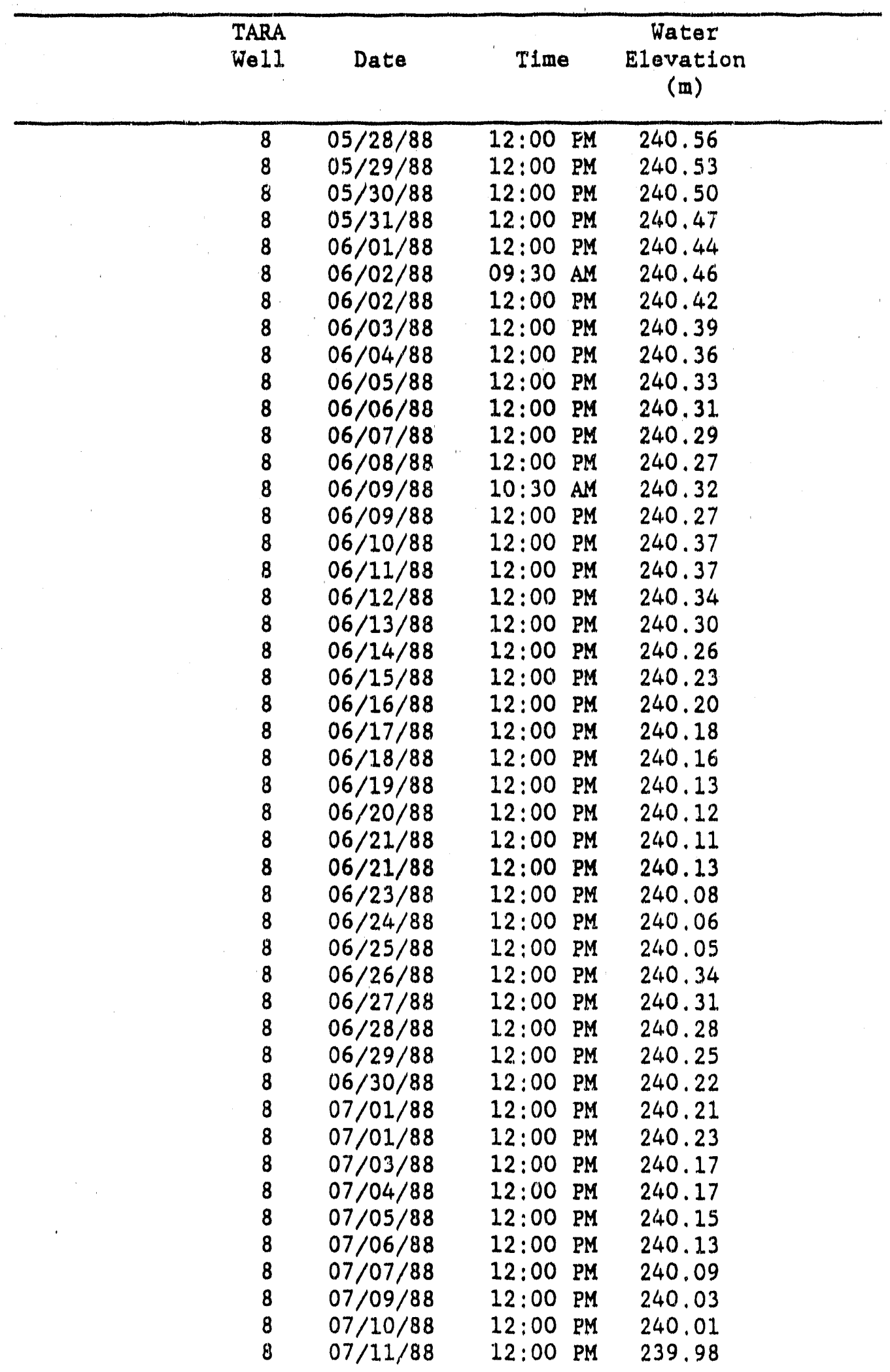


APPENDIX III

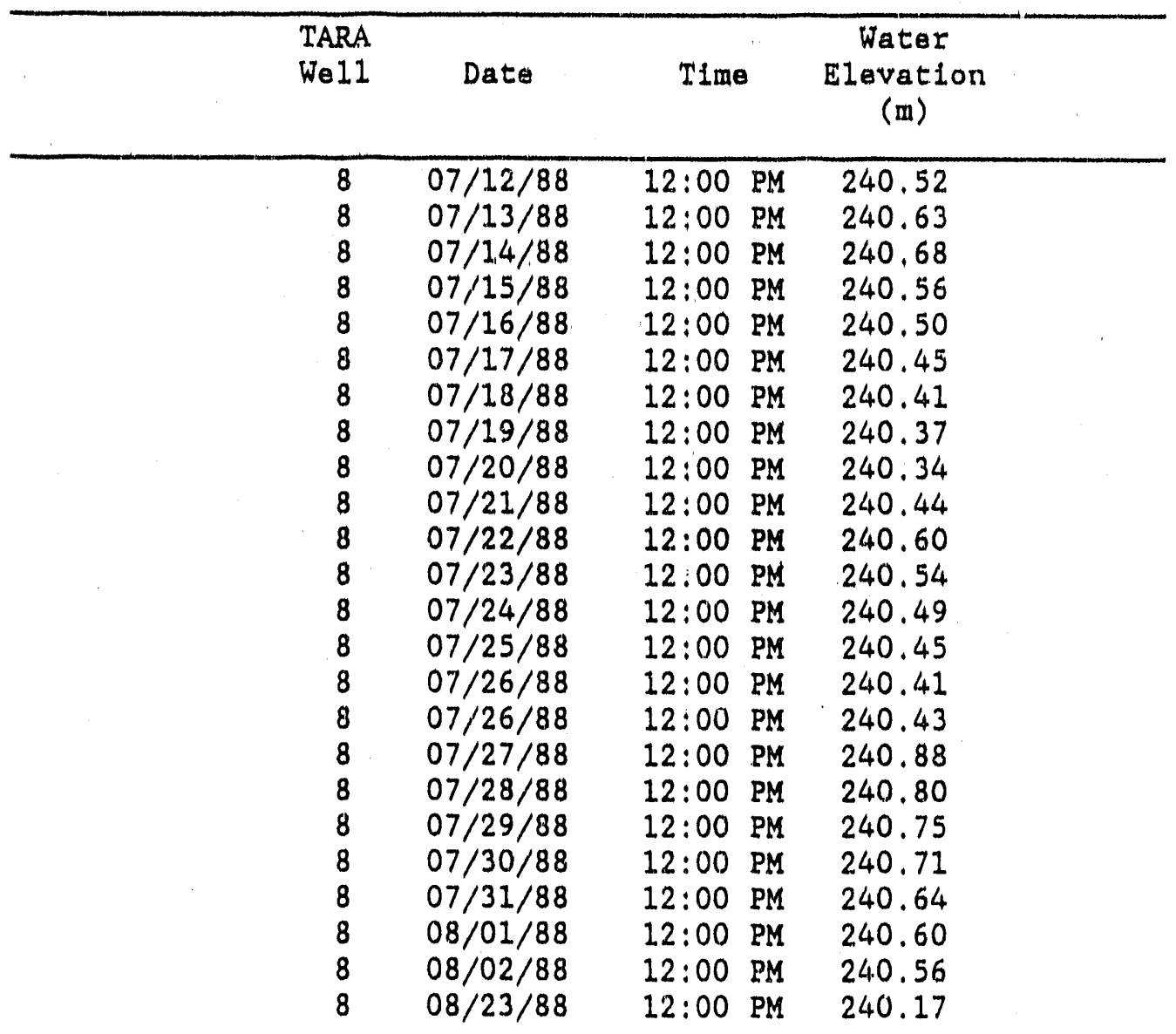


APPENDIX III

\begin{tabular}{|c|c|c|c|}
\hline $\begin{array}{l}\text { TARA } \\
\text { Wel1 }\end{array}$ & Date & Time & $\begin{array}{c}\text { Water } \\
\text { Elevation } \\
\text { (m) }\end{array}$ \\
\hline $\begin{array}{l}9 \\
9 \\
9 \\
9 \\
9 \\
9 \\
9 \\
9 \\
9 \\
9 \\
9 \\
9 \\
9 \\
9 \\
9 \\
9 \\
9 \\
9 \\
9 \\
9 \\
9 \\
9 \\
9 \\
9 \\
9 \\
9 \\
9 \\
9 \\
9 \\
9 \\
9 \\
9 \\
9 \\
9 \\
9 \\
9 \\
9 \\
9 \\
9 \\
9 \\
9 \\
9 \\
9 \\
9 \\
9 \\
9\end{array}$ & $\begin{array}{l}05 / 21 / 87 \\
06 / 15 / 87 \\
07 / 13 / 87 \\
07 / 31 / 87 \\
08 / 03 / 87 \\
08 / 04 / 87 \\
08 / 04 / 87 \\
08 / 05 / 87 \\
08 / 05 / 87 \\
08 / 06 / 87 \\
08 / 07 / 87 \\
08 / 10 / 87 \\
08 / 12 / 87 \\
08 / 14 / 87 \\
08 / 17 / 87 \\
08 / 21 / 87 \\
09 / 04 / 87 \\
09 / 11 / 87 \\
09 / 18 / 87 \\
09 / 25 / 87 \\
10 / 01 / 87 \\
10 / 08 / 87 \\
10 / 15 / 87 \\
10 / 19 / 87 \\
10 / 20 / 87 \\
10 / 21 / 87 \\
10 / 22 / 87 \\
10 / 23 / 87 \\
10 / 26 / 87 \\
10 / 27 / 87 \\
10 / 28 / 87 \\
10 / 29 / 87 \\
10 / 30 / 87 \\
11 / 02 / 87 \\
11 / 04 / 87 \\
11 / 05 / 87 \\
11 / 10 / 87 \\
11 / 12 / 87 \\
11 / 17 / 87 \\
11 / 19 / 87 \\
12 / 03 / 87 \\
12 / 11 / 87 \\
12 / 16 / 87 \\
12 / 21 / 87 \\
12 / 28 / 87 \\
12 / 31 / 87\end{array}$ & 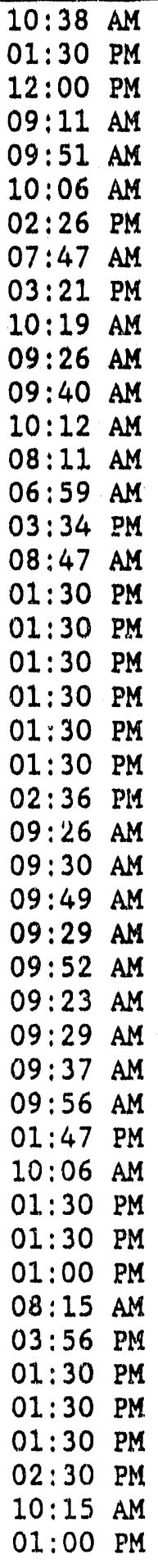 & $\begin{array}{l}239.84 \\
239.78 \\
239.89 \\
239.46 \\
239.42 \\
239.40 \\
239.41 \\
239.39 \\
239.40 \\
239.38 \\
239.37 \\
239.34 \\
239.32 \\
239.40 \\
239.39 \\
239.35 \\
239.18 \\
239.12 \\
239.52 \\
239.44 \\
239.46 \\
239.38 \\
239.32 \\
239.30 \\
239.30 \\
239.29 \\
239.27 \\
239.27 \\
239.29 \\
239.29 \\
239.28 \\
239.27 \\
239.27 \\
239.28 \\
239.29 \\
239.29 \\
239.44 \\
239.60 \\
239.64 \\
239.51 \\
239.63 \\
239.57 \\
239.73 \\
239.68 \\
239.92 \\
239.82\end{array}$ \\
\hline
\end{tabular}


APPENDIX III

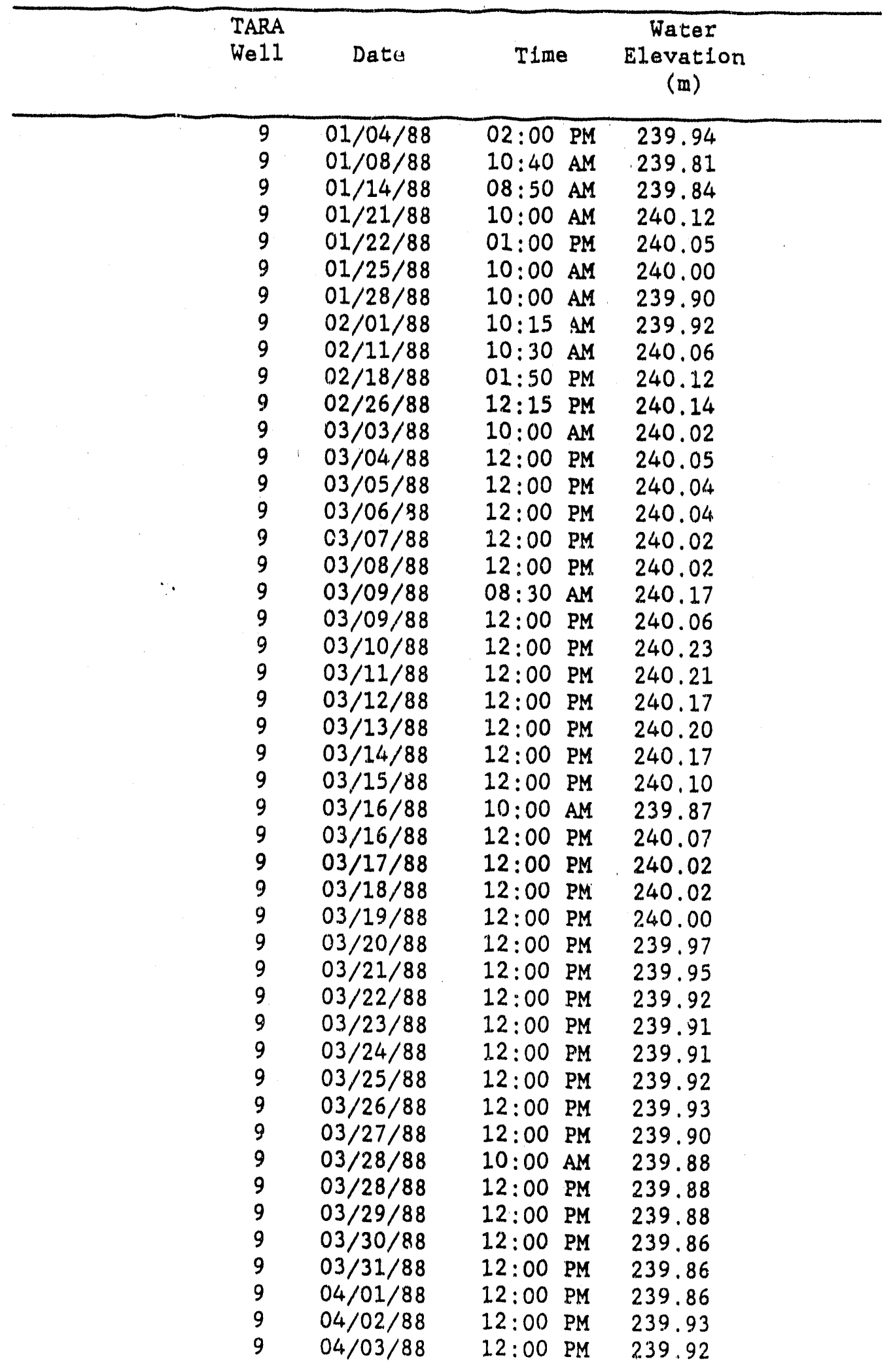


APPENDIX III

\begin{tabular}{|c|c|c|c|}
\hline $\begin{array}{l}\text { TARA } \\
\text { Wel1 }\end{array}$ & Date & Time & $\begin{array}{c}\text { Water } \\
\text { Elevation } \\
\text { (m) }\end{array}$ \\
\hline $\begin{array}{l}9 \\
9 \\
9 \\
9 \\
9 \\
9 \\
9 \\
9 \\
9 \\
9 \\
9 \\
9 \\
9 \\
9 \\
9 \\
9 \\
9 \\
9 \\
9 \\
9 \\
9 \\
9 \\
9 \\
9 \\
9 \\
9 \\
9 \\
9 \\
9 \\
9 \\
9 \\
9 \\
9 \\
9 \\
9 \\
9 \\
9 \\
9 \\
9 \\
9 \\
9 \\
9 \\
9 \\
9 \\
9 \\
9\end{array}$ & $\begin{array}{l}04 / 04 / 88 \\
04 / 04 / 88 \\
04 / 05 / 88 \\
04 / 06 / 88 \\
04 / 07 / 88 \\
04 / 08 / 88 \\
04 / 09 / 88 \\
04 / 10 / 88 \\
04 / 11 / 88 \\
04 / 12 / 88 \\
04 / 13 / 88 \\
04 / 14 / 88 \\
04 / 15 / 88 \\
04 / 16 / 88 \\
04 / 17 / 88 \\
04 / 18 / 88 \\
04 / 19 / 88 \\
04 / 20 / 88 \\
04 / 21 / 88 \\
04 / 22 / 88 \\
04 / 23 / 88 \\
04 / 24 / 88 \\
04 / 25 / 88 \\
04 / 26 / 88 \\
04 / 27 / 88 \\
04 / 28 / 88 \\
04 / 29 / 88 \\
04 / 30 / 88 \\
05 / 01 / 88 \\
05 / 02 / 88 \\
05 / 03 / 88 \\
05 / 03 / 88 \\
05 / 04 / 88 \\
05 / 05 / 88 \\
05 / 06 / 88 \\
05 / 07 / 88 \\
05 / 08 / 88 \\
05 / 09 / 88 \\
05 / 10 / 88 \\
05 / 11 / 88 \\
05 / 12 / 88 \\
05 / 12 / 88 \\
05 / 13 / 88 \\
05 / 14 / 88 \\
05 / 15 / 88 \\
05 / 16 / 88\end{array}$ & 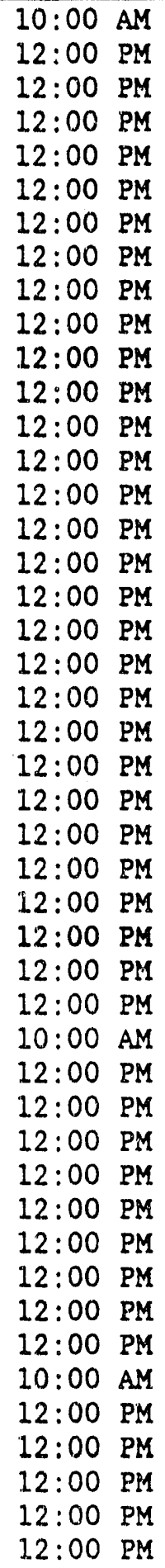 & $\begin{array}{l}239.96 \\
239.95 \\
239.94 \\
239.99 \\
240.03 \\
240.00 \\
239.98 \\
239.98 \\
239.98 \\
239.96 \\
239.95 \\
239.93 \\
239.91 \\
239.93 \\
239.93 \\
240.00 \\
240.06 \\
240.06 \\
240.06 \\
240.04 \\
240.01 \\
239.99 \\
239.98 \\
239.96 \\
239.94 \\
239.91 \\
239.91 \\
239.89 \\
239.88 \\
239.87 \\
239.90 \\
239.86 \\
239.94 \\
239.96 \\
239.94 \\
239.91 \\
239.88 \\
239.92 \\
239.95 \\
239.92 \\
239.91 \\
239.89 \\
239.87 \\
239.85 \\
239.84 \\
239.82\end{array}$ \\
\hline
\end{tabular}


APPENDIX III

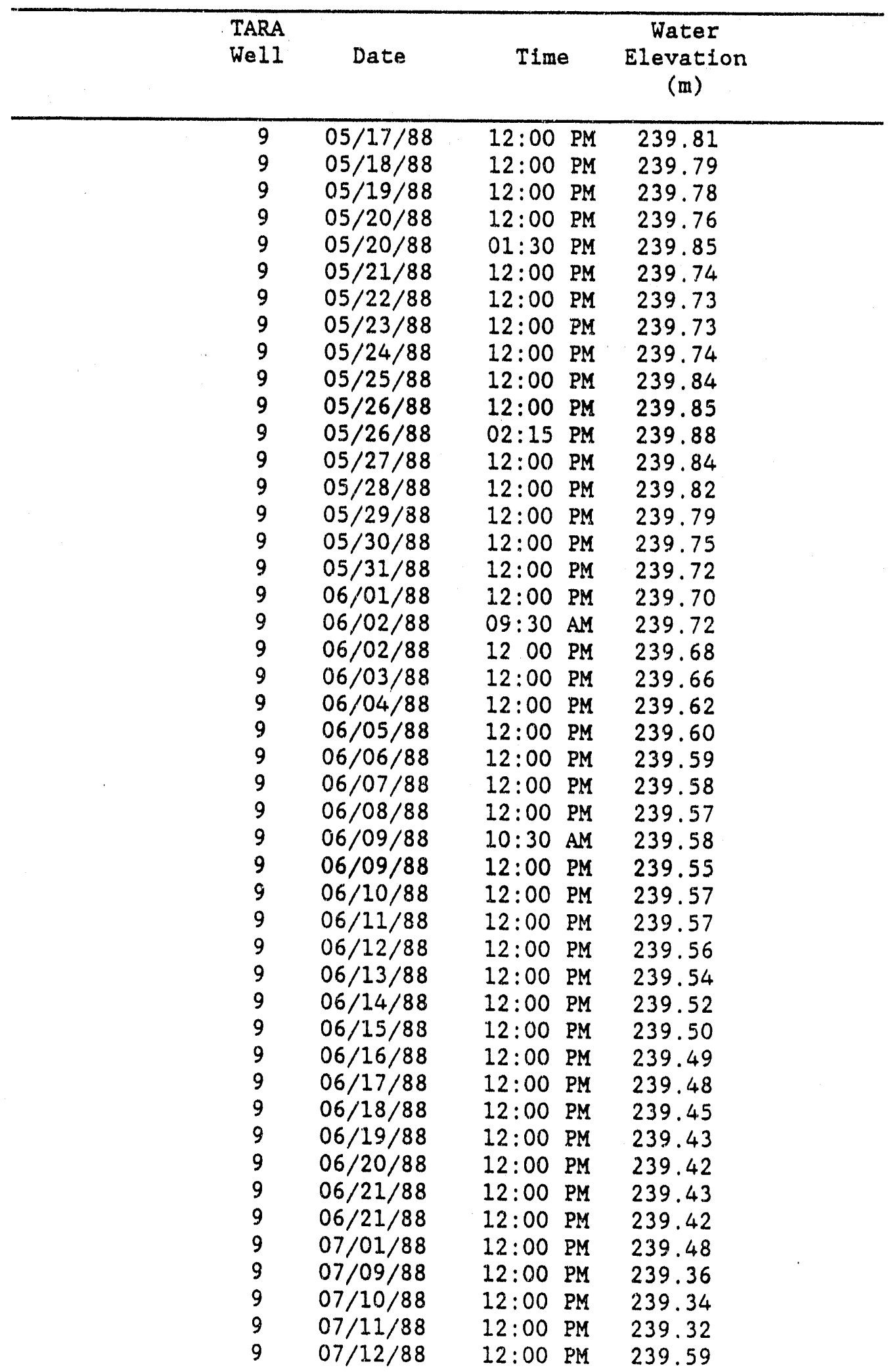


APPENDIX III

\begin{tabular}{lllll}
\hline & $\begin{array}{c}\text { TARA } \\
\text { Wel1 }\end{array}$ & Date & Time & $\begin{array}{c}\text { Water } \\
\text { Elevation } \\
\text { (m) }\end{array}$ \\
\hline 9 & $07 / 13 / 88$ & $12: 00 \mathrm{PM}$ & 239.71 \\
9 & $07 / 14 / 88$ & $12: 00 \mathrm{PM}$ & 239.88 \\
9 & $07 / 15 / 88$ & $12: 00 \mathrm{PM}$ & 239.85 \\
9 & $07 / 16 / 88$ & $12: 00 \mathrm{PM}$ & 239.79 \\
9 & $07 / 17 / 88$ & $12: 00 \mathrm{PM}$ & 239.74 \\
9 & $07 / 18 / 88$ & $12: 00 \mathrm{PM}$ & 239.70 \\
9 & $07 / 19 / 88$ & $12: 00 \mathrm{PM}$ & 239.66 \\
9 & $07 / 20 / 88$ & $12: 00 \mathrm{PM}$ & 239.62 \\
9 & $07 / 21 / 88$ & $12: 00 \mathrm{PM}$ & 239.63 \\
9 & $07 / 22 / 88$ & $12: 00 \mathrm{PM}$ & 239.85 \\
9 & $07 / 23 / 88$ & $12: 00 \mathrm{PM}$ & 239.83 \\
9 & $07 / 24 / 88$ & $12: 00 \mathrm{PM}$ & 239.78 \\
9 & $07 / 25 / 88$ & $12: 00 \mathrm{PM}$ & 239.74 \\
9 & $07 / 26 / 88$ & $12: 00 \mathrm{PM}$ & 239.70 \\
9 & $07 / 26 / 88$ & $12: 00 \mathrm{PM}$ & 239.72 \\
9 & $07 / 27 / 88$ & $12: 00 \mathrm{PM}$ & 239.92 \\
9 & $07 / 28 / 88$ & $12: 00 \mathrm{PM}$ & 239.89 \\
9 & $07 / 29 / 88$ & $12: 00 \mathrm{PM}$ & 239.85 \\
9 & $07 / 30 / 88$ & $12: 00 \mathrm{PM}$ & 239.80 \\
9 & $07 / 31 / 88$ & $12: 00 \mathrm{PM}$ & 239.76 \\
9 & $08 / 01 / 88$ & $12: 00 \mathrm{PM}$ & 239.72 \\
9 & $08 / 02 / 88$ & $12: 00 \mathrm{PM}$ & 239.68 \\
9 & $08 / 23 / 88$ & $12: 00 \mathrm{PM}$ & 239.48 \\
& & & &
\end{tabular}


APPENDIX III

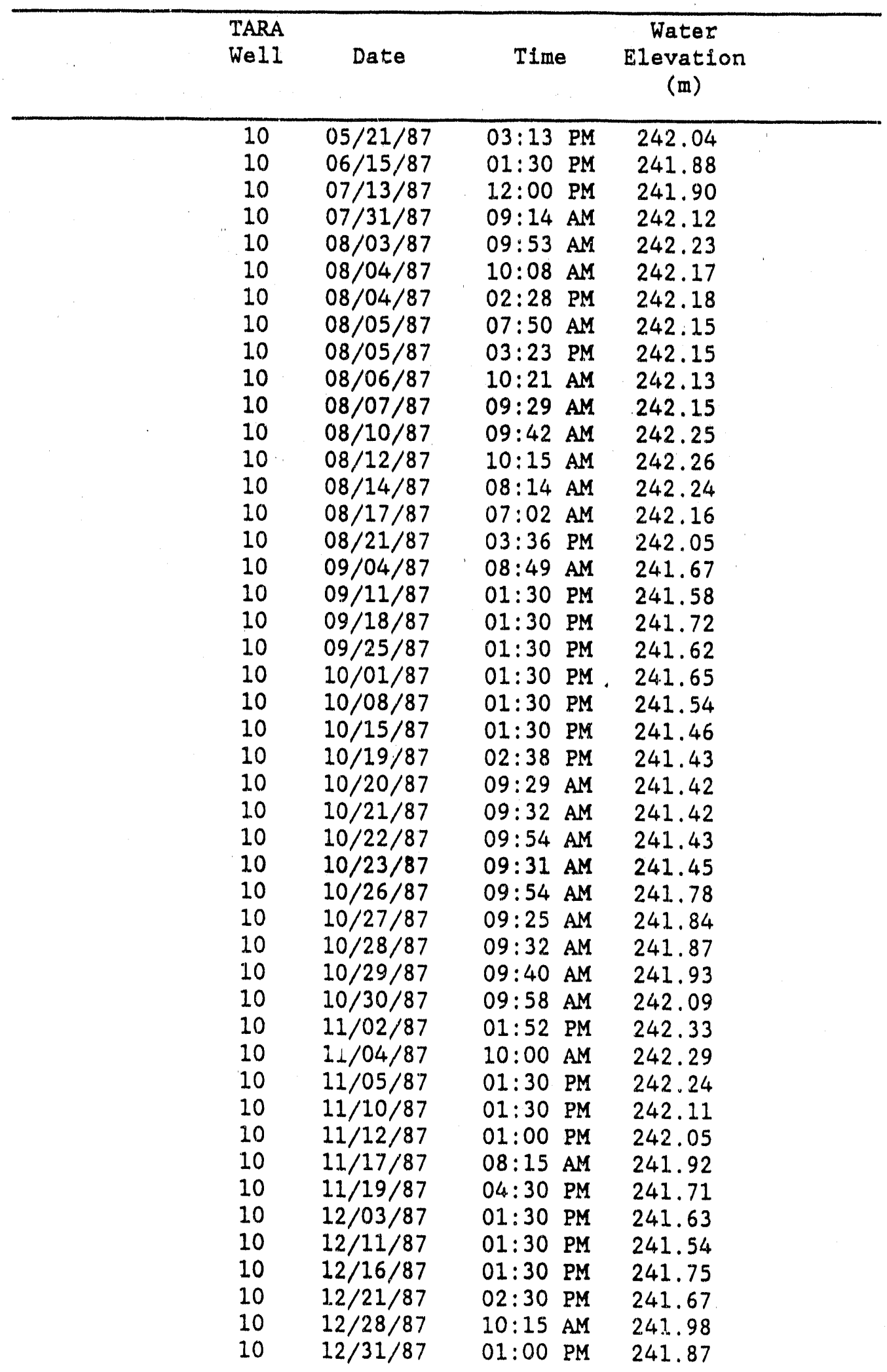


APPENDIX III

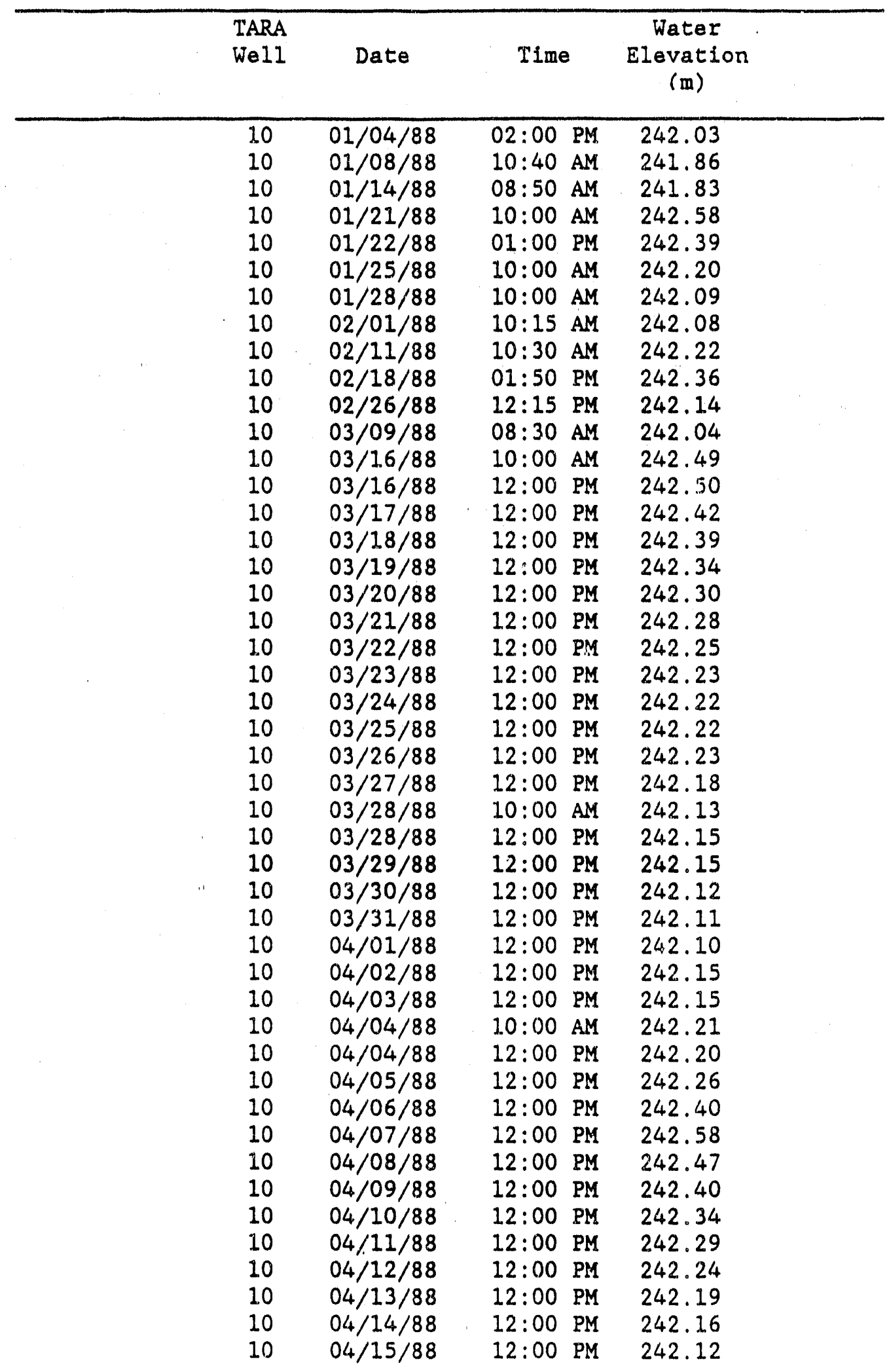


APPENDIX III

\begin{tabular}{|c|c|c|c|}
\hline $\begin{array}{l}\text { TARA } \\
\text { WeII }\end{array}$ & Date & Time & $\begin{array}{c}\text { Water } \\
\text { Elevation } \\
\text { (m) }\end{array}$ \\
\hline 10 & $04 / 16 / 88$ & $12: 00 \mathrm{PM}$ & 242.12 \\
\hline 10 & $04 / 17 / 88$ & $12: 00 \mathrm{PM}$ & 242.10 \\
\hline 10 & $04 / 18 / 88$ & $12: 00 \mathrm{PM}$ & 242.30 \\
\hline 10 & $04 / 19 / 88$ & $12: 00 \mathrm{PM}$ & 242.64 \\
\hline 10 & $04 / 20 / 88$ & $12: 00 \mathrm{PM}$ & 242.61 \\
\hline 10 & $04 / 21 / 88$ & $12: 00 \mathrm{PM}$ & 242.51 \\
\hline 10 & $04 / 22 / 88$ & $12: 00 \mathrm{PM}$ & 242.42 \\
\hline 10 & $04 / 23 / 88$ & $12: 00 \mathrm{PM}$ & 242.31 \\
\hline 10 & $04 / 24 / 88$ & $12: 00 \mathrm{PM}$ & 242.25 \\
\hline 10 & $04 / 25 / 88$ & $12: 00 \mathrm{PM}$ & 242.21 \\
\hline 10 & $04 / 26 / 88$ & 12:00 PM & 242.18 \\
\hline 10 & $04 / 27 / 88$ & $12: 00 \mathrm{PM}$ & 242.13 \\
\hline 10 & $04 / 28 / 88$ & $12: 00 \mathrm{PM}$ & 242.11 \\
\hline 10 & $04 / 29 / 88$ & $12: 00 \mathrm{PM}$ & 242.08 \\
\hline 10 & $04 / 30 / 88$ & $12: 00 \mathrm{PM}$ & 242.06 \\
\hline 10 & $05 / 01 / 88$ & $12: 00 \mathrm{PM}$ & 242.05 \\
\hline 10 & $05 / 02 / 88$ & $12: 00 \mathrm{PM}$ & 242.03 \\
\hline 10 & $05 / 03 / 88$ & $10: 00 \mathrm{AM}$ & 242.02 \\
\hline 10 & $05 / 03 / 88$ & $12: 00 \mathrm{PM}$ & 242.02 \\
\hline 10 & $05 / 04 / 88$ & $12: 00 \mathrm{PM}$ & 242.08 \\
\hline 10 & $05 / 05 / 88$ & $12: 00 \mathrm{PM}$ & 242.08 \\
\hline 10 & $05 / 06 / 88$ & $12: 00 \mathrm{PM}$ & 242.05 \\
\hline 10 & $05 / 07 / 88$ & $12: 00 \mathrm{PM}$ & 242.02 \\
\hline 10 & $05 / 08 / 88$ & $12: 00 \mathrm{PM}$ & 241.99 \\
\hline 10 & $05 / 09 / 88$ & $12: 00 \mathrm{PM}$ & 242.05 \\
\hline 10 & $05 / 10 / 88$ & $12: 00 \mathrm{PM}$ & 242.04 \\
\hline 10 & $05 / 11 / 88$ & 12:00 PM & 242.01 \\
\hline 10 & $05 / 12 / 88$ & $10: 00 \mathrm{AM}$ & 241.97 \\
\hline 10 & $05 / 12 / 88$ & $12: 00 \mathrm{PM}$ & 241.98 \\
\hline 10 & $05 / 13 / 88$ & $12: 00 \mathrm{PM}$ & 241.96 \\
\hline 10 & $05 / 14 / 88$ & $12: 00 \quad \mathrm{PM}$ & 241.94 \\
\hline 10 & $05 / 15 / 88$ & $12: 00 \mathrm{PM}$ & 241.93 \\
\hline 10 & $05 / 16 / 88$ & $12: 00 \mathrm{PM}$ & 241.92 \\
\hline 10 & $05 / 17 / 88$ & $12: 00 \mathrm{PM}$ & 241.91 \\
\hline 10 & $05 / 18 / 88$ & 12:00 PM & 241.91 \\
\hline 10 & $05 / 19 / 88$ & $12: 00 \mathrm{PM}$ & 241.89 \\
\hline 10 & $05 / 20 / 88$ & $12: 00 \mathrm{PM}$ & 241.87 \\
\hline 10 & $05 / 20 / 88$ & $01: 30 \mathrm{PM}$ & 241.88 \\
\hline 10 & $05 / 21 / 88$ & $12: 00 \mathrm{PM}$ & 241.86 \\
\hline 10 & $05 / 22 / 88$ & $12: 00 \mathrm{PM}$ & 241.86 \\
\hline 10 & $05 / 23 / 88$ & $12: 00 \mathrm{PM}$ & 241.85 \\
\hline 10 & $05 / 24 / 88$ & $12: 00 \mathrm{PM}$ & 241.86 \\
\hline 10 & $05 / 25 / 88$ & $12: 00 \mathrm{PM}$ & 241.97 \\
\hline 10 & $05 / 26 / 88$ & $12: 00 \mathrm{PM}$ & 241.94 \\
\hline 10 & $05 / 26 / 88$ & $02: 15 \mathrm{PM}$ & 241.94 \\
\hline 10 & $05 / 27 / 88$ & $12: 00 \mathrm{PM}$ & 241.92 \\
\hline
\end{tabular}


APPENDIX III

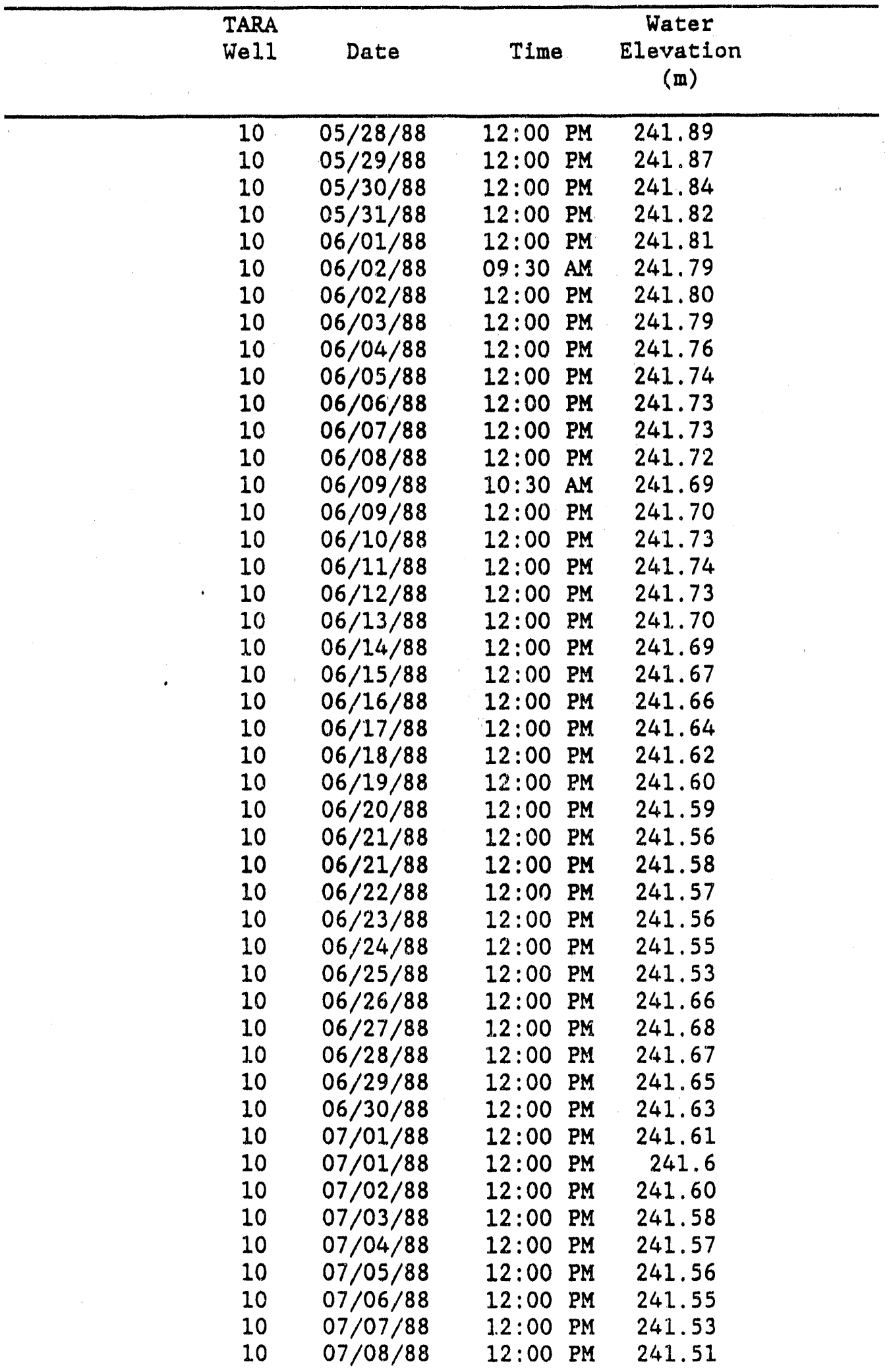


APPENDIX III

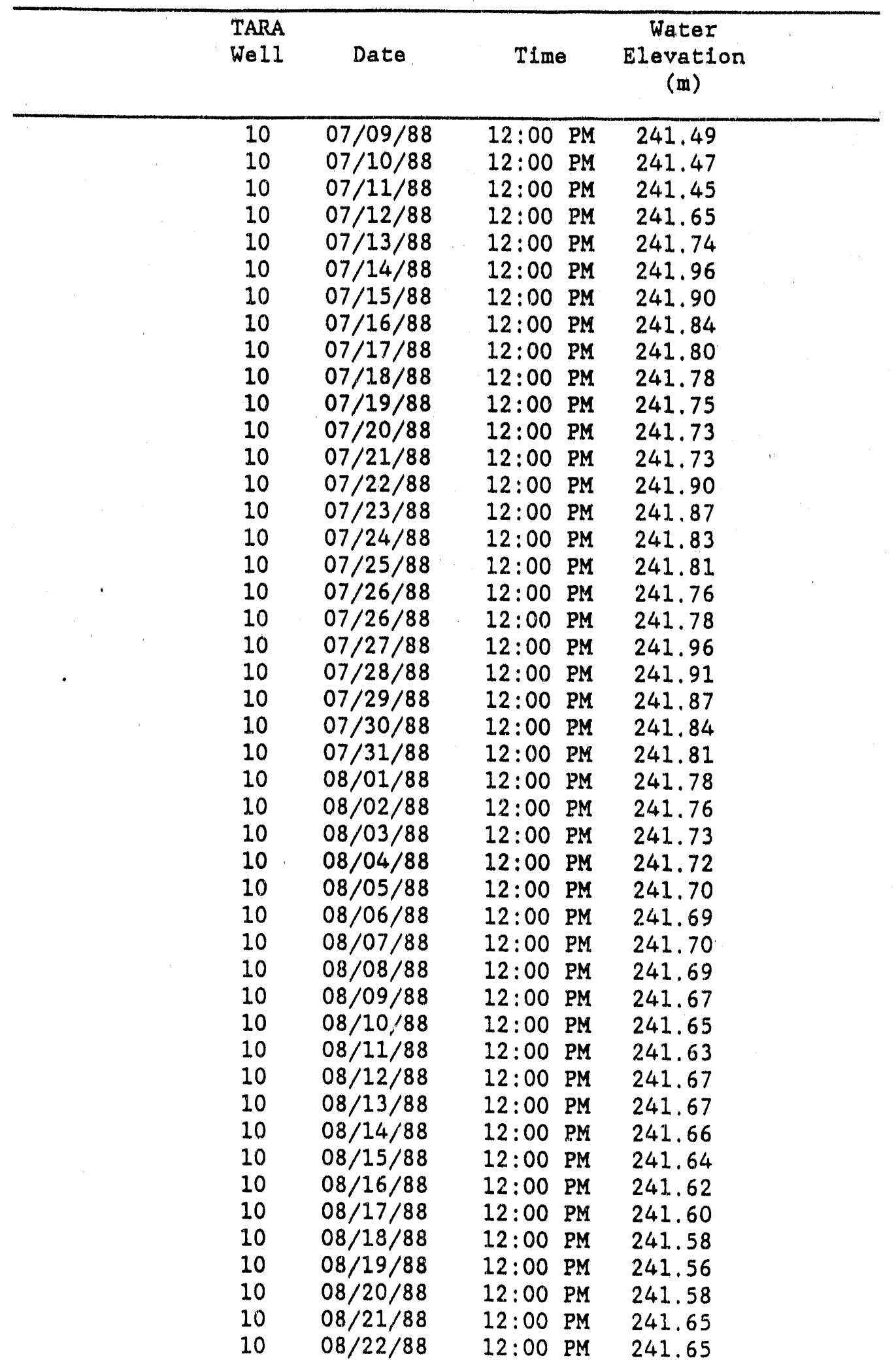


APPENDIX III

\begin{tabular}{ccccc}
\hline $\begin{array}{c}\text { TARA } \\
\text { Well }\end{array}$ & Date & Time & $\begin{array}{c}\text { Water } \\
\text { Elevation } \\
(\mathrm{m})\end{array}$ \\
\hline 10 & $08 / 23 / 88$ & $12: 00 \mathrm{PM}$ & 241.61
\end{tabular}


APPENDIX III

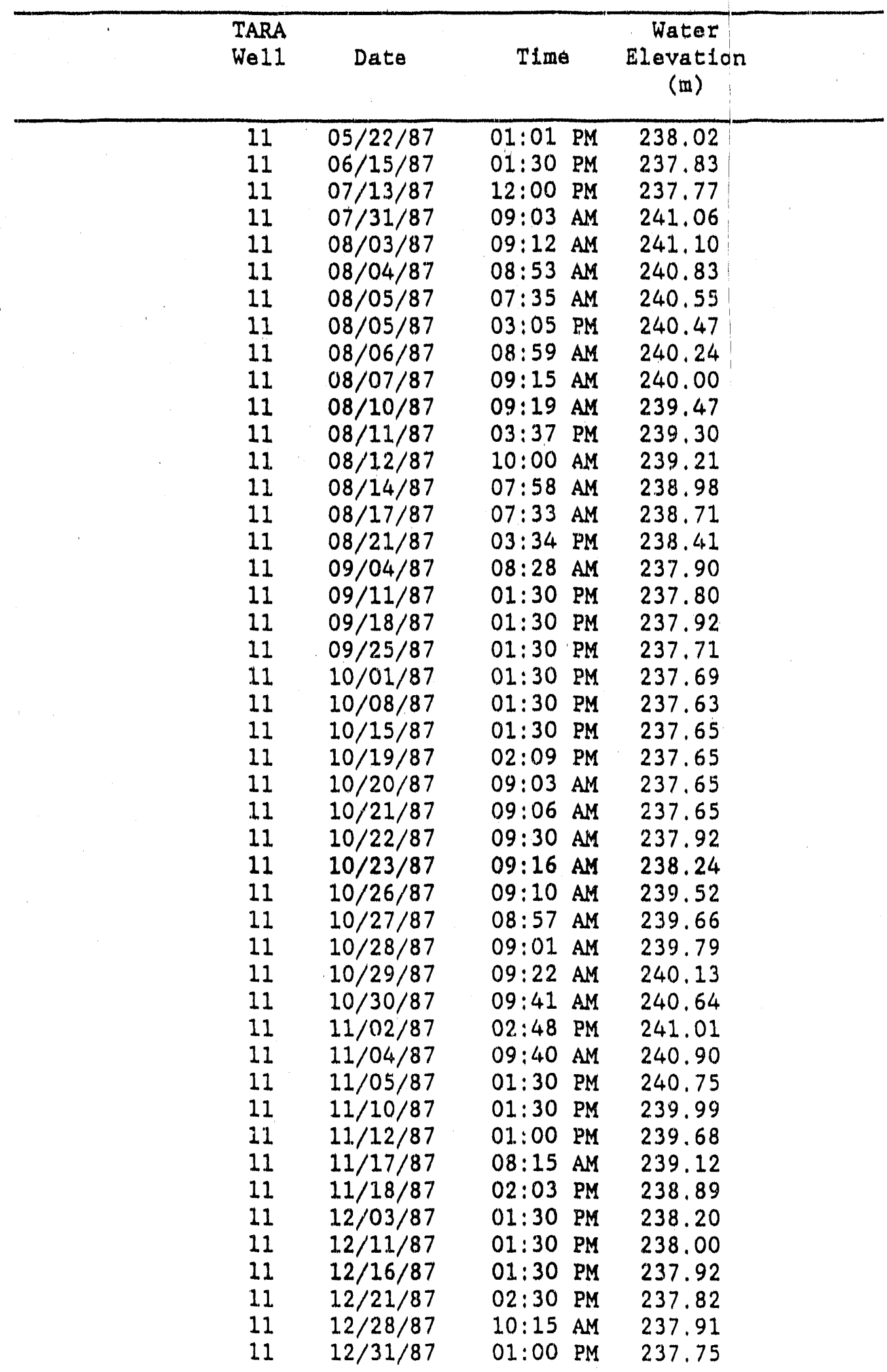


APPENDIX III

\begin{tabular}{|c|c|c|c|}
\hline $\begin{array}{l}\text { TARA } \\
\text { Woll }\end{array}$ & Date & Time & $\begin{array}{l}\text { Water } \\
\text { Elevation } \\
\text { (m) }\end{array}$ \\
\hline $\begin{array}{l}11 \\
11 \\
11 \\
11 \\
11 \\
11 \\
11 \\
11 \\
11 \\
11 \\
11 \\
11 \\
11 \\
11 \\
11 \\
11 \\
11 \\
11 \\
11 \\
11 \\
11 \\
11 \\
11 \\
11 \\
11 \\
11 \\
11 \\
11 \\
11 \\
11 \\
11 \\
11 \\
11 \\
11 \\
11 \\
11 \\
11 \\
11 \\
11 \\
11 \\
11 \\
11 \\
11 \\
11 \\
11 \\
11\end{array}$ & $\begin{array}{l}01 / 04 / 88 \\
01 / 08 / 88 \\
01 / 14 / 88 \\
01 / 21 / 88 \\
01 / 22 / 88 \\
01 / 25 / 88 \\
01 / 28 / 88 \\
02 / 01 / 88 \\
02 / 11 / 88 \\
02 / 18 / 88 \\
02 / 26 / 88 \\
03 / 03 / 88 \\
03 / 09 / 88 \\
03 / 16 / 88 \\
03 / 16 / 88 \\
03 / 17 / 88 \\
03 / 18 / 88 \\
03 / 19 / 88 \\
03 / 20 / 88 \\
03 / 21 / 88 \\
03 / 22 / 88 \\
03 / 23 / 88 \\
03 / 24 / 88 \\
03 / 25 / 88 \\
03 / 26 / 88 \\
03 / 27 / 88 \\
03 / 28 / 88 \\
03 / 28 / 88 \\
03 / 29 / 88 \\
03 / 30 / 88 \\
03 / 31 / 88 \\
04 / 01 / 88 \\
04 / 02 / 88 \\
04 / 03 / 88 \\
04 / 04 / 88 \\
04 / 04 / 88 \\
04 / 05 / 88 \\
04 / 06 / 88 \\
04 / 07 / 88 \\
04 / 08 / 88 \\
04 / 09 / 88 \\
04 / 10 / 88 \\
04 / 11 / 88 \\
04 / 12 / 88 \\
04 / 13 / 88 \\
04 / 14 / 88\end{array}$ & 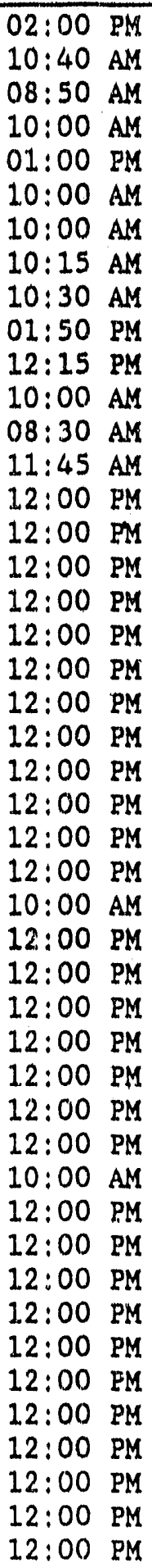 & $\begin{array}{l}237.73 \\
237.73 \\
237.76 \\
238.00 \\
238.27 \\
238.21 \\
238.55 \\
238.51 \\
238.34 \\
238.29 \\
238.25 \\
238.07 \\
238.02 \\
238.18 \\
238.15 \\
238.18 \\
238.22 \\
238.24 \\
238.25 \\
238.26 \\
238.25 \\
238.2 .4 \\
238.23 \\
238.23 \\
238.23 \\
238.19 \\
238.19 \\
238.17 \\
238.15 \\
238.13 \\
238.11 \\
238.09 \\
238.07 \\
238.07 \\
238.08 \\
238.05 \\
238.03 \\
238.02 \\
238.02 \\
237.99 \\
237.98 \\
237.97 \\
237.98 \\
237.95 \\
237.93 \\
237.91\end{array}$ \\
\hline
\end{tabular}


APPENDIX III

\begin{tabular}{|c|c|c|c|}
\hline $\begin{array}{l}\text { TARA } \\
\text { We11 }\end{array}$ & Date & Time & $\begin{array}{c}\text { Water } \\
\text { Elevation } \\
\text { (m) }\end{array}$ \\
\hline $\begin{array}{l}11 \\
11 \\
11 \\
11 \\
11 \\
11 \\
11 \\
11 \\
11 \\
11 \\
11 \\
11 \\
11 \\
11 \\
11 \\
11 \\
11 \\
11 \\
11 \\
11 \\
11 \\
11 \\
11 \\
11 \\
11 \\
11 \\
11 \\
11 \\
11 \\
11 \\
11 \\
11 \\
11 \\
11 \\
11 \\
11 \\
11 \\
11 \\
11 \\
11 \\
11 \\
11 \\
11 \\
11 \\
11 \\
11\end{array}$ & $\begin{array}{l}04 / 15 / 88 \\
04 / 16 / 88 \\
04 / 17 / 88 \\
04 / 18 / 88 \\
04 / 19 / 88 \\
04 / 20 / 88 \\
04 / 21 / 88 \\
04 / 22 / 88 \\
04 / 23 / 88 \\
04 / 24 / 88 \\
04 / 25 / 88 \\
04 / 26 / 88 \\
04 / 27 / 88 \\
04 / 28 / 88 \\
04 / 29 / 88 \\
04 / 30 / 88 \\
05 / 01 / 88 \\
05 / 02 / 88 \\
05 / 03 / 88 \\
05 / 03 / 88 \\
05 / 04 / 88 \\
05 / 05 / 88 \\
05 / 06 / 88 \\
05 / 07 / 88 \\
05 / 08 / 88 \\
05 / 09 / 88 \\
05 / 10 / 88 \\
05 / 11 / 88 \\
05 / 12 / 88 \\
05 / 12 / 88 \\
05 / 13 / 88 \\
05 / 14 / 88 \\
05 / 15 / 88 \\
05 / 16 / 88 \\
05 / 17 / 88 \\
05 / 18 / 88 \\
05 / 19 / 88 \\
05 / 20 / 88 \\
05 / 20 / 88 \\
05 / 21 / 88 \\
05 / 22 / 88 \\
05 / 23 / 88 \\
05 / 24 / 88 \\
05 / 25 / 88 \\
05 / 26 / 88 \\
05 / 26 / 88\end{array}$ & 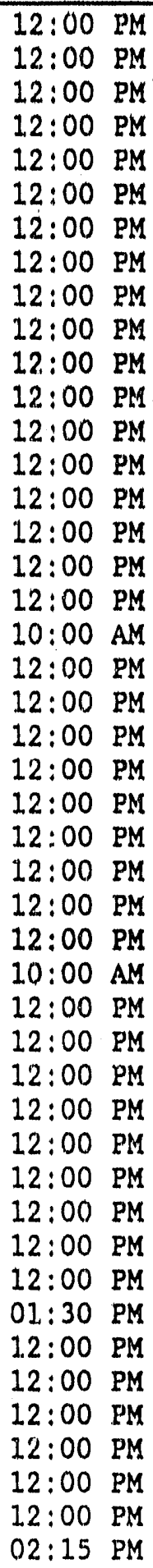 & $\begin{array}{l}237.89 \\
237.87 \\
237.87 \\
237.88 \\
237.87 \\
237.87 \\
237.87 \\
237.88 \\
237.86 \\
237.85 \\
237.85 \\
237.84 \\
237.83 \\
237.82 \\
237.81 \\
237.80 \\
237.80 \\
237.79 \\
237.83 \\
237.79 \\
237.80 \\
237.79 \\
237.79 \\
237.78 \\
237.78 \\
237.78 \\
237.77 \\
237.77 \\
237.80 \\
237.76 \\
237.76 \\
237.75 \\
237.75 \\
237.75 \\
237.75 \\
237.76 \\
237.74 \\
237.74 \\
237.78 \\
237.74 \\
237.74 \\
237.73 \\
237.73 \\
237.72 \\
237.71 \\
237.75\end{array}$ \\
\hline
\end{tabular}


APPENDIX III

\begin{tabular}{|c|c|c|c|}
\hline $\begin{array}{l}\text { TARA } \\
\text { WeII }\end{array}$ & Date & Time & $\begin{array}{l}\text { Water } \\
\text { Elevation } \\
\text { (m) }\end{array}$ \\
\hline $\begin{array}{l}11 \\
11 \\
11 \\
11 \\
11 \\
11 \\
11 \\
11 \\
11 \\
11 \\
11 \\
11 \\
11 \\
11 \\
11 \\
11 \\
11 \\
11 \\
11 \\
11 \\
11 \\
11 \\
11 \\
11 \\
11 \\
11 \\
11 \\
11 \\
11 \\
11 \\
11 \\
11 \\
11 \\
11 \\
11 \\
11 \\
11 \\
11 \\
11 \\
11 \\
11 \\
11 \\
11 \\
11 \\
11 \\
11\end{array}$ & $\begin{array}{l}05 / 27 / 88 \\
05 / 28 / 88 \\
05 / 29 / 88 \\
05 / 30 / 88 \\
05 / 31 / 88 \\
06 / 01 / 88 \\
06 / 02 / 88 \\
06 / 02 / 88 \\
06 / 03 / 88 \\
06 / 04 / 88 \\
06 / 05 / 88 \\
06 / 06 / 88 \\
06 / 07 / 88 \\
06 / 08 / 88 \\
06 / 09 / 88 \\
06 / 09 / 88 \\
06 / 10 / 88 \\
06 / 11 / 88 \\
06 / 12 / 88 \\
06 / 13 / 88 \\
06 / 14 / 88 \\
06 / 15 / 88 \\
06 / 16 / 88 \\
06 / 17 / 88 \\
06 / 18 / 88 \\
06 / 19 / 88 \\
06 / 20 / 88 \\
06 / 21 / 88 \\
06 / 21 / 88 \\
06 / 22 / 88 \\
06 / 23 / 88 \\
06 / 24 / 88 \\
06 / 25 / 88 \\
06 / 26 / 88 \\
06 / 27 / 88 \\
06 / 28 / 88 \\
06 / 29 / 88 \\
06 / 30 / 88 \\
07 / 01 / 88 \\
07 / 01 / 88 \\
07 / 02 / 88 \\
07 / 03 / 88 \\
07 / 04 / 88 \\
07 / 05 / 88 \\
07 / 06 / 88 \\
07 / 07 / 88\end{array}$ & 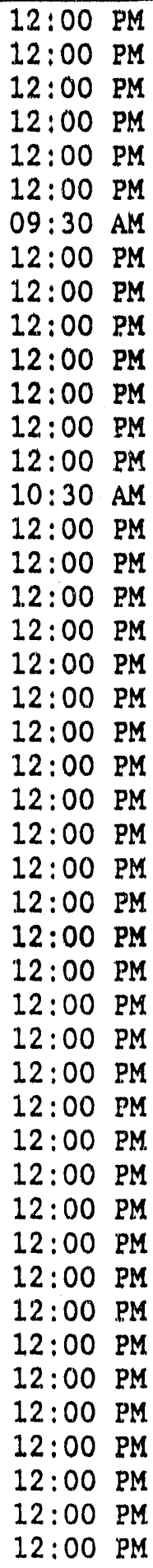 & $\begin{array}{l}237.71 \\
237.71 \\
237.71 \\
237.70 \\
237.70 \\
237.70 \\
237.73 \\
237.70 \\
237.70 \\
237.69 \\
237.69 \\
237.69 \\
237.69 \\
237.69 \\
237.65 \\
237.69 \\
237.67 \\
237.67 \\
237.67 \\
237.67 \\
237.66 \\
237.66 \\
237.66 \\
237.66 \\
237.66 \\
237.65 \\
237.65 \\
237.68 \\
237.65 \\
237.65 \\
237.65 \\
237.64 \\
237.64 \\
237.64 \\
237.64 \\
237.64 \\
237.64 \\
237.64 \\
237.66 \\
237.63 \\
237.63 \\
237.63 \\
237.63 \\
237.63 \\
237.63 \\
237.63\end{array}$ \\
\hline
\end{tabular}


APPENDIX III

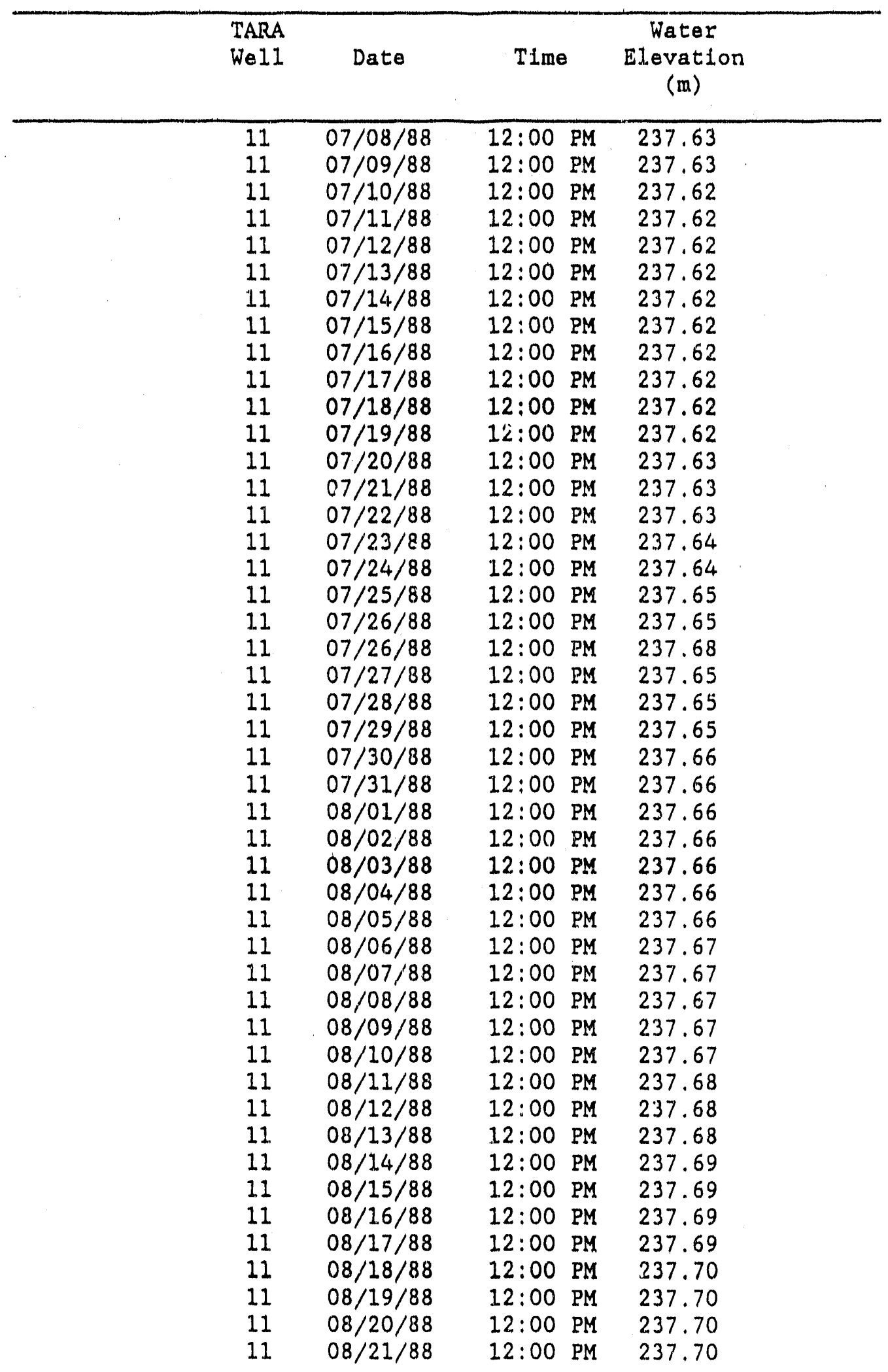


APPENDIX III

\begin{tabular}{ccccc}
\hline & $\begin{array}{c}\text { TARA } \\
\text { Well }\end{array}$ & Date & Tine & $\begin{array}{c}\text { Water } \\
\text { Elevation } \\
(\mathrm{m})\end{array}$ \\
\hline 11 & $08 / 22 / 88$ & $12: 00 \mathrm{PM}$ & 237.70 \\
11 & $08 / 23 / 88$ & $12: 00 \mathrm{PM}$ & 237.72
\end{tabular}


APPENDIX III

\begin{tabular}{|c|c|c|c|}
\hline $\begin{array}{l}\text { TARA } \\
\text { We1I }\end{array}$ & Date & Time & $\begin{array}{c}\text { Water } \\
\text { Elevation } \\
\text { (m) }\end{array}$ \\
\hline $\begin{array}{l}12 \\
12 \\
12 \\
12 \\
12 \\
12 \\
12 \\
12 \\
12 \\
12 \\
12 \\
12 \\
12 \\
12 \\
12 \\
12 \\
12 \\
12 \\
12 \\
12 \\
12 \\
12 \\
12 \\
12 \\
12 \\
12 \\
12 \\
12 \\
12 \\
12 \\
12 \\
12 \\
12 \\
12 \\
12 \\
12 \\
12 \\
12 \\
12 \\
12 \\
12 \\
12 \\
12 \\
12 \\
12 \\
12\end{array}$ & $\begin{array}{l}05 / 22 / 87 \\
06 / 15 / 87 \\
07 / 13 / 87 \\
08 / 04 / 87 \\
08 / 04 / 87 \\
08 / 05 / 87 \\
08 / 05 / 87 \\
08 / 06 / 87 \\
08 / 07 / 87 \\
08 / 10 / 87 \\
08 / 11 / 87 \\
08 / 12 / 87 \\
08 / 14 / 87 \\
08 / 17 / 87 \\
08 / 21 / 87 \\
09 / 04 / 87 \\
09 / 11 / 87 \\
09 / 18 / 87 \\
09 / 25 / 87 \\
10 / 01 / 87 \\
10 / 08 / 87 \\
10 / 15 / 87 \\
10 / 19 / 87 \\
10 / 20 / 87 \\
10 / 21 / 87 \\
10 / 22 / 87 \\
10 / 23 / 87 \\
10 / 26 / 87 \\
10 / 27 / 87 \\
10 / 28 / 87 \\
10 / 29 / 87 \\
10 / 30 / 87 \\
11 / 02 / 87 \\
11 / 04 / 87 \\
11 / 05 / 87 \\
11 / 10 / 87 \\
11 / 12 / 87 \\
11 / 17 / 87 \\
11 / 18 / 87 \\
12 / 03 / 87 \\
12 / 11 / 87 \\
12 / 16 / 87 \\
12 / 21 / 87 \\
12 / 28 / 87 \\
12 / 31 / 87 \\
01 / 04 / 88\end{array}$ & 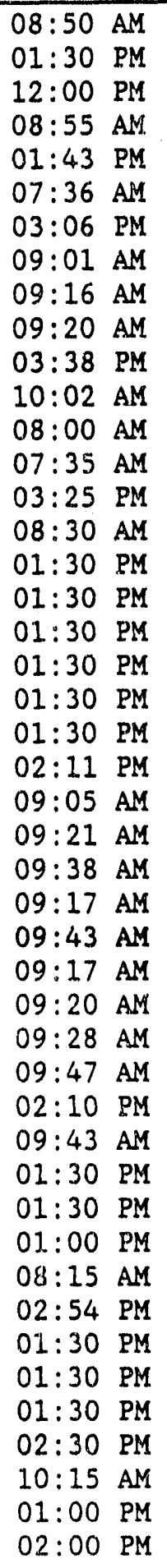 & $\begin{array}{l}235.60 \\
235.34 \\
235.20 \\
236.22 \\
236.22 \\
236.20 \\
236.23 \\
236.23 \\
236.32 \\
236.52 \\
236.54 \\
236.51 \\
236.46 \\
236.35 \\
236.14 \\
235.46 \\
235.24 \\
235.15 \\
235.03 \\
234.94 \\
234.90 \\
234.83 \\
234.78 \\
234.77 \\
234.78 \\
234.83 \\
234.92 \\
235.48 \\
235.60 \\
235.66 \\
235.73 \\
235.92 \\
236.31 \\
236.31 \\
236.27 \\
236.07 \\
235.89 \\
235.67 \\
235.57 \\
235.06 \\
234.89 \\
234.86 \\
234.82 \\
235.10 \\
235.00 \\
235.13\end{array}$ \\
\hline
\end{tabular}


APPENDIX III

\begin{tabular}{|c|c|c|c|}
\hline $\begin{array}{l}\text { TARA } \\
\text { Well }\end{array}$ & Date & Time & $\begin{array}{c}\text { Water } \\
\text { Elevation } \\
\text { (m) }\end{array}$ \\
\hline $\begin{array}{l}12 \\
12 \\
12 \\
12 \\
12 \\
12 \\
12 \\
12 \\
12 \\
12 \\
12 \\
12 \\
12 \\
12 \\
12 \\
12 \\
12 \\
12 \\
12 \\
12 \\
12 \\
12 \\
12 \\
12 \\
12 \\
12 \\
12 \\
12 \\
12 \\
12 \\
12 \\
12 \\
12 \\
12 \\
12 \\
12 \\
12 \\
12 \\
12 \\
12 \\
12 \\
12 \\
12 \\
12 \\
12 \\
12\end{array}$ & $\begin{array}{l}01 / 08 / 88 \\
01 / 14 / 88 \\
01 / 21 / 88 \\
01 / 22 / 88 \\
01 / 25 / 88 \\
01 / 28 / 88 \\
02 / 01 / 88 \\
02 / 11 / 88 \\
02 / 18 / 88 \\
02 / 26 / 88 \\
03 / 03 / 88 \\
03 / 09 / 88 \\
03 / 16 / 88 \\
03 / 16 / 88 \\
03 / 17 / 88 \\
03 / 18 / 88 \\
03 / 19 / 88 \\
03 / 20 / 88 \\
03 / 21 / 88 \\
03 / 22 / 88 \\
03 / 23 / 88 \\
03 / 24 / 88 \\
03 / 25 / 88 \\
03 / 26 / 88 \\
03 / 27 / 88 \\
03 / 28 / 88 \\
03 / 28 / 88 \\
03 / 29 / 88 \\
03 / 30 / 88 \\
03 / 31 / 88 \\
04 / 01 / 88 \\
04 / 02 / 88 \\
04 / 03 / 88 \\
04 / 04 / 88 \\
04 / 04 / 88 \\
04 / 05 / 88 \\
04 / 06 / 88 \\
04 / 07 / 88 \\
04 / 08 / 88 \\
04 / 09 / 88 \\
04 / 10 / 88 \\
04 / 11 / 88 \\
04 / 12 / 88 \\
04 / 13 / 88 \\
04 / 14 / 88 \\
04 / 15 / 88\end{array}$ & 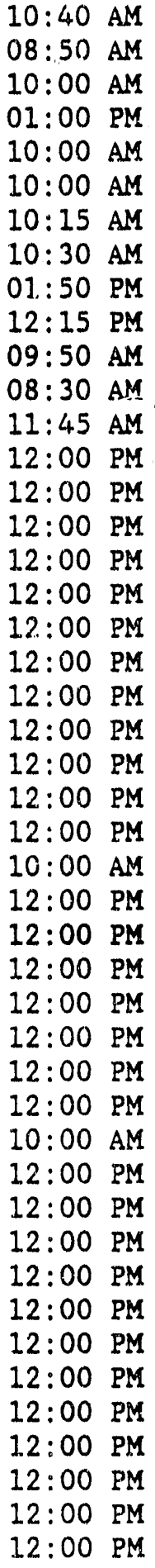 & $\begin{array}{l}234.97 \\
234.93 \\
235.61 \\
235.50 \\
235.51 \\
235.50 \\
235.46 \\
235.67 \\
235.69 \\
235.52 \\
235.42 \\
235.38 \\
235.89 \\
235.86 \\
235.84 \\
235.85 \\
235.81 \\
235.80 \\
235.79 \\
235.75 \\
235.75 \\
235.73 \\
235.73 \\
235.77 \\
235.68 \\
235.68 \\
235.67 \\
235.66 \\
235.60 \\
235.59 \\
235.56 \\
235.60 \\
235.59 \\
235.65 \\
235.61 \\
235.57 \\
235.72 \\
235.80 \\
235.74 \\
235.73 \\
235.69 \\
235.69 \\
235.63 \\
235.60 \\
235.58 \\
235.53\end{array}$ \\
\hline
\end{tabular}


APPENDIX III

\begin{tabular}{|c|c|c|c|}
\hline $\begin{array}{l}\text { TARA } \\
\text { We11 }\end{array}$ & Date & Time & $\begin{array}{l}\text { Water } \\
\text { Elevation } \\
\text { (m) }\end{array}$ \\
\hline $\begin{array}{l}12 \\
12 \\
12 \\
12 \\
12 \\
12 \\
12 \\
12 \\
12 \\
12 \\
12 \\
12 \\
12 \\
12 \\
12 \\
12 \\
12 \\
12 \\
12 \\
12 \\
12 \\
12 \\
12 \\
12 \\
12 \\
12 \\
12 \\
12 \\
12 \\
12 \\
12 \\
12 \\
12 \\
12 \\
12 \\
12 \\
12 \\
12 \\
12 \\
12 \\
12 \\
12 \\
12 \\
12 \\
12 \\
12\end{array}$ & $\begin{array}{l}04 / 16 / 88 \\
04 / 17 / 88 \\
04 / 18 / 88 \\
04 / 19 / 88 \\
04 / 20 / 88 \\
04 / 21 / 88 \\
04 / 22 / 88 \\
04 / 23 / 88 \\
04 / 24 / 88 \\
04 / 25 / 88 \\
04 / 26 / 88 \\
04 / 27 / 88 \\
04 / 28 / 88 \\
04 / 29 / 88 \\
04 / 30 / 88 \\
05 / 01 / 88 \\
05 / 02 / 88 \\
05 / 03 / 88 \\
05 / 03 / 88 \\
05 / 04 / 88 \\
05 / 05 / 88 \\
05 / 06 / 88 \\
05 / 07 / 88 \\
05 / 08 / 88 \\
05 / 09 / 88 \\
05 / 10 / 88 \\
05 / 11 / 88 \\
05 / 12 / 88 \\
05 / 12 / 88 \\
05 / 13 / 88 \\
05 / 14 / 88 \\
05 / 15 / 88 \\
05 / 16 / 88 \\
05 / 17 / 88 \\
05 / 18 / 88 \\
05 / 19 / 88 \\
05 / 20 / 88 \\
05 / 20 / 88 \\
05 / 21 / 88 \\
05 / 22 / 88 \\
05 / 23 / 88 \\
05 / 24 / 88 \\
05 / 25 / 88 \\
05 / 26 / 88 \\
05 / 26 / 88 \\
05 / 27 / 88\end{array}$ & $\begin{array}{l}12: 00 \\
12: 00\end{array}$ & $\begin{array}{l}235.52 \\
235.51 \\
235.62 \\
235.81 \\
235.82 \\
235.80 \\
235.76 \\
235.71 \\
235.66 \\
235.65 \\
235.59 \\
235.55 \\
235.51 \\
235.48 \\
235.46 \\
235.44 \\
235.43 \\
235.46 \\
235.39 \\
235.45 \\
235.43 \\
235.39 \\
235.34 \\
235.34 \\
235.36 \\
235.33 \\
235.36 \\
235.34 \\
235.28 \\
235.27 \\
235.27 \\
235.24 \\
235.22 \\
235.21 \\
235.26 \\
235.22 \\
235.18 \\
235.22 \\
235.15 \\
235.14 \\
235.13 \\
235.14 \\
235.19 \\
235.16 \\
235.20 \\
235.13\end{array}$ \\
\hline
\end{tabular}


APPENDIX III

\begin{tabular}{|c|c|c|c|}
\hline $\begin{array}{l}\text { TARA } \\
\text { Wel1 }\end{array}$ & Date ${ }^{\circ}$ & Time & $\begin{array}{l}\text { Water } \\
\text { Elevation } \\
\text { (m) }\end{array}$ \\
\hline $\begin{array}{l}12 \\
12 \\
12 \\
12 \\
12 \\
12 \\
12 \\
12 \\
12 \\
12 \\
12 \\
12 \\
12 \\
12 \\
12 \\
12 \\
12 \\
12 \\
12 \\
12 \\
12 \\
12 \\
12 \\
12 \\
12 \\
12 \\
12 \\
12 \\
12 \\
12 \\
12 \\
12 \\
12 \\
12 \\
12 \\
12 \\
12 \\
12 \\
12 \\
12 \\
12 \\
12 \\
12 \\
12 \\
12 \\
12\end{array}$ & $\begin{array}{l}05 / 28 / 88 \\
05 / 29 / 88 \\
05 / 30 / 88 \\
05 / 31 / 88 \\
06 / 01 / 88 \\
06 / 02 / 88 \\
06 / 02 / 88 \\
06 / 03 / 88 \\
06 / 04 / 88 \\
06 / 05 / 88 \\
06 / 06 / 88 \\
06 / 07 / 88 \\
06 / 08 / 88 \\
06 / 09 / 88 \\
06 / 09 / 88 \\
06 / 10 / 88 \\
06 / 11 / 88 \\
06 / 12 / 88 \\
06 / 13 / 88 \\
06 / 14 / 88 \\
06 / 15 / 88 \\
06 / 16 / 88 \\
06 / 17 / 88 \\
06 / 18 / 88 \\
06 / 19 / 88 \\
06 / 20 / 88 \\
06 / 21 / 88 \\
06 / 21 / 88 \\
06 / 22 / 88 \\
06 / 23 / 88 \\
06 / 24 / 88 \\
06 / 25 / 88 \\
06 / 26 / 88 \\
06 / 27 / 88 \\
06 / 28 / 88 \\
06 / 29 / 88 \\
06 / 30 / 88 \\
07 / 01 / 88 \\
07 / 01 / 88 \\
07 / 02 / 88 \\
07 / 03 / 88 \\
07 / 04 / 88 \\
07 / 05 / 88 \\
07 / 06 / 88 \\
07 / 07 / 88 \\
07 / 08 / 88\end{array}$ & 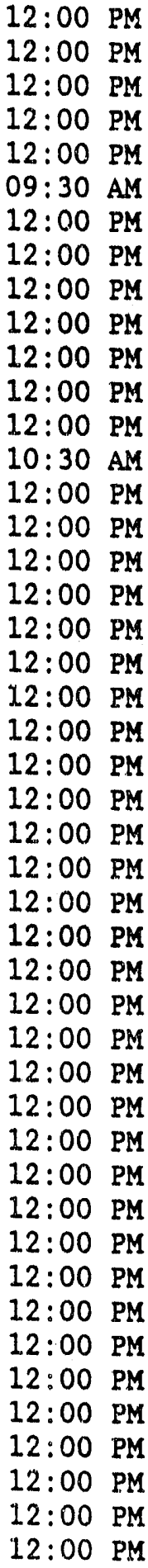 & $\begin{array}{l}235.11 \\
235.10 \\
235.08 \\
235.07 \\
235.07 \\
235.11 \\
235.06 \\
235.05 \\
235.03 \\
235.02 \\
235.02 \\
235.01 \\
235.00 \\
235.05 \\
235.00 \\
234.99 \\
234.98 \\
234.98 \\
234.97 \\
234.96 \\
234.94 \\
234.93 \\
234.92 \\
234.91 \\
234.89 \\
234.88 \\
234.94 \\
234.90 \\
234.89 \\
234.88 \\
234.86 \\
234.86 \\
234.94 \\
234.90 \\
234.87 \\
234.86 \\
234.85 \\
234.85 \\
234.88 \\
234.84 \\
234.84 \\
234.84 \\
234.81 \\
234.80 \\
234.80 \\
234.79\end{array}$ \\
\hline
\end{tabular}


APPENDIX III

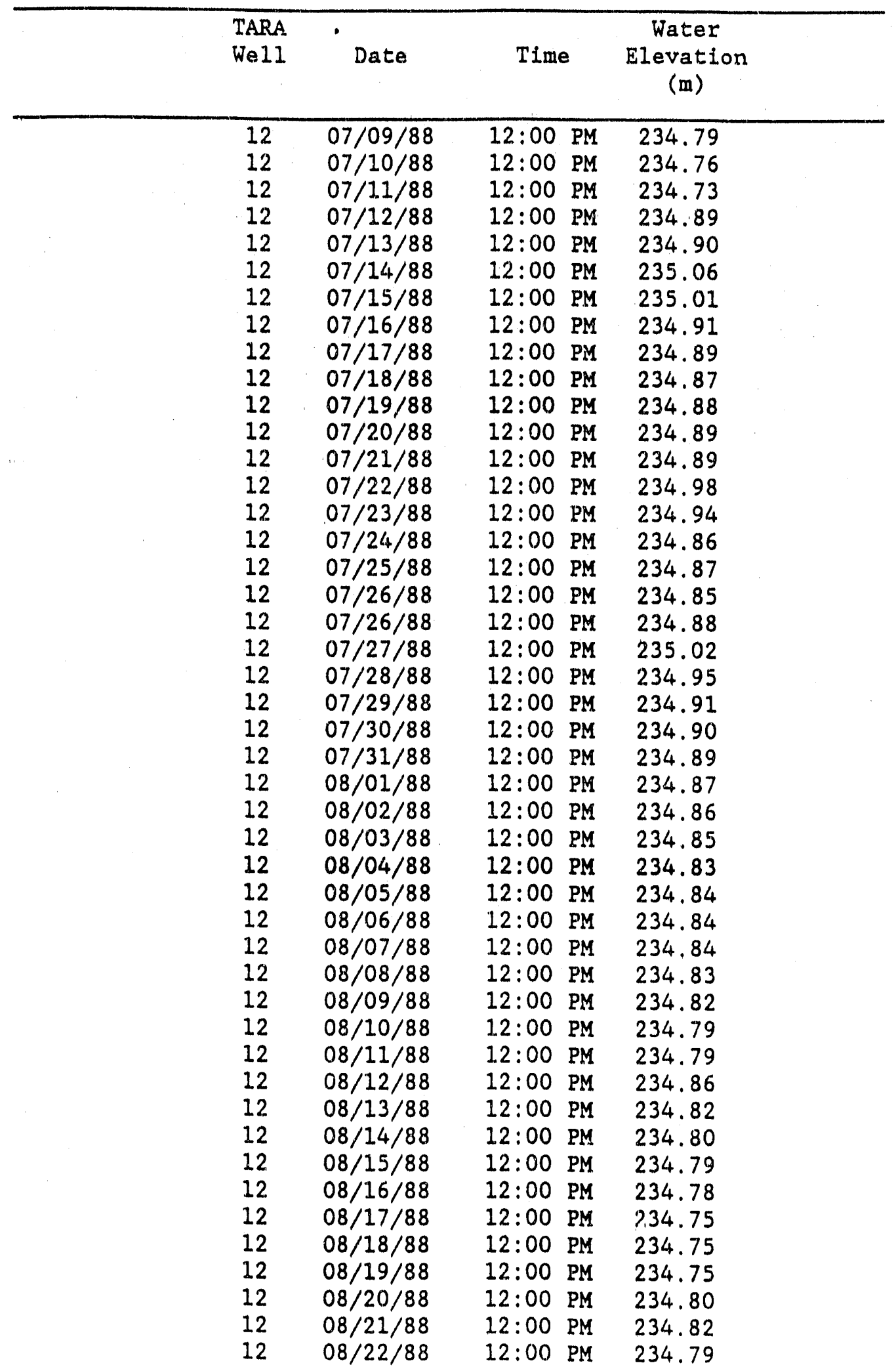


APPENDIX III

\begin{tabular}{cccc}
\hline $\begin{array}{c}\text { TARA } \\
\text { We11 }\end{array}$ & Date & Time & $\begin{array}{c}\text { Water } \\
\text { Elevation } \\
\text { (m) }\end{array}$ \\
\hline 12 & $08 / 23 / 88$ & $12: 00$ PM & 234.79
\end{tabular}


APPENDIX III

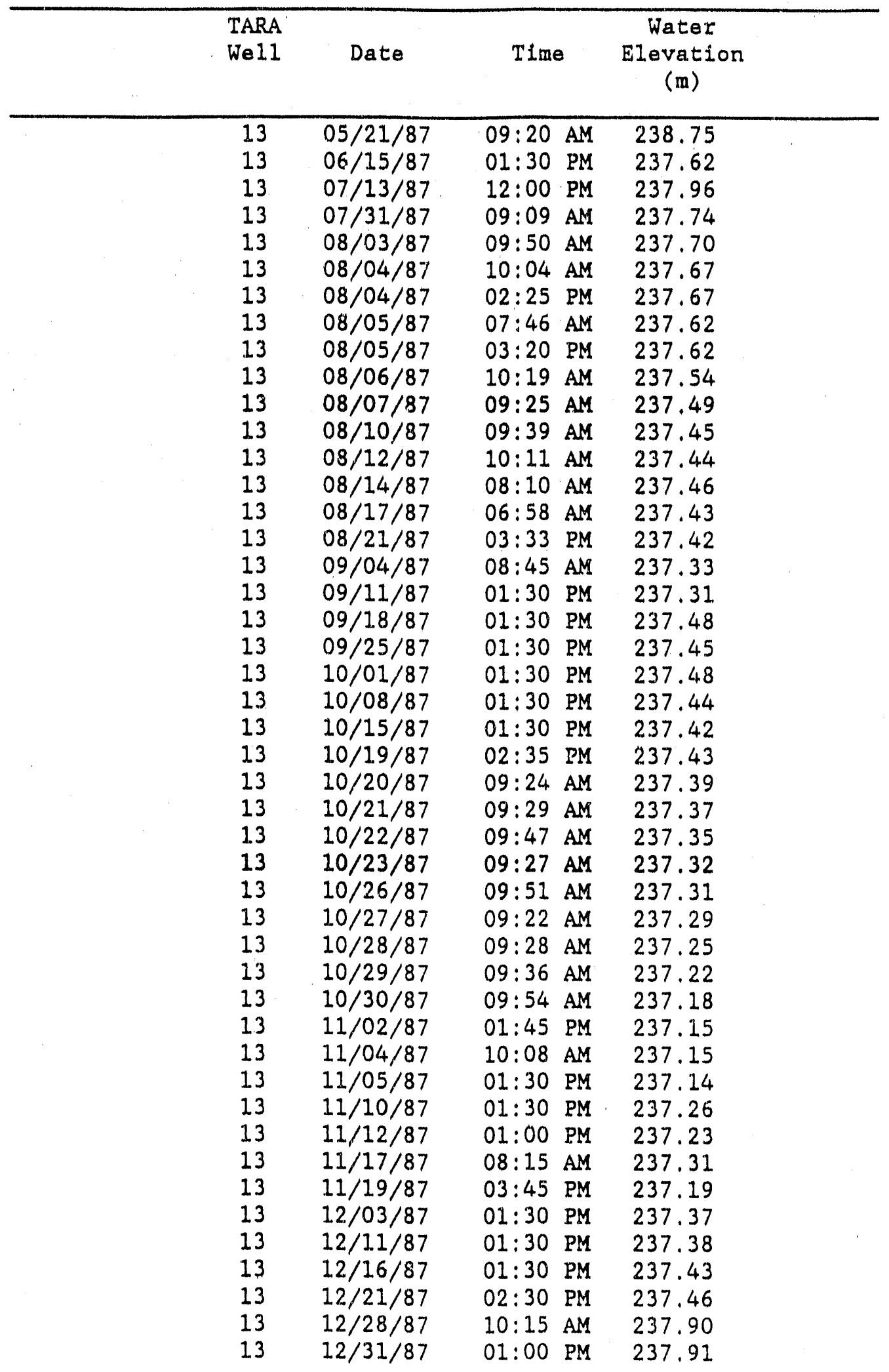


APPENDIX III

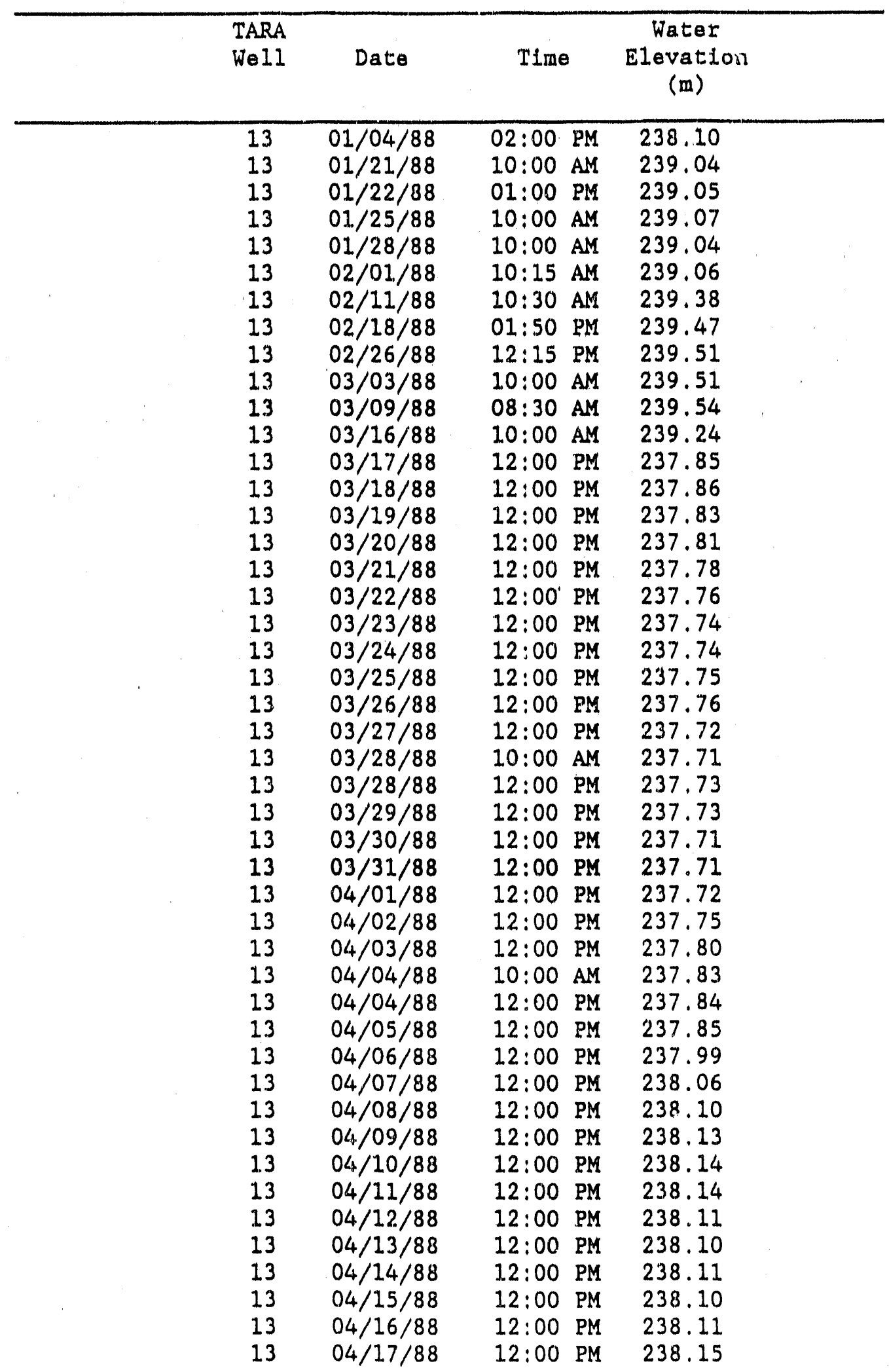


APPENDIX III

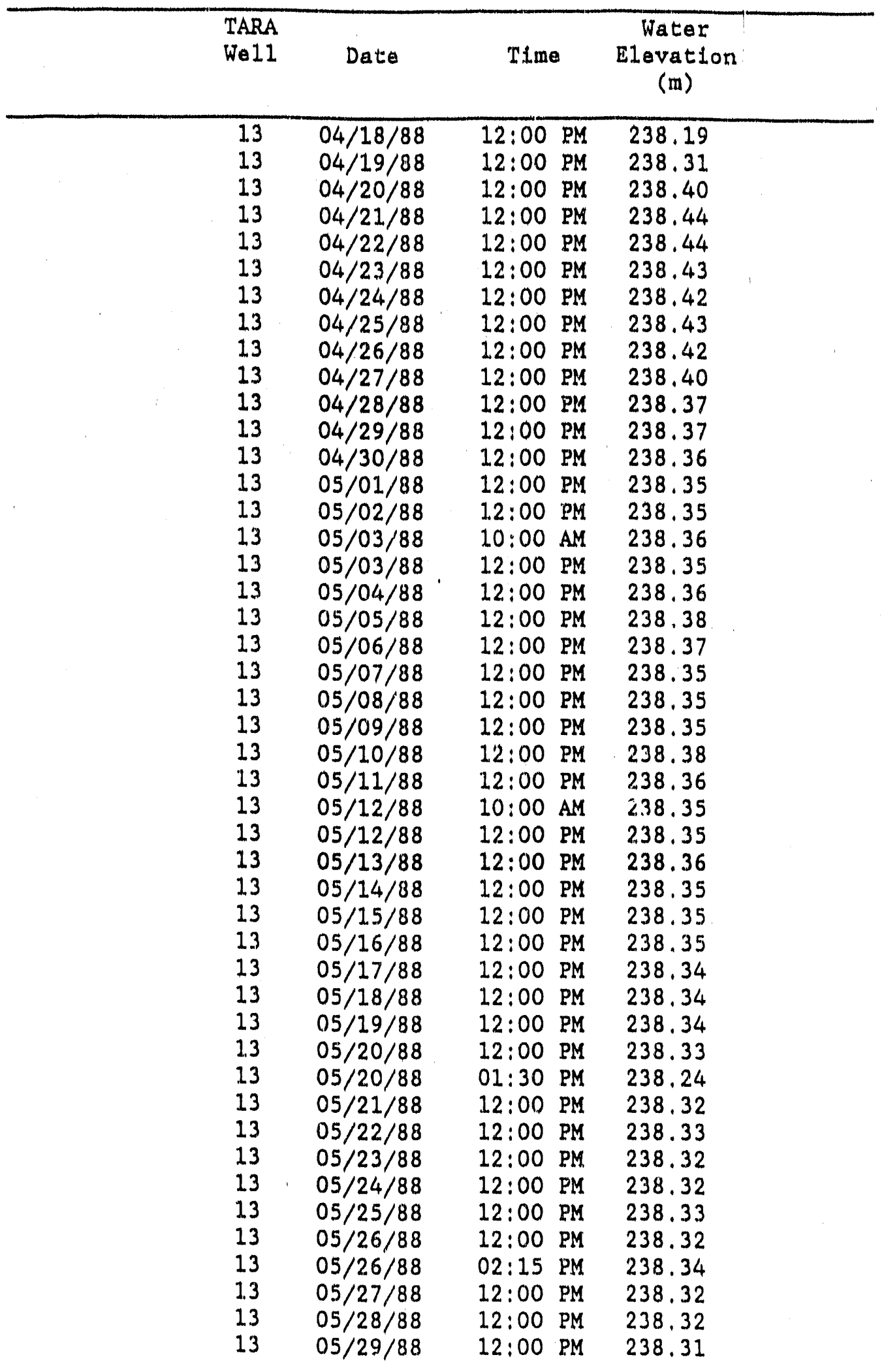


APPENDIX III

\begin{tabular}{|c|c|c|c|c|}
\hline & $\begin{array}{l}\text { TARA } \\
\text { WeI1 }\end{array}$ & Date & Time & $\begin{array}{l}\text { Water } \\
\text { Elevation } \\
\text { (m) }\end{array}$ \\
\hline . & $\begin{array}{l}13 \\
13 \\
13 \\
13 \\
13 \\
13 \\
13 \\
13 \\
13 \\
13 \\
13 \\
13 \\
13 \\
13 \\
13 \\
13 \\
13 \\
13 \\
13 \\
13 \\
13 \\
13 \\
13 \\
13 \\
13 \\
13 \\
13 \\
13 \\
13 \\
13 \\
13 \\
13\end{array}$ & $\begin{array}{l}05 / 30 / 88 \\
05 / 31 / 88 \\
06 / 01 / 88 \\
06 / 02 / 88 \\
06 / 02 / 88 \\
06 / 03 / 88 \\
06 / 04 / 88 \\
06 / 05 / 88 \\
06 / 06 / 88 \\
06 / 07 / 88 \\
06 / 08 / 88 \\
06 / 09 / 88 \\
06 / 09 / 88 \\
06 / 10 / 88 \\
06 / 11 / 88 \\
06 / 12 / 88 \\
06 / 13 / 88 \\
06 / 14 / 88 \\
06 / 15 / 88 \\
06 / 16 / 88 \\
06 / 17 / 88 \\
06 / 18 / 88 \\
06 / 19 / 88 \\
06 / 20 / 88 \\
06 / 21 / 88 \\
06 / 21 / 88 \\
06 / 23 / 80 \\
06 / 24 / 88 \\
06 / 25 / 88 \\
07 / 01 / 88 \\
07 / 26 / 88 \\
08 / 23 / 88\end{array}$ & 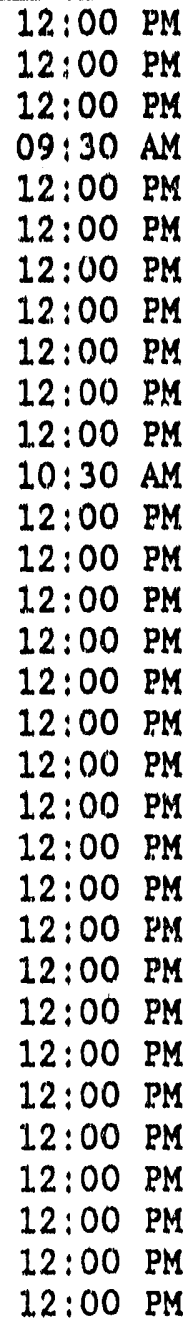 & $\begin{array}{l}238.30 \\
238.30 \\
238.31 \\
238.31 \\
238.30 \\
238.29 \\
238.27 \\
238.26 \\
238.27 \\
238.27 \\
238.27 \\
238.26 \\
238.25 \\
238.24 \\
238.24 \\
238.24 \\
238.22 \\
238.22 \\
238.22 \\
238.23 \\
238.22 \\
238.20 \\
238.19 \\
238.19 \\
238.20 \\
238.20 \\
238.18 \\
238.17 \\
238.17 \\
238.17 \\
238.43 \\
238.45\end{array}$ \\
\hline
\end{tabular}


APPENDIX III

\begin{tabular}{|c|c|c|c|c|}
\hline & $\begin{array}{l}\text { TARA } \\
\text { Wel1 }\end{array}$ & Date & Tlme & $\begin{array}{c}\text { Water } \\
\text { Elevation } \\
\text { (m) }\end{array}$ \\
\hline ' & $\begin{array}{l}367 \\
367 \\
367 \\
367 \\
367 \\
367 \\
367 \\
367 \\
367 \\
367 \\
367 \\
367 \\
367 \\
367 \\
367 \\
367 \\
367 \\
367 \\
367 \\
367 \\
367 \\
367 \\
367 \\
367 \\
367 \\
367 \\
367 \\
367 \\
367 \\
367 \\
367 \\
367 \\
367 \\
367 \\
367 \\
367 \\
367 \\
367 \\
367 \\
367 \\
367 \\
367 \\
367 \\
367 \\
367 \\
367\end{array}$ & $\begin{array}{l}06 / 03 / 87 \\
06 / 15 / 87 \\
07 / 13 / 87 \\
07 / 27 / 87 \\
07 / 27 / 87 \\
07 / 27 / 87 \\
07 / 27 / 87 \\
07 / 28 / 87 \\
07 / 28 / 87 \\
07 / 28 / 87 \\
07 / 28 / 87 \\
07 / 28 / 87 \\
07 / 28 / 87 \\
07 / 28 / 87 \\
07 / 29 / 87 \\
07 / 29 / 87 \\
07 / 30 / 87 \\
07 / 30 / 87 \\
07 / 31 / 87 \\
08 / 03 / 87 \\
08 / 04 / 87 \\
08 / 05 / 87 \\
08 / 05 / 87 \\
08 / 06 / 87 \\
08 / 07 / 87 \\
08 / 10 / 87 \\
08 / 12 / 87 \\
08 / 14 / 87 \\
08 / 17 / 87 \\
08 / 21 / 87 \\
09 / 04 / 87 \\
09 / 11 / 87 \\
09 / 18 / 87 \\
09 / 25 / 87 \\
10 / 01 / 87 \\
10 / 08 / 87 \\
10 / 15 / 87 \\
10 / 19 / 87 \\
10 / 20 / 87 \\
10 / 20 / 87 \\
10 / 21 / 87 \\
10 / 22 / 87 \\
10 / 23 / 87 \\
10 / 26 / 87 \\
10 / 28 / 87 \\
10 / 29 / 37\end{array}$ & 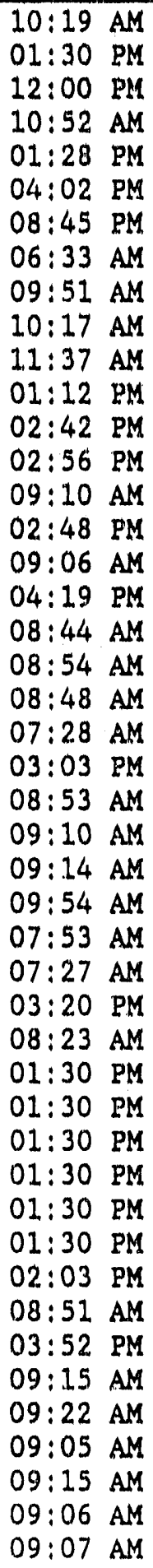 & $\begin{array}{l}240.19 \\
239.80 \\
239.69 \\
239.58 \\
239.58 \\
239.58 \\
239.58 \\
242.29 \\
243.14 \\
243.24 \\
243.55 \\
243.85 \\
244.18 \\
244.25 \\
245.94 \\
246.03 \\
245.97 \\
245.94 \\
245.99 \\
244.37 \\
243.62 \\
243.00 \\
242.82 \\
242.44 \\
242.01 \\
241.25 \\
240.91 \\
240.62 \\
240.28 \\
239.99 \\
239.63 \\
239.49 \\
239.41 \\
239.34 \\
239.29 \\
239.24 \\
239.19 \\
239.17 \\
239.16 \\
239.16 \\
239.32 \\
240.58 \\
241.65 \\
243.64 \\
245.09\end{array}$ \\
\hline
\end{tabular}


APPENDIX III

\begin{tabular}{|c|c|c|c|}
\hline $\begin{array}{l}\text { TARA } \\
\text { We11 }\end{array}$ & Date & Time & $\begin{array}{l}\text { Water } \\
\text { Elevation } \\
\text { (m) }\end{array}$ \\
\hline $\begin{array}{l}367 \\
367 \\
367 \\
367 \\
367 \\
367 \\
367 \\
367 \\
367 \\
367 \\
367 \\
367 \\
367 \\
367 \\
367 \\
367 \\
367 \\
367 \\
367 \\
367 \\
367 \\
367 \\
367 \\
367 \\
367 \\
367 \\
367 \\
367 \\
367 \\
367 \\
367 \\
367 \\
367 \\
367 \\
367 \\
367 \\
367 \\
367 \\
367 \\
367 \\
367 \\
367 \\
367 \\
367 \\
367 \\
367\end{array}$ & $\begin{array}{l}10 / 30 / 87 \\
11 / 02 / 87 \\
11 / 04 / 87 \\
11 / 05 / 87 \\
11 / 10 / 87 \\
11 / 12 / 87 \\
11 / 17 / 87 \\
11 / 18 / 87 \\
12 / 03 / 87 \\
12 / 11 / 87 \\
12 / 16 / 87 \\
12 / 21 / 87 \\
12 / 28 / 87 \\
12 / 31 / 87 \\
01 / 04 / 88 \\
01 / 08 / 88 \\
01 / 14 / 88 \\
01 / 21 / 88 \\
01 / 22 / 88 \\
01 / 25 / 88 \\
01 / 28 / 88 \\
02 / 01 / 88 \\
02 / 11 / 88 \\
02 / 18 / 88 \\
02 / 26 / 88 \\
03 / 03 / 88 \\
03 / 09 / 88 \\
03 / 16 / 88 \\
03 / 17 / 88 \\
03 / 18 / 88 \\
03 / 19 / 88 \\
03 / 20 / 88 \\
03 / 21 / 88 \\
03 / 22 / 88 \\
03 / 23 / 88 \\
03 / 24 / 88 \\
03 / 25 / 88 \\
03 / 26 / 88 \\
03 / 27 / 88 \\
03 / 28 / 88 \\
03 / 28 / 88 \\
03 / 29 / 88 \\
03 / 30 / 88 \\
03 / 31 / 88 \\
04 / 01 / 88 \\
04 / 02 / 88\end{array}$ & 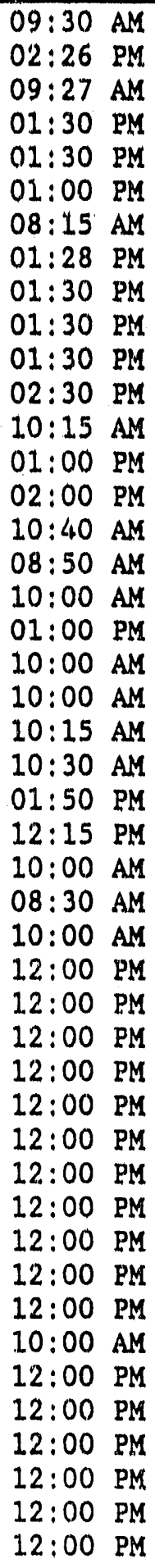 & $\begin{array}{l}245.79 \\
244.60 \\
243.96 \\
243.54 \\
242.06 \\
241.62 \\
240.94 \\
240.68 \\
239.93 \\
239.79 \\
239.69 \\
239.61 \\
239.54 \\
239.51 \\
239.51 \\
239.59 \\
239.77 \\
240.63 \\
241.01 \\
241.33 \\
241.21 \\
240.95 \\
240.68 \\
240.52 \\
240.24 \\
240.17 \\
240.09 \\
240.51 \\
240.44 \\
240.52 \\
240.55 \\
240.57 \\
240.56 \\
240.53 \\
240.51 \\
240.48 \\
240.48 \\
240.44 \\
240.40 \\
240.47 \\
240.34 \\
240.32 \\
240.26 \\
240.23 \\
240.20 \\
240.17\end{array}$ \\
\hline
\end{tabular}


APPENDIX III

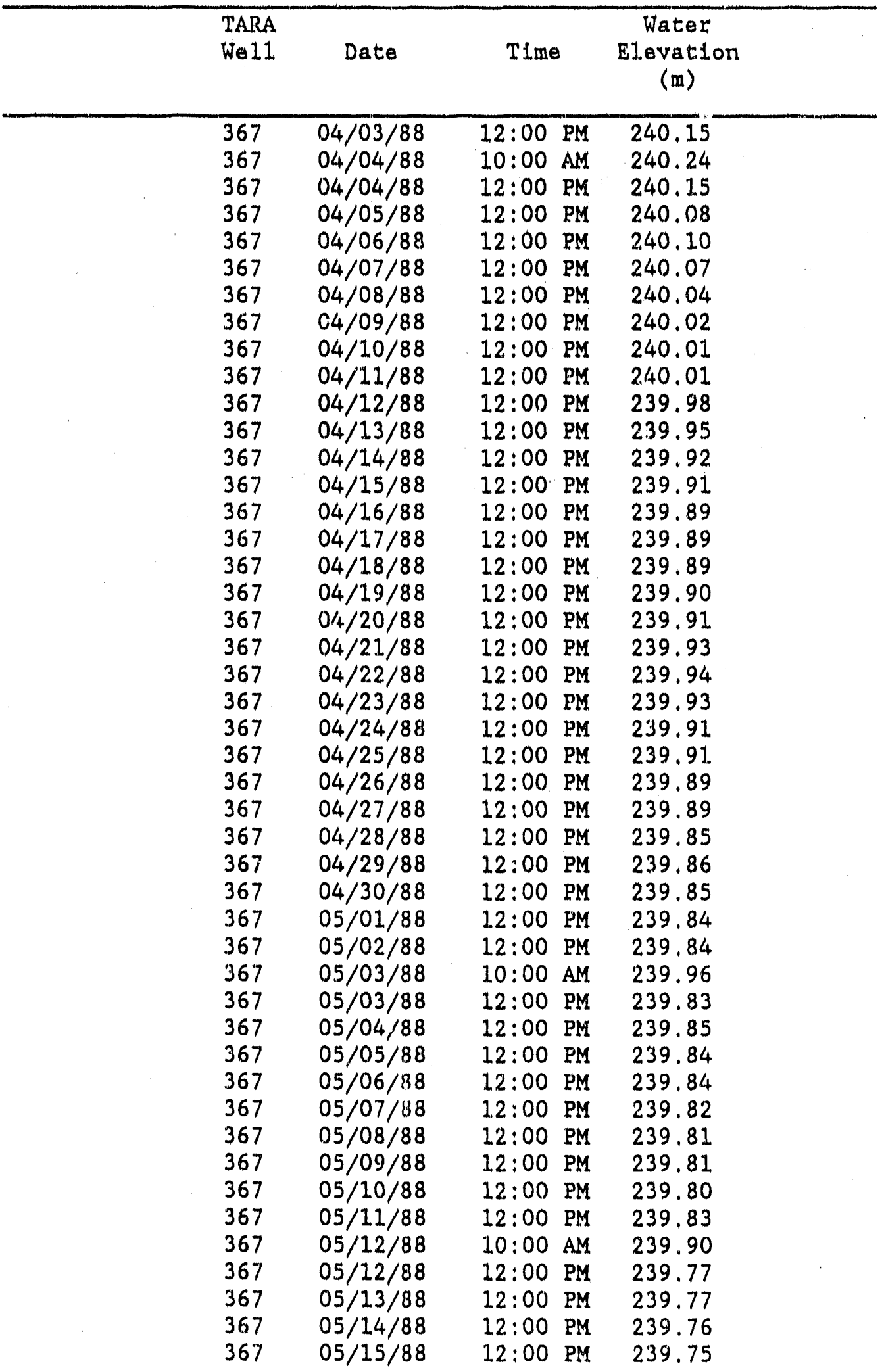


APPENDIX III

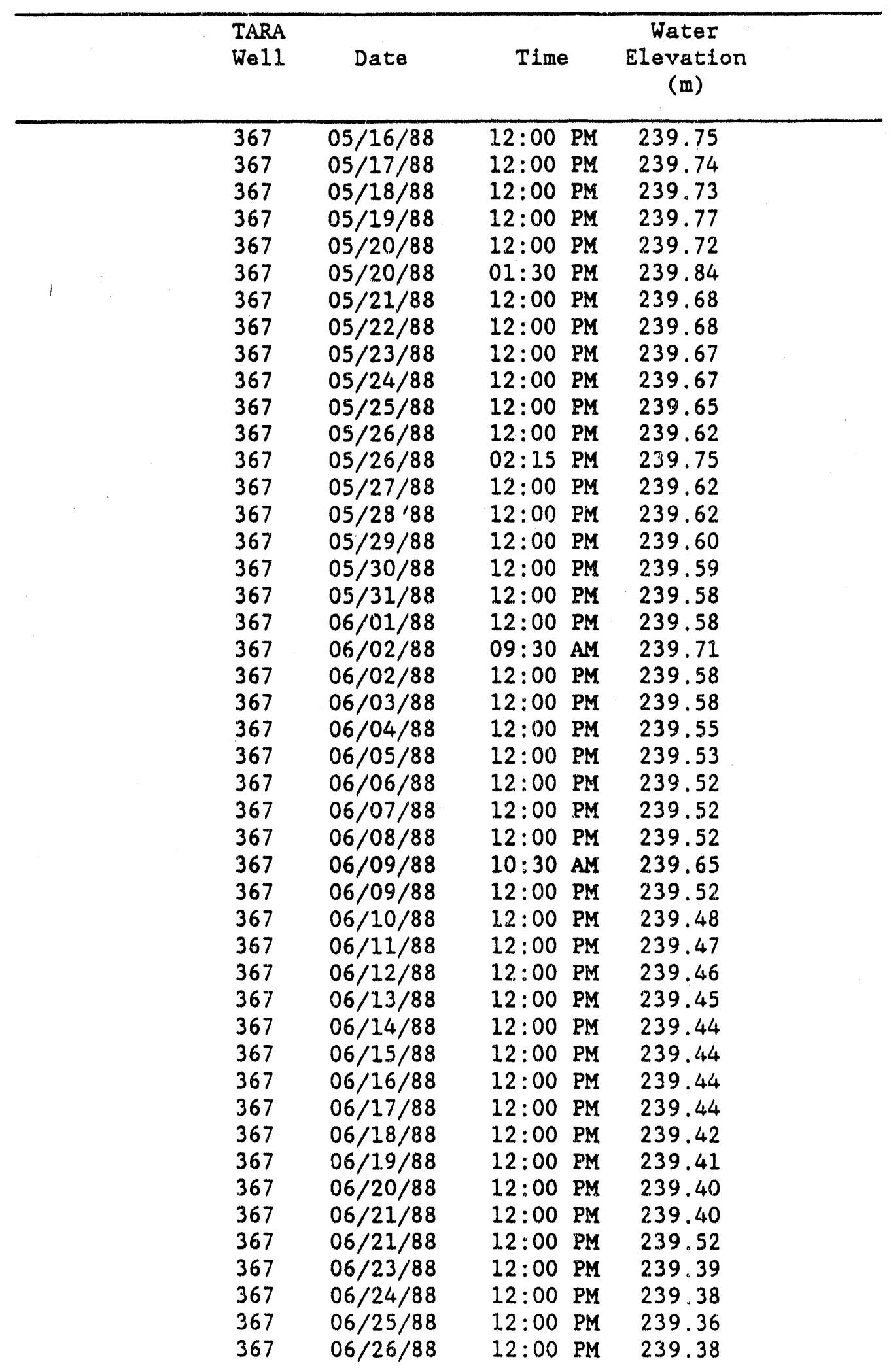


APPENDIX III

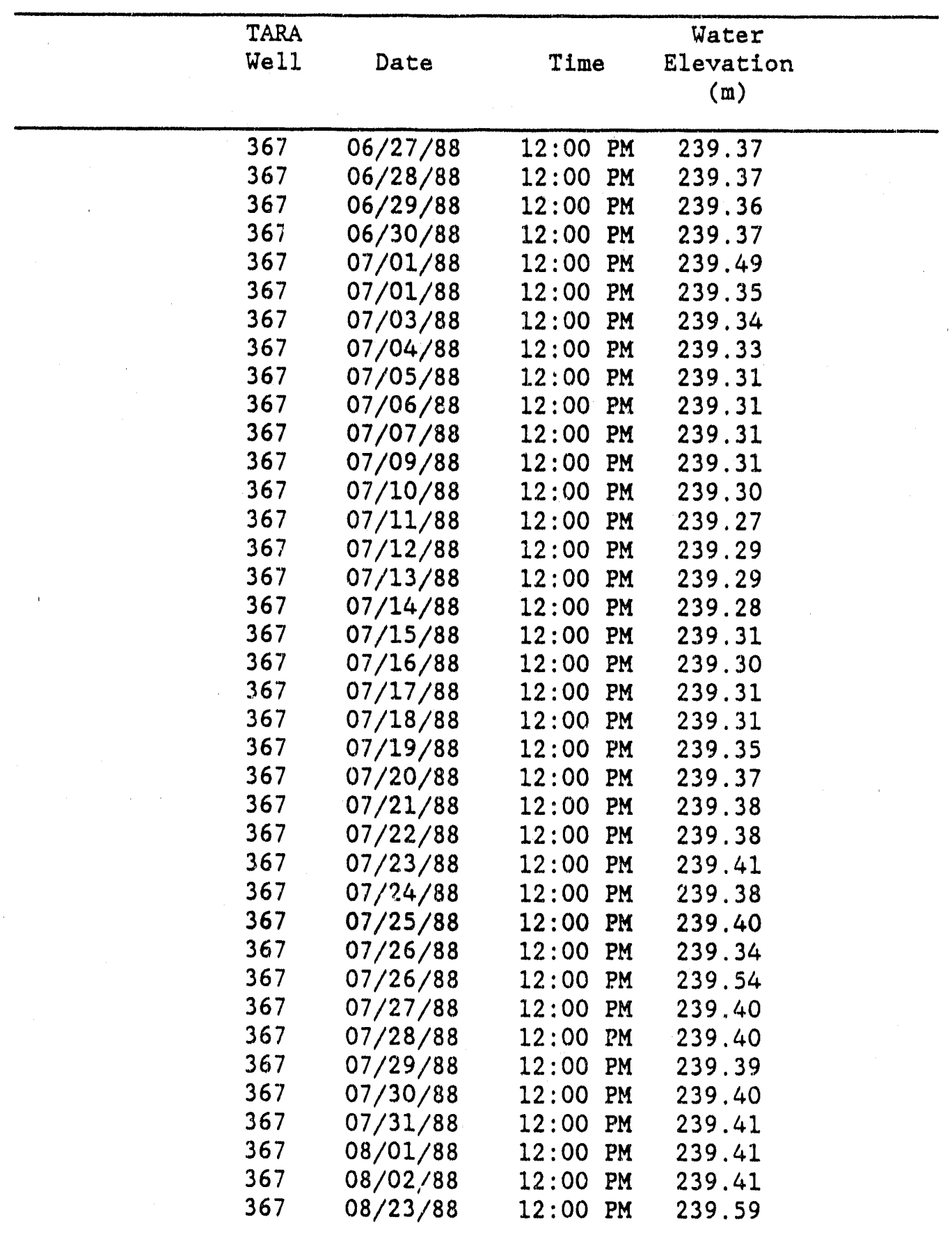


APPENDIX III

\begin{tabular}{|c|c|c|c|}
\hline $\begin{array}{l}\text { TARA } \\
\text { Well }\end{array}$ & Date & Time & $\begin{array}{l}\text { Water } \\
\text { Elevation } \\
\text { (m) }\end{array}$ \\
\hline $\begin{array}{l}646 \\
646 \\
646 \\
646 \\
646 \\
646 \\
646 \\
646 \\
646 \\
646 \\
646 \\
646 \\
646 \\
646 \\
646 \\
646 \\
646 \\
646 \\
646 \\
646 \\
646 \\
646 \\
646 \\
646 \\
646 \\
646 \\
646 \\
646 \\
646 \\
646 \\
646 \\
646 \\
646 \\
646 \\
646 \\
646 \\
646 \\
646 \\
646 \\
646 \\
646 \\
646 \\
646 \\
646 \\
646 \\
646\end{array}$ & $\begin{array}{l}06 / 15 / 87 \\
07 / 13 / 87 \\
08 / 04 / 87 \\
08 / 04 / 87 \\
08 / 05 / 87 \\
08 / 05 / 87 \\
08 / 06 / 87 \\
08 / 07 / 87 \\
08 / 10 / 87 \\
08 / 11 / 87 \\
08 / 12 / 87 \\
08 / 14 / 87 \\
08 / 17 / 87 \\
08 / 21 / 87 \\
09 / 04 / 87 \\
10 / 19 / 87 \\
10 / 20 / 87 \\
10 / 21 / 87 \\
10 / 22 / 87 \\
10 / 23 / 87 \\
10 / 26 / 87 \\
10 / 28 / 87 \\
10 / 29 / 87 \\
10 / 30 / 87 \\
11 / 02 / 87 \\
11 / 04 / 87 \\
11 / 12 / 87 \\
11 / 17 / 87 \\
11 / 19 / 87 \\
12 / 03 / 87 \\
12 / 11 / 87 \\
12 / 16 / 87 \\
12 / 21 / 87 \\
12 / 28 / 87 \\
12 / 31 / 87 \\
01 / 04 / 88 \\
01 / 08 / 88 \\
01 / 14 / 88 \\
01 / 21 / 88 \\
01 / 22 / 88 \\
01 / 25 / 88 \\
01 / 28 / 88 \\
02 / 01 / 88 \\
02 / 11 / 88 \\
02 / 18 / 88 \\
02 / 26 / 88\end{array}$ & 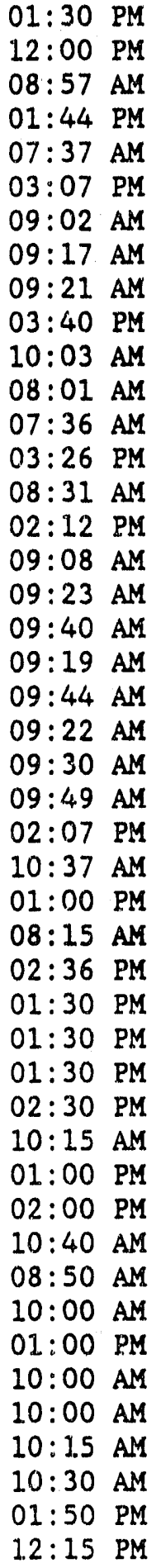 & $\begin{array}{l}235.40 \\
235.34 \\
235.18 \\
235.18 \\
235.21 \\
235.22 \\
235.29 \\
235.42 \\
235.67 \\
235.69 \\
235.70 \\
235.71 \\
235.68 \\
235.59 \\
235.29 \\
234.86 \\
234.85 \\
234.89 \\
234.86 \\
234.87 \\
234.92 \\
234.98 \\
235.02 \\
235.03 \\
235.15 \\
235.24 \\
235.32 \\
235.26 \\
235.26 \\
234.69 \\
234.63 \\
234.60 \\
234.68 \\
235.18 \\
235.03 \\
235.25 \\
235.11 \\
234.99 \\
235.61 \\
235.54 \\
235.48 \\
235.36 \\
235.31 \\
235.51 \\
235.55 \\
235.44\end{array}$ \\
\hline
\end{tabular}


APPENDIX III

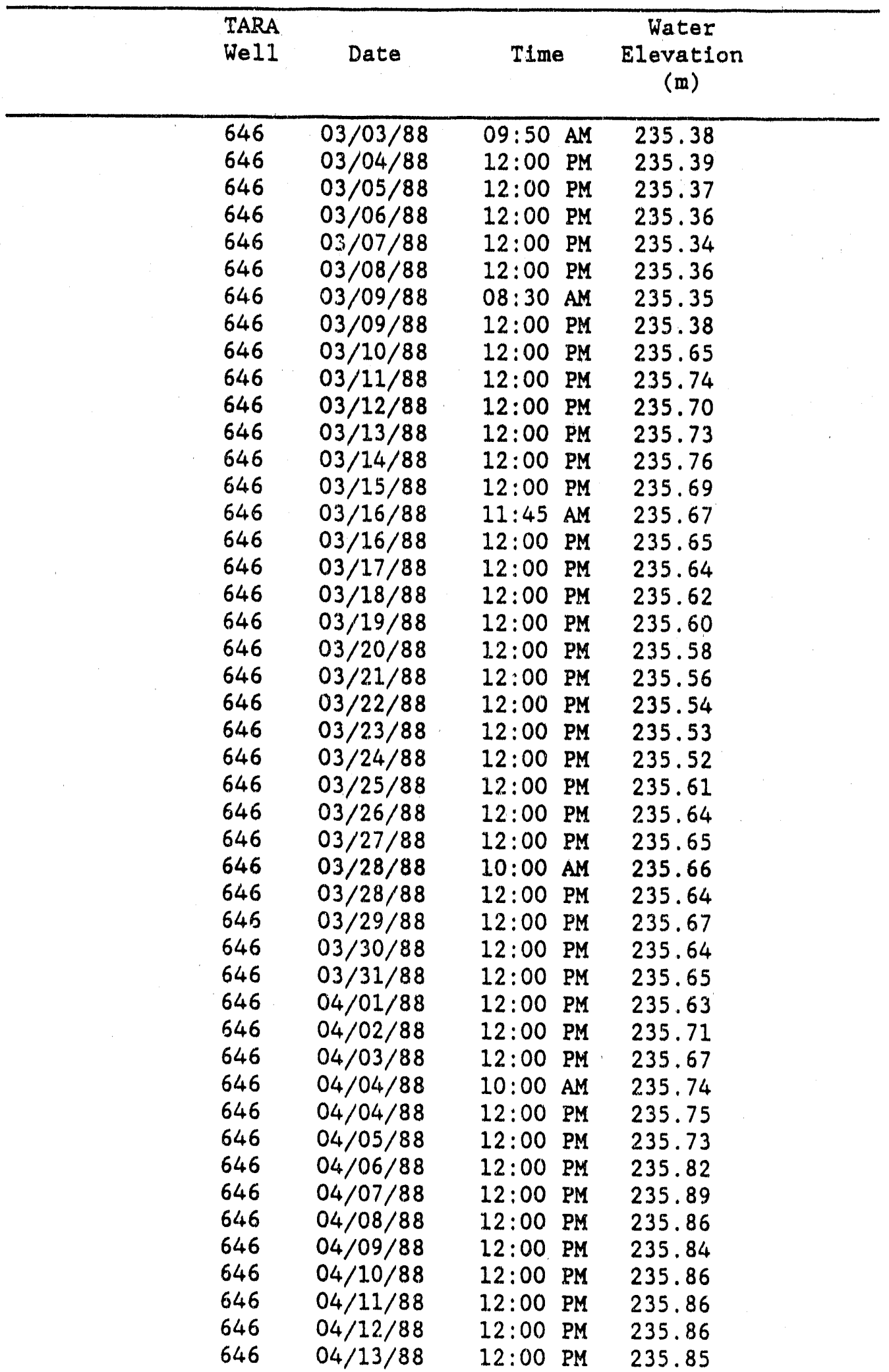


APPENDIX III

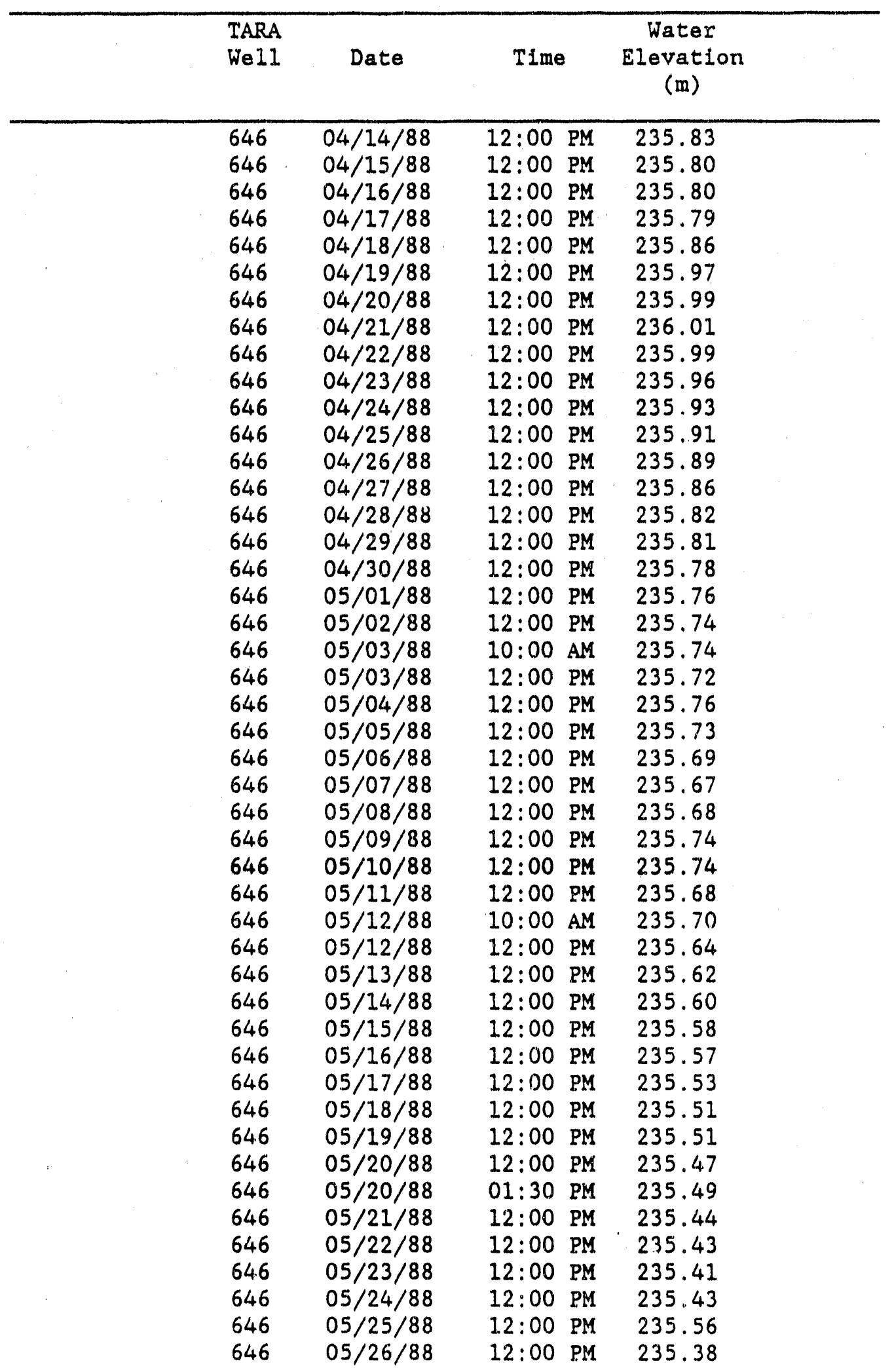


APPENDIX III

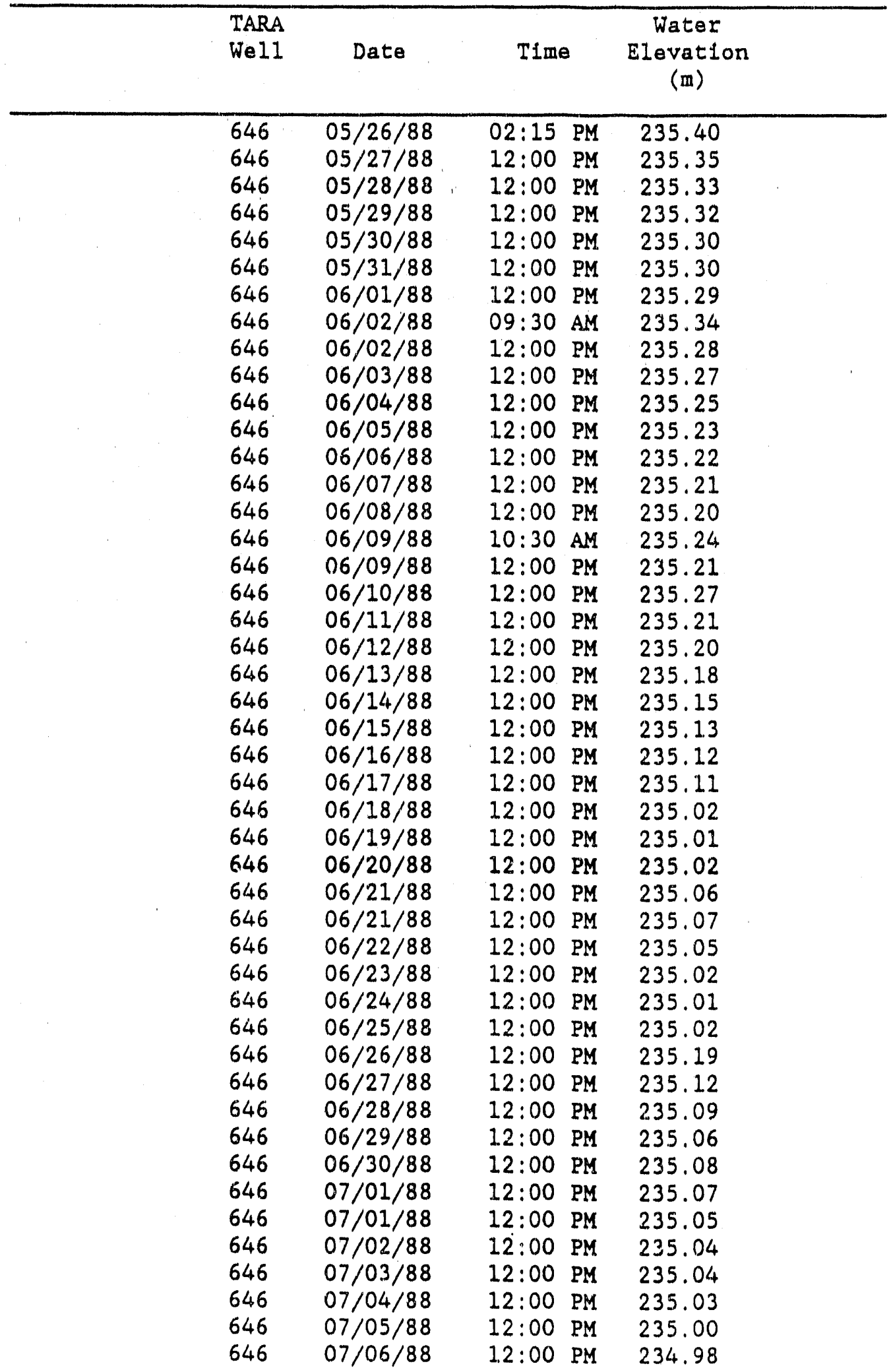


APPENDIX III

\begin{tabular}{|c|c|c|c|}
\hline $\begin{array}{l}\text { TARA } \\
\text { Well }\end{array}$ & Date & Time & $\begin{array}{l}\text { Water } \\
\text { Elevation } \\
\text { (m) }\end{array}$ \\
\hline $\begin{array}{l}646 \\
646 \\
646 \\
646 \\
646 \\
646 \\
646 \\
646 \\
646 \\
646 \\
646 \\
646 \\
646 \\
646 \\
646 \\
646 \\
646 \\
646 \\
646 \\
646 \\
646 \\
646 \\
646 \\
646 \\
646 \\
646 \\
646 \\
646 \\
646 \\
646 \\
646 \\
646 \\
646 \\
646 \\
646 \\
646 \\
646 \\
646 \\
646 \\
646 \\
646 \\
646 \\
646 \\
646 \\
646 \\
646\end{array}$ & $\begin{array}{l}07 / 07 / 88 \\
07 / 08 / 88 \\
07 / 09 / 88 \\
07 / 10 / 88 \\
07 / 11 / 88 \\
07 / 12 / 88 \\
07 / 13 / 88 \\
07 / 14 / 88 \\
07 / 15 / 88 \\
07 / 16 / 88 \\
07 / 17 / 88 \\
07 / 18 / 88 \\
07 / 19 / 88 \\
07 / 20 / 88 \\
07 / 21 / 88 \\
07 / 22 / 88 \\
07 / 23 / 88 \\
07 / 24 / 88 \\
07 / 25 / 88 \\
07 / 26 / 88 \\
07 / 26 / 88 \\
07 / 27 / 88 \\
07 / 28 / 88 \\
07 / 29 / 88 \\
07 / 30 / 88 \\
07 / 31 / 88 \\
08 / 01 / 88 \\
08 / 02 / 88 \\
08 / 03 / 88 \\
08 / 04 / 88 \\
08 / 05 / 88 \\
08 / 06 / 88 \\
08 / 07 / 88 \\
08 / 08 / 88 \\
08 / 09 / 88 \\
08 / 10 / 88 \\
08 / 11 / 88 \\
08 / 12 / 88 \\
08 / 13 / 88 \\
08 / 14 / 88 \\
08 / 15 / 88 \\
08 / 16 / 88 \\
08 / 17 / 88 \\
08 / 18 / 88 \\
08 / 19 / 88 \\
08 / 20 / 88\end{array}$ & 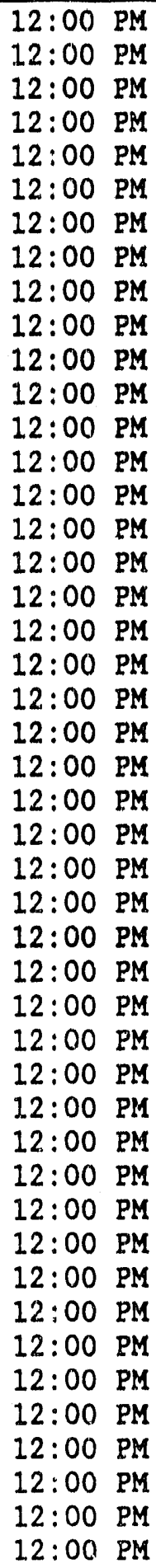 & $\begin{array}{l}234.96 \\
234.96 \\
234.96 \\
234.94 \\
234.93 \\
235.18 \\
235.17 \\
235.44 \\
235.24 \\
235.18 \\
235.14 \\
235.11 \\
235.10 \\
235.10 \\
235.18 \\
235.37 \\
235.25 \\
235.16 \\
235.14 \\
235.12 \\
235.14 \\
235.48 \\
235.32 \\
235.33 \\
235.29 \\
235.25 \\
235.22 \\
235.20 \\
235.17 \\
235.15 \\
235.15 \\
235.14 \\
235.17 \\
235.13 \\
235.10 \\
235.07 \\
235.05 \\
235.19 \\
235.13 \\
235.09 \\
235.07 \\
235.04 \\
235.03 \\
235.03 \\
235.02 \\
235.18\end{array}$ \\
\hline
\end{tabular}


APPENDIX III

\begin{tabular}{ccccc}
\hline $\begin{array}{c}\text { TARA } \\
\text { We11 }\end{array}$ & Date & TIme & $\begin{array}{c}\text { Water } \\
\text { Elevation } \\
(\mathrm{m})\end{array}$ \\
\hline 646 & $08 / 21 / 88$ & $12: 00 \mathrm{PM}$ & 235.21 \\
646 & $08 / 22 / 88$ & $12: 00 \mathrm{PM}$ & 235.13 \\
646 & $08 / 23 / 88$ & $12: 00 \mathrm{PM}$ & 235.12
\end{tabular}




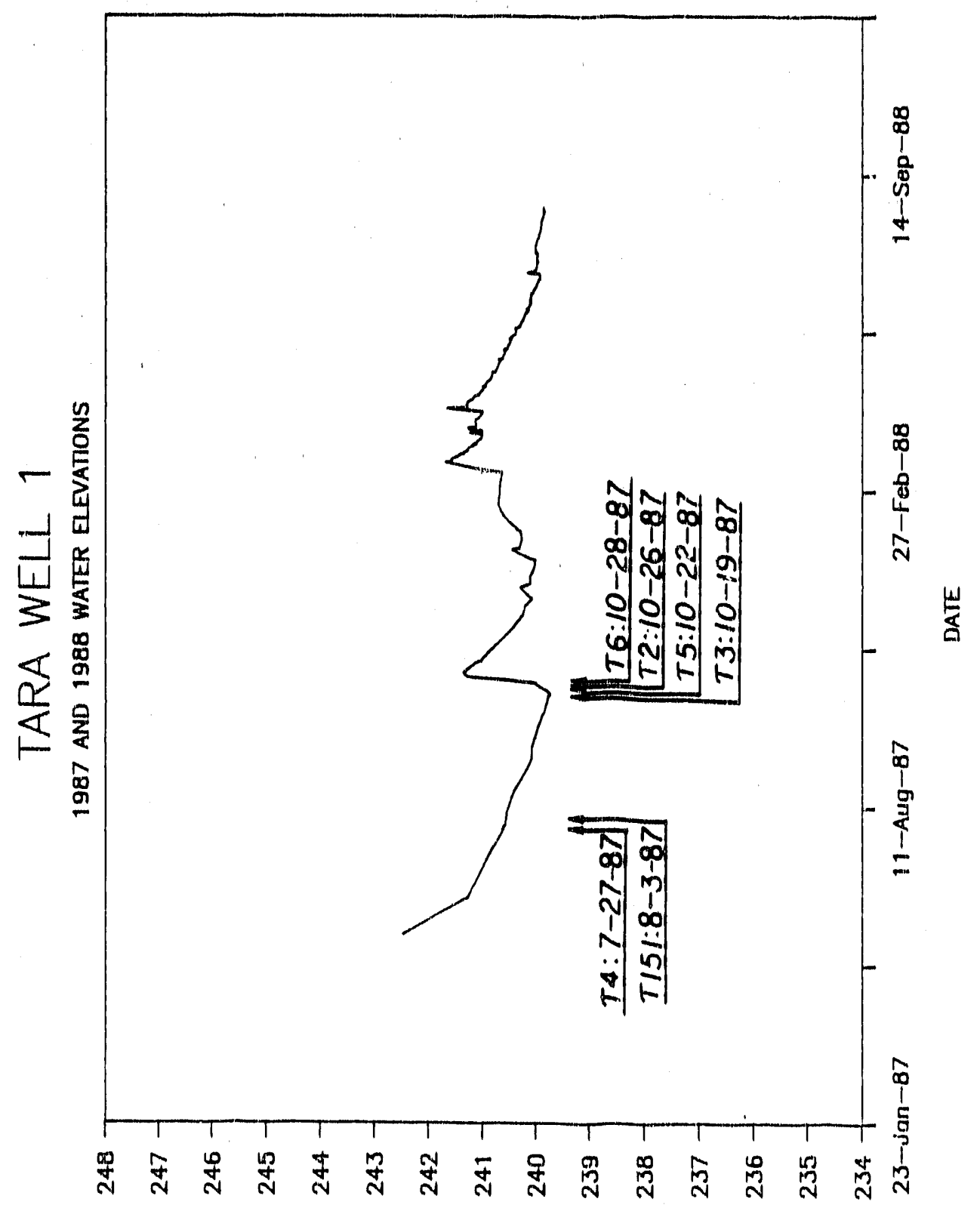

( $75 W \exists \wedge$ W

HYDROGRAPH FOR TARA WELL 1 
III. 88

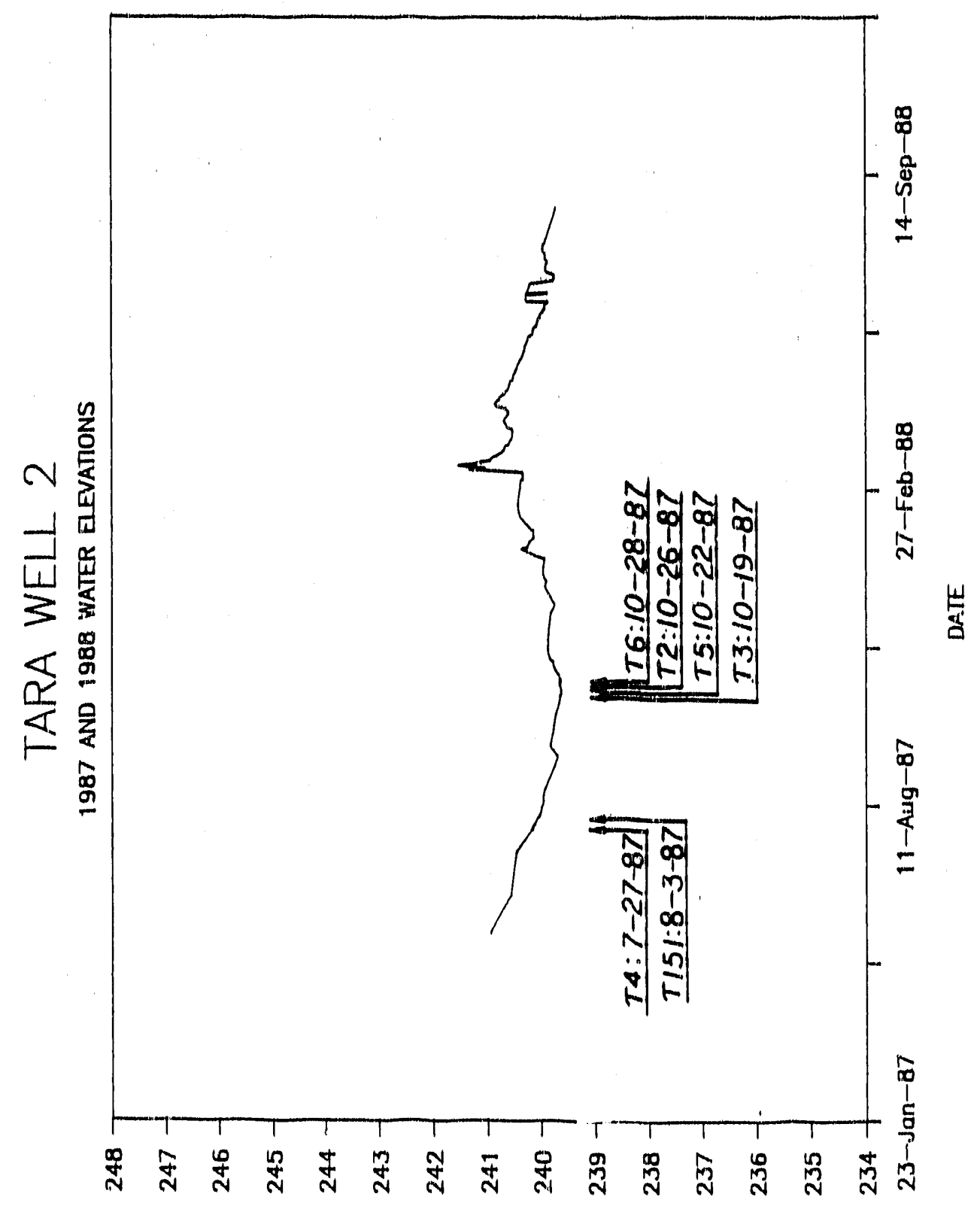

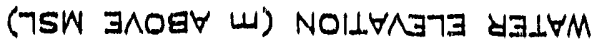

HYDROGRAPH FOR TARA WELL 2 


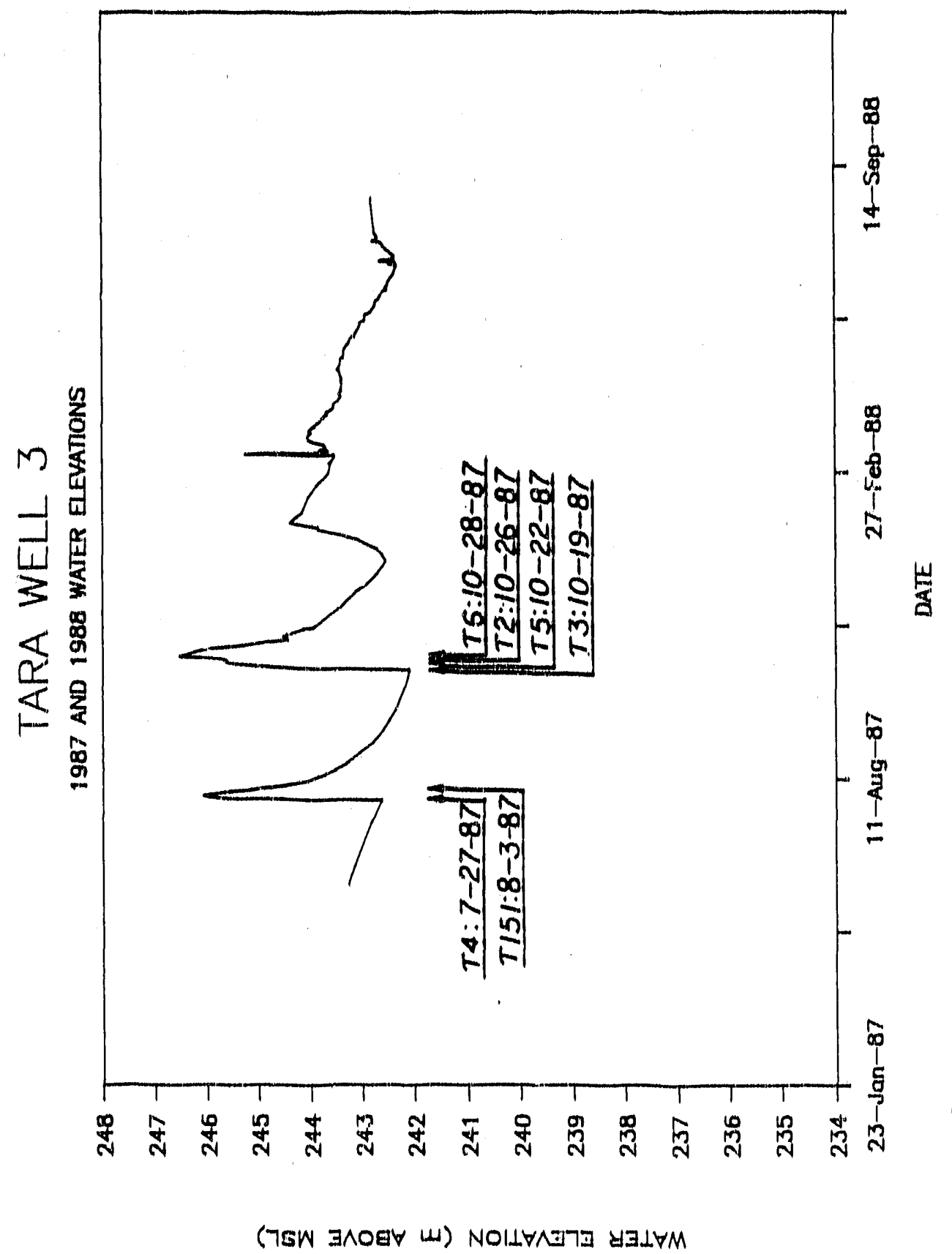

HYDROGRAPH FOR TARA WELI 3 


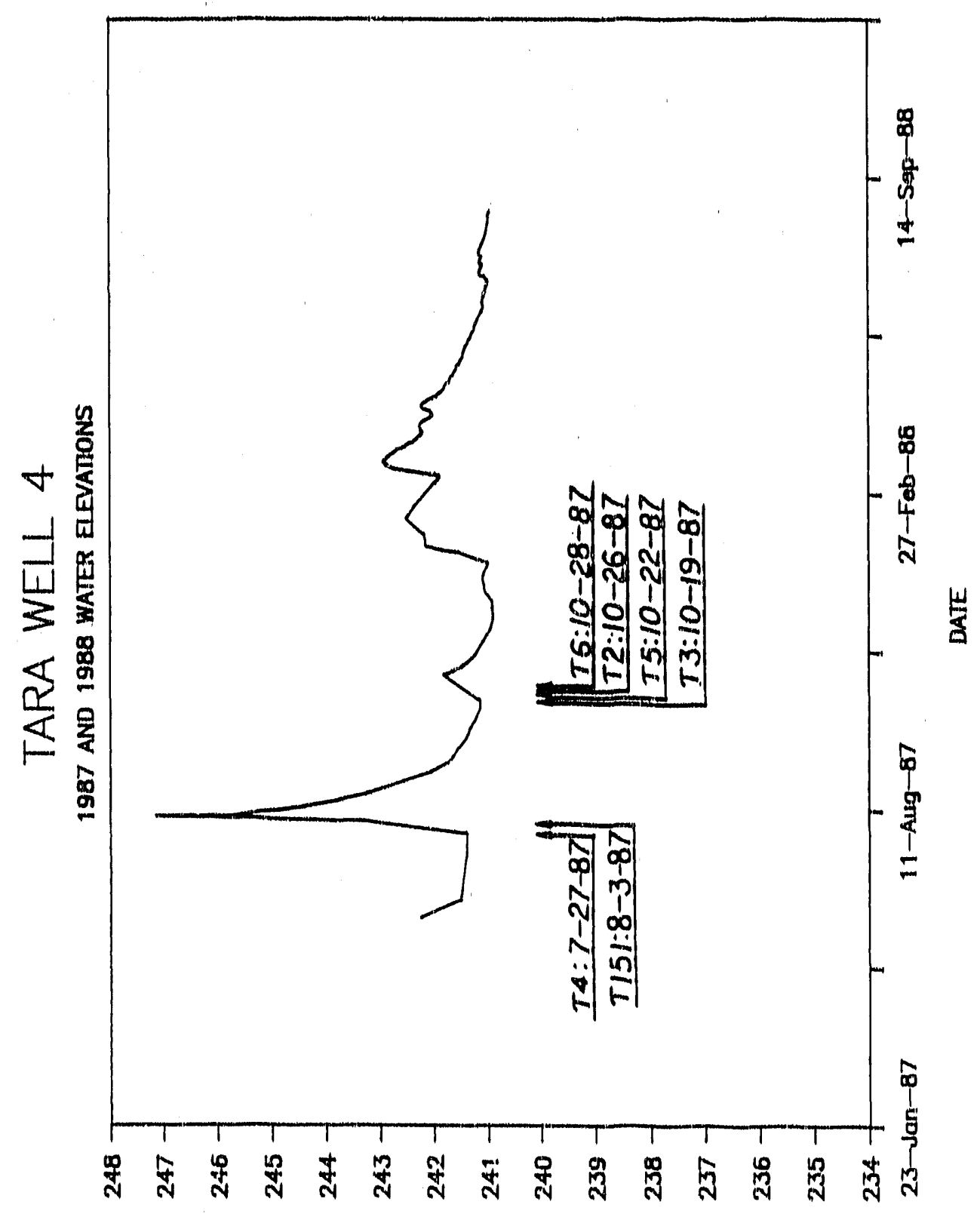

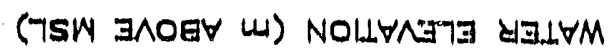
HYDROGRAPH FOR TARA WELL 4 


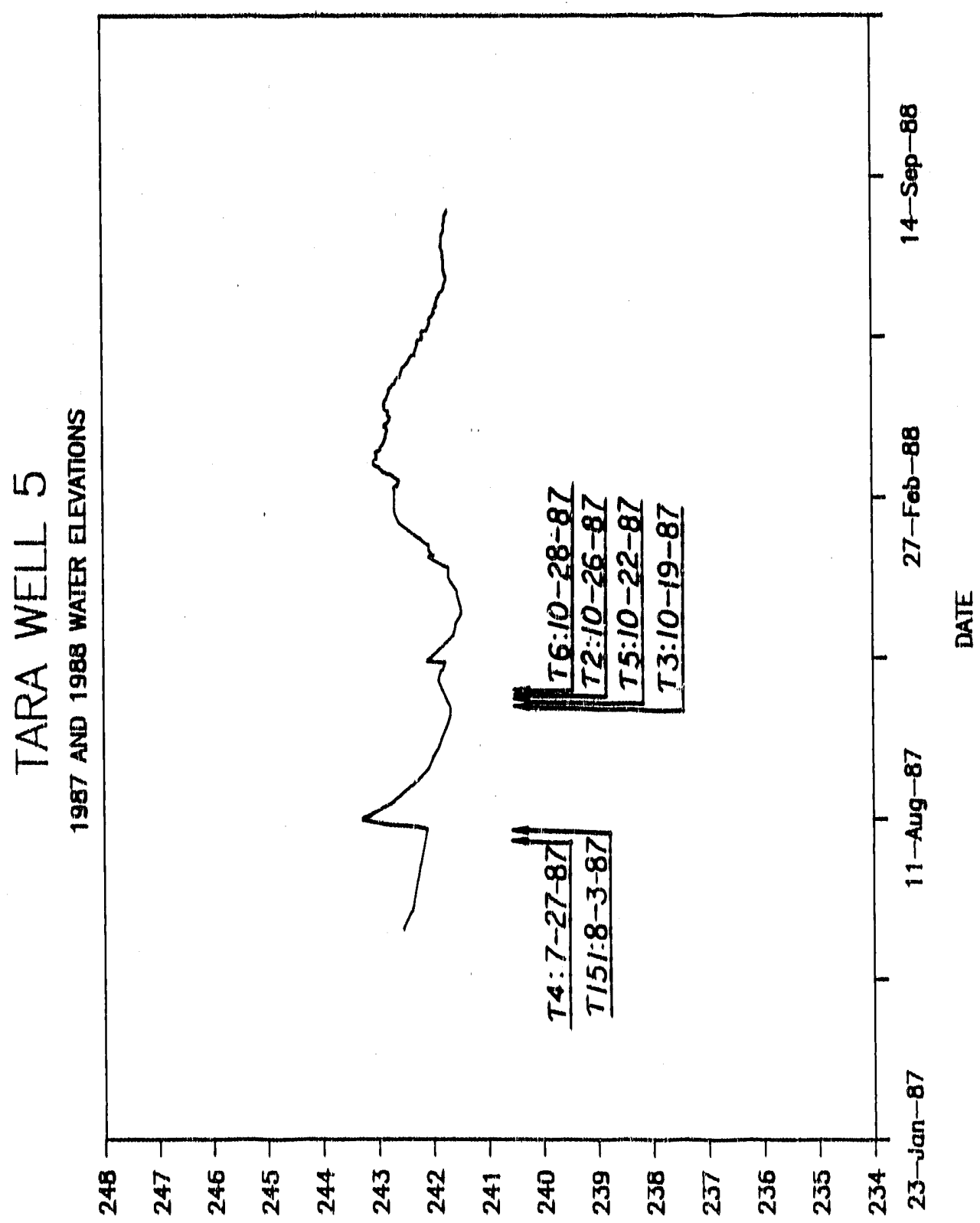

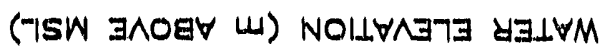

HYDROGRAPH FOR TARA WELL 5 


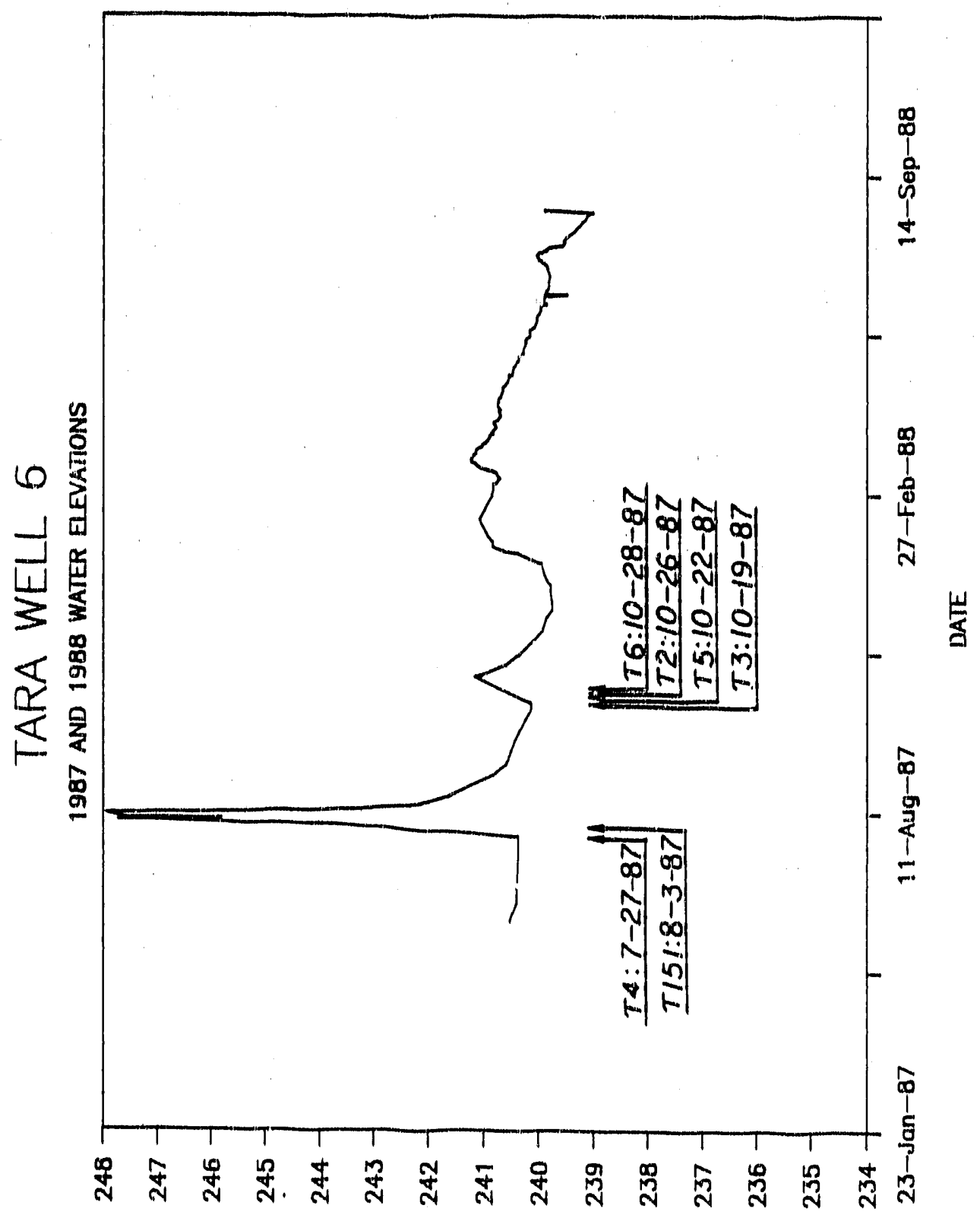

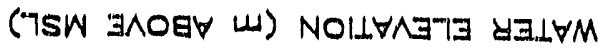

HYDROGRAPH FOR TARA WELL 6 
III -93

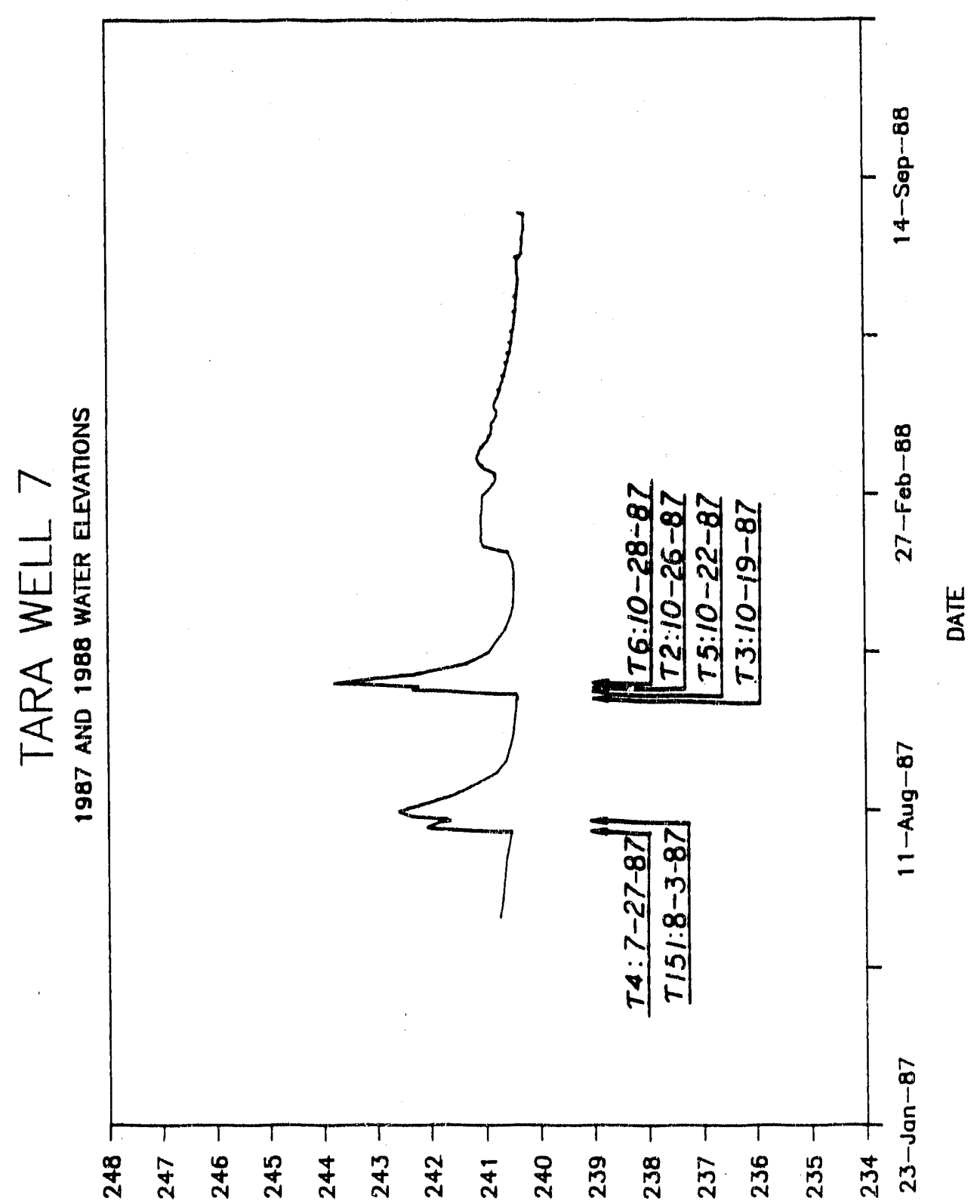

(7SW $3 \wedge$

HYDROGRAPH FOR TARA WELL 7 
III -94

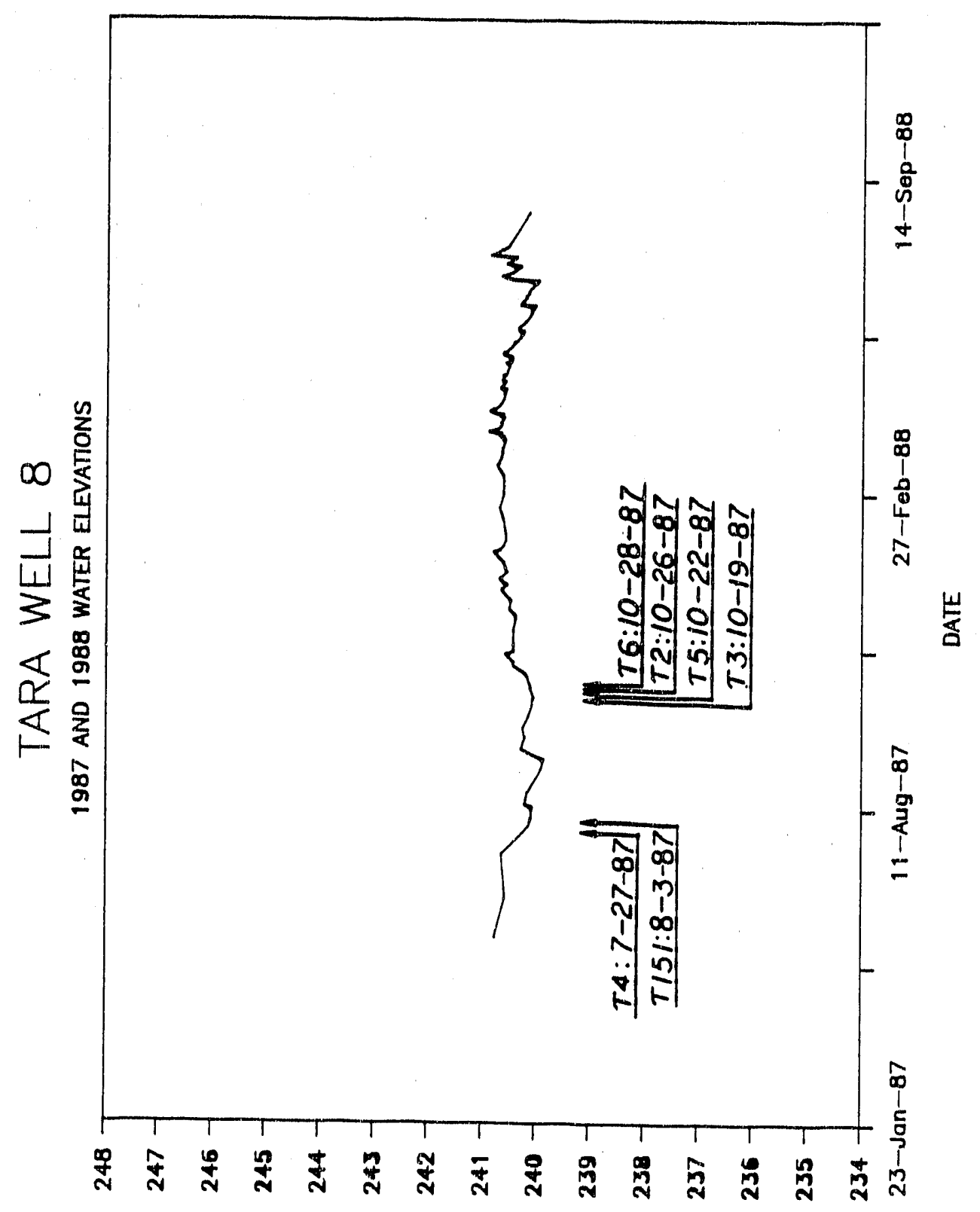

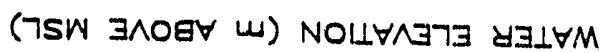

HYDROGRAPH FOR TARA WELL 8 


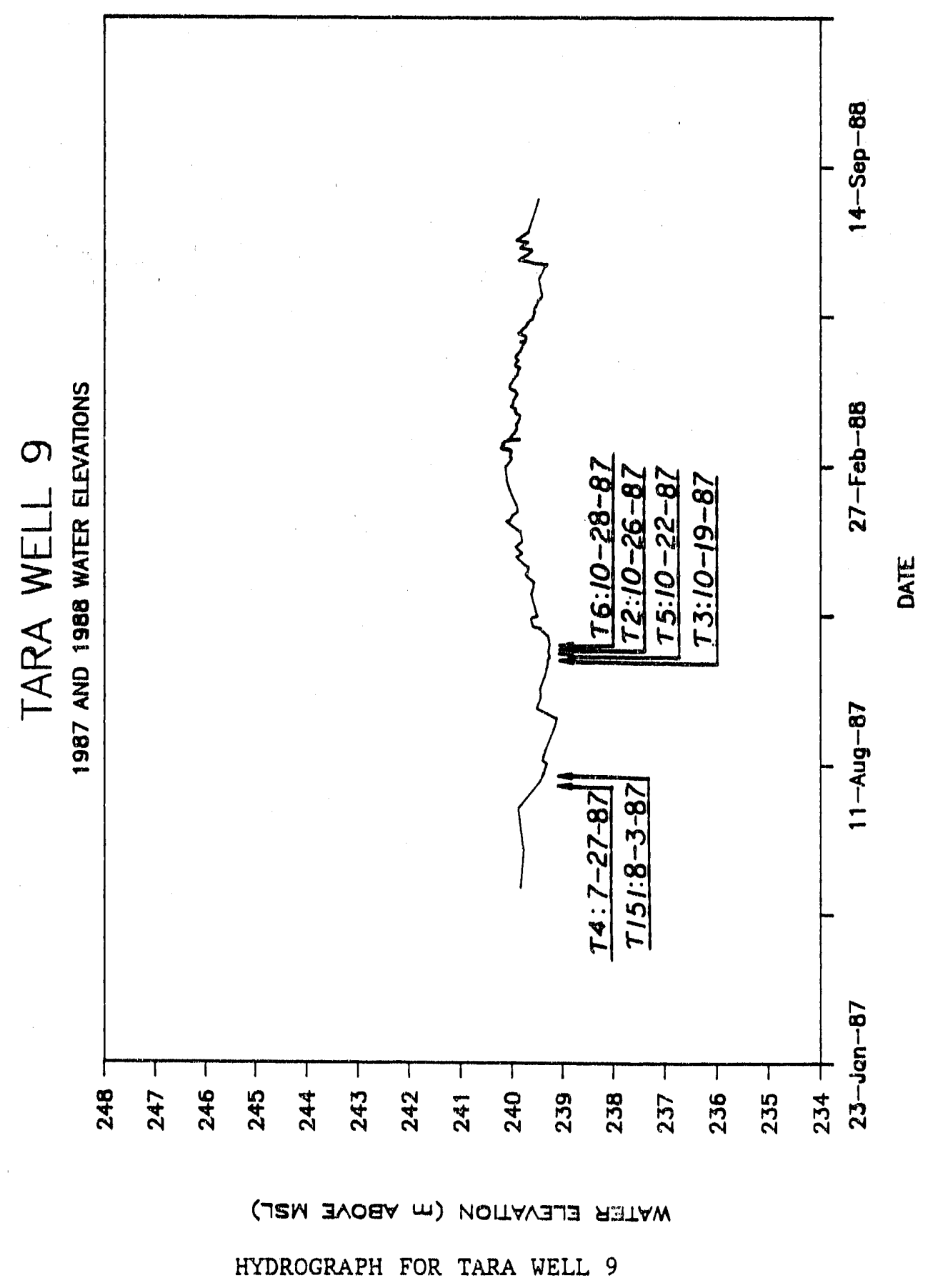




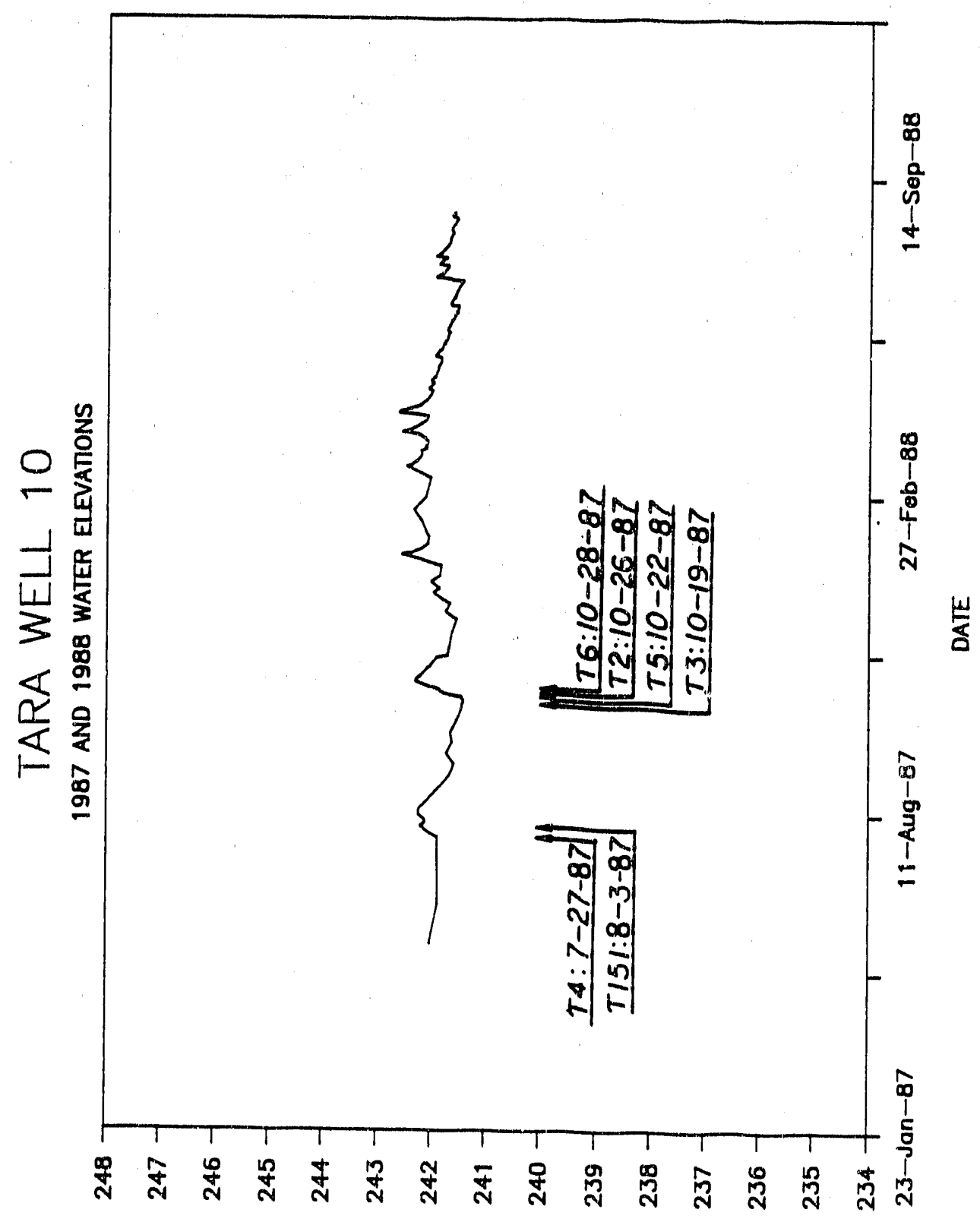

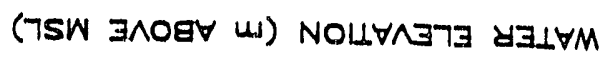

HYDROGRAPH FOR TARA WELL 10 


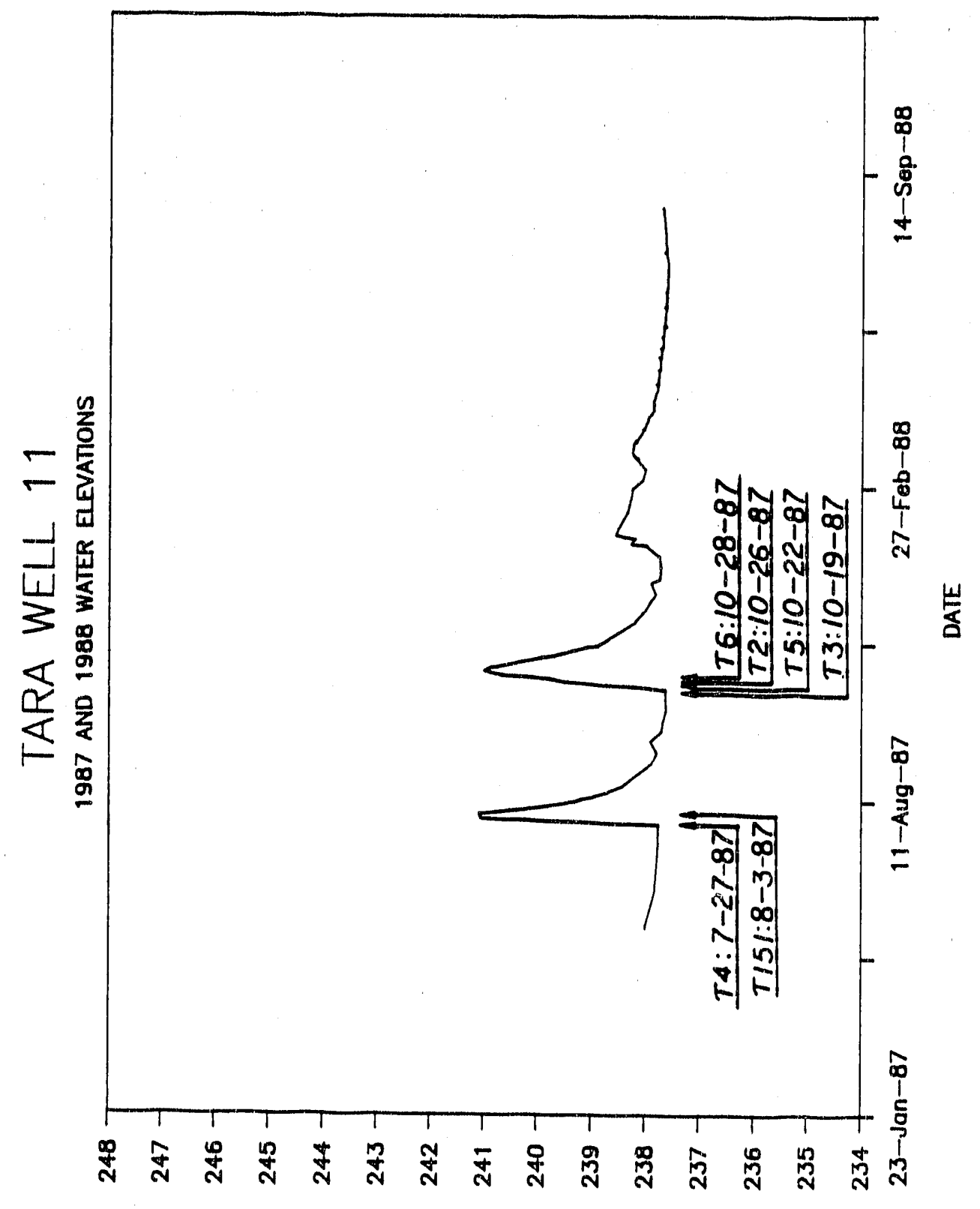

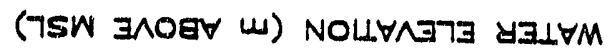

HYDROGRAPH FOR TARA WELL 11 


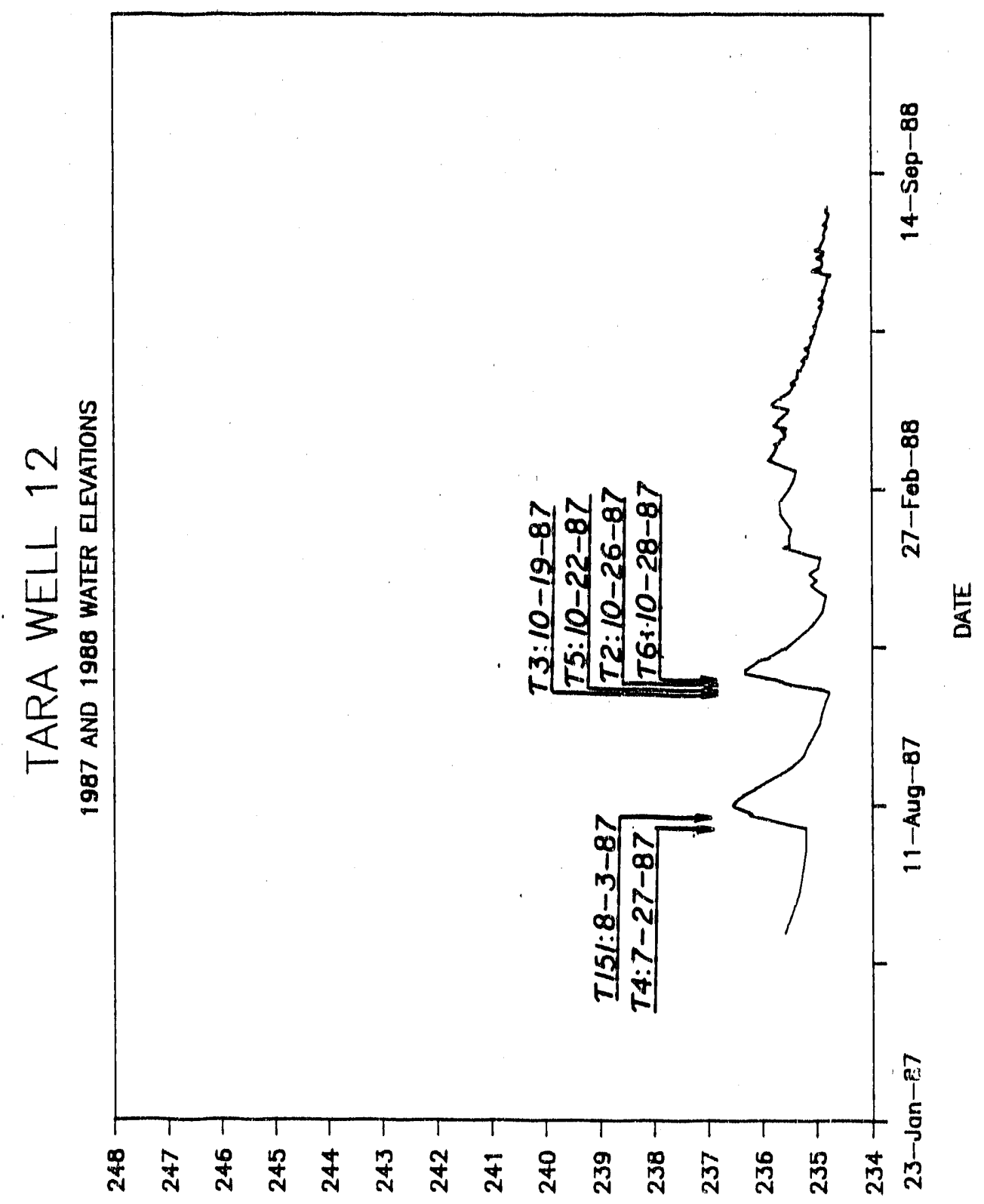

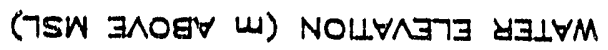

HYDROGRAPH FOR TARA WELL 12 
III -99

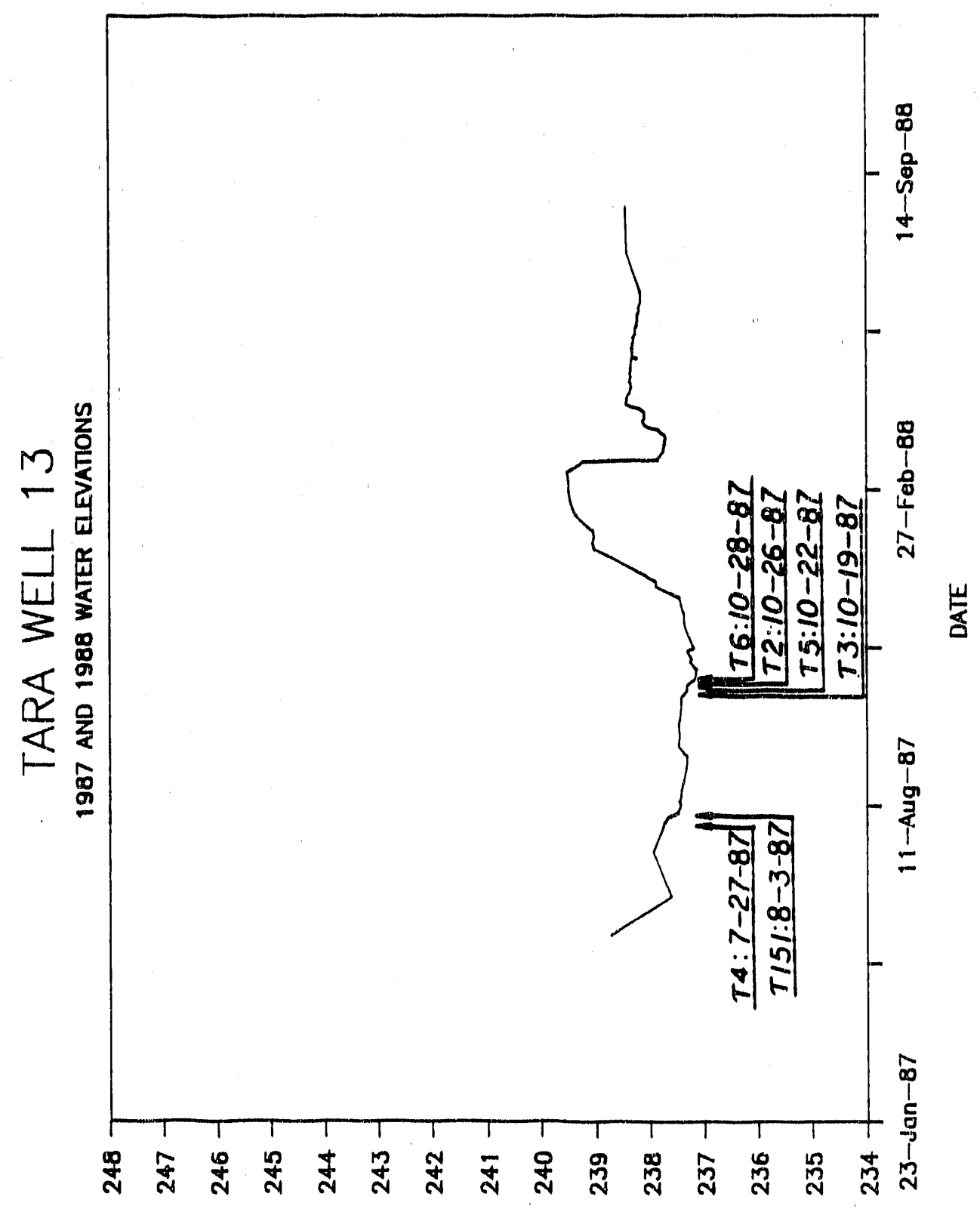

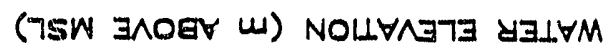

HYDROGRAPH FOR TARA WELL 13 
III -100

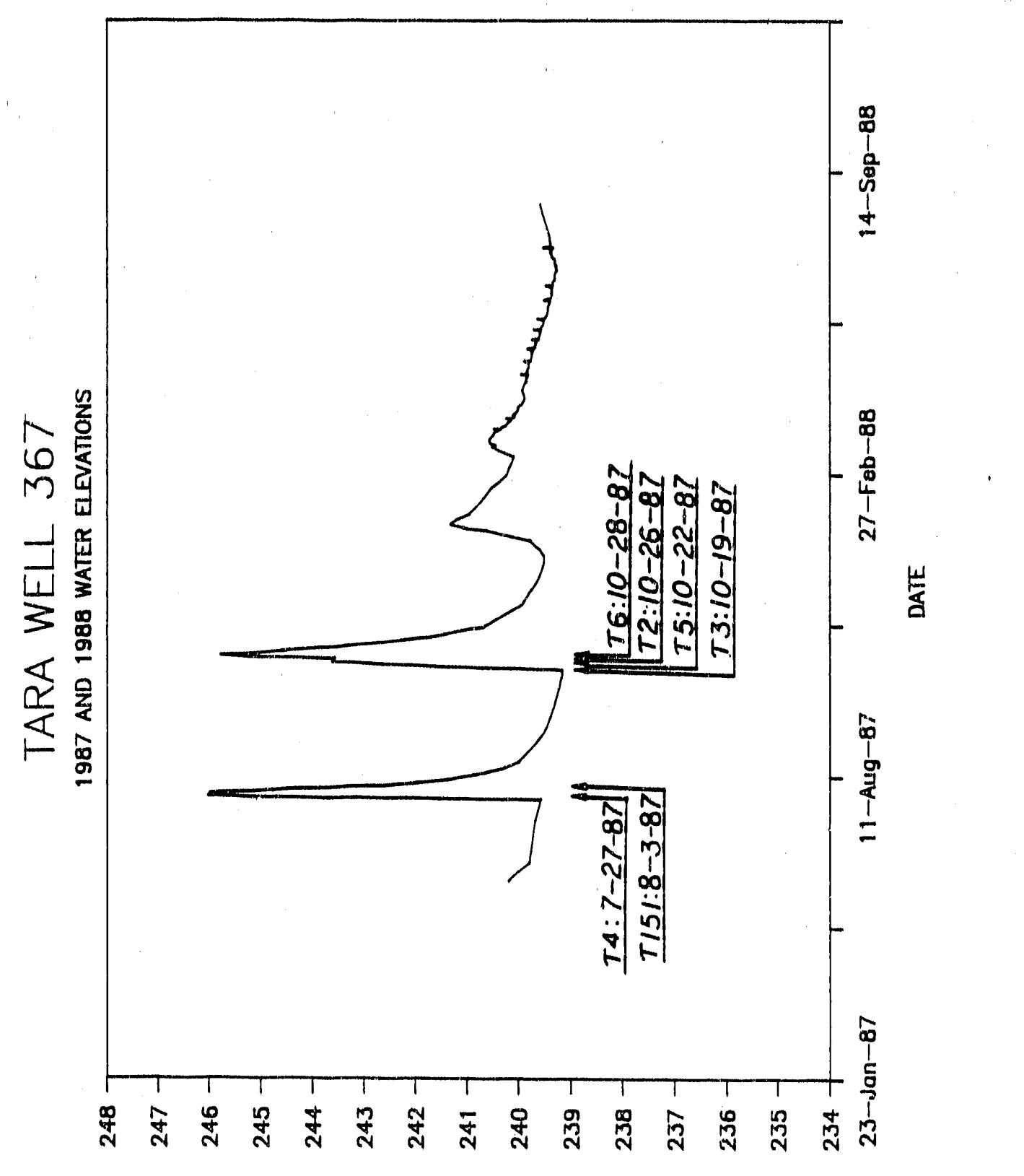

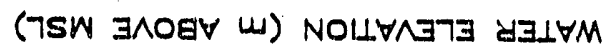

HYDROGRAPH FOR TARA WELL 367 


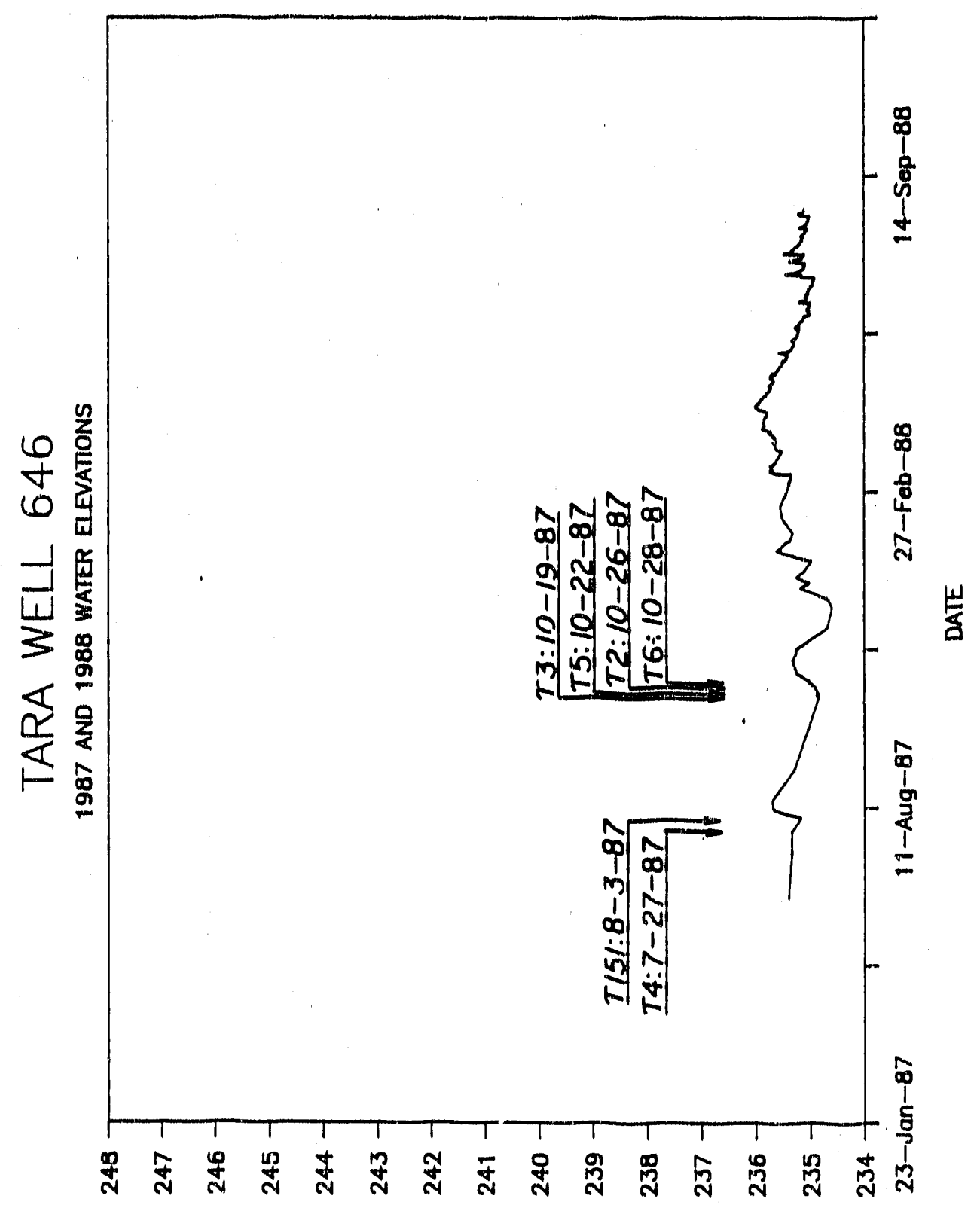

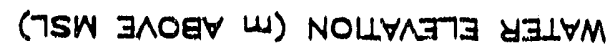

HYDROGRAPH FOR TARA WELL 646 
SWSA 6 PRECIPITATION

\begin{tabular}{|c|c|c|c|c|}
\hline Date & $\begin{array}{l}\text { TARA } \\
\text { Preclp. } \\
\text { (mm) }\end{array}$ & $\begin{array}{l}\text { SWSA } 6 \\
\text { Proolp. } \\
\text { Gauge } 1 \\
\text { (mm) }\end{array}$ & $\begin{array}{l}\text { SWSA } 6 \\
\text { Precip. } \\
\text { Gauge } 2 \\
\text { (mm) }\end{array}$ & $\begin{array}{l}\text { SWSA } 6 \\
\text { Average } \\
\text { Preolp. } \\
\text { (mm) }\end{array}$ \\
\hline $\begin{array}{l}01 / 01 / 87 \\
01 / 02 / 87 \\
01 / 03 / 87 \\
01 / 04 / 87 \\
01 / 05 / 87 \\
01 / 06 / 87 \\
01 / 07 / 87 \\
01 / 08 / 87 \\
01 / 09 / 87 \\
01 / 10 / 87 \\
01 / 11 / 87 \\
01 / 12 / 87 \\
01 / 13 / 87 \\
01 / 14 / 87 \\
01 / 15 / 87 \\
01 / 16 / 87 \\
01 / 17 / 87 \\
01 / 18 / 87 \\
01 / 19 / 87 \\
01 / 20 / 87 \\
01 / 21 / 87 \\
01 / 22 / 87 \\
01 / 23 / 87 \\
01 / 24 / 87 \\
01 / 25 / 87 \\
01 / 26 / 87 \\
01 / 27 / 87 \\
01 / 28 / 87 \\
01 / 29 / 87 \\
01 / 30 / 87 \\
01 / 31 / 87 \\
02 / 01 / 87 \\
02 / 02 / 87 \\
02 / 03 / 87 \\
02 / 04 / 87 \\
02 / 05 / 87 \\
02 / 06 / 87 \\
02 / 07 / 87 \\
02 / 08 / 87 \\
02 / 09 / 87 \\
02 / 10 / 87 \\
02 / 11 / 87 \\
02 / 12 / 87 \\
02 / 13 / 87 \\
02 / 14 / 87\end{array}$ & 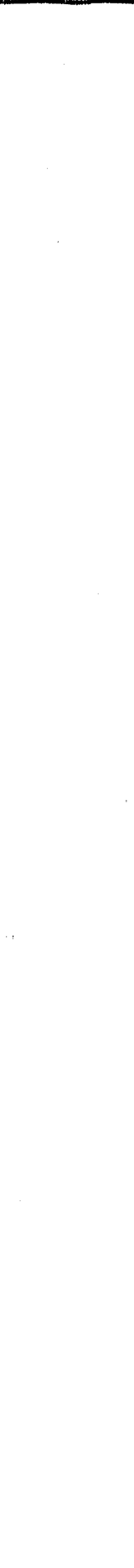 & $\begin{array}{r}2.78 \\
0.00 \\
0.00 \\
0.00 \\
0.00 \\
0.00 \\
0.00 \\
0.00 \\
3.06 \\
2.02 \\
0.00 \\
0.00 \\
0.00 \\
4.33 \\
2.52 \\
0.00 \\
3.59 \\
52.15 \\
17.17 \\
0.00 \\
0.00 \\
11.18 \\
0.00 \\
0.51 \\
22.50 \\
0.00 \\
2.29 \\
0.00 \\
0.00 \\
0.00 \\
0.76 \\
0.00 \\
9.88 \\
0.00 \\
0.00 \\
0.00 \\
0.00 \\
0.00 \\
0.00 \\
0.00 \\
0.00 \\
0.00 \\
0.00 \\
0.00 \\
4.84\end{array}$ & $\begin{array}{r}3.04 \\
0.00 \\
0.00 \\
0.00 \\
0.00 \\
0.00 \\
0.00 \\
0.00 \\
3.06 \\
1.90 \\
0.00 \\
0.00 \\
0.00 \\
4.60 \\
1.71 \\
0.00 \\
3.69 \\
51.79 \\
15.63 \\
0.00 \\
0.00 \\
10.93 \\
0.00 \\
0.51 \\
21.84 \\
0.00 \\
2.03 \\
0.00 \\
0.00 \\
0.00 \\
0.00 \\
0.00 \\
9.92 \\
0.00 \\
0.00 \\
0.00 \\
0.00 \\
0.00 \\
0.00 \\
0.00 \\
0.00 \\
0.00 \\
0.00 \\
0.00 \\
4.57\end{array}$ & $\begin{array}{r}2.91 \\
0.00 \\
0.00 \\
0.00 \\
0.00 \\
0.00 \\
0.00 \\
0.00 \\
3.06 \\
1.96 \\
0.00 \\
0.00 \\
0.00 \\
4.47 \\
2.12 \\
0.00 \\
3.64 \\
51.97 \\
16.40 \\
0.00 \\
0.00 \\
11.06 \\
0.00 \\
0.51 \\
22.17 \\
0.00 \\
2.16 \\
0.00 \\
0.00 \\
0.00 \\
0.38 \\
0.00 \\
9.90 \\
0.00 \\
0.00 \\
0.00 \\
0.00 \\
0.00 \\
0.00 \\
0.00 \\
0.00 \\
0.00 \\
0.00 \\
0.00 \\
4.71\end{array}$ \\
\hline
\end{tabular}


SWSA 6 PRECLPITATION

\begin{tabular}{|c|c|c|c|c|}
\hline Date & $\begin{array}{l}\text { TARA } \\
\text { Preolp. } \\
\text { (mm) }\end{array}$ & $\begin{array}{l}\text { SWSA } 6 \\
\text { Prec1p. } \\
\text { Gauge i } \\
\text { (mm) }\end{array}$ & $\begin{array}{l}\text { SWSA } 6 \\
\text { Preclp. } \\
\text { Gauge } 2 \\
\text { (mm) }\end{array}$ & $\begin{array}{l}\text { SWSA } 6 \\
\text { Average } \\
\text { Precip. } \\
\text { (uma) }\end{array}$ \\
\hline $\begin{array}{l}02 / 15 / 87 \\
02 / 16 / 87 \\
02 / 17 / 87 \\
02 / 18 / 87 \\
02 / 19 / 87 \\
02 / 20 / 87 \\
02 / 21 / 87 \\
02 / 22 / 87 \\
02 / 23 / 87 \\
02 / 24 / 87 \\
02 / 25 / 87 \\
02 / 26 / 87 \\
02 / 27 / 87 \\
02 / 28 / 87 \\
03 / 01 / 87 \\
03 / 02 / 87 \\
03 / 03 / 87 \\
03 / 04 / 87 \\
03 / 05 / 87 \\
03 / 06 / 87 \\
03 / 07 / 87 \\
03 / 08 / 87 \\
03 / 09 / 87 \\
03 / 10 / 87 \\
03 / 11 / 87 \\
03 / 12 / 87 \\
03 / 13 / 87 \\
03 / 14 / 87 \\
03 / 15 / 87 \\
03 / 16 / 87 \\
03 / 17 / 87 \\
03 / 18 / 87 \\
03 / 19 / 87 \\
03 / 20 / 87 \\
03 / 21 / 87 \\
03 / 22 / 87 \\
03 / 23 / 87 \\
03 / 24 / 87 \\
03 / 25 / 87 \\
03 / 26 / 87 \\
03 / 27 / 87 \\
03 / 28 / 87 \\
03 / 29 / 87 \\
03 / 30 / 87 \\
03 / 31 / 87\end{array}$ & & $\begin{array}{r}3.19 \\
20.05 \\
3.79 \\
1.26 \\
0.00 \\
3.05 \\
0.76 \\
20.57 \\
0.00 \\
0.00 \\
0.00 \\
11.97 \\
27.92 \\
21.08 \\
0.76 \\
0.00 \\
0.00 \\
0.00 \\
0.00 \\
0.00 \\
0.00 \\
2.55 \\
9.65 \\
0.00 \\
4.84 \\
0.62 \\
0.00 \\
0.00 \\
0.00 \\
2.79 \\
0.00 \\
17.55 \\
9.90 \\
0.00 \\
0.00 \\
0.00 \\
0.00 \\
7.38 \\
0.76 \\
0.00 \\
2.79 \\
0.00 \\
0.00 \\
15.76 \\
0.00\end{array}$ & $\begin{array}{r}3.20 \\
21.18 \\
2.54 \\
2.55 \\
0.00 \\
3.05 \\
0.89 \\
20.93 \\
0.00 \\
0.00 \\
0.00 \\
13.40 \\
25.20 \\
21.34 \\
0.25 \\
0.00 \\
0.00 \\
0.00 \\
0.00 \\
0.00 \\
0.00 \\
2.16 \\
9.15 \\
0.00 \\
4.06 \\
1.01 \\
0.00 \\
0.00 \\
0.00 \\
3.43 \\
0.00 \\
16.26 \\
12.19 \\
0.00 \\
0.00 \\
0.00 \\
0.00 \\
7.38 \\
0.76 \\
0.00 \\
2.79 \\
0.00 \\
0.00 \\
15.76 \\
0.00\end{array}$ & $\begin{array}{r}3.20 \\
20.62 \\
3.17 \\
1.91 \\
0.00 \\
3.05 \\
0.83 \\
20.75 \\
0.00 \\
0.00 \\
0.00 \\
12.69 \\
26.56 \\
21.21 \\
0.51 \\
0.00 \\
0.00 \\
0.00 \\
0.00 \\
0.00 \\
0.00 \\
2.36 \\
9.40 \\
0.00 \\
4.45 \\
0.82 \\
0.00 \\
0.00 \\
0.00 \\
3.11 \\
0.00 \\
16.91 \\
11.05 \\
0.00 \\
0.00 \\
0.00 \\
0.00 \\
7.38 \\
0.76 \\
0.00 \\
2.79 \\
0.00 \\
0.00 \\
15.76 \\
0.00 \\
0.00\end{array}$ \\
\hline
\end{tabular}


SWSA 6 PRECIPITATION

\begin{tabular}{|c|c|c|c|c|}
\hline Date & $\begin{array}{l}\text { TARA } \\
\text { Preolp } \\
\text { (nm) }\end{array}$ & $\begin{array}{l}\text { SWSA } 6 \\
\text { Pron 1p } \\
\text { Gaugo } 1 \\
\text { (mim) }\end{array}$ & $\begin{array}{l}\text { SWSA } 6 \\
\text { Pred Lp } \\
\text { Gauge } 2 \\
\text { (miil) }\end{array}$ & $\begin{array}{l}\text { SWSA } 6 \\
\text { Averaga } \\
\text { Preolp. } \\
\text { (mm) }\end{array}$ \\
\hline $\begin{array}{l}04 / 01 / 87 \\
04 / 02 / 87 \\
04 / 03 / 87 \\
04 / 04 / 87 \\
04 / 05 / 87 \\
04 / 06 / 87 \\
04 / 07 / 87 \\
04 / 08 / 87 \\
04 / 09 / 87 \\
04 / 10 / 87 \\
04 / 11 / 87 \\
04 / 12 / 87 \\
04 / 13 / 87 \\
04 / 14 / 87 \\
04 / 15 / 87 \\
04 / 16 / 87 \\
04 / 17 / 87 \\
04 / 18 / 87 \\
04 / 19 / 87 \\
04 / 20 / 87 \\
04 / 21 / 87 \\
04 / 22 / 87 \\
04 / 23 / 87 \\
04 / 24 / 87 \\
04 / 25 / 87 \\
04 / 26 / 87 \\
04 / 27 / 87 \\
04 / 28 / 87 \\
04 / 29 / 87 \\
04 / 30 / 87 \\
05 / 01 / 87 \\
05 / 02 / 87 \\
05 / 03 / 87 \\
05 / 04 / 87 \\
05 / 05 / 87 \\
05 / 06 / 87 \\
05 / 07 / 87 \\
05 / 08 / 87 \\
05 / 09 / 87 \\
05 / 10 / 87 \\
05 / 11 / 87 \\
05 / 12 / 87 \\
05 / 13 / 87 \\
05 / 14 / 87 \\
05 / 15 / 87\end{array}$ & & 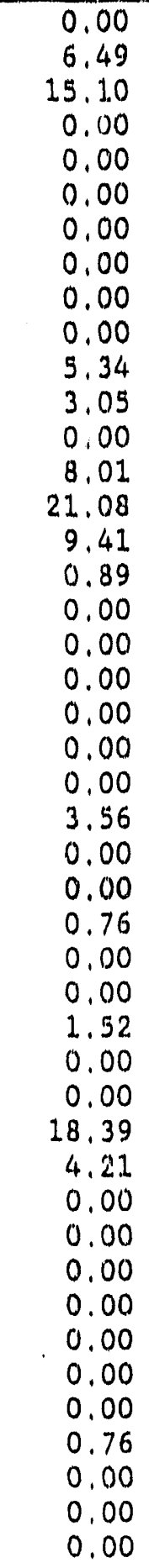 & 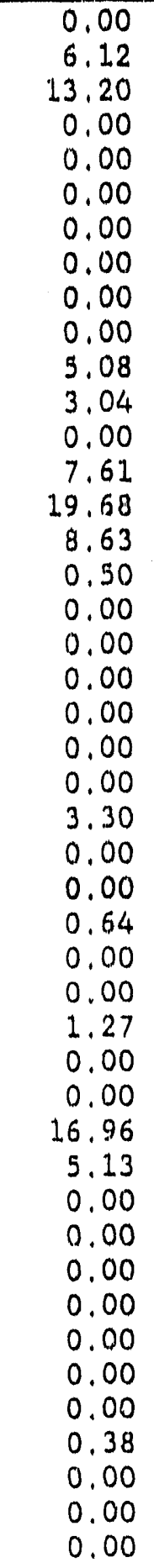 & 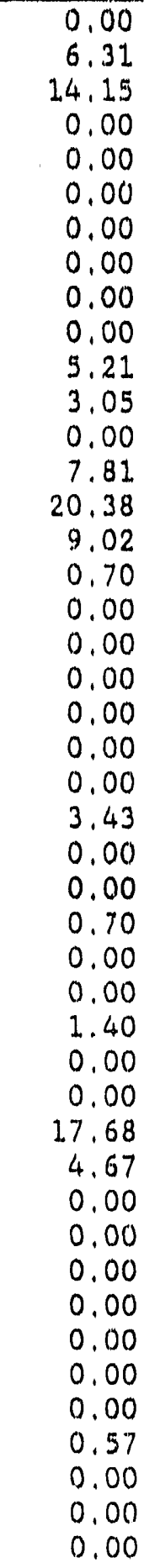 \\
\hline
\end{tabular}


SWSA 6 PREOTPTTATION

\begin{tabular}{|c|c|c|c|c|}
\hline Data & $\begin{array}{l}\text { TARA } \\
\text { Pracip. } \\
\text { (mu) }\end{array}$ & $\begin{array}{l}\text { SWSA 6 } \\
\text { Prec1p. } \\
\text { Gauga } 1 \\
\text { (min) }\end{array}$ & $\begin{array}{l}\text { SWSA } 6 \\
\text { PrecLP. } \\
\text { Gauge } 2 \\
\text { (mm) }\end{array}$ & $\begin{array}{l}\text { SWSA } 6 \\
\text { Average } \\
\text { Preotp. } \\
\text { (mm) }\end{array}$ \\
\hline $\begin{array}{l}05 / 16 / 87 \\
05 / 17 / 87 \\
05 / 18 / 87 \\
05 / 19 / 87 \\
05 / 20 / 87 \\
05 / 21 / 87 \\
05 / 22 / 87 \\
05 / 23 / 87 \\
05 / 24 / 87 \\
05 / 29 / 87 \\
05 / 26 / 87 \\
05 / 27 / 87 \\
05 / 28 / 87 \\
05 / 29 / 87 \\
05 / 30 / 87 \\
05 / 31 / 87 \\
06 / 01 / 87 \\
06 / 02 / 87 \\
06 / 03 / 87 \\
06 / 04 / 87 \\
06 / 05 / 87 \\
06 / 06 / 87 \\
06 / 07 / 87 \\
06 / 08 / 87 \\
06 / 09 / 87 \\
06 / 10 / 87 \\
06 / 11 / 87 \\
06 / 12 / 87 \\
06 / 13 / 87 \\
06 / 14 / 87 \\
06 / 15 / 87 \\
06 / 16 / 87 \\
06 / 17 / 87 \\
06 / 18 / 87 \\
06 / 19 / 87 \\
06 / 20 / 87 \\
06 / 21 / 87 \\
06 / 22 / 87 \\
06 / 23 / 87 \\
06 / 24 / 87 \\
06 / 25 / 87 \\
06 / 26 / 87 \\
06 / 27 / 87 \\
06 / 28 / 87 \\
06 / 29 / 87\end{array}$ & & $\begin{array}{r}2.79 \\
2.3 .12 \\
0.00 \\
0.00 \\
3.31 \\
9.51 \\
0.00 \\
0.00 \\
1.27 \\
3.31 \\
0.00 \\
0.00 \\
0.00 \\
19.69 \\
14.73 \\
0.00 \\
0.00 \\
0.00 \\
1.27 \\
0.00 \\
0.00 \\
0.00 \\
0.00 \\
0.00 \\
0.00 \\
0.00 \\
0.00 \\
8.89 \\
1.27 \\
0.00 \\
0.64 \\
0.00 \\
3.17 \\
5.08 \\
3.17 \\
2.54 \\
13.33 \\
40.64 \\
0.64 \\
0.00 \\
0.00 \\
0.64 \\
0.00 \\
0.00 \\
0.00\end{array}$ & $\begin{array}{r}1.77 \\
23.62 \\
0.00 \\
0.00 \\
3.05 \\
9.65 \\
0.00 \\
0.00 \\
1.52 \\
5.59 \\
0.00 \\
0.00 \\
0.00 \\
21.58 \\
13.97 \\
0.00 \\
0.00 \\
0.00 \\
0.64 \\
0.00 \\
0.00 \\
0.00 \\
0.00 \\
0.00 \\
0.00 \\
0.00 \\
0.00 \\
8.89 \\
1.27 \\
0.00 \\
0.64 \\
0.64 \\
2.54 \\
5.71 \\
3.81 \\
2.54 \\
12.95 \\
41.27 \\
0.64 \\
0.00 \\
0.00 \\
1.27 \\
0.00 \\
0.00 \\
0.00\end{array}$ & $\begin{array}{r}2.28 \\
2.3 .37 \\
0.00 \\
0.00 \\
3.18 \\
9.58 \\
0.00 \\
0.00 \\
1.40 \\
4.45 \\
0.00 \\
0.00 \\
0.00 \\
20.64 \\
14.35 \\
0.00 \\
0.00 \\
0.00 \\
0.96 \\
0.00 \\
0.00 \\
0.00 \\
0.00 \\
0.00 \\
0.00 \\
0.00 \\
0.00 \\
8.89 \\
1.2 \% \\
0.00 \\
0.64 \\
0.32 \\
2.86 \\
5.40 \\
3.49 \\
2.54 \\
13.14 \\
40.96 \\
0.64 \\
0.00 \\
0.00 \\
0.96 \\
0.00 \\
0.00 \\
0.00\end{array}$ \\
\hline
\end{tabular}


SWSA 6 PRECIPITATION

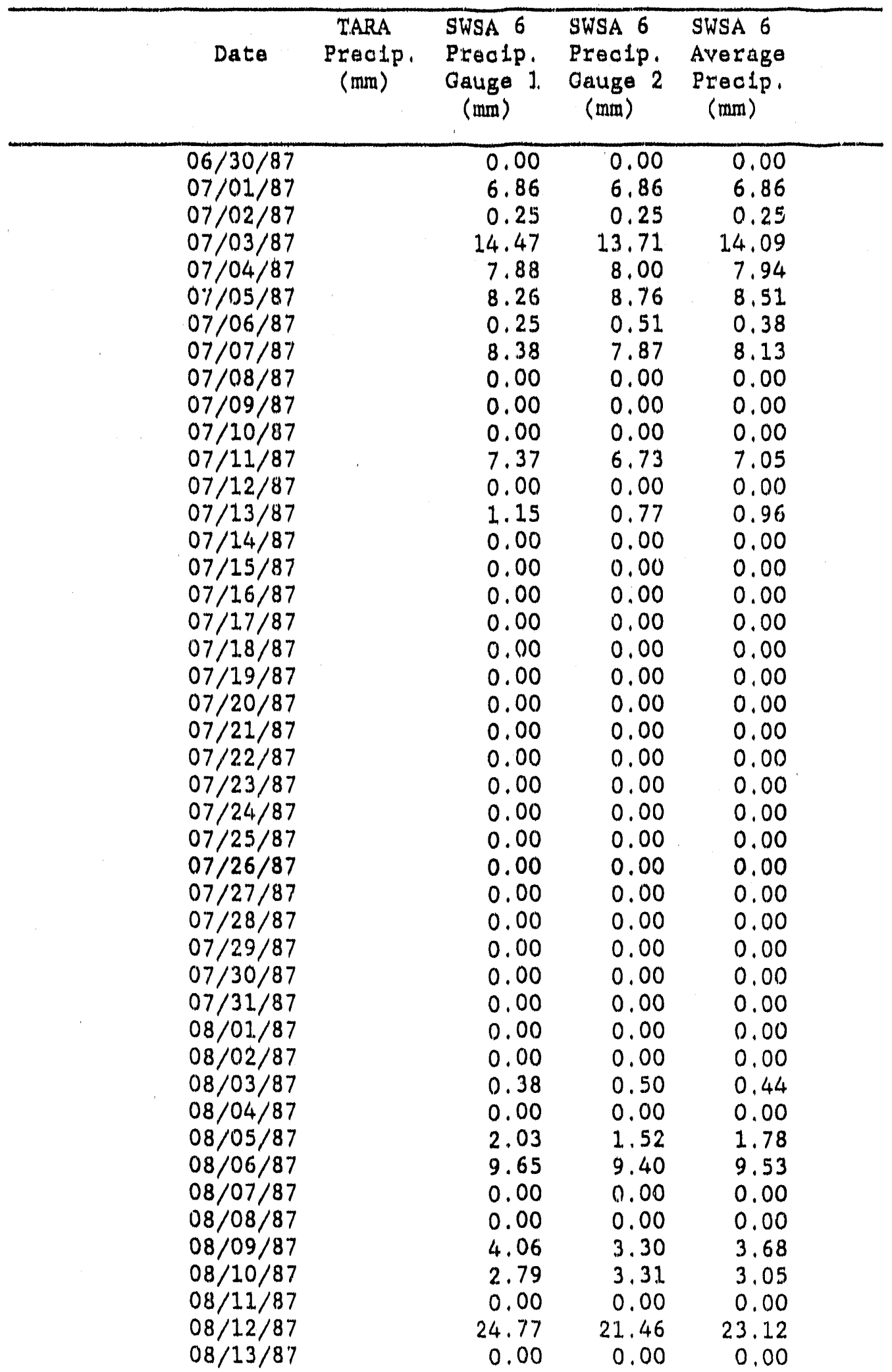


SWSA 6 PRECIPITATION

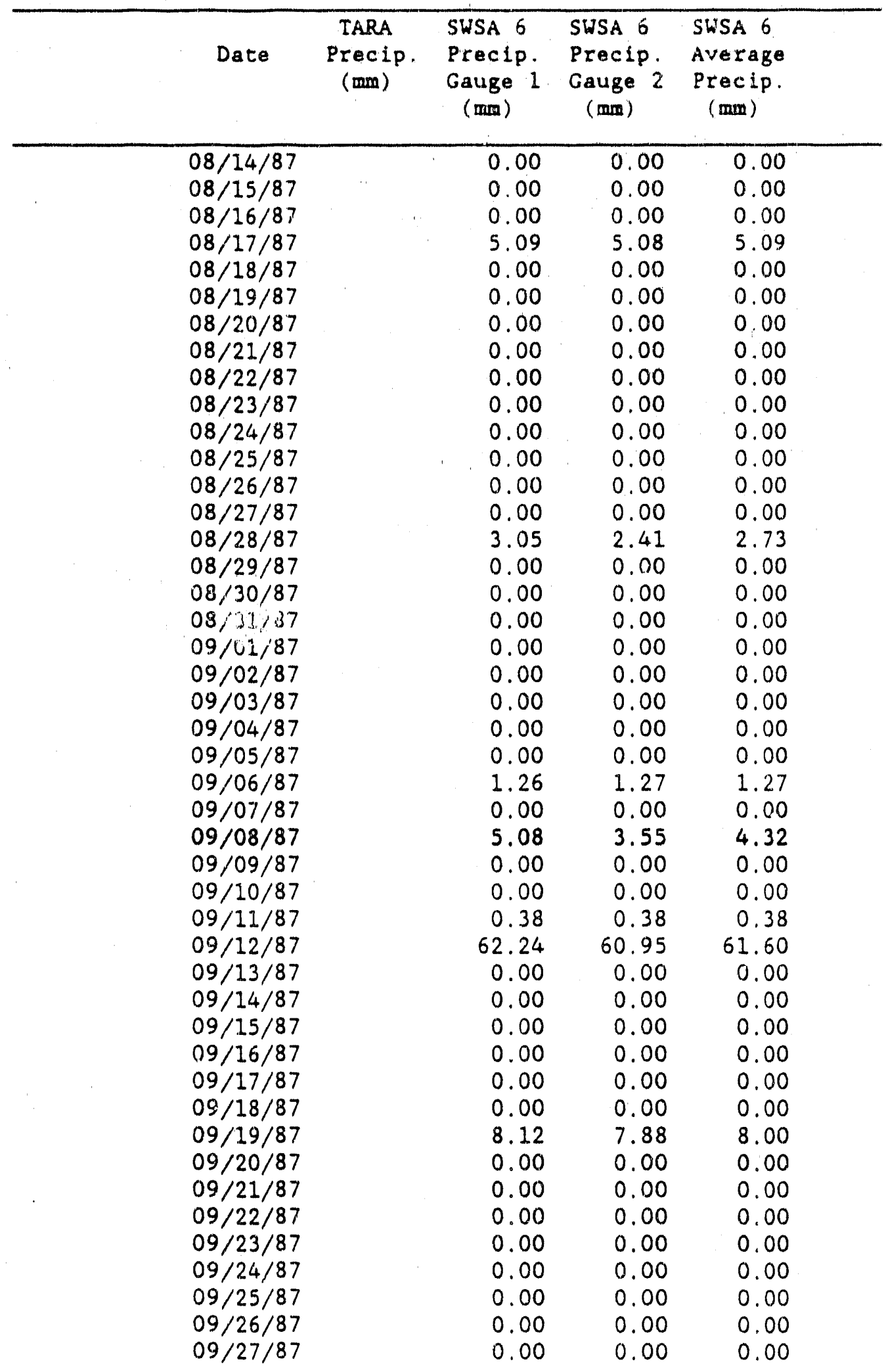


SWSA 6 PRECIPITATION

\begin{tabular}{|c|c|c|c|c|}
\hline Dace & $\begin{array}{c}\text { TARA } \\
\text { Precip. } \\
\text { (mns) }\end{array}$ & $\begin{array}{l}\text { SWSA } 6 \\
\text { Precip. } \\
\text { Gauge } 1 \\
(\mathrm{~mm})\end{array}$ & $\begin{array}{c}\text { SWSA } 6 \\
\text { Precip. } \\
\text { Gauge } 2 \\
(\mathrm{~mm})\end{array}$ & $\begin{array}{l}\text { SWSA } \dot{0} \\
\text { Average } \\
\text { Precip. } \\
\text { (mm) }\end{array}$ \\
\hline $09 / 28 / 87$ & & 0.00 & 0.00 & 0.00 \\
\hline $09 / 29 / 87$ & & 16.51 & 17.26 & 16.89 \\
\hline $09 / 30 / 87$ & & 0.00 & 0.00 & 0.00 \\
\hline $10 / 01 / 87$ & & 0.00 & 0.00 & 0.00 \\
\hline $10 / 02 / 87$ & & 0.00 & 0.00 & 0.00 \\
\hline $10 / 03 / 87$ & & 0.00 & 0.00 & 0.00 \\
\hline $10, / 04 / 87$ & & 0.00 & 0.00 & 0.00 \\
\hline $10 / 05 / 87$ & & 0.00 & 0.00 & 0.00 \\
\hline $10 / 06 / 87$ & & 0.76 & 1.02 & 0.89 \\
\hline $10 / 07 / 87$ & & 0.00 & 0.00 & 0.00 \\
\hline $10 / 08 / 87$ & & 0.00 & 0.00 & 0.00 \\
\hline $10 / 09 / 87$ & & 0.00 & 0.00 & 0.00 \\
\hline $10 / 10 / 87$ & & 0.00 & 0.00 & 0.00 \\
\hline $10 / 11 / 87$ & & 0.00 & 0.00 & 0.00 \\
\hline $10 / 12 / 87$ & & 0.00 & 0.00 & 0.00 \\
\hline $10 / 13 / 87$ & & 0.00 & 0.00 & 0.00 \\
\hline $10 / 14 / 87$ & & 0.00 & 0.00 & 0.00 \\
\hline $10 / 15 / 87$ & & 0.00 & 0.00 & 0.00 \\
\hline $10 / 16 / 87$ & & 0.00 & 0.00 & 0.00 \\
\hline $10 / 17 / 87$ & & 0.00 & 0.00 & 0.00 \\
\hline $10 / 18 / 87$ & & 0.00 & 0.00 & 0.00 \\
\hline $10 / 19 / 87$ & & 0.51 & 0.37 & 0.44 \\
\hline $10 / 20 / 87$ & & 7.12 & 7.36 & 7.24 \\
\hline $10 / 21 / 87$ & & 0.00 & 0.00 & 0.00 \\
\hline $10 / 22 / 87$ & & 0.00 & 0.00 & 0.00 \\
\hline $10 / 23 / 87$ & & 0.00 & 0.00 & 0.00 \\
\hline $10 / 24 / 87$ & & 0.00 & 0.00 & 0.00 \\
\hline $10 / 25 / 87$ & & 0.76 & 0.64 & 0.70 \\
\hline $10 / 26 / 87$ & & 1.53 & 1.29 & 1.41 \\
\hline $10 / 27 / 87$ & & 2.03 & 2.03 & 2.03 \\
\hline $10 / 28 / 87$ & & 0.00 & 0.00 & 0.00 \\
\hline $10 / 29 / 87$ & & 2.54 & 2.03 & 2.29 \\
\hline $10 / 30 / 87$ & & 0.00 & 0.00 & 0.00 \\
\hline $10 / 31 / 87$ & & 0.00 & 0.00 & 0.00 \\
\hline $11 / 01 / 87$ & & 0.00 & 0.00 & 0.00 \\
\hline $11 / 02 / 87$ & & 0.00 & 0.00 & 0.00 \\
\hline $11 / 03 / 87$ & & 0.00 & 0.00 & 0.00 \\
\hline $11 / 04 / 87$ & & 0.00 & 0.00 & 0.00 \\
\hline $11 / 05 / 87$ & & 0.00 & 0.00 & 0.00 \\
\hline $11 / 06 / 87$ & & 0.00 & 0.00 & 0.00 \\
\hline $11 / 07 / 87$ & & 0.00 & 0.00 & 0.00 \\
\hline $11 / 08 / 87$ & & 0.00 & 0.00 & 0.00 \\
\hline $11 / 09 / 87$ & & 7.02 & 8.70 & 7.86 \\
\hline $11 / 10 / 87$ & & 20.55 & 19.50 & 20.03 \\
\hline $11 / 11,87$ & & 0.00 & 0.00 & 0.00 \\
\hline
\end{tabular}


SWSA 6 PRECIPITATION

\begin{tabular}{|c|c|c|c|c|}
\hline Date & $\begin{array}{l}\text { TARA } \\
\text { Precip. } \\
\text { (mm) }\end{array}$ & $\begin{array}{l}\text { SWSA } 6 \\
\text { Precip. } \\
\text { Gauge } 1 \\
\text { (mm) }\end{array}$ & $\begin{array}{l}\text { SWSA } 6 \\
\text { Precip. } \\
\text { Gauge } 2 \\
\text { (mm) }\end{array}$ & $\begin{array}{l}\text { SWSA } 6 \\
\text { Average } \\
\text { Precip. } \\
\text { (mm) }\end{array}$ \\
\hline $\begin{array}{l}11 / 12 / 87 \\
11 / 13 / 87 \\
11 / 14 / 87 \\
11 / 15 / 87 \\
11 / 16 / 87 \\
11 / 17 / 87 \\
11 / 18 / 87 \\
11 / 19 / 87 \\
11 / 20 / 87 \\
11 / 21 / 87 \\
11 / 22 / 87 \\
11 / 23 / 87 \\
11 / 24 / 87 \\
11 / 25 / 87 \\
11 / 26 / 87 \\
11 / 27 / 87 \\
11 / 28 / 87 \\
11 / 29 / 87 \\
11 / 30 / 87 \\
12 / 01 / 87 \\
12 / 02 / 87 \\
12 / 03 / 87 \\
12 / 04 / 87 \\
12 / 05 / 87 \\
12 / 06 / 87 \\
12 / 07 / 87 \\
12 / 08 / 87 \\
12 / 09 / 87 \\
12 / 10 / 87 \\
12 / 11 / 87 \\
12 / 12 / 87 \\
12 / 13 / 87 \\
12 / 14 / 87 \\
12 / 15 / 87 \\
12 / 16 / 87 \\
12 / 17 / 87 \\
12 / 18 / 87 \\
12 / 19 / 87 \\
12 / 20 / 87 \\
12 / 21 / 87 \\
12 / 22 / 87 \\
12 / 23 / 87 \\
12 / 24 / 87 \\
12 / 25 / 87 \\
12 / 26 / 87\end{array}$ & . & $\begin{array}{r}0.00 \\
0.00 \\
0.00 \\
0.00 \\
0.00 \\
18.28 \\
0.00 \\
0.00 \\
0.00 \\
0.00 \\
0.00 \\
0.00 \\
0.00 \\
0.00 \\
0.25 \\
0.00 \\
6.35 \\
0.00 \\
0.00 \\
0.63 \\
0.00 \\
0.76 \\
0.00 \\
0.00 \\
0.00 \\
0.00 \\
0.00 \\
0.00 \\
0.00 \\
0.25 \\
0.00 \\
0.00 \\
5.08 \\
17.03 \\
0.00 \\
0.00 \\
0.00 \\
0.00 \\
3.80 \\
0.00 \\
0.00 \\
0.00 \\
18.10 \\
7.28 \\
9.91\end{array}$ & $\begin{array}{r}0.00 \\
0.00 \\
0.00 \\
0.00 \\
0.00 \\
18.53 \\
0.00 \\
0.00 \\
0.00 \\
0.00 \\
0.00 \\
0.00 \\
0.00 \\
0.00 \\
0.38 \\
0.00 \\
6.09 \\
0.00 \\
0.00 \\
0.63 \\
0.00 \\
0.89 \\
0.00 \\
0.00 \\
0.00 \\
0.00 \\
0.00 \\
0.00 \\
0.00 \\
0.63 \\
0.00 \\
0.00 \\
4.77 \\
17.59 \\
0.00 \\
0.00 \\
0.00 \\
0.00 \\
3.55 \\
0.00 \\
0.00 \\
0.00 \\
17.81 \\
7.18 \\
8.77\end{array}$ & 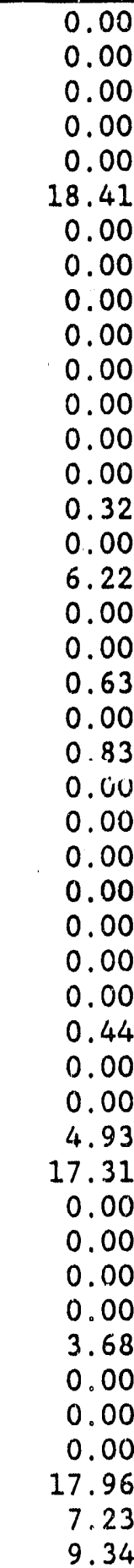 \\
\hline
\end{tabular}


SWSA 6 PRECIPITATION

\begin{tabular}{|c|c|c|c|c|}
\hline Date & $\begin{array}{l}\text { TARA } \\
\text { Precip. } \\
\text { (mm) }\end{array}$ & $\begin{array}{l}\text { SWSA } 6 \\
\text { Precip. } \\
\text { Gauge } 1 \\
\quad \text { (mm) }\end{array}$ & $\begin{array}{l}\text { SWSA } 6 \\
\text { Precip. } \\
\text { Gauge } 2 \\
\text { (mm) }\end{array}$ & $\begin{array}{l}\text { SWSA } 6 \\
\text { Average } \\
\text { Precip. } \\
\text { (mm) }\end{array}$ \\
\hline $\begin{array}{l}12 / 27 / 87 \\
12 / 28 / 87 \\
12 / 29 / 87 \\
12 / 30 / 87 \\
12 / 31 / 87 \\
01 / 01 / 88 \\
01 / 02 / 88 \\
01 / 03 / 88 \\
01 / 04 / 88 \\
01 / 05 / 88 \\
01 / 06 / 88 \\
01 / 07 / 88 \\
01 / 08 / 88 \\
01 / 09 / 88 \\
01 / 10 / 88 \\
01 / 11 / 88 \\
01 / 12 / 88 \\
01 / 13 / 88 \\
01 / 14 / 88 \\
01 / 15 / 88 \\
01 / 16 / 88 \\
01 / 17 / 88 \\
01 / 18 / 88 \\
01 / 19 / 88 \\
01 / 20 / 88 \\
01 / 21 / 88 \\
01 / 22 / 88 \\
01 / 23 / 88 \\
01 / 24 / 88 \\
01 / 25 / 88 \\
01 / 26 / 88 \\
01 / 27 / 88 \\
01 / 28 / 88 \\
01 / 29 / 88 \\
01 / 30 / 88 \\
01 / 31 / 88 \\
02 / 01 / 88 \\
02 / 02 / 88 \\
02 / 03 / 88 \\
02 / 04 / 88 \\
02 / 05 / 88 \\
02 / 06 / 88 \\
02 / 07 / 88 \\
02 / 08 / 88 \\
02 / 09 / 88\end{array}$ & 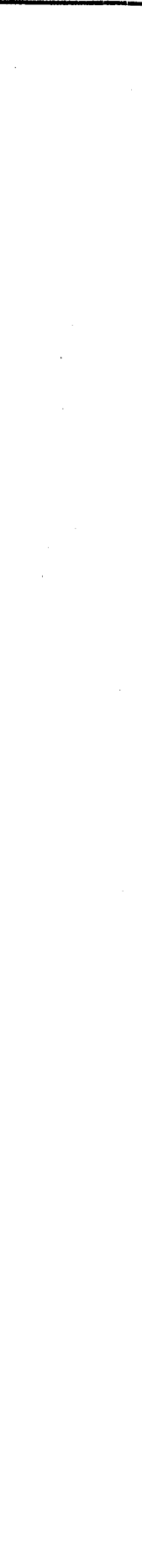 & $\begin{array}{r}7.12 \\
9.89 \\
0.00 \\
0.00 \\
2.67 \\
12.57 \\
0.00 \\
8.38 \\
0.00 \\
0.00 \\
0.00 \\
14.45 \\
0.76 \\
0.00 \\
0.00 \\
0.00 \\
0.51 \\
1.53 \\
0.00 \\
0.00 \\
0.00 \\
14.84 \\
0.00 \\
75.44 \\
0.00 \\
0.00 \\
0.00 \\
0.00 \\
0.26 \\
1.28 \\
0.00 \\
0.00 \\
0.00 \\
0.00 \\
0.00 \\
0.00 \\
0.76 \\
0.00 \\
13.71 \\
14.73 \\
14.99 \\
0.00 \\
0.00 \\
0.00 \\
0.00\end{array}$ & 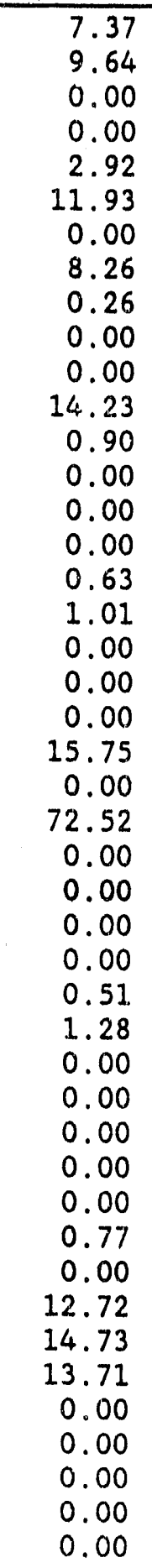 & $\begin{array}{r}7.25 \\
9.77 \\
0.00 \\
0.00 \\
2.80 \\
12.25 \\
0.00 \\
8.32 \\
0.13 \\
0.00 \\
0.00 \\
14.34 \\
0.83 \\
0.00 \\
0.00 \\
0.00 \\
0.00 \\
0.57 \\
1.27 \\
0.00 \\
0.00 \\
0.00 \\
0.00 \\
0.00 \\
0.00 \\
15.30 \\
0.00 \\
0.00 \\
73.90 \\
0.00 \\
0.00 \\
0.00 \\
0.00 \\
0.00 \\
0.00 \\
0.00 \\
13\end{array}$ \\
\hline
\end{tabular}


SWSA 6 PRECIPITATION

\begin{tabular}{|c|c|c|c|c|}
\hline Date & $\begin{array}{l}\text { TARA } \\
\text { Precip. } \\
\text { (mm) }\end{array}$ & $\begin{array}{l}\text { SWSA } 6 \\
\text { Precip. } \\
\text { Gauge } 1 \\
\text { (mm) }\end{array}$ & $\begin{array}{l}\text { SWSA } 6 \\
\text { Precip. } \\
\text { Gauge } 2 \\
\text { (mm) }\end{array}$ & $\begin{array}{l}\text { SWSA } 6 \\
\text { Average } \\
\text { Precip. } \\
\text { (mm) }\end{array}$ \\
\hline $\begin{array}{l}02 / 10 / 88 \\
02 / 11 / 88 \\
02 / 12 / 88 \\
02 / 13 / 88 \\
02 / 14 / 88 \\
02 / 15 / 88 \\
02 / 16 / 88 \\
02 / 17 / 88 \\
02 / 18 / 88 \\
02 / 19 / 88 \\
02 / 20 / 88 \\
02 / 21 / 88 \\
02 / 22 / 88 \\
02 / 23 / 88 \\
02 / 24 / 88 \\
02 / 25 / 88 \\
02 / 26 / 88 \\
02 / 27 / 88 \\
02 / 28 / 88 \\
02 / 29 / 88 \\
03 / 01 / 88 \\
03 / 02 / 88 \\
03 / 03 / 88 \\
03 / 04 / 88 \\
03 / 05 / 88 \\
03 / 06 / 88 \\
03 / 07 / 88 \\
03 / 08 / 88 \\
03 / 09 / 88 \\
03 / 10 / 88 \\
03 / 11 / 88 \\
03 / 12 / 88 \\
03 / 13 / 88 \\
03 / 14 / 88 \\
03 / 15 / 88 \\
03 / 16 / 88 \\
03 / 17 / 88 \\
03 / 18 / 88 \\
03 / 19 / 88 \\
03 / 20 / 88 \\
03 / 21 / 88 \\
03 / 22 / 88 \\
03 / 23 / 88 \\
03 / 24 / 88 \\
03 / 25 / 88\end{array}$ & $\begin{array}{r}7.37 \\
0.00 \\
0.00 \\
0.00 \\
0.00 \\
4.06 \\
55.12 \\
0.00 \\
14.48 \\
0.25 \\
0.00 \\
0.00 \\
0.00 \\
0.00 \\
3.56 \\
0.00 \\
0.00 \\
0.25 \\
0.00 \\
0.00 \\
0.00 \\
2.79\end{array}$ & $\begin{array}{r}0.00 \\
5.09 \\
0.00 \\
0.00 \\
0.00 \\
14.98 \\
0.00 \\
0.00 \\
0.00 \\
4.83 \\
0.00 \\
0.00 \\
0.00 \\
4.44 \\
0.00 \\
0.00 \\
0.00 \\
0.00 \\
0.00 \\
0.00 \\
0.00 \\
0.00 \\
1.40 \\
8.50 \\
0.00 \\
0.00 \\
0.00 \\
0.00 \\
3.30 \\
54.09 \\
0.00 \\
14.21 \\
0.76 \\
0.00 \\
0.00 \\
0.00 \\
0.00 \\
3.30 \\
0.00 \\
0.00 \\
0.00 \\
0.00 \\
0.00 \\
0.00 \\
2.54\end{array}$ & $\begin{array}{r}0.00 \\
4.32 \\
0.00 \\
0.00 \\
0.00 \\
13.96 \\
0.00 \\
0.00 \\
0.00 \\
4.32 \\
0.00 \\
0.00 \\
0.00 \\
4.56 \\
0.00 \\
0.00 \\
0.00 \\
0.00 \\
0.00 \\
0.00 \\
0.00 \\
0.00 \\
1.27 \\
6.61 \\
0.00 \\
0.00 \\
0.00 \\
0.00 \\
2.04 \\
54.75 \\
0.00 \\
13.08 \\
0.76 \\
0.00 \\
0.00 \\
0.00 \\
0.00 \\
2.91 \\
0.00 \\
0.00 \\
0.00 \\
0.00 \\
0.00 \\
0.00 \\
2.29\end{array}$ & $\begin{array}{r}0.00 \\
4.71 \\
0.00 \\
0.00 \\
0.00 \\
14.47 \\
0.00 \\
0.00 \\
0.00 \\
4.58 \\
0.00 \\
0.00 \\
0.00 \\
4.50 \\
0.00 \\
0.00 \\
0.00 \\
0.00 \\
0.00 \\
0.00 \\
0.00 \\
0.00 \\
1.34 \\
7.49 \\
0.00 \\
0.00 \\
0.00 \\
0.00 \\
3.13 \\
54.65 \\
0.00 \\
13.92 \\
0.59 \\
0.00 \\
0.00 \\
0.00 \\
0.00 \\
3.26 \\
0.00 \\
0.00 \\
0.08 \\
0.00 \\
0.00 \\
0.00 \\
2.54\end{array}$ \\
\hline
\end{tabular}


SWSA 6 PRECIPITATION

\begin{tabular}{|c|c|c|c|c|}
\hline Date & $\begin{array}{l}\text { TARA } \\
\text { Precip. } \\
\text { (mm) }\end{array}$ & $\begin{array}{l}\text { SWSA } 6 \\
\text { Precip. } \\
\text { Gauge } 1 \\
\text { (mm) }\end{array}$ & $\begin{array}{l}\text { SWSA } 6 \\
\text { Precip. } \\
\text { Gauge } 2 \\
\text { (rinip) }\end{array}$ & $\begin{array}{l}\text { SWSA } 6 \\
\text { Average } \\
\text { Precip. } \\
\text { (tumi) }\end{array}$ \\
\hline $\begin{array}{l}03 / 26 / 88 \\
03 / 27 / 88 \\
03 / 28 / 88 \\
03 / 29 / 88 \\
03 / 30 / 88 \\
03 / 31 / 88 \\
04 / 01 / 88 \\
04 / 02 / 88 \\
04 / 03 / 88 \\
04 / 04 / 88 \\
04 / 05 / 88 \\
04 / 06 / 88 \\
04 / 07 / 88 \\
04 / 08 / 88 \\
04 / 09 / 88 \\
04 / 10 / 88 \\
04 / 11 / 88 \\
04 / 12 / 88 \\
04 / 13 / 88 \\
04 / 14 / 88 \\
04 / 15 / 88 \\
04 / 16 / 88 \\
04 / 17 / 88 \\
04 / 18 / 88 \\
04 / 19 / 88 \\
04 / 20 / 88 \\
04 / 21 / 88 \\
04 / 22 / 88 \\
04 / 23 / 88 \\
04 / 24 / 88 \\
04 / 25 / 88 \\
04 / 26 / 88 \\
04 / 27 / 88 \\
04 / 28 / 88 \\
04 / 29 / 88 \\
04 / 30 / 88 \\
05 / 01 / 88 \\
05 / 02 / 88 \\
05 / 03 / 88 \\
05 / 04 / 88 \\
05 / 05 / 88 \\
05 / 06 / 88 \\
05 / 07 / 88 \\
05 / 08 / 88 \\
05 / 09 / 88\end{array}$ & $\begin{array}{r}2.54 \\
0.00 \\
0.00 \\
0.00 \\
0.25 \\
1.02 \\
10.67 \\
0.25 \\
7.11 \\
0.00 \\
0.00 \\
18.29 \\
0.00 \\
0.00 \\
0.00 \\
0.00 \\
2.03 \\
5.84 \\
0.00 \\
0.00 \\
6.35 \\
0.00 \\
0.00 \\
20.83 \\
5.33 \\
0.00 \\
0.00 \\
0.00 \\
3.05 \\
1.27 \\
0.00 \\
0.00 \\
0.00 \\
0.00 \\
0.00 \\
0.00 \\
0.00 \\
0.00 \\
7.62 \\
9.14 \\
0.00 \\
0.00 \\
0.00 \\
0.00 \\
10.92\end{array}$ & $\begin{array}{r}3.56 \\
0.00 \\
0.00 \\
0.00 \\
0.25 \\
1.01 \\
9.53 \\
0.00 \\
5.96 \\
0.00 \\
0.00 \\
17.02 \\
0.00 \\
0.00 \\
0.00 \\
0.00 \\
1.53 \\
4.70 \\
0.00 \\
0.00 \\
6.35 \\
0.00 \\
0.00 \\
18.30 \\
5.20 \\
0.00 \\
0.00 \\
0.00 \\
3.17 \\
1.27 \\
0.00 \\
0.00 \\
0.00 \\
0.00 \\
0.00 \\
0.00 \\
0.00 \\
0.00 \\
7.62 \\
8.37 \\
0.00 \\
0.00 \\
0.00 \\
0.00 \\
10.67\end{array}$ & $\begin{array}{r}2.14 \\
0.60 \\
0.00 \\
0.00 \\
0.38 \\
0.77 \\
9.13 \\
0.00 \\
5.70 \\
0.00 \\
0.00 \\
16.52 \\
0.00 \\
0.00 \\
0.00 \\
0.00 \\
1.53 \\
4.83 \\
0.00 \\
0.00 \\
5.47 \\
0.00 \\
0.00 \\
17.91 \\
4.95 \\
0.00 \\
0.00 \\
0.00 \\
2.54 \\
1.02 \\
0.00 \\
0.00 \\
0.00 \\
0.00 \\
0.00 \\
0.00 \\
0.00 \\
0.00 \\
7.11 \\
8.64 \\
0.00 \\
0.00 \\
0.00 \\
0.00 \\
9.78\end{array}$ & $\begin{array}{r}2.88 \\
0.00 \\
0.00 \\
0.00 \\
0.29 \\
0.93 \\
9.78 \\
0.08 \\
6.26 \\
0.00 \\
0.00 \\
17.28 \\
0.00 \\
0.00 \\
0.00 \\
0.00 \\
1.70 \\
5.12 \\
0.00 \\
0.00 \\
6.06 \\
0.00 \\
0.00 \\
19.01 \\
5.16 \\
0.00 \\
0.00 \\
0.00 \\
2.92 \\
1.19 \\
0.00 \\
0.00 \\
0.00 \\
0.00 \\
0.00 \\
0.00 \\
0.00 \\
0.00 \\
7.45 \\
8.72 \\
0.00 \\
0.00 \\
0.00 \\
0.00 \\
10.46\end{array}$ \\
\hline
\end{tabular}


SWSA 6 PRECIPITATION

\begin{tabular}{|c|c|c|c|c|}
\hline Date & $\begin{array}{l}\text { TARA } \\
\text { Precip. } \\
\text { (mm) }\end{array}$ & $\begin{array}{l}\text { SWSA } 6 \\
\text { Precip. } \\
\text { Gauge } 1 \\
\text { (mm) }\end{array}$ & $\begin{array}{l}\text { SWSA } 6 \\
\text { Precip. } \\
\text { Gauge } 2 \\
\text { (mm) }\end{array}$ & $\begin{array}{l}\text { SWSA } 6 \\
\text { Average } \\
\text { Prectp. } \\
\text { (mm) }\end{array}$ \\
\hline $\begin{array}{l}05 / 10 / 88 \\
05 / 11 / 88 \\
05 / 12 / 88 \\
05 / 13 / 88 \\
05 / 14 / 88 \\
05 / 15 / 88 \\
05 / 16 / 88 \\
05 / 17 / 88 \\
05 / 18 / 88 \\
05 / 19 / 88 \\
05 / 20 / 88 \\
05 / 21 / 88 \\
05 / 22 / 88 \\
05 / 23 / 88 \\
05 / 24 / 88 \\
05 / 25 / 88 \\
05 / 26 / 88 \\
05 / 27 / 88 \\
05 / 28 / 88 \\
05 / 29 / 88 \\
05 / 30 / 88 \\
05 / 31 / 88 \\
06 / 01 / 88 \\
06 / 02 / 88 \\
06 / 03 / 88 \\
06 / 04 / 88 \\
06 / 05 / 88 \\
06 / 06 / 88 \\
06 / 07 / 88 \\
06 / 08 / 88 \\
06 / 09 / 88 \\
06 / 10 / 88 \\
06 / 11 / 88 \\
06 / 12 / 88 \\
06 / 13 / 88 \\
06 / 14 / 88 \\
06 / 15 / 88 \\
06 / 16 / 88 \\
06 / 17 / 88 \\
06 / 18 / 88 \\
06 / 19 / 88 \\
06 / 20 / 88 \\
06 / 21 / 88 \\
06 / 22 / 88 \\
06 / 23 / 88\end{array}$ & $\begin{array}{l}0.76 \\
0.00 \\
0.00 \\
0.00 \\
0.51 \\
0.00 \\
0.00 \\
0.00 \\
0.00 \\
0.00 \\
0.00 \\
0.00 \\
0.51 \\
0.00 \\
20.57 \\
1.78 \\
0.00 \\
0.00 \\
0.00 \\
0.00 \\
0.00 \\
0.00 \\
0.00 \\
0.00 \\
0.00 \\
0.00 \\
0.00 \\
0.00 \\
0.00 \\
0.00 \\
14.48 \\
0.00 \\
0.00 \\
0.00 \\
0.00 \\
0.00 \\
0.00 \\
0.00 \\
0.00 \\
0.00 \\
0.00 \\
4.57 \\
0.00 \\
0.00 \\
0.00\end{array}$ & $\begin{array}{r}0.64 \\
0.00 \\
0.00 \\
0.00 \\
0.63 \\
0.00 \\
0.00 \\
0.00 \\
0.00 \\
0.00 \\
0.00 \\
0.00 \\
0.76 \\
0.00 \\
23.11 \\
1.78 \\
0.00 \\
0.00 \\
0.00 \\
0.00 \\
0.00 \\
0.00 \\
0.00 \\
0.00 \\
0.00 \\
0.00 \\
0.00 \\
0.00 \\
0.00 \\
0.00 \\
11.69 \\
0.00 \\
0.00 \\
0.00 \\
0.00 \\
0.00 \\
0.00 \\
0.00 \\
0.00 \\
0.00 \\
0.00 \\
3.94 \\
0.00 \\
0.00 \\
0.00\end{array}$ & $\begin{array}{r}0.76 \\
0.00 \\
0.00 \\
0.00 \\
0.51 \\
0.00 \\
0.00 \\
0.00 \\
0.00 \\
0.00 \\
0.00 \\
0.00 \\
0.63 \\
0.00 \\
21.84 \\
1.65 \\
0.00 \\
0.00 \\
0.00 \\
0.00 \\
0.00 \\
0.00 \\
0.00 \\
0.00 \\
0.00 \\
0.00 \\
0.00 \\
0.00 \\
0.00 \\
0.00 \\
11.93 \\
0.00 \\
0.00 \\
0.00 \\
0.00 \\
0.00 \\
0.00 \\
0.00 \\
0.00 \\
0.00 \\
0.00 \\
5.21 \\
0.00 \\
0.00 \\
0.00\end{array}$ & $\begin{array}{l}0.72 \\
0.00 \\
0.00 \\
0.00 \\
0.55 \\
0.00 \\
0.00 \\
0.00 \\
0.00 \\
0.00 \\
0.00 \\
0.00 \\
0.63 \\
0.00 \\
21.84 \\
1.74 \\
0.00 \\
0.00 \\
0.00 \\
0.00 \\
0.00 \\
0.00 \\
0.00 \\
0.00 \\
0.00 \\
0.00 \\
0.00 \\
0.00 \\
0.00 \\
0.00 \\
12.70 \\
0.00 \\
0.00 \\
0.00 \\
0.00 \\
0.00 \\
0.00 \\
0.00 \\
0.00 \\
0.00 \\
0.00 \\
4.57 \\
0.00 \\
0.00 \\
0.00\end{array}$ \\
\hline
\end{tabular}


SWSA 6 PRECIPITATION

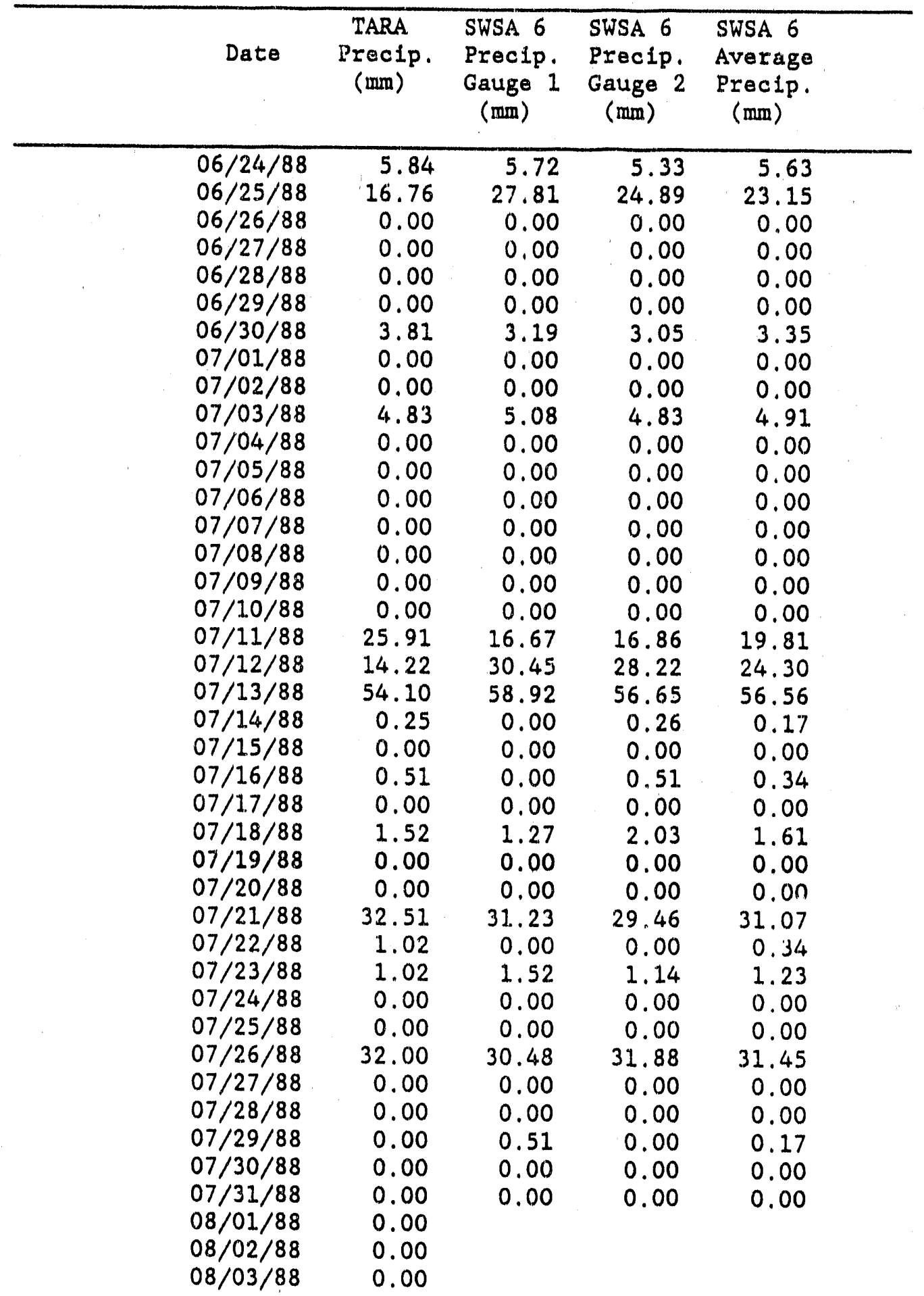




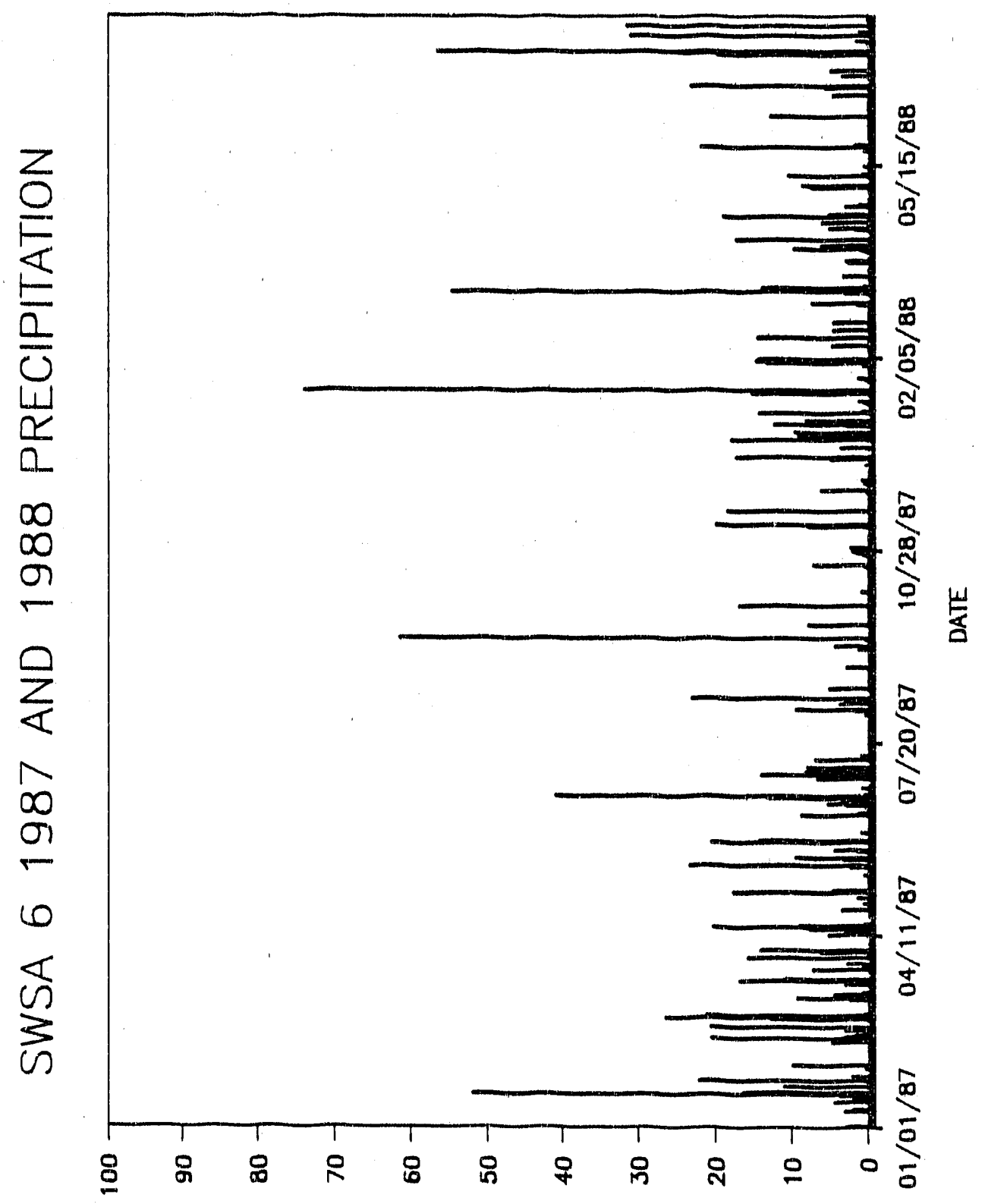

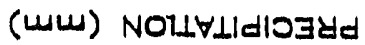


APPENDIX IV

Nonstandard Soll Penetration Tests Over Waste Trenches 
IV - 2

APPENDIX IV

\begin{tabular}{|c|c|c|c|c|c|c|c|c|c|}
\hline $\begin{array}{l}\text { Trench } \\
\text { Number }\end{array}$ & $\begin{array}{l}\text { Hole } \\
\text { Number }\end{array}$ & Date & $\begin{array}{l}\text { ft from } \\
N \text { End }\end{array}$ & Contam. & $\begin{array}{r}1-f t \\
\text { Blok:s }\end{array}$ & $\begin{array}{r}2 . \mathrm{ft} \\
\text { Blows }\end{array}$ & $\begin{array}{r}\text { 3-ft } \\
\text { Blows }\end{array}$ & $\begin{array}{r}4 \cdot f t \\
\text { Blows }\end{array}$ & $\begin{array}{r}5 . \mathrm{ft} \\
\text { Blows }\end{array}$ \\
\hline 2 & 1 & $02 / 03 / 87$ & $20 \mathrm{~N}$ & NO & 4 & 5 & 3 & 1 & 1 \\
\hline 2 & 2 & $02 / 03 / 87$ & $35 \mathrm{~N}$ & No & 4 & 3 & 3 & 1 & 1 \\
\hline 2 & 3 & $02 / 03 / 87$ & $48.5 \mathrm{~N}$ & No & 3 & 5 & 6 & 6 & 5 \\
\hline 2 & 4 & $02 / 03 / 87$ & $60.5 \mathrm{~N}$ & No & 5 & 4 & 7 & 4 & 4 \\
\hline 2 & 5 & $02 / 03 / 87$ & $18 \mathrm{~s}$ & No & 3 & 4 & 10 & 8 & 7 \\
\hline 3 & 1 & $02 / 03 / 87$ & $12.5 \mathrm{~N}$ & No & 3 & 4 & 3 & 2 & 1 \\
\hline 3 & 2 & $02 / 03 / 87$ & $24.5 \mathrm{~N}$ & No & 4 & 6 & 7 & 3 & 3 \\
\hline 3 & 3 & $02 / 03 / 87$ & $40.5 \mathrm{~N}$ & No & 5 & 3 & 5 & 7 & 8 \\
\hline 3 & 4. & $02 / 03 / 87$ & $53.5 \mathrm{~N}$ & YES & 4 & 5 & 6 & 4 & 4 \\
\hline 3 & 5 & $02 / 04 / 87$ & $22 \mathrm{~s}$ & YES & 4 & 5 & 7 & 6 & 5 \\
\hline 4 & 1 & $02 / 04 / 87$ & $7 \mathrm{~N}$ & No & 3 & 3 & 6 & 4 & 3 \\
\hline 4 & 2 & $02 / 04 / 87$ & $20 \mathrm{~N}$ & YES & 4 & 5 & 8 & 5 & 3 \\
\hline 4 & 3 & $02 / 04 / 87$ & $33.5 \mathrm{~N}$ & No & 4 & 4 & 8 & 9 & 8 \\
\hline 4 & 4 & $02 / 04 / 87$ & $47 \mathrm{~N}$ & No & 4 & 4 & 7 & 9 & 12 \\
\hline 4 & 5 & $02 / 04 / 87$ & $65.5 \mathrm{~N}$ & NO & 4 & 4 & 5 & 3 & 3 \\
\hline 5 & 1 & $02 / 04 / 87$ & $8.5 \mathrm{~N}$ & NO & 3 & 5 & 7 & 6 & 5 \\
\hline 5 & 2 & $02 / 04 / 87$ & $22.5 \mathrm{~N}$ & No & 4 & 4 & 8 & 10 & 11 \\
\hline 5 & 3 & $02 / 05 / 87$ & $40 \mathrm{~N}$ & No & 4 & 5 & 7 & 8 & 7 \\
\hline 5 & 4 & $02 / 05 / 87$ & $52.5 \mathrm{~N}$ & No & 5 & 6 & 6 & 5 & 4 \\
\hline 5 & 5 & $02 / 05 / 87$ & $67.5 \mathrm{~N}$ & No & 4 & 3 & 3 & 5 & 5 \\
\hline 6 & 1 & $02 / 05 / 87$ & $9 \mathrm{~N}$ & No & 4 & 4 & 8 & 7 & 4 \\
\hline 6 & 2 & $02 / 05 / 87$ & $25 \mathrm{~N}$ & NO & 4 & 4 & 8 & 3 & 3 \\
\hline 6 & 3 & $02 / 05 / 87$ & $41 \mathrm{~N}$ & NO & 5 & 7 & 8 & 3 & 3 \\
\hline 6 & 4 & $02 / 05 / 87$ & $57 \mathrm{~N}$ & No & 6 & 7 & 8 & 4 & 4 \\
\hline 6 & 5 & $02 / 05 / 87$ & $70 \mathrm{~N}$ & No & 4 & 4 & 8 & 5 & 3 \\
\hline 7 & 1 & $02 / 05 / 87$ & $9 \mathrm{~N}$ & No & 4 & 5 & 10 & 7 & 4 \\
\hline 7 & 2 & $02 / 05 / 87$ & $25 \mathrm{~N}$ & No & 5 & 3 & 7 & 7 & 7 \\
\hline 7 & 3 & $02 / 05 / 87$ & $36 \mathrm{~N}$ & No & 5 & 4 & 9 & 3 & 3 \\
\hline 7 & 4 & $02 / 06 / 87$ & $51 \mathrm{~N}$ & NO & 5 & 6 & 13 & 8 & 6 \\
\hline 7 & 5 & $02 / 06 / 87$ & $64 \mathrm{~N}$ & NO & 7 & 5 & 7 & 5 & 4 \\
\hline 8 & 1 & $02 / 06 / 87$ & $10 \mathrm{~N}$ & No & 4 & 6 & 10 & 12 & 13 \\
\hline 8 & 2 & $02 / 06 / 87$ & $21.5 \mathrm{~N}$ & YES & 4 & 5 & 6 & 7 & 4 \\
\hline 8 & 3 & $02 / 06 / 87$ & $36.5 \mathrm{~N}$ & NO & 5 & 4 & 9 & 7 & 6 \\
\hline 8 & 4 & $02 / 06 / 87$ & $49.5 \mathrm{~N}$ & NO & 5 & 7 & 11 & 9 & 4 \\
\hline 8 & 5 & $02 / 06 / 87$ & $60.5 \mathrm{~N}$ & No & 4 & 4 & 10 & 6 & 5 \\
\hline 9 & 1 & $02 / 06 / 87$ & $11 \mathrm{~N}$ & No & 5 & 5 & 8 & 4 & 4 \\
\hline 9 & 2 & $02 / 06 / 87$ & $20 \mathrm{~N}$ & No & 4 & 5 & 7 & 7 & 5 \\
\hline 9 & 3 & $02 / 09 / 87$ & $30.5 \mathrm{~N}$ & No & 6 & 6 & 9 & 12 & 8 \\
\hline 9 & 4 & $02 / 09 / 87$ & $42 \mathrm{~N}$ & NO & 6 & 5 & 7 & 11 & 9 \\
\hline 9 & 5 & $02 / 09 / 87$ & $53 \mathrm{~N}$ & No & 6 & 5 & 1.2 & 9 & 6 \\
\hline 126 & 1 & $02 / 09 / 87$ & $8 \mathrm{~N}$ & No & 4 & 3 & 6 & 8 & 5 \\
\hline 126 & 2 & $02 / 09 / 87$ & $18.5 \mathrm{~N}$ & NO & 5 & 4 & 3 & 3 & 5 \\
\hline 126 & 3 & $02 / 09 / 87$ & $30 \mathrm{~N}$ & NO & 5 & 5 & 5 & 8 & 9 \\
\hline 126 & 4 & $02 / 09 / 87$ & $41 \mathrm{~N}$ & NO & 5 & 4 & 7 & 8 & 10 \\
\hline 126 & 5 & $02 / 09 / 87$ & $53.5 \mathrm{~N}$ & No & 4 & 1 & 8 & 11 & 12 \\
\hline 142 & 1 & $02 / 11 / 87$ & $7.5 \mathrm{~N}$ & No & 4 & 2 & 6 & 6 & 8 \\
\hline 142 & 2 & $02 / 11 / 87$ & $19 \mathrm{~N}$ & No & 5 & 4 & 8 & 8 & 8 \\
\hline
\end{tabular}


IV - 3

APPENDIX IV

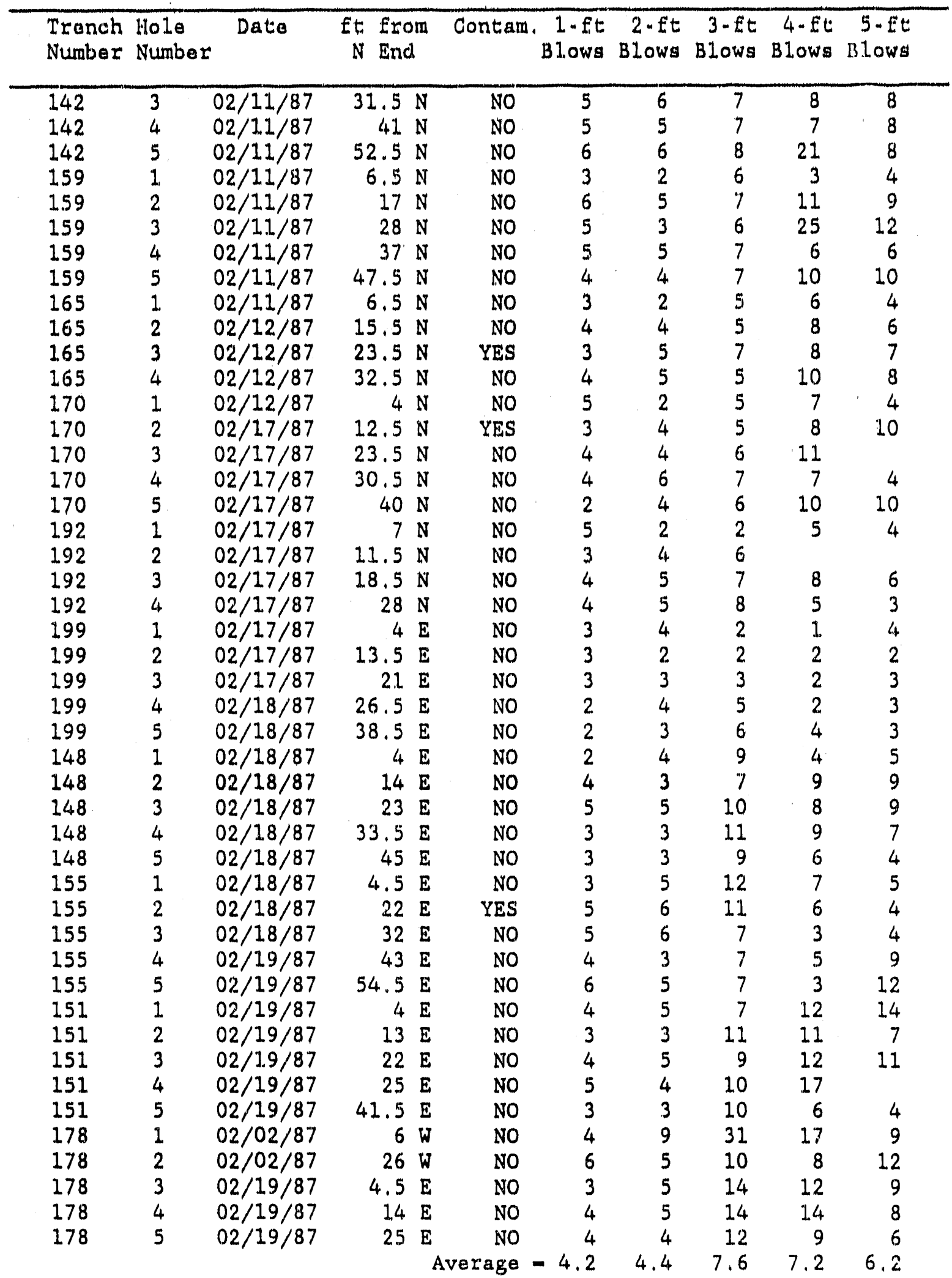


APPENDIX IV

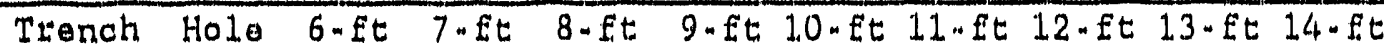

Number Number Blows Blows Blows Blows Blows Blows Blows Blows Blows

\begin{tabular}{|c|c|c|c|c|c|c|c|c|c|c|}
\hline $\begin{array}{l}2 \\
2 \\
2\end{array}$ & $\begin{array}{l}1 \\
2 \\
3\end{array}$ & $\begin{array}{r}3 \\
6 \\
15\end{array}$ & $\begin{array}{r}3 \\
10\end{array}$ & $\begin{array}{l}2 \\
3\end{array}$ & $\begin{array}{l}4 \\
5\end{array}$ & $\begin{array}{l}10 \\
11\end{array}$ & $\begin{array}{r}39 \\
7\end{array}$ & 9 & 32 & \\
\hline 2 & 4 & 4 & 5 & 19 & 18 & 17 & 13 & 20 & 42 & 24 \\
\hline 2 & 5 & 8 & 4 & 3 & 7 & 6 & 8 & 6 & 5 & 8 \\
\hline 3 & 1 & 2 & 1 & 4 & & & & & & \\
\hline 3 & 2 & 4 & 1 & 3 & 2 & 1 & 3 & 3 & 10 & \\
\hline 3 & 3 & 10 & 6 & 7 & 4 & 4 & 6 & 2. & 10 & 20 \\
\hline 3 & 4 & 4 & 4 & 4 & 3 & 3 & 5 & & & \\
\hline 3 & 5 & 4 & 2 & 4 & 3 & 3 & 13 & 7 & 7 & 14 \\
\hline 4 & 1 & 1 & 2 & 4 & 3 & 10 & 3 & 3 & 3 & 20 \\
\hline 4 & 2 & 2 & 1 & 1 & 7 & 2 & 3 & 3 & 3 & 3 \\
\hline 4 & 3 & 6 & 5 & 6 & 10 & & & & & \\
\hline 4. & 4 & 11 & 39 & & & & & & & \\
\hline 4 & 5 & 1 & 1 & 1 & 1 & 1 & 2 & 1 & 1 & 0 \\
\hline 5 & 1 & 4 & 4. & 4 & 4 & 7 & 11 & 11 & 19 & \\
\hline 5 & 2 & 11 & 9 & 9 & 12 & 11 & 13 & 24 & 24 & 24 \\
\hline 5 & 3 & 5 & 6 & 6 & 1.1 & 7 & 9 & 11 & 11 & 10 \\
\hline 5 & 4 & 2 & 3 & 2 & 6 & 1. & 4 & 7 & 5 & 8 \\
\hline 5 & 5 & 5 & 6 & 6 & 6 & 5 & 5 & 5 & 6 & 6 \\
\hline 6 & 1 & 4 & 3 & 4 & 3 & 4 & 2 & 2. & 2 & 3 \\
\hline 6 & 2 & 2 & 1 & 1 & 2 & 3 & 1 & 3 & 2 & 2 \\
\hline 6 & 3 & 1 & 2 & 2 & 1 & 3 & 1 & 3 & 2 & 2 \\
\hline 6 & 4 & 2 & 4 & 3 & 2 & 3 & 1 & 2 & 3 & 4 \\
\hline 6 & 5 & 2 & 3 & 2 & 1 & 3 & 1 & 5 & 10 & 15 \\
\hline 7 & 1 & 2 & 3 & 2 & 1 & 1 & 2 & & & \\
\hline 7 & 2 & 7 & 6 & 7 & 5 & 6 & 7 & 13 & & \\
\hline 7 & 3 & 3 & 3 & 4 & 2 & 4 & 3 & 5 & 9 & 5 \\
\hline 7 & 4 & 4 & 5 & 17 & 9 & 4 & 6 & 10 & 18 & 9 \\
\hline 7 & 5 & 2 & 2 & 2 & 1 & 1 & 11 & & & \\
\hline 8 & 1 & 13 & 1.8 & 17 & 18 & 21. & 24 & 44 & 25 & \\
\hline 8 & 2 & 4 & 7 & 6 & 6 & 5 & 6 & 7 & 8 & 6 \\
\hline 8 & 3 & 2 & 2 & 2 & 2 & 2 & 4 & 6 & 8 & 6 \\
\hline 8 & 4 & 2 & 4 & 2 & 6 & & & & & \\
\hline 8 & 5 & 3 & 2 & 4 & 6 & 7 & 8 & 7 & 8 & 8 \\
\hline 9 & 1 & 6 & 4 & 4 & 3 & 3 & 8 & 9 & 7 & 5 \\
\hline 9 & 2 & 5 & 5 & 5 & 4 & 7 & 4 & 6 & 4 & 8 \\
\hline 9 & 3 & 7 & 10 & 18 & 13 & 10 & 12 & & & \\
\hline 9 & 4 & 8 & 9 & 8 & 6 & 6 & 5 & 5 & 4 & 5 \\
\hline 9 & 5 & 3 & 3 & 2 & 2 & 2 & 13 & 2 & 1 & 1 \\
\hline 126 & 1 & 5 & 4 & 4 & 2 & & & & & \\
\hline 126 & 2 & 3 & 1 & 2 & 1 & 12 & 5 & 3 & 3 & \\
\hline 126 & 3 & 6 & 10 & 14 & 10 & 8 & 8 & 11 & 11 & 9 \\
\hline 126 & 4 & 14 & 15 & 13 & 14 & 11 & 15 & 15 & 15 & 16 \\
\hline 126 & 5 & 6 & 6 & 4 & 3 & 7 & 10 & 15 & 10 & 11 \\
\hline 142 & 1 & 6 & 6 & 4 & 4 & 3 & & & & \\
\hline 142 & 2 & 7 & 8 & 9 & 8 & 7 & 7 & 8 & 8 & 7 \\
\hline
\end{tabular}


APPENDIX IV

Trench Hole 6-ft 7 -ft 8 -ft 9 -ft 10 -ft 11 -ft 12 -ft 13 -ft 14 -ft

Number Number Blows Blows Blows Blows Blows Blows Blows Blows Blows

\begin{tabular}{|c|c|c|c|c|c|c|c|c|c|c|}
\hline 142 & 3 & 7 & 10 & 29 & & & & & & \\
\hline 142 & 4 & 7 & 6 & 7 & 7 & 6 & 7 & 12 & 13 & 11 \\
\hline 142 & 5 & 5 & 5 & 3 & 7 & 8 & $\varepsilon$ & 5 & 4 & 4 \\
\hline 159 & 1 & 2 & 2 & 2 & 3 & 3 & 1 & 1 & 2 & 22 \\
\hline 159 & 2 & 9 & 5 & 11 & 3 & 11 & 4 & 6 & 15 & \\
\hline 159 & 3 & 9 & 11 & 8 & 8 & 7 & 8 & 8 & & \\
\hline 159 & 4 & 5 & 6 & 5 & 7 & 10 & & & & \\
\hline 159 & 5 & 6 & 12 & 12 & 14 & 13 & 16 & 12. & & \\
\hline 165 & 1 & 4 & 4 & 4 & 4 & 3 & 4 & 3 & 4 & 4 \\
\hline 165 & 2 & 5 & 3 & 3 & 3 & 3 & 3 & 8 & & \\
\hline 165 & 3 & 7 & 6 & 6 & 7 & 8 & 7 & 8 & 7 & 8 \\
\hline 165 & 4 & 7 & 7 & 7 & 6 & 10 & 7 & 14 & 13 & 14 \\
\hline 170 & 1 & 7 & 13 & 21 & 14 & 13 & 14 & 27 & 30 & 29 \\
\hline 170 & 2 & 12 & 11 & 1.2 & 10 & 9 & 18 & 15 & 19 & 26 \\
\hline 170 & 3 & & & & & & & & & \\
\hline 170 & 4 & 4 & 3 & 4 & 4 & 2 & 1 & 2 & 4 & \\
\hline 170 & 5 & 8 & 7 & 6 & 3 & 6 & 11 & & & \\
\hline 192 & 1 & 2 & 3 & 2 & 2 & 8 & & & & \\
\hline 192 & 2 & & & & & & & & & \\
\hline 192 & 3 & 3 & 4 & 5 & 3 & 4 & 3 & 4 & 4 & 6 \\
\hline 192 & 4 & 2 & 1 & 2 & 2 & 4 & 3 & 1 & 13 & \\
\hline 199 & 1 & 3 & 4 & 3 & 4 & 4 & 5 & 5 & 11 & 27 \\
\hline 199 & 2 & & & & & & & & & \\
\hline 199 & 3 & 0 & 0. & 0 & 1 & 3 & 10 & 1 & 3 & 9 \\
\hline 199 & 4 & 6 & & & & & & & & \\
\hline 199 & 5 & 3 & 3 & 4 & 27 & & & & & \\
\hline 148 & 1 & 5 & 6 & 5 & 5 & 5 & 4 & 5 & 5 & 22 \\
\hline 148 & 2 & 9 & 7 & 6 & 8 & & & & & \\
\hline 148 & 3 & 14 & 11 & 10 & 7 & 10 & 9 & 12 & 10 & 25 \\
\hline 148 & 4 & 5 & 6 & 5 & 3 & 8 & 4 & 2 & 15 & \\
\hline 148 & 5 & 4 & 4 & 15 & 6 & & & & & \\
\hline 1.55 & 1 & 3 & 9 & 3 & 5 & 6 & 5 & 8 & 26 & \\
\hline 155 & 2 & 5 & 3 & 4 & 4 & 4 & 3 & 4 & 16 & \\
\hline 155 & 3 & 2 & 2 & 1 & 2 & 1 & 1 & 2 & 1 & 12 \\
\hline 155 & 4 & 3.4 & 1,3 & 6 & 7 & 23 & 9 & 8 & 9 & 29 \\
\hline 155 & 5 & & & & & & & & & \\
\hline 151 & 1 & 11 & 14 & 15 & 13 & 14 & 15 & 15 & 17 & 21 \\
\hline 151 & 2 & 6 & 6 & 18 & 22 & 11 & 9 & 11 & 14 & 19 \\
\hline 151 & 3 & 9 & 9 & 13 & 17 & 7 & 14 & & & \\
\hline 151 & 4 & & & & & & & & & \\
\hline 151 & 5 & 3 & 3 & 2 & 5 & 3 & 2 & 3 & 2 & 16 \\
\hline 178 & 1 & 8 & 7 & 8 & 3 & 7 & 19 & 32 & 25 & 16 \\
\hline 178 & 2 & 60 & 29 & 12 & 22 & 14 & 17 & & & \\
\hline 178 & 3 & 6 & 16 & & & & & & & \\
\hline 178 & 4 & 6 & 6 & 5 & 2 & 10 & 8 & 18 & 45 & \\
\hline \multirow[t]{2}{*}{178} & 5 & 2 & 2 & 5 & 5 & 7 & 10 & 25 & & \\
\hline & Average & $=6$ & 6.2 & 6.4 & 6.3 & 6.7 & 7.8 & 8.8 & 11 & 12.1 \\
\hline
\end{tabular}


APPENDIX IV

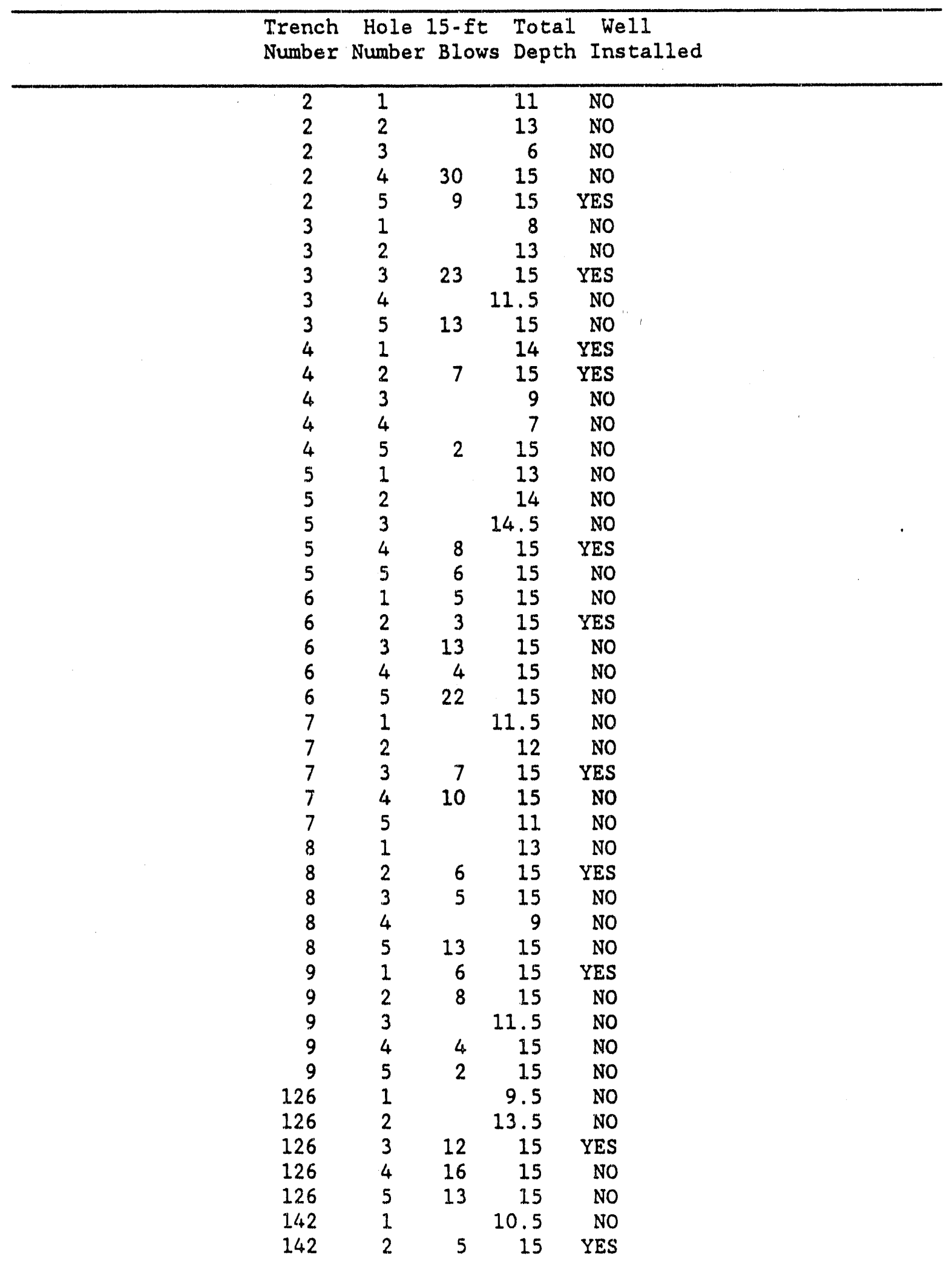


APPENDIX IV

Trench Hole 15-ft Total Well

Number Number Blows Depth Installed

$\begin{array}{rrrrr}142 & 3 & & 8 & \text { NO } \\ 142 & 4 & 7 & 15 & \text { NO } \\ 142 & 5 & 9 & 15 & \text { NO } \\ 159 & 1 & 41 & 15 & \text { NO } \\ 159 & 2 & & 13 & \text { NO } \\ 159 & 3 & & 12 & \text { NO } \\ 159 & 4 & & 10.5 & \text { NO } \\ 159 & 5 & & 12.5 & \text { NO } \\ 165 & 1 & 13 & 15 & \text { NO } \\ 165 & 2 & & 12 & \text { NO } \\ 165 & 3 & 9 & 15 & \text { YES } \\ 165 & 4 & 8 & 15 & \text { NO } \\ 170 & 1 & 26 & 15 & \text { NO } \\ 170 & 2 & & 14 & \text { NO } \\ 170 & 3 & & 4 & \text { NO } \\ 170 & 4 & & 13 & \text { NO } \\ 170 & 5 & & 11 & \text { NO } \\ 192 & 1 & & 10 & \text { NO } \\ 192 & 2 & & 3 & \text { NO } \\ 192 & 3 & 13 & 15 & \text { YES } \\ 192 & 4 & & 13 & \text { NO } \\ 199 & 1 & & 14 & \text { NO } \\ 199 & 2 & & 5.5 & \text { NO } \\ 199 & 3 & 20 & 15 & \text { YES } \\ 199 & 4 & & 6 & \text { NO } \\ 199 & 5 & & 9 & \text { NO } \\ 148 & 1 & 44 & 15 & \text { YES } \\ 148 & 2 & & 9 & \text { NO } \\ 148 & 3 & & 14 & \text { NO } \\ 148 & 4 & & 13 & \text { NO } \\ 148 & 5 & & 9 & \text { NO } \\ 155 & 1 & & 13 & \text { NO } \\ 155 & 2 & & 13 & \text { NO } \\ 155 & 3 & 46 & 15 & \text { YES } \\ 155 & 4 & & 14 & \text { NO } \\ 155 & 5 & & 5 & \text { NO } \\ 151 & 1 & 58 & 15 & \text { YES } \\ 151 & 2 & 31 & 15 & \text { NO } \\ 151 & 3 & & 11 & \text { NO } \\ 151 & 4 & & 4 & \text { NO } \\ 151 & 5 & & 14 & \text { YES } \\ 178 & 1 & 28 & 15 & \text { NO } \\ 178 & 2 & & 11.5 & \text { NO } \\ 178 & 3 & & 7 & \text { NO } \\ 178 & 4 & & 13 & \text { NO } \\ 178 & 5 & & 12 & \text { NO } \\ \text { Average } & 15.1 & & \end{array}$


APPENDIX V

Nonstandard Soil Penetration Tests in Conasauga Shale 
APPENDIX V

\begin{tabular}{|c|c|c|c|c|c|c|c|c|c|c|}
\hline $\begin{array}{c}\text { Control } \\
\text { Hole }\end{array}$ & Date & $\begin{array}{l}\text { Contam. } \\
\text { Found }\end{array}$ & $\begin{array}{r}1-f t \\
\text { Blows }\end{array}$ & $\begin{array}{r}2-f t \\
\text { Blows }\end{array}$ & $\begin{array}{r}3-\mathrm{ft} \\
\text { Blows }\end{array}$ & $\begin{array}{r}4-\mathrm{ft} \\
\text { Blows }\end{array}$ & $\begin{array}{r}5-\mathrm{ft} \\
\text { Blows }\end{array}$ & $\begin{array}{r}6-\mathrm{ft} \\
\text { Blows }\end{array}$ & $\begin{array}{r}7 \text {-ft } \\
\text { Blows }\end{array}$ & $\begin{array}{r}8-f t \\
\text { Blows }\end{array}$ \\
\hline 1 & $2 / 29 / 88$ & NO & 6 & 12 & 17 & 36 & 52 & 52 & 75 & \\
\hline 2 & $2 / 29 / 88$ & No & 5 & 6 & 6 & 10 & 14 & 25 & 40 & 41 \\
\hline 3 & $2 / 29 / 88$ & No & 6 & 4 & 5 & 6 & 10 & 10 & 22 & 27 \\
\hline 4 & $2 / 29 / 88$ & No & 2 & 1 & 2 & 1 & 1 & 24 & 50 & 95 \\
\hline 5 & $2 / 29 / 88$ & NO & 6 & 4 & 2 & 8 & 18 & 21 & 27 & 31 \\
\hline 6 & $3 / 1 / 88$ & No & 5 & 4 & 7 & 13 & 27 & 33 & 36 & 50 \\
\hline 7 & $3 / 1 / 88$ & No & 6 & 5 & 8 & 9 & 11 & 23 & 43 & 76 \\
\hline 8 & $3 / 1 / 88$ & No & 5 & 11 & 16 & 30 & 43 & 57 & 81 & 57 \\
\hline 9 & $3 / 1 / 88$ & No & 5 & 4 & 6 & 9 & 20 & 30 & 48 & 53 \\
\hline 10 & $3 / 1 / 88$ & No & 5 & 4 & 12 & 21 & 42 & 42 & 52 & 51 \\
\hline 11 & $3 / 1 / 88$ & No & 7 & 6 & 7 & 11 & 15 & 18 & 21 & 30 \\
\hline 12 & $3 / 1 / 88$ & NO & 4 & 3 & 8 & 12 & 24 & 41 & 119 & \\
\hline 13 & $3 / 1 / 88$ & NO & 6 & 5 & 5 & 8 & 15 & 25 & 36 & 44 \\
\hline 14 & $3 / 2 / 88$ & No & 6 & 5 & 18 & 32 & 55 & 43 & 43 & 63 \\
\hline 15 & $3 / 2 / 88$ & No & 8 & 4 & 7 & 11 & 16 & 19 & 24 & 29 \\
\hline 16 & $3 / 2 / 88$ & NO & 5 & 4 & 8 & 17 & 18 & 22 & 19 & 34 \\
\hline 17 & $3 / 2 / 88$ & No & 5 & 3 & 4 & 9 & 10 & 14 & 22 & 33 \\
\hline 18 & $3 / 2 / 88$ & NO & 6 & 4 & 6 & 9 & 19 & 29 & 36 & 45 \\
\hline 19 & $3 / 2 / 88$ & No & 8 & 7 & 8 & 17 & 26 & 37 & 82 & 115 \\
\hline 20 & $3 / 3 / 88$ & NO & 7 & 7 & 14 & 14 & 15 & 19 & 25 & 37 \\
\hline 21 & $3 / 3 / 88$ & NO & 6 & 6 & 37 & 37 & 36 & 39 & 38 & 52 \\
\hline 22 & $3 / 3 / 88$ & No & 4 & 4 & 5 & 11 & 15 & 31 & 52 & 78 \\
\hline 1 & $2 / 2 / 87$ & No & 5 & 12 & 31 & 20 & 17 & 18 & 1.4 & 28 \\
\hline 2 & $2 / 2 / 87$ & No & 5 & 4 & 10 & 14 & 14 & 14 & 2.7 & 26 \\
\hline 3 & $2 / 24 / 87$ & No & 3 & 5 & 4 & 6 & 10 & 13 & 1.6 & 22 \\
\hline 4 & $2 / 24 / 87$ & No & 3 & 10 & 5 & 3 & 7 & 12 & 26 & 21 \\
\hline 5 & $2 / 24 / 87$ & No & 4 & 4 & 4 & 3 & 8 & 13 & 23 & 28 \\
\hline 6 & $2 / 24 / 87$ & No & 5 & 4 & 9 & 4 & 5 & 7 & 16 & 23 \\
\hline 7 & $2 / 24 / 87$ & No & 4 & 3 & 9 & 7 & 15 & 24 & 23 & 28 \\
\hline 8 & $2 / 24 / 87$ & No & 3 & 4 & 10 & 19 & 30 & 134 & & \\
\hline 9 & $2 / 25 / 87$ & No & 4 & 5 & 7 & 6 & 11 & 33 & 51 & 44 \\
\hline 10 & $2 / 25 / 87$ & No & 5 & 4 & 26 & & & & & \\
\hline 11 & $2 / 25 / 87$ & No & 5 & 4 & 12 & 6 & 20 & 45 & 58 & \\
\hline 12 & $2 / 25 / 87$ & No & 4 & 8 & 19 & 21 & 16 & 19 & 17 & 10 \\
\hline \multicolumn{3}{|c|}{ Average } & $=5.1$ & 5.3 & 10.4 & 13.3 & 19.8 & 29.9 & 39.1 & 43.8 \\
\hline
\end{tabular}


APPENDIX V

\begin{tabular}{|c|c|c|c|c|c|c|c|}
\hline $\begin{array}{c}\text { Control } \\
\text { Hole }\end{array}$ & $\begin{array}{r}9-\mathrm{ft} \\
\text { Blows }\end{array}$ & $\begin{array}{l}\text { 10-ft } \\
\text { Blows }\end{array}$ & $\begin{array}{l}\text { 11-ft } \\
\text { Blows }\end{array}$ & $\begin{array}{l}12-\mathrm{ft} \\
\text { Blows }\end{array}$ & $\begin{array}{l}\text { 13-ft } \\
\text { Blows }\end{array}$ & $\begin{array}{l}\text { 14-ft } \\
\text { Blows }\end{array}$ & $\begin{array}{l}\text { 15-ft Total } \\
\text { Blows Depth }\end{array}$ \\
\hline 1 & & & & & & & $\overline{7}$ \\
\hline 2 & 32 & 28 & 28 & 32 & 47 & & 13 \\
\hline 3 & 41 & 44 & 55 & 62 & & & 12 \\
\hline 4 & & & & & & & 8 \\
\hline 5 & 62 & 112 & & & & & 10 \\
\hline 6 & 51 & 52 & & & & & 10 \\
\hline 7 & 62 & 57 & & & & & 10 \\
\hline 8 & & & & & & & 7.5 \\
\hline 9 & 54 & 41 & 57 & & & & 11 \\
\hline 10 & 39 & 32 & & & & & 10 \\
\hline 11 & 26 & 24 & 31 & 29 & 45 & 30 & 14 \\
\hline 12 & & & & & & & 6.5 \\
\hline 13 & 52 & 60 & 44 & & & & 11 \\
\hline 14 & 35 & & & & & & 8.5 \\
\hline 15 & 42 & 43 & 58 & 50 & 53 & & 13 \\
\hline 16 & 106 & & & & & & 9 \\
\hline 17 & 40 & 46 & 45 & 69 & & & 12 \\
\hline 18 & 44 & 34 & 31 & 67 & & & 12 \\
\hline 19 & & & & & & & 8 \\
\hline 20 & 40 & 42 & 34 & 28 & 49 & 48 & 14 \\
\hline 21 & 49 & & & & & & 9 \\
\hline 22 & & & & & & & 8 \\
\hline 1 & 38 & 58 & & & & & 10 \\
\hline 2 & 31 & 26 & 41 & 63 & 75 & & 13 \\
\hline 3 & 36 & 42 & 51 & 37 & & & 12 \\
\hline 4 & 28 & 38 & 48 & 62 & 82 & & 13 \\
\hline 5 & 33 & 35 & 45 & & & & 11 \\
\hline 6 & 32 & 24 & 26 & 31 & 34 & & 13 \\
\hline 7 & 35 & 52 & & & & & 10.5 \\
\hline 8 & & & & & & & 6.5 \\
\hline 9 & 45 & & & & & & 9 \\
\hline 10 & & & & & & & 3.5 \\
\hline 11 & & & & & & & 7 \\
\hline 12 & 46 & & & & & & 9 \\
\hline Average & $=44$ & 44.5 & 42.4 & 48.2 & 55 & 39 & \\
\hline
\end{tabular}


$\mathrm{VI}-1$

APPENDIX VI

Standard Soil Penetration Resistance, Soll Moisture, and Bulk Density Data 
APPENDIX VI

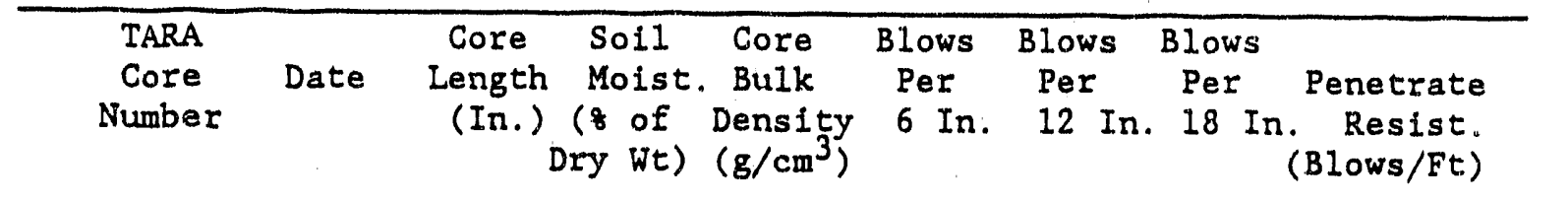

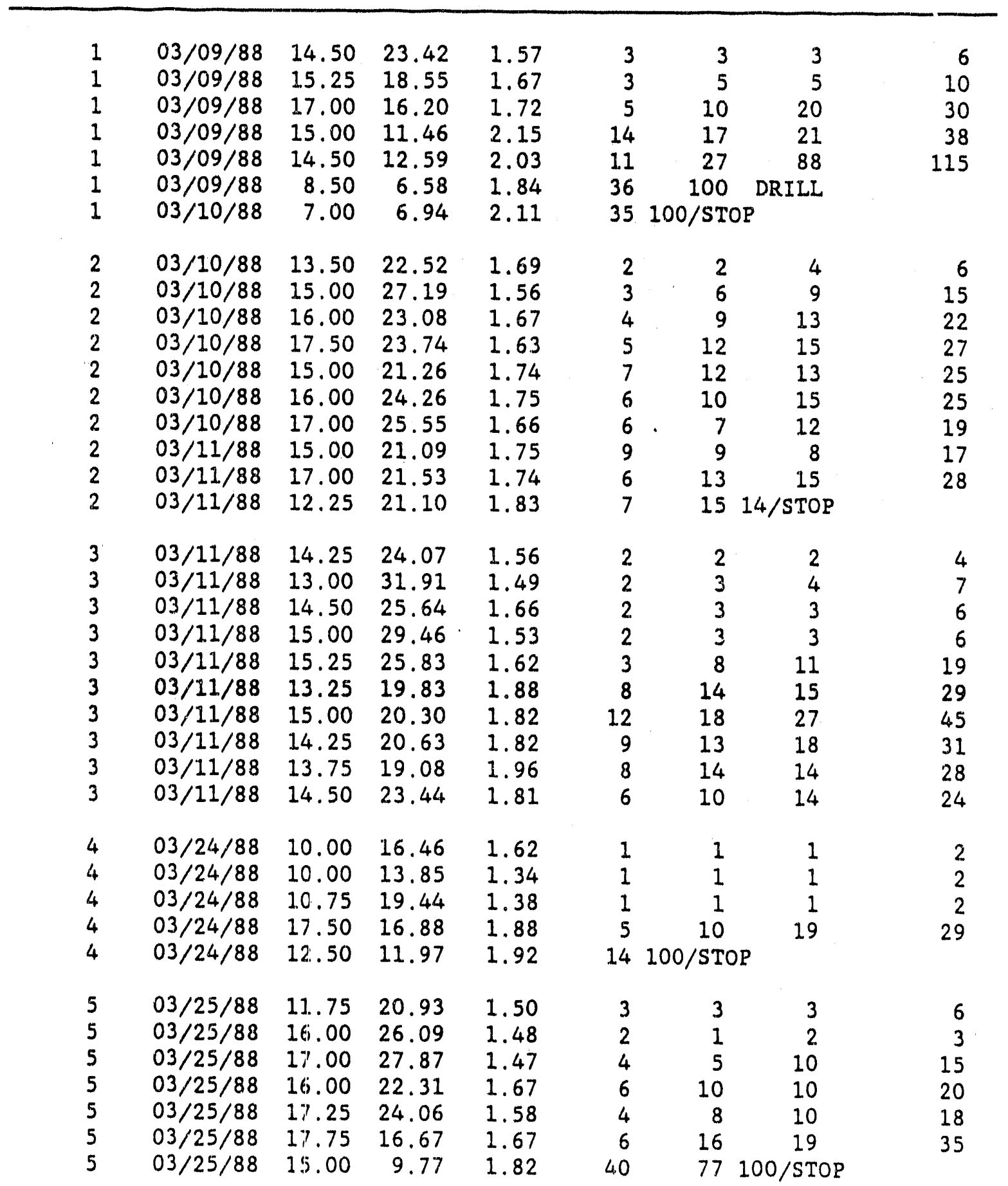


APPENDIX VI

\begin{tabular}{|c|c|c|c|c|c|c|c|c|}
\hline $\begin{array}{l}\text { TARA } \\
\text { Core } \\
\text { Number }\end{array}$ & Date & $\begin{array}{l}\text { Core } \\
\text { Length } \\
\text { (In.) }\end{array}$ & $\begin{array}{l}\text { Soil } \\
\text { Moist. } \\
\text { (8 of } \\
\text { ry Wt) }\end{array}$ & $\begin{array}{l}\text { Core } \\
\text { Bulk } \\
\text { Density } \\
\left(\mathrm{g} / \mathrm{cm}^{3}\right)\end{array}$ & $\begin{array}{l}\text { Blows } \\
\text { Per } \\
6 \text { In. }\end{array}$ & $\begin{array}{l}\text { Blows } \\
\text { Per } \\
12 \mathrm{In} .\end{array}$ & $\begin{array}{l}\text { Blows } \\
\text { Per } \\
18 \text { In }\end{array}$ & $\begin{array}{l}\text { Penetrate } \\
\text { Resist. } \\
\text { (Blows/Ft) }\end{array}$ \\
\hline $\begin{array}{l}6 \\
6 \\
6 \\
6 \\
6 \\
6 \\
6 \\
6 \\
6 \\
6\end{array}$ & $\begin{array}{l}03 / 28 / 88 \\
03 / 28 / 88 \\
03 / 28 / 88 \\
03 / 28 / 88 \\
03 / 28 / 88 \\
03 / 28 / 88 \\
03 / 28 / 88 \\
03 / 28 / 88 \\
03 / 28 / 88 \\
03 / 28 / 88\end{array}$ & $\begin{array}{l}15.00 \\
16.25 \\
17.00 \\
17.50 \\
16.50 \\
13.25 \\
17.00 \\
17.25 \\
14.50 \\
15.00\end{array}$ & $\begin{array}{l}21.82 \\
30.25 \\
23.48 \\
21.23 \\
21.23 \\
18.49 \\
13.22 \\
23.73 \\
22.31 \\
25.00\end{array}$ & $\begin{array}{l}1.51 \\
1.50 \\
1.60 \\
1.71 \\
1.82 \\
1.85 \\
2.10 \\
1.69 \\
1.71 \\
1.86\end{array}$ & $\begin{array}{r}3 \\
2 \\
4 \\
8 \\
6 \\
7 \\
10 \\
3 \\
8 \\
3\end{array}$ & $\begin{array}{r}3 \\
3 \\
7 \\
14 \\
12 \\
10 \\
50 \\
10 \\
9 \\
13\end{array}$ & $\begin{array}{r}2 \\
5 \\
14 \\
15 \\
17 \\
10 \\
29 \\
18 \\
9 \\
17\end{array}$ & $\begin{array}{r}5 \\
8 \\
21 \\
29 \\
29 \\
20 \\
79 \\
28 \\
18 \\
30\end{array}$ \\
\hline $\begin{array}{l}7 \\
7 \\
7 \\
7 \\
7 \\
7 \\
7\end{array}$ & $\begin{array}{l}03 / 16 / 88 \\
03 / 16 / 88 \\
03 / 16 / 88 \\
03 / 16 / 88 \\
03 / 16 / 88 \\
03 / 16 / 88 \\
03 / 16 / 88\end{array}$ & $\begin{array}{l}13.75 \\
13.50 \\
13.75 \\
15.00 \\
15.50 \\
14.50 \\
14.25\end{array}$ & $\begin{array}{l}22.64 \\
25.00 \\
21.90 \\
22.41 \\
23.39 \\
26.09 \\
20.87\end{array}$ & $\begin{array}{l}1.58 \\
1.40 \\
1.57 \\
1.59 \\
1.64 \\
1.63 \\
1.66\end{array}$ & $\begin{array}{l}3 \\
3 \\
3 \\
5 \\
4 \\
5 \\
5\end{array}$ & $\begin{array}{r}3 \\
6 \\
4 \\
5 \\
9 \\
9 \\
11\end{array}$ & $\begin{array}{r}2 \\
7 \\
5 \\
8 \\
11 \\
15 \\
16\end{array}$ & $\begin{array}{r}5 \\
13 \\
9 \\
13 \\
20 \\
24 \\
27\end{array}$ \\
\hline $\begin{array}{l}8 \\
8 \\
8 \\
8 \\
8\end{array}$ & $\begin{array}{l}03 / 24 / 88 \\
03 / 24 / 88 \\
03 / 24 / 88 \\
03 / 24 / 88 \\
03 / 24 / 88\end{array}$ & $\begin{array}{r}14.75 \\
15.25 \\
15.75 \\
15.50 \\
8.25\end{array}$ & $\begin{array}{r}16.42 \\
14.29 \\
14.16 \\
9.59\end{array}$ & $\begin{array}{l}1.81 \\
1.83 \\
1.83 \\
1.82\end{array}$ & $\begin{array}{r}3 \\
6 \\
8 \\
9 \\
35\end{array}$ & $\begin{array}{r}4 \\
8 \\
14 \\
12 \\
101 / \text { STOP }\end{array}$ & $\begin{array}{r}6 \\
10 \\
21 \\
46\end{array}$ & $\begin{array}{l}10 \\
18 \\
35 \\
58\end{array}$ \\
\hline $\begin{array}{l}9 \\
9 \\
9 \\
9 \\
9 \\
9 \\
9 \\
9 \\
9 \\
9\end{array}$ & $\begin{array}{l}03 / 29 / 88 \\
03 / 29 / 88 \\
03 / 29 / 88 \\
03 / 29 / 88 \\
03 / 29 / 88 \\
03 / 29 / 88 \\
03 / 29 / 88 \\
03 / 29 / 88 \\
03 / 29 / 88 \\
03 / 29 / 88\end{array}$ & $\begin{array}{r}14.25 \\
16.50 \\
15.25 \\
16.00 \\
15.50 \\
14.75 \\
16.50 \\
15.50 \\
8.50 \\
16.25\end{array}$ & $\begin{array}{l}21.10 \\
21.05 \\
22.05 \\
22.31 \\
23.66 \\
21.60 \\
25.17 \\
21.74 \\
17.72 \\
13.82\end{array}$ & $\begin{array}{l}1.57 \\
1.66 \\
1.71 \\
1.84 \\
1.74 \\
1.74 \\
1.78 \\
1.83 \\
1.91 \\
1.92\end{array}$ & $\begin{array}{r}3 \\
4 \\
4 \\
7 \\
3 \\
7 \\
3 \\
9 \\
14 \\
32\end{array}$ & $\begin{array}{c}3 \\
6 \\
8 \\
10 \\
10 \\
14 \\
11 \\
12 \\
35 / \text { STOP } \\
29\end{array}$ & $\begin{array}{r}2 \\
7 \\
11 \\
11 \\
13 \\
15 \\
18 \\
19 \\
\text { DRILL } \\
13\end{array}$ & $\begin{array}{r}5 \\
13 \\
19 \\
21 \\
23 \\
29 \\
29 \\
31\end{array}$ \\
\hline
\end{tabular}


APPENDIX VI

\begin{tabular}{|c|c|c|c|c|c|c|c|c|}
\hline $\begin{array}{c}\text { TARA } \\
\text { Core } \\
\text { Number }\end{array}$ & Date & $\begin{array}{c}\text { Core } \\
\text { Length } \\
\text { (In.) }\end{array}$ & $\begin{array}{l}\text { Soll } \\
\text { Moist. } \\
\text { ( } 8 \text { of } \\
\text { Dry } W t)\end{array}$ & $\begin{array}{l}\text { Core } \\
\text { Bulk } \\
\text { Densitty } \\
\left(\mathrm{g} / \mathrm{cm}^{3}\right)\end{array}$ & $\begin{array}{l}\text { Blows } \\
\text { Per } \\
6 \text { In. }\end{array}$ & $\begin{array}{l}\text { Blows } \\
\text { Per } \\
12 \text { In }\end{array}$ & $\begin{array}{l}\text { Blows } \\
\text { Per } \\
18 \mathrm{In} .\end{array}$ & $\begin{array}{r}\text { Penetrate } \\
\text { Resist. } \\
\text { (Blows/Ft) }\end{array}$ \\
\hline $\begin{array}{l}10 \\
10 \\
10 \\
10 \\
10 \\
10 \\
10 \\
10 \\
10 \\
10\end{array}$ & $\begin{array}{l}03 / 29 / 88 \\
03 / 29 / 88 \\
03 / 29 / 88 \\
03 / 30 / 88 \\
03 / 30 / 88 \\
03 / 30 / 88 \\
03 / 30 / 88 \\
03 / 30 / 88 \\
03 / 30 / 88 \\
03 / 30 / 88\end{array}$ & $\begin{array}{l}12.25 \\
16.50 \\
17.00 \\
15.75 \\
16.50 \\
15.50 \\
17.50 \\
14.00 \\
16.00 \\
14.00\end{array}$ & $\begin{array}{l}20.65 \\
28.46 \\
25.93 \\
20.29 \\
31.20 \\
\\
15.48 \\
13.97 \\
15.86 \\
14.00\end{array}$ & $\begin{array}{l}1.54 \\
1.53 \\
1.63 \\
1.80 \\
1.56 \\
1.82 \\
2.00 \\
1.86 \\
2.20\end{array}$ & $\begin{array}{r}3 \\
2 \\
5 \\
6 \\
6 \\
6 \\
10 \\
13 \\
10 \\
11\end{array}$ & $\begin{array}{r}2 \\
2 \\
10 \\
14 \\
7 \\
10 \\
15 \\
23 \\
17 \\
254\end{array}$ & $\begin{array}{r}2 \\
7 \\
11 \\
17 \\
9 \\
19 \\
23 \\
32 \\
22 \\
\text { 40/STOP }\end{array}$ & $\begin{array}{r}4 \\
9 \\
21 \\
31 \\
16 \\
29 \\
38 \\
55 \\
39\end{array}$ \\
\hline $\begin{array}{l}11 \\
11 \\
11 \\
11 \\
11 \\
11 \\
11 \\
11 \\
11 \\
11\end{array}$ & $\begin{array}{l}03 / 14 / 88 \\
03 / 14 / 88 \\
03 / 14 / 88 \\
03 / 14 / 88 \\
03 / 14 / 88 \\
03 / 14 / 88 \\
03 / 14 / 88 \\
03 / 15 / 88 \\
03 / 15 / 88 \\
03 / 15 / 88\end{array}$ & $\begin{array}{l}13.50 \\
15.50 \\
15.50 \\
15.75 \\
14.50 \\
10.50 \\
13.00 \\
16.00 \\
16.50 \\
15.00\end{array}$ & $\begin{array}{l}25.49 \\
32.67 \\
31.13 \\
31.68 \\
29.33 \\
25.77 \\
29.31 \\
29.36 \\
20.16\end{array}$ & $\begin{array}{l}1.55 \\
1.34 \\
1.38 \\
1.43 \\
1.47 \\
1.53 \\
1.49 \\
1.36 \\
1.77\end{array}$ & $\begin{array}{l}3 \\
3 \\
3 \\
3 \\
3 \\
3 \\
4 \\
2 \\
5 \\
6\end{array}$ & $\begin{array}{r}3 \\
4 \\
4 \\
7 \\
4 \\
5 \\
6 \\
8 \\
4 \\
10\end{array}$ & $\begin{array}{r}3 \\
5 \\
5 \\
7 \\
8 \\
6 \\
9 \\
12 \\
5 \\
13\end{array}$ & $\begin{array}{r}6 \\
9 \\
9 \\
14 \\
12 \\
11 \\
15 \\
20 \\
9 \\
23\end{array}$ \\
\hline $\begin{array}{l}12 \\
12 \\
12 \\
12 \\
12 \\
12 \\
12 \\
12\end{array}$ & $\begin{array}{l}03 / 21 / 88 \\
03 / 21 / 88 \\
03 / 21 / 88 \\
03 / 21 / 88 \\
03 / 21 / 88 \\
03 / 23 / 88 \\
03 / 23 / 88 \\
03 / 23 / 88\end{array}$ & $\begin{array}{r}8.00 \\
16.25 \\
15.50 \\
16.00 \\
14.00 \\
10.75 \\
13.50 \\
15.50\end{array}$ & $\begin{array}{r}21.43 \\
26.61 \\
18.80 \\
20.47 \\
14.04 \\
12.50 \\
9.91 \\
8.67\end{array}$ & $\begin{array}{l}1.44 \\
1.57 \\
1.76 \\
1.63 \\
1.67 \\
1.99 \\
2.10 \\
1.99\end{array}$ & $\begin{array}{r}2 \\
2 \\
4 \\
6 \\
8 \\
19 \\
26 \\
28\end{array}$ & $\begin{array}{r}2 \\
4 \\
11 \\
10 \\
16 \\
42 \\
54 \\
96\end{array}$ & $\begin{array}{c}2 \\
6 \\
16 \\
14 \\
21 \\
93 \\
65 \\
101 / \text { STOP }\end{array}$ & $\begin{array}{r}4 \\
10 \\
27 \\
24 \\
37 \\
135 \\
119\end{array}$ \\
\hline $\begin{array}{l}13 \\
13 \\
13 \\
13 \\
13 \\
13 \\
13 \\
13 \\
13 \\
13\end{array}$ & $\begin{array}{l}04 / 04 / 88 \\
04 / 04 / 88 \\
04 / 04 / 88 \\
04 / 04 / 88 \\
04 / 04 / 88 \\
04 / 04 / 88 \\
04 / 04 / 88 \\
04 / 04 / 88 \\
04 / 04 / 88 \\
04 / 04 / 88\end{array}$ & $\begin{array}{l}14.75 \\
16.00 \\
18.00 \\
17.00 \\
15.00 \\
14.00 \\
15.25 \\
16.50 \\
17.75 \\
17.50\end{array}$ & $\begin{array}{l}20.54 \\
31.46 \\
35.71 \\
31.71 \\
32.23 \\
21.37 \\
18.42 \\
22.39 \\
23.08 \\
13.79\end{array}$ & $\begin{array}{l}1.56 \\
1.43 \\
1.44 \\
1.49 \\
1.66 \\
1.72 \\
1.54 \\
1.67 \\
1.50 \\
1.70\end{array}$ & $\begin{array}{r}2 \\
2 \\
2 \\
4 \\
7 \\
6 \\
5 \\
5 \\
8 \\
19\end{array}$ & $\begin{array}{r}3 \\
3 \\
3 \\
6 \\
12 \\
10 \\
9 \\
9 \\
9 \\
19\end{array}$ & $\begin{array}{r}4 \\
4 \\
6 \\
11 \\
14 \\
10 \\
7 \\
13 \\
10 \\
24\end{array}$ & $\begin{array}{r}7 \\
7 \\
9 \\
17 \\
26 \\
20 \\
16 \\
22 \\
19 \\
43\end{array}$ \\
\hline
\end{tabular}


APPENDIX VI

\begin{tabular}{|c|c|c|c|c|c|c|c|c|}
\hline $\begin{array}{c}\text { TARA } \\
\text { Core } \\
\text { Number }\end{array}$ & Date & $\begin{array}{c}\text { Core } \\
\text { Length } \\
\text { (In.) }\end{array}$ & $\begin{array}{l}\text { Soll } \\
\text { Moist. } \\
\text { ( } 8 \text { of } \\
\text { ory Wt) }\end{array}$ & $\begin{array}{l}\text { Core } \\
\text { Bulk } \\
\text { Density } \\
\left(\mathrm{g} / \mathrm{cm}^{3}\right)\end{array}$ & $\begin{array}{l}\text { Blows } \\
\text { Per } \\
6 \text { In. }\end{array}$ & $\begin{array}{l}\text { Blows } \\
\text { Per } \\
12 \text { In }\end{array}$ & $\begin{array}{l}\text { Blows } \\
\text { Per } \\
18 \mathrm{In} .\end{array}$ & $\begin{array}{l}\text { Penetrate } \\
\text { Resist. } \\
\text { (Blows/Ft) }\end{array}$ \\
\hline $\begin{array}{l}14 \\
14 \\
14 \\
14 \\
14 \\
14 \\
14 \\
14 \\
14 \\
14\end{array}$ & $\begin{array}{l}04 / 05 / 88 \\
04 / 05 / 88 \\
04 / 05 / 88 \\
04 / 05 / 88 \\
04 / 05 / 88 \\
04 / 05 / 88 \\
04 / 05 / 88 \\
04 / 05 / 88 \\
04 / 05 / 88 \\
04 / 05 / 88\end{array}$ & $\begin{array}{l}13.50 \\
16.75 \\
16.50 \\
17.50 \\
16.00 \\
17.00 \\
16.00 \\
14.50 \\
18.00 \\
16.50\end{array}$ & $\begin{array}{r}21.59 \\
30.08 \\
21.26 \\
17.12 \\
14.97 \\
17.02 \\
15.17 \\
17.05 \\
16.99 \\
9.93\end{array}$ & $\begin{array}{l}1.34 \\
1.51 \\
1.58 \\
1.71 \\
1.89 \\
1.70 \\
1.86 \\
1.83 \\
1.75 \\
1.88\end{array}$ & $\begin{array}{r}2 \\
3 \\
6 \\
7 \\
11 \\
11 \\
11 \\
12 \\
8 \\
24\end{array}$ & $\begin{array}{r}3 \\
3 \\
10 \\
14 \\
16 \\
14 \\
18 \\
19 \\
15 \\
39\end{array}$ & $\begin{array}{r}4 \\
6 \\
16 \\
22 \\
24 \\
18 \\
26 \\
22 \\
24 \\
100 / \text { STOP }\end{array}$ & $\begin{array}{r}7 \\
9 \\
26 \\
36 \\
40 \\
32 \\
44 \\
41 \\
39\end{array}$ \\
\hline $\begin{array}{l}15 \\
15 \\
15 \\
15 \\
15 \\
15 \\
15 \\
15 \\
15 \\
15\end{array}$ & $\begin{array}{l}03 / 17 / 88 \\
03 / 17 / 88 \\
03 / 17 / 88 \\
03 / 17 / 88 \\
03 / 17 / 88 \\
03 / 17 / 88 \\
03 / 17 / 88 \\
03 / 17 / 88 \\
03 / 17 / 88 \\
03 / 17 / 88\end{array}$ & $\begin{array}{l}11.50 \\
15.00 \\
15.00 \\
14.75 \\
15.50 \\
13.50 \\
15.00 \\
12.50 \\
15.75 \\
16.75\end{array}$ & $\begin{array}{l}20.43 \\
29.09 \\
26.85 \\
25.00 \\
14.93 \\
28.71 \\
29.41 \\
27.78 \\
31.78 \\
28.21\end{array}$ & $\begin{array}{l}1.66 \\
1.51 \\
1.48 \\
1.45 \\
1.78 \\
1.54 \\
1.40 \\
1.48 \\
1.40 \\
1.44\end{array}$ & $\begin{array}{l}4 \\
3 \\
3 \\
5 \\
3 \\
3 \\
3 \\
3 \\
3 \\
4\end{array}$ & $\begin{array}{l}3 \\
5 \\
7 \\
7 \\
8 \\
6 \\
6 \\
5 \\
7 \\
7\end{array}$ & $\begin{array}{r}3 \\
6 \\
8 \\
8 \\
10 \\
10 \\
8 \\
6 \\
8 \\
7\end{array}$ & $\begin{array}{l}6 \\
11 \\
15 \\
15 \\
18 \\
16 \\
14 \\
11 \\
15 \\
14\end{array}$ \\
\hline $\begin{array}{l}16 \\
16 \\
16 \\
16 \\
16 \\
16 \\
16 \\
16\end{array}$ & $\begin{array}{l}03 / 21 / 88 \\
03 / 21 / 88 \\
03 / 21 / 88 \\
03 / 21 / 88 \\
03 / 21 / 88 \\
03 / 21 / 88 \\
03 / 21 / 88 \\
03 / 21 / 88\end{array}$ & $\begin{array}{l}13.75 \\
15.50 \\
16.75 \\
17.00 \\
17.00 \\
14.75 \\
11.50 \\
10.00\end{array}$ & $\begin{array}{r}23.23 \\
28.95 \\
23.88 \\
23.91 \\
29.27 \\
17.60 \\
8.65 \\
8.05\end{array}$ & $\begin{array}{l}1.48 \\
1.51 \\
1.64 \\
1.67 \\
1.49 \\
1.74 \\
1.86 \\
1.79\end{array}$ & $\begin{array}{r}2 \\
2 \\
4 \\
7 \\
5 \\
6 \\
29 \\
47\end{array}$ & $\begin{array}{r}2 \\
3 \\
9 \\
9 \\
6 \\
11 \\
84 / \text { STOP } \\
58 / \text { STOP }\end{array}$ & $\begin{array}{r}2 \\
5 \\
11 \\
11 \\
7 \\
16 \\
\text { DRILL }\end{array}$ & $\begin{array}{r}4 \\
8 \\
20 \\
20 \\
13 \\
27\end{array}$ \\
\hline $\begin{array}{l}17 \\
17 \\
17 \\
17 \\
17 \\
17 \\
17 \\
17 \\
17 \\
17\end{array}$ & $\begin{array}{l}04 / 06 / 88 \\
04 / 06 / 88 \\
04 / 06 / 88 \\
04 / 06 / 88 \\
04 / 06 / 88 \\
04 / 06 / 88 \\
04 / 07 / 88 \\
04 / 07 / 88 \\
04 / 07 / 88 \\
04 / 07 / 88\end{array}$ & $\begin{array}{l}13.75 \\
16.50 \\
18.00 \\
14.25 \\
17.75 \\
16.25 \\
15.50 \\
16.00 \\
16.25 \\
11.00\end{array}$ & $\begin{array}{r}22.33 \\
24.81 \\
35.65 \\
32.67 \\
\\
24.43 \\
20.00 \\
\\
15.75 \\
8.94\end{array}$ & $\begin{array}{l}1.54 \\
1.66 \\
1.31 \\
1.46 \\
1.66 \\
1.79 \\
1.85 \\
2.30\end{array}$ & $\begin{array}{r}3 \\
3 \\
3 \\
4 \\
3 \\
5 \\
7 \\
10 \\
8 \\
40\end{array}$ & $\begin{array}{r}3 \\
4 \\
4 \\
4 \\
4 \\
9 \\
13 \\
22 \\
13 \\
50 / \text { S'TOP }\end{array}$ & $\begin{array}{r}3 \\
5 \\
4 \\
4 \\
9 \\
14 \\
15 \\
26 \\
46 / \text { STOP }\end{array}$ & $\begin{array}{r}6 \\
9 \\
8 \\
8 \\
13 \\
23 \\
28 \\
48\end{array}$ \\
\hline
\end{tabular}


APPENDIX VI

\begin{tabular}{|c|c|c|c|c|c|c|c|c|}
\hline $\begin{array}{c}\text { TARA } \\
\text { Core } \\
\text { Number }\end{array}$ & Date & $\begin{array}{c}\text { Core } \\
\text { Length } \\
\text { (In.) }\end{array}$ & $\begin{array}{l}\text { Soil } \\
\text { Moist. } \\
\text { ( } 8 \text { of } \\
\text { Dry Wt) }\end{array}$ & $\begin{array}{l}\text { Core } \\
\text { Bulk } \\
\text { Densitty } \\
\left(\mathrm{g} / \mathrm{cm}^{3}\right)\end{array}$ & $\begin{array}{l}\text { Blows } \\
\text { Per } \\
6 \text { In. }\end{array}$ & $\begin{array}{l}\text { Blows } \\
\text { Per } \\
12 \mathrm{In} .\end{array}$ & $\begin{array}{l}\text { Blows } \\
\text { Per } \\
18 \mathrm{In} .\end{array}$ & $\begin{array}{l}\text { Penetrate } \\
\text { Resist. } \\
\text { (Blows/Ft) }\end{array}$ \\
\hline $\begin{array}{l}18 \\
18 \\
18 \\
18 \\
18 \\
18 \\
18 \\
18 \\
18 \\
18\end{array}$ & $\begin{array}{l}04 / 07 / 88 \\
04 / 07 / 88 \\
04 / 07 / 88 \\
04 / 07 / 88 \\
04 / 08 / 88 \\
04 / 08 / 88 \\
04 / 08 / 88 \\
04 / 08 / 88 \\
04 / 08 / 88 \\
04 / 08 / 88\end{array}$ & $\begin{array}{l}15.00 \\
13.75 \\
11.25 \\
12.50 \\
14.50 \\
15.75 \\
15.25 \\
16.00 \\
15.25 \\
15.50\end{array}$ & $\begin{array}{l}15.32 \\
26.47 \\
17.95 \\
18.95 \\
20.49 \\
20.90 \\
22.05 \\
20.59 \\
20.74 \\
16.55\end{array}$ & $\begin{array}{l}1.70 \\
1.52 \\
1.42 \\
1.56 \\
1.73 \\
1.75 \\
1.71 \\
1.75 \\
1.82 \\
1.92\end{array}$ & $\begin{array}{l}2 \\
3 \\
4 \\
5 \\
5 \\
8 \\
7 \\
6 \\
7 \\
9\end{array}$ & $\begin{array}{r}3 \\
3 \\
5 \\
6 \\
10 \\
9 \\
8 \\
6 \\
10 \\
15\end{array}$ & $\begin{array}{r}2 \\
2 \\
8 \\
6 \\
12 \\
14 \\
10 \\
9 \\
12 \\
20\end{array}$ & $\begin{array}{r}5 \\
5 \\
13 \\
12 \\
22 \\
23 \\
18 \\
15 \\
22 \\
35\end{array}$ \\
\hline $\begin{array}{l}19 \\
19 \\
19 \\
19 \\
19 \\
19 \\
19 \\
19 \\
19 \\
19\end{array}$ & $\begin{array}{l}03 / 18 / 88 \\
03 / 18 / 88 \\
03 / 18 / 88 \\
03 / 18 / 88 \\
03 / 18 / 88 \\
03 / 18 / 88 \\
03 / 18 / 88 \\
03 / 18 / 88 \\
03 / 18 / 88 \\
03 / 18 / 88\end{array}$ & $\begin{array}{l}14.00 \\
15.00 \\
15.50 \\
16.25 \\
14.75 \\
14.50 \\
17.00 \\
18.00 \\
17.00 \\
1.5 .00\end{array}$ & $\begin{array}{l}20.69 \\
27.83 \\
27.68 \\
21.09 \\
21.67 \\
\\
40.17 \\
26.40 \\
29.36\end{array}$ & $\begin{array}{l}1.70 \\
1.58 \\
1.48 \\
1.62 \\
1.67\end{array}$ & $\begin{array}{r}4 \\
3 \\
4 \\
6 \\
8 \\
10 \\
6 \\
2 \\
6 \\
6\end{array}$ & $\begin{array}{r}3 \\
4 \\
6 \\
10 \\
15 \\
19 \\
3 \\
3 \\
7 \\
5\end{array}$ & $\begin{array}{r}4 \\
7 \\
8 \\
13 \\
19 \\
24 \\
4 \\
5 \\
8 \\
8\end{array}$ & $\begin{array}{r}7 \\
11 \\
14 \\
23 \\
34 \\
43 \\
7 \\
8 \\
15 \\
13\end{array}$ \\
\hline $\begin{array}{l}20 \\
20 \\
20 \\
20 \\
20 \\
20 \\
20 \\
20 \\
20 \\
20\end{array}$ & $\begin{array}{l}03 / 03 / 88 \\
03 / 03 / 88 \\
03 / 03 / 88 \\
03 / 03 / 88 \\
03 / 03 / 88 \\
03 / 07 / 88 \\
03 / 07 / 88 \\
03 / 07 / 88 \\
03 / 07 / 88 \\
03 / 07 / 88\end{array}$ & $\begin{array}{r}6.50 \\
16.00 \\
17.75 \\
16.50 \\
16.75 \\
16.50 \\
13.50 \\
17.50 \\
15.75 \\
15.25\end{array}$ & $\begin{array}{l}17.95 \\
26.19 \\
26.89 \\
30.97 \\
39.25 \\
32.56 \\
31.75 \\
27.73 \\
22.50\end{array}$ & $\begin{array}{l}1.23 \\
1.62 \\
1.48 \\
1.39 \\
1.33 \\
1.31 \\
1.48 \\
1.55 \\
1.62\end{array}$ & $\begin{array}{l}3 \\
4 \\
4 \\
4 \\
4 \\
2 \\
2 \\
3 \\
4 \\
5\end{array}$ & $\begin{array}{l}3 \\
6 \\
6 \\
8 \\
5 \\
3 \\
5 \\
6 \\
6 \\
8\end{array}$ & $\begin{array}{r}3 \\
9 \\
7 \\
9 \\
5 \\
6 \\
5 \\
9 \\
7 \\
12\end{array}$ & $\begin{array}{r}6 \\
15 \\
13 \\
17 \\
10 \\
9 \\
10 \\
15 \\
13 \\
20\end{array}$ \\
\hline $\begin{array}{l}21 \\
21 \\
21 \\
21 \\
21 \\
21 \\
21 \\
21\end{array}$ & $\begin{array}{l}03 / 07 / 88 \\
03 / 07 / 88 \\
03 / 07 / 88 \\
03 / 07 / 88 \\
03 / 07 / 88 \\
03 / 07 / 88 \\
03 / 08 / 88 \\
03 / 08 / 88\end{array}$ & $\begin{array}{r}15.00 \\
17.50 \\
14.75 \\
18.00 \\
15.75 \\
15.00 \\
17.25 \\
8.50\end{array}$ & $\begin{array}{l}29.46 \\
18.55 \\
15.69 \\
12.70 \\
16.26 \\
13.77 \\
16.95\end{array}$ & $\begin{array}{l}1.51 \\
1.73 \\
1.75 \\
1.64 \\
1.68 \\
1.64 \\
1.43\end{array}$ & $\begin{array}{r}2 \\
4 \\
6 \\
8 \\
12 \\
8 \\
10 \\
128\end{array}$ & $\begin{array}{r}3 \\
4 \\
9 \\
15 \\
26 \\
12 \\
15 \\
\text { /STOP }\end{array}$ & $\begin{array}{r}3 \\
7 \\
12 \\
22 \\
28 \\
14 \\
22\end{array}$ & $\begin{array}{r}6 \\
11 \\
21 \\
37 \\
54 \\
26 \\
37\end{array}$ \\
\hline
\end{tabular}


APPENDIX VI

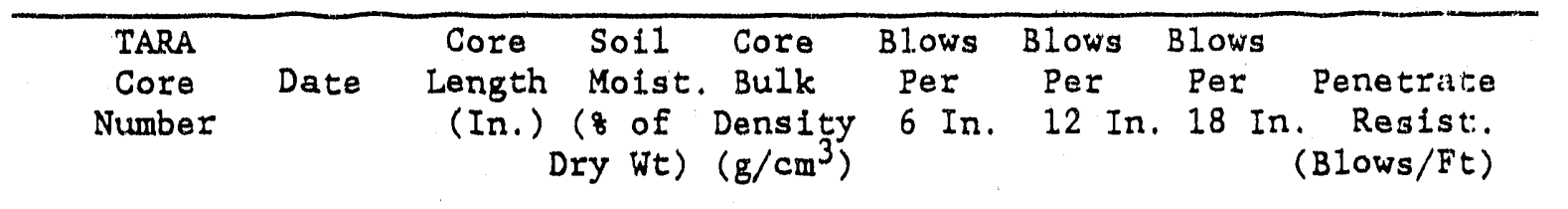

\begin{tabular}{|c|c|c|c|c|c|c|c|c|}
\hline 22 & $03 / 08 / 88$ & 13.50 & 21.65 & 1.48 & 2 & 2 & 2 & 4 \\
\hline 22 & $03 / 08 / 88$ & 15.25 & 33.01 & 1.39 & 1 & 2 & 4 & 6 \\
\hline 22 & $03 / 08 / 88$ & 15.75 & 32.35 & 1.33 & 3 & 4 & 4 & 8 \\
\hline 22 & $03 / 08 / 88$ & 17.00 & 33.33 & 1.38 & 4 & 5 & 9 & 14 \\
\hline 22 & $03 / 08 / 88$ & 16.50 & 21.50 & 1.60 & 4 & 12 & 16 & 28 \\
\hline 22 & $03 / 08 / 88$ & 17.50 & 20.71 & 1.64 & 7 & 14 & 15 & 29 \\
\hline 22 & $03 / 08 / 88$ & 17.50 & 18.25 & 1.61 & 9 & 17 & 17 & 34 \\
\hline 22 & $03 / 08 / 88$ & 18.00 & 19.61 & 1.75 & 7 & 11 & 9 & 20 \\
\hline 22 & $03 / 08 / 88$ & 16.75 & 19.58 & 1.75 & 8 & 9 & 13 & 22 \\
\hline 22 & $03 / 09 / 88$ & 16.00 & 25.47 & 1.36 & 3 & 5 & 12 & 17 \\
\hline $2 \mathrm{~A}$ & $04 / 11 / 88$ & 14.75 & & & 3 & 3 & 2 & 5 \\
\hline $2 \mathrm{~A}$ & $04 / 11 / 88$ & 12.00 & 24.72 & 1.52 & 2 & 3 & 5 & 8 \\
\hline $2 B$ & $04 / 12 / 88$ & 12.00 & 22.83 & 1.58 & 2 & 2 & 2 & 4 \\
\hline $2 B$ & $04 / 12 / 88$ & 11.50 & 21.65 & 1.73 & 4 & 3 & 5 & 8 \\
\hline $2 C$ & $04 / 12 / 88$ & 12.00 & 21.28 & 1.61 & 2 & 4 & 2 & 6 \\
\hline $2 \mathrm{C}$ & $04 / 12 / 88$ & 7.00 & 21.57 & 1.50 & 2 & 1 & 1 & 2 \\
\hline $3 \mathrm{~A}$ & $04 / 11 / 88$ & 11.50 & 22.35 & 1.52 & 3 & 2 & 2 & 4 \\
\hline $3 \mathrm{~A}$ & $04 / 11 / 88$ & 13.00 & 23.17 & 1.67 & 3 & 4 & 4 & 8 \\
\hline $3 B$ & $04 / 12 / 88$ & 12.00 & 22.99 & 1.49 & 3 & 2 & 3 & 5 \\
\hline $3 B$ & $04 / 12 / 88$ & 11.25 & 23.33 & 1.64 & 3 & 3 & 5 & 8 \\
\hline $3 C$ & $04 / 12 / 88$ & 15.00 & 23.28 & 1.59 & 2 & 2 & 3 & 5 \\
\hline $3 C$ & $04 / 12 / 88$ & 8.50 & 19.35 & 1.50 & 3 & 3 & 3 & 6 \\
\hline $4 \mathrm{~A}$ & $04 / 11 / 88$ & 12.00 & 22.35 & 1.46 & 2 & 2 & 2 & 4 \\
\hline $4 \mathrm{~A}$ & $04 / 11 / 88$ & 11.00 & 22.86 & 1.72 & 2 & 3 & 5 & 8 \\
\hline 4B & $04 / 11 / 88$ & 10.50 & 18.99 & 1.55 & 4 & 3 & 3 & 6 \\
\hline 4B & $04 / 11 / 88$ & 13.25 & 22.12 & 1.61 & 3 & 2 & 6 & 8 \\
\hline $4 \mathrm{C}$ & $04 / 12 / 88$ & 13.00 & 23.71 & 1.53 & 3 & 3 & 2 & 5 \\
\hline $4 C$ & $04 / 12 / 88$ & 11.50 & 22.83 & 1.64 & 3 & 4 & 5 & 9 \\
\hline $5 \mathrm{~A}$ & $04 / 11 / 88$ & 12.50 & 21.65 & 1.59 & 2 & 3 & 3 & 6 \\
\hline $5 \mathrm{~A}$ & $04 / 11 / 88$ & 11.50 & 23.88 & 1.54 & 2 & 3 & 3 & 6 \\
\hline $\begin{array}{l}5 B \\
5 B\end{array}$ & $\begin{array}{l}04 / 11 / 88 \\
04 / 11 / 88\end{array}$ & $\begin{array}{l}11.00 \\
11.50\end{array}$ & $\begin{array}{l}20.00 \\
24.47\end{array}$ & $\begin{array}{l}1.59 \\
1.68\end{array}$ & $\begin{array}{l}3 \\
3\end{array}$ & $\begin{array}{l}3 \\
4\end{array}$ & $\begin{array}{l}2 \\
5\end{array}$ & $\begin{array}{l}5 \\
9\end{array}$ \\
\hline
\end{tabular}


APPENDIX VI

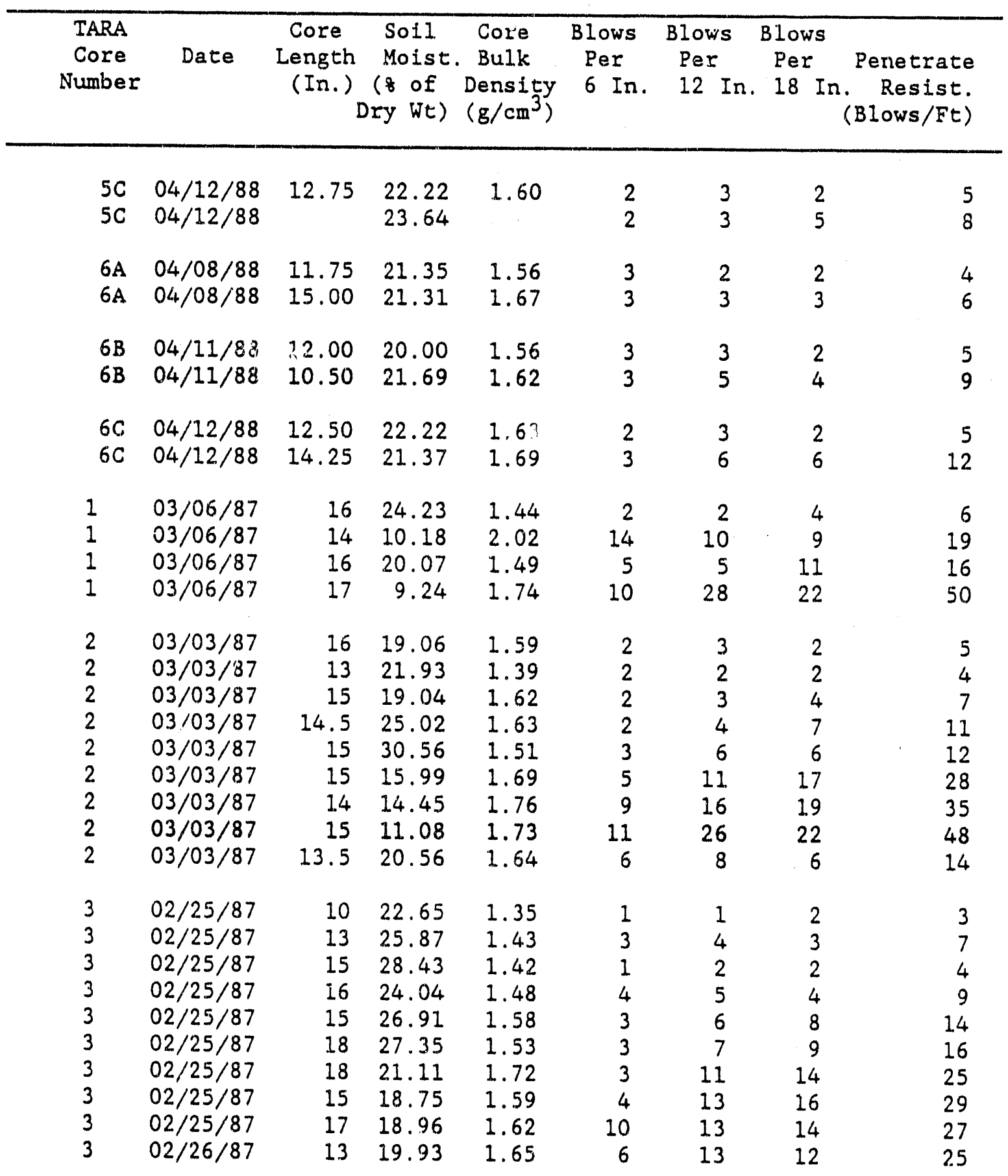


APPENDIX VI

\begin{tabular}{|c|c|c|c|c|c|c|c|c|}
\hline $\begin{array}{l}\text { TARA } \\
\text { Core } \\
\text { Number }\end{array}$ & Date & $\begin{array}{c}\text { Core } \\
\text { Length } \\
\text { (In.) }\end{array}$ & $\begin{array}{l}\text { Soll } \\
\text { Moist. } \\
\text { (z of } \\
\text { ry } w t)\end{array}$ & $\begin{array}{l}\text { Core } \\
\text { Bulk } \\
\text { Densitty } \\
\left(\mathrm{g} / \mathrm{cm}^{3}\right)\end{array}$ & $\begin{array}{l}\text { Blows } \\
\text { Per } \\
6 \mathrm{In} .\end{array}$ & $\begin{array}{l}\text { Blows } \\
\text { Per } \\
12 \mathrm{In} .\end{array}$ & $\begin{array}{l}\text { Blows } \\
\text { Per } \\
18 \text { In. }\end{array}$ & $\begin{array}{l}\text { Penetrate } \\
\text { Resist. } \\
\text { (Blows/Ft) }\end{array}$ \\
\hline 4 & $02 / 26 / 87$ & 14 & 23.49 & 1.60 & 1 & 2 & 2 & 4 \\
\hline 4 & $02 / 26 / 87$ & 13 & 25.18 & 1.46 & 3 & 3 & 3 & 6 \\
\hline 4 & $02 / 26 / 87$ & 17 & 29.42 & 1.48 & 1 & 2 & 3 & 5 \\
\hline 4 & $02 / 26 / 87$ & 14 & 30.92 & 1.45 & 2 & 3 & 4 & 7 \\
\hline 4 & $02 / 26 / 87$ & 15 & 35.60 & 1.33 & 2 & 5 & 3 & 8 \\
\hline 4 & $02 / 26 / 87$ & 17 & 15.42 & 1.36 & 2 & 3 & 5 & 8 \\
\hline 4 & $02 / 26 / 87$ & 16 & 25.81 & 1.55 & 3 & 5 & 9 & 14 \\
\hline 4 & $02 / 26 / 87$ & 15 & 15.67 & 1.48 & 6 & 13 & 19 & 32 \\
\hline 4 & $02 / 26 / 87$ & 14 & 16.82 & 1.64 & 8 & 14 & 15 & 29 \\
\hline 4 & $02 / 27 / 87$ & 13 & 20.64 & 1.58 & 5 & 9 & 9 & 18 \\
\hline 5 & $02 / 27 / 87$ & 12 & 22.47 & 1.49 & 2 & 2 & 2 & 4 \\
\hline 5 & $02 / 27 / 87$ & 14 & 25.87 & 1.54 & 3 & 2 & 3 & 5 \\
\hline 5 & $02 / 27 / 87$ & 12 & 31.11 & 1.28 & 1 & 4 & 3 & 7 \\
\hline 5 & $02 / 27 / 87$ & 13 & 25.57 & 1.43 & 2 & 5 & 6 & 11 \\
\hline 5 & $02 / 27 / 87$ & 15 & 19.05 & 1.62 & 4 & 10 & 15 & 25 \\
\hline 5 & $02 / 27 / 87$ & 12 & 16.16 & 1.63 & 6 & 12 & 10 & 22 \\
\hline 5 & $02 / 27 / 87$ & 14 & 28.00 & 1.57 & 3. & 8 & 10 & 18 \\
\hline 5 & $02 / 27 / 87$ & 15 & 25.67 & 1.52 & 4 & 8 & 8 & 16 \\
\hline 5 & $02 / 27 / 87$ & 17.5 & 28.86 & 1.44 & 5 & 6 & 6 & 12 \\
\hline 6 & $03 / 03 / 87$ & 14 & 18.71 & 1.54 & 2 & 2 & 2 & 4 \\
\hline 6 & $03 / 03 / 87$ & 14. & 19.20 & 1.61 & 1 & 3 & 3 & 6 \\
\hline 6 & $03 / 03 / 87$ & 15 & 23.58 & 1.42 & 1 & 1 & 1 & 2 \\
\hline 6 & $03 / 03 / 87$ & 15.5 & 19.78 & 1.59 & 2 & 3 & 4 & 7 \\
\hline 6 & $03 / 03 / 87$ & 15 & 15.42 & 1.74 & 4 & 9 & 11 & 20 \\
\hline 6 & $03 / 03 / 87$ & 15 & 17.18 & 1.76 & 6 & 8 & 10 & 18 \\
\hline 6 & $03 / 03 / 87$ & 14.5 & 21.94 & 1.61 & 5 & 6 & 8 & 14 \\
\hline 6 & $03 / 03 / 87$ & 17 & 29.87 & 1.41 & 4 & 4 & 5 & 9 \\
\hline 6 & $03 / 04 / 87$ & 19 & 30.49 & 1.39 & 3 & 4 & 5 & 9 \\
\hline 7 & $03 / 04 / 87$ & 14 & 16.73 & 1.49 & 2 & 3 & 3 & 6 \\
\hline 7 & $03 / 04 / 87$ & 14.5 & 19.81 & 1.57 & 1 & 5 & 5 & 10 \\
\hline 7 & $03 / 04 / 87$ & 14 & 20.78 & 1.54 & 2 & 4 & 5 & 9 \\
\hline 7 & $03 / 04 / 87$ & 13 & 17.17 & 1.62 & 3 & 8 & 6 & 14 \\
\hline 7 & $03 / 04 / 87$ & 15 & 21.93 & 1.63 & 5 & 7 & 7 & 14 \\
\hline 7 & $03 / 04 / 87$ & 14 & 19.98 & 1.71 & 3 & 8 & 6 & 14 \\
\hline 7 & $03 / 04 / 87$ & 15.5 & 13.13 & 1.97 & 5 & 14 & 27 & 41 \\
\hline 7 & $03 / 04 / 87$ & & 5.81 & & 23 & 51/STOP & & \\
\hline 8 & $03 / 04 / 87$ & 12 & 21.37 & 1.51 & 2 & 4 & 3 & 7 \\
\hline 8 & $03 / 04 / 87$ & 15 & 19.89 & 1.73 & 2 & 5 & 6 & 11 \\
\hline
\end{tabular}


APPENDIX VI

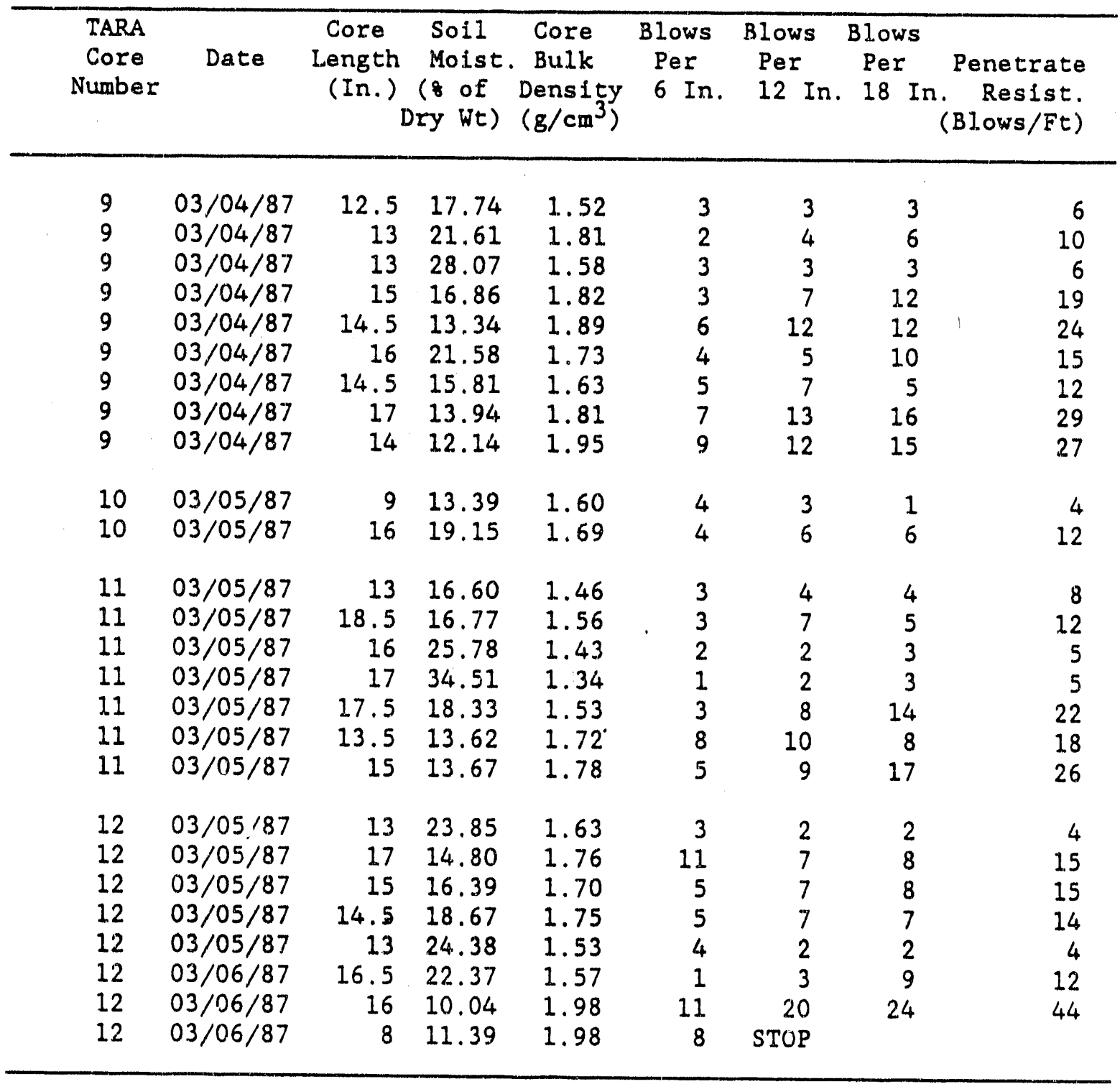




\section{APPENDIX VII}

Summary of the Number of Weight Drops Required During Trench Compaction.

Blows to Level - Leveling of Entire Section 
APPENDIX VII

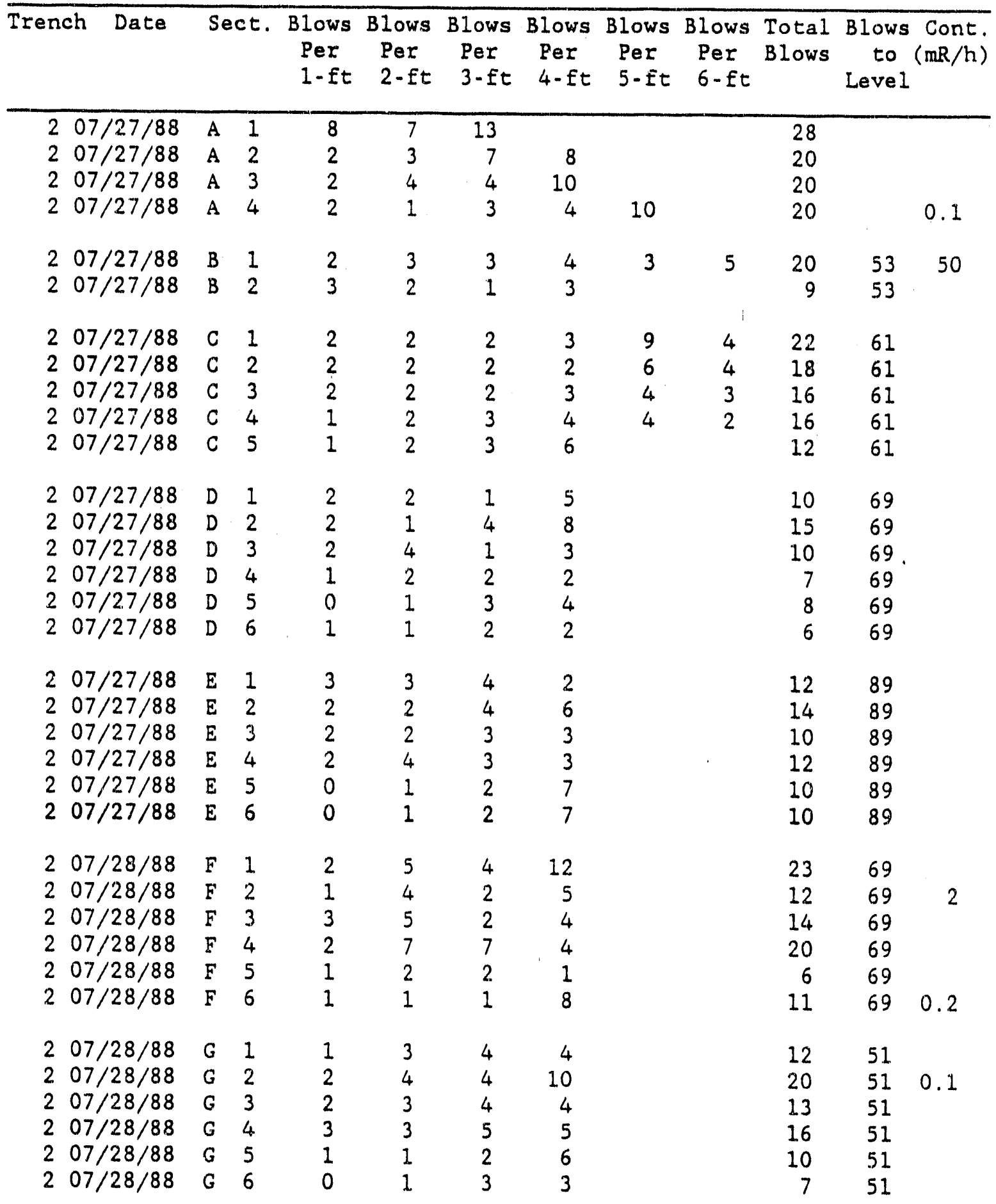


APPENDIX VII

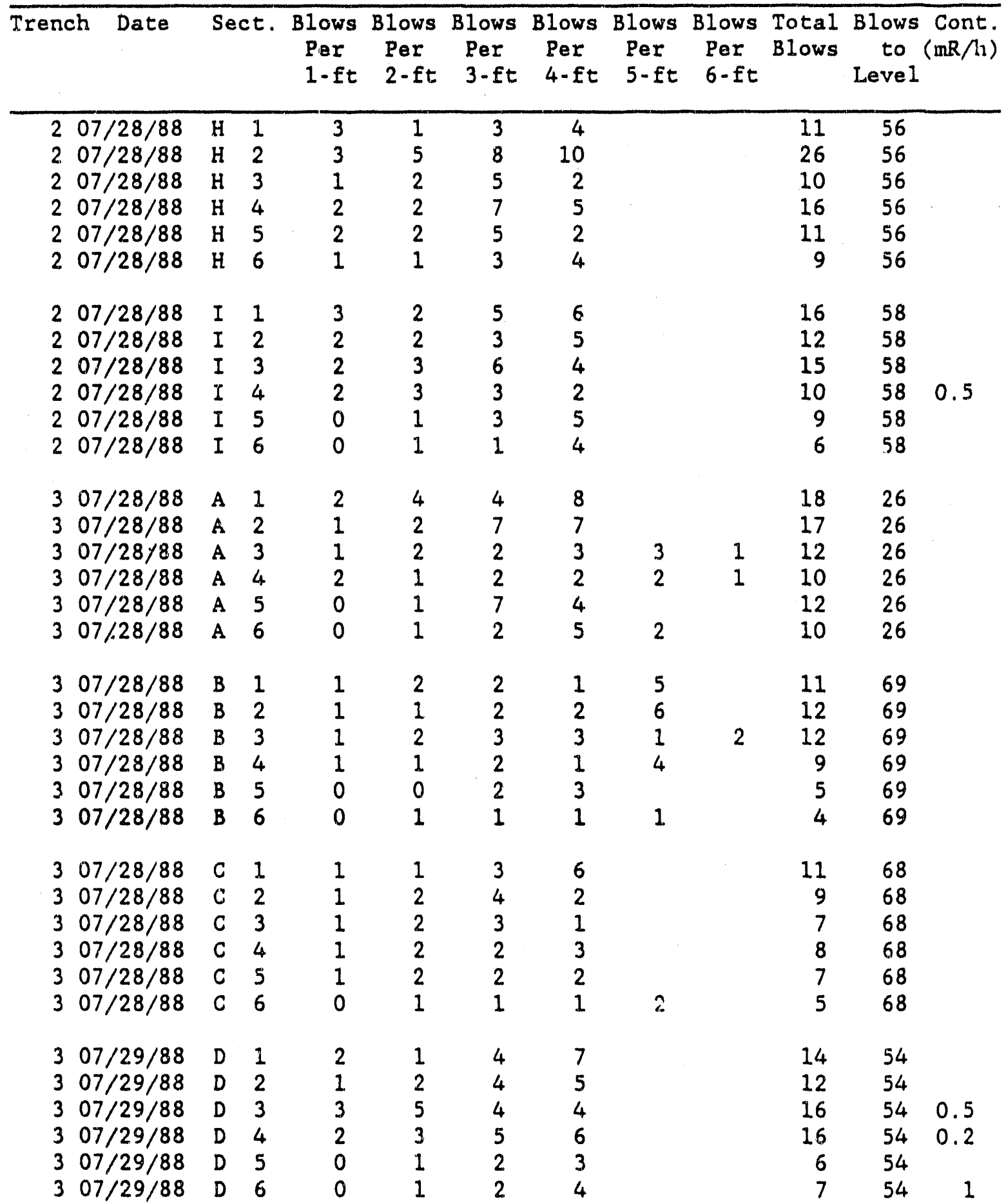


APPENDIX VII

\begin{tabular}{|c|c|c|c|c|c|c|c|c|c|c|c|c|}
\hline ren & h Date & $\mathrm{Se}$ & $\overline{c t .}$ & $\begin{array}{l}\text { Blows } \\
\text { Per } \\
1-f t\end{array}$ & $\begin{array}{l}\text { Blows } \\
\text { Per } \\
2-f t\end{array}$ & $\begin{array}{l}\text { Blows } \\
\text { Per } \\
3-f t\end{array}$ & $\begin{array}{l}\text { Blows } \\
\text { Per } \\
4-\mathrm{ft}\end{array}$ & $\begin{array}{l}\text { Blows } \\
\text { Per } \\
5-\mathrm{ft}\end{array}$ & $\begin{array}{l}\text { Blows } \\
\text { Per } \\
6-\mathrm{ft}\end{array}$ & $\begin{array}{l}\text { Total } \\
\text { Blows }\end{array}$ & $\begin{array}{c}\text { Blows } \\
\text { to } \\
\text { Level }\end{array}$ & $\begin{array}{l}\text { Cont. } \\
(\mathrm{mR} / \mathrm{h})\end{array}$ \\
\hline $\begin{array}{l}3 \\
3 \\
3 \\
3 \\
3 \\
3\end{array}$ & $\begin{array}{l}07 / 29 / 88 \\
07 / 29 / 88 \\
07 / 29 / 88 \\
07 / 29 / 88 \\
07 / 29 / 88 \\
07 / 29 / 88\end{array}$ & $\begin{array}{l}E \\
E \\
E \\
E \\
E \\
E\end{array}$ & $\begin{array}{l}1 \\
2 \\
3 \\
4 \\
5 \\
6\end{array}$ & $\begin{array}{l}2 \\
1 \\
2 \\
2 \\
0 \\
0\end{array}$ & $\begin{array}{l}2 \\
3 \\
2 \\
2 \\
1 \\
1\end{array}$ & $\begin{array}{l}3 \\
4 \\
3 \\
4 \\
1 \\
2\end{array}$ & $\begin{array}{l}3 \\
2 \\
5 \\
4 \\
2 \\
1\end{array}$ & & & $\begin{array}{r}10 \\
10 \\
12 \\
12 \\
4 \\
4\end{array}$ & $\begin{array}{l}62 \\
62 \\
62 \\
62 \\
62 \\
62\end{array}$ & 0.5 \\
\hline $\begin{array}{l}3 \\
3 \\
3 \\
3\end{array}$ & $\begin{array}{l}07 / 29 / 88 \\
07 / 29 / 88 \\
07 / 29 / 88 \\
07 / 29 / 88\end{array}$ & $\begin{array}{l}F \\
F \\
F \\
F\end{array}$ & $\begin{array}{l}1 \\
2 \\
3 \\
4\end{array}$ & $\begin{array}{l}2 \\
1 \\
1 \\
1\end{array}$ & $\begin{array}{l}2 \\
4 \\
3 \\
3\end{array}$ & $\begin{array}{l}5 \\
8 \\
5 \\
5\end{array}$ & $\begin{array}{l}4 \\
6 \\
2 \\
4\end{array}$ & & & $\begin{array}{l}13 \\
19 \\
11 \\
13\end{array}$ & $\begin{array}{l}57 \\
57 \\
57 \\
57\end{array}$ & \\
\hline $\begin{array}{l}3 \\
3 \\
3 \\
3 \\
3 \\
3 \\
3\end{array}$ & $\begin{array}{l}07 / 29 / 88 \\
07 / 29 / 88 \\
07 / 29 / 88 \\
07 / 29 / 88 \\
07 / 29 / 88 \\
07 / 29 / 88\end{array}$ & $\begin{array}{l}\text { G } \\
\text { G } \\
\text { G } \\
\text { G } \\
\text { G } \\
\text { G }\end{array}$ & $\begin{array}{l}1 \\
2 \\
3 \\
4 \\
5 \\
6\end{array}$ & $\begin{array}{l}2 \\
1 \\
3 \\
2 \\
1 \\
0\end{array}$ & $\begin{array}{l}5 \\
3 \\
2 \\
2 \\
2 \\
1\end{array}$ & $\begin{array}{l}5 \\
3 \\
2 \\
3 \\
4 \\
3\end{array}$ & $\begin{array}{l}5 \\
6 \\
6 \\
2 \\
6 \\
3\end{array}$ & & & $\begin{array}{r}17 \\
13 \\
13 \\
9 \\
13 \\
7\end{array}$ & $\begin{array}{l}57 \\
57 \\
57 \\
57 \\
57 \\
57\end{array}$ & 0.2 \\
\hline $\begin{array}{l}3 \\
3 \\
3 \\
3\end{array}$ & $\begin{array}{l}07 / 29 / 88 \\
07 / 29 / 88 \\
07 / 29 / 88 \\
07 / 29 / 88\end{array}$ & $\begin{array}{l}\mathrm{H} \\
\mathrm{H} \\
\mathrm{H} \\
\mathrm{H}\end{array}$ & $\begin{array}{l}1 \\
2 \\
3 \\
4\end{array}$ & $\begin{array}{l}2 \\
1 \\
1 \\
1\end{array}$ & $\begin{array}{l}4 \\
1 \\
2 \\
1\end{array}$ & $\begin{array}{l}5 \\
4 \\
3 \\
4\end{array}$ & $\begin{array}{l}7 \\
8 \\
4 \\
6\end{array}$ & & & $\begin{array}{l}18 \\
14 \\
10 \\
12\end{array}$ & $\begin{array}{l}60 \\
60 \\
60 \\
60\end{array}$ & \\
\hline $\begin{array}{l}4 \\
4 \\
4 \\
4\end{array}$ & $\begin{array}{l}07 / 29 / 88 \\
07 / 29 / 88 \\
07 / 29 / 88 \\
07 / 29 / 88\end{array}$ & $\begin{array}{l}\text { A } \\
\text { A } \\
\text { A } \\
\text { A }\end{array}$ & $\begin{array}{l}1 \\
2 \\
3 \\
4\end{array}$ & $\begin{array}{l}2 \\
1 \\
1 \\
1\end{array}$ & $\begin{array}{l}2 \\
3 \\
1 \\
1\end{array}$ & $\begin{array}{l}3 \\
3 \\
4 \\
3\end{array}$ & $\begin{array}{l}4 \\
6 \\
2 \\
3\end{array}$ & & & $\begin{array}{r}11 \\
13 \\
8 \\
8\end{array}$ & $\begin{array}{l}26 \\
26 \\
26 \\
26\end{array}$ & \\
\hline $\begin{array}{ll}4 & 0 \\
4 & 0 \\
4 & 0 \\
4 & 0 \\
4 & 0 \\
4 & 0\end{array}$ & $\begin{array}{l}07 / 29 / 88 \\
07 / 29 / 88 \\
07 / 29 / 88 \\
07 / 29 / 88 \\
07 / 29 / 88 \\
07 / 29 / 88\end{array}$ & $\begin{array}{l}\text { B } \\
\text { B } \\
\text { B } \\
\bar{B} \\
\text { B } \\
\text { B }\end{array}$ & $\begin{array}{l}1 \\
2 \\
3 \\
4 \\
5 \\
6\end{array}$ & $\begin{array}{l}1 \\
1 \\
1 \\
1 \\
0 \\
0\end{array}$ & $\begin{array}{l}2 \\
1 \\
2 \\
1 \\
1 \\
0\end{array}$ & $\begin{array}{l}3 \\
3 \\
2 \\
2 \\
1 \\
1\end{array}$ & $\begin{array}{l}4 \\
4 \\
4 \\
5 \\
1 \\
1\end{array}$ & & & $\begin{array}{r}10 \\
9 \\
9 \\
9 \\
3 \\
2\end{array}$ & $\begin{array}{l}32 \\
32 \\
32 \\
32 \\
32 \\
32\end{array}$ & \\
\hline $\begin{array}{l}40 \\
40\end{array}$ & $\begin{array}{l}07 / 29 / 88 \\
07 / 29 / 88\end{array}$ & $\begin{array}{l}\mathrm{C} \\
\mathrm{C}\end{array}$ & $\begin{array}{l}1 \\
2\end{array}$ & $\begin{array}{l}1 \\
1\end{array}$ & $\begin{array}{l}2 \\
1\end{array}$ & $\begin{array}{l}3 \\
3\end{array}$ & $\begin{array}{l}6 \\
2\end{array}$ & & & $\begin{array}{r}12 \\
7\end{array}$ & $\begin{array}{l}24 \\
24\end{array}$ & \\
\hline $\begin{array}{ll}4 & 0 \\
4 & 0 \\
4 & 0 \\
4 & 0 \\
4 & 0 \\
4 & 0\end{array}$ & $\begin{array}{l}08 / 01 / 88 \\
08 / 01 / 88 \\
08 / 01 / 88 \\
08 / 01 / 88 \\
08 / 01 / 88 \\
08 / 01 / 88\end{array}$ & $\begin{array}{l}D \\
D \\
D \\
D \\
D \\
D\end{array}$ & $\begin{array}{l}1 \\
2 \\
3 \\
4 \\
5 \\
6\end{array}$ & $\begin{array}{l}2 \\
2 \\
2 \\
1 \\
0 \\
0\end{array}$ & $\begin{array}{l}2 \\
2 \\
2 \\
2 \\
1 \\
1\end{array}$ & $\begin{array}{l}2 \\
4 \\
3 \\
3 \\
1 \\
1\end{array}$ & $\begin{array}{l}6 \\
4 \\
4 \\
3 \\
2 \\
3\end{array}$ & & & $\begin{array}{r}1.2 \\
12 \\
11 \\
9 \\
4 \\
5\end{array}$ & $\begin{array}{l}70 \\
70 \\
70 \\
70 \\
70 \\
70\end{array}$ & \\
\hline
\end{tabular}


APPENDIX VII

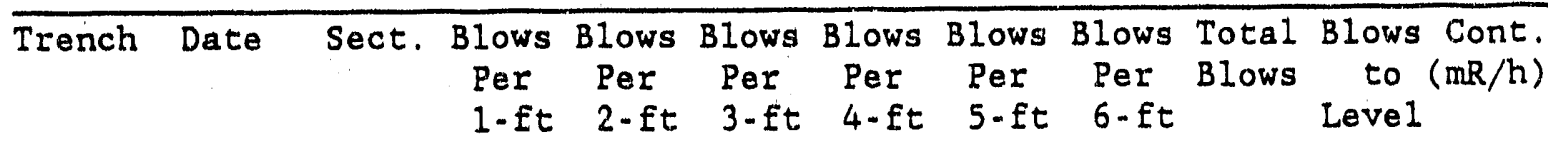

\begin{tabular}{|c|c|c|c|c|c|c|c|c|c|}
\hline $\begin{array}{ll}4 & 08 / 01 / 88 \\
4 & 08 / 01 / 88 \\
4 & 08 / 01 / 88 \\
4 & 08 / 01 / 88 \\
4 & 08 / 01 / 88 \\
4 & 08 / 01 / 88\end{array}$ & $\begin{array}{l}\mathrm{E} \\
\mathrm{E} \\
\mathrm{E} \\
\mathrm{E} \\
\mathrm{E} \\
\mathrm{E}\end{array}$ & $\begin{array}{l}1 \\
2 \\
3 \\
4 \\
5 \\
6\end{array}$ & $\begin{array}{l}1 \\
1 \\
1 \\
1 \\
1 \\
0\end{array}$ & $\begin{array}{l}3 \\
3 \\
2 \\
2 \\
1 \\
1\end{array}$ & $\begin{array}{l}4 \\
3 \\
3 \\
3 \\
2 \\
1\end{array}$ & $\begin{array}{l}2 \\
4 \\
2 \\
2 \\
2 \\
2\end{array}$ & $\begin{array}{r}10 \\
11 \\
8 \\
8 \\
6 \\
4\end{array}$ & $\begin{array}{l}59 \\
59 \\
59 \\
59 \\
59 \\
59\end{array}$ & \\
\hline $\begin{array}{ll}4 & 08 / 01 / 88 \\
4 & 08 / 01 / 88 \\
4 & 08 / 01 / 88 \\
4 & 08 / 02 / 88 \\
4 & 08 / 02 / 88 \\
4 & 08 / 02 / 88\end{array}$ & $\begin{array}{l}F \\
F \\
F \\
F \\
F \\
F\end{array}$ & $\begin{array}{l}1 \\
2 \\
3 \\
4 \\
5 \\
6\end{array}$ & $\begin{array}{l}1 \\
1 \\
1 \\
1 \\
0 \\
0\end{array}$ & $\begin{array}{l}3 \\
3 \\
3 \\
2 \\
1 \\
1\end{array}$ & $\begin{array}{l}3 \\
2 \\
2 \\
2 \\
1 \\
1\end{array}$ & $\begin{array}{l}6 \\
6 \\
6 \\
4 \\
3 \\
3\end{array}$ & $\begin{array}{r}13 \\
12 \\
12 \\
9 \\
5 \\
5\end{array}$ & $\begin{array}{l}62 \\
62 \\
62 \\
62 \\
62 \\
62\end{array}$ & \\
\hline $\begin{array}{ll}4 & 08 / 02 / 88 \\
4 & 08 / 02 / 88 \\
4 & 08 / 02 / 88 \\
4 & 08 / 02 / 88 \\
4 & 08 / 02 / 88 \\
4 & 08 / 02 / 88\end{array}$ & $\begin{array}{l}\text { G } \\
\text { G } \\
\text { G } \\
\text { G } \\
\text { G } \\
\text { G }\end{array}$ & $\begin{array}{l}1 \\
2 \\
3 \\
4 \\
5 \\
6\end{array}$ & $\begin{array}{l}1 \\
1 \\
1 \\
1 \\
0 \\
0\end{array}$ & $\begin{array}{l}2 \\
1 \\
3 \\
2 \\
1 \\
1\end{array}$ & $\begin{array}{l}2 \\
2 \\
1 \\
2 \\
1 \\
1\end{array}$ & $\begin{array}{l}2 \\
3 \\
2 \\
3 \\
3 \\
1\end{array}$ & $\begin{array}{l}7 \\
7 \\
7 \\
8 \\
5 \\
3\end{array}$ & $\begin{array}{l}77 \\
77 \\
77 \\
77 \\
77 \\
77\end{array}$ & \\
\hline $\begin{array}{ll}4 & 08 / 02 / 88 \\
4 & 08 / 02 / 88 \\
4 & 03 / 02 / 88\end{array}$ & $\begin{array}{l}\mathrm{H} \\
\mathrm{H} \\
\mathrm{H}\end{array}$ & $\begin{array}{l}1 \\
2 \\
3\end{array}$ & $\begin{array}{l}1 \\
1 \\
0\end{array}$ & $\begin{array}{l}2 \\
2 \\
1\end{array}$ & $\begin{array}{l}3 \\
2 \\
1\end{array}$ & $\begin{array}{l}2 \\
2 \\
3\end{array}$ & $\begin{array}{l}8 \\
7 \\
5\end{array}$ & & \\
\hline $\begin{array}{ll}5 & 08 / 02 / 88 \\
5 & 08 / 02 / 88 \\
5 & 08 / 02 / 88 \\
5 & 08 / 02 / 88 \\
5 & 08 / 02 / 88 \\
5 & 08 / 02 / 88\end{array}$ & $\begin{array}{l}\text { A } \\
\text { A } \\
\text { A } \\
\text { A } \\
\text { A } \\
\text { A }\end{array}$ & $\begin{array}{l}1 \\
2 \\
3 \\
4 \\
5 \\
6\end{array}$ & $\begin{array}{l}2 \\
1 \\
1 \\
0 \\
0 \\
0\end{array}$ & $\begin{array}{l}2 \\
2 \\
1 \\
1 \\
0 \\
0\end{array}$ & $\begin{array}{l}2 \\
2 \\
1 \\
1 \\
1 \\
1\end{array}$ & $\begin{array}{l}2 \\
4 \\
2 \\
3 \\
1 \\
2\end{array}$ & $\begin{array}{l}8 \\
9 \\
5 \\
5 \\
2 \\
3\end{array}$ & $\begin{array}{l}31 \\
31 \\
31 \\
31 \\
31 \\
31\end{array}$ & \\
\hline $\begin{array}{ll}5 & 08 / 02 / 88 \\
5 & 08 / 02 / 88 \\
5 & 08 / 02 / 88 \\
5 & 08 / 02 / 88 \\
5 & 08 / 02 / 88 \\
5 & 08 / 02 / 88\end{array}$ & $\begin{array}{l}\text { B } \\
\text { B } \\
\text { B } \\
\text { B } \\
\text { B } \\
\text { B }\end{array}$ & $\begin{array}{l}1 \\
2 \\
3 \\
4 \\
5 \\
6\end{array}$ & $\begin{array}{l}1 \\
1 \\
2 \\
1 \\
0 \\
0\end{array}$ & $\begin{array}{l}2 \\
1 \\
2 \\
1 \\
0 \\
1\end{array}$ & $\begin{array}{l}1 \\
1 \\
3 \\
3 \\
1 \\
1\end{array}$ & $\begin{array}{l}3 \\
3 \\
2 \\
3 \\
2 \\
1\end{array}$ & $\begin{array}{l}7 \\
6 \\
9 \\
8 \\
3 \\
3\end{array}$ & $\begin{array}{l}69 \\
69 \\
69 \\
69 \\
69 \\
69\end{array}$ & 0.5 \\
\hline $\begin{array}{ll}5 & 08 / 02 / 88 \\
5 & 08 / 02 / 88 \\
5 & 08 / 02 / 88 \\
5 & 08 / 02 / 88 \\
5 & 08 / 02 / 88 \\
5 & 08 / 02 / 88\end{array}$ & $\begin{array}{l}c \\
C \\
C \\
C \\
C \\
C\end{array}$ & $\begin{array}{l}1 \\
2 \\
3 \\
4 \\
5 \\
6\end{array}$ & $\begin{array}{l}2 \\
1 \\
1 \\
1 \\
0 \\
0\end{array}$ & $\begin{array}{l}2 \\
2 \\
2 \\
4 \\
1 \\
1\end{array}$ & $\begin{array}{l}3 \\
3 \\
4 \\
4 \\
3 \\
2\end{array}$ & $\begin{array}{l}2 \\
3 \\
3 \\
3 \\
5 \\
7\end{array}$ & $\begin{array}{r}9 \\
9 \\
10 \\
12 \\
9 \\
10\end{array}$ & $\begin{array}{l}87 \\
87 \\
87 \\
87 \\
87 \\
87\end{array}$ & $\begin{array}{l}0.1 \\
0.2\end{array}$ \\
\hline
\end{tabular}


APPENDT.X VII

\begin{tabular}{|c|c|c|c|c|c|c|c|c|c|c|c|c|}
\hline renc & ih Date & & $\overline{c t}$. & $\begin{array}{l}\text { Blows } \\
\text { Per } \\
1-f t\end{array}$ & $\begin{array}{l}\text { Blows } \\
\text { Per } \\
2-f t\end{array}$ & $\begin{array}{c}\text { Blows } \\
\text { Per } \\
3 \text {-ft }\end{array}$ & $\begin{array}{c}\text { Blows } \\
\text { Per } \\
4-f t\end{array}$ & $\begin{array}{l}\text { Blows } \\
\text { Per } \\
5-f t\end{array}$ & $\begin{array}{l}\text { Blows } \\
\text { Per } \\
6-f t\end{array}$ & $\begin{array}{l}\text { Total } \\
\text { Blows }\end{array}$ & $\begin{array}{c}\text { Blows } \\
\text { to } \\
\text { Level }\end{array}$ & $\begin{array}{l}\text { Cont } \\
(\mathrm{mR} / \mathrm{h})\end{array}$ \\
\hline $\begin{array}{l}5 \\
5 \\
5 \\
5 \\
5 \\
5\end{array}$ & $\begin{array}{l}08 / 02 / 88 \\
08 / 02 / 88 \\
08 / 02 / 88 \\
08 / 02 / 88 \\
08 / 02 / 88 \\
08 / 02 / 88\end{array}$ & $\begin{array}{l}D \\
D \\
D \\
D \\
D \\
D\end{array}$ & $\begin{array}{l}1 \\
2 \\
3 \\
4 \\
5 \\
6\end{array}$ & $\begin{array}{l}1 \\
1 \\
2 \\
1 \\
1 \\
0\end{array}$ & $\begin{array}{l}3 \\
2 \\
2 \\
3 \\
1 \\
1\end{array}$ & $\begin{array}{l}2 \\
3 \\
2 \\
3 \\
1 \\
2\end{array}$ & $\begin{array}{l}7 \\
4 \\
5 \\
2 \\
2 \\
1\end{array}$ & & & $\begin{array}{r}13 \\
10 \\
11 \\
9 \\
5 \\
4\end{array}$ & $\begin{array}{l}70 \\
70 \\
70 \\
70 \\
70 \\
70\end{array}$ & \\
\hline $\begin{array}{l}5 \\
5 \\
5 \\
5 \\
5 \\
5\end{array}$ & $\begin{array}{l}08 / 02 / 88 \\
08 / 02 / 88 \\
08 / 02 / 88 \\
08 / 02 / 88 \\
08 / 02 / 88 \\
08 / 02 / 88\end{array}$ & $\begin{array}{l}E \\
E \\
E \\
E \\
E \\
E\end{array}$ & $\begin{array}{l}1 \\
2 \\
3 \\
4 \\
5 \\
6\end{array}$ & $\begin{array}{l}2 \\
2 \\
3 \\
2 \\
0 \\
0\end{array}$ & $\begin{array}{l}2 \\
2 \\
3 \\
2 \\
1 \\
1\end{array}$ & $\begin{array}{l}4 \\
4 \\
2 \\
5 \\
2 \\
1\end{array}$ & $\begin{array}{l}2 \\
5 \\
5 \\
2 \\
3 \\
2\end{array}$ & & & $\begin{array}{r}10 \\
13 \\
13 \\
11 \\
6 \\
4\end{array}$ & $\begin{array}{l}81 \\
81 \\
81 \\
81 \\
81 \\
81\end{array}$ & \\
\hline $\begin{array}{l}5 \\
5 \\
5 \\
5 \\
5 \\
5\end{array}$ & $\begin{array}{l}08 / 02 / 88 \\
08 / 02 / 88 \\
08 / 02 / 88 \\
08 / 02 / 88 \\
08 / 03 / 88 \\
08 / 03 / 88\end{array}$ & $\begin{array}{l}\text { F } \\
\text { F } \\
\text { F } \\
\text { F } \\
\text { F } \\
\text { F }\end{array}$ & $\begin{array}{l}1 \\
2 \\
3 \\
4 \\
5 \\
6\end{array}$ & $\begin{array}{l}2 \\
1 \\
2 \\
2 \\
0 \\
0\end{array}$ & $\begin{array}{l}3 \\
2 \\
3 \\
3 \\
1 \\
0\end{array}$ & $\begin{array}{l}4 \\
1 \\
4 \\
4 \\
1 \\
1\end{array}$ & $\begin{array}{l}4 \\
2 \\
2 \\
4 \\
1 \\
1\end{array}$ & & & $\begin{array}{r}13 \\
6 \\
11 \\
13 \\
3 \\
2\end{array}$ & $\begin{array}{l}58 \\
58 \\
58 \\
58 \\
58 \\
58\end{array}$ & \\
\hline $\begin{array}{l}5 \\
5 \\
5 \\
5 \\
5\end{array}$ & $\begin{array}{l}08 / 03 / 88 \\
08 / 03 / 88 \\
08 / 03 / 88 \\
08 / 03 / 88 \\
08 / 03 / 88\end{array}$ & $\begin{array}{l}G \\
G \\
G \\
G \\
G\end{array}$ & $\begin{array}{l}1 \\
2 \\
3 \\
4 \\
5\end{array}$ & $\begin{array}{l}1 \\
2 \\
1 \\
2 \\
0\end{array}$ & $\begin{array}{l}4 \\
2 \\
1 \\
1 \\
1\end{array}$ & $\begin{array}{l}3 \\
3 \\
1 \\
2 \\
2\end{array}$ & $\begin{array}{l}3 \\
4 \\
2 \\
2 \\
4\end{array}$ & & & $\begin{array}{r}11 \\
11 \\
5 \\
7 \\
7\end{array}$ & $\begin{array}{l}65 \\
65 \\
65 \\
65 \\
65\end{array}$ & \\
\hline $\begin{array}{l}6 \\
6 \\
6 \\
6 \\
6 \\
6\end{array}$ & $\begin{array}{l}08 / 03 / 88 \\
08 / 03 / 88 \\
08 / 03 / 88 \\
08 / 03 / 88 \\
08 / 03 / 88 \\
08 / 03 / 88\end{array}$ & $\begin{array}{l}\text { A } \\
\text { A } \\
\text { A } \\
\text { A } \\
\text { A } \\
\text { A }\end{array}$ & $\begin{array}{l}1 \\
2 \\
3 \\
4 \\
5 \\
6\end{array}$ & $\begin{array}{l}2 \\
1 \\
1 \\
1 \\
0 \\
0\end{array}$ & $\begin{array}{l}4 \\
2 \\
2 \\
2 \\
1 \\
0\end{array}$ & $\begin{array}{l}3 \\
3 \\
2 \\
1 \\
2 \\
1\end{array}$ & $\begin{array}{l}5 \\
3 \\
9 \\
3 \\
3 \\
1\end{array}$ & & & $\begin{array}{r}14 \\
9 \\
14 \\
7 \\
6 \\
2\end{array}$ & $\begin{array}{l}44 \\
44 \\
44 \\
44 \\
44 \\
44\end{array}$ & \\
\hline $\begin{array}{ll}6 & 0 \\
6 & 0 \\
6 & 0 \\
6 & 0 \\
6 & 0 \\
6 & 0\end{array}$ & $\begin{array}{l}08 / 03 / 88 \\
08 / 03 / 88 \\
08 / 03 / 88 \\
08 / 03 / 88 \\
08 / 03 / 88 \\
08 / 03 / 88\end{array}$ & $\begin{array}{l}\text { B } \\
\text { B } \\
\text { B } \\
\text { B } \\
\text { B } \\
\text { B }\end{array}$ & $\begin{array}{l}1 \\
2 \\
3 \\
4 \\
5 \\
6\end{array}$ & $\begin{array}{l}1 \\
1 \\
1 \\
2 \\
0 \\
0\end{array}$ & $\begin{array}{l}2 \\
2 \\
2 \\
2 \\
0 \\
0\end{array}$ & $\begin{array}{l}2 \\
4 \\
4 \\
1 \\
1 \\
1\end{array}$ & $\begin{array}{l}4 \\
2 \\
2 \\
3 \\
3 \\
1\end{array}$ & & & $\begin{array}{l}9 \\
9 \\
9 \\
8 \\
4 \\
2\end{array}$ & $\begin{array}{l}90 \\
90 \\
90 \\
90 \\
90 \\
90\end{array}$ & 0.3 \\
\hline
\end{tabular}


APPENDIX VII

\begin{tabular}{|c|c|c|c|c|c|c|c|c|c|c|c|}
\hline Trench Date & $\mathrm{Sec}$ & & $\begin{array}{c}\text { Blows } \\
\text { Per } \\
1 \text {-ft }\end{array}$ & $\begin{array}{l}\text { Blows } \\
\text { Per } \\
2-f t\end{array}$ & $\begin{array}{l}\text { Blows } \\
\text { Per } \\
3-\mathrm{ft}\end{array}$ & $\begin{array}{l}\text { Blows } \\
\text { Per } \\
4 . \mathrm{ft}\end{array}$ & $\begin{array}{c}\text { Blows } \\
\text { Per } \\
5-f t\end{array}$ & $\begin{array}{l}\text { Blows } \\
\text { Per } \\
6-f t\end{array}$ & $\begin{array}{l}\text { Total } \\
\text { Blows }\end{array}$ & $\begin{array}{c}\text { Blows } \\
\text { to } \\
\text { Level }\end{array}$ & $\begin{array}{l}\text { Cont } \\
(\mathrm{mR} / \mathrm{h})\end{array}$ \\
\hline $\begin{array}{ll}6 & 08 / 03 / 88 \\
6 & 08 / 03 / 88 \\
6 & 08 / 03 / 88 \\
6 & 08 / 03 / 88 \\
6 & 08 / 03 / 88 \\
6 & 08 / 03 / 88\end{array}$ & $\begin{array}{l}\mathrm{C} \\
\mathrm{C} \\
\mathrm{C} \\
\mathrm{C} \\
\mathrm{C} \\
\mathrm{C}\end{array}$ & $\begin{array}{l}1 \\
2 \\
3 \\
4 \\
5 \\
6\end{array}$ & $\begin{array}{l}2 \\
1 \\
2 \\
1 \\
0 \\
0\end{array}$ & $\begin{array}{l}2 \\
2 \\
4 \\
2 \\
1 \\
0\end{array}$ & $\begin{array}{l}3 \\
3 \\
3 \\
2 \\
1 \\
1\end{array}$ & $\begin{array}{l}4 \\
2 \\
6 \\
4 \\
2 \\
2\end{array}$ & & & $\begin{array}{r}11 \\
8 \\
15 \\
9 \\
4 \\
3\end{array}$ & $\begin{array}{l}83 \\
83 \\
83 \\
83 \\
83 \\
83\end{array}$ & $\begin{array}{l}0.2 \\
1 \\
0.2 \\
0.3 \\
0.5 \\
0.5\end{array}$ \\
\hline $\begin{array}{ll}6 & 08 / 03 / 88 \\
6 & 08 / 03 / 88 \\
6 & 08 / 03 / 88 \\
6 & 08 / 03 / 88 \\
6 & 08 / 03 / 88 \\
6 & 08 / 03 / 88\end{array}$ & $\begin{array}{l}D \\
D \\
D \\
D \\
D \\
D\end{array}$ & $\begin{array}{l}1 \\
2 \\
3 \\
4 \\
5 \\
6\end{array}$ & $\begin{array}{l}1 \\
3 \\
2 \\
1 \\
0 \\
1\end{array}$ & $\begin{array}{l}5 \\
2 \\
2 \\
2 \\
1\end{array}$ & $\begin{array}{l}5 \\
3 \\
3 \\
2 \\
2 \\
1\end{array}$ & $\begin{array}{r}11 \\
4 \\
5 \\
4 \\
3 \\
5\end{array}$ & & & $\begin{array}{r}22 \\
12 \\
12 \\
9 \\
6 \\
7\end{array}$ & $\begin{array}{l}44 \\
44 \\
44 \\
44 \\
44 \\
44\end{array}$ & $\begin{array}{r}2 \\
5 \\
0.5\end{array}$ \\
\hline $\begin{array}{ll}6 & 08 / 03 / 88 \\
6 & 08 / 03 / 88 \\
6 & 08 / 03 / 88 \\
6 & 08 / 03 / 88\end{array}$ & $\begin{array}{l}\mathrm{E} \\
\mathrm{E} \\
\mathrm{E} \\
\mathrm{E}\end{array}$ & $\begin{array}{l}1 \\
2 \\
3 \\
4\end{array}$ & $\begin{array}{l}1 \\
1 \\
1 \\
1\end{array}$ & $\begin{array}{l}2 \\
2 \\
2 \\
2\end{array}$ & $\begin{array}{l}2 \\
1 \\
3 \\
2\end{array}$ & $\begin{array}{l}6 \\
2 \\
3 \\
4\end{array}$ & & & $\begin{array}{r}11 \\
6 \\
9 \\
9\end{array}$ & $\begin{array}{l}34 \\
34 \\
34 \\
34\end{array}$ & \\
\hline $\begin{array}{ll}6 & 08 / 04 / 88 \\
6 & 08 / 04 / 88 \\
6 & 08 / 04 / 88 \\
6 & 08 / 04 / 88 \\
6 & 08 / 04 / 88 \\
6 & 08 / 04 / 88\end{array}$ & $\begin{array}{l}F \\
F \\
F \\
F \\
F \\
F\end{array}$ & $\begin{array}{l}1 \\
2 \\
3 \\
4 \\
5 \\
6\end{array}$ & $\begin{array}{l}2 \\
2 \\
2 \\
1 \\
0 \\
0\end{array}$ & $\begin{array}{l}2 \\
3 \\
4 \\
2 \\
1 \\
1\end{array}$ & $\begin{array}{l}3 \\
3 \\
3 \\
3 \\
1 \\
1\end{array}$ & $\begin{array}{l}4 \\
4 \\
4 \\
3 \\
2 \\
1\end{array}$ & & & $\begin{array}{r}11 \\
12 \\
13 \\
9 \\
4 \\
3\end{array}$ & $\begin{array}{l}39 \\
39 \\
39 \\
39 \\
39 \\
39\end{array}$ & \\
\hline $\begin{array}{ll}6 & 08 / 04 / 88 \\
6 & 08 / 04 / 88 \\
6 & 08 / 04 / 88 \\
6 & 08 / 04 / 88 \\
6 & 08 / 04 / 88 \\
6 & 08 / 04 / 88\end{array}$ & $\begin{array}{l}\text { G } \\
\text { G } \\
G \\
G \\
G \\
G\end{array}$ & $\begin{array}{l}1 \\
2 \\
3 \\
4 \\
5 \\
6\end{array}$ & $\begin{array}{l}2 \\
2 \\
4 \\
2 \\
0 \\
0\end{array}$ & $\begin{array}{l}4 \\
3 \\
4 \\
3 \\
1 \\
1\end{array}$ & $\begin{array}{l}4 \\
4 \\
8 \\
3 \\
3 \\
1\end{array}$ & $\begin{array}{l}5 \\
6 \\
7 \\
5 \\
5 \\
3\end{array}$ & & & $\begin{array}{r}15 \\
15 \\
23 \\
13 \\
9 \\
5\end{array}$ & $\begin{array}{l}51 \\
51 \\
51 \\
51 \\
51 \\
51\end{array}$ & \\
\hline $\begin{array}{ll}\text { C } & 08 / 04 / 88 \\
\text { C } & 08 / 04 / 88 \\
\text { C } & 08 / 04 / 88 \\
\text { C } & 08 / 04 / 88 \\
\text { C } & 08 / 04 / 88 \\
\text { C } & 08 / 04 / 88\end{array}$ & $\begin{array}{l}\text { A } \\
\text { A } \\
\text { A } \\
\text { A } \\
\text { A } \\
\text { A }\end{array}$ & $\begin{array}{l}1 \\
2 \\
3 \\
4 \\
5 \\
6\end{array}$ & $\begin{array}{l}5 \\
6 \\
3 \\
4 \\
0 \\
1\end{array}$ & $\begin{array}{r}7 \\
10 \\
4 \\
7 \\
2 \\
3\end{array}$ & $\begin{array}{r}13 \\
9 \\
5 \\
7 \\
2 \\
8\end{array}$ & $\begin{array}{r}5 \\
7 \\
4 \\
11\end{array}$ & & & $\begin{array}{r}25 \\
25 \\
17 \\
25 \\
8 \\
23\end{array}$ & $\begin{array}{l}35 \\
35 \\
35 \\
35 \\
35 \\
35\end{array}$ & \\
\hline
\end{tabular}


VIII-I

APPENDIX VIII

Task Plan for

Site Stabilization and Closure Technology Demonstration 
Task Plan Proposal for

Site Stabilization and Closure Technology Demonstration

\author{
Brian P. Spalding \\ Ed C. Davis \\ Gour-Tsyh Yeh
}

October 31,1986

\title{
SUMMARY
}

The basic objective of this task is to carry out a demonstration and evaluation of the stabilization and closure of a waste disposal. site at ORNL. A provisional plan for the stabilization and closure of a one acre section of Solid Waste Storage Area (SWSA) 6 is presented. The selected area contains 19 burial trenches of higher activity $(>200 \mathrm{mR} / \mathrm{hr}$ at package surface) low-level waste and has the advantage, for this demonstration, of being situated in a hydrologically isolable unit on the eastern side of SwSA 6. The provisional stabilization plan will be finalized during the initial twelve months of this task through negotiation and information exchange with U, S. Environmental Protection Agency, Tennessee Department of Health and Environment, the 
Site Stabilization and Closure Demonstration

DOE Low-Level Waste Management Program personnel as well as representatives of Martin Marietta Energy systems Central

Engineering and the ORNL Department of Environmental

Management. The provisional plan contains components

including trench dynamic compaction, trench grouting,

percolation barrfers of reinforced chlorosulfonated

polyethylene and bentonite, a biointrusion barrier of gravel

and cobble, and a graded and vegetationally-stabilized soll

cap. Materials and installation costs for this provisional

design are estimated to be $\$ 336,000$ to be spent in FY 1988 .

Each component, as well as the system as a whole,

will be tested and evaluated during and after completion to

verify and, where possible, quantify the degree of

hydrologic isolation actually achieved and its long-term

stability. By establishing the effectiveness of each

component and the integrated system, future planning for

corrective actions and stabilization of many ORNL

contaminated sites can proceed with the empirical assurance

that the various techniques will achieve a performance

adequate for site closure and pasive long-term stability.

Evaluation of each system component will consist of a

combination of geotechnical tests and environmental

monftoring. Stability of each of the nineteen trenches will be tested with standard penetrometers before and after their dynamic consolidation. Grouted trenches will be tested for hydrologic isolation by watex acceptance tests carried out 
at selected wells before and after grouting. The long-term performance of the percolation barrier will be ascertained by placing groundwater tracers in each trench to monitor any downard movement to the water table. Shorter-term evaluation will be based on a site water budget calculated from measurements of runoff, precipitation, and molsture storage in the soil cap. Additional tracers (stable cesium and strontium salts) will be placed directly below the percolation barrier so that any translocation to the forest cover will indicate areas of failure. Water and sediment yields from the soil cap will be monitored to establish erosion rates for estimates of long-term stability. Comparison of these geotechnical parameters with those from a geomorphically stable 'control' area will be included in the task. Additional tests are described within this task plan and will be performed at varying frequencies within a four year period of intensive monitoring following completion of the construction phase.

\section{OBJECTIVES}

The major objective of this task is to performa demonstration and evaluation of a stabilization and closure of a portion of a waste disposal area at ORNL. The final stabilization design will incorporate input and comments on a provisional plan by regulatory authorities (USEPA, TDHE, DOE, and NRC) and other MMES suborganizations with a direct 
interest in waste site stabilization planning. An ancillary objective is to establish regulatory involvement in the desisn and planning phases in order to develop a mutual understanding of, and an identification with, the goals and objectives of site stabilization and closure. The field verification of the effectiveness of the proposed stabilization techniques, as well as that of their integrated system, will be the major product of this task. The detailed chronology of the problems encountered and their attempted solutions in the implementation of these techniques should prove quite valuable in the design and planning of future stabilizations and closures of the many ORNL contaminated sites. Obviously, the experience of these techniques on an actual field scale will lead to a great improvement in the estimation of costs for future activities. The continued involvement of and information exchange with regulatory authorities could establish many operational precedents and procedures for future site remediation activities at ORNL. The communal experience gained could translate directy into an organizational confidence in the design and effectiveness of future stabilization projects at all ORNL contaminated sites.

\section{BACKGROUND}

The ORNL Site Corractive Measures Program is addressing the 
problems of corrective actions for many contaminated sites. Although the program is presently in a phase of inventory, characterization, and ranking of these sites, the longer range plan calls for the actual planning and implementation of corrective actions to begin in FY 1989 for some of the higher priority sites. Exactly what will be done, when this implementation stage is arrived at, is presently defined as a consideration and comparison of alternatives. There are several technology development tasks underway considering such techniques as drainage modification, grouting, and in situ vitrification. But practical, operational experience with an integrated system employing these techniques, which will presumably be necessary for any site stabilization and closure, is notably lacking. If more is to be accomplished in FY 1989 than extensive analysis and design activities, then experience in the implementation of these techniques wili need to be acquired.

There is considerable experience at ORNL in addressing short-term corrective actions. These activities include subsurface drainage modification in SWSA 6 (Davis and Stansfield 1984), surface runoff diversion in SWSA 4 (Melroy and Huff 1985), in situ grouting of burial trenches (Spalding et. al. 1985), dynamic compaction of burial trenches (Spalding 1986), bentonite surface seal evaluation (Arora et al. 1981), and trench lining with chlorosulfonated polyethylene fabric (Davis and Spalding 
1986). Additional corrective action projects, employing in situ grout curtains and asphaltic caps as infiltration barriers at liquid LLW Trench 7 , are presently underway. None of these actions, however, has attempted to address long-term stabilization and closure. The implicit objective of site stabilization and closure is a design which yields reasonable assurance of hydrological and biological isolation of interred waste and which requires minimum or, preferably, no maintenance. Thus, system passivity is an implicit performance objective for site stabilization and closure.

3. DESCRIPTION OF WORK

The first phase of this task is to present the provisional design for stabilization and closure to the group of regulatory authorities and advisors which is presently reviewing the entire ERFU program plan in early FY 1987. The area presently considered for this stabilization and closure demonstration is an approximately one acre hillock on the northeastern side of SWSA 6 . The area contains 19 low-level waste burial trenches (Figure 1) and, because of its topography, represents a hydrologically isolable and monitorable unit. The provisional stabilization and closure plan was prepared in such detail primarily for an initial estimate of construction costs (Table 1) although the final plan will probably contain many 
ORNL-OWG 79- 20420AR5

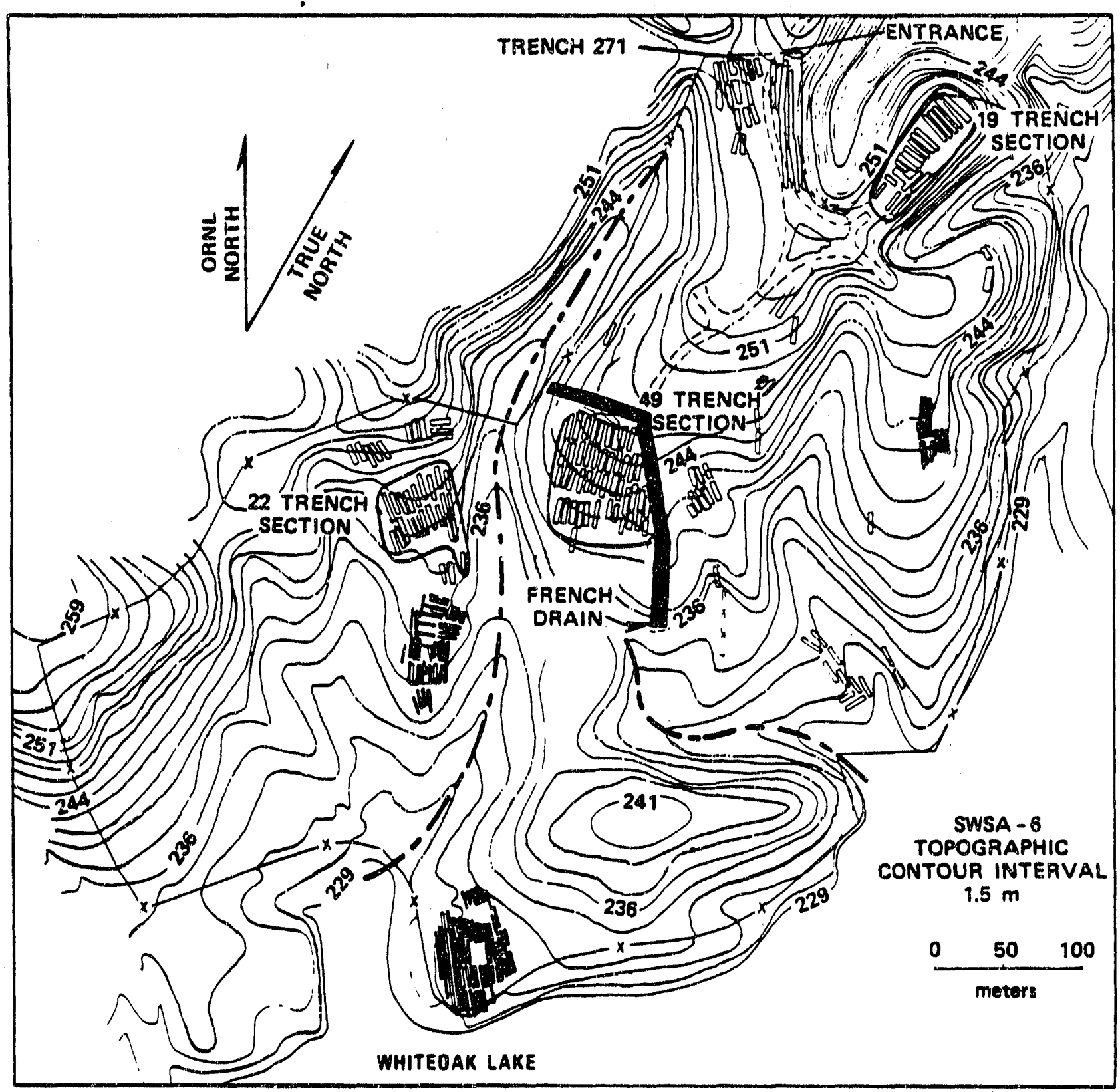

Figure 1. Map of Solid Waste Storage Area 6, ORNL, showing the location and topographic setting of the 19. trench section for tir site stabilization and closure demonstration. 
Table 1. Summary of Construction Costs for stabilization and Closure of 19 Trench Area, SWSA 6 .

\section{Component or operation

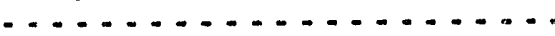 \\ 1. Dynamic Compaction (1abor $P+E$ ) \\ 2. Grouting Trenches
a. Sodium silicate
(materials)
b. Labor $(P+E)$

3. Backfill/Grading Compaction (labor)

4. Percolation Barrier
a. Hypalon (materials)
b. Bentonite mat
(materials)
c. Installation labor
(subcontract)

5. Biointrusion Barrier (gravel and spreading)

6. Geotextile Filter Fabric

7. Soil Cap/Cover

(labor, free soil)

Total

\section{Toral Units \\ ...........}

$20,000 \mathrm{ft} \mathrm{t}^{2}$

Unit Cost

$\$ 1.86 / f t^{2}$

$\begin{array}{ll}40,000 \mathrm{ft} \mathrm{t}^{3} & \$ 2.91 / \mathrm{ft} \mathrm{t}^{3} \\ 40,000 \mathrm{ft} & \$ 2.00 / \mathrm{ft}^{3}\end{array}$

$2,300 \mathrm{yd}^{3}$

$2,300 \mathrm{yd}^{3}$

$\$ 2.50 / \mathrm{yd}^{3}$

$\$ 2.17 / \mathrm{yd}^{3}$

$40,000 \mathrm{ft}^{2}$

$\$ 0.25 / f t^{2}$

$40,000 \mathrm{ft}^{2}$

$\$ 0.13 / f t^{2}$

$$
5,000 \mathrm{yd}^{3}
$$

$\$ 6.00 / \mathrm{yd}^{3}$

30,000

$40,000 f t^{2}$

$\$ 0.10 / f t^{2}$

4,000

$5,000 \mathrm{yd}^{3}$

$\$ 2.50 / \mathrm{yd}^{2}$

12.500

$$
\begin{aligned}
& 40,000 E t^{2} \quad \$ 8.40 / E t^{2} \\
& \text { (site area) } \\
& 200,200 f t^{3} \\
& \text { (trench volume) }
\end{aligned}
$$

10,000

5,200

30,000

Total Cost

37,200

116,400

80,000

5,750

5, 000

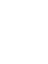


modifications. A subcontract with a project engineering firm, with experience with hazardous waste site remedial actions, will be established in FY 1987 to support ORNL in producing the final design. The provisional design encompases the deep dynamic compaction of all the trenches, in situ grouting of the resulting compacted trench volumes, and filling the compaction craters and grading to the original land surface. A percolation and biological intrusion barrier will then be coristructed as a unit over the entire area of these stabilized trenches (Figure 2). This subsurface percolation barrier is designed to prevent movement of water down the soll profile and contact with buried waste or contamination within the surrounding soil formation. This percolation barrier is protected from burrowing animals and plant roots by a layer of coarse eravel and cobble (nominally $1 \mathrm{~m}$ thick). The size of the cobble will preclude its transport or movement by burrowing animals. Above this biobarrier, will be a soil cap or cover which will be planted to grass for immediate erosion control but, ultimately, to trees for a maintenance-free vegetation cover. Its actual thickness and slope will be designed to manage site precipitation between runoff and infiltration. The objective will be to provide adequate soll moisture storage to support the needs of the incipient forest while facilitating site runoff without significant erosion. Rather than wait many years for natural succession to establish the forest, trees of 
$\frac{1}{0}$
$\frac{1}{0}$
0
0
3
0
1
$\frac{1}{2}$
$\frac{1}{0}$

VIII-II

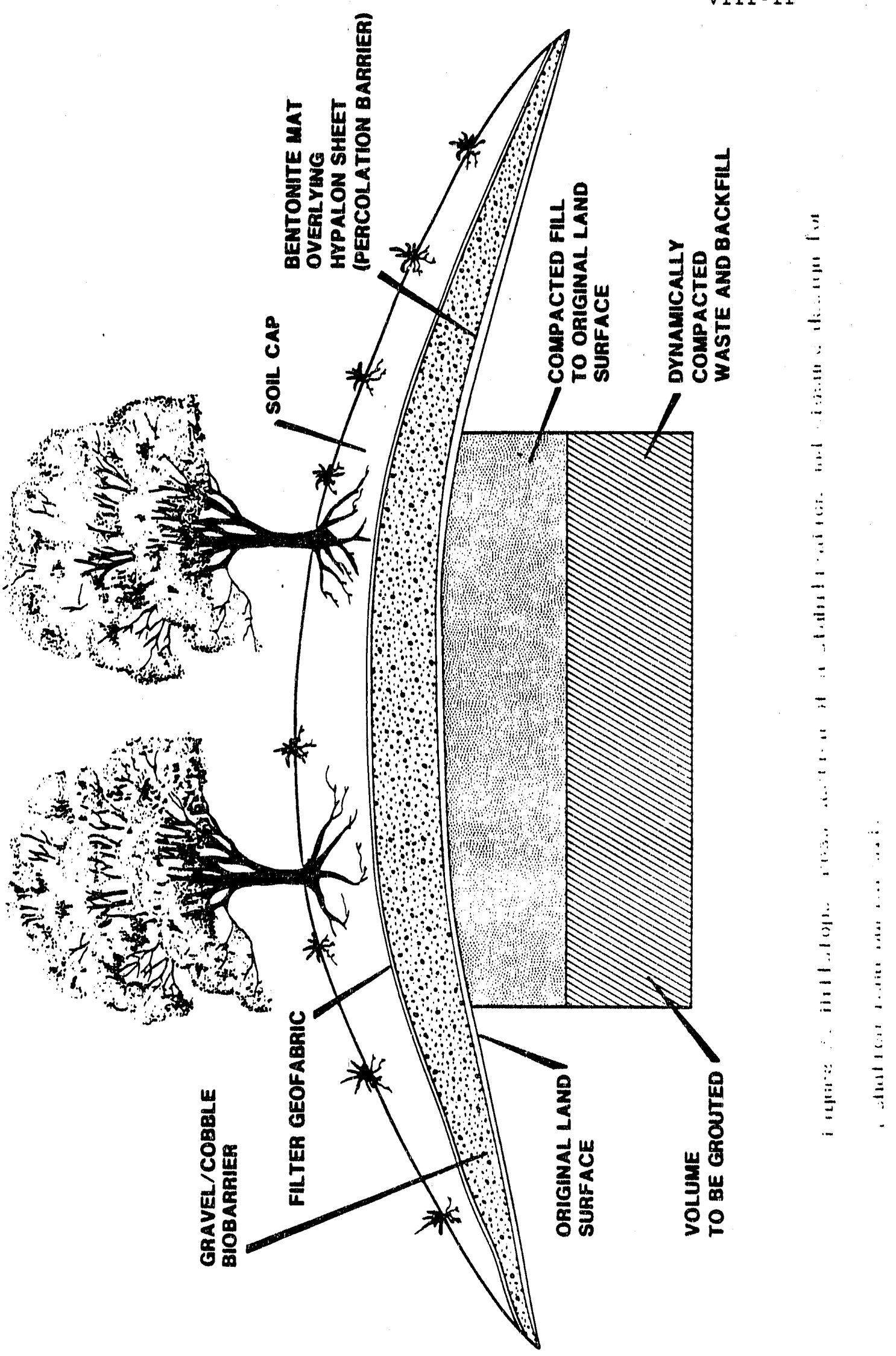


about ten-year-old size will be transplanted on the site and species composition will be maintained similar to that of the climax successional stage for the region.

Each component of the system will be tested extensively both during its construction and subsequently in a nondestructive manner by various site monitoring activities. These testing and evaluation methods are sumarized in Table 2. Most of the geotechnical tests will be replicated at least four times on each trench. Considerable driling, augering, and temporary well instaling is envisioned in most of these activities. To avold the compromising protrusion of many well casings from the ground surface and through the various barriers, angle well placement will be used for monitoring and sampling the water table beneath the site. Horizontal neutron probe access tubes will be employed beneath the percolation barrier to detect any moisture varlation indicative of barrier fallure. Access to these tubes could be gained from either the hillslopes around the site or from a centrally situated deep manhole. Additional moisture monitoring will be achieved by placing neutron probe access tubes into the soil cap but these will not penetrate the percolation barrier. Surface runoff monitoring stations will be constructed around the site to monitor both water and sediment flux from the site in response to individual precipitation events and as an annual flux. Groundwater at the site will be systematically 
Table 2. Summary of Testing and Evaluation of Provisional site Stabilization and closure Installation

Component or Process

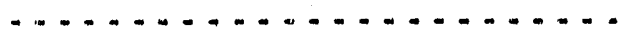

1. Dynamic compaction of waste and backfill

2. Grouting of compacted waste and backfill

3. Dynamic compaction of new soil fill

4. Chlorosulfonated polyethylene liner

5. Bentonite mat.

6. Gravel and Cobble

7. Soli cover

8. Vegetation (trees)

9. Whole system
Testing and Evaluation Methods

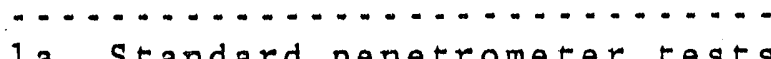

1b. Bulk density measurements

1c. Ground surface depression surveys

2a. Hydraulic conductivity, before and after

$2 b$. Volumetric vold filling calculation

3a. Bulk density measurements

3b. Standard compaction tests to high limit

4a. Moisture monitoring via buried neutron probe access tube (horizontal)

4b. Biointrusion via translocation of stable cesium and strontium tracers

4c. Shear strength and puncture testing

5a. In situ permeability tests

$5 b$. Biointrusion tests as in $4 \mathrm{~b}$.

6a. Size distribution testing

6b. Depth profile survey

7a. Runoff and sediment yields for erosion measurements

7b. Stored molsture measurement via neutron probe (vertical)

7c. Evapotranspiration via moisture balance

7d. Depth profile survey

8a. Survival + molsture stress of tree species

$8 \mathrm{~b}$. Above ground biomas and growth measurements

9a. Groundwater recharge via water table monitoring, before and after

9b. Migration of trench tracers ( $\mathrm{Na}$ and Li) placed in penetrometer holes

$9 c$. Water budget analysis and hydrologic performance model 
Site Stabilization and Closure Demonstration

VIII -14

monltored by analyses for the tracers placed in the trenches and for the tracers placed directly beneath the cap. Growth of trees will be measured and samples of the tree leaves will be taken on an annual basis from various arelas and analyzed for the stable ceslum and strontlum tracers. These elements are not toxic to the trees and have extremely low amblent background levels in vegetation. Burrowing animal activity will be monitored at the site and nondestructive probing and surveying of the burrows will be atteinted to ascertain the effectiveness of the blobarrier.

Hydrologic modeling will play an integrating role in both the design of the final stabilization and closure plan and in performance assessment of the system as deterinined from the field monitoring. The consequences of various failure scenarios wil be simulated with these hydrologic models. Water budgeting of the site will be compared with long-term predictions of forest molsture needs and growth. Soli erosion will be simulated with some models which will be verified by the empirical site erosion measurements.

The working relationship with the advisory group, which hopefully will be developed during the planning stages for the final stabilization and closure design, will be maintained throughout the construction and postconstruction monitoring phases of the project. Continued improvements in the evaluation phase will undoubtedly be needed and the 
Site Stabilization and Closure Demonstration

continued briefing of this group regarding problems and

Interpretations should prove useful to all partias.

Periodic formal and informal reporting of results will be maintalned. The major report on the design, construction, and installation evaluation will be produced at the end of the flrst quarter of FY 1989.

A breakdown of the various subtask activity costs by fiscal year is presented in Table 3 . A schedule for the project is presentod in Figure 3. 
Table 3 .

Subtask Activity Costs by Fiscal Year

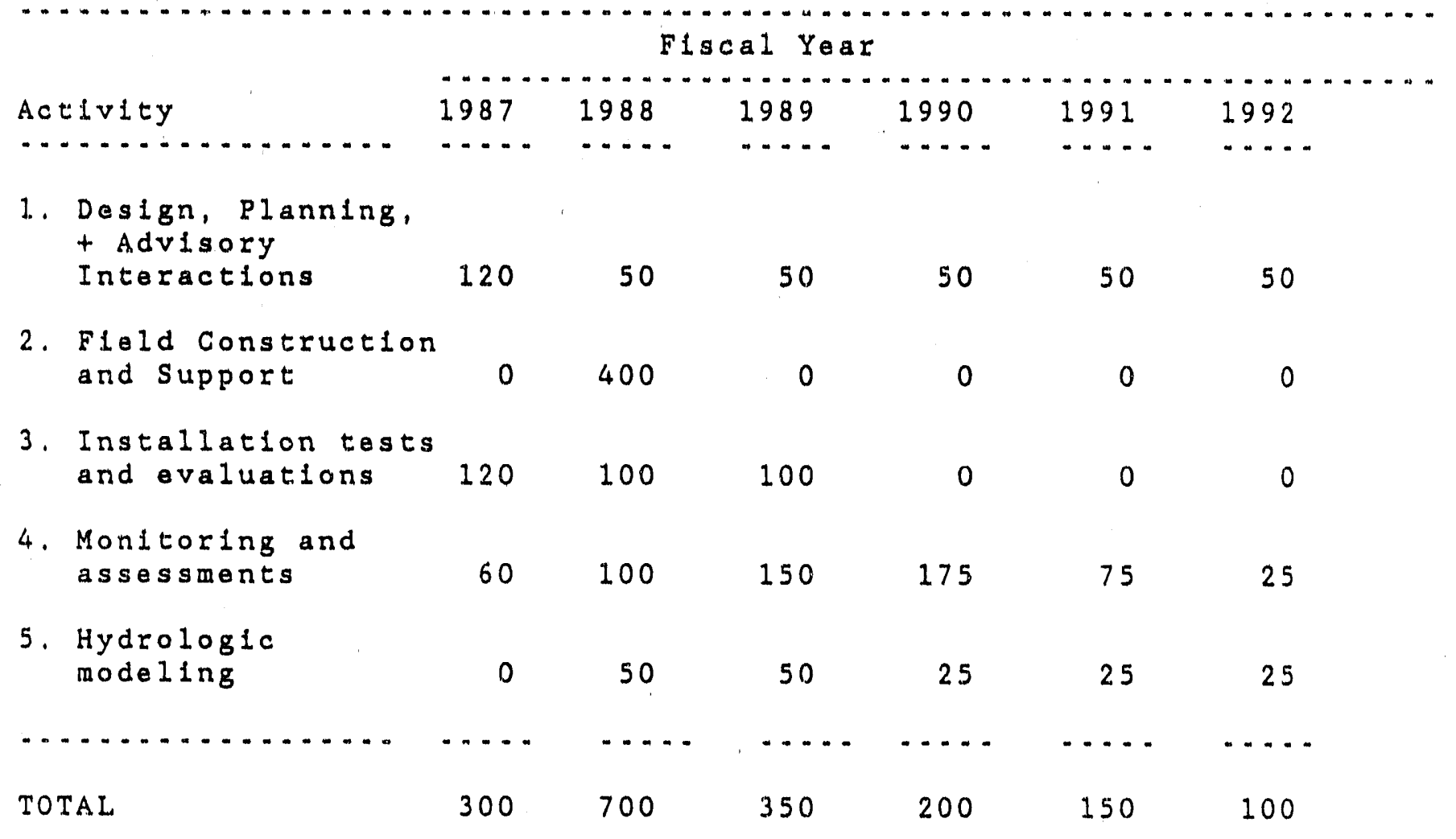


VIII -1.7

,

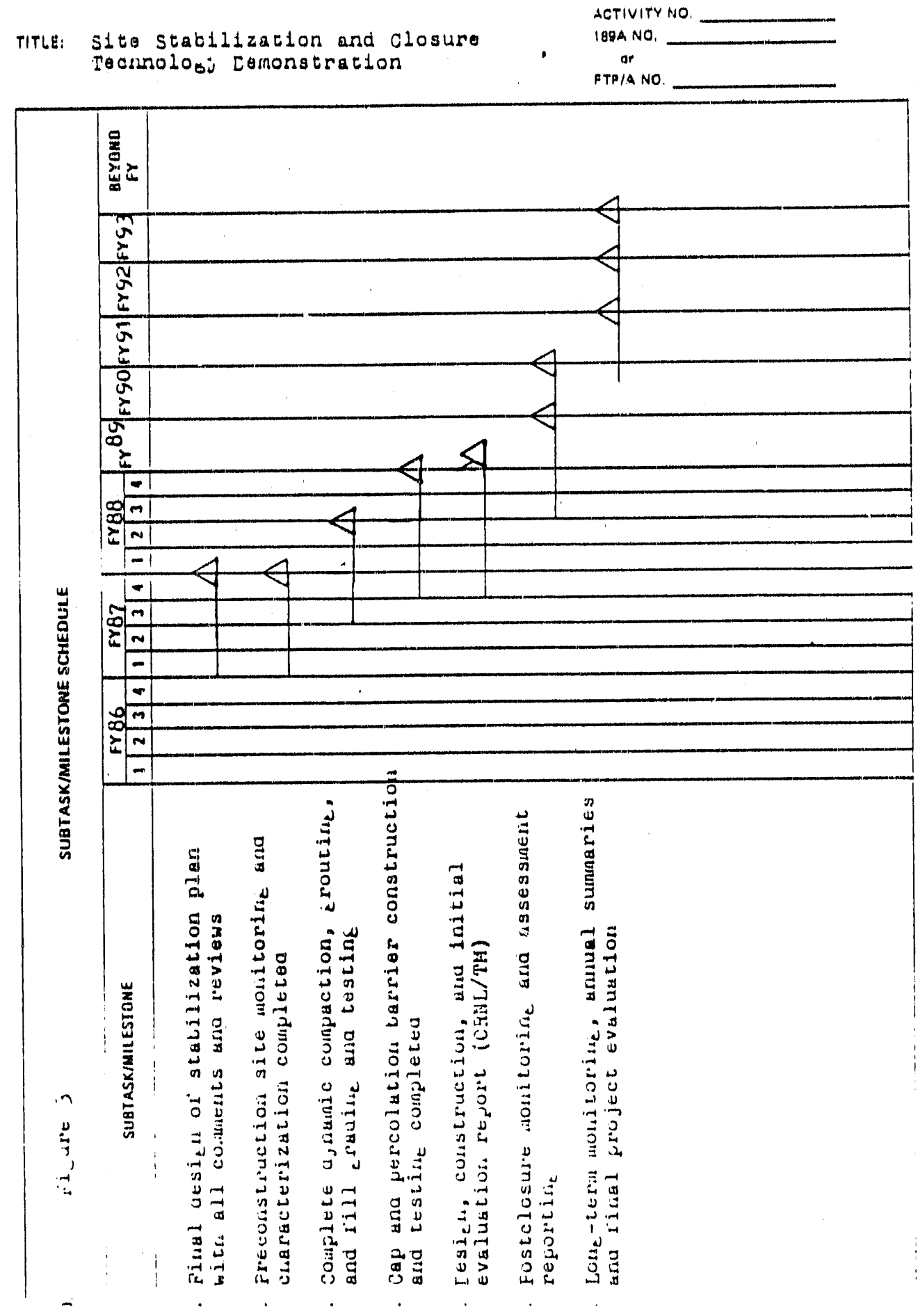




\section{REFERENCES}

Arora, H. S., D. D. Huff, D. S. Ward, and O. M. Sealand. 1.981. An assessment of the effect of a bentonite seal on groundwater storage in underlying waste disposal trenches at Oak Ridge National Laboratory. ORNL/TM-7416.

Davis, E. C. and B. P. Spalding. 1986. Field evaluation of a cement-bentonite grout and a chlorosulfonated polyethylene fabric liner in hydrologically isolating low-level radioactive solid waste. ORNL/TM-9742.

Davis, E. C. and R, G. Stansfield, 1984, Design and construction of a French drain for groundwater diversion in Solid Waste Storage Area 6 at the Oak Ridge National Laboratory, ORNL/TM-9014.

Melroy, L. A. and D. D. Huff, 1985. Evaluation of a flow diversion system for reducing 90 Sr migration from SWSA 4 to White Oak Creek. ORNL/TM-9374.

Spalding, B. P., L. K. Hyder, and I. L. Munro. 1985. Grouting as a remedial technique for buried low-level radioactive wastes. J. Environ. Qual. 14:389.396.

Spalding, B. P. 1986. Burlal trench dynamic compaction demonstration at a humid site. In, Seventh Annual DOE LLWMP Participants' Information Meting. CONF-8509121. EG\&G Idaho, Inc. Idaho Falls, Idaho, pp. 676-698. 


\section{APPENDIX IX}

\section{Final Plan}

for

The Demonstration and Evaluation of

Stabilization and Closure Techniques for

Low-Level Waste Burial Trenches at

Oak Ridge National Laboratory 
FINAL PIAN

FOR

THE DEMDNSTRATION AND EVALUATION

OF

STABIIIZATION AND CLOSTIRE TECHNIQUES

FOR

LOW-LEVEL WASTE BURTAL TRENCHES

AT

OAK RIDGE NATIONAL IABORATORY

\begin{abstract}
Access to the information in this report is limited to those indicated on the distribution list, to the U.S. Department of Energy and its contractors, to other Government Agencies and their contractors, and to Tennessee Government Agencies.
\end{abstract}

PREPARED BY:

AUTOMATED SCIENCES GROUP, INC.

800 OAK RIDGE TURNPIKE, STIIIE C-102

OAK RIDGE, TN 37830

SEPPIEMIBER 24, 1987

\title{
CAUTION
}

This document has not been given final patent clearance and is for internal use only. If this document is to be given public release, it must be cleared through the site Technical Information Office which will see that the proper patent and technical information reviews are completed in accordance with Energy Systems Policy. 
PAGE

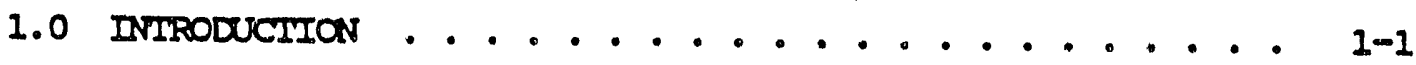

1.1 BAckGROAND .................. . . 1-1

1.2 OBTECTIVES ................... 1-2

2.0 DESIG DESCRTPIION ................ 2-1

2.1 DUNAMIL COMPACTION ............. 2-1

2.2 EARTHWORK .................. 2-. 2-4

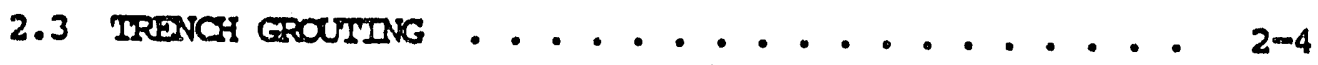

2.4 NEUTRON EROBE ACCDSS TUBES ........... 2- . 2-5

2.5 PERCOLATION BARRTER . . . . . . . . . . 2-5

2.5 .1 Iiner . . . . . . . . . . . 2-6

2.5 .2 Environat . . . . . . . . . . 2-6

2.5.3 Bentonite Mat ........... 2- 2-6

2.6 GDO-TEXIIIE FABRIC . . . . . . . . . . 2-6

2.7 BIO-BARRIER ................ 2-6

2.7.1 Drainage system . . . . . . . . 2-7

2.8 SOIL CAP ................. 2-. 2-7

2.9 SEEDTHG ................. 2- . . . . . .

2.10 TREES ................. . . 2-7

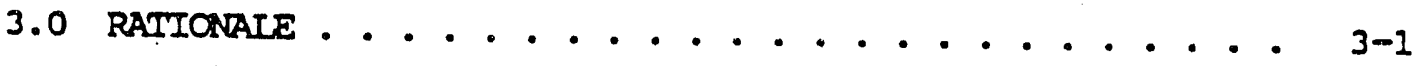

4.0 TRACERS ..................... . . 4-1

5.0 TESTING/MONTIORHNG ................ 5-1

6.0 SCHEDULE ...................... 6-1

7.0 COST ESTIMATE ................. . . . . . . 
8.0 POTENTIAL SUBCONIRACTORS ............ 8-1

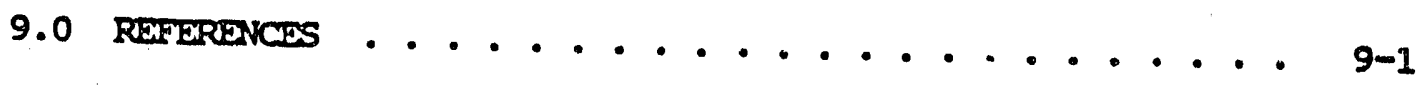

10.0 APPENDICES ........................ 10-1

\section{IIST OF FIGURES}

Figure 1 Map of SWSA-6 .............. 2- . . 2-2

Figure 2 Stabilization \& Closure Demonstration components . . $2-3$ 


\subsection{BACKGROUND}

The ORNL Site Corrective Measures Program is arrently addressing problems of corrective actions for many contaminated sites. Although the program is presently in a phase of inventory, characterization, and ranking of these sites, the longer range plan calls for the actual planning and implementation of corrective actions to begin in FY-1989 for same of the higher priority sites. There are several technology demonstration tasks underway considering such techniques as drainage modification, dynamic compacting, grouting, and in situ vitrification. Practical, operational experience with an integrated system employing these techniques, which will presumably be necessary for site stabilization and closure, is notably lacking. If more is to be accomplished in FY-1989 than extensive analysis and design activities, experience in the implementation and evaluation of these techniques needs to be acquired. This demonstration and evaluation of stabilization and closure techniques also constitutes the initial closure activities in solid waste storage Area 6 (SWSA-6) as presented in its closure plan (ORNL, 1986). The evaluation of these tectuniques should aid in planning the closure of additional areas in SWSA-6.

The area chosen for this stabilization and closure demonstration is an approximately one acre hillock on the northeastem side of solid Waste Storage Area (SWSA) No. 6 and contains 19 trenches. The rationale for choosing this site is as follows:

1. The area is hydrologically isolated from other burial sites in 5WSA-6.

2. the area is easy to monitor through a suite of perimeter monitoring wells.

3. Since the most significant vector for water contacting buried waste is by direct infiltration of precipitation, the topographical setting does not necessitate the construction of diversion or cut-off structures to prevent lateral groundwater intrusion. This allows cover evaluation independent of the perfomance of any drainage modification structure. 
4. This area was used for burial of higher-activity low-level waste IX-6 represents a significant waste inventory.

5. Stabilization and closure activities in this area will not interfere with, or be campromised, by ongoing waste disposal operations, or traffic, in SWSA-6.

6. Water is available in a nearby impoundment for hydrologic testing and possible cover stress testing via irrigation.

7. The area has been characterized for about a year for prestabilization and closure attributes.

The Resource Conservation and Recovery Act (RCRA) does not provide closure formats and requirements, however, it does impose this responsibility on owners and generators, subject to the approval of the Enviromental Protection Agency (EPA) regional acministrator. In this case the owner is the Department of Energy (DOE) and the generator is Martin Marietta Energy systems (MMES). It is anticipated that the evaluation of the techniques employed in this demonstration will provide the rationale for what will work in most of the SWSA's at ORNL. Although this demonstration will stabilize and close a small section of SWSA-6 it will not necessarily dictate the degree of stabilization and closure required for most waste trenches.

\subsection{OBTECTIVES}

The major objective of this project is to perform a demonstration and evaluation of stabilization and closure techniques on a portion of a waste disposal area at ORNL. An objective of this activity is to establish regulatory involvement in the design and planning phases in order to develop a mutual understanding of, and an identification with, the goals and objectives of site stabilization and closure. The field verification of the effectiveness of the proposed stabilization techniques, as well as that of their integrated system, will be the major product of this project.

The implicit objective of site stabilization and closure is a design which yields reasonable assurance of hydrological and biological isolation of interred waste and which requires no maintenance. 
The area chosen for this stabilization and closure demonstration is an approximately one acre hillock on the northeastern siple of solid waste Storage Area (SWSA) No. 6. The area contains 19 low-level waste burial trenches (Figure 1) and, because of its topography, represents a hydrologicallyisolable and monitorable unit.

The Final plan encompasses the dymamic compaction of all 19 trenches, grading the 5 most easterly trenches to a speciflc shape and slope, backilling and compacting the remining 14 trench craters, in situ grouting of the 5 easterly trenches, construction of a percolation and biological intrusition barrier over the 5 grouted trenches, and covering the 14 trench area with a surface plastic sheet to prevent recharge of the 5 trench area during the 4 year monitoring period. Figure 2 depicts the components, and the order in which they are placed, of the closure design.

\subsection{DNAMIC COMPACTION}

Dynamic compaction of waste contained in each trench will be acoomplished by dropping a 4 ton cylindrical weight, from a crane, on the trench from a height of 25 to 50 feet. The trench comers will be located and staked by the company. The drop pattern will be in the form of a square approximately 10 feet by 10 feet. The comers of the square will be compacted first, followed by the center, by dropping the weight in one place until penetration is negligible as determined by the company field engineer. He also detemines the height, from which the weight is dropped, by the amount of penetration achieved by the weight on each drop. Each trench is approximately 10 feet wide by 50 feet 1 ong and 15 feet deep. There is approximately 10 feet of waste at the bottom of each trench with 3 to 5 feet of cover soil over the waste. From past dymamic compaction operations reduction of waste volume has been as great as $64 \%$. (Ref. 1) 
IX $\cdot 8$

OANL-OWG $19 .$. IOATOANS

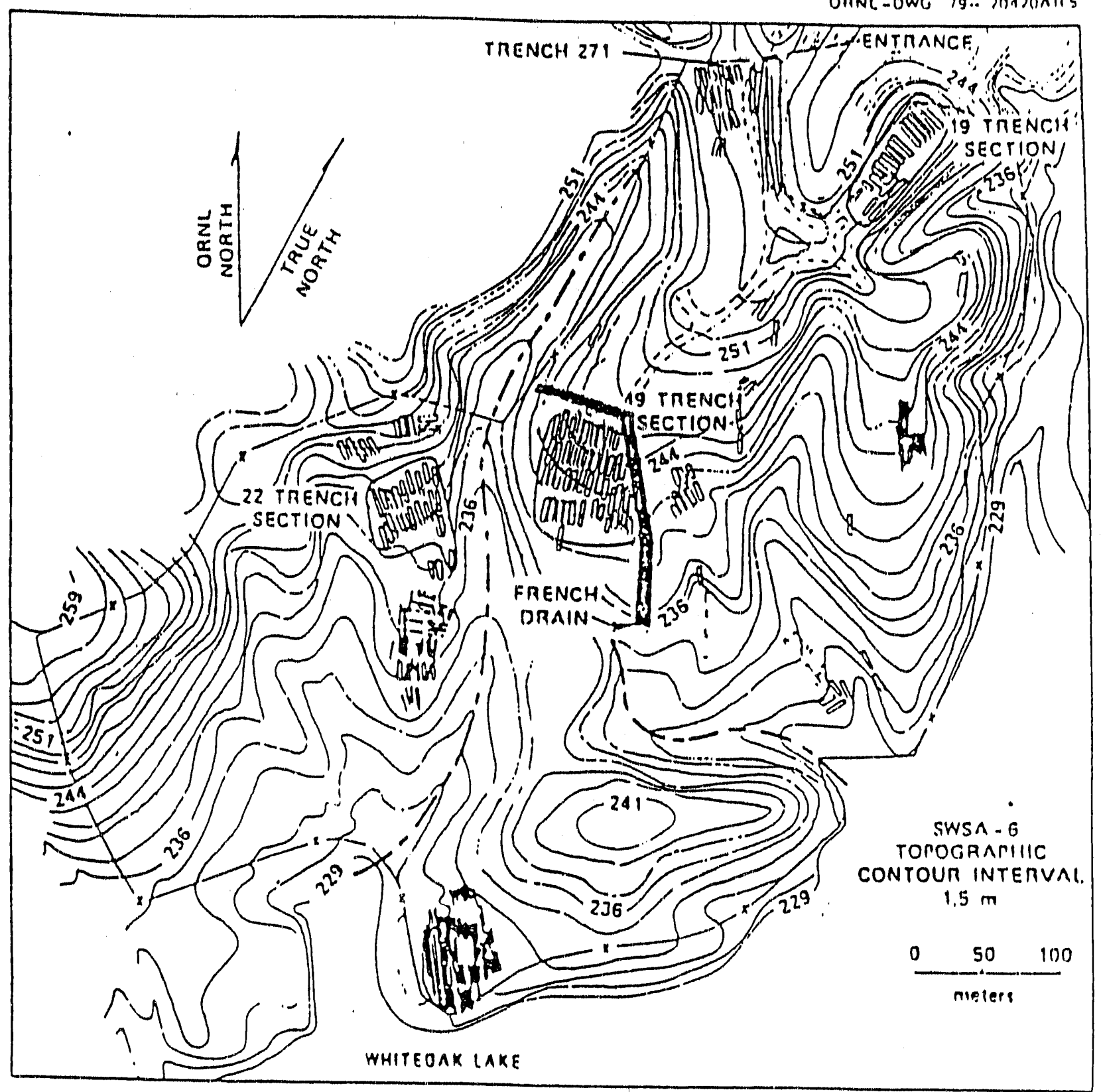

Firure 1. Map of Solid Wagte stornge Aren 6, ORNl, ghowing lihe

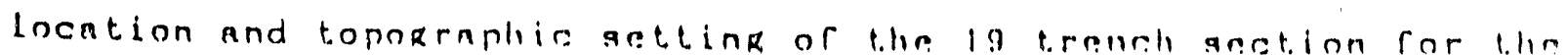
alte atubilizention nrid cloaure demonatirntion. 
Flgure 2

STABILIZATION and CLOSURE DEMONSTRATION COMPONENTS

IX-9

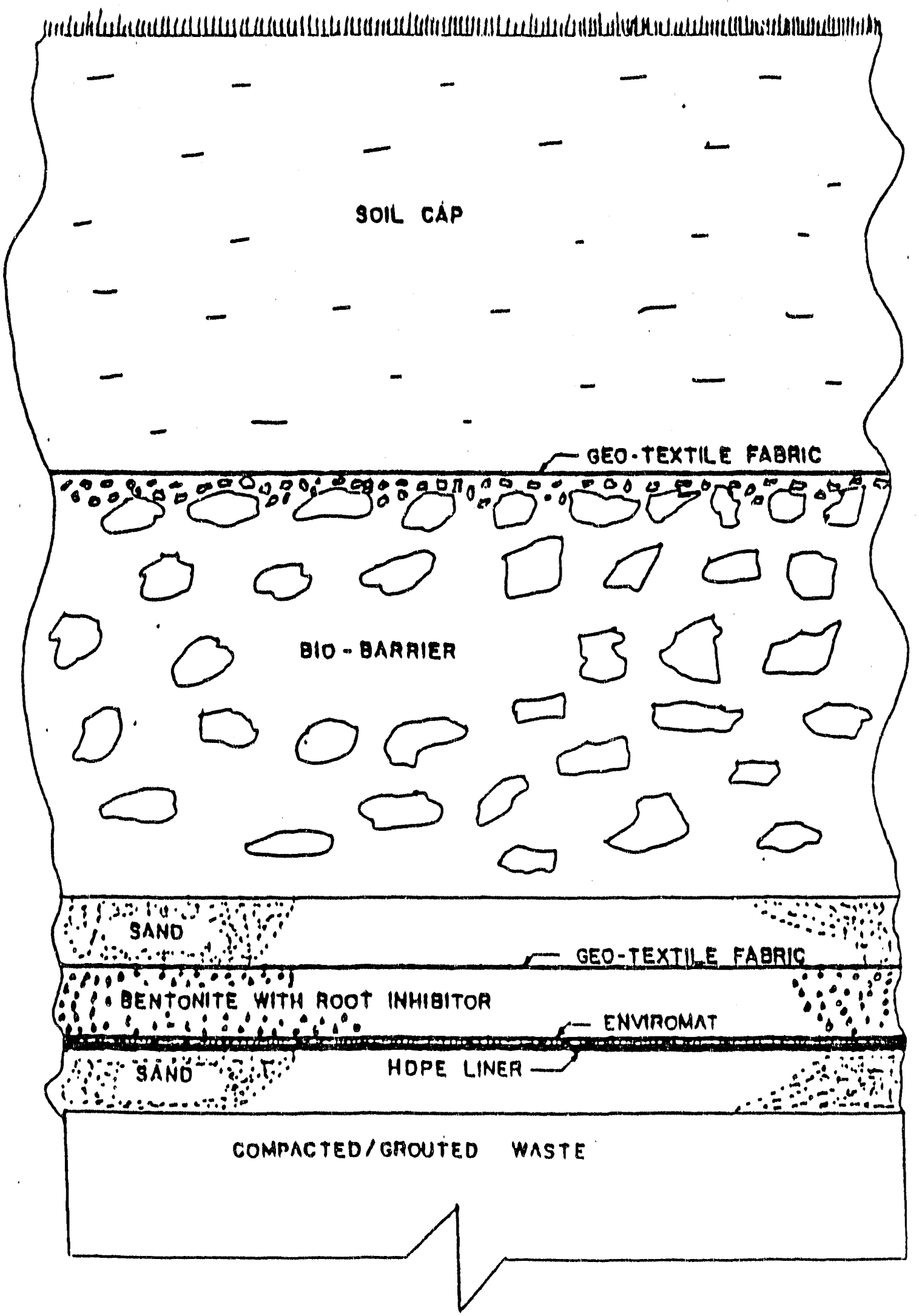


For Design purposes, reduced waste volume was assimed to be $50 \%$ and is considered conservative. Therefore, it is expected that the average reduction in top-of-trench elevation will be 5 feet.

\subsection{EARTIWORK}

Upon completion of the dymamic compaction operation the noncompacted soll surrounding the 5 most easterly trenches will be cut to the level of the top-of-trench elevations, shaped and sloped to provide drainage. The soil removed in this operation will be used to backfill the trench craters of the other 14 trenches. This backfill will be compacted to maximum density and the whole site will be seeded and mulched. Clearing and fence removal will be required in the vicinity of the 5 trench area so as to achieve non-eroding slopes. Silt fenoing will be installed in this area also. The site will remain in this condition for approximately 12 months while in situ grouting and subsequent testing of the 5 trenches is performed, primarily by MMEs.

The next earthwork activity will oocur after selected trenches have been grouted and the grout verification testing is complete. The site wi.1. be cut/Eliled/compacted in acoordance with the plans and specifications.

The soll placed over the percolation and intrusion barrier will be applied in 8 inch lifts with each lift compacted. Soil. from a SWSA-6 or nearby korrow pit will be used as required.

\section{3 'TRENCH GROUTTNG}

Further stabilization of the 5 most easterly trenches will be acoumlished by in situ grouting. The grout specified is AV-100 Chemical Grout, or equivalent, as distributed by Avanti International. This is an acrylamide base grout which allows a wide range of gel set time and has excellent dispersion capability. (Ref. 2) The approximate void volume within each of the 5 selected trenches will be determined by water injectlons. The 
grout will be infected in such a manner as to completely fill alli volds within and surrounding the compacted waste. Intra trench observation wells will be monitored during grout infection to verify dispersion of grout within each of the 5 trenches.

\subsection{NEUTRON PROBE ACCESS TUBES}

Neution probe access tubes will be placed beneath the percolation barrier horizontally to detect any moisture variation inalicative of barrier failure. These tubes will be placer horizontally and surface on the northerly and southerly sideslopes. When not in use they will be plugged with end caps. The tubes will be 1.55" I.D. aluminum and be placed approximately 12 inches below the liner.

\subsection{PERCOLATION BARRIER}

The percolation barrier is comprised of three materials; 1) a High Density Polyethylene (HDPE) membrane Iirer, 2) a bentonite mat (Enviromat), and 3) a layer of high swelling wyoming bentonite. This system is designed to provide a primary and secondary barrier to percolating surface water. The FIDPE Iiner will be placed on a $6 "$ sand bed which covers the compacted soil over the trenches. The Enviremat will be placed directly on the liner with a $6^{\prime \prime}$ layer of bentonite placed directly on the Euviromat. The bentonite will be sprayed with a commercially available root. inhibitor and inmediately covered with a geo-textile fabric. nnother 6" layer of sand will then be placed over the geo-textile fabric. The bentonite is confined between the liner and the geo-textile fabric thereby creating a watextight seal upon wetting of the bentonite. Any expansion of the bentonite layer will be absorbed by the sand bed overlaying the bentonite due to sand upsurging into void spaces created by the rip-rap biombarrier which is placed on the sand. 


\section{5 .1 Wher}

The Iiner specified is $60 \mathrm{mil}$ thick HDPE, equivalent to "Gundlire HD" as manufactured and installed by Gundle Lining system, Irxo. verification.

\subsubsection{Enviromat}

Enviramat is a bentonite-impregnated non-woven geotextile manufactured by Intermational Minerals and Chemical corporation. See specifications for

\subsubsection{Bentonite}

The bentonite specified is a high swelling wyoming bentonite.

\subsection{TEO-TEXIIIE FABRIC}

The geo-textile fabric specified is a non-bio-degradable and nonwoven fabric such as Construction Fabric 4561, as manufactured by Amooo. This fabric will be installed in two places; 1) over the bentonite layer, and 2) over the bio-barrier. This fabric is permeable and performs a material separation function only.

\subsection{BIO-BARRTER}

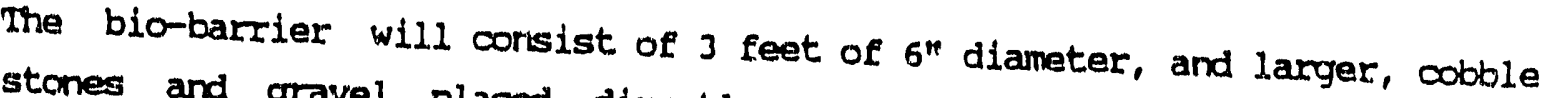
stcmes and gravel placed directly on the sand layer which oovers the bentonite. Gravel will be placed on top of the cobble to flill voids and provide a smoother surface on which to place a geo-textile fabric. The bio-barrier is designed to prevent intrusion of burrowing animals. Because of its negligible water-holding capacity, it will also aid as a barrier to plant root intrusion. 


\subsubsection{Drainage system}

The bio-barrier serves a secondary purpose in providing the necessary volds to drain percolating water to a perimeter drainage. pj.pe and then to a catch basin for quantification and qualification during the 4 year monitoring period succeeding construction.

\subsection{SOIL CAP}

The soil cap will consist of $3^{\prime}$ or more of spoil left over fram previous earthwork and make-up soil from a borrow pit located at, or near, SWSA-6. The cap will be placed in 8" lifts with each lift compacted to a density specified by the soil consultant. A ditch, as shown on the plans shall be art around the perimeter of the site to catch and transport rain water run-ofe to a catch basin to allow monitoring.

\subsection{SERDDVG}

Immediately upon Company approval of the soil cap, the site will be seded and mulched so as to minimize exosion. Seed will be Kentucky 31 Fescue applied at a rate of 100 pounds per acre. All disturbed areas shall be seeded. Mulch shall be applied immediately after seeding and wetting.

\subsection{TRETS}

Rather than wait many years for natural succession to establish a forest cover, trees of various ages will be transplanted to the site. Species composition will be maintained sindlar to that of the climax successional
stage for the region. 
The purpose of this section of the plan is to provide the rationale for those design items which differ signiflcantly fram an earlier provisional plan. Some of the differences are a result of the lack of detail in the provisional conceptual plan and scme are the result of recent research exposing a wider choice of material and methods.

Briefly, the major differences are as follows:

- arting surrounding natural ground to top-of-trench elevations after aynamic compacting is being done to minimize the effects of trench subsidenoe on the HDPE IIner.

Past reports indicate the major cause of liner failure is trench subsidence which allows excessive tensile forces to exceed the liner capability. With till soil surrounding and covering the trenches, camparted to optimu density, the potential for liner failure che to trench subsidence is mininized. This surface grading will also facilitate grout and drilling equipment placement churing grouting querations. The provisional plan proposed backeilling and compacting the trenches to the original elevations and then adiling the percolation and bio-barriers and soil cap.

- HDFE Iiner - The provisional plan proposed Hypalon for the membrane liner. The Gundle HDPE liner has greater elongation and puncture resistance properties.

- Enviromat - The Enviramat was added as a protective cover to the HDPE liner during constnuction. It will also function as an independent percolation barrier to the HDPE liner below and the locse bentonite above. 
- Root Inhibitor - Since the site will eventually be allowed to re-vegetate and large trees will be part of the vegetation, a means of preventing root intrusion into the waste layers, was investigated. Copper sulfate is the foremost irgredient in all effective root inhibitors. Ideally, an ion exchange will oocur between the onper sulfate and elements in bentonite such that the resultant compound will be a long-tem deterrent to root growth, should roots penetrate to the bentoritis layer. At this writing it is not known if an ion exchange will occur between oopper sulfate and bentonite. Laboratory experiments will be conducted during the regulatory review period to determine the feasibility of this approach. Solution concentration and dosage rate will also be deternined by laboratory analysis.

- Grout - The provisional plan proposed using sodium silicate as the waste stabilization agent. After evaluation of recent grouting experience at OFNL, it was determined that an acrylamide agent would be considerably more effective. The primary characteristic which makes acrylamide advantageous is its low viscosity which is very near that of water. This will allow a much higher confidence in the grout performance because of the hydrodynamic dispersibility of the acrylamide agent. Its disadrantage is in it's cost. 
The long-term performance of the peroolation barrier will be ascertained by placing groundwater tracers in selected trenches. to monitor any downard movement to the water table. A total of 1.3 water table wells have been recently installed on site to facilitate groundwater monitoring. Additioncil tracers (stable cesium and strontium salts) will be placed directly below the percolation barrier so that any translocation to the forest cover will indicate areas of failure. All tracer placement and monitoring will be performed by the company. 
The specifications, included in this plan, dictate the testing of materials and/or installations required to verify each stage of the construction activities. This section describes additional testing and monitoring not included in the specifications. This additional testing, for the most part, will be performed by the campany.

Each cumponent of the system will be tested extensively both during its construction and subsequently in a nondestructive manner by various site monitoring activities. These testing and evaluation methods are summarized in Table 1. Most of the geotechnical tests will be replicated at least four times on each trench. Considerable drilling, augering, and temporary well installing is envisioned in most of these activities. To avoid the compranising protrusion of many well casings from the grand surface and through the various barriers, angle well placement will be used for monitoring and sampling the water table beneath the site. Pressure transcucers and sampling tubes will be fitted in existing monitoring wells and routed to the sides of the site. This will allow continued monitoring withour potentially compramising the area cap. Horizontal neutron probe acoess tubes will be employed beneath the percolation barrier to detect any moisture variation indicative of barrier failure. Additional moisture monitoring will be achieved by placing vertical neutron probe access tubes into the soil cap, but these shallow tubes will not penetrate the peroolation barrier. surface runoff monitoring stations will be constructed around the site to monitor both water and sediment flux fram the site in response to individual precipitation events and as an anrual flux. Groundwater at the site will be systenatically monitored for tracers placed in the trenches and for the tracers placed directly beneath the cap. Growth of trees will be measured and samples of the tree leaves will be taken on an anmual basis from various areas and analyzed for stable cesium and strontium tracers. These 
1. Dymamic ampaction of waste and backfill

2. Grouting of compacted waste and backfill

3. Dymamic compaction of new soil fill

4. HDPE Iiner

5. Bentonite mat

6. Gravel and cobble

7. Soil cover

8. Vegetation (trees)

9. Whole system 1a. Standand penetrometer tests

1b. Bulk density mensurements

1c. Ground surface depression surveys

2a. Hydraulic conductivity, before and after

2b. Volumetric void filling calculation

3a. Bulk density measurements

3b. Standard compaction tests to high limits

4a. Moisture monitoring via buried neutron probe access tube (horizontal)

4b. Biointrusion via translocation of stable cesium and strontium tracers

4c. Shear strength and puncture testing

5a. In-situ permeability tests

5b. Biointrusion tests as in $4 b$

6a. Size distribution testing

6b. Depth profile survey

7a. Rumoff and sediment yields for erosion measurements

7b. Stored moisture measurement via neutron probe (vertical)

7c. Evaportranspiration via moisture balance

8a. Survival + moisture stress of tree species

8b. Above ground biomass and growth measurements

9a. Grounctwater recharge via water table monitoring, before and after

9b. Migration of trench tracers (Na and Li) placed in penetrometer holes

9c. Water budget analysis and hydrologic performance model 
elements are not toxic to the trees and have extremely low ambient background levels in vegetation. Burrowing animal activity will be monitored at the site and nondestructive probing and surveying of the burrows will be attempted to ascertain the effectiveness of the bio-barrier.

Hydrologic modeling will play an integrating role in both the design of the final stabilization and closure plan and in performance assessment of the system as determined fron the field monitoring. The consequences of various failure scenarios will be simulated with these hydrologic models. Water burigeting of the site will be compared with long-term predictions of forest moisture needs and growth. Soil erosion will be simulated with some models which will be verified by the empirical site ecosion measurements. 
6.1 FISCAL YEAR 1988

\begin{tabular}{|c|c|c|c|c|c|c|c|c|c|c|c|c|}
\hline & 0 & $\begin{array}{c}87 \\
N\end{array}$ & D & $\boldsymbol{J}$ & $F$ & $\mathbf{M}$ & $A^{1} 88$ & $M$ & $\boldsymbol{J}$ & $\mathbf{J}$ & A & $s$ \\
\hline $\begin{array}{l}\text { Dynamic Compaction } \\
\text { Cut Grade } \\
\text { Pentetration Testing } \\
\text { (Trenches) } \\
\text { Trench Grouting } \\
\text { Hydraulic Testing }\end{array}$ & & & & 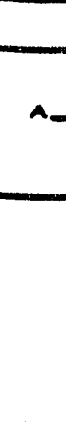 & & & & & . & & & \\
\hline
\end{tabular}

STABILIZATION \& CLOSURE

DEMONSTRATION

PROPOSED CONSTRUCTION SCKEDULE 


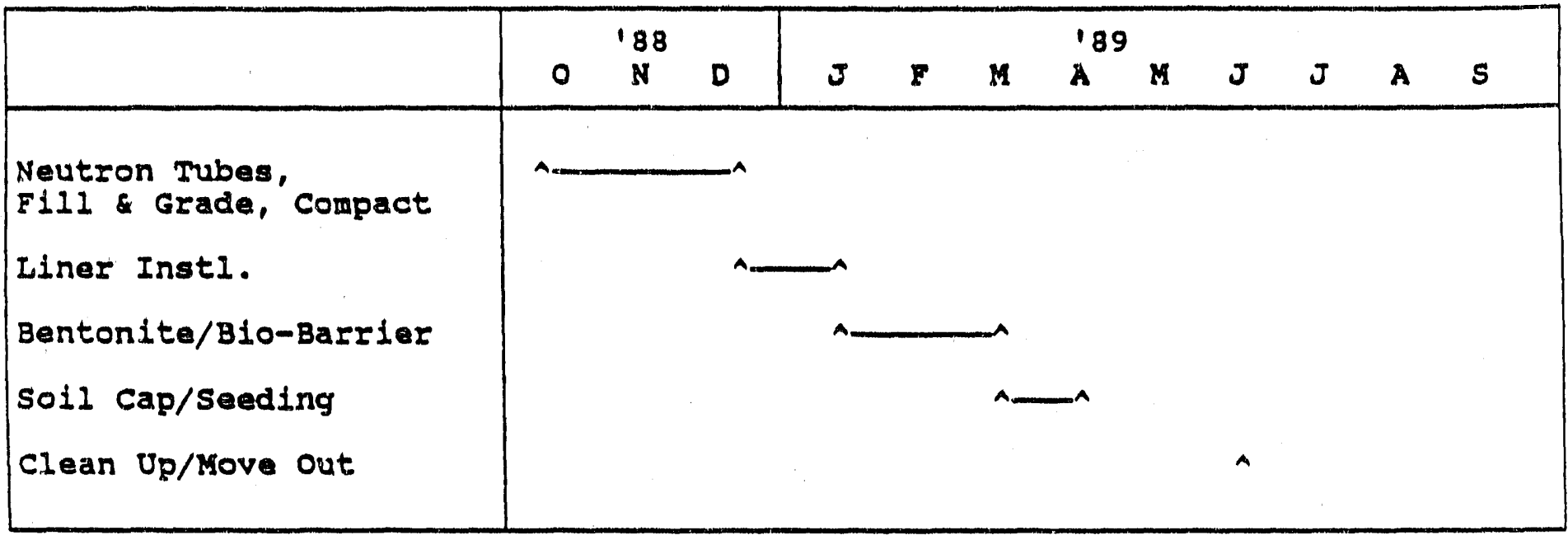

\section{STABILAZATION AND CLOSURE \\ DEMONSTRATION}

PROPOSED CONSTRUCTION SCHEDULE 
7.0 COST ESTIMATE

\section{AcTrVIry}

1. Dynamic compaction

2. Grouting (5 trenches)

$\begin{array}{lll} & \text { UNTT } & \text { TOTAL } \\ \text { UNTIS SUANTIY } & \text { SOST }\end{array}$

Sq. Ft.

13,100

$\$ 1.86$

$\$ 24,366$

a. Ft.

$$
6,700
$$

42.50

284,750

3. Earthwork
a. Cut
a. Yd.
980
2.50
2,450
b. Fill (Incl. soil cap) ou. Yd.
2,861
2.50
7,153
c. Compaction
cu. Ya.
2,861
2.17
6,208

4. Fercolation Barrier
a. HDPE Liner
b. Enviromat
c. Bentonite
d. Sand
e. Root Ininibitor

sq. Ft.

sq. Ft.

Ton

ar. Yd.

Gal.

$\begin{array}{rrr}13,800 & 1.23 & 16,974 \\ 13,800 & .60 & 8,280 \\ 242 & 189.00 & 45,738 \\ 511 & 10.00 & 5,110 \\ & & 2,500\end{array}$

5. Bio-Barrier
a. Rip-rap
b. Gravel

Cu. Ya.

1,227

7.50

9,203

307

10.00

3,070

6. Geo-textile Fabric

Sq. Ft.

27,600

0.19

5,244

7. Seeding/Mulch

SY.

$\begin{array}{lll}5,555 & 1.53 \quad 8,500\end{array}$




\section{ACTHVITY}

8. Drainage system

A. 6" perforated pipe

b. 6" solid pipe

c. $11 / 2^{\prime \prime}$ river gravel

d. surface ditching

a. Catch Basin

f. 10" solid pipe

g. Rip rap pad

TOTAL ESTIMATEU COST

\begin{tabular}{|c|c|c|c|}
\hline & & UNIT & TOTAL \\
\hline UNTIS & QUANITEY & gSST & cosst \\
\hline
\end{tabular}


8.1 Earthwork/General

a. Gaiter construction Co.

P. O. Box 14005

Kroxville, TN

(615) 524-4944

b. Blaine-liays construction $c o$.

9047 Execurtive Park, suite 206

Kroxville, TN

(615) 693 -0575

c. A. B. Long Construction Co.

6416 Deane Hill Dr.

Knoxvilile, TN

(615) 588-0661

8.2 Grouting

a. Noxthwest specialities

33 Yorkshire Dr.

Dak Brook, IL 60521

(312) 53.3-6644

b. Hayward Baker Co.

1875 Mayfleld Rd.

Odenton, MD 211.13

(301) 551-8200

c. W. G. Jaques Consturuction co.

218.3 N.W. 86th st.

Des Moines, IA 50322

(515) $276-5464$ 
a. Gundle IIIning systens, Ina.

1340 E. Richery Rd.

Houston, TX 77073

(713) 443-8564

b. Rouse Construction Co.

9050-B Executive Park Dr.

knoxville, IN

(615) 690-4312

c. Ceo-con, Inc.

P. O. Box 17380

Pittaburgh, PA 15235

(412) $244-8200$ 


\subsection{RTHFERENCES}

1. B. P. Spalding, "Procedings of the Seventh Anmual Participants" Information Meeting", DOE Low-Level Waste Management Proxgram, CaNF-8509121, pp. 676-698.

2. B. P. Spalding, S. Y. Lee, C. D. Farmar, L. K. Hyder, "Denonstration of In situ Immobilization of anded Transurario Waste using Acrylanide Grout", Septembar 1986, RAP 86-69.

3. B. P. Spalding, L. K. Hydar, I. I. Munro, "Grouting as a Remedial Technique for Buried Low-Leval Radioactive Wastes, Journal of Envirommental Quality", Vol. 14, No. 3, July-September 1985.

4. OFNLTM-9877, "Characterization Plan for Solid Waste Storage Area 6", Pub. No. 2638, Decembar 19, 1985.

5. "Draft closure Plan for solid Waste Storage Area $31 x, "$ Oak Ridge National Iaboratory, Oak Ridge, Tenmessee, ORNL/SUB/86-72127/1, 1986. 
10.0 APELNDICES

10.1 APFENDIX 1

DRANTNGS

$7819217 \mathrm{~K} / 11$ 


\section{APPENDIX X}

Correspondence with

The State of Tennessee

Department of Health and Environment

and

The United States

Environmental Protection Agency 


\section{STATE OF TENNESSEE \\ DEPARTMENT OF HEALTH AND ENVIRONMENT \\ 1605 PROSSER ROAD \\ KNOXVILLE, TENNESSEE 379143434}

February 1, 1988

Mr. W. Nelson Lingle

Department of Energy

Research and Waste Management Division

Waste Management Branch

P. O. Box E

Oak Ridge, IN 37831

RE: Tennessee Department of Bealth and Environment (TDEE) Review of Draft plan for the Tesc Area Remedial Action (TARA) at ORNL. ORNL/RAP-42

Dear Mr. Lingle:

The Tennessee Department of Eealth and Environnent (IDEE) has appreciated the opportunity to review the above referenced document. Associated with the TARA project were the review of the additional documents: (1) Environmental ALARA Memorandum for the Core Sampling, Trench 150, Solid Waste Storage Area (SWSA) 6; (2) Closure Techrology Demonstration, 19 Trench Section, SWSA 6 - Action Description Memurandum, and (3) Brian P. Spalding's November 2, 1987 White Paper on questions conceraing the filling of selected trenches with water at the SwSA 6 Test Area for Remedial Actions (TARA).

As previously noted in my letter to you of December 29, 1987, the Division of Solid Waste Management has determined that the activities outlined in the Draft IARA Plan are not approved as meeting initial RCRA closure in SWSA 6 and the Department of Energy (DOE) will need to modify the RCRA closure plan for SWSA 6 . It is important that DOE and ORNL give the SWSA 6 Closure Plan and schedule a high priority.

DOE and Martin Marietta is advised to discontinue the injection of water or other fluids into waste trenches for hydraulic conductivity and volumetric void filling calculations. This practice represents the potential for "flushing" of radioactive and/or hazardous materials from the trenches into the surrounding environment including groundwater. IDEE will be available to assist DOz and Martin Marietta Energy Systems in selecting acceptable alcernatives for making void filling calculations.

TDHE recognizes the importance of selecting the best available technologies for the effectipe closure of SWSA 6. The IARA project as a demonstration could with some modification help to serve that purpose. Geveral and specific coments are eaclosed for DOE's review and consideration.

BECEIVED

FEB $O 41988$

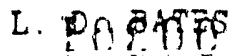

ID

PILE_TIC 
Mr. W. Nelson Lingle

Page 2

$X \cdot 3$

February 1,1988

If you have questions or need clarification please feel free to contact Gay Hashbarger or me.

Sincerely,

Gal C.Sam.

Earl C. Leming

ECL: GIH: P jm DWM $3 C$

Attachment

ce: Wayne Hibbitts

Mike Mitchell

Wanay Bates

Dave Hopkins 
General coments and questions concerning the TARA Plan include:
(1) Page 1-1:
How were the priorities deterwined for corrective actions?
(2) Page 1-1:
It is unclear how the initial TARA activities will mesh with the closure plan For SWSA 6 .

(3) Page 1-1:

Does data collected to date assure hydrologic isolation from the other burial sites, or merely indicate that such a condition is likely to exist?

(4) Page 1-1:

The fact that the most significant vector for infiltration is vertical does not preclude a horizontal influence. Please address this possibility.

(5) Page 2-1:

The liquid content in the trench or in the waste in the trencies is not documented. It appears that dyamic compaction has the potential to release liquids that may exist in some of the containers. Address this issue.

(6) Page 2-1:

Why cap only 5 of the trenches? How will the 5 treaches be hydrologically (both surface and ground) separated from the remaining 14 trenches? Why was the retaining wall deleted?

(7) Page 2-4:

The injection of fluids during grouting may constitute an injection under state or Federal OIC regulations. Has this been considered as a permitting requirement?

(8) Page 2-4:

Reference paragraph 3 regarding the measurement of void volumes by water injection. This method is unacceptable to TDHE.

(9) Page 2-4:

Has the soil over the 5 trenches, that is to be used to backfill the cracers of the remining 14 trenches been sampled for hazardous or radioactive contamiation?

(10) Page 2-4: Page 2-5, and Page 3-2

Does the acrylamide base grout contain a monomer which is toxic? Given the proximity to the Emergency Waste Basin and a creek whith flows into White Oak Lake, what measures will be taken to prevent possible 
(11) Page 2-4:

(12) Page 2-5:

(13) Page 2-5:

(14) Page 2-5:

(15) Page 2-5:

(16) Page 2-5:

(17) Page 2-7:

(18) Page 2-7:

(19) Page 2-7:

(20) Page 2-7:

(21) Page 2-7 and Page 3-2:

release of contaminates to surface or ground water? Does the grout contain any other toxic constituents which might be released to surface or ground waters?

Provide specifics regarding, "grout verification testing" method(s).

Given that numerous wells are to be installed, i.e. intra trench observation wells, etc..., will membrane of plastic be placed beneath and around drilling rigs to minimize any dispersion of liquids and Eacilitate site clean-up?

Should the removal of any liquids or contaminated soil from the trench occur during drilling or other operations, how will these be handled?

Why was 6 inches of bentonite selected instead of clay?

When the swelling of the 6 inches of bentonite occurs will adequate expansion of the geo-textile fabric be available to prevent tearing or ripping? How would this be monitored or detected?

Why not use the neutron probes at different levels?

Re: 2.8 Soil Cap, where in the plans is the drainage ditch illustrated? To what plans does this sentence refer?

What will be the final slope of the cap? What will be the stability of the cap, given the steepaess of the current outslopes? Will the cap remain in place permanently? If not, how long is it expected to remain in place? What is the final fate of the cap?

What parameters will be monitored for the surface waters carried by the ditch?

Rentucky 31 Fescue alone is inadequace. A quickly establishing annual rye and a legume should be included, species dependeat upon season of seeding. Anaual evaluation of vegaterive success and annual fertilization should be included in the plan.

The establishment of trees on this cap is unacceptable. If trees are to be evaluated it should occur on a "cold" demonstration site where the consequences will not potentially be environmentally harmful. 
(22) Page 4-1:

(23) Page CV-1.3: 7 of 12

(24) General

(25) General

GIB: pjm DKM 3C
Additional information is needed regarding the specifications of the monitoring system. This is particularily important for the angled monitoring wells.

The mulch rates are inadequate at $100 \mathrm{lb} /$ $1000 \mathrm{ft}^{2}$. They should be 3 to 4 times the suggested rate.

Has EPA commented on the $3004(u)$ impact of this project?

An alternative cap-cover that provides high run-off and low infiltration is suggested in NUREG/CR-4918 Vol. 1, Control of Water Infiltration into Near surface LlW Disposal Onits, by R. R. Schulz, R. W. Ridky, and E. O'Donnel1. How does the proposed TARA cap compare? 
Mr. Rodger A. Jump

Waste Management Branch

Department of Energy, Oak RIdge Operations

Post Office Box E

Oak Ridge, Tennessee 37831

Dear Mr. Jump:

\section{Besponse to TDHE Comments on the TARA Plan}

Enclosed are individual responses to the comments from the Tennessee Department of Health and Environment (TDHE) on the Test Area for Remedial Actions (TARA) Plan as contained in the letter from Earl C. Leming to Mr. W. Nelson Lingle dated February 1, 1988. Please forward this response to TDHE as appropriate.

Major issues identified in the TDHE comments will be discussed during the March 16, 1988, meeting with TDHE and Environmental Protection Agency in Chattanooga, Tennessee. Therefore, the enclosed material provides information regarding the content of those discussions. If you have questions or concerns, please let us know as soon as possible. other comments addressing minor technical details can be handled sufficiently through transmission of this response.

If you have any questions, please do not hesitate to call either myself $(6-4438)$ or Brian Spalding (4-7265).

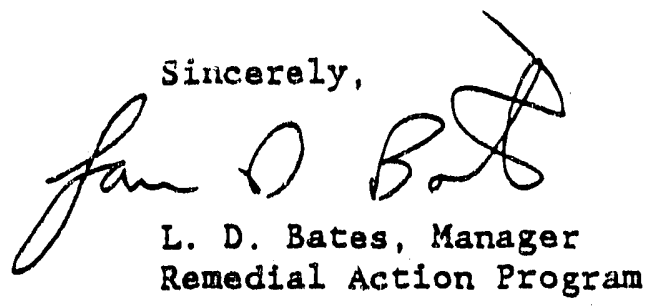

LDB:msc (E031088)

Enclosure

cc/enc: H. M. Braunstein

K. W. Cook

H. R. Gaddis

R. A. Jump

J. R. Lawson

L. W. Long
L. E. McNeese

T. E. Myrick

C. E. Nix

I. P. Perry

P. S. Rohwer

B. P. Spalding

F-TARA Demo 
To: L. D. Bates

From: B. P. Spalding

Beply to TDHE Revtew of the TARA Plan

The TARA closure techniques demonstration project is a phased approach to testing trench stabilization techniques. project involves three distinct phases in sequence: dynamic compaction, grouting, and covering. By the very nature of the activity, the task does not lend itself to elther a rigid schedule or extreme procedural detafl as might be expected in an actual closure plan for a waste site. Each phase has a flexible schedule for its implementation imposed by the necessity to evaluate the effectiveness of that phase before planning details of a subsequent phase. Each phase will generate information that will be neoded to plan the subsequent phase. For instance, we cannot provide final design of the araa cap until we know the final elevation of the graded site which will depend on how deep our dynamic compaction proceeds. Nor can we be specific about the volume of grout, which will be required, until we determine the residual volds within the compacted trenches. Because the project is, in essence, an ovaluation of stablization and closure techniques and not a closure demonstration, the task plan will romain a living document with only as much detall as reasonable given that we will not know the effectiveness of the various techniques until they are completed.

Getting a consensus or approval for all issues and concerns, which we do not believe is required, from the regulators will take considerable time. We still have not heard from EPA although they were sent copies of the plan on october 21, 1987. For now, we can address in depth only the TDHE comments. We sincerely appreciate the time and effort on their part in providing these comments. They have identified a number of regulatory and institutional concerns with the proposed actions, all of which we will be facing in the larger venture of actual site riosures in the near future. We believe that all of these issues and concerns have been addressed herein and we should be allowed to proceed with these critical activities. As polnted out in detall. in some these replies, we must assume some risk in proceeding with these activities to gain the benefit of learning their effectiveness. Otherwise, we will have to face the same issues when we propose actual closure methods for our waste sites and still have no data or experlence from which to answer them. 
TDHE Coments and Replies 2

I have grouped the IDHE comments by phase and suggest that we proced with the planned activities when we have satisfled ourselves as to thelr resolution. The specific TDHE comments have been quoted below, prior to each reply, so that an interested reader does not have to divide his/her attention between two documents.

Dynamic Compaction Phase

(5) The liquid content in the trench or in the waste in the trenches is not documented. It appears that dynamic compaction has the potential to release liquids that may exist in some of the contalners. Address this issue."

I will address the osiest part of this comment first. We have placed a monitoring well into each trench about a year ago. At that time (Fobruary 1987), we observed standing water in only three trenches but only of nominal depth (less than 1 foot). During the following spiling and summer, this standing water disappeared in all these trenches. Water filling measurements later that year inundated seven trenches with water. This water soeped away within two wooks of filling and the trenches returned to their unsaturated condition. Thus, at the time wo had originaliy planned to inftiate compaction (October 1987), the tronchos would have been free of standing water. When we finally initiate compaction, we anticipate similar unsaturated conditions.

The more difficult part of this coment centers on potential release of liquids in the waste within the trenches due to dynamic compaction. I belleve that we will all agree that any containers, for liquids or solids, will be destroyed by dynamic compaction. Thus, any contained liquids will no longer be contained after dynamic compaction. Thus, the issue reduces to assessing just how much contained liquid might be in these trenches and, if present, what the consequences of loss of contalnment might be. Let's go at these questions in order. How much liquid is likely to be in containers in these trenches? Probably, there is not much! The reason I reach this conclusion is based largely on the operation of ORNL radioactive solid wasta disposal system at the time these trenches were being used. The first trench (No. 2) was opened on November 2, 1972 and the last trench (199) was closed June 16,1976 at the TARA site. During this interval ORNL's radloactive liquid waste disposal system was operational and accessible through a cost. free (to the user) drain system. Not only were potential generators provided with free bulk liquid disposal in their labs, but disposal of bulk liquids was prohibited for solid waste disposal as described in waste management practices at that time (ORNL-CF-72-9-1). We are reviewing the 602 disposal records (UCC Form 2822) of waste shipments to these 19 trenches in an effort to ldentify how many might have contained aqueous or nonaqueous 
TDHE Coments and Replies 3

11quids. At best, this exerclse will probably yiald qualitative confirmation of the 'not much' liquid character of lts contalned waste. These records lack much detall with many entries reading 'mlscollaneous Junk'. In addition, bulk quantities of contaminated solvent were disposed into augar holes in other axeas of SWSA 6 . Thus, 1t $1 \mathrm{~s}$ extremely likely that this area does not contain bulk quantities of aqueous or nonaqueous 11quids. However, that does leave open the posslbility that these trenches may contain small or incidental quantitios of both aqueous of nonaqueous liquids within small contalners or vials. But again, there is probably not much of this in the area oither. The area was reserved for higher lovel low-level (>200 mrem/hr at the package surface) solid waste. The area was, and still is, high and dry; it is generaliy over thirty feet to the water table at most places at the TARA site. Thus, the higher. lovel waste was disposed there in an effort to keep it out of groundwater. Thus, the bulk of lower level waste (e.g., scintiliation vials which are contact handled) would ilkely end up in other aroas of SWSA 6 used for disposal of <200 mrem/hr waste. Sampling of trench leachate ( 1.0 . s sanding water) in low-lovel trenches in other areas of SWSA 6 in 1986 by solomonet al. (RAP/LTR-87/37) detected the presence of dissolved organics in the mg/L range for several but not all trenches. Notably, al 1 were at last an order of magnitude below their solubility limit indicating that no large amount of these liquids was present in these trenches. Detected compounds were often characteristic of scintiliation fluids (naphthalene, toluene, ethylbenzene, etc.). As pointed out above, scintillation vials would not be an expected component of higher-level wiste in the TARA trenches. Nevertheless, residual fiulds and solvent may be present in the TARA tranches in small quantities in disposed labware from hotcell operations and other waste.

What might be the consequences of releasing these minor amounts of aqueous fluids or solvents during dynamic compaction? An instantaneous release of fluid at the trench floor during compaction is likely to be adsorbed by the soil backfill within the trench which would likely be in an unsaturated condition. However, the adsorbed fluid is free to mix and move via advection with percolating water subsequent to compaction. How long would it take for a dissolved fluid to reach the watertable approximately 20 feet below the trench floor? Probably several yoars even if compaction were the sole step in stabilizing these trenches. But we plan to grout these trenches and cap all the trenches within one yoar of completing compaction. In theory, therefore, fluld movement to the watertable would then be solely by diffusion because the cover would prevent further advection of water through the trench. In addition, the grouting would encapsulate residual material within the erench. In the brief time between the compaction phase and the grouting plus capping phases, released fluids could move under unsaturated conditions. Unsaturated condtions means hydraulic conductivities very much 
Lower than saturated (about $10^{-5} \mathrm{~cm} / \mathrm{soc}$ ) and oxtromely small hydraul1.0 gradionts, 1. . , 11ttlo movement.

It is also important to ralize that wo would not be taking the suali risk of fluld reluases bilndly. There la a sute of is groundwater monltoring welis within and around the TARA site. These wolls have beon samplod for hazaxdous constituones but. analyses havo not yet been completad. Radiochemleal analyses have indicated that they contain low levels of tritium as do fust about all groundwater samples in SWSA 6 . Wo w11 have a good understanding of groundwater contamination bofore dynamic compaction. We plan to sample theso wells porlodically during the life of the project to observe how water quality may change. Hopefully, we will observe no decorioration but, if any id observad. wo can collect groundwater as needed. Welis in this area are extromely low yleld (1. . less than 50 liters per day) so collection would not be a significant expenso were lt requirad.

Thus, based on avallable disposal recoxds and disposal practices in use in SWSA 6 at the time the trenches at TARA were filled, it is unlikely that signiflcant amounts of liquids were disposed there in any type of contalner. Although the risks may be groater in other areas of SWSA 6 , the risk of container destruction releasing detectable amounts of flulds would appar to be very small at TARA. The benefit from taking such a $i s k$ is substantial. We wil gain the technical evidence that dynamic compaction can or cannot obviate trench subsidence. In addition we wil decermine the compatibility of grouting with dynamic compaction so that we can save enormous amounts of money by not having to purchase grout to fill large trench volds which can be cheaply and effectively eliminated by dynamic compaction. If the combination of dynamic compaction and grouting proves succossful in this low-risk area of SwSA 6 , then we will have a good position to ovaluate whether to apply the technique to higher risk areas of SWSA 6 .

(8) "Reference paragraph 3 regarding the measurement of vold volumes by water injection. This method is unacceptable to TDHE."

The comment is moot because we do not have to, nor do we plan to, carry out any more water injections into the TARA trenches. (See the addendum "White Paper" on the benefits and risks of trench water fliling.) If we need to inject water into trenches or wells, we may have to obtain an Underground Injection Permit.

(9) "Has the soil over the 5 trenches, that is to be used to backfill the craters of the remaining 14 trenches been sampled for hazardous or radioactive contamination?"

It should be emphasized that the soil directly over the 
TDHE Comments and Replles 5

tronohes to be compactod w111 be pushod down lnto the compacted ass and there are no plans to move or disturb this soll. The soll around these flve trenches will be pushed over to the other 14 trenohes to level thelr grade to the orfginal land surfaco. In the area not directy over tronohes, twolve undisturbed soll coro ware obtalned to dapth of 15 feot during standard penetration tests In 1987. Each 18 - Inoh long soction of core was conned for radioactivity with oelger-Mulier detector. None was obsarvad. In addition. during constiuction of the 13 new monitoring wolls at the TARA site in 1987, drill cuttings ware continuously monltorad for radioactive contanination by our Health physles personnel. Agaln, none was detected. Hazardous substances wera not analyzed in elther the soll oores or drill cuttings al though the former have been archived.

It is quite unilkely that any of this soli, which we propose to move, would contaln hazardous or radloactive contamination. First, all of this soll lies above the depth of wasto burlal and any posslble waste contamination migration would have been down or latoral with the flux of water. Second, it is extremely unlikely that hazardous substances would be present without co. contamination by radioactive substances. This is probablo because the TARA tronches were used for disposal of highor-level low-lovel waste. We have very speciflo radiologle safety procedures which must be followed during all excavations to protect workers and the enviromment. As a contingency, if we do encounter radioactive contamination during ol ther dynamic compaction or site grading, wa plan to dispose of lt in situ by covering with clean fill and dynamically compacting. It is axtremaly unlikely that this contingency wili arise but we plan the health physlcs coverage to deal with it. A third observation, which supports our planning that radioactive contamination will not be encountered, is the fact that this site has beon graded befort. In 1976 the site had the top two feet of cover removed and a bentonite seal emplaced at that depth by mixing into the soll. The cover soll was then replaced and seoded to grass. No reports of radioactive contamination during that operation were made during continuous health physics coverage.

(24) "Has EPA commented on the 3004 (u) impact of this profect?"

No, not to my knowledge. Because the TARA site tranches were used prior to 1980 , the aroa is currently not classified as a RCRA waste area. However, the trenches contaln the same physfcal types of waste and the trenches were constructed and closed by procedures 1dantical to the RCRA area trenches. Thus, the stablilzation evaluations gained on this site will be directiy applicable to RCRA areas of SWSA 6 and other SWSAs. 
TDHE Commants and Repliea 6

(7) "The Injootion of flulds during grouting way oondtetute an infootion under state or Fodaral UIC ragulations. Has thls boan oonsiderod as poratting requiroment?n

The Action Description Memorandum (ADM), whioh was propared for thls projoct, ls a formal ravlow of proposed actions by ORNL's Env1xonmental Coupliance Dopartunt for conformity to anvironmantal lawa and rogulations. Thls lasue was not ralad at the tima the ADM was propared, at whioh time the state regulations had boon in affact for one yoar, sa lt was prosumad that the proposad grouting was in sompliano with those regulations (as wore the proposed tronoh water filings). Although tha UIO regulations do not prohlblt this grouting, wo may nead to apply for a pormit co perform the grouting of the tranches.

A roading of the Tanwasae Rulas for Undarground Injection Control (Chaptar 1200-4.6 effectre June 7, 1985), seams to indicate that grout injoction into tronohes is not prohiblted. Wo do not propose to place the grout into ground water. The grout will be conflned strletly to trenchas whose floors lia about 20 foet above the watar table. Whan the grout sats, about an hour aftar injoction, it is no longor eluld and there is no possiblitty of lts migration to the water tablo.

(10) "Does the acrylamide base grout contaln monomer which 1 s toxic? Given the proximity to the Emergency Wasto Basin and a crook which flows into whito oak Lake, what moasures wili bo taken to prevent possible release of contaminants to surface or ground water? Does the grout contaln any other toxic constituents which might be released to surface or ground wators?"

Yes, the mafor component of the grout, acrylamide, is toxio as dofined by EPA regulations. We plan double contalnment of the grout during its preparation and mixing and pouring into tho tranches. The portable liquid mixing and storage tanks will be contalned within a "Port-a-Berm" which is a self-supporting 11quid contalnment pond of sufficient capactey that should all tanks break simultanoously, tho fluids could be contalned. The polymerization catalyst, ammonium persulfate, will be on site so that dotoxifloation of any spilied acrylamide can be performed by inftiating polymerization. The polymer is nelther toxio nor hazardous. Subsequent blodegradation of the polymer is extremely slow and produces no toxic or hazardous products. Posslble release to ground water is protected by the same double contalnient: system. Possible release to ground water as a result of injection is controlied by the set time of the grout. As when we performed trench grouting in 1986 , ach basch of grout and catalyst is tested before injection to verify that the set time is less than one hour. Thus, there would be inadequate time for 
TDHE Commonte and Roplitos 7

tha grout to raah tho wator tablo bafore set oven at maximum ground wator valooltlea of weters por day whloh have boon obsarved in fractures in tha soll formation within SwSA 6.

The grout lo contalns mathylonablsacrylamlde (a polymer oroso-linkling agant) whose toxiolty would be alinilar to the aorylamlde. The othor conatitunta of tha grout aro not classlfied as hazardous or toxio. These 1nolude the ammonium paralfata (tho oatalyat), triothanolamino (tho radioal transear agont), potassium tortiayanide (tho at rotardant). Unilike our provious uas of this grout, wa do not plan to las a triothanolamine grade which ontalns thylone glyool as a freazing point deprossant.

(11) "providn opocifios ragarding, "grout verifleation tosting" mathod $(\theta)$."

Th1s was mant to rofer to Tablo l whlch lists the grouting verifloation and ovaluation methods. Theso mothods inoludo measurements of tranch hydraulio conduotivity before and after grouting and volumetrio vold tilling oaloulations. We have alraady porformed tranch vold measuraments, us discussed in 1 tem (8) above. After compaction, we will datarmine what fraction of thase volds have boun coliapsed via olovation ourvays of the land surface depreaston. The differenco betwoen these two measurements will be a masure of the remalning volds in the tranch. From our measurements of the volumes af grout actualiy placed into oach tronch, wo should be ablo to ovaluate the dogrea of fliling of these rasidual volds.

Because wo have boen spocifically prosortbod from puteing - ven small amounts of water into burlal trenches, the measurement of hydraulic conductivitios before and after wili be difficult. Hopofuliy, the injection of the grout itsalf can bo used as a masure of the before hydraulic conductivitios. It would be quite advantagooua to know what the finjaction well fluld acceptance rates will be before we inject because that would allow us to plan our work schedule and regulate set times of the grout accordingly. We could also measure the post grouting hydraulic conductivity with grout but that is a one-shat ovaluation, sinca onco the additional grout sets, further measuraments over time are meaningless to interpret any change in grout porformanoe. However, if we are fortunate as we have been in provious grouting dotonstrations, post grouting hydraulic conductivities approach zoro (unmeasurable). In that ase, we may bo able to put water into the well oasing, demonstrate that it does not flow out into the trench, and ramove the sama volume of watar so that there is no net injection.

\section{Gover censtructen Phase}

(14) "Why was 6 inches of bentonte selucted instead of clay?" 
He selocted bentonite, which is a clay, over local deposits because we do not have geotechnical information on the hydraulic propertios of local clays. Bentonite would be the pramium grade of olay for cover construction and, without an extensiva program of hydrulic testing, its use would prasent no compromige in the assurance of the quality of materials. Obviously, 1 t is more oxpenalve than local clays. But the cost of geotechnical testing for use in such amall-soalo domonstration exceads the extra costs assoolatad with procuring the premlum bentonite.

(15) When the swoling of the 6 inches of bentonite occurs will adequaten expansion of the geo-textile fabric be avallable to provant tearling or ripplag? How will this be monitoring or detoctod?"

Tho sole function of the goo-textile fabric is to provide a matarials soparation and, in the caso referred to, this in betwoen the bontonite and sand layers. This materlals separation 1s required malniy during the construction phase where we will be placing a spociflc thicknoss of sand over a potentialiy moist and allppery bentonite. The tachnical specifications of the fabric are glvan in the Appencix of the plan. Its tensile strength, a longation, and puncture rosistance are quite large and would be ablo to ondure the swelling prossures of the bentonite. One of 1ts mafor commerclal usos is in distributing loads over unstable ground, 1.e., roadbod support. It is extremely permeable and is not designed for paroolation protection. During construction of our proposed cap, it will function to distribute the load of cobbio so that penetration of the bentonite does not occur rosulting in a nonuniform thickness.

\section{(16) "Why not use the noutron probes at different levels?"}

The position of the neutron probe access tubes is directiy below the percolation barrier. Thelr sole purpose ls to detect possiblo molsture Eluctuations in this region (1.e., barrier fallura). Putting them at different levels would not supply additlonal information. It would, however, ralse an additional hazard in their construction. Putting the tubes fust below the cap roquires a 'ditah witch' trench, about 6 linches deep, to be placed across the site. To go any deeper, would entall digging down into the depth interval of the buried waste which we would prefer to avold. We have additional vertical accas tubes planned for the soll and cobble levels of the cap. But tubes should not penetrate the percolation bartier because that might compromise its function.

(1.7) "Re: 2.8 Soll Cap, where in the plans is the drainage ditch 11lustrated? To what plans does this sentonce refer?"

This sentence refers to the plan drawings (See sheet 3 of 3 ) 
TDHE Comments and Replies 9

which should have been recelved with the text of the plan. The ditch is a small iltch to colloct and route surface runoff froa the cap to our monicoring point.

(18) What will be the flnal slope of the cap? What will be the stablitty of the cap, glven the steepnoss of the current outslopes? Will the cap remain in place permanently? If not. how long is it expacted to romain in place? What is the final fate of the cap?"

As depicted on the drawing ( Sheet 3 of 3 ) the cap w111 slope 18 In both the northwest and southeast direction peaking in the middle. The cap 111 also slope 1 toward the northease over about $3 / 4$ of 1 s longth and increase to 7 at the oxtreme northeast. This sloping pattern was designed to routa all surface runeff to a single tonttoring point for gaging. The proposed cap is over the five trenches in the extreme northeast section of the TARA site where the hillock widens out noticeably. The outslopes in this area are not particularly steep and no ground instability is anticipated. This is contrasted with an earlier version of the plan. Which encompassed all 19 trenchos at the site being capped, where the steep and narrow part of the hillock to the southest would present stability problems.

Unless there a gross faflure in performance, the cap is designed to be permanent. It is planned to monitor its performance through site water balances and dynamics for at least five years. At that time, presuming 1 t is still performing well, its continued monitoring would be integrated with the total swSA 6 post-closure monitoring.

(19) "What parameters will be monitored for the surface waters carried by the ditch?"

It is planned to menitor regularly only flow and suspended sediment in the surface runoff. On a quarterly basis, we plan to screen runoff samples for gross alpha, beta, and tritium and gross quality characteristics (i.e., pH, e.c..d.o.,hardness, alkalinity, and acidity). Since ali cap materials will be clean, no contamination in its surface runoff would be expected. The main reason for measuring flow of this runoff is to construct a water balance for the cap and to determine its rate of erosion from the amount of suspended solids carried off.

(20) "Kentucky 31 Fescue alone is inadequate. A quickly establishing annual rye and a legume should be included, species dependent upon season of seeding. Annual evaluation of vegetative success and annul fertilization should be included in the plan."

The plan can accommodate whatever type of quick vegetative cover is preferred. We can include some annual rye and a legume, such 
a white clover or alfalfa, with che fescue. Its main purpose was to prevent eroslon of the soll cap while the treas are gecting ostablished in the flrst few yoars. (See 1 tea 21 below). The plan does laclude an annual evaluation as implied by the -valuation wethods in Table l. Thlo ovaluation includes bove ground blogads and groveb aeasureant. inspection of survival and aolsture croas stefus and vegocation sapling for analysis of stontlum and cestum tractis placed beneach the percolacton barrier. Thls lateer analysia will be perforaed to establish vather or not root Intrusion bas occurred through the percolation berrier. The ceslua and erontium are nelcher toxic nor hazardous and axe present only ac trace background lovels in vegetation. Thus. such sapliag offers faclle and safe method to asuas possible barrlar fallure. Annual fertilization will not composise any project goals and will bo included in the plan.

(21) The establishaent of trees on this cap is unacceptable. If troes are to be ovaluaced it should occur on "cold" denonstration site where the consequences will not potentially be onvironaontally haraful."

We will concede to this prescription and modffy the plan so that soll cover contains only grasses and legumes and no woody species. We bellove that the basis for this objoction to trees 1103 in the common alsconception that tras are deep rooted and pasture species (grasses and legumes) are not. Both trees and forage spectes can be lther deep or shallow rooted depending on soll horizon charactaristics much more than spacies characteristics. We feel that the cobble, bentonite, and liner layers would offer sufficient resistance to root penetration by troes. But forage species on the soll cap will offer the same potential stresses to the performance of the percolation barrier. Thus, the experimental goals of the profect will not be compromised by the use of forage vegetation on the cap instead of trees.

It should be noted that, at some point in time, all of the caps on all of our hazardous and radioactive waste sites will be covered with trees. This will occur whenever we abandon these sites. Our goal in originally proposing to use trees on this cover was to disprove the common misconception about trees so that we do not have to go about continualiy maintaining these caps under the prejudice that keeping trees out is doing some good. Whatever cap is finally placed over our hazardous and radioactive waste sites will have to resist root penetration whether by trees or grasses. Our desire to perform the tree vegetation on a 'real' site was motivated by the common reaction of so many people that, when a 'cold' test is performed, significant skepticisin always remains because "you haven't done it on a real site." Obviously, had the TARA trees become radioactively contaminated, we would eradicate them similarly to 
TDHE Comments and Replies 11

what wo would have to do if any vegetative cover over a capped araa became contaminated. A change to tree cover on the TARA cap can be ade at any time in the future whenever the times will allow 1t. So, for the present, we will plan to establish only forage species on the TARA cap.

(23) The mulch rates are inadequate at $100 \mathrm{lb} / 1000 \mathrm{ft}^{2}$. They need to be 3 to 4 times the suggested rate."

The proposed nulch rates were simply taken from standard englneering speciflcations for finishing earthwork. The suggestion to increase the mulch rate will be followed. We will use 10 bales of straw instead of 2 on the cap and on interim covering before final cap construction. We will be watching durfing all phases of construction and, should insufficient mulching have occurred due to an arbitrary specification, we would have modified it as necessary.

(25) "An alternative cap-cover that provides high run-off and low infiltration is suggested in NUREG/CR-4918 Vol. 1 , Control of Water Infiltration ince Near Surface liW Disposal Units, by $R$. $K$. Schulz, R. W. Ridky, and E. O'Donnell. How does the proposed TARA cap compare?"

The referenced NRC 'cap' offots no protection to either root or burrowing anfal intrusion and has no subsurface percolation barzier. It is essentially a roof over the ground with trees (Junipers) planced in holes in the roof to dry up any moisture that might leak through the roof. The ancept implies active roof maintenance. [The liners depicted in sketches within the subject report are not part of the cap concept but are there solely to collect and estimate of any water which may penetrate the cap.] No protection for lnexusion into the waste by the Junipe: roots is presented. It should also be noted that this NRC cap is a high runoff cap while the TARA cap is designed for low runoff. We believe that caps over large areas of ORNL disposal areas will need to be low or delayed runoff types. Otherwise the increased runoff for a large area, e.g. ten acres, will represent a significant erosion hazard for adjoining areas. We believe that the TARA cap is superior in concept and design to the referenced cap.

Comments Related to All Phases

(1) "How were the priorities determined for corrective actions?"

There has been no determination of prioritles for corrective action. We will not know what corrective actions may be required for the TARA site until the RI/FS for SWSA 6 is completed. In other words, we have little idea what the inherent hazard of doing nothing to the TARA site is. But we are reasonably sure 
TDHE Comments and Replies 12

that whatever corrective actions may prove to be required at TARA will encompass stabilization and closure techniques less than or equal to, but not greater than, what we have proposed in this demonstration. Our goal is to determine the effectiveness of each component of stabilization and closure so that any benefits for large-scale closure can be pursued with confidence rather than discarded due to lack of proven effectiveness. We need to know whlch components of a cover or cap work and why, not that a multicomponent system succeeds or falls without knowing why. This is an experimontal closure to help us do the real thing right. We may make mistakes on a little area like TARA but that is a risk we believe we must take so that we do not make mistakes on our larger problens.

(2) "It is unclear how the inftial TARA activities will mesh with the closuro plan for SWSA 6 ."

As of the date of this writing, we do not have a closure plan for SwSA 6. At the time the TARA plan was prepared, we believed that we had one but that was judged to be unacceptable by EPA. The TARA activities will mesh with whatever tha SWSA 6 closure plan turns out to be. The technical information of the - ffectiveness of dynamic compaction, grouting, and their comblnation, as woll as cover performance data, should be valuable to planning the stabilization and closure of SWSA 6 and all the other SwSAs which will eventually have to closed. If the motivgion for this question centers on how physically the demonstration site will mesh with the rest of the site, we do not know specifically. Presumably, the five trench cap will remain because there are probably miny ways to integrate it with whatever must be done over the rest of the site. Physicaliy, it poses no more of an obstacle than a buliding, road, power line, or dralnago ditch. The technical information will be the most valuable product we gain by testing techniques on less than is of the burial trenches in SwSA 6 .

(3) Does data collected to date assure hydrologic isolation from the other burial sites, or merely indicate that such a condition is likely to exist?"

The data collected to date do assure hydrologic isolation of the flve trenches to be covered from other trenches in the area. When trench 6 ( 1 .e.. the western most trench to be covered) was filled with water, no water was observed in trench 7 just to the west. This observation provides excellent evidence of hydrologic isolation and could not be attained without water filing tests. The water table in this region also is isolated from the western region. Pump-in tests at the five trenches to be covered did not produce a response in wells on the western side of the TARA site and did produce a response in wells on geologic strike (i.e., the direction roughly parallel to trench orfentation). Therefore, it 
TDHE Comments and Replies 13

seems assured that percolation on the western side of the proposed five-trench cap will not influence moisture within the five covered trenches or the water table below them.

(4) "Tho fact that the most significant vector for infiltration is vortical does not proclude a horizontal influence. Please address this possibility."

We agrea strongly with this statement. We believed that we had to establish this hydrologlc isolation of the trenches to be covered particularly from possible lateral recharge. Our water pump in tests, as discussed above, clearly eliminate such a possibility for the trench area to be covered.

(5) "Why cap only 5 of the trenches? How will the 5 trenches be hydrologlcally (both surface and ground) separatod from the remalning 14 tranches? Why was the retaining wall deleted?"

Perhaps a brief history of the evolution of this project would explain this issue. Initialiy, it was planned to carry out this demonstration of stabilization and closure techniques on all 19 trenches at the TARA site. However, in order to contain a cap over the western half of the site, lateral support would be required to prevent it from slipping down the steep slopes on the northwest and southeast sides. The instability of the present slope is quite apparent from the leaning of the perimeter fence on the northwest side of the site. However, in order to produce sufficient 'toe' for a possible retalning wall in this area, the helght of the wall became large (1.e., 26 feet). With no feasible means of supporting the hillside during the construction of such a wall, it became apparent that the wall was not buildabla. It became moot issue that the wall, wera it bulldable, would cost over a million dollars (labor and materials). However, on the eastern side of the site, the hillock widens noticeably and, we concluded that the cap was possible without any additional lateral support in this region. Thus, we scaled down the project to what was possible. We believe that we can gather sufficient information on the stabilization and closure of these five trenches to attain the project goals.

The orfinal scope of the project called for stabilizing all 19 trenches at the TARA site. Such a scope was necessary because, at that stage of the project, we had no evidence for the hydrologic isolation of any subunits at the TARA site. Thus, the compaction, grouting, and covering of all trenches would have been necessary. However, our site characterization efforts, particularly the water pump-in tests last fall, have established the isolation of the five trenches on the eastern side. Thus, the project was scoped down to these five trenches. The remaining 14 trenches, like the other hundreds of trenches in 
TDHE Comments and Replies 14

SWSA 6, will have to awalt the completion of the RI/FS before their stabilization and closure can be attempted.

(12) "Given that numerous wells are to bo lingalled, 1.e. intra trench observation wells, etc..., wil of prane of plastc be placad beneath and around driling ring to minimiza any dispersion of liquids and facilitate site/elen-up?"

Yes, during driling, plastle sheeting was used under both the drili stem of the rig and the engine section to contain possible hydraulic fluid leaks. These procedures are detalled in the profect Activitios Description Memorandum (ADM). The procedures for waste handing from drililing operations are also described in the ADM. For intratrench wells, we have employed a technique of driving woll points with stainless steel casing. This technique produces no drill cuttings and was devised to avold the hazards of bringing unknown and radioactive trench contents to the surface.

(13) "Should the removal of any liquids or contaminated soil from the trench occur during driling or other operations, how wil these be handled?"

The only fluids, which have been removad from the trenches, have boen few samples (approximately $100 \mathrm{~mL}$ ach) during and after trench filling experiments. We have no plans to sample trench contents. See ltem (9) for a discussion of soll contamination probable during site grading operations and contingency plans.

(22) "Additional information is needed regarding the speciflcations of the monitoring system. This is particularly important for the angled monitoring wells."

At the time the original draft of this plan was produced (September 1986), no new monitoring wells had been installed at the site. The 13 new wells were installed in the spring of 1987. Construction details, locations, development procedures, and sampling procedures are now available but were not available in the original the plan. When the scope of the project encompassed all 19 trenches, almost all of these monitoring wells would have been sacrificed so that none would protrude through, and potentially compromise, the area cap. Thus, after cap construction, new angled wells were envisioned which would give access to the water table under the cap from the surrounding hilislopes. However, with the smaller area to be capped, most monitoring wells will now not need to be sacrificed. We have also devised a method to continue use of the two existing wells which will be under the soil cap. These wells will be cut at the grade below the percolation barrier. Sampling tubes and pressure transducers (for water table monitoring) will be placed into the 
TDHE Comments and Replies 15

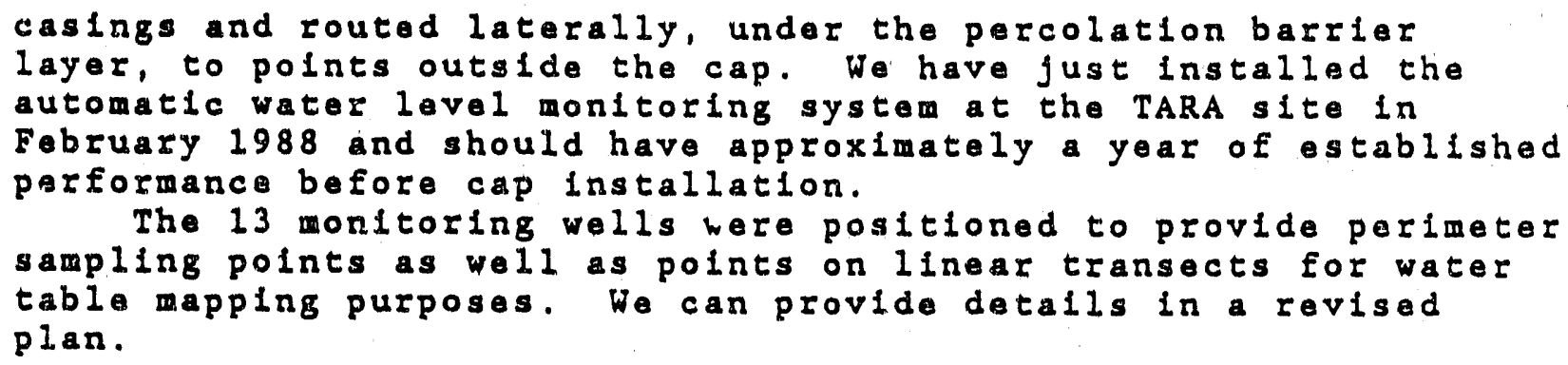


TDHE Comments and Replies 16

Addendum

November 2, 1987

Questions concerning the flling of selected trenches with water at the Solid Waste Storage Area (SWSA) 6 Test Area for Remedial Actions (TARA).

\section{B. P. Spalding}

Please excuse the dialogue format but I thought 1 t would be the most stralght forward approach to document how we have addressed the many obvious concerns about filling burlal trenches with watar.

Why is it necessary to flll radioactive waste burlal trenches with water? There is a consensus that the goal of remedial actlons is to keep water out of the trenches. So why do you deliberately put water into trenches?

The purpose of filling selected trenches with water is to obtain a diect measure of the vold volume within these trenches. When the seven solected trenches (out of a total of 508 in SWSA 6) are dynamically comacted later this fiscal yoar, surface depressions will result whose volume can be determined by surveying

techniques. By comparing the depression volumes to the trench vold volumes from the water filling, a quantitative measure of the effectiveness of dynamic compaction will be obtainod. It is also planned to grout these compactod trenches later in the fiscal year. The effectiveness of grouting will also be evaluated using the water filling volumes. The difference between the total tronch vold volume and the compaction crater volume will be a direct measure of the volume of grout which the trench should require to flil its remalning volds. The volume of grout, which can actually be placed into the trench, can then be compared with the grout holding capacity of the trench.

Has not the effectiveness of dynamic compaction been evaluated previously? Why is it necessary to repeat these water filling experiments?

Yes, dynamic compaction was evaluated by the above procedure on one trench in SWSA 6 in 1985. It was found that 64 of the total trench vold volume could be collapsed by dynamic compaction. This degree of trench compaction made the trench similar to the unperturbed soli formation and represented a very promising result. However, we are not sure how representative this one sample of 508 trenches really is. In addition, the 1985 trench was not grouted and we have no quantitative information on just how compatible dynamic compaction and grouting might be. In the various SwSAs, we have approximately 2,000 burial trenches for which dynamic compaction and selected grouting will probably play an important role in final stabilization. Without additional 
Tranch Water Filing 17

evaluation on the afectiveness of these techniques, we could fall into two possibly undesirable situations. Wo could be misleading ourselves, based on our limited experience, as to the effectiveness of dynamic compaction. If In actual practice, dynamic compaction proves less effective, we could wasto considerable money implementing trench stabilization which is tot effective. Jithout evaluation, we would not know about our lack of effectiveness for many years when the trenches would begin to manifest additional subsidence. Alternately, if dynamic compaction is more effective than our experience to date, then grouting may prove to bo unnecossary for mast burial trenches. The only way to proceed is to bulld more experience and quantify $1 t$.

What would be the consequences of not performing these water fill1ng tasts?

From a Iimited perspective, the question is moot. We have completed all the filing tests planned at the TARA site. Post-compaction evaluation will involve water acceptance tests, not complete fliling, of the dynamically compacted trenches. Such tosts will involve pumping in fow galions of water to measure the acceptance rate of the trenches in order to ovaluate the possible hydrologic effects and to plan the grouting procedures. In a larger perspective, it may be necessary to perform such tests in other swSAs so that the question is not moot. If we do not have the quantitative evaluation of the effectiveness of these techniques, the RI/FS process will be affected. When performing a feasibility study, techniques with unknown offectiveness get poor marks when compared to lternatives (e.g., exhumation, treatment, and redisposal) regardless of coses. In situ stabilization and isolation techniques aro infrequently chosen in fasibility studies of both hazardous and radioactive waste sites because of poor documentation of effectivans. We believe that they may prove equaliy effective to exhumation and redisposal and pose considerably less risk of contaminant dispersal. Without such qualitative analysis, however, we are left only wich our favorable dispositions and intultive judgments.

What are the risks of fliling these trenches with water? Do you not exacerbate leaching of radionuclides? How bad have you made the situation just to get some information on how to improve it?

Typlcally, it has required about 15,000 gallons of water to fill an average TARA trench of about 700 square feet. In terms of equivalent rainfali or infiltration, this would amount to 344 inches of raln. This amount of water is probably more than these TARA trenches would see in 10 years. Although this impact seems dramatic, It should be pointed out that many trenches in other areas of swSA 6 routinely flood and receive an amount of water equivalent to our filling volume several times per year. The 
Trench Water Filling 18

TARA site is unique in that all of its trenches are well above the seasonally high wator table. However, several of the TARA tronches did have porched water within thom whon wolls were first installed last year. From another perspective, the total water applied to the site $(105,000$ gallons, $1.0 .7 \times 15,000$ gallons) is equivalent to 1.8 inches of infiltrated rainfali on the two acre site.

We monitor the water table elevation at the site and occaslonally have seen an upward response of some of the near. flold welis to filling tests. However, we did not see a response in the perimeter monitoring wells. We collect samples of the standing water in each trench after filling although no analysas are yet avallable for the present tests. We are not, however, proceeding blindly to the possibllity of accelerated leaching of radionuclides. In two provious tests of trench filing, we observed no lmpact on leaching from the tranch. In 1986, two small trenches in swSA 4 we filied with water as part of a grout ovaluation. In twalvo wells within throe foet of these trenches, wo obsorved no radioactivity (hard beta and/or alpha) ither bofore, after, or during the fliling. Nor did we observe any incroase in the dissolved radloactivity within the tranch. In 1985, during tho filing of the trench in SwSA 6 prior to 1 ts dynamic compaction, leachate concontrations within the trench were not changed. Radioactivity is groundwater outside the trench was not affected. Glvon the high distribution coefficlent of most radionuclides between SWSA soli and groundwater, these rosults are not too surprising. It ls our common observation that radionuclides, other than tritfum, wove quite slowly in so11. Where SWSAs are discharging Sr-90 or Cs-137, it is usually due to trench overflow and resulting gurface runoff not groundwater leaching. We are particularly careful to avold overfiling the trenches during a test for just this reason. In summary, we belleve the risks to be low and the beneflts to bo high. But we are strongly aware of the risks.

Are there not other ways to make these measurements and evaluations?

No, none that we are aware of. We have other methods to evaluate dynamic compaction (e.g., penetration resistance testing). Unfortunately, these do not, oven indirectly, measure void collapse. We could concelvably increase penetration resistance without a collapse of the majority of volds although this would seom unilkely. The ponetration resistance hopefuliy will be correlated with the measured vold reductions. We need that inforiation so that penetration resistance can be employed for routine ovaluation of dynamic compaction during actual SwSA-wide application. Hopefully, penetration resistance will become an effective and inexpensive evaluation technique but only after the correlation has been established.

Alternately, we have considered gas permeation but have not found a viable cechnique. Gas permeabilities in soil are usualiy 
Trench Water Filing 19

several orders of magnitude greater than those for water. It is unlikely that the tranches would be tight anough to determine volumes by pressure testing such as is done with underground tanks. Fililng with a fluid, which subsequently can be removed or allowed to drain away, seens to be the only approach to make this detormination.

Is anything else learned from water filling besldes vold volume?

Yos. We determine vold volume as a function of trench depth. This documents where volds are located. In the previous test in SWSA 6 , the greatest vold volume was located just benoath the three foot thick soll cap. We also determine the hydraulic conductivity of the soll formation in which the trench was placed. The variablilty of hydraulic conductivity with depth is also determined. These measurements are valuable in modeling the hydrology of the site. We also learn the directional effects on water tablo response which usually corrolates with the geologic structure. Such tests aid in the placement and monitoring frequency of groundwater wells. The response of adjacent trenches to a tronch filling also provides us with information on the hydrologic connection between trenches In one case, we fliled an adfacent trench simultaneously which is why we filled seven instead of the plannod six trenches at the site. In other work, not related to TARA, groundwater tracers have been introduced into trenches during water filiting. 
OAK RIDGE NATIONAL LABORATORY

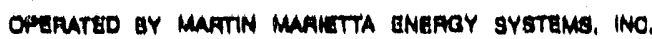

POST OPFICB BOX $X$ OAK RIDCAR, TENNESSES JTEI

May $17,1.988$

Mr. Rodger A. Jump, Manager

Waste Management Branch

Department of Energy, Oak RIdge Operations

Post Offlce Box 2001

Oak Ridge, Tennessee 37831

Deax Mr. Jump:

Notification of Federal and state Regulators of Initiation of Dynamic Compaction in Solid Waste Storage Area 6

The draft Task Plan for the Shallow Land Burial stabilization and Closure Demonstration at the Test Area for Remedial Actions (TARA) in Solid Waste Storage Area (SWSA) 6 was submitted to the Tennessee Department of Health and Environment (TDHE) and the U.S. Environmental Protection Agenoy (EPA)-Region IV on September 30, 1987. Comments on this plan were recelved from TDHE on February 1, 1988, and modifications to the plan were made in a formal reply (enclosed) on February 22, 1988. To date, we have recelved no comments from EPA and have recelved no response to our comunents from TDHE.

In order to Initiate this activity this year to gain the critical information we need to plan stablization and closure of SWSA 6 and other areas, we propose to initiate the first phase of this stablilzation demonstration, the dynamic compaction of five shallow land burlal trenches at TARA. Because we cannot control the schedule for commenting by either EPA or TDHE and because formal written approval for these activities could probably never be obtained, we propose that you notify these agencies of our intent to start the dynamic compaction phase on June 20,1988, invite them to come watch this activity, and notify us if they do not want us to perform this activity. Such notification and offer of "right of refusal" is the only method that we perceive to get approval by default.

Enclosed is a suggested text for such a transmittal to TDHE and EPA-Region IV. Early transmittal should afford them adequate time (30 days) in which to respond to you if they decide that our planned dynamic compaction activities are objectionable. If you have questions, please feel free to concact me $(6-4438)$.

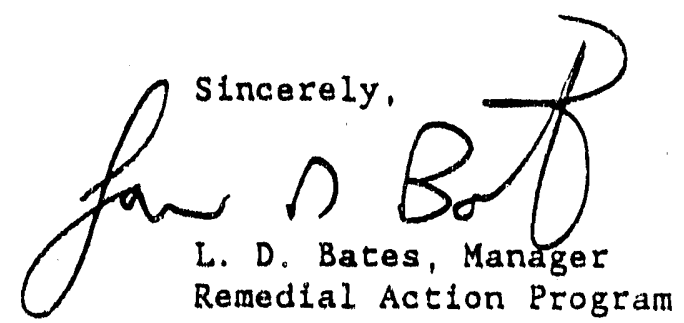

LDB:bps 
Ericlosures (3)

1. Suggested Text

2. Draft Eimal Plan for the Demonstration and Eysluation of Stablifization and Closure Techniques for Low-Level Waste Burlal Irenches at Oak Ridge National Laboratory. ORNL/RAP-42

3. TDHE Comments and Replies co/enc:
E. C. Davis:
J. R. Lawson
L. W. Long
L. E. MoNeese
T. H. Row

R. C. Sleeman

B. R. Spalding

J. E. Van Cleve

FII. - LDB (2) 
STATE OF TENNESSEE

\section{DEPARTMENT OF HEALTH AND ENVIRONMENT 1605 PAOSSEA ROAD KNOXVILLE, TENNESSEE 379143434}

June 30,1988
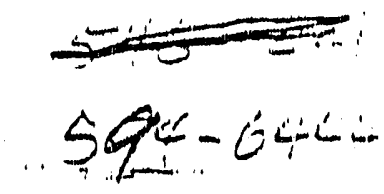

Mr. Rodger A. Jump

Waste Managewent Branch

Department of Energy

Post office Box E

Oak Ridge, Tennesget 37831

RE: Test Aree Remedial Action (TARA) Demonstration

Demonstration at Solid Waste

Storage Area (SWSA) 6

RECEIVED

Jut:- 1988

L. D. 淂男

ID

011685

FIIE TIC

HOLD

Dear Mr. Jump:

The Tennessee Department of Health and Environment (TDHE) recuived Oak Ridge National Laboratories (ORNL) response to our comments of February 1 , 1988 on March 25, 1988. I received a letter on May 31, 1988 from Mr. Brian Spalding of ORNL adviaing TDHE that compaction of the five (5) trenches at the TARA gite in Solid Wagte Storage Area (SWSA) 6 would occur the week of June 20,1988. The attached comments represent TDHE's reply to ORNL's response of March 25, 1988 and outline unresolved concerna. We recognize the activities as outlined are ongoing, however we anticipate ORNL's acknowledgement and response to our concerng and that activities on site will accomodate, as appropriate, the following TDHE coments:

(1) Concurrence is provided by TDHE on the value of this project as a d ronstration to assess the desirability of compaction and glouting - dative to trench tabilization and avoidance of subsidence. However, this technology should not be adopted on a larger acale until a thorough assesswent of the results of the demonatration has been performed and concurrence provided by TDHE.

(2) Additional characterization of the leachate is necessary. Quantities of disaolved organics in the mg/l range are conaidered to be significant, as most RMCL's for these compounda fall in the low ppt range.

(3) An assegsment of the effect of the dynamic compaction on the incegrity of the subourface ocrata is recomended. The posaibility of creating fractures which might provide new pachways through the substrata into groundwater must be asgessed. 
(4) Because this technology may be used in closure activities, it is important to determine the fate of liquids in the trenches, not only as protective measures in this demonstration but as a predictive measure in later demongtrations. The focus of this demonstration should be to provide evidence that the technology is useful or applicable to a wide variety of trench conditions. The results should be asaessed as applicable not only in this narrowly defined situation, but for a broader range of considerations reflecting the most comon condicions of trenches in SWSA 6.

(5) It appears additional clarification of State UIC regulations is needed. (The use of these fluids may constitute a Class $V$ injection well under Chapter 1200-4-6-.06(5)(J). Class V injection wells are only atuthorized by rule, if the operator can meet the conditions specified in $1200-4-6-.14(2)(a) \&(b)$. The Division will require a permit if the class $V$ well has. the potential to violate water quality criteria as specified in 1200-4-6-.14(4).

(6) Were the bulk quantities of solvents poured into auger holes or are they suitably contained and stored in these auger holes? (Page 3)

(7) Scanning a core section with GM tube could, at best, give an indication of a very gross radioactive material contamination. The inclusion of this, as a measure of radioactive material contamination, indicates a lack of undergtanding of good health physics or radiation detection. (Page 5)

(8) The risk associated with additional sampling is worth the effort to collect additional information. It would be of great benefit to understand what is happening in the trench and under it. Why can't access tubes be laid in longitudinal to the cap? (Page 8)

(9) Are the cesium and strontium radioactive? DOE should do analyses on fertilizers, otherwise $U$, Th, or other macerials may show up from that source. (Page 10)

(10) The discussion on Page 12 supports the Division of Radiological Health's coments and ideas for more extensive monitoring for any and all demonstration projects. (Page 12)

(11) "No radioactivity" is defined as no "hard beta and/or alpha." What about soft beta, e.8., H-3 or gama? (Page 18)

Your response to our previously nored concerna ia appreciated. We anticipate continuing to assess the desirability of these technologies.

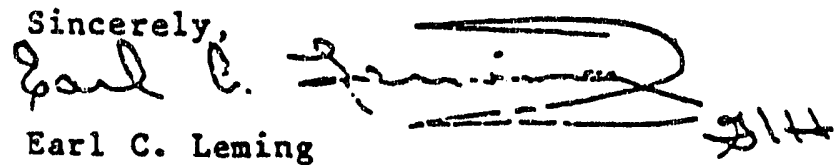

DOE Project Coordinator

ECL/GIH: arb/DWM 1B2

$$
\begin{aligned}
& \text { W.E. Hibbitta } \\
& \text { T.D. Bates, ORNL } \\
& \text { W.E. Cantrel } 1 \\
& \text { Dave Hopkins }
\end{aligned}
$$


OAK RIDGE NATIONAL LABORATORY

OPERATED BY MATTIN MARIETTA ENERGY SYSTEMS. INC.
POST OFFICE BOX 2008

OAK RIDGE, TENNESSEE 37831

December 14,1988

Mr. Tom J. Wheeler

Waste Management Branch

Department of Energy, Oak Ridge Operations

Post Office Box 2001

Oak Ridge, Tennessee 37831-8621

Dear Mr. Wheeler:

Reply to Regulatory Comments on Task Plan for Test Area for Remedial Actions, Solid Waste Storage Area 6

Reference: State of Tennessee, Department of Health and Environment, Comments of June 30, 1988, on Test Area for Remedial Actions (TARA) at Solid Waste Storage Area 6

We are grateful for the comments of the Tennessee Department of Health and Environment (TDHE) on the subject project. We believe that we have accommodated these comments and concerns as described in the following specific replies. We would appreciate your forwarding of these replies to them. To facilitate comparison of our replies with their comments, we have repeated their numbered comments, in bold letters, prior to our reply and discussion of each.

1. Concurrence is provided by TDHE on the value of this project as a demonstration to assess the desirablifty of compaction and grouting relative to trench stabilization and avoidance of subsidence.

However, this technology should not be adopted on a larger scale until a thorough assessment of the results of the demonstration has been performed and concurrence provided by TDHE.

We appreciate the concurrence of TDHE on the value of this project. We do not plan to adopt either the in situ grouting or dynamic compaction on any scale larger than the originally proposed scale of the TARA. We too are anxious to perform an assessment of the demonstration results and will seek the concurrence of TDHE in that assessment before including this technology in any stabilization or closure plans at ORNL remedial action sites. The TARA Project plan is considered amended by any of the changes which we acknowledge in our replies to TDHE comments.

We would like, at this time, to modify the original proposed activities included under the in situ grouting phase. We had originally planned to perform the in situ grouting of the five TARA trenches which had been compacted the week of August 1, 1988. As discussed in conment (5), we will not initiate this planned grouting 
until concerns over underground injection control (UIC) regulations are resolved and TDHE and EPA concur on our assessment of the grout compatibility testing information. Assuming resolution of the technical concerns about in situ grouting, we would like to perform in situ grouting on, at most, three additional uncompacted trenches (No. 7, 8, and 9) at TARA. This additional grouting will provide us with data for a direct comparison of the effectiveness of in situ grouting on both compacted and uncompacted trenches. This information on grouting of uncompacted trenches would be most useful for application to other areas of SWSA 6 where the breaking of any ambient liquid containment in burial trench waste packages might pose a significant impact on groundwater quality following dynamic compaction. If such areas are identified during the remedial investigation of SWSA 6 , then in situ grouting, without dynamic compaction, may be more desirable for selected trenches or auger holes. Thus, a direct comparison of in situ grouting effectiveness, via a measurement of degree of hydrologic isolation, for compacted versus undisturbed burial trenches will be necessary. Our proposed modification of the TARA in situ grouting phase would provide this information. We see no new technical issues raised by this modification which have not already been addressed in the present proposed in situ grouting activities.

We would also like to grout one additional trench (No. 150) in SWSA 6 , but not at: TARA, to demonstrate an additional capability of the acrylamide grout. In August 1986, this trench was grouted by injection of a blend of Portland cement (398), fly ash (55.5\%), and bentonite (5.5\%). The grout take on this trench was excellent and accounted for all of the measured voids as derermined by a water-filling test performed prior to grouting (T. Tamura, et al., In Situ Waste Grouting of an ORNL Trench Using a Particulate-Tvpe Grout, 1987, ORNL/RAP-23). Good postgrouting penetration resistance was also exhibited by this trench indicating that good geotechnical stability had been achieved. However, water acceptance rates by monitoring wells within the trench were still significant although reduced from pregrouting values. It is concluded that the particulate-based grout filled all of the large voids but failed to penetrate into smaller voids which provided the residual features to conduct water through the trench. We believe that with a minimal amount of acrylamide grout (probably less than 500 gallons), these residual voids could be sealed and hydrologic isolation of the burfed waste demonstrated. The demonstration of the effectiveness of combining a cheap particulate grout to fill most trench voids with an expensive acrylamide grout to fill residuals may represent an extremely low cost stabilization technique for ORNL burial trenches. We propose to test compatibility of the acrylamide polymerization with both the grout and waste from this trench before attempting the acrylamide field demonstration. Samples from the trench were taken as part of the postgrouting evaluation and are avallable for testing. Compatibility of acrylamide with both cement 
and bentonite is well documented as these substances have been used as additives for acrylamide grouts to increase viscosity and strength. Thus, this small additional grouting could provide valuable information on potential stabilization techniques for selected trenches which, for whatever reason, may pose too much risk for the very cheap dynamic compaction technique.

2. Additional characterization of the leachate is necessary. Quantities of dissolved organics in the $\mathrm{mg} / \mathrm{l}$ range are considered to be significant, as most RMCL's for these compounds fall in the low ppb range.

We will have difficulty performing additional characterization of trench "leachate" as recommended. The samples of trench "leachate", which we collected, are somewhat artificial in that they were not "natural" standing water within the trenches. They were collected from the perched water in the trenches following the water filling tests. We have used these samples for radiochemical (gross alpha and beta and tritium) and gross chemical (pH, electrical conductivity, alkalinity, hardness, and total dissolved solids) analyses as well as for testing their compatibility with acrylamide grout (Item 5 below.). We have only limited amounts remaining $(<50 \mathrm{~mL}$ ) for the analyses of possible organic contamination. We will attempt to analyze our residual samples for volatile and semivolatile organics (EPA method 624) but the detection limits will be quite high because of the limited sample size. We will continue to monitor the trenches for transient standing water and will sample any "natural" leachate if possible. Only 3 of the 19 TARA trenches to date have exhibited transient standing water following sustained wet weather periods. We will also continue to monitor and analyze groundwater at the TARA site.

3. An assessment of the ffect of the dynamic compaction on the integrity of the subsurface strata is recommended. The possibility of creating fractures which might provide new pathways through the substrata into groundwater must be assessed.

We cannot, at present, provide any direct measurements to support an assessment of the effect of dynamic compaction on the integrity of subsurface strata. We anticipate no adverse effect on the shallow subsurface due to two generalized experiences with dynamic compaction. First, an evaluation of dynamic compaction for construction engineering planning (P. W. Mayne, J. S. Jones, and J. C. Dumas. 1984. "Ground Response to Dynamic Compaction" I. Geotechnical Engineering, $110: 757-774$ ) has led to the general conclusion that the maximum depth of influence of dynamic compaction (Di) is: 


where $\begin{aligned} D i & -(M, H) 1 / 2 / 2 \\ M & =\text { drop weight in tonnes } \\ \text { and } H & =\text { drop height in tneters }\end{aligned}$

For the TARA dynamic compaction, we designed a drop weight of 4 tonne $(\mathrm{Mg})$ which was dropped from a maximum height of 8 meters. Thus, our Di would be only 9.3 feet which, following an average of 4 feet of ground subsidence at the point of dropping in response to the dynamic compaction, would give a total depth of influence of just over 13 feet (approximately the burfal trench depth). This would put the depth of influence well above the water table at TARA which is a minimum of 35 feet below the ground surface in the burial trench area.

Second, the material in the zone of influence of dynamic compaction at TARA is soil or saprolite and not rock. In response to compression, the soil would be expected to deform plastically not brittlely. Thus, we anticipate that whatever hydrologically conductive features may be in the depth of influence of dynamic compaction, will be deformed plastically and result in a decreased hydraulic conductivity after dynamic compaction. This effect is exactly the same as the decreased hydraulic conductivity of clay during its compaction in the construction of a RCRA-type cover over a hazardous waste site. The difference, of course, is in the depth of influence of dynamic compaction versus the relatively shallow depth of influence of conventional surface compaction machinery. If dynamic compaction were used in an attempt to compact hard or brittle material, such as unweathered shale or limestone, fracturing would be expected; and the resulting new fractures would be expected to provide new conduits for fluid movement.

During the initial stages of the in situ grouting of the five compacted trenches at TARA, we will be able to calculate whole-trench hydraulic conductivities and compare these values to those determined during precompaction water-filling tests. Most likely, any subtle differences between pre- and postcompaction hydraulic conductivities will not be discernible. However, if this issue remains a significant concern, we could devise methods to test the influence of dynamic compaction on soll and saprolite hydraulic conductivity. Because of the destructive sampling methods involved, 1.e., excavations to sequential depths under a region of compacted surface, and the necessity to measure water intake rates into the subsurface, this activity would probably have to be performed in areas of SWSA 6 which did not contain buried waste. However, we would anticipate that a significant effect, either positive or negative, would not be detectable because of the inherent large variability in hydraulic conductivity from point-to-point in the Conasuaga formation (R. J. Luxmoore, B. P. Spalding, and I. L. 
December 14, 1989

Munro. 1981. "Areal Variation and Chemical Modification of Weathered Shale Infiltration Characteristics. Soil Sci. Soc. Amer. I $45: 687-691$ ).

4. Because this technology may be used in closure activities, it is important to determine the fate of liquids in the trenches, not only as protective measures in this demonstration but as a predictive measure in later demonstrations. The focus of this demonstration should be to provide evidence that the technology is useful or applicable to a wide variety of trench conditions. The results should be assessed as applicable not only in this narrowly defined situation, but for a broader range of considerations reflecting the most common conditions of trenches in SWSA 6 .

We agree completely with this comment and believe that the results of the TARA demonstration will be applicable to most of the trench conditions in SWSA 6 and other ORNL areas without too much ambiguity. We see only two general areas of concern in extrapolating the TARA results to the rest of SWSA 6 and other ORNL remedial action sites. First is the concern over the impact of the loss of any ambient liquid containment in buried waste packages following dynamic compaction. As we have emphasized previously, it seems unlikely that significant amounts of fluids were disposed at the TARA site. Nevertheless, we will verify the extent of radioactive contamination around all the trenches following dynamic compaction through extensive soil sampling following the sampling strategy employed for the precompaction characterization. (The precompaction characterization data is contained in a draft manuscript which should be released in final form by November 31 , 1988.) As discussed in our previous correspondence, we plan to gather the geotechnical data at TARA to quantify the benefits of dynamic compaction. These data will be applicable to all ORNL burial trenches. They will clearly define the benefits to be achieved in taking the risks of breach of liquid contalnment. Once, or if, the benefits of dynamic compaction are established, a TARA Phase II demonstration is planned to demonstrate and assess the environmental consequences of a breach of liquid containment during dynamic compaction. At this point, the planning for Phase II is only conceptual as outlined in the SWSA 6 Closure Plan. We would emphasize that whatever ambient liquid containment exists in SWSA 6 burial trenches for the unknown amounts of liquids disposed was not designed for any containment during disposal but only to get the material to the site. Thus, whatever containment of whatever fluids may exist in SWSA 6 will disappear sooner or later. Ambient containment will provide no environmental protection in the long term, and the protection of ground and surface water will depend entirely on the performance of infiltration and groundwater intrusion barriers. The performance of these barriers, in turn, depends heavily on the stability of their foundation which is the fundamental problem addressed by dynamic compaction. 
The second issue of concern regarding liquids in burial trenches centers on the applicablifty of dynamic compaction to inundated or partially inundated burfal trenches. Obviously, water in burlal trenches is not coupressible and would have to be removed prior to dynamic compaction. We are looking into methods of groundwater traatment, as part of the SWSA 6 closure Plan, as a technique of addressing inundated trenches prior to dynamic compaction and possible groundwater collection and treatment if contamination were to occur during dynamic compaction. Once water has been removed from a trench, its sultability for dynamic compaction would be equivalent to a burial trench in an unsaturated condition like those at TARA.

5. It appears additional clarfication of state UIC regulations is needed. The use of fluids may constitute a Class $v$ injection well under Chapter 1200-4-6-.06(5)(J). Class $V$ injection wells are only authorized by rule, if the operator can meet the conditions specified in 1200-4-6-.14(2)(a)\&( b). The Division will require a permit if the class $V$ well has the potential to violate water quality criteria as specifled in 1200-4-6-.14(4).

Our interpretation of this comment is that we must provide enough information to TDHE to show that our proposed in situ grouting at TARA "does not present a hazard to any existing or future use of a ground water classified pursuant to Rule 1200-4-6.05(1)." We have provided, under separate transmittal, detalled testing results of acrylamide grout reaction with samples of TARA burial trench soil and "leachate." In sumnary, we found that no burial trench bottom soil or leachate retarded grout set time nor was the degree of acrylamide polymerization affected in the presence of soil or leachate. The resulting hydraulic conductivity of polyacrylamide grouted trench soll was too low to be measured in the laboratory tests. We believe that we have demonstrated our ability to control the polymerization of the acrylamide grout and that no potentially interfering substances are present in the TARA trenches. It should also be emphasized that the proposed in situ grouting at TARA will be carried out at shallow depth well above the water table. The trenches at TARA were dug to a maximum depth of 15 feet below the surface, and the water table at the site is an additional $20 \pm 3$ feet below the trench bottoms. Grout injection will be limited to depths above the trench bottoms. Thus, because our proposed grouting will be in a zone not containing groundwater and because of our ability to control acrylamide grout polymerization, we belfeve that there is no hazard to the existing or future use of groundwater at SWSA 6 . 
6. Were the bulk quantities of solvents poured into auger holes or are they suitably contained and stored in these auger holes? (Page 3)

The contaminated solvents, which were disposed in SWSA 6 auger holes, were always contained prior to burial according to our conversations with former disposal operators. However, this contalnment was not designed for groundwater protection or suitability against environmental release. The containers were minimal, 1.e., whatever was necessary to safely transport the solvents to the site. The integrity of any of these containers should be regarded as suspect.

7. Scanning a core section with a GM tube could, at best, give an indication of a very gross radioactive material contamination. The Inclusion of this, as a measure of radioactive material contamination, indicates a lack of understanding of good health physics or radiation detection. (Page 5).

We agree that GM surveys provide only a gross estimation of radioactive contamination. However, the GM survey, along with alpha derection survey, provides our primary assurance for the health and safety of our field workers. Even when we observe no beta-gamma or alpha emissions in the field, we treat the soll samples as contaminated until low-level beta and gamma counting has been completed in the laboratory. Our reply in the March 25, 1988, comments was meant only to inform TDHE of what information we had about site contamination. At that time, we had just completed the field soil sampling but had not initiated the sample preparation for low-level coupfing. Since then we have completed the lownlevel counting for ${ }^{137} \mathrm{Cs},{ }^{60} \mathrm{Co}$, and $90 \mathrm{Sr}$. We have reported these activities in the draft TARA Project report which will be available in final form by November 30, 1988 .

8. The risk associated with additional sampling is worth the effort to collect additional information. It would be a great benefit to understand what is happening in the trench and under it. Why can't access tubes be laid in longitudinal to the cap? (Page 8)

We do plan to put neutron probe access tubes longitudinal to the cap, i.e., horizontal, to the ground surface. We also plan to use tubes at different depths within the cap. The tubes above the infiltration barrier will be vertical and situated at many positions within the cap area. The tubes under (within six inches) of the infiltration barrier will be horizontal and are designed co detect liner leakage or, to phrase it more optimistically, to verify the lack of leakage. What we found difficult in the original TDHE comment was what we interpreted as a suggestion to place additional horizontal tubes at greater depths which we envision would require excavation into the burial trenches. To avoid this hazard, we plan to construct at least one vertical well and neutron access tube inco 
each of the five trenches. Of necessity these will penetrate the various infiltration barriers to provide access from the surface. These vertical wells will allow us to verify the molsture condition of the trenches through time.

Assuming that the trenches are grouted with acrylamide, it is anticipated that neutron probe readings will indicate saturated conditions at all times after grouting. The polyacrylamide grout is 908 water and the neutron probe cannot distinguish between this bound water and free liquid water. However, the neutron probe roadings should allow us to verify that the grout does not desiccate under field conditions through time. The access wells, however, will allow us to verify that no free standing water is present in the grouted trenches and to sample any water which might be present.

9. Are the cesium and strontium radioactive? DOE should do analyses on fertilizers, otherwise $U$, Th, or other materials may show up from that source. (Page 10)

The cesium and strontium will not be radioactive. We will employ the stable isotopes of the elements, 1.e., just the routine chemical grade forms. Because $C s$ and $S r$ are present naturally at only trace levels in plarits (1.e., $<1$ and $<10 \mathrm{mg} / \mathrm{kg}$, respectively), they represent a safe way to detect any root penetration of the infiltration and biointrusion barriers via vegetation sampling. Neither element is toxic to plant growth and neither is classified as 7 a hazargous or toxic element. They are also ideal tracers for $137 \mathrm{Cs}$ and $90 \mathrm{Sr}$ which are the radionuclides of greatest concern for the performance of SWSA 6 .

We will also analyze whatever fertilizer we use for trace amounts of $U$ and Th. We will alse provide, in annual summaries of site performance, an assessment of what these small additions of natural radionuclides mean in terms of site performance and environmental monitoring.

10. The discussion on Page 12 supports the Division of Radiological Health's comments and ideas for more extensive monitoring for any and all demonstration projects. (Page 12)

We will continue our extensive monitoring of the TARA demonstration and will continue to modify our monitoring strategy to accomodate additional concerns as appropriate.

11. "No radioactivity" is defined as no "hard beta and/or alpha." What about soft beta, e.g., H-3 or gamma? (Page 18)

We have analyzed samples from the monitoring wells at the SWSA 4 in situ grouting demonstration site for tritium and, surprisingly, detected none unlike samples from the TARA site. Our low-level 
alpha-beta counter has a gamma detector which is used for colncident counting event rejection; but we do not report gamma affivity per sf. Our gamma-emitting isotopes of greatest concern, $13 \mathrm{Cs}_{\mathrm{Cs}}$ and 60 co, are also hard beta emitters. Because no hard beta was detected in these samples, we did not proceed to the next level of identification, gamma spectroscopy. This tiered samplo analysis protocol, saves us from doing a lot of unnecessary radiochemical analyses. It was not our intention in the discussion on $p .18$ to present details of our methods but only to point out that in past water-filling tests, we were in a position to detect any adverse environmental effect of these tests. Because no contamination was found in the surrounding groundwater monitoring wells before, after, or during the tests, we offered this information to support our assessment of the safety of the water-filling tests.

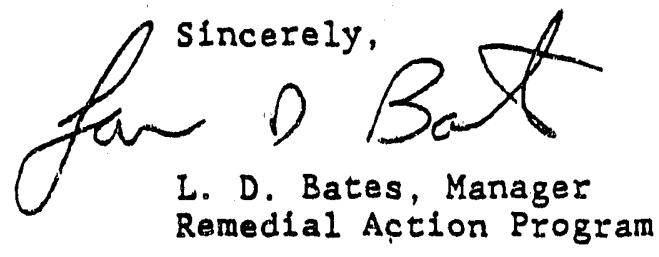

L.DB : ms (E121488)

cc: H. M. Braunstein

K. W. Cook

E. C. Davis

C. E. Nix

B. P. Spalding

C. L. Stair

file - LDB 
REGION IV

$34 S$ COURTLAND STREET

ATLANTA. GEORGIA $303 G 3$

\section{JUL 11 1988:}

REII: 4 WM-GP

Mr. Joseph A. Lenhard

Assistant Manager for

inergy Researdh and Development

Departiment of Energy

oak Ridge operations

P. O. BOX E

Cak Ridge, Tennessee 37831

Dear Mr. Lenhard:

The Underground Injection Control (UIC) Permits unit of the U.S. Environmental Protection Agency (EPA), Region IV has reviewed the information submitted on May 19, 1988, on the proposed demonstration project grout injection wells. Based on this review and the meeting between EPA and the Department of Energy (DOE) an June 24, 1988, we feel that significant concerns with the project exist.

In order to further assess the need for a UIC permit for this project, we ask that you submit existing information or prepare a written report on the Eollowing:

- Characterization of waste in trenches to be grouted;

- Characterization of surficial geologic conditions including soils, depth to the water table, and the uppermost aquifer;

- Compatibility of the grout with arious waste materials and fluids including the results of any bench or pilot tests;

- Results of past on-site demonstration activities;

- Past testing procedures and future testing procedures to demonstrate (1) successiul polymerization of injected grout and (2) non-migration of grout outside of trench; and

- Iong term stability of the grout including the effects of biodegradation and dehydration. 


$$
-2-
$$

After arr review of this infornation we would like to met with DOE to discuss any concerns we may have. If you have any questions, please call Ms. Annie codfrey, of my staff at 404/347-3866.

sincerely yours,

$$
\text { Willing/fayjor }
$$

underground Injection cantrol section

Ground-Water Protection Branch

c: Art Linton, Ervirommental Assessment Branch

$$
\begin{aligned}
& \text { lewing } \\
& \text { Hob6ift } \\
& \text { slecusen }
\end{aligned}
$$




\section{Stabilization of Waste Trenches bv Grout Injection October 6, 1988 \\ revised edition}

This document is to supplement information formerly submitted by P. S. Rohwer on April 22, 1988 which addressed requirements of the TDHE Rule 1200-4-6, concerning Class $V$ wells. Some questions about this demonstration project were raised by the EPA and are addressed in this document.

The proposed demonstration is part of the Test Area Remedial Action (TARA) project in ORNL's solid Waste storage Area (SWSA) 6 . The project involves the installation of a group of class $V$ well. The wells will be used to inject grout into the trenches, solidifying and stabilizing the waste. Figures 1-3 present the location of SWSA 6 and the trench locations.

1. Characterizalion of surficial geologic conditions including the uppermost aquifer, depth to the water table and soils:

\section{UPPERMOST AQUIFER:}

Solid Waste Storage Area (SWSA) 6 is underlain by the Nolichucky shale and Maryvilie Iimestone formations of the Conasauga Group. The formations strike northwesterly at 56 degrees and dip is to the southeast at angles between 30 and 40 degrees (Tucci, 1986) The Conasauga is heavily fractured, providing microscale conduits. The aquifer system is anisotropic: the or 1 ginal bedrock was impermeable, but subsequent folding and weathering has created a secondary fracture system which permits the movement of water in all directions. In the topographic high regions the unconsolidated zone is as deep as $12 \mathrm{~m}(39 \mathrm{ft})$, and the water table aquifer may extend $61 \mathrm{~m}(198 \mathrm{ft})$ below the ground surface (Davis et al., 1987 p. 91).

The hydraulic conductivity for the unconsolidated zone varies from less than $0.1 \mathrm{ft} /$ day $(3.5 \times 1.0-5 \mathrm{~cm} / \mathrm{s})$ to $1.0 \mathrm{ft} /$ day $(3.5 \times 10-4 \mathrm{~cm} / \mathrm{s})$. The anisotropy likely ranges between $1: 1$ to $0.333: 1$ (strike normal/strike parallel) (Davis et al., 1987, p. 92).

\section{DEPTH TO WATER TABLE}

Water table measurements have been taken by the U. S. Geological survey since 1975. Well number $367,256.55 \mathrm{~m}$ (841.7 ft) above mean sea level, is located in the trench area proposed for the grouting demonstration. According to the ORNL Remedial Action Database, the water level reading taken on January 8 , 1988, (during the wet season of the year when groundwater levels are the highest) in well 367 was $239.50 \mathrm{~m}(785.79 \mathrm{ft}$ ) making the depth to groundwater $17.05 \mathrm{~m}(55.93 \mathrm{ft})$. The hydrograph showillg the seasonal fluctuation in groundwater levels for 1977.1079 is presented in Figure 4 (Webster et al., 1980). The highest level recorded was approximately $14.5 \mathrm{~m}(47.6 \mathrm{ft})$ below ground 
surface. Data taken on January 8, 1988, from other wells located among the trenches yielded the following information:

\begin{tabular}{c} 
welly \\
\hline 1 \\
2 \\
3 \\
7
\end{tabular}

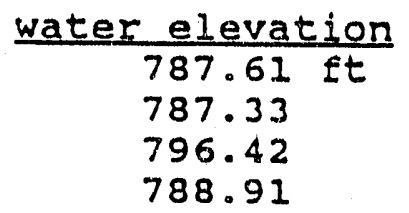

land elevation
$832.29 \mathrm{ft}$
837.27
838.13
839.38

\begin{tabular}{c} 
depth to water \\
\hline $44.88 \mathrm{ft}$ \\
49.94 \\
41.71 \\
50.47
\end{tabular}

The grout will only be injected to the bottom of the trenches. The trenches are $5 \mathrm{~m}(16.4 \mathrm{ft})$ in depth. During the highest groundwater level recorded, the bottom of the trench was still $9.5 \mathrm{~m}$ (31.2 ft) above the water tabie.

\section{SOIL CHARACTERISTICS}

The five trenches are located in rupeic ultic dystrochrepts: young soils with high silt content, intermittent clay enriched horizons and organic content. These soils are derived from the Maryville limestone. The slope ranges from 12-25\% and is weathered (Davis et al., 1987, pp. 31, 47-49). THe soil map is presented in Figure 5. The following tables are attached to provide additional information about the soils (Davis et al., 1987):

Table 1 Physical properties

Table 2 Engineering properties

Table 3 Chemical properties

2. Compatibility of the grout with various waste materials and fluids including the results of any bench or pilot tests:

Larson and May (1983) performed experiments to test the compatibility of various types of hazardous waste with grout. First, the effect of the various wastes on set time were tested. Adverse effects on set time were noted when the acrylamide was mixed with HCl solution (acid), ammonium and sodium hydroxid? solutions (bases), and cupric sulfate (salt). All were $10 \%$ solutions. No adverse effects were noted with ammonium chloride (salt) or several hydrocarbons: benzene, trichloroethylene, unleaded gas or oil (SAE 30$)$.

Secondly, Larson and May tested the effect of various wastes on grout that had already set. After twenty days, the wastes caused either shrinking or swelling of the grout: 
SHRINKING

Hydrochloric acid

cupric sulfate

\author{
SWELLING \\ Potassium Chromate \\ Ammonium hydroxide \\ Sodium hydroxide \\ Toluene \\ Ammonium chloride \\ Benzene \\ Trichloroethylene \\ Phenol \\ Gas (unleaded) \\ Oil (SAE 30)
}

Because the trenches proposed for the grouting demonstration were used specifically for low-level radioactive waste, it is highly unlikely that any strong acids, bases or salt solutions are present.

To test the compatibility of the acrylamide with the types of waste that are found in the five SWSA 6 trenches, samples of trench leachate and bottom soil were taken from each of the trenches for laboratory testing. Not only was the "set" time for the grout tested, but the percentage of grout that polymerized was measured by assaying for the residual acrylamide monomer as well. The results of the stucy are shown in the following table taken from written correspondence with B. Spalding on July 25, 1988, pp. 9-11:

\begin{tabular}{|c|c|c|c|c|c|}
\hline \multirow{2}{*}{$\begin{array}{l}\text { SAMPLE } \\
\text { water } \\
\text { Trench } \\
\text { Trench } \\
\text { Trench } \\
\text { Trench }\end{array}$} & & IYPE & $\frac{\text { ING }}{2(M I N)}$ & POLYMERIZATION & $\frac{\text { POST-GROUTINC }}{\text { CONDUCTIVITY }}$ \\
\hline & $\begin{array}{l}2 \\
3 \\
5 \\
6\end{array}$ & $\begin{array}{l}\text { water } \\
\text { leachate } \\
\text { leachate } \\
\text { leachate } \\
\text { leachate }\end{array}$ & $\begin{array}{l}9 \\
9 \\
9 \\
9 \\
9\end{array}$ & $\begin{array}{l}99.52 \\
99.56 \\
99.49 \\
99.49\end{array}$ & \\
\hline $\begin{array}{l}\text { Trench } \\
\text { Trench } \\
\text { Trench } \\
\text { Trench } \\
\text { Trench }\end{array}$ & $\begin{array}{l}2 \\
3 \\
4 \\
5 \\
6\end{array}$ & $\begin{array}{l}\text { soil } \\
\text { soil } \\
\text { soil } \\
\text { soil } \\
\text { soil }\end{array}$ & $\begin{array}{r}11 \\
7 \\
5 \\
10 \\
10\end{array}$ & $\begin{array}{l}99.50 \\
99.66 \\
49.65 \\
99.43 \\
99.49\end{array}$ & $\begin{array}{l}<2.4 \times 10-7 \\
<2.5 \times 10-7 \\
<2.6 \times 10-7 \\
<2.2 \times 10-7 \\
<2.5 \times 10-7\end{array}$ \\
\hline
\end{tabular}

na=data is not available

None of the samples posed any interference with the set time of the grout, nor were there any adverse effects on the percent of grout that polymerized. The proposed demonstration project will use 190,000 liters of grout which will contain $0.5 \%$ residual free acrylamide monomer in i impermeable matrix. Most likely, the monomer would be permanently trapped within the polymerized grout. If any monomer leached from the grout, it is expected that 
it would be easily degraded by the soil microorganisms (Lande et al., 1979).

3. Characterization of the waste in the trenches to be grouted:

The waste in the trenches is primarily solid low-level radioactive waste. Because this is a solid low-level waste trench, only minimal amounts of liquid waste may be present. The following table lists examples of the waste found in each trench, and the isotopes present. The radioactive waste is either encased in lead shielding or bagged in plastic.

\begin{tabular}{|c|c|c|}
\hline Trench & Waste & Radionuclides \\
\hline 2 & $\begin{array}{l}\text { Cell waste, paper, shoe covers, } \\
\text { gloves, filters }\end{array}$ & $\begin{array}{l}\mathrm{Co}, \mathrm{Ir}, \mathrm{Ra}, \mathrm{Sb} \text {, } \\
\mathrm{Cs}\end{array}$ \\
\hline 3 & $\begin{array}{l}\text { reactor ash, NO3 pellets, celi } \\
\text { furnace, } C V \text { filters }\end{array}$ & $\begin{array}{l}\text { U, Pu, } \mathrm{Np}, \mathrm{C}, \\
\mathrm{Sr}, \mathrm{Cs} \mathrm{Be,} \\
\mathrm{Ca}, \mathrm{Eu}, \mathrm{Co}\end{array}$ \\
\hline 4 & $\begin{array}{l}\text { EDM dielectric oil, scrap from cell A } \\
\text { hoses, clothing, Cao lime }\end{array}$ & $\begin{array}{l}\text { Pu, Cs, U, } \\
\text { Sr, Ag, H, Cm }\end{array}$ \\
\hline 5 & $\begin{array}{l}\text { Cell waste, plastic suits, shoe } \\
\text { covers, gloves, filters }\end{array}$ & $\begin{array}{l}\text { Ir, Eu, Gd, } \\
\mathrm{K}_{,} \mathrm{Au}, \mathrm{CO}, \mathrm{Sr},\end{array}$ \\
\hline 6 & $\begin{array}{l}\text { No shippment papers are available } \\
\text { for this trench, but the type of } \\
\text { waste is similar to that of the other } \\
\text { four trenches. }\end{array}$ & \\
\hline
\end{tabular}

This information was taken from an incomplete set of waste shipment records. The list should be regarded as examples of the typical types of waste found in the trenches.

Samples of trench leachate and groundwater were used to characterize the waste in the absence of thorough records. The following characteristics are presented in Tables 4 and 5 from written correspondence with B. Spalding, July 25, 1988: pH, conductivity, hardness, alkalinity, dissolved solids, gross alpha and beta activity levels, moisture and radionuclide concentration.

4. Results of past on-site demonstration activities:

A 1985 study tested seven grout formulations using scils from Oak.Ridge, TN, and Maxey Flats, KY. for ability to reduce hydraulic conductivity and ability to penetrate backfilled soils. Three small, pilot-scale trenches were grouted; two were grouted with sodium silicate and one with acrylamide. Acrylamide grout was more effective than particulate grouts in soil penetration 
(Table 2, p. 392) and performed more consistently than the other soluble grouts (p. 392) (Spalding et al., 1985 pp. 389-396). The polyacrylamide-filled trench exhibited essentially immeasurable hydraulic conductivity.

Another field study was conducted at ORNL in SWSA 4 in 1987. Two small waste trenches were filled with $34,000 \mathrm{~L}$ of polyacrylamide grout. The grout significantly reduced hydraulic conductivity; in four wells conductivity in the trenches was below detection limits (Spalding et al., 1987).

No detectable amounts of acrylamide or grout by-products have been detected in the monitoring wells surrounding either of the test sites (personal communication with B. Spalding, August 9, 1988).

5. Long term stability of the grout including the effects of biodegradation and dehydration:

The acrylamide gels are subject to mechanical deterioration as a result of freezing and dehydration. However, in temperate, humid climates deterioration is minimal. Under moist soil conditions, the polymer is resistant to microorganisms, dilute acids and bases, as well as the salts and gases ordinarily found in soils (Lande et al., 1979).

The acrylamide monomer that is released into the environment is degraded by microorganisms found naturally in soils and water. Because it is easily degraded, the toxic monomer would only persist a few days and does not bioaccumulate. soil microorganisms degrade the acrylamide monomers in only six days after a lag time of two days (Lande et al., 1979). Although acrylamide monomers are leachable, it is unlikely that any will reach either wells used for drinking water or surface water before degradation occurs.

A microbial degradation study of the set polymer resulted in calculations that estimate the grout to have an average half-life of 362 years with a decomposition rate constant of $5.5 \times 10-6 /$ day (Spalding et al., 1987, p. 47. Tables p. 49). The degradation is a first-order rate reaction (ie. after two half-lives, $25 \%$ of the grout is remaining).

6. Past testing procedures and future testing procedures to demonstrate (1) successful polymerization of injected grout and (2) non-migration of grout outside the trench:

The bench test analyzing grout compatibility with the trench leachate samples involved adding $10 \mathrm{~mL}$ of grout solution to $5 \mathrm{~mL}$ of leachate. The grout solution was made of acrylamide, methylenebisacrylamide, triethanolamine and potassium ferricyanide. Time of grout set was measured when grout would no longer flow in the beaker. To test the soil compatibility the same procedure was used with $5.00 \mathrm{~g}$ of soil. 
After overnight storage, the samples were extracted with water to determine the amount of residual monomer. Samples were placed in a blender with $100 \mathrm{~mL}$ of water and macerated. The homogenate was filtered. The filtrate was analyzed for acrylamide and methylenebisacrylamide using a direct injection on a high pressure liquid chromatograph (HPLC). The following table lists the residual concentrations of acrylamide and methylenebisacrylamide from grout prepared in trench leachate:

Sample

Acrylamide (mg/L)

methylenebisacbylamide (mg/L)

uncatalyzed grout (no polymerization)

100,800

480

462

486

510
5360
0.9
0.7
0.7
0.9

For specific details of the procedure, please refer to the attached document Compatibility of Acrylamide Grout with Burial Trench Contents in Test Area for Remedial Actions at Oak Ridge National Iaboratory Solid Waste Storage Area 6, pp 4-6.

Field procedures for testing polymerization of the acrylamide grout are less quantitative, but offer a high degree of confidence in the control of grout set. First, each batch of grout and catalyst is tested before injection into the trench by mixing equal volume samples and determining set time. This procedure verifies that the batch (normally 3000 galions) was prepared and blended correctly. This also confixms that the reactivity of the catalyst, ammonium persulfate, is within the desired range of set times, from 20 to 60 minutes. After a batch is pumped into a trench, the liguid level in the trench is measured at the injection wells and intratrench monitoring wells. Probing of the liquid with a steel weight on a measuring tape is continued until the grout has set in all wells. Both set time and depth to set grout are recorded before the injection of another batch. Water levels in surrounding water monitoring wells are recorded. Water samples from monitoring wells are taken daily during the grouting campaign and at exponentially decreasing intervals after completion for laboratory analysis. 


\section{Citations:}

Avanti International AV-100 Chemical Grout Technical Manual.

Davis, E.C., D.K. Solomon, R.B. Dreier, S.Y. Lee, P.M. Craig, A.D. Kelmers, and D.A. Leitzke. 1987. Summary of Environmental Characterization Activities at the Oak Ridge National Laboratory Solid Waste Storage Area Six FY 1986 through FY 1987. ORNL/RAP/LTR-87/68.

Karol, R.H., Chemical Grouts and their properties. In Proceedings of the Conference on Grouting in Geotechnical Engineering. ed. W.H. Baker.

Lande, S.S, S.J. Bosch and P.H. Howard. 1979. Degradation and Leaching of Acrylamide in Soil. J. Environ. Vol. 8, no.1.

Larson, R.J. and J.H. May. 1983. Geotechnical Aspects of Bottom Sealing Existing Hazardous Waste Landfills by Injection Grouting (Phase I - Compatibility Studies). pp. 513-529 In Proceedings of the First Annual Hazardous Materials Management Conference. Tower Conference Management Company, Wheaton, Illinois.

Spalding, Brian (Environmental Sciences Division) Personal communication to Susan Michaud (Environmental and Health Protection) 9 August 1988.

Spalding, Brian (Environmental Sciences Division). Written communication: Compatibility of Acrylamide Grout with Burial Trench Contents in Area of Remedial Actions at Oak Ridge National Laboratory Solid Waste Storage Area 6 . to Susan Michaud (Environmental and Health Protection) $25 \mathrm{Ju}$ Y, 1988.

Spalding, B.P., L.K. Hyder and I.I. Munro. 1985. Grouting as a Remedial Technique for Buried Low-Level Radioactive Wastes. J. Environ. Qual. 14:389-396.

Spalding, B.P., S.Y. Lee, C.D. Farmer, L.K. Hyder and P. Supaokit. 1987. In situ Grouting of Buried Transuranic Waste with Polyacrylamide. in Oak Ridge Conference Proceedings. pp. 39-76. Conf-871075, Vol. I, Part 3. Martin Marietta Energy Systems, Inc. Oak Ridge, TN.

Spooner, P.A., G.E. Hunt, V.E. Hodge, P.M. Wagner and I.R. Melnyk. 1984. Compatibility of Grolits ith liazardous Wastes. United States Environmental prntection Agency EPA-600/S2-84-015 Mar. 
Tucci, P. 1986. Groundwater Flow in Melton Valley, Oak Ridge Reservation, Roane County, Tennessee - Preliminary Model Analysis. U.S. Geological Survey. Nashville, Tennessee. WRI $85-4221$.

Webster, D.A., J.S. Beatty, P.M. Benjamin, and W.M. Tranum. 1980. Water Level Data for Wells in Burial Ground 6, oak Ridge National Laboratory, Tennessee, 1975-19.77 U.S. Geological Survey Open-file Report 81-57. 

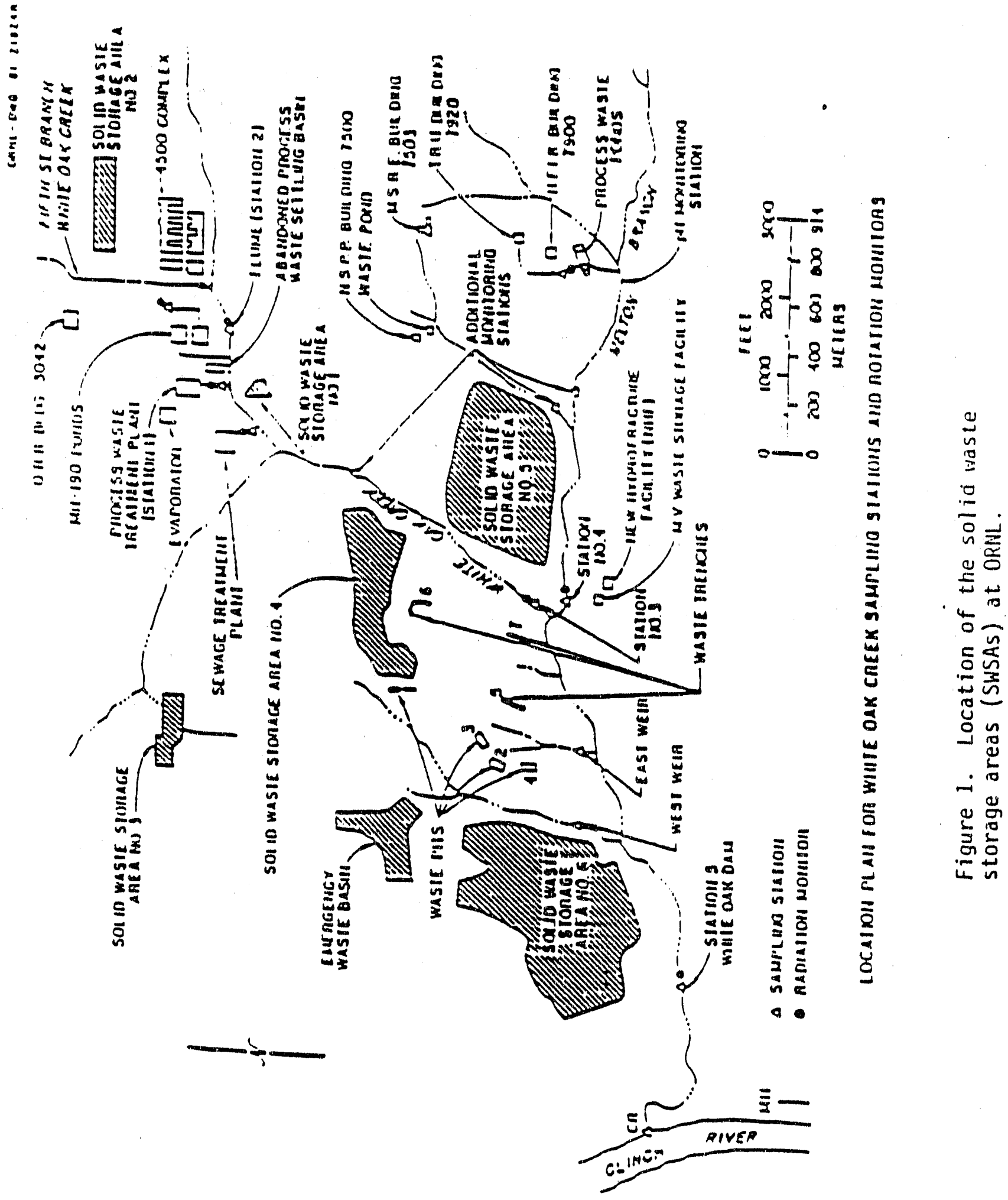


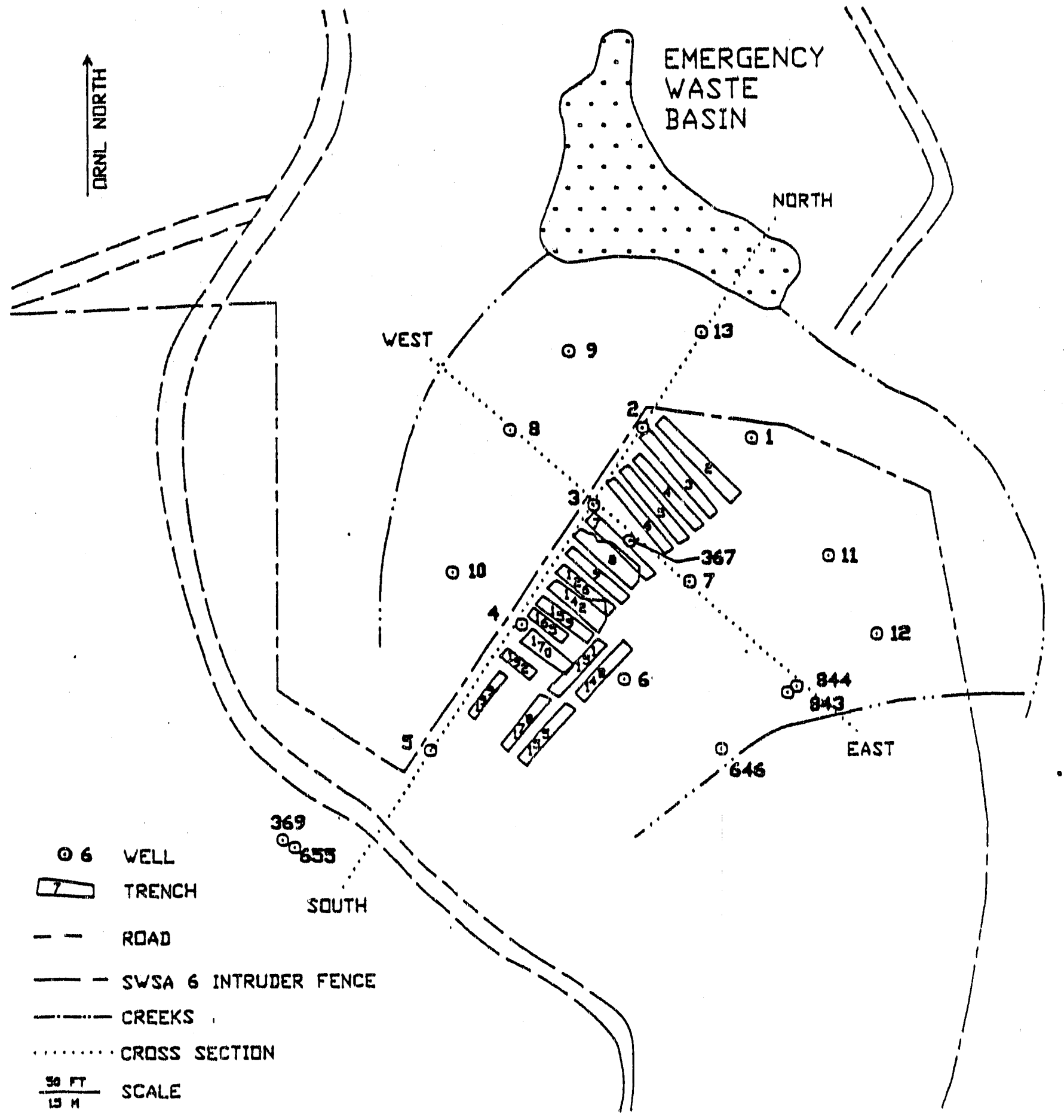

Fig. 2. Location of TARA site groundwater monitoring wells. 


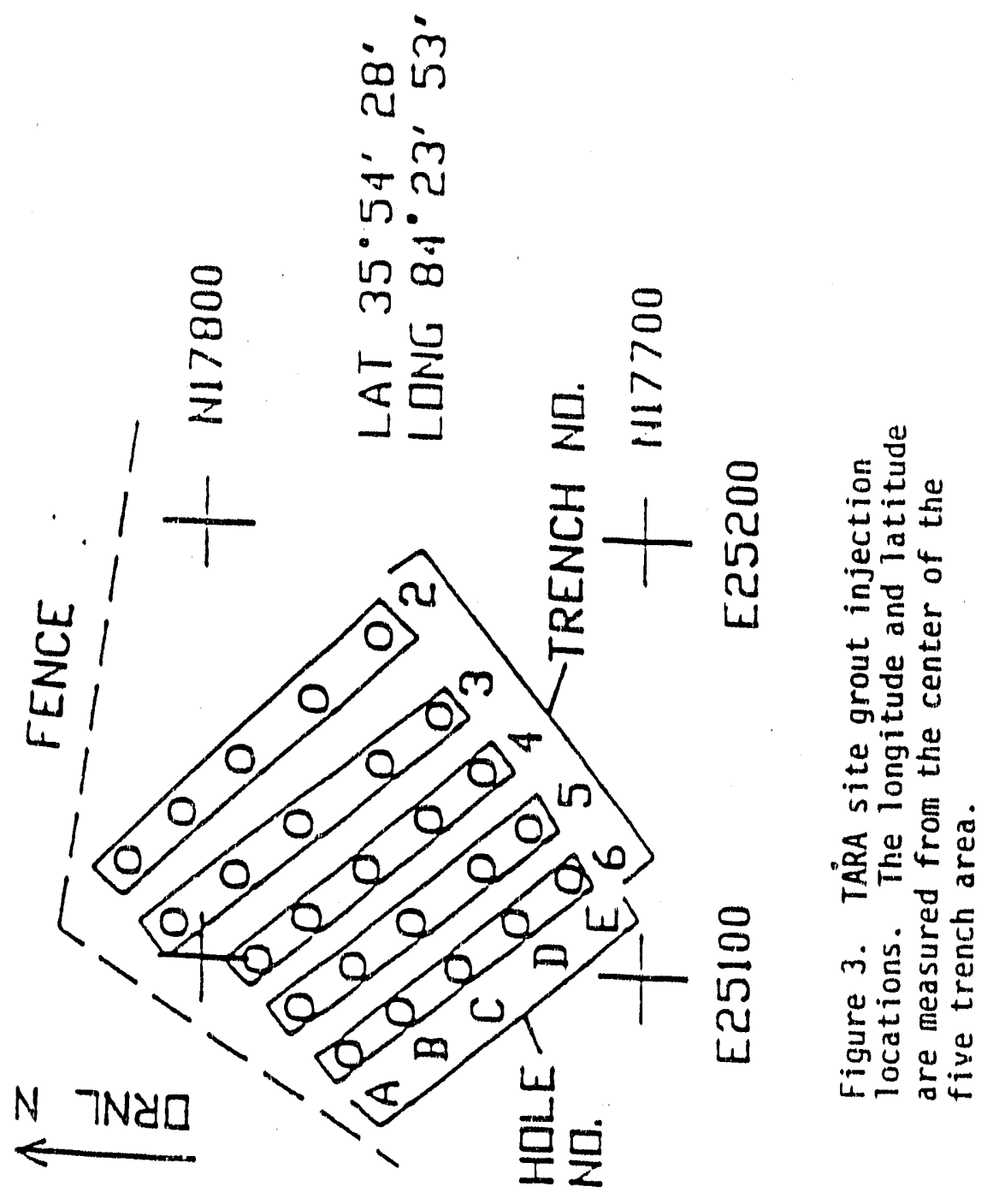




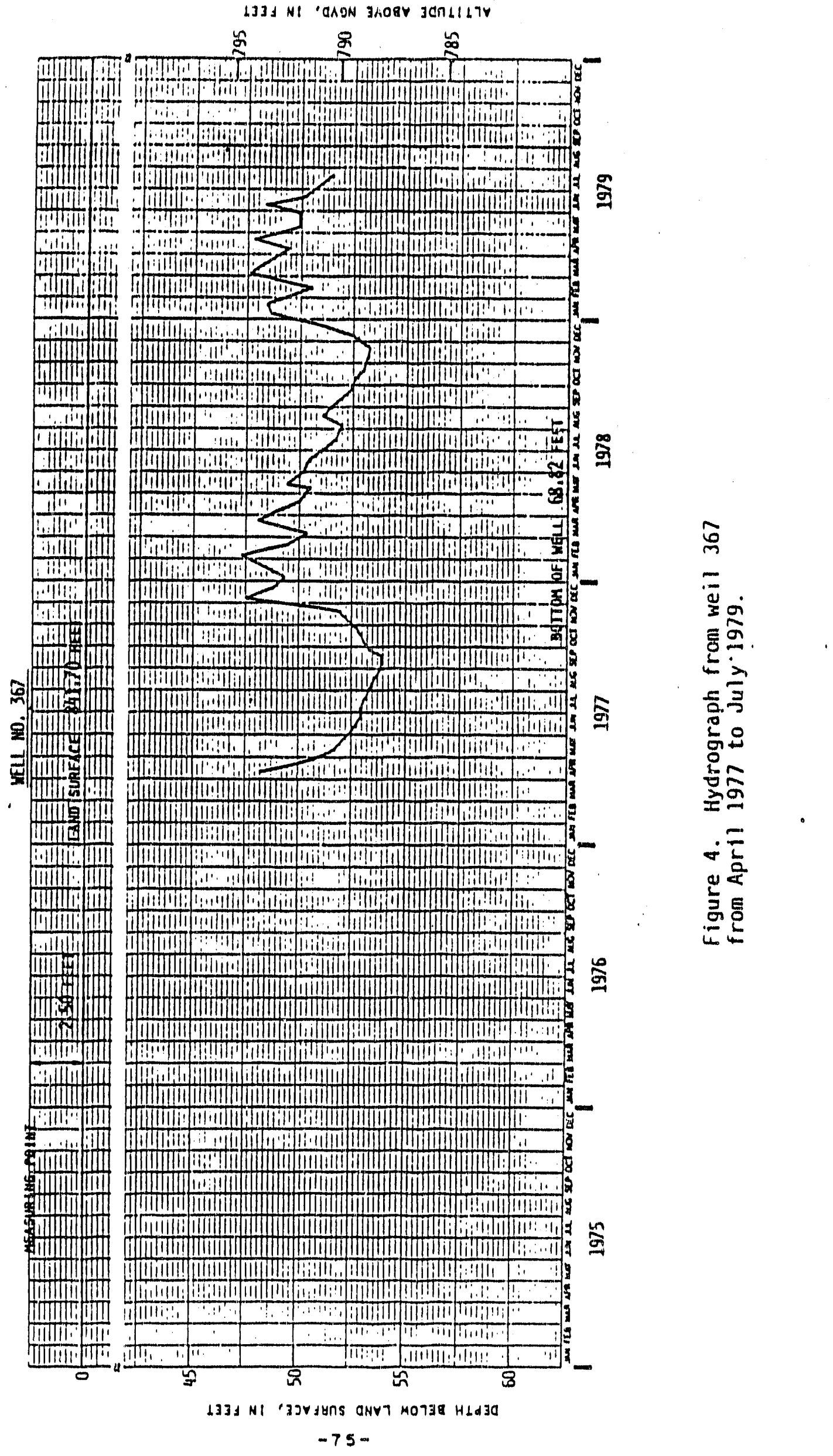




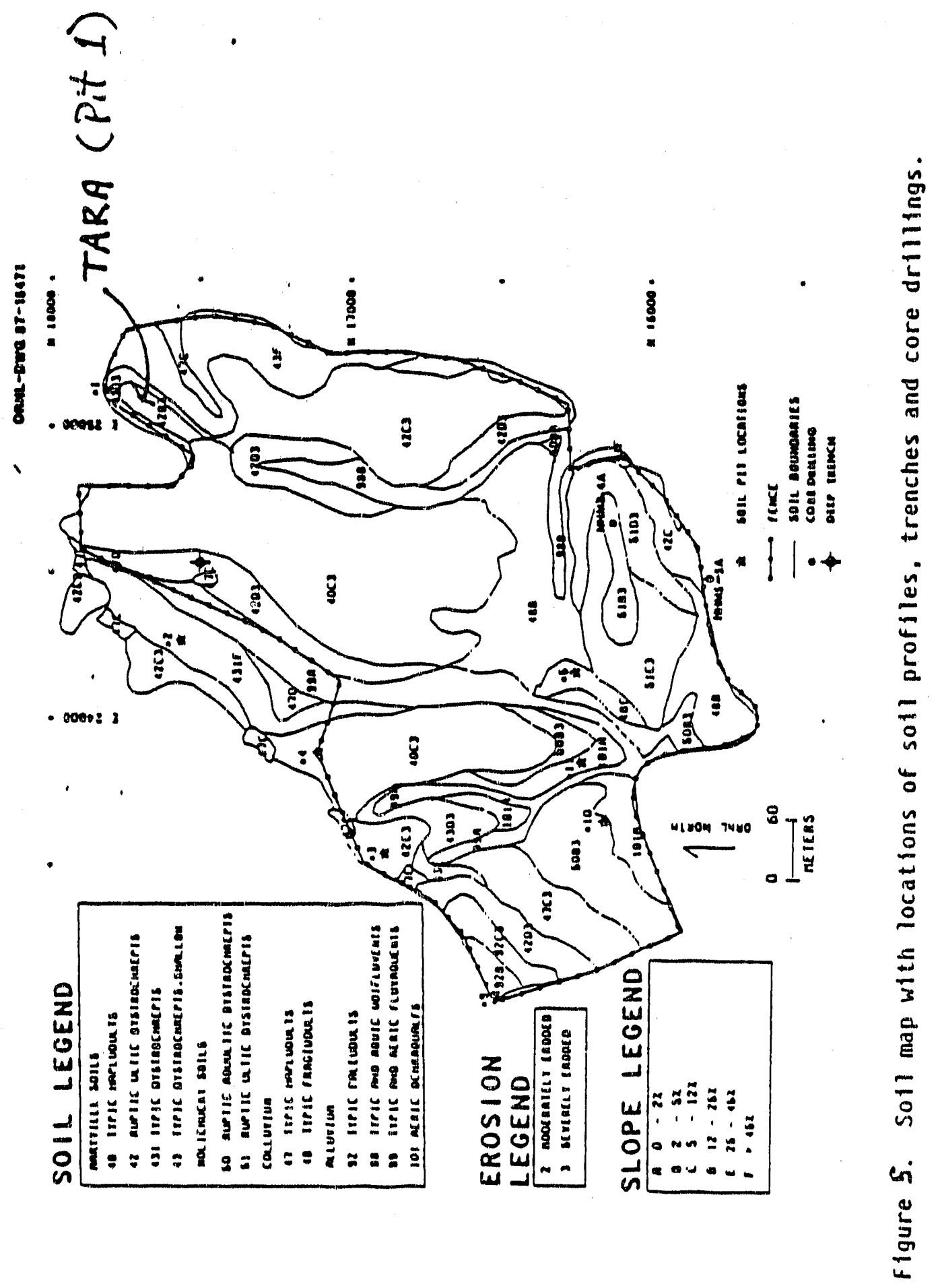




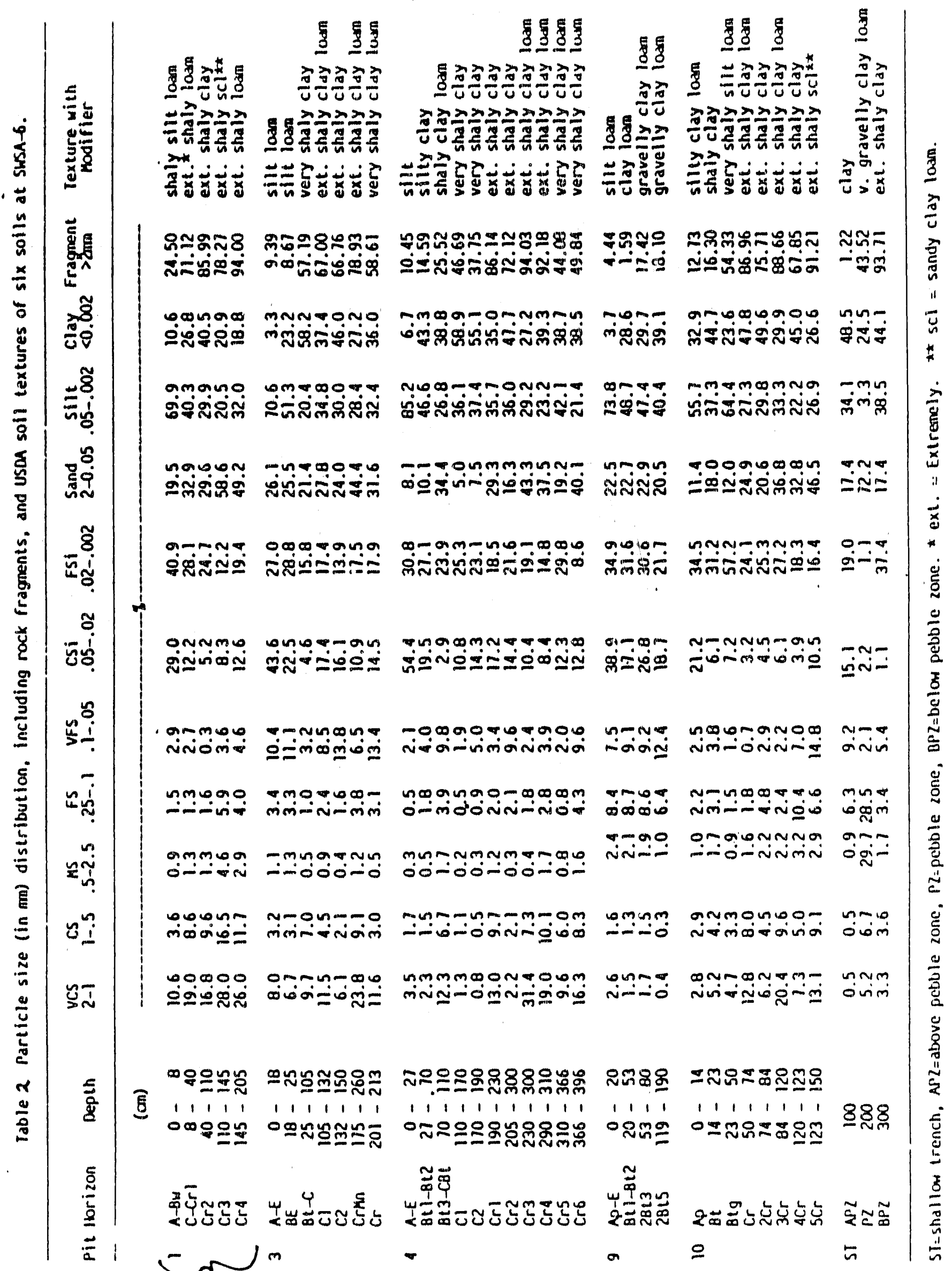


Table 2 Atterburg limits of five soils at SHSA-6

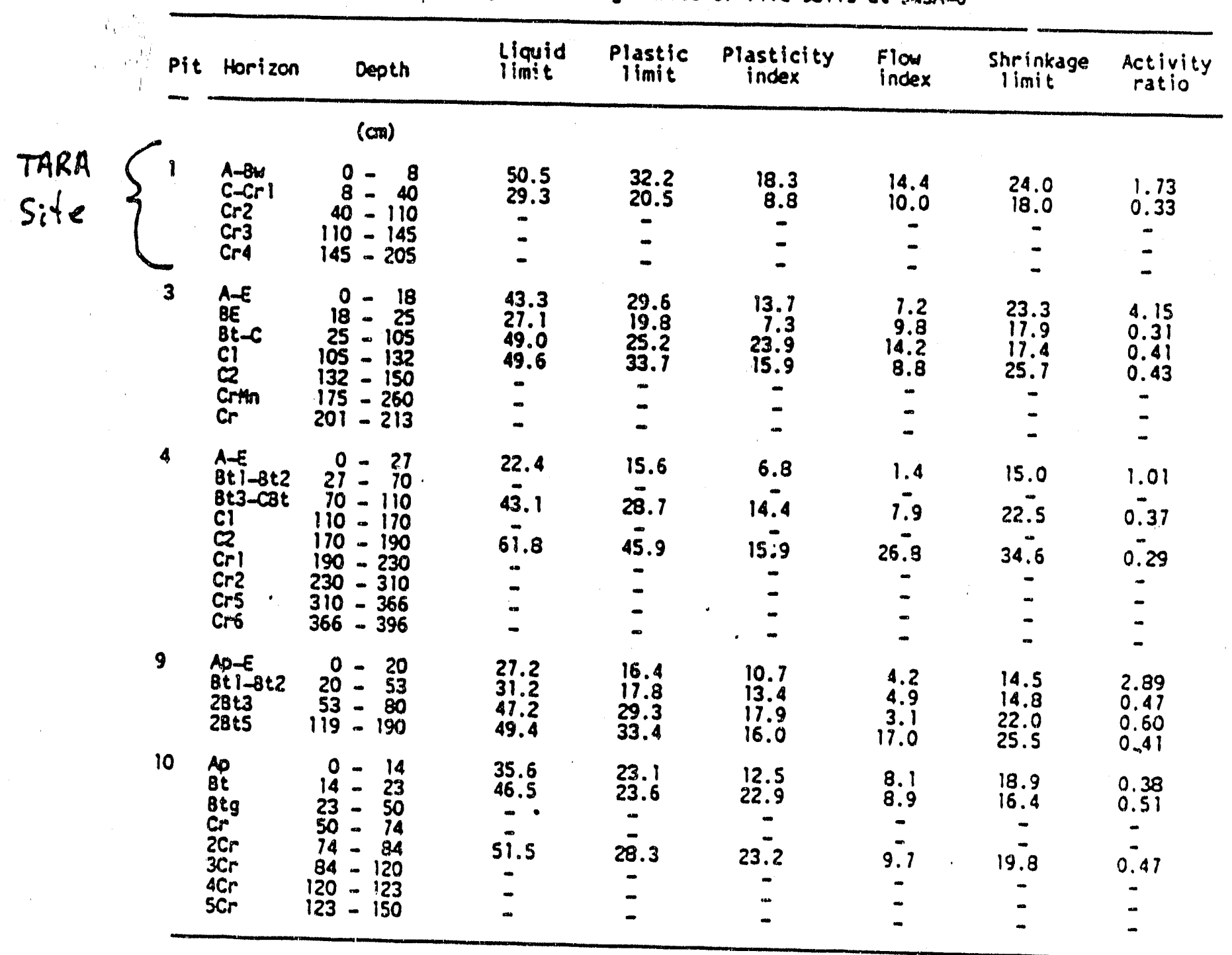


Table 3. The distribution of pH, ammonium acetate extractable bases, sodium dithionite extractable (CSO) iron and manganese, and hydroxylamine reducible (HA) manganese for five soil profiles at SWSA-6

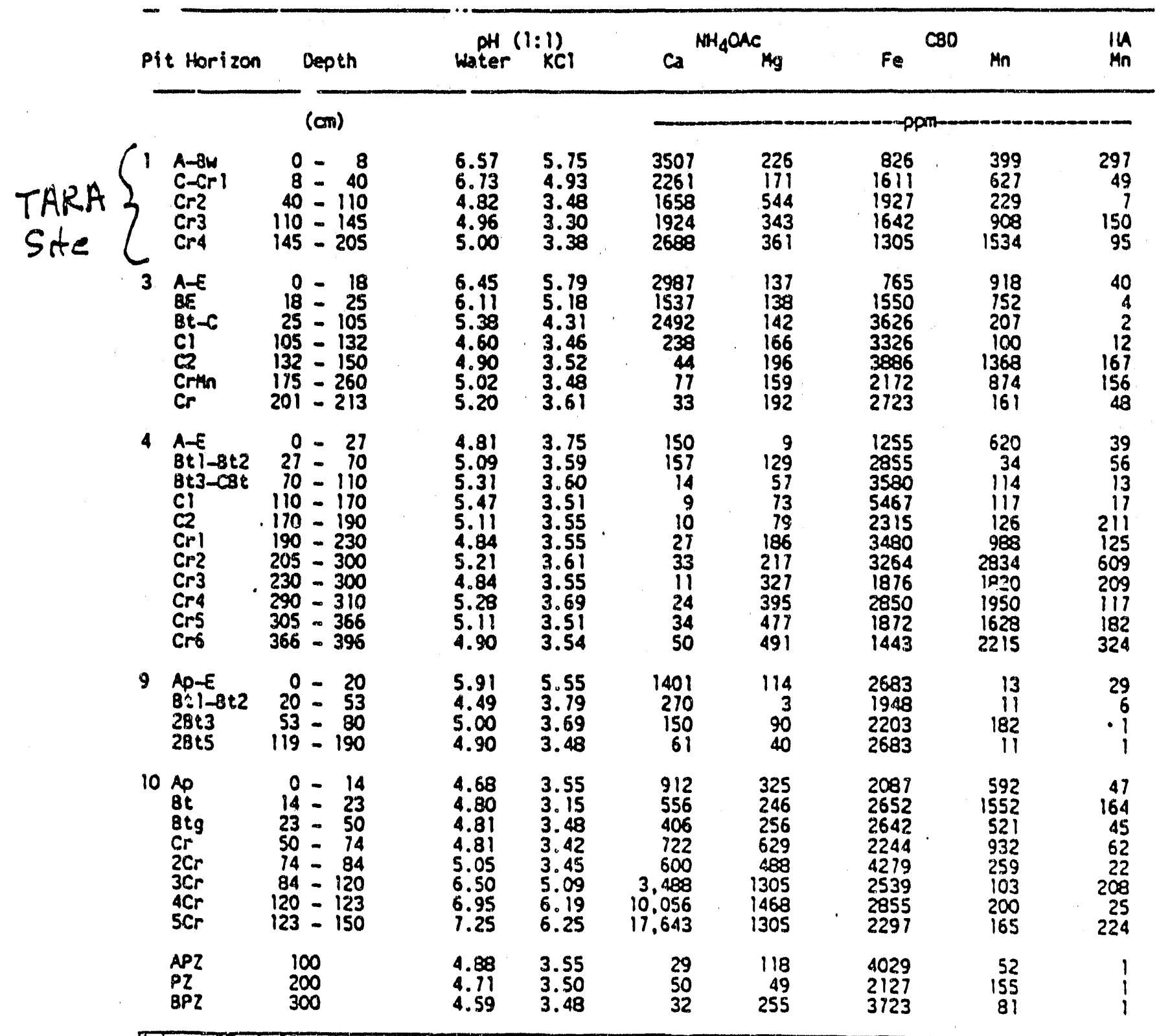

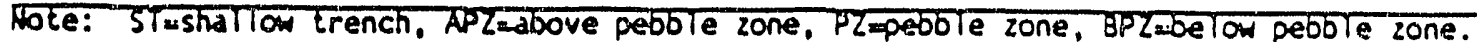


Tabie 3 sumation of mineralogical analyses from $x$-ray diffraction and differential scanning calorimetry determinations.

Minerals present in clay fraction $(<.002 \mathrm{~mm})$

Pit Horizon Depth Smectite Vermiculite HIV Chlorite Kaolinite Illte Oxides Gibbsite

\begin{tabular}{|c|c|c|c|c|c|c|c|c|c|c|}
\hline & $\begin{array}{l}A-8 w \\
C r 4\end{array}$ & $\begin{array}{c}\text { on } \\
0-10 \\
145-205\end{array}$ & $\begin{array}{l}\text { No } \\
\text { ND }\end{array}$ & $\begin{array}{l}H \\
H\end{array}$ & $\begin{array}{l}\text { Tr } \\
\text { NO }\end{array}$ & $\begin{array}{l}\text { NO } \\
\text { ND }\end{array}$ & $\begin{array}{l}\text { Tr } \\
T r\end{array}$ & $\stackrel{H}{H}$ & Tr & $\begin{array}{l}\text { NO } \\
\text { NO }\end{array}$ \\
\hline 3 & $\begin{array}{l}A-E \\
B_{t-C} \\
C Z \\
C r\end{array}$ & $\begin{array}{c}0-18 \\
84-105 \\
132-150 \\
201-213\end{array}$ & $\begin{array}{l}\text { NO } \\
\text { NO } \\
\text { NO } \\
\text { NO }\end{array}$ & $\begin{array}{l}M \\
H \\
H \\
H\end{array}$ & $\begin{array}{c}n \\
i \\
T\end{array}$ & $\begin{array}{l}\text { NO } \\
\text { ND } \\
\text { No } \\
\text { NO }\end{array}$ & $\begin{array}{l}T r \\
T r \\
T r \\
T r\end{array}$ & M & $\begin{array}{l}\text { Ir } \\
\text { Ir } \\
\text { Tr } \\
\text { Tr }\end{array}$ & $\begin{array}{l}\text { NO } \\
\text { ND } \\
\text { NO } \\
\text { NO }\end{array}$ \\
\hline 4 & $\begin{array}{l}A-E \\
B+1-8+2 \\
C r \mid \\
C r 4\end{array}$ & $\begin{array}{c}0-27 \\
27-70 \\
190-230 \\
290-310\end{array}$ & $\begin{array}{l}\text { NO } \\
\text { NO } \\
\text { NO } \\
\text { NO }\end{array}$ & $\stackrel{T r}{h}$ & $\begin{array}{l}H \\
H \\
H \\
L\end{array}$ & $\begin{array}{l}\text { Tr } \\
\text { Tr } \\
\text { NO } \\
\text { No }\end{array}$ & $\begin{array}{l}\text { Tr } \\
\text { Tr } \\
T r \\
T r\end{array}$ & $\begin{array}{l}L \\
L \\
H \\
H\end{array}$ & $\begin{array}{l}T_{r} \\
\text { Ir } \\
\text { Tr }\end{array}$ & $\begin{array}{l}\text { NO } \\
\text { NO } \\
\text { NO } \\
\text { NO }\end{array}$ \\
\hline 9 & $\begin{array}{l}\text { Ap-E } \\
8+1-B+2 \\
28+3 \\
28+5\end{array}$ & $\begin{array}{c}0-20 \\
20-53 \\
53-95 \\
119-190\end{array}$ & $\begin{array}{l}\text { NO } \\
\text { ND } \\
\text { ND } \\
\text { ND }\end{array}$ & $i_{i r}^{l}$ & $\begin{array}{l}H \\
H \\
H \\
H\end{array}$ & $\begin{array}{c}T r \\
L \\
i r\end{array}$ & $\begin{array}{c}\text { Tr } \\
b \\
l\end{array}$ & $\begin{array}{l}L \\
b \\
L\end{array}$ & $\begin{array}{l}\text { Tr } \\
\text { Tr } \\
\text { Tr } \\
\text { Tr }\end{array}$ & $\begin{array}{l}\text { NO } \\
\text { NO } \\
\text { NO } \\
\text { Tr }\end{array}$ \\
\hline 10 & $\begin{array}{l}\text { Ap } \\
8 t g \\
C r \\
5 C r\end{array}$ & $\begin{array}{c}0-14 \\
23-50 \\
50-74 \\
.123-150\end{array}$ & $\begin{array}{l}\text { Tr } \\
\text { Tr } \\
\text { Tr } \\
\text { Tr }\end{array}$ & $\begin{array}{l}\stackrel{H}{H} \\
H \\
H \\
H\end{array}$ & $\begin{array}{l}\text { Tr } \\
\text { Tr } \\
\text { ir } \\
\text { r }\end{array}$ & $\begin{array}{l}\text { ND } \\
\text { AD } \\
\text { ND } \\
\text { NO }\end{array}$ & $\begin{array}{l}\text { Tr } \\
\text { Tr } \\
\text { Tr }\end{array}$ & $\begin{array}{c}M \\
H \\
H \\
H\end{array}$ & $\begin{array}{l}\text { Tr } \\
\text { Tr } \\
\text { Tr } \\
\text { Tr }\end{array}$ & $\begin{array}{l}\text { NO } \\
\text { ND } \\
\text { NO } \\
\text { ND }\end{array}$ \\
\hline ST & $\begin{array}{l}A P Z \\
P Z \\
B P Z\end{array}$ & $\begin{array}{l}100 \\
200 \\
300\end{array}$ & $\begin{array}{l}\text { ND } \\
\text { NO } \\
\text { NO }\end{array}$ & $\begin{array}{l}b \\
L\end{array}$ & $\begin{array}{l}H \\
H \\
H\end{array}$ & $\begin{array}{l}\text { ND } \\
\text { ND } \\
\text { NO }\end{array}$ & $\frac{l}{i r}$ & $\begin{array}{l}n \\
⿱ n \\
H\end{array}$ & $\begin{array}{l}\text { Tr } \\
\text { Ir } \\
\text { Tr }\end{array}$ & $\begin{array}{l}\text { NO } \\
\text { NO } \\
\text { NO }\end{array}$ \\
\hline
\end{tabular}

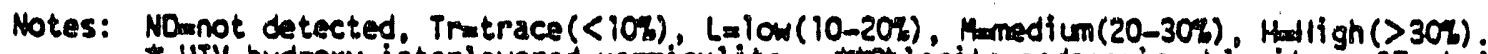

* HIV=hydroxy interlayered vermiculite. **Chlóritezoedogenic chiorite. ST=shailow trench, ApZadove pebble zone, PZ-pebble zone, BPZubelaw pebole zone. 

Table 3. Organic carbon distributions in
six solis at SWSA-6.

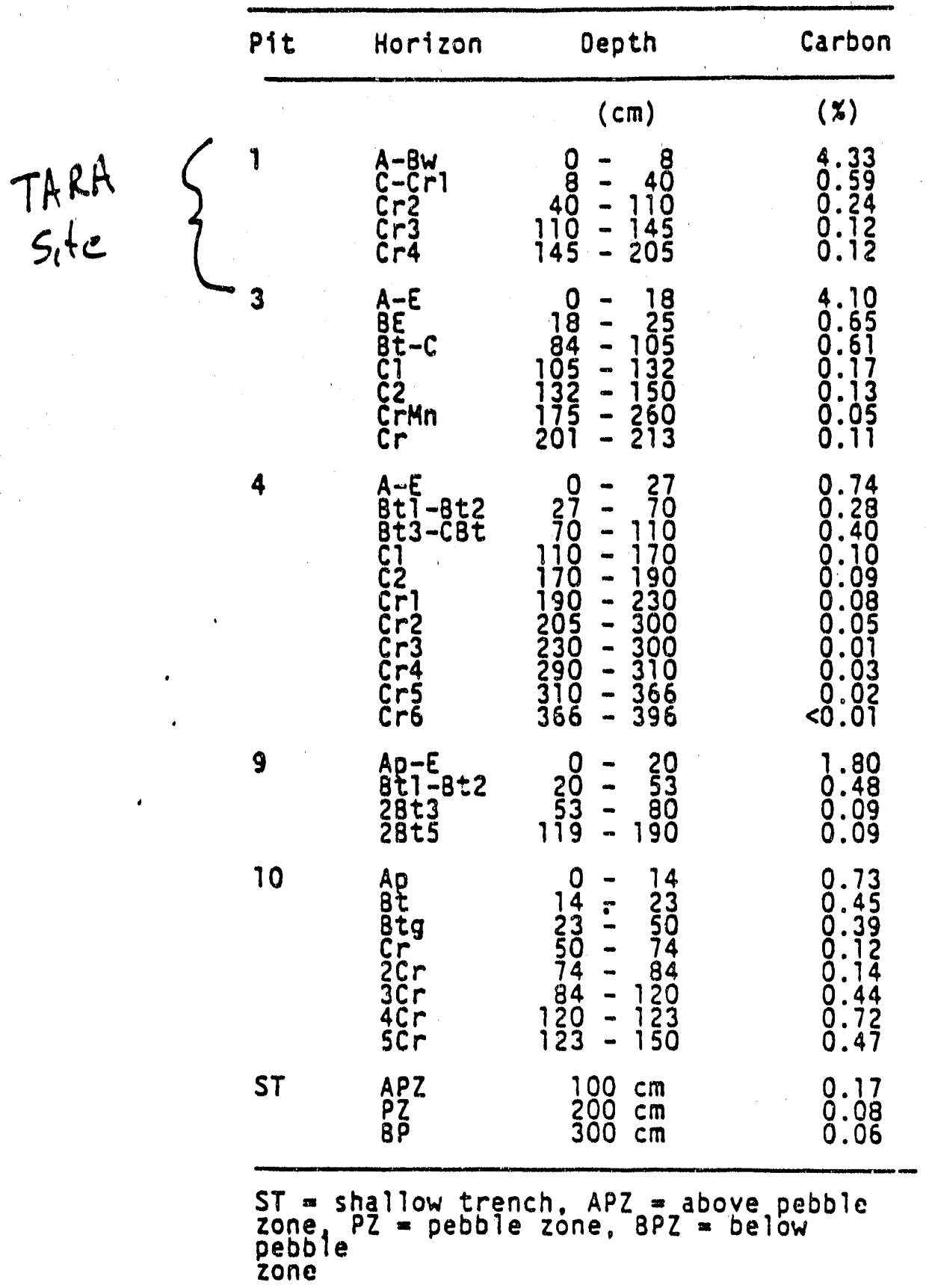


Table 4 - Gross chemical and radiochemical characteristics of burial trench leachate and groundwater samples.

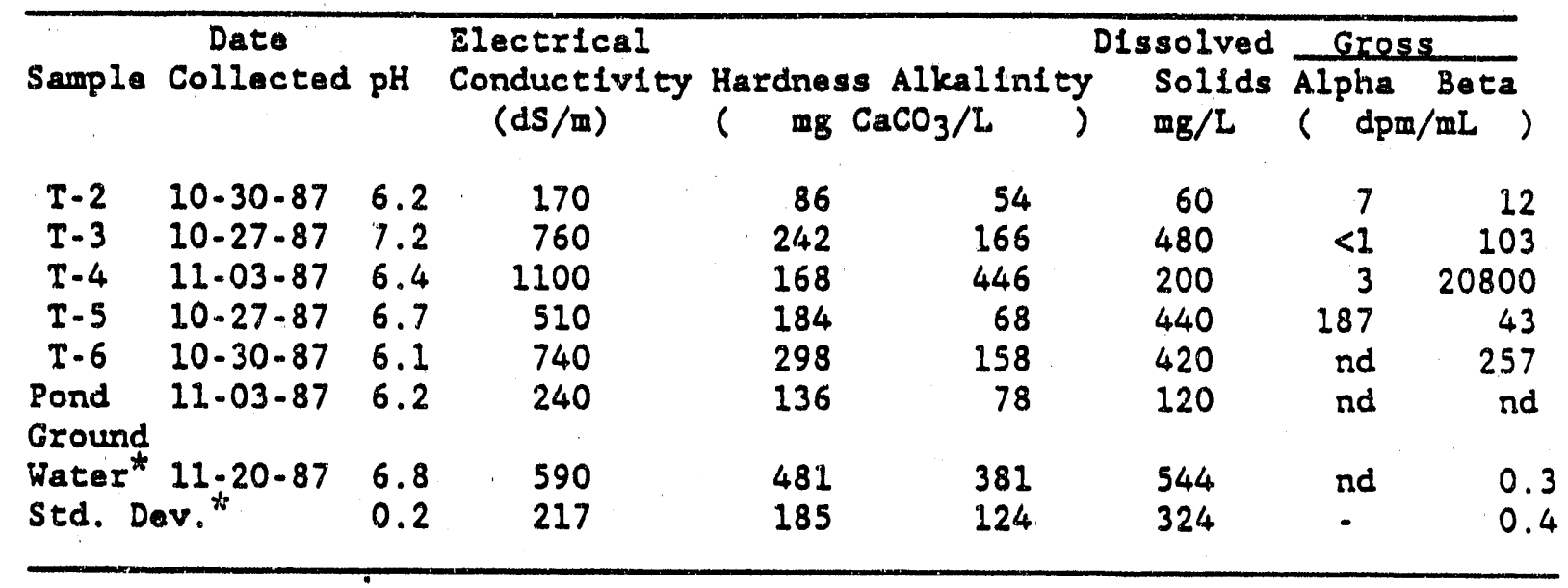

* Groundwater characteristics are the average and standard deviation for 15 samples collected from the monitoring welis in and surrounding the test area.

nd - not detected. 
Table 5 - Radionuclide and moisture contents of burial trench soil samples.

\begin{tabular}{|c|c|c|c|c|}
\hline Sample & Moisture & ${ }^{137} \mathrm{Cs}$ & ${ }^{60} \mathrm{Co}$ & ${ }^{90} \mathrm{Sr}$ \\
\hline & $(8)$ & $\bar{T}$ & $\mathrm{dpm} / \mathrm{g}$ & $\bar{T}$ \\
\hline Trench 2 & 17.9 & 1060 & nd & 3590 \\
\hline Trench 3 & 18.3 & 3350 & nd & 72800 \\
\hline Trench 4 & 16.4 & 128 & nd & 410 \\
\hline Trench 5 & 5.9 & 622 & 995 & nd \\
\hline Trench 6 & 13.7 & 9580 & nd & 15800 \\
\hline $\begin{array}{c}\text { Trench } 3 \\
\text { Cap }\end{array}$ & 15.2 & 17 & nd & nd \\
\hline
\end{tabular}

nd - not detected. Detection limits were $1.4 \mathrm{dpm} / \mathrm{g}, 2 \mathrm{dpm} / \mathrm{g}$, and $6 \mathrm{dpm} / \mathrm{g}$ for ${ }^{137} \mathrm{Cs},{ }^{60} \mathrm{Co}$, and ${ }^{90} \mathrm{Sr}$, respectively. 


\title{
UNITED STATES ENVIRONMENTAL PROTECTION AGENCY
}

\author{
REGION IV
}

345 COURTLAND STREET

ATLANTA, GEORGIA 303 S

DEC 161980

Mr. Joseph A. Lenhard

Assistant Manager for Energy Research and Development

Department of Energy

Oak Ridge Operations

P.O. Box 2001

Oak Ridge, Tennessee 37831

Dear Mr. Lenhard:

The Underground Injection Control (UIC) Program of the U.S.

Environmental Protection Agency (EPA) Region IV has received your

letter and the attached documents dated October 25, 1988, concerning the proposed stabilization of waste trenches in Waste Area Grouping (WAG) 6 by grout injection. Your letter stated that the information submitted was intended to be a Class V UIC permit application; however, the submittal appears to be a response to my July 11, 1988, letter where I requested additional technical information regarding the stabilization proposal. For clarifieation purposes, the submittal was not reviewed or considered to be a permit application, but was reviewed only as an informational package.

After reviewing the information submitted, the UIC Program continues to have technical concerns with the proposed grout injection project. We are concerned that the trenches have not been adequately characterized such that grout compatibility with the waste is assured. We also have other concerns including questions about the long term effectiveness of the acrylamide grout, especially in trenches located above the water table.

To help us resolve these concerns, we have requested that the EPA Risk Reduction Engineering Laboratory (RREL) in Cincinnati, Ohio review your injection/stabilization proposal in order to help us assess if the proposed demonstration project is appropriate. We have a meeting scheduled with RREL in Cincinnati in mid January. We will be providing you with comments and recommendations developed from this meeting as soon as possible. We will also notify you at that time concerning our decision of the need for ORNL to obtain a UIC permit for the demonstration project. 
We are coordinating the UIC review with the RCRA and CERCLA programs since the demonstration project is part of a RCRA/CERCLA remedial investigation and feasibility study. It is our understanding that grout stabilization is one of several remediation alternatives being considered for the trenches in WAG 6 . From our discussions with staff of the RCRA and CERCIA programs, it is important that information generated from the test demonstration project be useful in assessing the feasibility of this remediation alternative for remediation of other trenches in the WAG 6 area. We will be taking the RCRA and CERCIA program needs into consideration as we make our decision regarding the UIC issues.

If you have any questions, please phone me at FTS 257-3866.

Sincerely Yours,

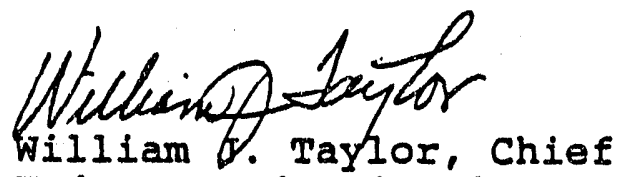

Underground Injection Control Section

Ground-Water Protection Branch 


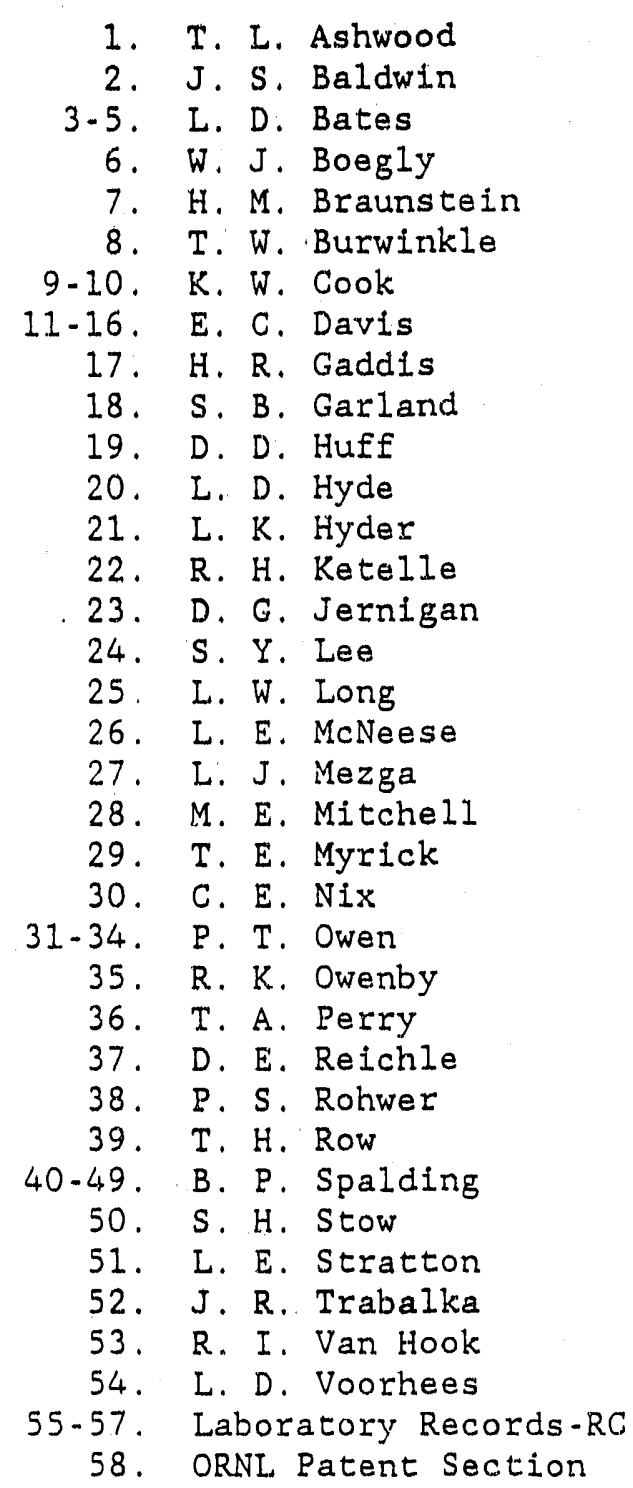

EXTERNAL DISTRIBUTION

59. R. D. Glenn, Bechtel National Inc, P.O. Box 350, Oak Ridge, TN $\quad 37831.0350$

60. OFFICE OF ASSISTANT MANAGER, ENERGY RESEARCH AND DEVELOPMENT, U.S. DEPARTMENT OF ENERGY, DOE FIELD OFFICE, OAK RIDGE P.O. BOX 2001, OAK RIDGE, TN 37831-8600

61-62. OFFICE OF SCIENTIFIC AND TECHNICAL INFORMATION, P.O. BOX 62, OAK RIDGE, TENNESSEE 37831 

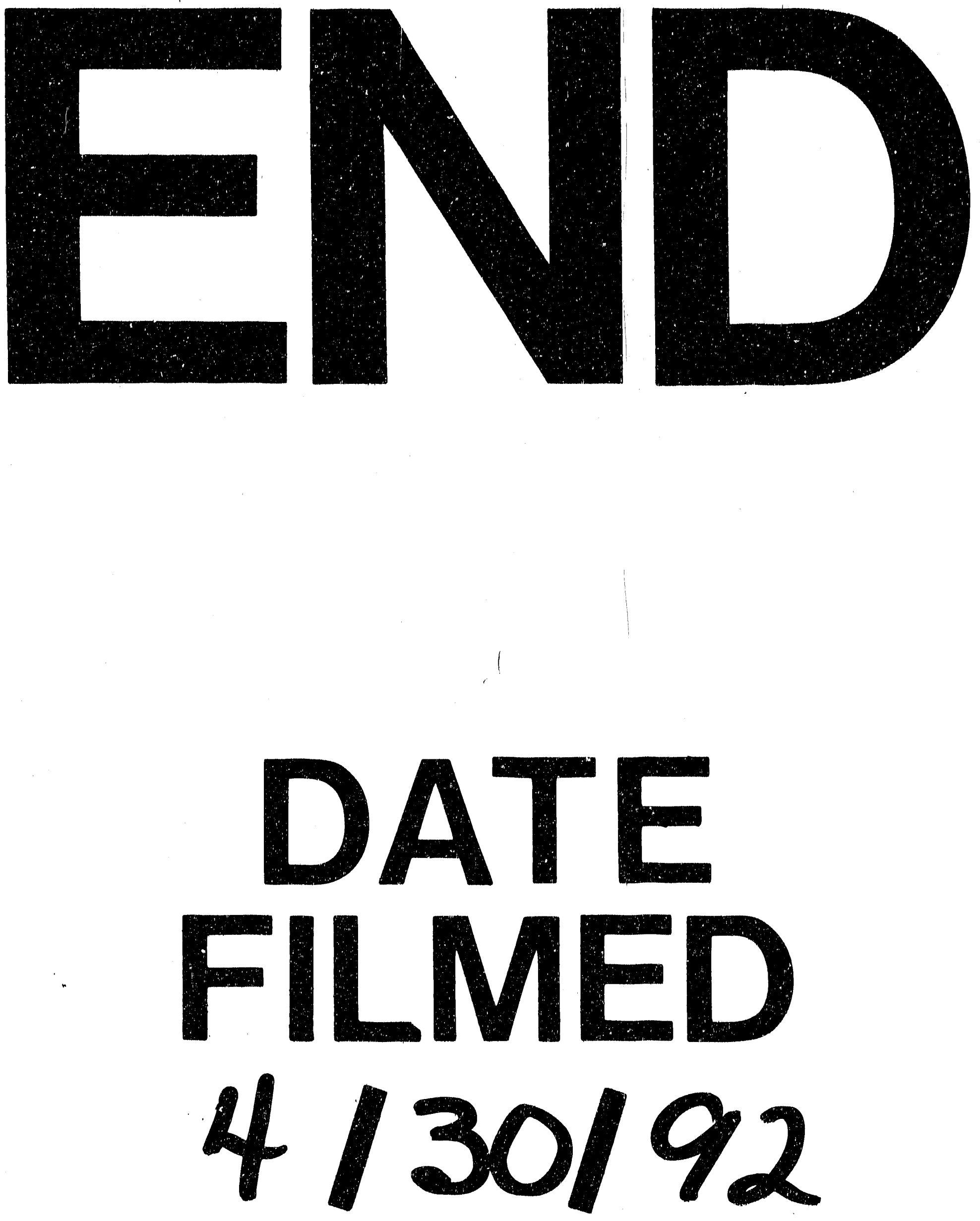
